\title{
Zorgvernieuwing : een kwestie van routine : een studie naar de vorming van interorganisationele netwerken en naar systeemveranderingen in de thuiszorg vanuit interactionistisch perspectief
}

Citation for published version (APA):

van Raak, A. J. A. (1998). Zorgvernieuwing : een kwestie van routine : een studie naar de vorming van interorganisationele netwerken en naar systeemveranderingen in de thuiszorg vanuit interactionistisch perspectief. [Doctoral Thesis, Maastricht University]. Universiteit Maastricht.

https://doi.org/10.26481/dis.19980611ar

Document status and date:

Published: 01/01/1998

DOI:

10.26481/dis.19980611ar

Document Version:

Publisher's PDF, also known as Version of record

Please check the document version of this publication:

- A submitted manuscript is the version of the article upon submission and before peer-review. There can be important differences between the submitted version and the official published version of record. People interested in the research are advised to contact the author for the final version of the publication, or visit the DOI to the publisher's website.

- The final author version and the galley proof are versions of the publication after peer review.

- The final published version features the final layout of the paper including the volume, issue and page numbers.

Link to publication

\footnotetext{
General rights rights.

- You may freely distribute the URL identifying the publication in the public portal. please follow below link for the End User Agreement:

www.umlib.nl/taverne-license

Take down policy

If you believe that this document breaches copyright please contact us at:

repository@maastrichtuniversity.nl

providing details and we will investigate your claim.
}

Copyright and moral rights for the publications made accessible in the public portal are retained by the authors and/or other copyright owners and it is a condition of accessing publications that users recognise and abide by the legal requirements associated with these

- Users may download and print one copy of any publication from the public portal for the purpose of private study or research.

- You may not further distribute the material or use it for any profit-making activity or commercial gain

If the publication is distributed under the terms of Article 25fa of the Dutch Copyright Act, indicated by the "Taverne" license above,

Download date: 26 Apr. 2023 


\section{Zorgvernieuwing: een kwestie van routine}

Een studie naar de vorming van interorganisationele netwerken en naar systeemveranderingen in de thuiszorg vanuit interactionistisch perspectief 
(c) 1998 A.J.A. van Raak, Tilburg.

ISBN 90-73892-11-2

Productie: $\quad$ Datawyse B.V., Maastricht

Omslagontwerp: Jan Eggen, Unigraphic, Maastricht

Lay-out: Jan van Emmerik, Maastricht 


\title{
Zorgvernieuwing: een kwestie van routine
}

Een studie naar de vorming van interorganisationele netwerken en naar systeemveranderingen in de thuiszorg vanuit interactionistisch perspectief

\author{
PROEFSCHRIFT \\ ter verkrijging van de graad van doctor \\ aan de Universiteit Maastricht, \\ op gezag van de Rector Magnificus, \\ Prof. Dr. A.C. Nieuwenhuijzen Kruseman, \\ volgens het besluit van het College van Decanen, \\ in het openbaar te verdedigen \\ op donderdag 11 juni 1998 om 14.00 uur
}

door

Amoldus Johannes Adrianus van Raak. geboren te Loon op Zand op 18 januari 1959. 
Promotor:

Prof.dr. J.A.M. Maarse

Co-promotor:

Dr. I.M. Mur-Veeman

Beoordelingscommissie:

Prof.dr. C. Spreeuwenberg (voorzitter)

Prof.dr. A.J.A. Godfroij (Katholieke Universiteit Nijmegen)

Prof.dr.ir. A.C.J. De Leeuw (Rijksuniversiteit Groningen)

Prof.dr. H. Philipsen

Prof.dr. G.A.M. Widdershoven 


\section{Inhoudsopgave}

Voorwoord $\ldots \ldots \ldots \ldots \ldots \ldots \ldots \ldots \ldots \ldots \ldots \ldots \ldots \ldots \ldots \ldots$

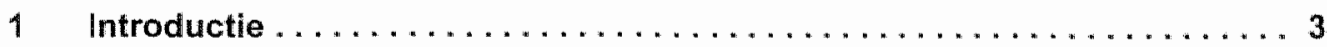

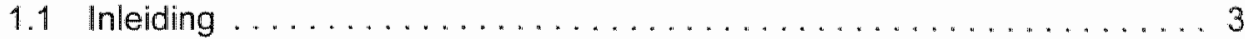

1.2 Doel en object van studie: netwerken in de thuiszorg . . . . . . . . 4

1.2.1 Zorgvernieuwingsbeleid van het Ministerie van WVC . . . . . . . 5

1.2.2 Doelstellingen van het Programma van WVC . . . . . . . . . . . . 5 5

1.2.3 Selectievoorwaarden voor het Programma en samenstelling . . . . . 7

1.2.4 Overheidssteun aan de projecten in het Programma van WVC . . . .

1.2.5 Doel en functie van het evaluatie-onderzoek . . . . . . . . . . . 10

1.3 Probleemstelling: sturing en netwerkontwikkeling $\ldots \ldots \ldots \ldots \ldots \ldots 10$

1.4 Paradigma, theorie en methodologie . . . . . . . . . . . . . . 14

1.5 Onderzoeksstrategie: uitvoering van de studie ............. 15

1.6 Opbouw van het verslag: een tafereel, naar het leven geschilderd . . . . 16

2 Preparering van het doek: paradigma en theorie $\ldots \ldots \ldots \ldots \ldots \ldots \ldots$

2.1 Inleiding . ............................... 19

2.2 Paradigma en verenigbaarheid van inzichten uit functionalistische benaderingen . . . . . . . . . . . . . . . . . . 20

2.2.1 Functionalisme: social system theory en interactionisme . . . . . 20

2.2.2 Vereniging van inzichten en primaat van het interactionisme . . . 21 21

2.3 Eerste opbouwfase van de theorie: selectie van verschijnselen . . . . . 25

2.3.1 Eerste selectie van verschijnselen ................. 27

2.3 .2 Tweede selectie van verschijnselen $\ldots \ldots \ldots \ldots \ldots \ldots \ldots \ldots 28$

2.3.3 Derde selectie van verschijnselen . . . . . . . . . . . . . . . 29

2.4 Tweede opbouwfase van de theorie: conceptueel raam-werk voor het dynamisch samenspel van verschijnselen . . . . . . . . . . . 32

2.4.1 Cultuur, structuur en macht (inclusief sturing) . . . . . . . . 32

2.4.2 Regels (ontwikkeling en handelen volgens regels) $\ldots \ldots \ldots \ldots 33$

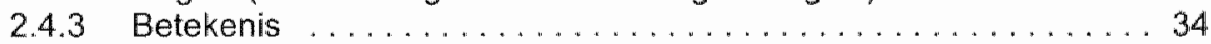

2.5 Derde opbouwfase van de theorie. beschrijving van de concepten . . . . 34 34

2.5.1 Betekenis .............................. . . 35

2.5.2 Context: cultuur (routines en actorperspectief) .......... 37

2.5.3 Context: structuur (afhankelijkheidsrelaties en patroonsgewijs handelen) ........................... 41

2.5.4 Context: macht (asymmetrische afhankelijkheidsrelaties) . . . . . 46

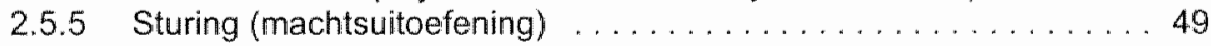

2.5 .6 Handelingsregels ....................... 52

2.6 Vierde opbouwfase van de theorie: beschrijving van de relaties tussen concepten ............................... 55

2.6.1 Eerste relatie tussen verschijnselen ............... . 56

2.6.2 Tweede relatie tussen verschijnselen . . . . . . . . . . . . . . 59

2.6.3 Derde relatie tussen verschijnselen . . . . . . . . . . . . . . . 59

2.6.4 Eerste relatie tussen verschijnselen (bis) $\ldots \ldots \ldots \ldots \ldots \ldots \ldots$

2.7 Slotopmerkingen . . . . . . . . . . . . . . . . . . . 60 
3 Penselen en verf: paradigma en methodologie ...............61 61

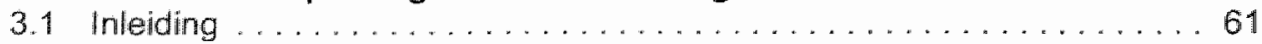

3.2 Paradigma en methodologie van het interactionisme: beoordeling van het onderzoek en de studie . . . . . . . . . . . . . . . . . . . 61

3.2 .1 Het vraagstuk van de beoordelingsmaatstaf . . . . . . . . . . 62

3.2 .2 Toetsende en explorerende benadering . . . . . . . . . . . 63

3.2.3 Beoordeling van het uitgevoerde onderzoek en de studie . . . . . 65

3.3 'Case study' benadering volgens Yin: beoordeling van het onderzoek en de studie . . . . . . . . . . . . . . . . . . . . . . . . 69

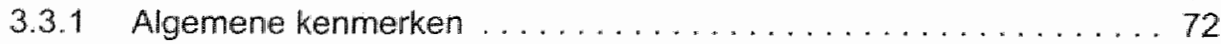

3.3 .2 "Case study design" . . . . . . . . . . . . . . . . . . . 72

3.3.3 Theorie .............................. 74

3.3.4 Voorbereiding van dataverzameling: opstellen van een 'case study' protocol .............................. 74

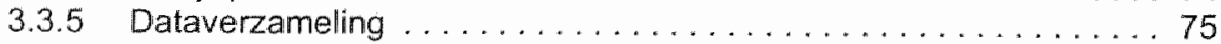

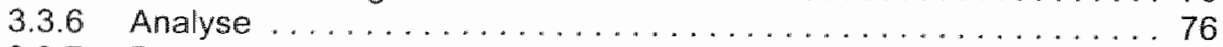

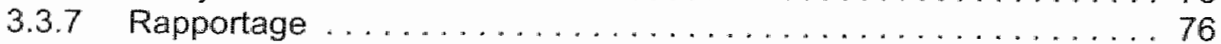

3.3.8 Validiteit en betrouwbaarheid ................. 76

3.3.9 Beoordeling van het uitgevoerde onderzoek en de studie . . . . . . 79

3.4 Dataverzameling gedurende het onderzoek ............... . 79

3.4.1 Methoden en instrumenten voor dataverzameling . . . . . . . . . 80

3.4.2 'Fit' tussen latere concepten en eerder verzamelde data . . . . . . . 81 81

3.4.3 Bruikbaarheid van de verzamelde gegevens voor de studie . . . . . 81

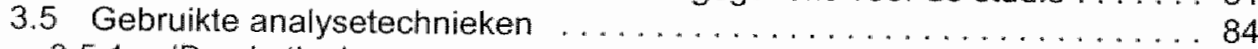

3.5 .1 'Bracketing' . . . . . . . . . . . . . . . . . . . . 86

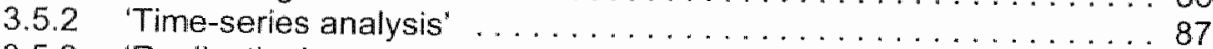

3.5 .3 "Replication' . . . . . . . . . . . . . . . . . . . . . 87

3.6 Nadere toelichting op de uitgevoerde analyses . . . . . . . . . . 95

3.6.1 Wat-vraag: netwerken en veranderingen in structuur, macht en

3.6 .2 Hoe-vraag: veranderingen

3.6.2 Hoe-vraag: veranderingen door handelingen volgens regels, als

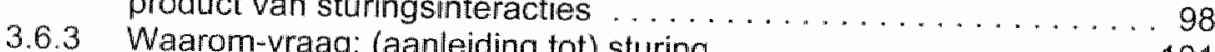

3.7 Slotopmerkingen

4 Houtskoolschetsen: veranderingen in structuur, macht en cultuur ..... 103

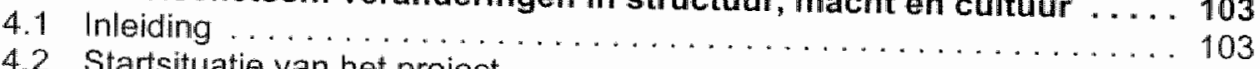

4.2 Startsituatie van het project . . . . . . . . . . . . . . . . . . 104

4.3 Veranderingen in structuur en macht: vervlechting en ontvlechting op het niveau van de projectorganisatie

4.3.1 De eerste configuratie de eenvoudig. . . . . . . . . . . . . . 107

4.3 .2 De tweede configuratio . de hybride structuur . . . . . . . . . . . 116

4.3.3 De derde configuratie: terug naar de eenvatie ............ 117 4.4 Veranderingen in structuur en macht: vervlechting en ontvlechting in de 121

4.4 .1 Eerste model. verve thuiszorg $\ldots \ldots \ldots \ldots \ldots \ldots \ldots \ldots \ldots . \ldots \ldots$

4.4.2 Tweede model: ontvlechting van relaties tussen hulpverleners . . . . 124

4.5 Veranderingen in cultuur: vervlechting en ontvisen hulpverleners ... 130 van de projectorganisatie .

4.5 .1 Situatie in het secundaire proces to . . . . . . . . . . . 132 
4.5.2 Situatie in het secundaire proces tot eind 1992

4.5.3 Beschouwing van vervlechting en ontvlechting in de projectorganisatie: geen cultuurverandering

4.6 Veranderingen in cultuur: vervlechting en ontvlechting in de organisatie van intensieve thuiszorg

4.6.1 Situatie op het secundaire niveau van het primaire proces tot medio 1990

4.6.2 Situatie op het secundaire niveau van het primaire proces tot eind 1992

4.6.3 Beschouwing van vervlechting en ontvlechting in de organisatie van de hulpverlening: wel cultuurverandering

4.7 Slotopmerkingen

5 Eerste verflaag: sturingsinteracties en handelingen volgens regels

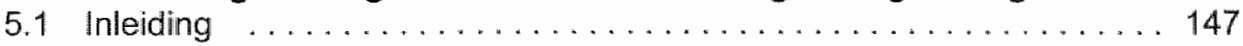

5.2 Sturingsinteracties . . . . . . . . . . . . . . . . . . . 148

5.2.1 Patronen van these, antithese en synthese: vervlechting en ontvlechting in de projectorganisatie

5.2.2 Patronen van these, antithese en synthese: vervlechting en ontvlechting in de organisatie van de hulpverlening

5.2 .3 Bestuurders en bestuurden . . . . . . . . . . . . . . . . . . . . . 160

5.3 Handelen volgens (de betekenis van) projectinterne regels $\ldots \ldots \ldots 162$

5.3.1 Veranderingen door patroonsgewijze handelingen . . . . . . . . 164

5.3.2 Veranderingen door handelingen volgens regels: oprichting en opheffing van netwerken .................... 165

5.3.3 Veranderingen door handelingen volgens regels: handelingen binnen en tussen de eerste en tweede cirkel

5.4 Sturingsinteracties volgens regels $\ldots \ldots \ldots \ldots \ldots \ldots \ldots \ldots \ldots \ldots \ldots$

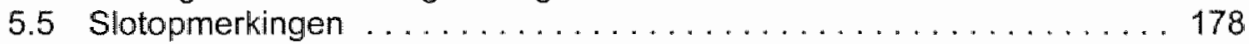

6 Tweede verflaag: sturing en haar aanleiding $\ldots \ldots \ldots \ldots \ldots \ldots \ldots$

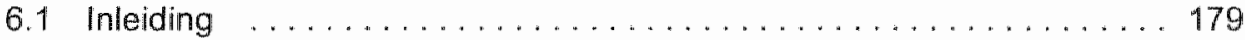

6.2 Algemene aanleiding tot de uitvoering van het project itz ....... 183

6.3 De case van het convergentiecollege ................. 184

6.3.1 Weergave van de gebeurtenissen aan de hand van de concepten

6.3.2 Empirische gegevens over het verloop van de gebeurtenissen ... 186

6.3.3 Reflectie op de gebeurtenissen vanuit de machts- en routinever-

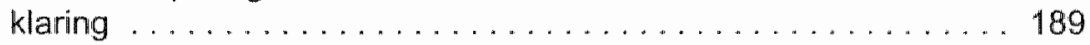

6.4 De case van de stichting itz . . . . . . . . . . . . . . . . 189

6.4.1 Weergave van de gebeurtenissen aan de hand van de concepten

6.4.2 Empirische gegevens over het verloop van de gebeurtenissen ... 192

6.4.3 Reflectie op de gebeurtenissen vanuit de machts- en routineverklaring ................................ 197

6.5 De case van de organisatie van itz aan pg-patiënten . . . . . . . . . 198

6.5.1 Weergave van de gebeurtenissen aan de hand van de concepten

6.5.2 Empirische gegevens over het verloop van de gebeurtenissen 
6.5.3 Reflectie op de gebeurtenissen vanuit de machts- en routineverklaring

6.6 Slotopmerkingen . . . . . . . . . . . . . . . . . . . . 207

7 Het tafereel gevernist en bekeken: conclusies en discussie . . . . . . . . . 209

7.1 Inleiding . . . . . . . . . . . . . . . . . . . . . . . 209

7.2 Sturing van en binnen netwerken ................... 209

7.2 .1 Richting van ontwikkelingen ................... 210

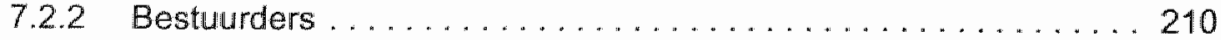

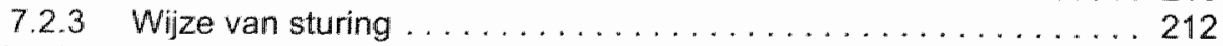

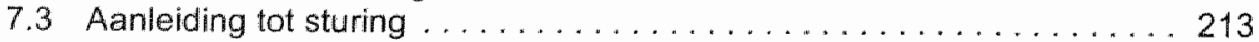

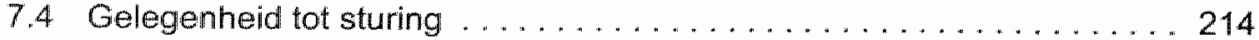

7.4.1 Macht en (de betekenis van) middelen . . . . . . . . . . . 214

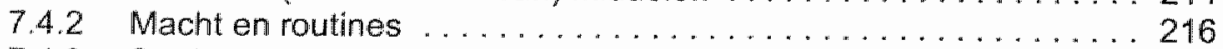

7.4 .3 Sturingsvormen ......................... 216

7.5 Ontwikkelingen van en binnen netwerken .............. 217

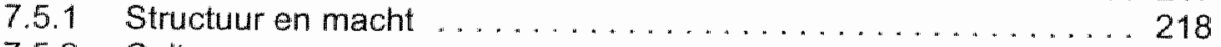

7.5 .2 Cultuur ................................ 219

7.6 Sturing naar beoagde thuiszorg . . . . . . . . . . . . . 220

7.6.1 Kennis van routines en betekenissen als uitgangspunt voor

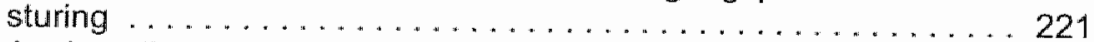

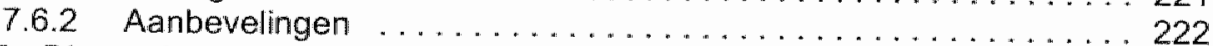

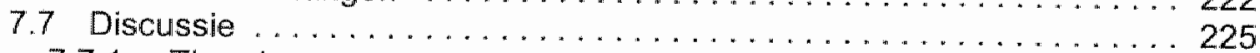

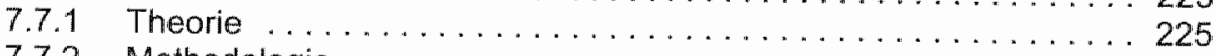

7.7 .2 Methodologie ....................... 228

Zorgvernieuwing: een kwestie van routine. Samenvatting $\ldots \ldots \ldots \ldots \ldots 231$

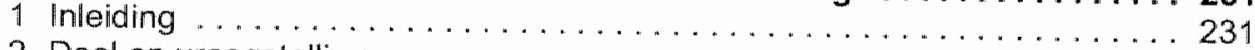

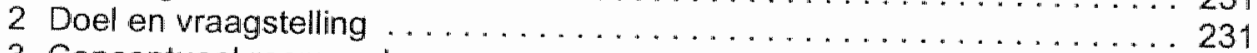

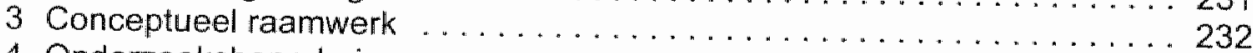

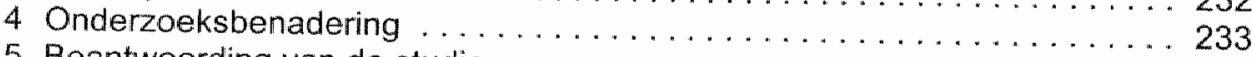

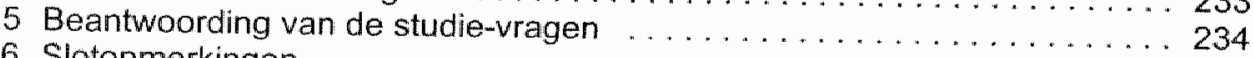

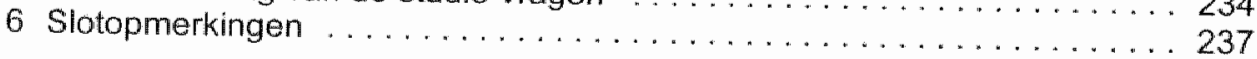

Health care innovation: a matter of routine. Summary ........... 239

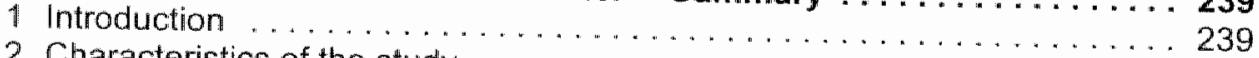

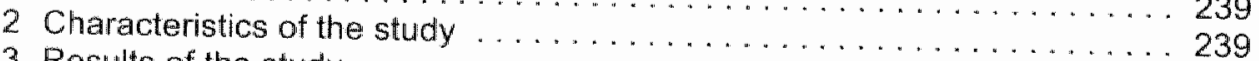

3 Results of the study ............................... 240

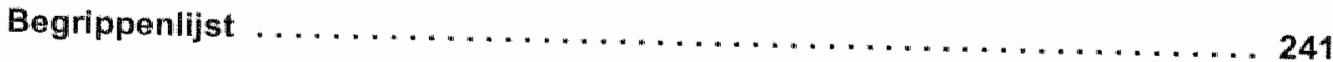

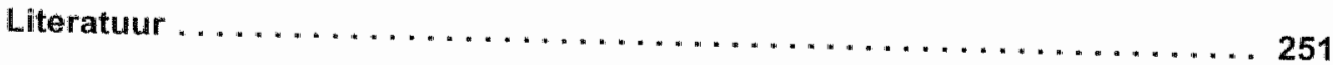

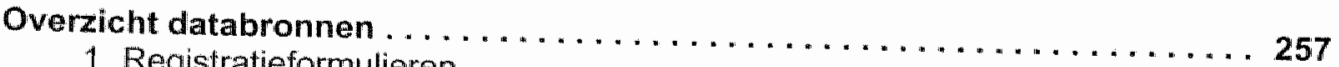

1 Registratieformulieren $\ldots \ldots \ldots \ldots \ldots \ldots \ldots \ldots \ldots \ldots \ldots \ldots \ldots \ldots \ldots \ldots \ldots \ldots \ldots \ldots \ldots \ldots \ldots$
2 Verslagen vraage 257

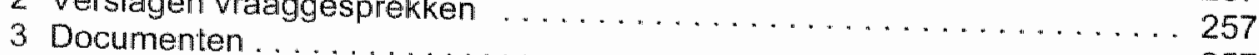


Instrumenten voor dataverzameling . . . . . . . . . . . . . . 267

1 'Themalijst interviews projectleiders, najaar 1990' (selectie) . . . . . . . 267

2 'Vragenlijst interviews projectleiders, najaar 1991 (selectie) . . . . . . . 268

3 'Themalijst interviews projectleiders, najaar 1992 ' (selectie) . . . . . . . 268

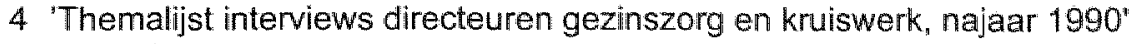
(selectie) . . . . . . . . . . . . . . . . . . . . . . 270

5 'Voortgangsregistratie projecten, najaar 1992 ' (selectie) . . . . . . . . . 272

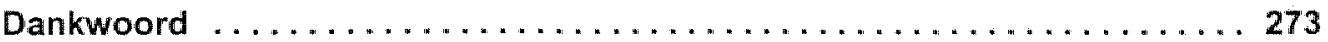

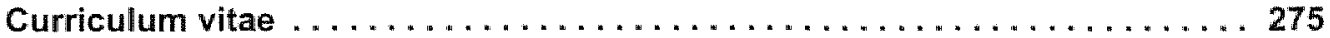





\section{Voorwoord}

In 1989 haalde de Onderzoeksgroep Zorgvernieuwing van de huidige vakgroep Beleid, Economie en Organisatie van de Zorg (BEOZ) van de Universiteit Maastricht haar grootste onderzoeksopdracht binnen sinds haar oprichting aan het einde van de jaren tachtig. Het Ministerie van WVC verzocht de Onderzoeksgroep Zorgvernieuwing een evaluatie-onderzoek uit te voeren naar een van zijn beleidsprogramma's, genaamd het 'Programma Zorgvernieuwingsprojecten Thuiszorg' (1990-1992). Dit Programma omvatte een aantal locale en regionale samenwerkingsinitiatieven, gericht op verandering en verbetering van de thuiszorg ('zorgvernieuwing').

Trots op de verwerving van de opdracht, vastberaden een mooi onderzoek te verrichten, maar tevens beducht voor de valkuilen tijdens de speurtocht naar kennis over zorgvernieuwing, besloot de Onderzoeksgroep haar onderzoeksstrategie zorgvuldig te formuleren. Gekozen werd voor toepassing van principes van de 'case study' benadering volgens Yin (1989).

Dankzij een van deze principes kon dit proefschrift worden geschreven. Kenmerkend voor de genoemde 'case study' benadering is namelijk dat een grote hoeveelheid data wordt verzameld. Omdat wij trouw vasthielden aan de principes van Yin (en bevreesd waren ook maar het kleinste stukje informatie te moeten missen), hadden wij een grote hoeveelheid gegevens verkregen over de projecten in het Programma, die wij onderzochten. Lang niet alle data konden tijdens het onderzoek volledig worden bestudeerd. Veel bleef in de schappen van ons kennismagazijn liggen.

Al aan het begin van onze expeditie in zorgvernieuwingsland was het voor ons duidelijk dat wij de weg kwijt zouden kunnen raken, wanneer onze theoretische blik troebel zou zijn. Door een rondgang te maken langs allerlei disciplines uit de sociale wetenschappen trachtten wij onze blik te verscherpen. Aanvankelijk bleef het gezichtsveld vaag en we maakten tijdens onze expeditie weleens een struikelpartij mee. Maar na enige veranderingen in de theorie werd het zicht beter. Struikelpartijen werden minder frequent en we haalden zonder veel blauwe plekken het eindpunt van onze reis, volgepakt met foto's van zorgvernieuwingsprojecten, schetsen, schilderijtjes en andere souvenirs.

Toen wij tijdens een avondje herinneringen ophaalden aan onze reis, moesten wij lachen bij de gedachte aan de struikelpartijen die we hadden meegemaakt. We zeiden tegen elkaar dat het toch jammer was dat de souvenirs in ons magazijn lagen te verstoffen. Zo werd het idee geboren een tweede reis te maken, maar nu langs de stellingen in ons kennismagazijn. We zouden bovendien niet langer de wijde wereld van de zorgvernieuwing in trekken, maar juist onder het aardoppervlak verdwijnen. We wilden eens goed uitzoeken welke funderingen, spelonken en breuken zich onder dat oppervlak bevonden. Tijdens het evaluatie-onderzoek waren wij daar onvoldoende aan toegekomen. Een van ons zou van deze reis verslag doen in een proefschrift, als er tenminste geld zou zijn om een nieuwe expeditie uit te rusten.

Nadat de financiering eind 1993 rond was, kon de tocht beginnen. We trokken onze stofjas aan, namen de lift naar de kelders van ons kennisinstituut en openden daar de deur van ons magazijn. 



\section{Introductie}

\subsection{Inleiding}

Thuiszorg (zorg in de eigen woon- en leefsituatie van de hulpvrager) is van oudsher een belangrijke sector van de Nederlandse gezondheidszorg. Zij was lange tijd vooral bestemd voor patiënten met 'enkelvoudige' zorgvragen. Dit waren personen die relatief eenvoudige zorg, hulp en medische behandeling nodig hadden en die meestal vanuit één discipline werden geholpen. Deze "traditionele" thuiszorg werd lange tijd vooral verstrekt door instellingen en beroepsbeoefenaren uit de eerstelijn (eerste echelon), met name huisartsen, kruiswerk, gezinsverzorging en maatschappelijk werk. Zij hadden ieder hun eigen, min of meer exclusieve taakdomein.

In de jaren tachtig deden in Nederland nieuwe groepen zorgvragers in de thuiszorg hun intrede: (veelal) oudere patiënten met meervoudige, complexe zorgvragen die voorheen meestal een beroep deden op intramurale voorzieningen. Deze intrede was het gevolg van allerlei ontwikkelingen zoals (dubbele) vergrijzing, reductie van intramurale capaciteit, technologische ontwikkelingen, een toenemende voorkeur van ouderen voor thuiszorg en afnemende mantelzorg (Mur-Veeman en Maarse, 1993; Mur-Veeman et al, 1994).

Zorgaanbieders uit het eerste echelon kwamen tot de conclusie dat hun diensten te zeer waren bestemd voor "traditionele" gebruikers. Voor de nieuwe groepen was de traditionele thuiszorg naar inhoud en organisatie niet toereikend. Zij hadden zorg nodig die vanuit meerdere disciplines gezamenlijk of gelijktijdig werd verleend: 'moderne thuiszorg'. Echter, disciplines waren duidelijk van elkaar gescheiden en functioneerden veelal onafhankelijk van elkaar. Bovendien konden zij tot verschillende echelons behoren. Enerzijds bestond daardoor tussen de verschillende zorgproducten overlap. anderzijds waren er tekorten en hiaten. Verder sloten de inspanningen van de diverse zorgaanbieders niet voldoende op elkaar aan. Fragmentatie overheerste, afstemming liet te wensen over (Van Raak et al, 1993).

Om in de behoeften van de nieuwe zorgvragers te kunnen voorzien, achtten de aanbieders het noodzakelijk zowel het zorgaanbod als de organisatie van de zorgverlening (taakverdeling en afstemming) te veranderen. De bijdragen van de verschillende zorgaanbieders, ieder met eigen deskundigheden en organisatievormen, moesten naadloos op elkaar aansluiten. Voor de verlening van moderne thuiszorg werden door het gehele land samenwerkingsprojecten tussen instellingen en beroepsbeoefenaren opgezet en uitgevoerd. Een aantal daarvan maakte deel uit van het 'Programma Zorgvernieuwingsprojecten Thuiszorg' (1990-1992) van thet Ministerie 
van WVC (hierna "Programma' of 'Programma van WVC' genoemd). Kortweg gesteld is een 'zorgvernieuwingsproject' een samenhangend geheel van handelingen die binnen een begrensde tijd zijn gericht op het creëren van duidelijk gespecificeerde nieuwe én betere organisatievormen ten behoeve van de thuiszorg".

Dit Programma is geevvalueerd door de Onderzoeksgroep Zorgvernieuwing van de vakgroep Beleid, Economie en Organisatie van de Zorg (BEOZ) van de Universiteit Maastricht. Gedurende het evaluatie-onderzoek is over het Programma en zijn onderdelen een grote hoeveeiheid gegevens verzameld. Na afloop van het onderzoek is besloten een deel daarvan diepgaand te bestuderen, ten behoeve van de onderhavige, sociologische studie.

In dit eerste hoofdstuk geven wij de contouren aan van onze studie met behulp van vier kernaspecten die bij wetenschappelijk onderzoek kunnen worden onderscheiden. In par. 1.2 introduceren wij het object van de studie (wat bestudeerden wij?), par. 1.3 bevat de vragen die wij wilden beantwoorden (probleemstelling: wat wilden wij over het studie-object weten?). In par. 1.4 wijden wij een aantal zinnen aan de theoretische en methodologische achtergrond van onze studie naar netwerken en het paradigma waartoe de studie behoort (vanuit welke invalshoek bestudeerden wij het object?) en in par. 1.5 geven wij de weg aan waarlangs wij tot een antwoord op de gestelde vragen zijn gekomen (uitvoering van de studie: welke onderzoeksstrategie volgden wij?). Met uitzondering van de 'probleemstelling' komen de onderzoeksaspecten uitvoerig terug na dit hoofdstuk. Par. 1.6 bevat de opbouw van het verslag van de studie.

\subsection{Doel en object van studie: netwerken in de thuiszorg}

Evenals bij alle andere vormen van zorg het geval is, moet de verlening van thuiszorg worden georglaniseerd. Dit impliceert verdeling van taken en afstemming (coördinatie) van deze taken (Mintzberg, 1983). Wanneer een instelling aanwezig zou zijn die in staat was alle noodzakelijke zorg zelf te bieden, dan zou kunnen worden volstaan met taakverdeling en coördinatie binnen deze ene organisatie. Een dergelijke instelling was gedurende de Programmaperiode echter niet voorhanden: de zorgtaken waren verdeeld over verschillende zorgaanbieders (instellingen en beroepsbeoefenaren). In zo'n geval vereist moderne thuiszorg coördinatie tussen voorzieningen (Hendrix en Van Raak, 1994). Om hun taken op elkaar te kunnen afstemmen moesten deze voorzieningen onderling relaties aangaan: zij moesten een netwerk vormen.

Uitzonderingen daargelaten golden de beschreven omstandigheden anno 1998 nog. In deze omstandigheden is de ontwikikeling van netwerken van zorgaanbiedende instellingen en beroepsbeoefenaren een cruciale voorwaarde voor verlening van moderne thuiszorg. Wetenschappelijke kennis van de ontwikkeling van deze netwerken in de thuiszorg is dan ook relevant, maar is niet altijd voorhanden. Het verwerven van verdere kennis over dit onderwerp is het centrale doel van de onderhavige studie.

Ter verwezenlijking van dit doel hebben wij een theorie opgebouwd, met behulp van veronderstellingen uit de literatuur en van empirische gegevens over netwerken in de thuiszorg. Wij hebben de theorie niet alleen geconstrueerd om de kennis waarover wij reeds beschikten te verdiepen, maar ook om onszelf een basis te verschaffen voor toekomstig onderzoek naar netwerken. In dit opzicht kan de theorie een prototype 
worden genoemd, dat door confrontatie van veronderstellingen met empirische gegevens tijdens de onderhavige studie een eerste maal is beproefd en dat gedurende vervolgonderzoek verder op zijn merites kan worden beoordeeld.

Bestudering van projectgegevens, verzameld in de loop van het Programma van WVC, bood voor de opbouw van de theorie een goed aanknopingspunt. In elk van de projecten uit dit Programma stond de ontwikkeling van netwerken namelijk centraal. In alle projecten zijn ook netwerken tot ontwikkeling gekomen.

Op een aantal van deze netwerken, die werden aangetroffen in de empirie, concentreren wij ons in het navolgende. Zij zijn ons studie-abject. De netwerken die wij hebben bestudeerd, bestonden uit (vertegenwoordigers van) zorgverlenende instellingen en beroepsbeoefenaren bininen de eerste lijn en uit vertegenwoordigers van organisaties die bij de zorgverlening waren betrokken, zoals de zorgverzekeraar. Individuen en verzamelingen van individuen (zoals organisaties en beroepsgroepen) noemen wij 'actoren'.

\subsubsection{Zorgvernieuwingsbeleid van het Ministerie van WVC}

In de periode dat wij het evaluatie-onderzoek uitvoerden naar het Programma van WVC, werd in Nederland reeds op grote schaal geëxperimenteerd met vernieuwingen in de thuiszorg (Tijssen et al, 1991). In het toenmalige beleid van het Ministerie van WVC was veel belangstelling voor zorgvernieuwingsprojecten vanwege de bijdrage die zij wellicht konden leveren aan de verbetering van kwaliteit en doelmatigheid van de zorgverlening (Ministerie van WVC, 1988, 1990a). Dit beleid, zoals vastgelegd in 'Werken aan zorgvernieuwing' (Ministerie van WVC, 1990a), was erop gericht het stelsel van gezondheidszorgvoorzieningen ingrijpend te herzien.

Een belangrijk streven was de verschuiving van aanbodgerichte naar functiegerichte zorgverlening. Niet langer moesten de instellingen die zorg verleenden centraal staan, maar zorgfuncties en de behoeften van hulpvragers. Functionele samenhang, flexibiliteit, kwaliteit, zorg op maat, samenwerking, substitutie en doelmatigheid waren de nieuwe sleutelwoorden in het beleid.

De belangstelling van WVC voor zorgvernieuwingsprojecten (hierna 'projecten' genoemd) betrof niet de locale of regionale betekenis daarvan, maar de landelijke betekenis. WVC zocht naar mogelijkheden om ervaringen met projecten te vertalen in beleid op het llandelijk niveau. Met het oog daarop besloot WVC een aantal locale en regionale projecten gericht te stimuleren en tevens te evalueren. Hiertoe werd het genoemde Programma opgezet. Om beleidsondersteunende informatie te verkrijgen gaf WVC aan de Onderzoeksgroep Zorgvernieuwing de opdracht een evaluatieonderzoek uit te voeren.

\subsubsection{Doelstellingen van het Programma van WVC}

Met het Programma van WVC werd beoogd bij te dragen aan de verbetering van het thuiszorgaanbod als alternatief voor intramurale opname. Thuiszorg werd in het Programma beschouwd als georganiseerde gezondheidszorg en dienstverlening in de eigen woon-en leefsituatie van de hulpvrager, afgestemd op de individuele behoeften van het cliëntsysteem. Het doel van de thuiszorg was mensen, die door gebrek en/of ziekte afhankelijk waren van de hulp van anderen thuis te ondersteunen, verzorgen, verplegen en/of behandelen, tot zij of hun directe omgeving daartoe zelf in staat waren. 
Tevens werd beoogd dat mensen zo lang mageijk in de eigen leefomgeving konden blijven (Ministerie van WVC, 1989).

Overzicht 1.1 Programma van WWC: deelnemende zorgvemieuwingsprojecten en hun doel $(\mathbb{N}=12)$

\begin{tabular}{|c|c|}
\hline Project & Doal \\
\hline $\begin{array}{l}\text { Project "Regionala ontwikkelingen van de } \\
\text { (thisis)zorg Midden Kennemerland" }\end{array}$ & $\begin{array}{l}\text { Verbetering van hel thuiszorgaanbod dat is toegesneden op de zorguraag: } \\
\text { éen regie realiseren woor projecten. }\end{array}$ \\
\hline Project 'Beler Thuis' Hearlem & $\begin{array}{l}\text { Streven naar een samenhangend, gebruikerswriendelijk en doelmatig } \\
\text { aanbod; invoering van éen organisatorisch, inhoudelijk en financieel model } \\
\text { woor thuiszorg in de regio. }\end{array}$ \\
\hline $\begin{array}{l}\text { Project "intensieve Thuiszong Zuld-Kenne- } \\
\text { merland" }\end{array}$ & $\begin{array}{l}\text { Invering van een model voor de verlening wan intensieve thuiszorg met als } \\
\text { uitgangspunt de noden van de palient; ontwikkeling van zorgprotocollen; } \\
\text { convergentie van ontwikkelingem en projecten in de regio. }\end{array}$ \\
\hline 'Protocollenproject' Amsterdam & $\begin{array}{l}\text { Ontwikkeling en beproeving van protocollen, ontwikkeling van methoden } \\
\text { vaor de invoering van protocollen; verzameling van beleidsrelevante } \\
\text { informalie over protocollen. }\end{array}$ \\
\hline Project 'Thuilszorg Amsterdam Zuidoost' & $\begin{array}{l}\text { Realisering van een integraal zorgaanbod; verbetering van samenwerking } \\
\text { tussen aanbieders en wan de samenhang tussen activiteiten; scheppen wan } \\
\text { randvoorwaarden woor de uilwoering van zorg; opbouwen wan regie. }\end{array}$ \\
\hline Project "Kempenzorg": & $\begin{array}{l}\text { Vormgeving van samenwerking lussen aanbieders; bevordering van } \\
\text { continuliteit van zorg; worming van een netwerk van instellingen; verandering } \\
\text { van het indicatiebeleid; oprichting wan een centrale woor thuiszorg. }\end{array}$ \\
\hline Project "Thuiszarg" Brunssum & $\begin{array}{l}\text { Eevorderen dat het meest geëigende echelon hulp verleent; bevordering van } \\
\text { verlening van goede en econornisch werantwoorde zorg; voorkomen van } \\
\text { opnamen en bekorting wan opnamedur; stbostitutie van zorg. }\end{array}$ \\
\hline $\begin{array}{l}\text { Project 'Integraal regionaal' Westelijke } \\
\text { Miignstreek }\end{array}$ & $\begin{array}{l}\text { Beëindiging van verkeerde plaats-problematiek; onderzoek doem naar } \\
\text { mogeilikheden tot ziekenhuis- of verpleeghuisvervangende thuiszorg. }\end{array}$ \\
\hline $\begin{array}{l}\text { Project "Intensieve thuiszorglsamenwarking } \\
\text { ziekenhuis/oerstelin Zaetermeer" }\end{array}$ & $\begin{array}{l}\text { Vorm gewen aan samenhangende zorgwerlening in een passend ecitelon; het } \\
\text { organiseren wan intensieve, goed afgestemde thuiszorg; continuiteil } \\
\text { realiseren tussen thuiszorg en intramurale zorg. }\end{array}$ \\
\hline $\begin{array}{l}\text { Project "Thuiszorg/nazorg' Sint Laurentius } \\
\text { Ziekenhuis Roermond }\end{array}$ & $\begin{array}{l}\text { Vormgeven aan een zorgmodel woor thuiszorg nazorg van de eerste en } \\
\text { tweede lip. }\end{array}$ \\
\hline $\begin{array}{l}\text { Projecl 'Experiment zorgcoördinatie eerste- } \\
\text { tweedelign' Enschede }\end{array}$ & $\begin{array}{l}\text { Ontwikkeling van een zorgcoórdinatie-functie en een lokethunctie voor } \\
\text { informatie-overdracht van eerste- naar tweede lijn; verlening wan betere zorg. }\end{array}$ \\
\hline $\begin{array}{l}\text { Project "Thuiszorg wanuit de tongerschans" } \\
\text { Heerenveen }\end{array}$ & $\begin{array}{l}\text { Creëren van samenhangende zorg, bevordering yan ontslag en voorkomen } \\
\text { van opname; goede zorg bieden tegen lagere kosten; onderzoeken hoe het } \\
\text { ziekenhuis thuiszorg kan bieden. }\end{array}$ \\
\hline
\end{tabular}

In het Programma lag het accent op vormen van thuiszorg die het beschikbare reguhiere aanbod van de eerstelijn te boven gingen. Deze vormen werden aangeduid als 'aanvullende' of 'intensieve' thuiszorg. Zij betroffen patiëntencategorieën met complexe zorgvragen, die moderne thuiszorg nodig hadden. Verschillende instellingen en disciplines moesten bij de zorgverlening zijn betrokken. 
Onder de noemer 'zorgvernieuwing' diende in de projecten het realiseren van zorgcircuits rondom thuiszorg centraal te staan als middel om de afstemming tussen de verschillende aanbieders van zorg te verbeteren. Zorgcircuits zijn netwerken van organisaties en hulpverleners die samenwerkingsrelaties aangaan om een samenhangend zorgaanbod te kunnen leveren. De zorgcircuits moesten de volgende kenmerken hebben:

- Deelnemers aan het zorgcircuit moesten binnen een gemeenschappelijk werkgebied aanspreekbaar zijn op een samenhangend zorgaanbod (dienstverlening, verzorging, verpleging en/of behandeling) in de thuissituatie. Dit zorgaanbod diende te zijn afgestemd op de behoeften van het clientsysteem (zorg op maat).

Binnen het zorgcircuit moesten duidelijke afspraken bestaan over het aandeel van de diverse aanbieders in de zorg en de onderlinge samenwerking. ook met intramurale voorzieningen.

Er moest zoveel mogelijk worden gewerkt met een geintegreerde intake. Indicatie... stellingen voor de verschillende zorgfuncties moesten op elkaar zijn afgestemd.

Het zorgcircuit moest over een coördinatiepunt beschikken dat $7 \times 24$ uur bereikbaar was en dat ervoor kon zorgen dat binmen 24 uur thuiszorg werd gerealiseerd.

Binnen het kader van deze kenmerken gezamenlijk was het de bedoeling dat de projecten verschillende mogelijkheden voor de organisatorische vormgeving van zorgcircuits gingen uitproberen.

\subsubsection{Selectievoorwaarden voor het Programma en samenstelling}

Om in het Programma te kunnen worden opgenomen moesten zorgvernieuwingsprojecten niet alleen zorgcircuits realiseren. Er waren zes algemene bepalingen (Ministerie van WVC.1989):

1 De hulpverlenende instellingen in het werkgebied van het project moesten achter het project staan. Er diende voldoende draagvlak te zijn. Dit moest blijken uit een intentieverklaring die in elk geval door huisartsen, kruiswerk, gezinszorg en ziekenhuizen was ondertekend.

2 Er moest een projectplan zijn met daarin een beschrijving van de volgende onderwerpen: aanleiding tot het project, situatie-analyse, doelstelling en doelgroep, middelen ter realisering van de doelstelling, participanten, activiteitenplan en fasering, beoordelingscriteria voor de projectresultaten.

3 Participerende zorgvertenende instellingen en beroepsgroepen en zorgverzekeraars moesten overeenstemming hebben bereikt over de exploitatiogevolgen van een eventuele uitbreiding van het thuiszorgaanbod.

4 De participanten moesten jaarlijks aan WVC rapport uitbrengen over de voortgang van het project.

5 De participanten moesten medewerking verlenen aan het evaluatie-onderzoek dat door ons werd uitgevoerd.

6 Een 'projectleider' moest ervoor zorgen dat de inspanningen van participanten op eikaar werden afgestemd en dat in hun project voortgang werd geboekt. ledere 
projectleider moest deelnemen aan het 'Overlegorgaan Zorgvernieuwing Thuiszorg' dat in het kader van het Programma diende te worden ingesteld?.

Behalve deze bepalingen, die golden voor alle projecten in het Programma, had WVC de mogelijkheid aan subsidieverlening voonwaarden te verbinden per project afzonderlijk.

Het Programma van WVC, waarin 12 projecten werden opgenomen, ging op 1 januari 1990 van start met een looptijd van drie jaar. De projecten waren verspreid over Nederland. Overzicht 1.1 bevat de projecten en een korte aanduiding van hun doel (Tijssen et al, 1991; Van Raak et al, 1992, 1993).

Elk project werd uitgevoerd door een samenwerkingsverband van instellingen en beroepsbeoefenaren in de gezondheidszorg. Gezamenlijk vormden hun vertegenwoordigers de projectorganisatie die doorgaans bestond uit een of meer netwerken zoals een toporgaan, werkgroepen en een projectbureau (projectleider, secretaresse en/of andere medewerkers). Deelnemende actoren (instellingen $n_{n}$ beroepsgroepen of individuen) noemen wij 'participanten'.

Tabel 1.1 Participerende instellingen en beroepsgroepen bij, aanvang van het Programma naar het aantal projecten $(\mathbb{N}=12)$

\begin{tabular}{|l|c|}
\hline Instellingen en beroepsgroepen & Aantal projecten \\
\hline Eerstelijn & 11 \\
Huisarisen & 12 \\
Kraiswerk & 11 \\
Gezinswerzorging & 7 \\
Maasschappelijk Werk & 5 \\
Anders & \\
\hline Tweecelijn & 9 \\
Ziekenhuis & 5 \\
Verpleeghuis & 4 \\
Verzorgingstehuis & \\
\hline Overig & 2 \\
Patlimlenorganisalie & 4 \\
\hline Zorgverzekeraar & \\
\hline
\end{tabular}

Tabel 1.1 toont de soorten instellingen en beroepsgroepen en het aantal projecten waarin zij bij de start van het Programma van WVC participeerden (Tijssen et al, 1991).

Uit de plannen die de participanten voor de start van het Programma bij WVC hebben ingediend, blijkt dat werd beoogd gedurende de projecten zorg te verlenen aan uiteenlopende doelgroepen. Dezelfde doelgroepen konden in de projectplannen met verschillende bewoordingen zijm aangeduid. Nu eens werd bijvoorbeeld de categorie 'ouderen' in haar geheel als afzonderlijke doelgroep genoemd. Dan weer was een deel van deze categorie ondergebracht bij 'terminale patiënten', 'psychogeriatrische patienten et cetera. Tabel 1.2 bevat de doelgroepen zoals deze in de projectplannen zijn genoemd (Tijssen et al, 1991). 
Tabel 1.2 Doelgroepen projecten bij aanvang wan het Programma naar het aantal projecten $(N=12)$

\begin{tabular}{|c|c|c|c|}
\hline Doelgroepen & $\begin{array}{c}\text { Aantal } \\
\text { projecten }\end{array}$ & Doelgroepen & $\begin{array}{c}\text { Aarital } \\
\text { projecten }\end{array}$ \\
\hline ADL-afhankelike patiënten & 1 & Patienten bij wie mantelzorg wegwalt & I \\
\hline Aidspatiententen & 2 & Patiènten met heupfracturer & 2 \\
\hline Cara-patiënten & 2 & Patiënten met liesbreuk & 1 \\
\hline Catuelerisatie-patiênten & 1 & Pattënten met open been & 2 \\
\hline Chronisch zieken & 3 & Psychiatrische patiënten & 1 \\
\hline CVA-paliênten & 3 & Psychogerialtrische patienten & 6 \\
\hline Diabetes-patiëntem & 2 & Reuma-pafiènten: & 1. \\
\hline Gelhamdicapten & 1 & Revalidatiepatiènien & 2 \\
\hline Geriatrische patiènten & 2 & Somatische verpleeghuispatiènten & 1 \\
\hline Intensieve thuiszorgpatiênten & 3 & Stoma-patiênten & 1 \\
\hline Oncologie-patiènten & 3 & Terminale patiënten & 4 \\
\hline Orthopedie-patienten & 1 & Tractie-patienten & 4 \\
\hline Oudleren & 1 & Zwangeren & 2 \\
\hline
\end{tabular}

De projectdeelnemers streefden ernaar gedurende de zorgverlening aan de doelgroepen met behulp van verschillende instrumenten afstemming teweeg te brengen. In Tabel 1.3 is elk van deze instrumenten ingedeeld bij een van de drie basisvormen van coördinatie die Mintzberg (1983) onderscheidt: onderling overleg. directe supervisie en standaardisatie.

Tabel 1.3 Instrumenten woor afstemming in de zorgverlening bij aanvang van het Programma naar coördinatiemechanisme en het aantal projecten ( $N=12)$

\begin{tabular}{|c|c|c|c|}
\hline Insfrumenten naar coürdinatiemechanisme & $\begin{array}{c}\text { Aantal } \\
\text { projecten }\end{array}$ & Instrumenten maar coürdinaliemechanisme & $\begin{array}{c}\text { Aantal } \\
\text { projecten }\end{array}$ \\
\hline $\begin{array}{l}\text { Onderting overleg } \\
\text { interdisciplinair wijkowerleg } \\
\text { Wikkleams }\end{array}$ & $\begin{array}{l}2 \\
1\end{array}$ & $\begin{array}{l}\text { Standardisatie } \\
\text { Zorgprotocollen } \\
\text { Coördinatlepunt } \\
\text { Zorgplan }\end{array}$ & $\begin{array}{l}9 \\
8 \\
4\end{array}$ \\
\hline $\begin{array}{l}\text { Directe supervisie } \\
\text { Zorgcoördiritor } \\
\text { Caselload-ymanagement } \\
\text { Circuitmanager }\end{array}$ & $\begin{array}{l}3 \\
4 \\
1\end{array}$ & $\begin{array}{l}\text { Geintegreerce indicatiestelling } \\
\text { Centraal meldpun! } \\
\text { Gezamentilke intake } \\
\text { Deskundigheidsbevordering }\end{array}$ & $\begin{array}{l}3 \\
3 \\
2 \\
2 \\
1\end{array}$ \\
\hline
\end{tabular}

\subsubsection{Overheidssteun aan de projecten in het Programma van WVC}

De ondersteuning van de projecten in het kader van het Programma was erop gericht bestaande knelpunten in de thuiszorg op te heffen en nieuwe ontwikkelingen te stimuleren. De ondersteuning door WVC was tweeledig.

Ten eerste verleende WVC gedurende de looptijd wan het Programma subsidie ten behoeve van projectleiding. Kosten die waren verbonden aan de levering van zorg vielen buiten de reikwijdte van deze subsidie. Daarvoor moesten de participanten geldelijke middelen uit andere bronnen trachten te verkrijgen. In totaal stelde WVC op 
jaarbasis twee miljoen gulden beschikbaar voor projectleiding en $f 230.000$ voor het evaluatiemonderzoek.

Ten tweede stelde WVC ter ondersteuning van de projecten twee begeleidingsorganen in (Nivel, 1990): de 'Werkgroep Zorgvernieuwing Thuiszorg (WVC)' en het reeds genoemde 'Overlegorgaan Zorgvernieuwing Thuiszorg'. De werkgroep moest de algehele bewaking van het Programma voor haar rekening nemen. Zij diende onder andere zicht te houden op de voortgang van de projecten en het Programma en te zorgen woor eventuele bijstelling van het Programma (budget, aantal projecten, gekozen projecten). Doel van het overlegorgaan was vooral dat de deelnemers (projectleiders, vertegenwoordigers van WVC en de leden van de Onderzoeksgroep Zorgvernieuwing) elkaar inspireerden en stimuleerden door middel van informatieuitwisseling over ervaringen binnen de projecten.

In de visie van WVC dienden de projecten een demonstratiefunctie voor zorgvernieuwing te vervullen. Met het oog op deze functie besloot WVC dat jaarlijks een 'conferentie zorgvernieuwing thuiszorg' plaats zou vinden. Met de conferenties werd onder andere beoogd de informatie die in de projecten werd geproduceerd te verspreiden naar relevante derden, zoals koepelorganisaties en zorgverzekeraars.

\subsubsection{Doel en functie van het evaluatie-onderzoek}

In aansluiting op de doelstellingen van het Programma van WVC diende het evaluatie-onderzoek (januari 1990 - juli 1993) vooral inzicht te verschaffen in de bijdrage die de 12 projecten konden leveren aan de verbetering van de organisatie van de zorgverlening.

Met het oog daarop moesten de diverse modellen van zorgcircuits die in de projecten werden uitgeprobeerd worden bestudeerd, beschreven, vergeleken en beoordeeld in termen van hun voor-en nadelen, voorwaarden en gevolgen. Met behulp van gegevens over individuele projecten moesten conclusies op projectoverstijgend niveau worden getrokken. Beschrijvingen, vergelijkingen en beoordelingen moesten vervolgens het uitgangspunt zijn voor beleidsadviezen aan WVC. Tevens dienden de ontwikkelingen en praktijkervaringen in de projecten te worden vertaald in voor het veld bruikbare informatie. Daartoe moesten relevante vernieuwingen op het terrein van de thuiszorg worden gesignaleerd die ook elders zouden kunnen worden ingevoerd.

Ten behoeve van het evaluatie-onderzoek werd een begeleidingscommissie ingesteld. Deze had tot taak de voortgang van het onderzoek te bewaken, ondersteuning te bieden aan de onderzoekers (klankbordgroep), mede richting te geven aan de verdere invulling van het onderzoek en de resultaten van het onderzoek te beoordelen. Deze taakstelling liet overigens onverlet dat de onderzoekers publicatievrijheid hadden.

\subsection{Probleemstelling: sturing en netwerkontwikkeling}

Het onderzoek naar het Programma van WVC heeft ons geleerd dat netwerken in de thuiszorg geen statische verschijnselen zijn. Niet alleen een netwerk als geheel kan veranderen, ook binnen het netwerk kunnen zich allerlei ontwikkelingen voordoen. 'Ontwikkeling' betekent hier 'vorming', 'ontstaan'. Ontwikkelingen doen zich voor tijdens processen en kunnen meerdere richtingen uitgaan. Ook kunnen zij van richting 
veranderen. Een proces beschouwen wij als een opeenvolging van handelingen en interacties, gedurende welke bijwoorbeeld een netwerk tot ontwikkeling komt.

De richting van deze ontwikkelingen vormde het centrale punt van aandacht voor onze studie en voor de theorie die wij ontwikkelden. Hoe is (en kan) aan de ontwikkelingen richting (worden) gegeven? Met andere woorden, de probleemstelling van deze studie betreft het vraagstuk van sturing van ontwikkelingen wan/binnen netwerken gedurende processen. Een netwerk is een verzameling actoren en hun relaties. Binnen deze relaties, die wij ook afhankelikheidsrelaties noemen, vinden handelingen en interacties plaats. Interacties ('samenhandeling") zijn een deelverzameling van handelingen. Bij handelingien en interacties kunnen regels worden gebruikt. Tijdens handelingen en interacties kunnen regels tot ontwikkeling komen.

Met het oog op deze probleemstelling hebben wij de volgende algemene vragen geformuleerd: 'Binnen welke context is aan ontwikkeling(en) van/binnen netwerken in de thuiszorg sturing gegeven (deel a), in welke richting(en) hebben netwerken in de thuiszorg zich ontwikkeld (deel b), en hoe kan aan dergelijke ontwikkelingen sturing worden gegeven (deel c)?". Sturing betreft handelingen door actoren om anderen zodanig te beïnvloeden dat zij handelen conform de wensen van de eersten (gebaseerd op Pröpper en Henweijer, 1992).

Deze drie algemene vragen hebben wij vervolgens uiteengelegd en nader gespecificeerd in vijf vragen. Vragen 1, 2 en 3 betreffen deel a van de algemene vraag; vraag 4 betreft deel $b$; vraag 5 betreft deel $c$.

1 Door wie, hoe en in welke richting is aan ontwikkelling(en) van/binnen netwerken van instellingen en beroepsbeoefenaren in de thuiszorg sturing gegeven?

2 Welke omstandigheden (situlatie) hebben aanleiding gegeven tot deze sturing?

3 Welke omstandigheden (situatie) hebben al dan niet gelegenheid geboden tot sturing?

4 Tot welke ontwikkelingen van/binnen de netwerken heeft de sturing geleid?

5 Door wie, hoe en onder welke omstandigheden (in welke context) is het mogelijk zodaning sturing te verrichten, dat zich netwerken ontwikkelen die door een of meerdere actoren beoogde thuilszorg leveren?

Beantwoording van vraag 1 tot en met 4 dient inzichten op te leveren, met behulp waarvan vraag 5 kan worden beantwoord. Beantwoording van de eerste vier vragen staat dus in dienst van beantwoording van de vijfde vraag. In de navolgende toelichting op de vragen worden de belangrijkste verschijnselen in onze studie gepresenteerd, alsmede de begrippen (concepten) waarmee zi] worden aangeduid.

\section{Vraag 1}

Een van de centrale veronderstellingen van deze studie is dat ontwikkelingen wan/binnen netwerken (zlie vraag 4) het product zijn van handelingen door actoren. Handelingen zijn de motor in de ontwikkelingen. Ten behoeve van gebruik tijdens handelingen worden regels ontwikkeld en ingevoerd. Deze regels komen tot stand gedurende sturing. Handhaving of verandering van deze 'handelingsregels' is in onze studie hét object van sturing. Wij kijken niet alleen naar de aard van de regels. Wij laten ook zien in hoeverre de regels die werden ontwikkeld en ingevoerd, bij het handelen werden gebruikt.

Gezlien het bellang van sturing woor hel ontstaan van regels die (wanneer zij bij het handelen worden glebruikt) leiden tot de ontwikkelingen, hebben wij aan deze sturing nader aandacht besteed. Sturing gebeurt door actoren tijdens interacties. 
In de literatuur zijn twee rivaliserende perspectieven op sturing te vinden. Het ene is zichtbaar in modelien waarin wordt uitgegaan van sturing door één actor (rationeleactorperspectief; zie o.a. Klijn en Telsman, 1992). Het andere perspectief komt tot uiting in modellen waarin word verondersteld dat door meer dan één actor fof door alle actoren) wordt gestuurd (interactiebenadering). De bruikbaarheid van deze perspectieven voor de bestudering van het gekozen object hebben wij becommentarieerd. Met de beantwoording van vraag 1 hebben wij voorall nagestreefd die actor (of actoren) te identificeren, door wie aan ontwikkelingen sturing is gegeven. Sturende actoren kunnen zich in netwerken bevinden of daarbuiten. In de vraag wordt onderscheid gemaakt tussen sturing wan ontwikkeling van een netwerk als geheel en sturing van ontwikkelingen binnen een netwerk. Dit onderscheid is mede gemaakt om de aandacht te kunnen richten op de locatie van de sturende actor(en), respectievelijk buiten en binnen het netwerk.

Indien onderzoekers ontwikkelingen van netwerken en ontwikkelingen daarbinnen bestuderen vanuit een interactiebenadering, dienen zij rekening te houden met de mogelijkheid dat de wijze waarop een netwerk zich ontwikkelt niet rechtstreeks te herleiden hoeft te zijn tot de afzonderlijke sturingsactiviteiten van individuele actoren. Sturingspogingen van de ene actor kunnen door anderen worden beantwoord met sturingpogingen, processen kunnen verlopen volgens een patroon van these (stelling), antithese (tegenstelling) en synthese (samengestelde eenheid; Van Dale, 1989).

\section{Vraag 2}

Fundament van elke sociaal-wetenschappelijke studie is een actorperspectief, dat hetzij expliciet, hetzij impliciet wordt verwoord. Het actorperspectief dat wij hanteren komt in het kort op het volgende neer. Wij gaan ervan uit dat actoren situaties percipiëren (waarnemen) en daaraan betekenis geven. Percepties zijn 'betekenisvol". Op basis van die betekenis handelen zij. Ook wordt ervan uitgegaan dat actoren niet zonder reden trachten te handelen. Zij hebben doelen. Een doel beschouwen wij niet als een beoogd eindresultaat van handelingen. Een definitie waarin wordt gesproken over een "eindresultaat" is niet bruikbaar in een studie die handelt over processen. Kenmerkend woor een proces is namelijk dat van een begin- of eindpunt geen sprake is. Handelingen en interacties gaan voort of volgen elkaar op, processen lopen dus door. Een doel als beoogd eindresultaat van een proces is derhalve een contradictio in terminis.

Een doel vatten wij niet op in temen van een 'definitieve afsluiting' van een reeks handelingen, maar juist in termen van 'handelen' zèlf. In deze studie betreft het concept 'doel" de door de actor beoogde handelingspatronen (hiernaar verwijst het begrip 'routine"), alsmede die regels en afhankelijkheidsrelaties met andere actoren (binnen of buiten een netwerk) die deze voor genoemde handelingen wenselijk vindt. Actoren hebben woor het handelen middelen (zoals geld) nodig. De verwerving van middelen is in deze studie eveneens onderdeel van 'doel'.

Onder "omstandigheden" ofwel "situatie" in deze vraag verstaan wij de afhankelijkheidsrelaties van de actor met anderen binnen of buiten een netwerk en handelingen en interacties binnen die relaties. Actoren maken zelf deel uit van de situatie.. Nu eens is de situatie in de waarneming vam de actor gunstig om op de door hem beoogde wijze te handelen, dan weer is zij ongunstig. In het eerste geval ziet de actor aanleiding sturingspogingen te ondernemen om te voorkomen dat de situatie verandert. Tussen de als feitelijk bestaand beschouwde situatie en de gewenste situatie is geen verschil. In het tweede geval daarentegen bestaat verschil tussen de situatie die de actor wenselijk vindt en de situatie die door deze als bestaand wordt beschouwd. Dit verschil 
is voor de actor de aanleiding sturingspogingen te ondememen die zijn gericht op verandering van de ongewenste situatie. Verandering van deze situatie kan zijn doel zijn. Worden deze aanleidingen niet bestudeerd, dan is het onmogelijk sturingsactiviteiten te begrijpen. Aangezien de functie van regels is handelingen te geleiden, vormen regels bij uitstek een onderwerp voor sturing. Sturing gebeurt binnen situaties, situaties veranderen door sturing. Sturen is handelen.

\section{Vraag 3}

Onze veronderstelling is dat sturing plaatsvindt binnen een situatie die niet alleen grenzen stelt aan het handelen, maar daartoe ook mogelijkheden biedt. Inzicht in deze situatie is niet alleen nodig om te kunnen begrijpen wat de aanleiding tot sturing is, maar ook om te kunnen begrijpen of en hoe sturing mogelijk is.

\section{Vraag 4}

Gedurende een proces ontwikkelt zich een netwerk dat kenmerken (een 'aard') heeft. Om de tussentijdse toestand in ontwikkelingen van/binnen netwerken zichtbaar te kunnen maken, moeten de netwerken op meerdere momenten worden getypeerd. Er moeten momentopnamen worden gemaakt gedurende ontwikkelingen. In de literatuur is een aantal typologieën van netwerken te vinden (zie o.a. Godfroij, 1981; Mijs, 1987). Hierin worden typen netwerken aan de hand van enkelle begrippen of dimensies vam elkaar onderscheiden. Op basis van in de empirie aangetroffen overeenkomsten en verschillen tussen netwerken wordt door de ondezoeker bepaald tot welk type een netwerk behoort. Typering van zich ontwikkelende netwerken kan met behulp van tal van begrippen en dimensies gebeuren, zoals samenstelling, aard van de relaties, taakdomein, taakverdeling-coördinatie, geledingen/organen en communicatie. MurVeeman en Tijssen (1992) typeerden netwerken aan de hand van begrippen van Mintzberg (1983). Een aantal van deze begrippen (zoals 'strategische top') gebruiken wij eveneens.

Het begrip "typering" kan de indruk wekken dat een statische beschrijving van een netwerk wordt nagestreefd: een netwerk als eindresultaat van een proces. Wanneer wij een dergelijke beschrijving zouden beogen, dan zouden wij orvoldoende recht doen aan onze uitspraak dat netwerken zich ontwikkelen. Daarom spraken wij bij 'typering' over momentopnamen gedurende ontwikkelingen. Deze momentopnamen zijn nodig om ontwikkelingen zichtbaar te maken. De typering vomt een aanknopingspunt om dynamiek te tonen. Deze dynamiek wordt beschreven met behulp van de concepten 'structuur' (betreft onder andere afhankelijkheidsrelaties), "cultuur' (routines) en "macht" (asymmetrie in afhankelijkheidsrelaties).

\section{Vraag 5}

Wetenschappelijke inzichten dienen door de beantwoording van de eerste vier onderzoeksvragen bij vraag 5 een maatschappelijke functie te krijgen. Zij kunnen een belang dienen dat door verschillende actoren in de samenleving, zoals overheid, zorgaanbieders en vragers wordt gekoesterd: zorgverlening moet adequaat gebeuren. Het begrip 'adequaat' kan op verschillende manieren worden ingevuld, afhankelijk van de vraag wie de belanghebbende is. Zo kunnen zorgvragers zorgverlening adequaat vinden, wanneer de verleende zorg naadloos aansluit bij hun behoeften. Zorgaanbieders kunnen zorgverlening adequaat vinden, wanneer de zorg bijvoorbeeld tegen zo laag mogenlijke kosten wordt geleverd, terwijl de kwaliteit volgens bepaalde criteria toereikend is. 
Door vele actoren binnen de Nederlandse samenleving wordt levering van goede thuiszorg van groot maatschappelijk belang geacht (Mur-Veeman et al, 1994). In veel netwerken wordt geprobeerd dergelijke thuiszorg te verlenen (De Groot en Ketelaars, 1993). In deze studie gaat de aandacht uit naar sturing van ontwikkelingen en niet naar het concrete zorgproduct waartoe de ontwikkelingen ten gevolge van sturing eventueel hebben geleid. De studie richt zich op het organiseren van zorgverlening, in plaats van op de aard van de verleende zorg zèlf. Een evaluatie van effecten in termen van goede of minder goede thuiszorg valt daarmee buiten de kaders van de studie. Voor unformatie over deze effecten wordt werwezen naar de drie rapporten die zijn verschenen over het onderzoek naar het Programma van WVC (Tijssen et al, 1991; Van Raak et al, 1992, 1993).

Wel dient de studie handvaten te bieden aan diegenen die ontwikkelingen van en binnen netwerken zodanig willen sturen, dat thuiszorg kan worden geleverd die naar hün inzicht (niet óns inzicht, want dan zouden wij normatief bezig zijn) goed is. Daarmee wordt wetenschappelijke kennis praktisch toepasbaar gemaakt, met het oog op een hooggewaardeerd maatschappelijk doel.

\subsection{Paradigma, theorie en methodologie}

De theoretische achtergrond van begrippen en dimensies, waarop typologieën in publicaties over interorganisationele netwerken zijn gebaseerd, is niet altijd helder verwoord en het paradigma waarbinnen een onderzoek naar netwerken past blijft meer dan eens implliciet. Theorieën zijn stelsels van uitspraken die dienen om beschrijvingen, voorspellingen en verklaringen van de werkelijkheid mogelijk te maken (Swanborn, 1987).

De keuze voor bepaalde theoretische uitgangspunten is niet vrijblijvend. Zij plaatst het werk van de onderzoeker binnen of buiten het domein van een paradigma. Wij beschouwen een paradigma als een fundamentele voorstelling van het object binnen een wetenschap. Deze voorstelling dient om te bepalen wat bestudeerd behoort te worden, welke vragen moeten worden gesteld, hoe deze moeten worden gesteld en welke regels moeten worden toegepast om verkregen antwoorden te interpreteren. Het paradigma is de meest omvattende eenheid van consensus binnen een gemeenschap welke dient om de ene wetenschappelijke (sub)gemeenschap van de anderen te onderscheiden. Het paradigma brengt de vaorbeelden, theorieën, methoden en technieken onder éen gezichtspunt bij elkaar, definieert deze onderdelen en regelt de betrekkingen ertussen (Ritzer, 1975).

Bij de bestudering van een object is explicitering van het paradigma noodzakelijk. Pas dan wordt duidelijk tot welke wetenschappelijke gemeenschap de onderzoeker behoort. Pas dan wordt het kader zichtbaar, waarbinnen een studie op haar wetenschappelijke kwaliteit kan worden beoordeeld. Het gaat erom dat de onderzoeker in de uitvoering van zijn studie de regels hanteent zoals die binnen de wetenschappelijke gemeenschap waartoe hij zichzelf rekent, algemeen zijn aanvaard (methodologie) en dat hij zich aansluit bij de theoretische opvattingen die door deze gemeenschap worden gehuldigd over empirische verschijnselen en hun relaties. Is het paradigma anders, dan zijn ook de wetenschappelijke gemeenschap en het beoordelingskader
anders.

De formulering van vraag 2,3 en 4 kan enerzijds aanleiding geven tot de interpretatie dat in de studie een "toetsende benadering" is gehanteerd. In onderzoek 
volgens deze benadering wordt de empirische cyclus eenmalig dloorlopen. Zaken zoals de werkwijze, hypothesen, meetinstrumenten en de populatie liggen vast voordat het onderzoek begint. Vooraf geformuleerde voorspellingen kunnen gedurende het onderzoek niet worden bijgesteld (Swanborn, 1987). Anderzijds is de interpretatie mogelijk dat een 'explorerende benadering' is toegepast. Binnen onderzoek volgens deze benadering wordt niet begonnen met scherp geformuleerde hypothesen maar met vage veronderstellingen. De werkwijze en andere zaken worden niet tevoren vastgelegd en de empirische cyclus wordt herhaalde malen doorlopen. Veronderstellingen worden al doende aangepast, net zolang tot een redelijke 'fit' is verkregen ${ }^{3}$. In hoofdstuk 2 en 3 zal duidelijk worden welke benadering in onze studie is toegepast.

Om de wetenschappelijke gemeenschap waartoe wij behoren in staat te stellen onze studie met behulp van de door hen algemeen aanvaarde regels te beoordelen op haar wetenschappelijkheid, gaan wij in onze studie uitvoerig in op het paradigma waarbinnen deze kan worden gepositioneerd. In de literatuur worden verschillende paradigma's onderscheiden (zie o.a. Burrell en Morgan, 1982). Met de door ons gehanteerde theoretische uitgangspunten en de toegepaste methodologie, methoden en technieken plaatsen wij onze studie binnen het functionalistische paradigma (Burrell en Morgan, 1982). Daarbinnen ligt voor ons het primaat bij het interactionisme.

\subsection{Onderzoeksstrategie: uitvoering van de studie}

Ons object hebben wij op verschillende niveaus bestudeerd: het niveau van het individu, de organisatie, het netwerk, omgeving van het netwerk. Uitgangspunt bij de studie was dat gebruik werd gemaakt van de talrijke gegevens die in het kader van het evaluatie-onderzoek naar het Programma van WVC zijn verzameld.

Opdat wij binnen de beschikbare studietijd een zo diepgaand mogelijk inzicht konden verkrijgen, besloten wij onze analyses te beperken tot de gegevens over één project. Zorgvernieuwingsprojecten zijn namelijk zodanig rijk geschakeerd, dat naar elk afzonderlijk project uit het Programma van WVC een jarenlange studie kan worden gedaan. Deze constatering had ons tijdens het evaluatie-onderzoek reeds aangezet tot een taakverdeling. ledere afzonderlijke onderzoeker concentreerde zich op enkele van de twaalf projecten. Bestudering van de andere projecten werd door iedere onderzoeker aan groepsgenoten overgelaten. Door gezamenlijke besprekingen te organiseren en daarvoor stukken te schrijven wisselden de leden projectspecifieke ervaringen uit. Daarna werden conclusies getrokken die het niveau van de individuele projecten overstegen.

Om drie redenen kozen wij uit het Programma van WVC voor het Project Intensieve Thuiszorg Zuid-Kennemerland ('project itz'). In dit project deden zich de verschijnselen voor waarop onze vragen betrekking hebben; wij waren zeer vertrouwd met dit project; van dit project is een wel gevuld archief beschikbaar van projectdocumenten en verslagen van projectintern onderzoek, dat zeer geschikt is voor onze studiedoeleinden.

Een dergelijke exercitie kan ertoe leiden dat de veronderstellingen zodanig worden toegesneden op de bestudeerde empirische verschijnselen, dat zij alleen betrekking hebben op deze, wellicht unieke fenomenen. In zo'n gevall hebben de veronderstellingen geen wetenschappelijke meerwaarde. Op dit onderwerp komen wij nog terug. 
Aangezien de theorie die wij in het kader van deze studie opbouwden een prototype is, is de beperking tot één project geen bezwaar, temeer daar het gekozen project geen uniek geval is. Analyses tijdens het Programma van WVC leerden ons reeds dat verschijnselen die wij aangaande dit project waarnamen, zich ook in andere projecten uit het Programma voordeden (zie Tijssen et al, 1991; Van Raak et al, 1992, 1993). 4

Dataverzameling, analyse, formulering en gebruik van theoretische uitspraken, en hantering van methoden en technieken gebeurden in ons evaluatie-onderzoek naar het Programma van WVC volgens principes van de 'case study' benadering (Y'in, 1989). Samen vormden deze principes (zoals 'explanation building', triangulatie en het opstellen van een 'case study' protocol als scenario woor de studie) onze onderzoeksstrategie. Een aantal van deze principes vormen ook de basis van de studie waarover hier verslag wordt gedaan.

\subsection{Opbouw van het verslag: een tafereel, naar het leven geschilderd}

Onze studie is uitgevoerd op de wijze waarop kunstschilders uit de Gouden Eeuw een levend tafereel naschilderden. Zij begonnen met de preparering van het te beschilderen doek. Een linnen doek werd op een raamwerk gespannen, waarna een grondlaag werd aangebracht. Dit gebeurde door het doek in te smeren met lijm, een plamuurachtige substantie en preparerende verf. Deze grondlaag was nodig, opdat de verf zich aan het doek kon hechten.

Vervolgens werden met houtskool (of andere materialen) ruwe figuren op het doek geschetst, weer weggeveegd, opnieuw getekend en zolang bijgeschaafd, totdat de hooflijnen van het uiteindelijke schilderij zichtbaar werden. Ook werden de te gebruiken penselen gekozen en werd de verf aangemaakt, gemengd en op een palet aangebracht.

Daarna werd het doek een eerste maal beschilderd met behulp van grote vlakken verf. Zodra deze eerste verflaag (de onderschildering) gereed was kon streek na streek, laag na laag de verfiining van het tafereel beginnen. Contouren van figuren werden duidelijker gemaakt, nuances in kleuren werden aangebracht, details werden toegevoegd. Dit proces leverde lang niet altijd meteen een compositie op die de kunstenaar naar de zin was. Vaak werden hele vlakken overgeschilderd, zelfs wanneer de figuren ongeveer klaar waren. Soms gebeurde dit verscheidene malen, totdat de compositie het evenwicht, de variatie en de levendigheid had waarmee de kunstenaar tevreden was.

Uiteindelijk werd een beschermende vernislaag aangebracht, die het tafereel glans gaf, en was het schilderij klaar (Goris, 1986).

In hoofdlstuk 2 gaan wij in op de theorie van deze studie en het paradigma waarbinnen de studie past. Wij prepareren daarin het doek voor het tafereel dat wij willen schilderen door het op een conceptueel raamwerk te spannen en met behulp van

Ook in het "Project Wijkzorg voor Ouderen en Gehandicapten in Maastricht", dat wij na afloop van het Programma vain WVC onderzochten en dat met dit Programma niels te maken had, namen wij gelijkaardige werschijnselen waar. Evenals bij het project itz ging het hier om een interorganisatio-

neel samenwerkingsproject, waarmee verbetering van de zorgverlening werd beoogd (zie Van
Raak en Mur-Veeman, 1994, 1995 en 1997). 
theoretische inzichten van een grondlaag te voorzien. Daarop moet het schilderwerk zich gaan hechten. In hoofdstuk 3 (methodologie) pakken wij het palet van concepten en hun onderdelen op. Met een beschrijving van de methoden en instrumenten voor dataverzameling en van verzamelde gegevens selecteren wij de penselen en maken wij de verf klaar. In hoofdstuk 4 tot en met 7 presenteren wij een uitgebreid beeld van ons studie-object. Hoofdstuk 4 bevat de houtskoolschetsen, hoofdstuk 5 en 6 het schilderwerk. In hoofdstuk 7 wordt het schilderij vernist. Daarin blikken wij terug op onze ervaringen, opgedaan tijdens de studie en beantwoorden wij de vragen die wij op basis wan de probleemstelling hebben geformuleerd.

Hoofdstuk 7 wordt gevolgd door een samenvatting, begrippenlijst, literatuurlijst, overzicht van databronnen, instrumenten voor dataverzameling. Om de anonimiteit van actoren in zekere mate te kunnen waarborgen worden vertegenwoordigers van instellingen die in de hoofdstukken ter sprake komen aangeduid met de naam van hun voorziening (zoals gezinszorg en kruiswerk). 



\section{Preparering van het doek: para- digma en theorie}

\subsection{Inleiding}

De netwerken waarover wij spreken, zijn veranderlijke sociale verschijnselen die binnen meerdere paradigma's kunnen worden bestudeerd. Wij bewegen ons binnen het functionalistisch paradigma (Burrell en Morgan, 1982)5, waarin voor onze studie het primaat ligt bij het interactionisme.

In de definitie van 'paradigma' in par. 1.4 komen twee centrale bestanddelen naar voren: theorie en methodologie. In dit hoofdstuk wordt van ons paradigma het eerste bestanddeel besproken. Wij bouwen gaandeweg een theorie op. Aldus wordt het doek geprepareerd, waarop wij uiteindelijk het tafereel schilderen. Het tweede bestanddeel de methodologie, komt in hoofdstuk 3 aan bod.

De bouw van de theorie is tot stand gekomen volgens de explorerende benadering en niet volgens de toetsende benadering (zie par. 1.4). Dit bijkt bijvoorbeeld uit het feit dat het stelsel van uitspraken dat wij aanstonds presenteren, niet is opgesteld voordat de data werden verzameld en geanalyseerd. Zoals in hoofdstuk 3 wordt beschreven zijn wij begonnen met een aantal globale concepten (begrippen) en veronderstellingen over de relaties tussen verschijnselen, die werden aangescherpt en geherformuleerd terwijl wij de empirische cyclus enkele malen doorliepen. Datgene wat in dit hoofdstuk wordt gepresenteerd is het uiteindelijke resultaat van voornoemde werkwijze, die leidde tot een "fit" tussen theorie en empirie. Het gaandeweg tot stand komen van de 'fit' wordt hier niet beschreven. Uit het feit dat het theoretisch hoofdstuk voorafgaat aan de empirische hoofdstukken mag niet worden geconcludeerd dat onze veronderstellingen in latere hoofdstukken worden getoetst. Gezien de toegepaste, explorerende benadering zou dit onlogisch zijn.

Voor onze theorie hebben wij inzichten gebruikt uit meerdere functionalistische benaderingen, die behaive overeenkomsten ook verschillen kennen. In par. 2.2 betogen wij dat deze inzichten verenigbaar zijn, mede ten gevolge van ontwikkellingen

Burrell en Morgan zijn niet de enigen die hebben geschreven over paradigma's. Ook auteurs zoals Ritzer (1975) en -vooral- Kuhn (1970) deden dit. Van het begrip 'paradigma' zijn uiteeniopende omschrijvingen in omloop, indelingen van wetenschappelijke stromingen bij paradigma's verschillen. Hantering wan een andere omschrijwing en indeling kan leiden tot een andere beoordelingsmaatstal voor wetenschappelijk anderzoek. 
binnen de benaderingen zelf. Daarna wordt fasegewijs de theorie opgebouwd. In par. 2.3 komt de selectie van verschijnselen aan de orde, die wij met behulp van een aantal concepten hebben bestudeerd. In par. 2.4 beschrijven wij in het kort het dynamisch samenspel van de door de concepten aangeduide verschijnselen. Dit samenspel, dat wij met behulp van een conceptueel raamwerk weergeven, staat centraal bij onze bestudering van netwerken. Par. 2.5 en 2.6 bevatten achtereenvolgens een verdere beschrijving van de concepten en hun relaties uit het raamwerk. Aldus krijgt de theorie haar uiteindelijke inhoud. In par. 2.7 maken wij een aantal slotopmerkingen.

\subsection{Paradigma en verenigbaarheid van inzichten uit functionalistische benaderingen}

Voordat wij de theorie bespreken, is het van belang in te gaan op het paradigma waarbinnen zij thuishoort: het functionalisme. Aldus wordt duidelijk binnen welke wetenschappelijke richting onze studie kan worden gepositioneerd.

Het functionalistisch paradigma omvat meerdere benaderingen (Burrell en Morgan, 1982). Wij gebruiken kennis uit de volgende: 'social system theory' (resource dependence benaderingen, structureel functionalisme en systeem-theorie ${ }^{6}$ ) en het interactionisme (vooral het symbolisch interactionisme volgens Blumer).

In de navolgende discussie laten wij zien dat inzichten uit de genoemde benaderingen inmiddels vermengd zijn geraakt. Daardoor doet een eventuele uitspraak dat zij onverenigbaar zijn, er niet langer toe. Vermenging vindt plaats, dus vereniging is mogelijk. Verder betogen wij dat benutting op "interactionistische wijze" van inzichten uit de diverse benaderingen bevorderlijk is voor de kennis van de door ons bestudeerde verschijnselen. De grondslag van onze studie is derhalve een interactionistische.

Voorafgaand aan de discussie beschrijven wij in het kort het functionalistisch paradigma en de genoemde benadieringen.

\subsubsection{Functionalisme: sociall system theory en interactionisme}

Het functionalistische paradigma wordt gekenmerkt door 'a concern for providing explanations of the status quo, social order, consensus, social integration, solidarity, need satisfaction and actuality (...). In its overall approach it seeks to provide essentially rational explanations of social affairs" (Burrell en Morgan, 1982).

In resource dependence benaderingen wordt verondersteld dat de vorm van een organisatie (door Keuning en Eppink (1993) een doelrealiserend samenwerkingsverband genoemd) het resultaat is van aampassing aan de eisen die de omgeving stelt. Anderzijds oefent een organisatie vormende krachten uit op haar omgeving. Organisatie en omgeving krijgen in wisselwerking vorm. Een impuls bimnen deze beide

De twee laatstgenoemde benaderingen worden door Burrell en Morgan (1982) beschouwd als behorend tot het genoemde paradigma. Resource dependence benaderingen noemen zij niet. Ons baserend op publicaties wan Astley en wan de Ven (1983). Aldrich en Pfeffer (1976). Yuchtman en Seashore (1967) concluderen wij dat ook deze benaderingen onder "social system theory" kunnen worden geschaard. Zo gaat het bij resource dependence benaderingen om de wijze waarop organisaties als systemen omgaan met hun omgeving. Ter illustratie wijzen wij erop dat de titel van de aangehaalde publicatie van Yuchtman en Seashore 'A systern resource approach to 
vormgevingsprocessen is het streven van actoien de middelen (zoals geld, personeel, klanten en informatie) te verkrijgen die nodig zijn om de eigen activiteiten te kunnen uitwoeren (Aldrich en Pfeffer, 1976; Mindlin en Aldrich, 1975; Aldrich en Mindilin, 1978; Yuchtman en Seashore, 1967).

In de literatuur, behorend tot het structureel functionalisme en de systeemtheorie werd gedrag binnen bijwoorbeeld organisaties lange tijd voomamelijk gezien als het resultaat van de werking van een aantal mechanismen die optreden als externe beperkingen van het handelen door actoren (zie Astley en Van de Ven, 1983).

In het interactionisme tenslotte, een verzameling benaderingen waatoe onder andere het symbolisch interactionisme volgens Blumer wordt gerekend (zie Fine, 19907), gaat de aandacht uit naar de mens als actief handelende actor, die via interacties ('samenhandeling') vorm geeft aan zijn omgeving. 'Interactie' is een kernbegrip in het interactionisme en betreft een deelverzameling van handelingen.

De wartels van het functionalisme bevinden zich in het positivisme. Burrell en Morgan (1982) stellen dat het structureel functionalisme en de systeemtheorie het duidelijkst hun positivistische wortels laten zien: bij de studie van sociale verschijnselen wordt gebruik gemaakt van biologische en mechanische analogieën. Zij zijn relatief objectivistisch. Binnen het interactionisme worden elementen van positivisme en idealisme gecombineerd, hetgeen leidt tot een relatief subjectivistische positie binnen het paradigma.

\subsubsection{Vereniging van inzichten en primaat van het interactionisme}

Volgens Burrell en Morgan bestaan binnen het functionalistisch paradigma weliswaar verschil tussen bijwoorbeeld systeemtheorie en interactionisme, maar zij beschouwen dit als een gradueel verschil. 'Theorists located in the functionalist paradigm are linked by a shared view of the fundamental nature of the socio-scientific reality to which their work is addressed. They are committed to a view of the social world which regards society ontologically prior to man and seek to place man and his activities within that wider social context" (Burrell en Morgan, 1982).

Deze "shared view" heeft representanten van functionalistische benaderingen en nilet van weerhouden over en weer kritiek te uiten op elkaars werk. Door Blumer, die aan hel gedachtengoed van een van de grondleggers van het interactionisme -Meadeen methodologische uitwerking heeft gegeven, is vooral kritiek geleverd op het structureel functionalisme. Verklaringen van het handelen door actoren als verooraakt door bijvoorbeeld rollen en posities zijn volgens hem ontoereikend, omdat intermedierende processen van interpretatie en betekenisgeving worden genegeerd. Interpretatie is een proces gedurende welke betekenissen worden gebruikt en herzien als instrumenten voor de gleleiding en vormgeving van handelen. Betekenisgeving is onderdeel van interpretatie.

Hoewel interactionisten concepten zoals rol wel degelijk gebruiken ("role making" is een belangrijk begrip binnen het interactionisme) en zij bijvoorbeeld niet ontkennen

De namen 'interactionisme' en 'symbolisch interactionisme' worden in de literatuur nogal eens door elkarar gebruikl. Het "symbolisch interactionisme' mag niet worden beschouwd als een homogene stroming binnen het interactionisme. Fine (1990, 1993) en Meltzer et al (1975) Iaten zlen dat van homogeniteit geen sprake is. Om die reden prefereren wil de algemene naam 'interactionisme'. Niettemin ontkomen ook wil niet aan het gebruik wan beide namen, doordal die aangehaalde auteurs nu eens spreken over "interactionisme' en dan weer over 'symbolisch interaclionisme'. 
dat mensen tijdens interacties regels kunnen volgen of dat van aihankelijkheid sprake kan zijn (Blumer, 1969), bestuderen zij de verschijnselen die door deze concepten worden aangeduid op een andere manier dan de representanten van de door Blumer bekritiseerde benaderingen. Het gaat bij interactionisten niet om de verschijnselen zelf, maar om hun betekenis voor de actor, die in interactie treedt met anderen. De actor neemit niet een verschijnsel tot uilgangspunt voor zijn handelingen, maar de betekenis die het voor hem neeft.

Kritiek op het interactionisme behelsde vooral dat in deze benadering onvoldoende aandacht zou bestaan voor het belang van sociale organisatie en de sociale structuur waarbinnen de handelende actor zich bevindt. Ook al wijzen inventarisaties van interactionistische studies erop dat dit gebrek aan aandacht in de praktijk zichtbaar is geweest, dan nog betekent dit volgens Meltzer et al (1975) niet dat het symbolisch interactionisme onvermogend zou zijn sociale structuren adequaat te behandelen. Volgens Maines (1977) sluit het interactionisme bestudering van verschijnselen zoals instituties en machtsstructuren niet uit: 'there is nothing inherent in the perspective that precludes the analysis of sacial organization and social structure'. Evenmin heeft het ooit sociale structuren volledig genegeerd. Ook Blumer onderkent volgens Maines (1977) 'the presence and functioning of social organizational mechanisms that transcend individuals and have a constraining impact on human conduct'. Maines voegt eraan toe dat 'Blumer's message should not be lost, however, because these very' constraining processes are composed of and expressed through interacting individuals'. Kortom, de mechanismen (en krachten; zie Mintzberg. 1991) waarvan sprake is in 'social system theory', zijin mensenwerk (zie ook par. 2.3).

Fine (1993) gaat een stap verder. Interactionisten kúnnen niet alleen de context waarbinnen worden gehandeld in hun analyses betrekken, zij móeten dat ook doen: 'Because interaction is set within institutions and responds to obdurate reality, an adequate interactionist analysis must take structure into account'. Meltzer et al (1975) en Maines (1977) noemen een aantal studies waarin dit gebeurt. Aldus illustreren zij de ontwikkeling die het interactionisme heeft doorgemaakt.

Voor onze studie betekenen de weergegeven uitspraken dat 'actor' en verschijnselen zoals "organisatie" in onze analyses niet alleen goed samen kúnnen gaan, maar ook samen díenen te gaan. In par. 2.3 en volgende zijn wij conform deze conclusie te werk gegaan. Het samenspel van verschijnselen dat wij nog beschrijven, past goed bij de visie van de hier genoemde interactionisten ${ }^{8}$.

De vereniging van benaderingen in het functionalistisch paradigma is niet van recente datum. Sedert de eerste decennia van deze eeuw hebben in het functionalisme processen plaatsgevonden van vermenging van elementen uit verschillende sociologische stromingen. Inmiddels is de vermenging in allerlei studies zichtbaar. Zo zijn elementen van het idealisme uit het werk van Simmel opgenomen, waardoor in functionalistische theorieën een minder objectivistische en meer subjectivistische oriëntatie kan worden bespeurd. Invloeden vanuit het marxisme komen tot uiting in aandacht voor conflict en verandering in functionalistische studies (Burrell en Morgan, 1982).

De gecombineerde aandacht voor de actor en bijwoorbeeld sociale structuren kent niet alleen bij het interactionisme een aantal voorstanders. Ook in de cybernetische, open-systeembenadering volgens Baumgartner, Devilie en Burns (Geyer en Van der Zouwen, 1978; Burns en Flam, 1987; zie ook Scott, 1992) is een voorkeur voor deze combinatie zichtbaar. Veelzeggend in dit verband is de titel die Geyer en Van der Zouwen aan hun publicatie uit 1978 hebben gegeven: 'Sociocybernetics
vol. 1, An actor-oriented social systems approach'. 
Ook Fine (1993) en Hall (1987a) noemen een aantal voorbeelden. Richten wij ons op de vermenging binnen het interactionisme, dan zegt Fine (1993) daarover het volgende. 'Once interactionism may have had a partially deserved reputation as parochial and in-bred, but this is no longer deserved. In its post-Blumerian age, interactionism might be called intellectually promiscuous. Contemporary "interactionists" blend their interest in "classical" interactionism (micro-sociological, nonstatistical, robustly relativistic, and proudly anti-positivistic) with virtually all sociological traditions. As a result interactionists have integrated a Blumerian approach with theoretical approaches linked to Durkheim, Simmel, Weber, Freud, Habermas, Baudrillard, Wittgenstein, Marx, Schutz, phenomenology, post-modern theory, feminism, semiotics, and behaviorism'. Tevens noemt Fine voorbeelden van pogingen het interactionisme te verbinden aan Parsoniaanse theorie.

Fine (1993) acht deze praktijk in het geheel niet bezwaarlijk: "While these attempts at outreach may fragment coherence, a pragmatic approach ${ }^{9}$ should find such linkage bracing; after all, one should use the most productive tools'.

\section{Symbolisch interactionisme}

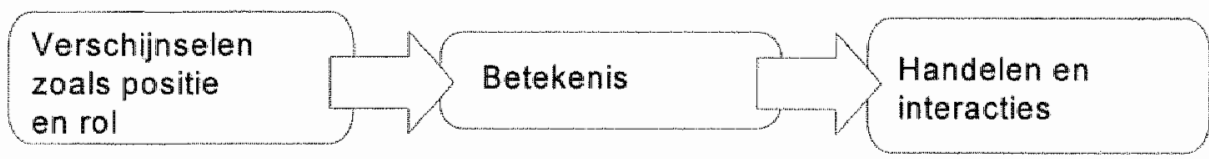

Structureel functionalisme

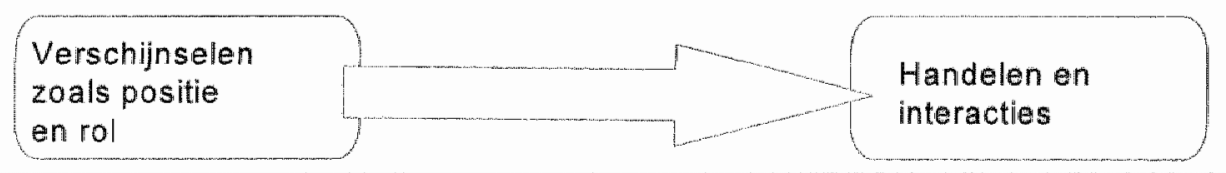

Fig. 2.1 Rol van verschijnselen bij handelingen en interacties: verschil volgens Blumer (1969) tussen het symbolisch interactionisme en benaderingen zoals het structureel functionalisme

Belangrijk voor onze discussie tenslotte is de vermenging op het niveau van de concepten. Hall (1987a) laat zien dat begrippen die binnen 'social system theory'benaderingen worden gebruikt (zoals asymmetrische relaties, afhankelijkheid van middelen, verdeling van middelen, waarden, doelen, regels, rolverwachtingen, relaties, gezagshiërarchieën, hiërarchische posities, interorganisationele relaties en sociale orde) ook in interactionistische studies te vinden zijn. Als voorbeelden noemt de auteur Becker's 'Art worlds' (1982); Faulkner's 'Music on demand' (1983). Wiener's 'The politic of alcoholism' (1981) en Strauss' 'Negotiation' (1978). 
Het fundamentele verschil tussen het interactionisme en de andere genoemde functionalistische benaderingen betreft naar ons inzicht noch de bestudeerde verschijnselen, noch de begrippen die ter aanduiding van deze verschijnselen worden gebruikt (ook al worden binnen de benaderingen naast dezelfdle begrippen ook verschillende begrippen gehanteerd). Integendeel. Ook volgens Blumer bestaan rollen, organisaties, normen, waarden, verhoudingen tussen instellingen, autoriteitsordeningen en dergelijke. Hij noemt ze bovendien belangrijk. Echter, voor de verklaring van handelingen moet naar de betékenis (zie par. 2.5) van de verschijnselen voor de actor worden gekeken (Fig. 2.1). Het was de aandacht voor het belang van betekenisgeving die volgens Blumer het interactionisme onderscheidde van bijvoorbeeld het structureel funictionalisme.

Het besef dat aandacht voor betekenissen noodzakelijk is, is inmiddels ook in een aantal systeemtheoretische studies doorgebroken. Burns en Flam (1987) besteden ruimschoots aandacht aan interpretatieprocessen. Binnen de resource dependence benaderingen stellen Aldrich en Pfeffer (1976) dat handelingen van managers van organisaties niet zijn gebaseerd op de werkelijkheid zelf, maar op hun perceptiesio (waarnemingen) van de werkelijkheid. De rol van deze percepties moet volgens hen worden benadrukt.

Het structureel functionalisme in de vorm die Blumer beschreef tenslotte is inmiddels een benadering geworden waarvoor de belangstelling is getaand. Wij hebben de benadering in deze paragraaf genoemd, amdat zij in de geschiedenis van bestudering van de anderhavige verschijnselen een belangrijke plaats heeft ingenomen. Begrippen die ook in onze studie worden gebruikt, zijn mede in het structureel functionalisime geworteld.

Onze conclusie is als volgt. Wij achten het legitiem 'op een interactionistische manier' gebruik te maken van concepten die binnen "social system theory'-benaderingen een vertrouwde plaats hebben en deze aan te vullen met interactionistische begrippen zoals 'interactie'. Door tussen het handelen van actoren en de verschijnselen die met concepten uit andere benaderingen worden aangeduid 'betekenissen voor de actor' te plaatsen, ontstaat meer inzicht. Het is deze werkwijze die wij in deze studie hebben gevolgd. Aldus trekken wij de lijn (de combinatie van inzichten uit het interactionisme en 'social system theory'), waarvan de aanzetten zichtbaar zijn in een aantal hier genoemde studies, nadrukkelijk door.

De beschreven wijze is éen mogelijkheid om op een 'interactionistische manier' om te gaan met concepten. Een tweede manier verwijst naar het onderscheid tussen 'sensitizing concepts' en 'definitive concepts', waarover wij in hoofdstuk 3 spreken.

Aldrich en Pfeffer komen tot de verwoorde uitspraak naar aanieiding van het argument van Child (197.2) dat personen binmen een organisatie omgevingskenmerken percipiëren en evalueren. verwolgens stellen zij dat verschillende mensen dezelfde kemmerken verschillend kumnen percilpiëren. De auteurs verwachten niet dat deze percepties binnen een organisatie volledig persoonsgebonden zullen zijn, vanwege de invloed van sociale processen. "While it"s true that actions are based on managerial perceptions of reality, and that Child (1972) is correct in stressing the role of perceptions, it is also the case that such perceptions are not likely to be completely idiosyncratic to a particular organization. A variety of social processes combine to induce a common perception of the environment within a subpopulation of organizations' (Aldrich en Pfeffer, 1976). Deze uitspraken laten zlen dat de visie van Aldrich en Pfeffer gelijkenis vertoont met de visie wan interactionisten. Hetzelfde kan overigens worden gezegd voor Burns en Flam. 


\subsection{Eerste opbouwfase van de theorie: selectie van verschijnselen}

De verschijnselen die wij voor bestudering hebben geselecteerd, duiden wij in onze theorie aan met behulp van concepten. Wij beginnen de bespreking in deze paragraaf met 'netwerk'. 'Netwerk' is het centrale verschijnsel in de onderhavige studie. Daarna wordt de selectie van de verschijnselen stap voor stap weergegeven.

Wij beschouwen een netwerk als een verzameling van actoren die onderling relaties hebben en daarbinnen handlelen. Een verzameling van netwerken kan ook een netwerk zijn. De netwerken die samen het project itz hebben uitgevoerd, vormden een dergelijke verzameling. Handelingen (waartoe interacties behoren) kunnen patroonsgewijs verlopen of incidenten zijn.

Actoren zijn individuen en verzamelingen van individuen zoals organisaties en beroepsgroepen. Onze definitie van netwerken vertoont gelijkenis met de interactionistische definitie van Hall (1987a). Volgens Hall is een netwerk 'the set of linkages, representing transactions and relationships, between the actors of a population'11. Auteurs zoals Dietz (1996) zouden een dergelijke verzameling een 'systeem' noemen. Wij nemen het concept 'systeem' over, ondanks de bezwaren die Blumer (1969) heeft geuit. Het grootste bezwaar van Biumer komt op het volgende neer. Volgens hem wordt in sociologische benaderingen zoals het structurele functionalisme de samenleving beschouwd als een systeem dat is opgebouwd uit posities en rollen. Dit systeem wordt beheerst door de werking van onpersoonlijke controlemechanismen die zijn gericht op de handhaving van een evenwichtssituatie. De individuele actor en diens handelen worden in dergelijke benaderingen ondergeschikt gemaakt aan en in dienst gesteld van het systeem. De actor is slechts het medium waarlangs de krachten of mechanismen van het systeem zich uitdrukken. Om te verklaren wat gaande is, kijken onderzoekers naar dergelijke krachten en mechanismen.

Blumer vindt zulke benaderingen statisch, terwijl juist het veranderlijke en dynamische alle aandacht verdient. Oolk wijst hij reificatie als gevolg van het primaat van het systeem boven de actor, af. Volgens hem moet bij verklaring van verschijnselen de belangstelling niet uitgaan naar genoemde krachten of mechanismen, noch naar actoren die in hun dagelijks leven bezig zouden zijn tegemoet te komen aan de vereisten van een systeem. De aandacht moet gericht zijn op de manier waarop deze actoren situaties definiëren en ermee omgaan. Verschijnselen zoals organisaties moeten worden bestudeerd als arrangementen van mensen die met elkaar zijn verbonden door middel van hun handelingen. Mensen bevinden zich op verschillende punten in het arrangement en worden daar geconfronteerd met handelingen van anderen. Bij hun eigen handelen moeten zij met deze handelingen rekening houden. Dit kan er bijvoorbeeld toe leiden dat voorgenomen handelingen worden afgebroken of een andere richting krijgen. In hun interacties met anderen geven mensen worm aan het arrangement.

Wij zijn het tot op zekere hoogte met Blumer eens. Relevant is dat in studies van netwerken als systemen de plaats van de actor niet van ondergeschikt belang dient te zijn. Wij wijzen er met nadruk op dat zonder actoren zulke systemen niet bestaan. Bovendien vinden wij het niet zinvol systemen als statische verschijnselen te zien.

11 De definitie kan de indruk wekken dat een netwerk alleen bestaat uit de onderlinge relaties tussen actoren en dat actoren niet tot het netwerk behoren. Deze indruk zou echter niet consistent zijn met de uitgangspunten van het interactionisme. 
Echter, Blumer's kritiek mag niet leiden tot de conclusie dat 'systeem", "actoren" en 'verandering' onverenigbare grootheden zijn. Dat dynamiek en veranderingen ook in studies van systemen kunnen worden bekeken, blijkt onder andere uit het feit dat in bepaalde systeemtheoretische benaderingen het verschijnsel 'systeem' inmiddels niet statisch is. Verder theeft binnen deze benaderingen de actor allengs nadrukkelijker een plaats gekregen als vormgever van zijn omgeving (zie Burns en Flam, 1987; Burns et al. 1985). Blumer's karittekeningen mogen van toepassing zijn geweest op het structureel functionalisme, zij gelden inmiddels niet voor alle studies naar systemen.

Gebruik van het concept 'systeem" vereist dat in analyses de actoren en hun handelingen hun 'rechtmatige plaats' krijgen. Zonder actoren en hun handelingen bestaan systemen niet (Giddens, 1979, 1984). Wij komen aan Blumer's kritiek in zoverre tegemoet, dat wij aan gebruik van het concept "systeem' niet de veronderstelling koppelen dat actoren slechts de vereisten van het systeem dienen. Ook gaan wij

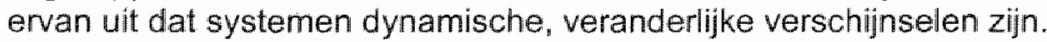

Wij beperken ons niet tot het systeem zelf. Wezenlijk in het werk van auteurs zoals Mintzberg (1979) is dat 'systeem' en 'omgeving" onafscheidelijke grootheden zijn. Een omgeving bestaat niet zonder systeem en omgekeerd. De grens tussen beide is overigens moeilijk te trekken (het vraagstuk van de systeemgrenzen: zie par. 2.3.3). In navolging van Mintzberg en anderen gaan wij ervan uit dat elk netwerk in een amgeving functioneert waarmee het relaties onderhoudt. De studie richt zich niet alleen op de dynamiek binnen het netwerk, maar ook tussen het netwerk en zijn omgeving.

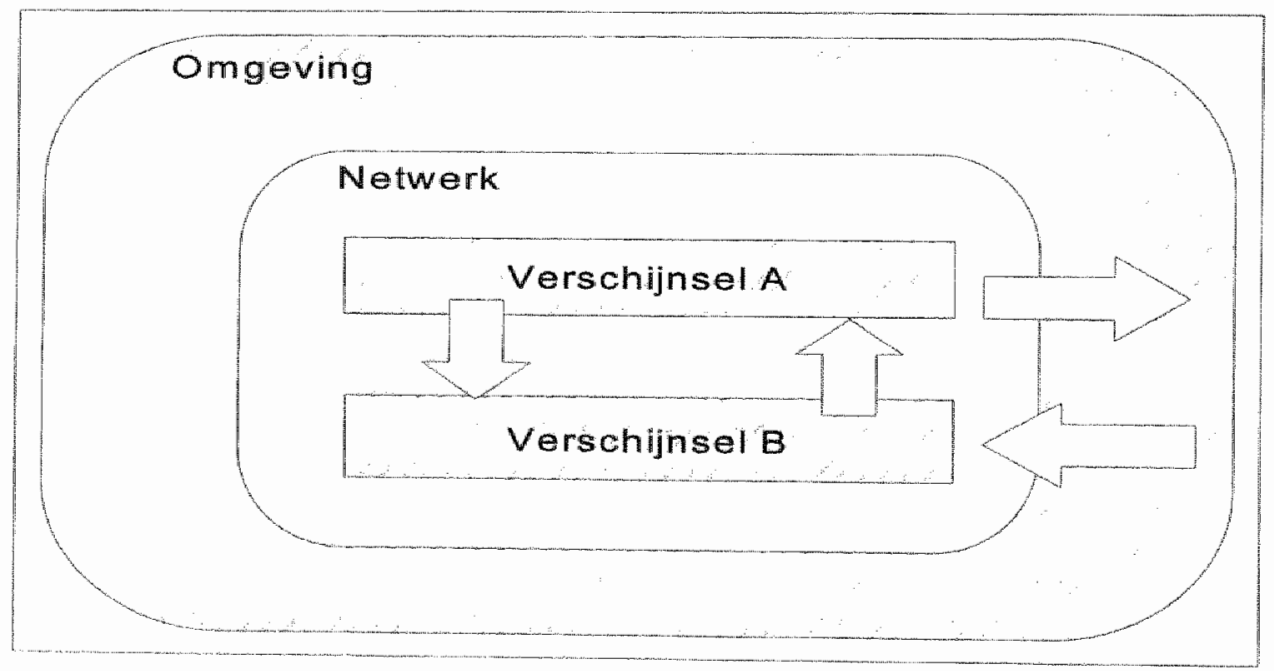

Fig. 2.2 Veronderstelling: wisselwerking tussen verschijnselen

De veronderstelling is dat de bestudeerde verschijnselen die door de concepten in onze theorie worden aangeduid, invloed op elkaar uitoefenen. Zij staan in wisselwerking met elkaar (Fig. 2.2). Verandering in het ene verschijnsel gaat gepaard met verandering in een ander verschijnsel, hetgeen weer kan leiden tot verandering in dit ene verschijnsel zelf. Dit standpunt loopt als een rode draad door de studie heen. 
Het dynamisch karakter van de verzameling verschijnselen en hun relaties illustreert dat de bestudeerde materie complex is. Gezien deze complexiteit is selectie wit verschijnselen onontbeerlijk om tot heldere inzichten te kunnen komen. Deze selectie wordt hieronder stapsgewijs toegelicht. Gaandeweg wordt duidelijk op welke verschijnselen onze theorie betrekking heeft.

\subsubsection{Eerste selectie van verschijnselen}

Onze theorie betreft drie hoofdverschijnselen en de relaties daartussen:

- de context waarin sturing plaatsvindt: de omstandigheden (situatie: actoren en hun relaties en handelingen daarbinnen) die de aanleiding vormen tot sturing en die al dan niet gelegenheid hebben geboden tot sturing (onderzoeksvraag 2 en 3 ; zie par. 1.3)

de sturing zèlf (onderzoeksvraag 1)

de ontwikkelingen binnen netwerken als gevolg van sturing (een deel van onderzoekswraag 4)

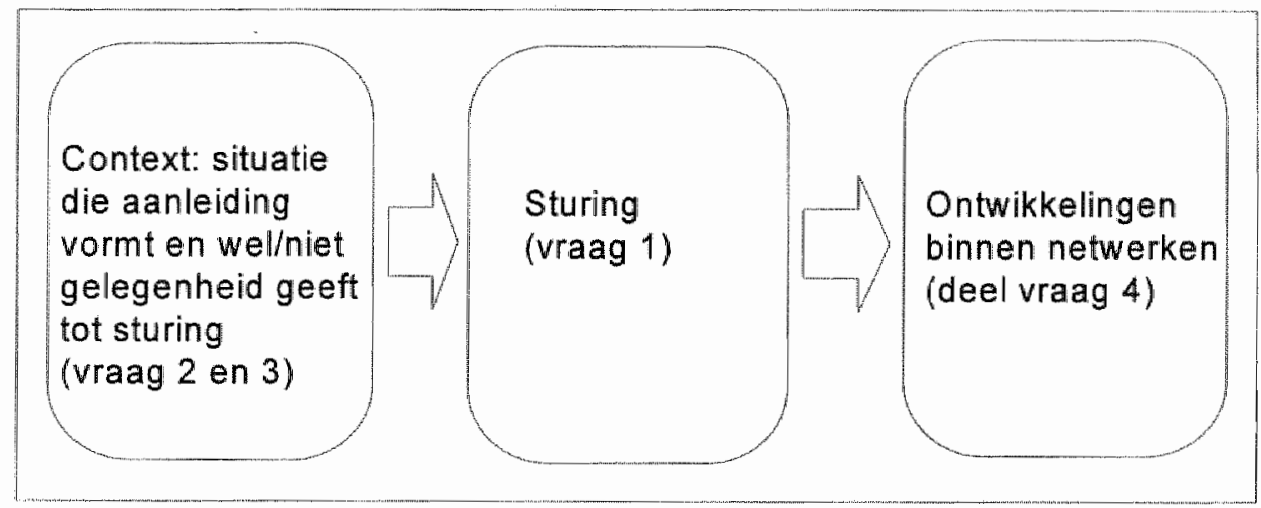

Fig. 2.3 Eerste selectie van verschilnselen

De ontwikkeling (worming, ontstaan) van netwerken wordt in beeld gebracht aan de hand van inzichten die de analyse wan verschijnselen en hun relaties oplevert. Deze werkwijze ligt voor de hand, aangezien op deze inzichten ook onze newwerktypering (zie par. 1.3) is gebaseerd. Analyse leidt derhalve tot beantwoording van onderzoeksvraag 4 (resterend deel) en 5.

Fig. 2.3 toont de hoofdverschinnselen en een eerste alanduiding van hun kenmerken en relaties. Tal wan relaties zijn denkbaar; de verschijnselen en hum onderlinge wisselwerkingen wormen één klluwen. De aangegeven relaties zijn voor deze studie enkele van de belangrijkste. Fig. 2,3 en de andere waarin de verschijnselen en hun relaties worden weergegeven, bevatten de opeenvolging van gebeurterissen. De pijlen in deze figuren zijn bedoeld om de opeenvolging uit te drukken ('stroomschema'). 


\subsubsection{Tweede selectie van verschijnselen}

De hoofdverschijnselen in Fig. 2.3 zijn veelomvattend. Zij kunnen weer worden uiteengelegd in tal van onderdelen. Ook daarbinnen is selectie noodzakelijk. De eerste inperking betreft 'ontwikkelingen in netwerken'. Vooruitlopend op de verdere beschrijving van concepten in par. 2.5 kan worden gesteld dat in de bestudeerde netwerken werd geprobeerd regels te formuleren en in gebruik te nemen, die waren bedoeld om de handelingen en interacties van actoren op een bepaalde manier te laten verlopen ('handelingsregels', hierna veelal aangeduid als 'regels'). De studie richt zich op de ontwikkeling en het gebruik in netwerken van deze regels (Fig. 2.4), die wij "intern" noemen. Een voorbeeld van interne regels zijn de statuten van een netwerk dat een rechtspersoon is.

Daarnaast is sprake van handelingsregels die buiten de bestudeerde netwerken tot ontwikkeling zijn gekomen. Deze hebben als 'externe regels' in Fig. 2.4 een afzonderlijke plaats gekregen. Wetten zijn een voorbeeld. De studie richt zich weliswaar op het gebruik van deze regels, maar niet op de ontwikkeling daarvan. Wij bestuderen dus bijvoorbeeld niet de formulering van wetsvoorstellen die, nadat zij zijn ingediend, kracht van wet krijgen. Voor een goed begrip moet worden benadrukt dat 'extern' hier betekent: buiten het bestudeerde netwerk ên de bestudeerde verzameling van netwerken die het project itz uitvoerden. Deze verzameling noemen wij de 'projectorganisatie'.

Actoren die relaties onderhouden en daarbinnen handelen (context, situatie), hebben kenmerken. Met betrekking tot deze kenmerken redeneren wij vanuit een actorperspectief waarin de mens bijvoorbeeld vindingrijk, creatief en oplossingsgericht is. Tevens belichten wij de manier waarop actoren gewend zijn te handelen of vinden dat moet worden gehandeld. In dit verband gebruiken wij het begrip 'routines'. Zoals nog duidelijk wordt, is dit begrip hier synoniem met 'cultuur'. Relaties in deze studie zijn afhankelijkheidsrelaties. Daarbinnen handelen actoren. Relaties zelf zijn het product van patroonsgewijze (herhaallde) interacties.

Interacties, als deelverzameling van handelingen, zijn in de studie sturingsinteracties. Daarom hebben wij deze in Fig. 2.4 uitgelicht en bij 'sturing' een tweede maal vermeld, samen met vormen van sturing. Fig. 2.4 laat zien dat de handelingen van actoren de motor in de veranderingen van de verschijnselen zijn. Het gegeven dat in de figuur handelingen niet alleen onder 'context' zijn vermeld, mag overigens niet de indruk wekken dat het hier gaat om handelingen buiten de context. Handelingen vinden namelijk altijd in een context plaats. Het was echter niet mogelijk het verloop van de gebeurtenissen op een andere manier inzichtelijk te maken.

Handelingsregels, in het bijzonder de ontwikkeling daarvan, zijn in onze studie het object van sturing. 'Sturing' en 'ontwikkeling van handelingsregels' beperken zich hier tot het creëren van randvoorwaarden voor zorgverlening, zoals financiële en bestuurlijke kaders ('het secundaire proces') en tot de organisatie van de uitvoering van de hulpverlening ('het secundair niveau van het primaire proces', waartoe bijvoorbeeld zorgcoördinatie en casusteambesprekingen behoren). De uitvoering van de zorgverlening zelf (het resterende deel van het primaire proces) bestuderen wij niet. 


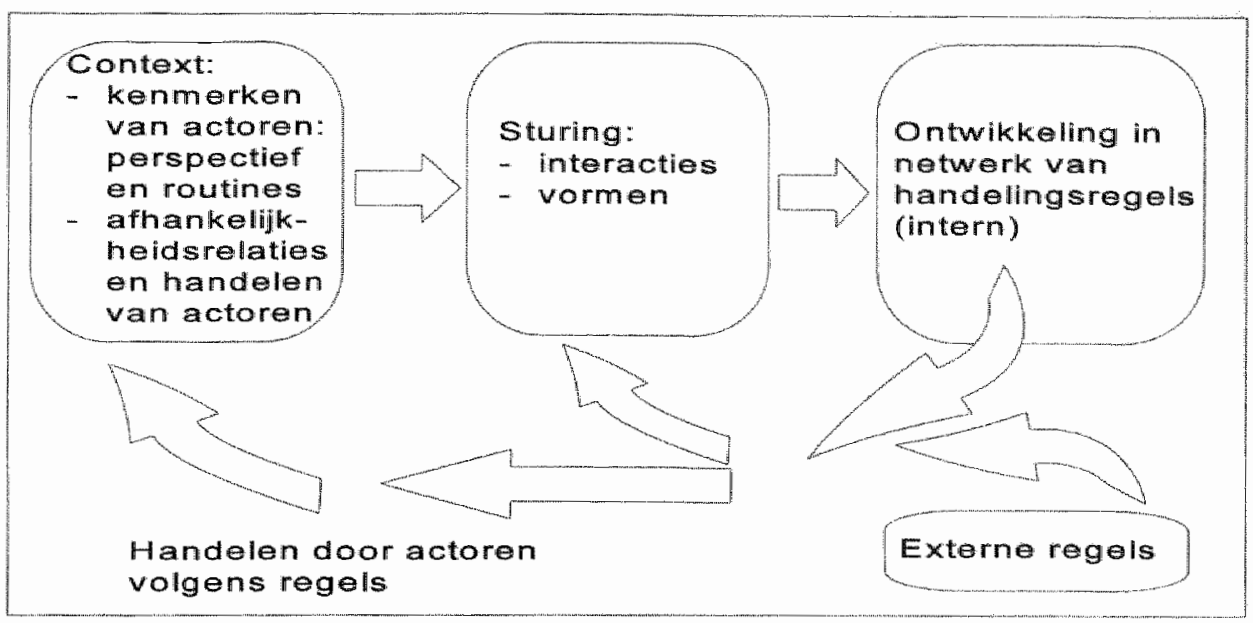

Fig. 2.4 Tweede selectie van verschijnselen

Regels zijn bedoeld om bij het handelen te worden gebruikt. Worden zij gebruikt, dan geleiden zij handelingen. 'Gebruik van regels' en 'handelen volgens regels' zijn hier synoniemen ${ }^{12}$. Handelen volgens regels leidt tot veranderingen in de context. Omdat sturing handelen is, kunnen daarbij ook regels worden gebruikt. Deze mogelijkheid nemen wij hierna in ogenschouw.

\subsubsection{Derde selectie van verschijnselen}

Zoals gezegd functioneert elk netwerk in een omgeving. Het heeft relaties met deze omgeving. De omgeving bestaat uit andere netwerken en organisaties. Grenzen tussen netwerk en omgeving zijn flexibel en dynamisch. Zo komen leden van het netwerk uit de omgeving en kunnen zij naar de omgeving terugkeren. Dit gegeven toont aan dat veranderingen van/binnen het netwerk kunnen leiden tot veranderingen in de omgeving en omgekeerd. Met de in- en uittreding van actoren veranderen ook relaties in netwerken en tussen netwerken en hun omgeving. Zulke veranderingen hebben wij beschreven.

De vraag is welke actoren tot het netwerk gerekend kunnen worden en welke niet (te vergelijken met het vraagstuk van de systeemgrenzen in systeembenaderingen; zie De Leeuw en Mur-Veeman, 1990). Onze definitie van een netwerk als een systeem is ruim. Er wordt bijwoorbeeld niet als voorwaarde gehanteerd dat iedere actor met alle andere actoren in het netwerk relaties moet hebben. Bovendien hebben wij aan 'relatie' geen specifieke criteria verbonden, zoals 'intensiteit'. De definitie maakt het daardoor

12 Dat wordt gehandeld volgens regels, hoeft nog niet per definitie te impliceren dat regels zijn gebruikt. Er zin gevallen denkbaar dat de verrichte handelingen bij toeval overeenkomen met de regels. Deze mogelijke betekenis van 'haandelingen volgens regels' blift hier buiten beschouwing. Regeis hebben in dergelijke gevallen namelik geen functie, waardoor het zinloos is deze gevallen te analyseren. 
mogelijk een zeer groot aantal actoren, die op een of andere wijze (bijvoorbeeld direct of indirect) aan elkaar zijn verbonden ( $A$ onderhoudt relaties met $B$; $B$ heeft weer een relatie met $C$ en $D$, die leder weer relaties hebben met $E$, etc.), als netwerk te beschouwen. Daardoor kan zelfs de hele mensheid tot één netwerk worden gerekend. Dit is natuurlijk niet zinvol.

Om netwerken te begrenzen zijn tal van criteria denkbaar. Wij hebben het valgende criterium gehanteerd. Vergaderingen waren in het bestudeerde project de belangrijkste wijze van interacteren. Een netwerk bestaat in deze studie uit alle personen die zijn genoemd op de deelnemerslijst van vergaderingen van dat systeem. Actoren die niet op een deelnemerslijst staan, maar die wel relaties onderhouden met genoemde deelnemers, behoren dus niet tot het netwerk (zie verder hoofdstuk 3). Dit lijkt een willekeurig criterium, maar is het niet. De deelnemersiijsten bevatten de personen die in de perceptie van de netwerkleden zelf tot het netwerk behoorden. Het gehanteerde criterium is daarmee consistent met het interactionistische gedachtengoed. 'Perceptie" ('waarneming') is betekenisvol. Wanneer wij over percepties en waarnemingen spreken, bedoelen wij 'betekenisvolle waarnemingen'.

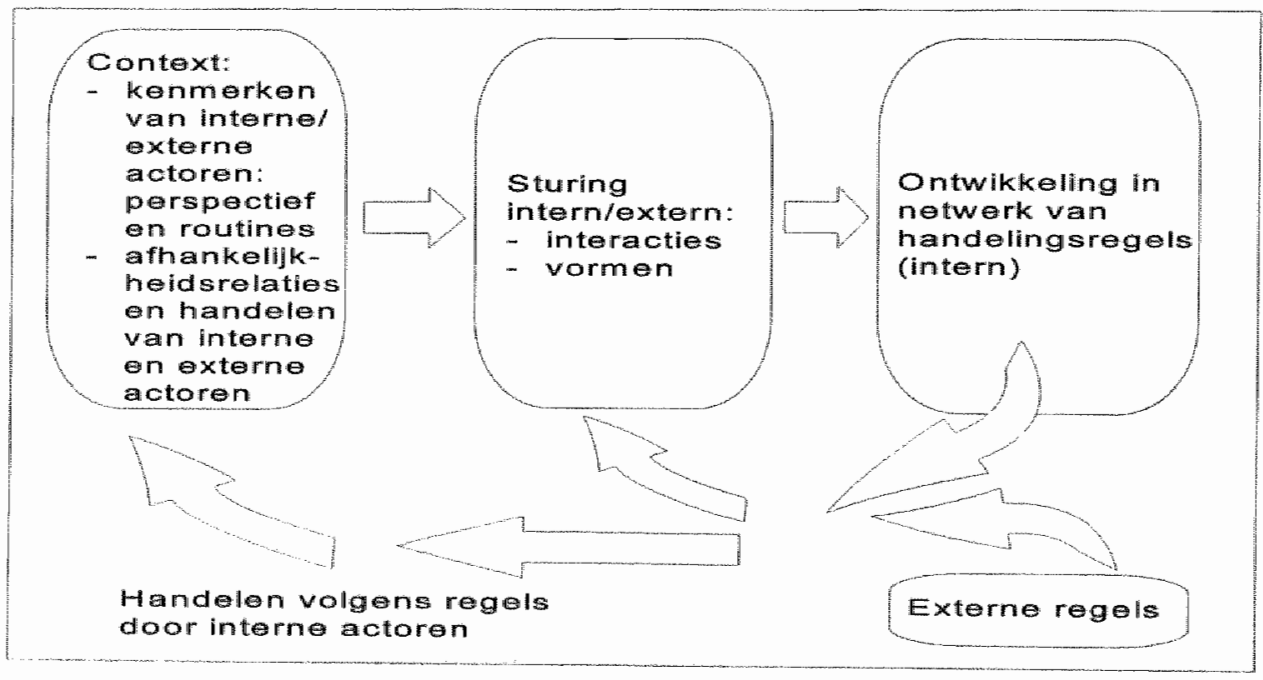

Fig. 2.5 Derde selectie van werschijnselen

Gezien onze definitie van 'netwerk' is een vermelding op een deelnemerslijst niet voldoende om personen tot een netwerk te kunnen rekenen. Het feit dat een persoon op een deelnemerslijst is vermeld, hoeft nog niet te betekenen dat deze ook daadwerkelijk in relaties met anderen in het netwerk heeft geinteracteerd. Zoals gezegd zijn relaties het product van patroonsgewijze interacties. Zonder dergelijke interacties is derhalve geen sprake van een relatie. Een actor die niet herhaaldelijk met anderen in het netwerk heeft geinteracteerd, is per definitie geen element in het systeem. Als 'deelnemers' hebben wij alleen die actoren op deelnemersijsten beschouwd, ten aanzien van wie met behulp van de data kon worden vastgesteld dat zij in de vergaderingen van het netwerk herhaaldelijk met anderen hebben geïnteracteerd. 
Actoren maken deel uit van een context. Een context kan te vinden zijn binnen of buiten het netwerk en de verzameling netwerken die het project itz hebben uitgevoerd. De studie richt zich op de kenmerken van interne en externe actoren (Fig. 2.5) , op de afhankelijkheidsrelaties tussen interne actoren onderling en tussen interne en externe actoren, alsmede op hun handelingen binnen die relaties. Voorbeelden van externe actoren zijn vertegenwoordigers van de rijksoverheid, die met het oog op subsidiëring van een zorgvernieuwingsproject in het kader van het Programma van WVC overleg voerden met de initiatiefnemers van het project. De vertegenwoordigers van de overheid behoorden tot de omgeving van de verzameling netwerken die het project itz uitvoerden, zij stonden niet op de deelnemerslijsten van de vergaderingen van deze netwerken en zij onderhielden een relatie met de initiatiefnemers, die tot de netwerken behoorden en die wél op de deelnemerslijsten stonden. De verdere specificatie van de bestudeerde externe actoren is beschreven in hoofdstuk 3 .

Over handelingen volgens regels tenslotte willen wij het volgende zeggen. Wij richten ons op handelingen van interne actoren. Uitzonderingen zijn de regels die worden gebruikt bij sturingsinteracties. Daarbij kijken wij zowel naar interne als externe actoren. Doen wij dit niet, dan moeten wij inzichten ontberen die in het licht van onze vraagstelling relevant zijn. Sturing kan namelijk zowel door interne als externe actoren worden verricht. Een voorbeeld van de eerste categorie is de voorzitter van een netwerk die tijdens vergaderingen het verloop van besprekingen kan bepalen. Een voorbeeld van de laatste categorie is de rijksoverheid die met behulp van regelgeving op het vlak van financiering zorgvernieuwing door een netwerk mogelijk of onmogelijk maakt. Wij bestudeerden sturing tussen interne actoren onderling en tussen interne en externe actoren alsmede de resultaten daarvan, in het bijzonder de ontwikkeling van netwerken en ontwikkelingen binnen netwerken (Fig. 2.6).

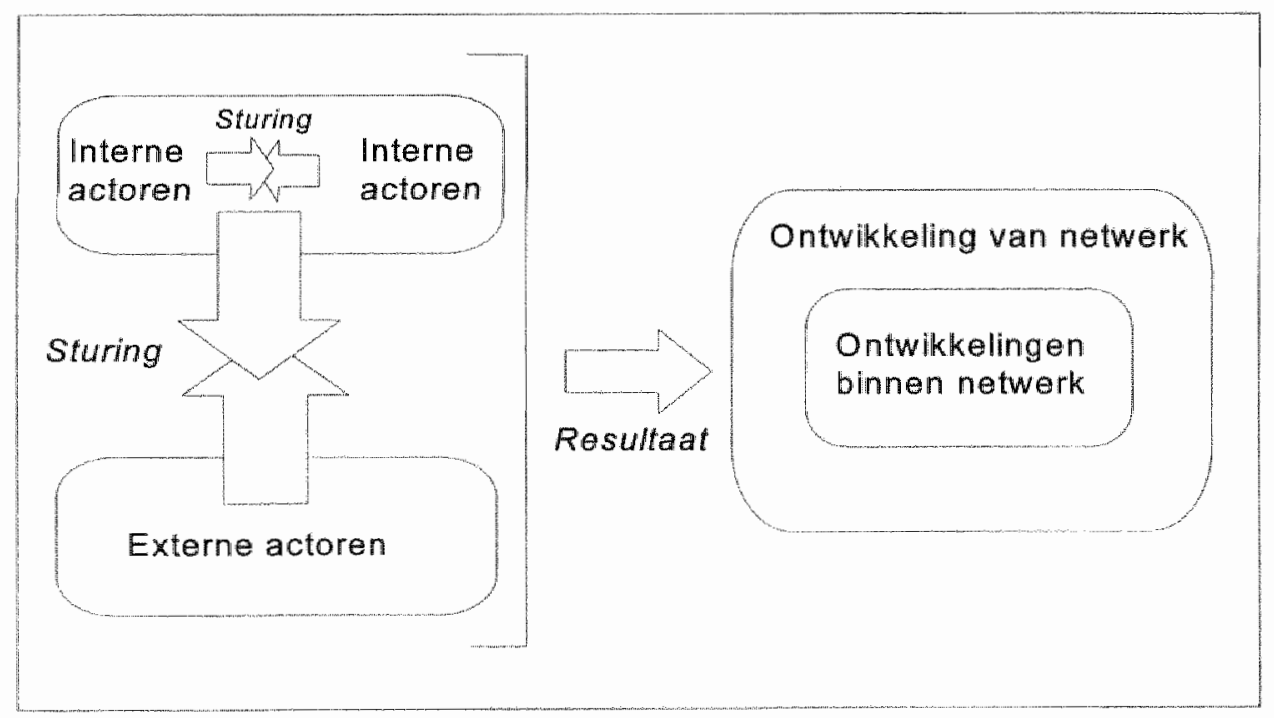

Fig. 2.6 Sturing en ontwikkeling van/binnen netwerken 


\subsection{Tweede opbouwfase van de theorie: conceptueel raam-werk voor het dynamisch samenspel van verschijnselen}

In onderlinge wisselwerking zorgen de genoemde verschijnselen voor verandering en dynamiek. Op dit dynamische samenspel van werschijnselen, dat hier centraal staat bij de bestudering van netwerken. gaan wij vanaf nu nader in. Dat gebeurt aan de hand van ons conceptueel raamwerk.

In deze paragraaf beschrijven wij in thet kort de begrippen die samen met hun onderlinge relaties het conceptueel raamwerk vormen van onze theorie (Fig. 2.7 ): cultuur; structuur; macht (en machtsuitoefening ofwel sturing); (handelen volgens) regels; betekenis. Zif omvatten gezamenlijk allie concepten waarmee de door ons bestudeerde verschijnsellen worden aangeduid. Zi fungeren als paraplu en ordeningskader voor de verdere beschrijving van concepten en hun relaties in par. 2.5 en 2.6. Gebruik van deze begrippen impliceert dan ook niet dat aan de verzameling bestudeerde verschijnselen andere worden toegevoegd.

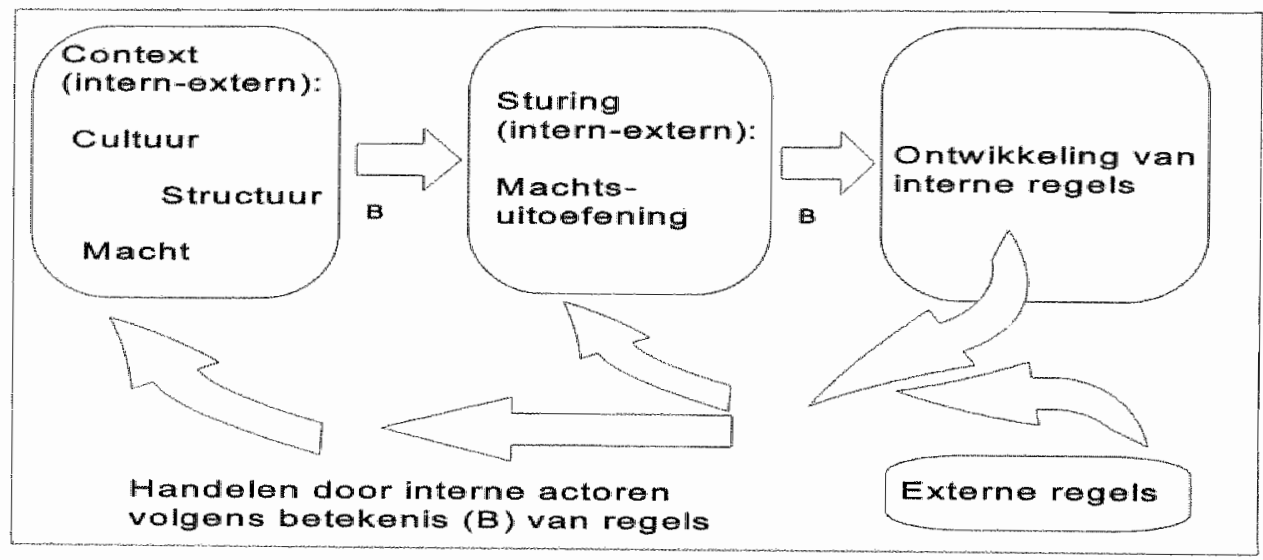

\section{Fig. 2.7 Conceptuéel raamwerk}

Wij spreken niet over een 'conceptueel model'. Dit is namelijk en begrip dat veelal wordt geassocieerd met hypothesentoetsende benaderingen (zie Segers, 1983). Gebruik van dit begrip zou hier tot verwarring leidem.

\subsubsection{Cultuur, structuur en macht (inclusief sturing)}

Met name in studies die behoren tot de 'social system theory'-benaderingen wordt veelal gepoogd met toepassing van drie concepten inzicht te krijgen in verschijnselen zoals organisaties en netwerken: cultuur (een cognitief systeem dat richting geeft aan het handelen), structuur (een verzameling relaties) en macht (het vermogen naar eigen wens te handelen, ook bij weerstand van anderen; uitoefening van macht is sturing). Deze publicaties kunnen globaal gesproken in twee categorieën worden ingedeeld. In de eerste categorie komen zowel structuur, cultuur en macht aan de orde bij de analyse van de verschijnselen, maar vormt één van deze de dominante invalshoek (zie 
Mintzberg. 1979; Schein, 1988; Pfeffer, 1981). In de tweede categorie wordt inzicht in deze verschijnselen nagestreefd vanuit alle drie invalshoeken, zonder dat bij eén van de drie het primaat ligt (zie Mur-Veeman en De Man, 1990; Wassenberg, 1992; Mijs; $198713)$

Tot de laatste categorie behoort onze studie. Ook hierin spelen de concepten structuur, cultuur en macht een evenredig belangrijke rol. Een aantal tot dusverre onderscheiden verschijnselen kunnen vanuit deze concepten worden belicht. Zoals in par. 2.5 blijkt hebben de zaken die wij in Fig. 2.5 onder "context" hebben geschaard alles te maken met structuur, cultuur en macht. Routines van actoren betreffen cultuur, het gebruikte actorperspectief is cultureel van aard. Structuur verwijst naar afhankelijkheidsrelaties tussen actoren als product van de patroonsgewijze interacties (een deelverzameling van handelingen). Relaties en handelingen daarbinnen worden door actoren beoordeeld vanüt cultuur. In afhankelijkheidsrelaties speelt macht altijd een rol.

\subsubsection{Regels (ontwilkkeling en handelen volgens regels)}

Het afbakenen van overeenkomsten en verschillen tussen structuur, cultuur en macht is problematisch. In de organisatiekundige literatuur wordt verondersteld dat $z i j$ weliswaar te onderscheiden zijn, maar dat zij niet kunnen worden gescheiden (MurVeeman en De Man, 1990). Vervolgens wordt gesteld dat tussen hen dwarsverbanden bestaan. Wat hen echter precies verbindt, blijkt moeilijk te kunnen worden aangegeven. Wij stellen dat handelingsregels een belangrijke schakel vormen. Regels die bij het handelen worden gebruikt, verbinden cultuur, structuur en macht (Fig. 2.8). "Worden gebruikt' is een belangrijke toevoeging. Regels die bij het handelen niet worden gebruikt, zijn 'dode letters'. Zij geleiden het handelen niet. Bij patroonsgewijze handelingen en de daaruit woortvloeiende structuur spelen zij geen rol.

Handellingsregels zijn geworteld in cultuur. De handelingen waarbij zij worden gebruikt produceren structuur en machtsrelaties tussen actoren. Macht biedt gelegenheid tot sturing. Ontwikkeling van regels vindt plaats door sturing (machtsuitoefening). Handelingen volgens nieuwe regels leiden weer tot veranderingen in structuum en macht, et cetera. Zij kunnen zelfs leiden tot veranderingen in cultuur. Ontwikkeling van de verschijnselen die wij met de genoemde begrippen hebben aangeduid, verloopt derhalve via ontwikkeling en gebruik van regels. Aldus ontstaat een voortdurende stroom van veranderingen.

13. Mijs' studie staat op de grens van beide categorieên publicaties en heeft een aantal raakvakken met deze sutudie. Mijs analyseert het ontstaan van interorganisationele samenwerking als een instifutionaliseringsproces. Hoewel in het ontstaan van deze samenwerking ook bij Mijs macht een rol speelt, ligt in de analyse het accent op de wissielwerking tussen cultuturworming en structurering als deelprocessen van institutionalisering. Ook Wassenberg's benadering (1992) toont geljkenis met anze benadering. Hij presenteert een model waarin de concepten structuur, cultuur en macht (door them met 'symmetrie' aangeduid) gezamenlijk enkele van de bouwstenen zijn voor een cyclus van onderhandelingen fussen actoren. 


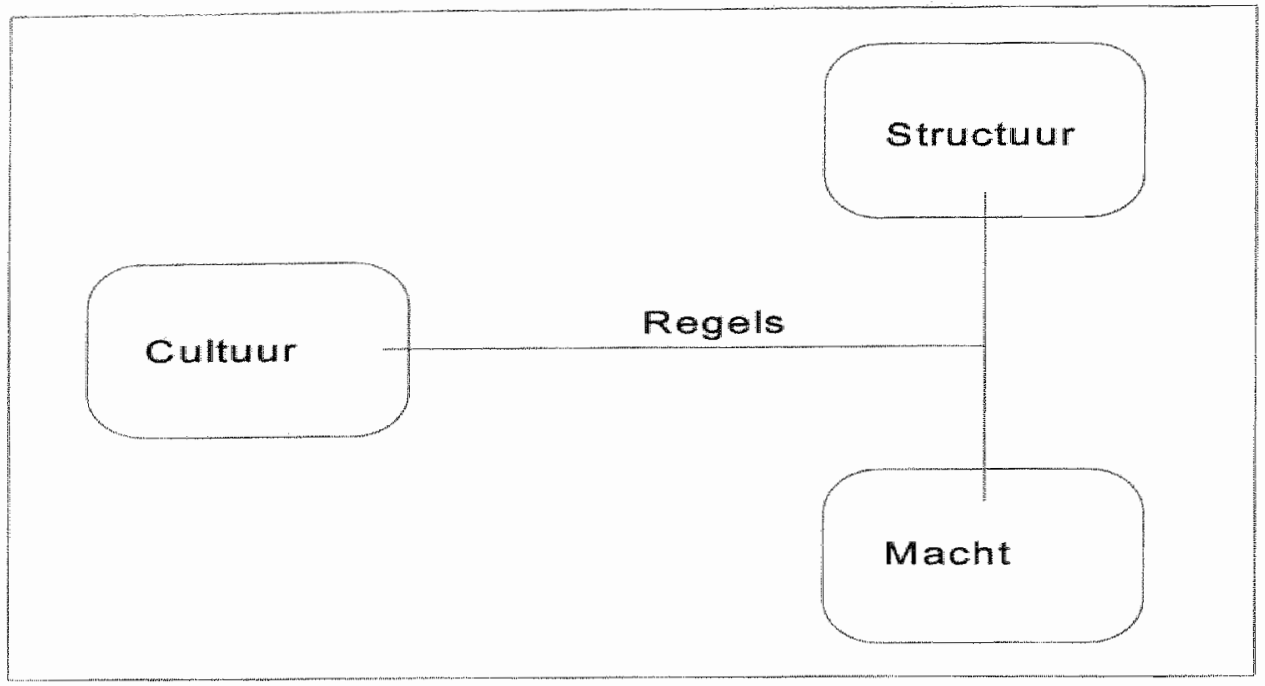

Fig. 2.8 Regels en culluur, structudur en macht

\subsubsection{Betekenis}

Met de voorgaande beschrijving hebben wij de essentie nog niet te pakken. Zoals in par. 2.2 .2 is aangegeven zijn niet de verschijnselen zelf, maar hun betekenis voor actorem uitgangspunt voor hun handelingen. Op basis van het gedachtengoed van Blumer's symbolisch interactionisme stellen wij dat actoren niet handelen volgens regels, maar volgens de betekenis die zij aan regels geven. Het concept "betekenis' omschrijven wij voorlopig als 'mentaal beeld' (Berns, 1981).

Betekenisgeving betreft meer dan regels. Actoren geven bijvoorbeeld ook betekenis aan afhankelijkheidsrelaties. Betekenisgeving speelt een rol bij alle verschijnselen die wij hebben bestudeerd en bij de veranderingen daarin.

\subsection{Derde opbouwfase van de theorie: beschrijving van de concepten}

Voor de navolgende beschrijving van concepten, waarmee wij onze theorie inhoud geven, nemen wij de inhoud van Fig. 2.7 als uitgangspunt. 'Betekenis' neemt in de theorie een centrale plaats in. Wij starten de beschrijving met dit begrip (par. 2.5.1). Daarna beschrijven wij 'context' (par. 2.5.2, 2.5.3 en 2.5.4), onder welke noemer wij het actorperspectief en routines (ofwel cultuur; zie par. 2.5.2.1), afhankelijkheidsrelaties (structuur en macht) en patroonsgewijze handelingen (structuur) bespreken. Wij beeindigen de beschrijving met "sturing" (par. 2.5.5) en 'handelingsregels" (par. 2.5.6). In het empirische gedeelte van dit verslag komen niet alle uitspraken aan de orde, die wij in dit hoofdstuk over de verschijnselen en hun relaties hebben gedaan. Wij hebben daaruit een samenhangende selectie gemaakt (zie par. 2.6). De totale beschrijving van 
de concepten en hun relaties verschaft aan de selectie het kader waarbinnen zij begrijpelijk is.

De verschijnselen en hun onderlinge wisselwerkingen hebben wij in par. 2.3 .1 een kluwen genoemd. Dit kluwen is niet volledig te ontrafelen, de delen overlappen elkaar. Het is daardoor onvermijdelijk dat in de afzonderlijke beschrijvingen van de concepten gelijksoortige uitspraken meerdere malen voorkomen.

\subsubsection{Betekenis}

Aangaande 'betekenis' heeft Blumer (1969) drie premissen geformuleerd. De eerste is al aangegeven: mensen handelen op basis van de betekenis die zaken woor hen hebben. Dit is een belangrijke stelling. Mensen nemen voor het handelen niet de zaken zelf als uitgangspunt, maar hun betekenis. Deze stelling, die wij in onze studie als assumptie overnemen (zie hoofdstuk 3 ), vormde een van de centrale richtsnoeren voor onze analyses.

Betekenis is volgens Blumer noch een intrinsiek onderdeel van een object, noch het product van de samenvoeging van elementen in de menselijke psyche. Betekenis is afgeleid uit of komt op tijdens interacties tussen mensen (tweede premisse) en wordt gehanteerd en gemodificeerd gedurende een interpretatieproces (derde premisse). Betekenis is een sociaal product en de mens is een 'meaning maker'. Interpretatie is geen automatische toepassing van bestaande betekenissen.

Opvallend is dat Blumer (1969) "betekenis' niet omschrijft. Denzin (1989) doet de volgende aanzet. 'Meaning: what an experience means to a person, defined in terms of intentions and consequences; meaning is always triadic, involving interaction between a person, an object, an action taken toward the object; meaning is interactional, interpretive, open-ended, often ambiguous, inconclusive, and conflictual". Echter, in deze omschrijving wordt vooral zichtbaar binnen welk kader interactionisten 'betekenis' plaatsen en welke karakteristieken het heeft. Wat betekenis is, wordt niet duidelijk gemaakt.

Wij omschreven 'betekenis' reeds als een 'mentaal beeld'. Dit is de descriptieve kant van de definitie. Wanneer wij bijwoorbeeld de klank 'kar' horen (Berns, 1981), dan roept dit bij ons het mentale beeld op van een object, bestaande uit vier wielen met daarboven een houten bak. Naast de genoemde descriptieve kant heeft het begrip 'betekenis' in onze studie een evaluatieve kant. Actoren kunnen het mentale beeld namelijk beoordelen. Het beeld op zichzelf krijgt ook betekenis, bijwoorbeeld goed of slecht, gewenst of ongewenst, gunstig of ongunstig. Het beoordelingskader bespreken wij in par. 2.5.2.

Het begrip "betekenis" strekt zich hier uit tot situaties. De actor attendeert zichzelf op bepaalde elementen van de situatie waarin hij verkeert en kent daaraan betekenissen toe (Van Hoof, 1983). Deze verzameling betekenissen, toegekend aan elementen van de situatie, noemen wij de 'definitie van de situatie". De 'definitie van de situatie' als resultaat van selectie en betekenisgeving is in het interactionisme een belangrijk begrip en is synoniem aan de "betekenis van de situatie'. 


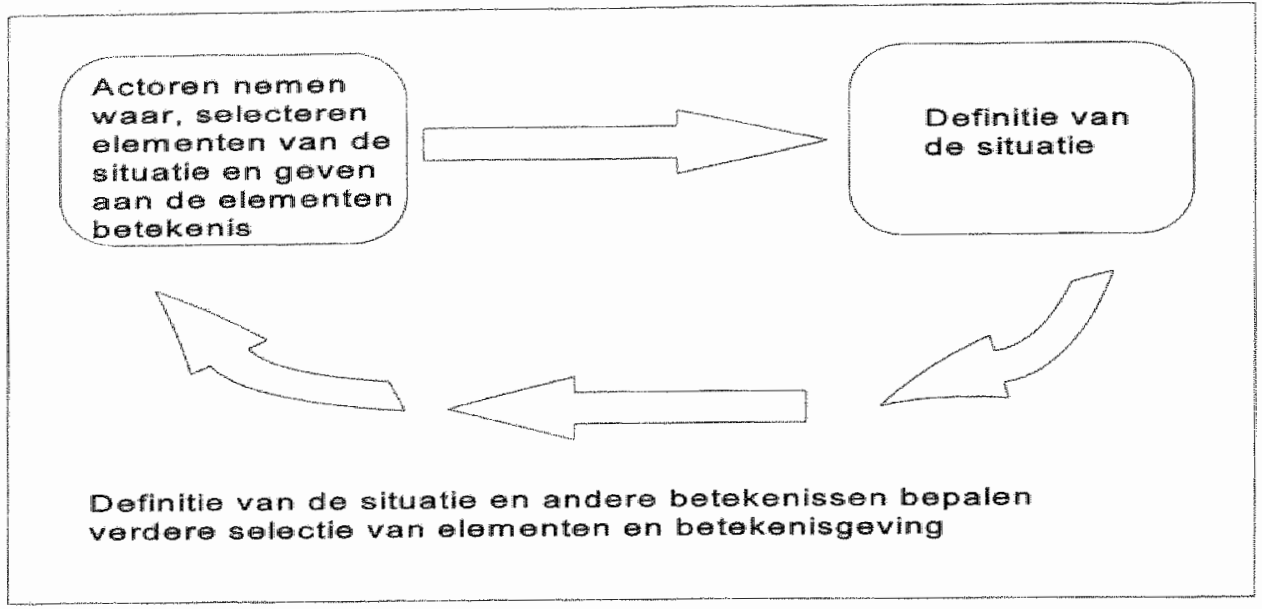

Fig. 2.9 Proces van definiering van de situatie

Het proces van betekenisgeving houdt niet op zodra de situatie is gedefinieerd. Actoren nemen ook gedurende hun verdere handelingen en interacties elementen van situaties waar, zij selecteren elementen, geven daaraan betekenis, komen aldus opnieuw tot een definitie van een situatie, et cetera. Zij maken daarbij gebruik van betekenissen die reeds zijn gevormd, zoals eerdere definities van de situatie. Het gaat hier om een dynamisch proces van betekenisgeving. Definities en betekenissen zijn voortdurend in ontwikkeling. Actoren maken gebruik van hun arsenaal aan betekenissen en definities, voegen daar steeds nieuwe betekenissen aan toe, passen aanwezige betekenissen aan, et cetera (Fig. 2.9).

Volgens Blumer's tweede premisse zijn een object en diens betekenis niet onlosmakelijk met elkaar verbonden. Combinatie van dit standpunt met de inhoud van de derde premisse laat de volgende conclusies toe. De betekenis van een en hetzelfide object, dezelfde zaak of situatie voor een actor kan veranderen. Verschillende actoren als 'meaning makers' kunnen aan dezelfde objecten, zaken of situaties verschillende betekenissen geven. Omdat betekenissen het uitgangspunt vormen voor het handelen, kunnen verschillende actoren in dezelfde situatie verschillend handelen, afhankelijk van de betekenis die deze situatie voor hen heeft.

Blumer's premissen tonen gelijkenis met het gedachtengoed van de semiotiek volgens Lacan. Peirce en Eco. Zo bestaan overeenkomsten in visie tussen Blumer en Eco. Evenals bij Eco (Santambrogio en Violi, 1988) is bij Blumer de gedachte herkenbaar dat betekenis het resultaat is van een sociaal productieproces. Overigens is Mead, als een van de grondleggers van het interactionisme, door Peirce beïnvloed (Collins, 1988). Daarmee willen wij echter niet zeggen dat een rechtstreekse ontwikkelingslijn kan worden getrokken vanuit de semiotiek naar het interactionisme, temeer daar elk van beide diverse varianten omvat. 


\subsubsection{Context: cultuur (routines en actorperspectief)}

Zoals in par. 2.5.2.2 blijkt, handelen actoren in deze studie doelgericht. Doelen maken onderdeel uit van 'cultuur'. Cultuur geeft daarmee richting aan het handelen. Cultuur is weliswaar niet de enige richtinggever aan het handelen, maar wel de belangrijkste. Cultuur is de 'prime mover' (Boudon, 1986), ook vergeleken met 'natuur'.

\subsubsection{Culturur en routines}

Cultuur omschrijven wij, in navolging van De Man (1992) als een collectief cognitief systeem dat richting geeft aan het handelen. Cultuur wordt door een verzameling actoren met zich mee gedragen. Dit 'collectief cognitief systeem' waarover De Man spreekt, zou door Hofstede (1985) worden omschreven als the collective programming of the mind which distinguishes the members of one category of people from another'. Deze programmering vindt plaats gedurende ons leven. Cultuur wordt verinnerlijkt door actoren en wordt tijdens langdurige interactieprocessen met anderen gevormd en veranderd (Adriaansens, 1983). Cultuur is tamelijk stabiel, maar niet statisch. Cultuur verandert, vaak langzaam en binnen bepaalde grenzen (zie Ott, 1989).

In het algemeen wordt ervan uitgegaan dat cultuur uit meerdere onderdelen bestaat. De literatuur bevat verschillende opsommingen daarvan. Uitgaande van publicaties van Hofstede (1985), Schein (1988) en De Man (1992) kunnen de volgende onderdelen worden genoemd: waarden, doelen, verwachtingen, normen, begrippen en taal. Belangrijk voor onze studie is dat ze alle te maken hebben met het handelen.

Waarden bepalen wat ons bevalt en wat ons niet bevalt, wat we goed en slecht, rationeel en irrationeel noemen. Het zijn algemene maatstaven waarmee handelingen en situaties (of, beter gezegd, de betekenis daarvan) wordt beoordeell. Waarden geven aan wat wel of niet "mag' worden nagestreefd, welke middelen geoorloofd zijn of niet, wat in een bepaalde situatie normaal, wreemd, gebruikelijk of afwijkend is (doelen en verwachtingen), et cetera. Normen zijn positieve en negatieve voorschriften voor handelingen en situaties. Doelen, verwachtingen, normen en waarden vertonen overlap.

Begrippen (concepten) zijn aanduidingen voor verschijnselen. Zij worden hier ondergebracht bij taal. Ons baserend op het werk van Lacan, Peirce en Eco (Eco, 1975; Berns, 1981; Mooij. 1977) beschouwen wij taal als een verzameling tekens en hun onderlinge relaties, alsmede betekenissen. Betekenissen rekenen wij derhalve tot de cultuur. Een verschijnsel dat in onze studie een belangrijke plaats inneemt, zijn regels. Regels zijn geschreven of ongeschreven. Zij ontstaan in de taal en makem daarvan deel uit. Daarmee zijn regels onderdeel van cultuur.

Een aantal interactionisten is geneigd zich in hun studies niet te concentreren op 'waarden en normen', maar op de begrippen 'practices and conventions'. Waarden en normen kunnen tijdens handelingen bijvoorbeeld worden geïnterpreteerd in relatie tot de situatie waarin de actor verkeert. Aldus kunnen 'practices and conventions' ontstaan, die 'reveal the concrete procedures by which collective activity is accomplished' (Hall, 1987a). Voordeel van deze interactionistische benadering is dat in 'practices and conventions' de dynamische wisselwerking tussen cultuur en handelingen tot uiting komt.

Een begrip dat met 'practices and conventions' overeenkomsten vertoont, is 'routines'. Bij Nelson en Winter (1982) verwijst dit begrip onder andere naar repetitieve activiteiten (in onze terminologie: 'handelingspatronen'). Routines behelzen meer dan 'practices and conventions'. Nelson en Winter vatten 'routines' breed op. Wij doen dat ook. Routines betreffen hier handelingspatronen die actoren wenselijk of noodzakelijk 
vinden of waaraan zij gewend zijn. Routines vormen het beoordelingskader voor (de betekenis van) handelingen en situaties. Actoren handelen, stellen handelingsregels op en creëren tijdens interacties betekenissen vanuit routines die zij hebben verinnerlijkt. Routines zijn het uitgangspunt bij handelingen en kunnen veranderen tijdens handelingen en interacties. Niettemin ziin zij tamelijk stabiel. Routines worden zichtbaar in het handelen (vgl. Glaser en Strauss, 1967; Blumer, 1969; Peterson, 1985; Schein, 1988 ) en in relaties als het product van handelingen (zie par. 2.5.3).

Het moge duidelijk zijn hoezeer het begrip 'routines', zoals wij dit gebruiken, overlap vertoont met de genoemde onderdelen van cultuur (zoals doelen, waarden, normen en regels). Deze en andere onderdelen kunnen niet van elkaar worden onderscheiden. Doordat de grens tussen de onderdelen van cultuur nief kan worden getrokken, is het niet mogelijk aan te geven waar cultuur en routines van elkaar verschillen. Wij hanteren de begrippen 'routines' en 'cultuur' daarom als synoniemen.

Belangrijk is de uitspraak dat routines tamelijk stabiel zijn. Aangezien vanuit routines wordt gehandeld, hebben ook interacties een hoge mate van stabiliteit. Wanneer veranderingen in situaties niet stroken met de routines (in het bijzonder die van dominante actoren; zie ook par. 2.5.5), is de kans groot dat zij niet beklijven. Zij veren dan terug naar deze routines. Veranderlijkheil van patronen van handelingen door actoren in hun onderlinge relaties is daardoor beperkt, de veranderlijkheid van systemen eveneens. Routines werpen voor zorgvernieuwing dus barrières op. Voor degenen die veranderingen teweeg willen brengen, is dit een relevant gegeven.

Routines zijn bij Nelson en Winter in grote mate gedepersonaliseerd. Actoren zijn bij hen vooral van belang als dragers van de routines. Het is in dit verband veelzeggend dat de auteurs routines vergelijken met 'genen'. Deze visie is niet compatibel met het gedachtengoed van het interactionisme. Wij nemen haar daarom niet over. In dit opzicht wijkt ons routine-begrip af van het begrip dat genoemde auteurs gebruiken. Wij hanteren het begrip vanwege zijn communicatieve, metaforische waarde. Het is zeer geschikt als middel om de inzichten over te dragen die wij hebben opgedaan.

\subsubsection{Actorperspectief}

Actoren en hun kenmerken vormen een cruciaal onderwerp. Zonder handelende actoren bestaan relaties noch netwerken en valt in deze studie niets te bestuderen. Het is dan ook van belang het actorperspectief te beschrijven, dat wij hanteren. Aangezien actoren handelen vanuit routines, kan ons actorperspectief een cultureel perspectief worden genoemd. De actoren in de netwerken die wij hebben onderzocht zijn nagenoeg allen vertegenwoordigers van organisaties. Veelal zijn zij managers.

Handelen is volgens Weber gedrag op basis van een motief, een beweegreden. Burns en Flam (1987) noemen handelen "purposefull". Actoren streven volgens diverse auteurs door te handelen iets na. Volgens Homans (1961) bijvoorbeeld is "iets" behoeftebevrediging, volgens Blau (1964) is dat winst. Hetgeen wordt nagestreefd Blumer (1969) spreekt over 'wishes', 'wants" en 'objectives'-, wordt ook wel een doel genoemd (De Man, 1992). Actoren handelen in deze studie dus doelgericht. Actoren kunnen zich meer of minder bewust zijn van het doel dat zij nastreven. Aan de 'mate van bewustzijn" gaan wij voorbij.

Een doel vatten wij niet op als datgene wat ter 'definitieve afsluiting' van een reeks handelingen wordt nagestreefd (geen statisch 'einddoel'). Verder plaatsen wij 'doel" in het kader van het handelen zèlf. Het begrip 'doel' betreft hier allereerst de door de actor als wenselijk of noodzakelijk beschouwde regels, handelingspatronen en afhankelijkheidsrelaties met andere actoren. Deze patronen en relaties zijn veranderlijk, hetgeen aan het begrip 'doel' zoals wij dat hanteren, een dynamische dimensie geeft. Doelen 
kunnen veranderen. Actoren hebben voor hun handelingen middelen (zoals geld) nodig. De verwerving van middelen is voor ons eveneens onderdeel van 'doel'. Dat een actor met zijn handelingen 'iets" wil bereiken, wordt dus niet uitgesloten. Dat "iets' betreft hier handhaving of verandering van situaties, de verwerving of het bezit van middelen of het voorkomen dat anderen middelen krijgen.

Actoren streven doorgaans meer dan één doel na. Actoren kunnen individuele doelen nastreven, alsmede de doelen van de organisatie of van het netwerk waarvan zij deel uitmaken. Doelen van actoren kunnen met elkaar overeenkomen ("gemeenschappelijke doelen'), maar dat hoeft niet. In netwerken kunnen daardoor meerdere individuele doelen worden nagestreefd naast een eventueel gemeenschappelijk doel. Ook kunnen de actoren aan doelen verschillende prioriteiten toekennen.

Zoals reeds is aangegeven handelen actoren op basis van betekenissen die bijvoorbeeld de elementen van een situatie voor hen hebben. Om aan elementen van de situatie betekenis te kunnen geven, moeten actoren zich op deze elementen kunnen attenderen. Daarvoor hebben zij signalen ofwel informatie nodig. Informatie is cruciaal voor doelgericht handelen. Actoren stippelen op basis van de betekenis die zij aan informatie geven wegen uit om doelen te bereiken (strategieën). Zij schatten de kans op doelbereiking in en maken daarbij gebruik van eerder opgedane kennis, ervaringen en betekenissen. Zij identificeren en selecteren middelen om die doelen te bereiken en zoeken naar oplossingen voor problemen in hun omgeving tegenover welke zij zich gesteld zien. Verwerving, verwerking, interpretatie en analyse van informatie vindt voortdurend plaats voor en tijdens het handelen (Burns en Flam, 1987; Aldrich en Pfeffer, 1976; Aldrich en Mindlin, 1978; Blumer, 1969).

De actor in dit perspectief is creatief, oplossingsgericht en kan keuzes maken. Hij streeft naar aanvaardbare situaties. Hij is geen alwetende actor die naar maximale doelbereiking streeft, zoals de zogenaamde 'homo oeconomicus". Het is genoegzaam bekend dat het 'homo oeconomicus-model' veel kritiek te verduren heeft gehad, hetgeen aanleiding gaf tot de introductie van "homo sociologicus'-modellen (Lindenberg, 1985). De kritiek geldt vooral de rationaliteit.

Vaak geciteerd in dit verband is Simon (1957). In het homo oeconomicus-model wordt het handelen van actoren als doelrationeel beschouwd: actoren maken een keuze uit een set van ter beschikking staande gedragsalternatieven welke keuze in overeenstemming is met de eigen preferenties. Simon (1957) wijst op de beperkte beschikbaarheid van de benodigde informatie om doelrationeel te kunnen handelen. Ook is volgens hem het vermogen van actoren om informatie te verwerken nooit optimaal. Er is dus sprake van 'bounded rationality'. Bovendien willen individuen volgens Simon niet per se maximale doelbereiking, maar kunnen zij zich tevreden stellen met een lager niveau van doelbereiking: aanvaardbaarheid boven maximaliteit, 'satisficing' in plaats van 'maximizing'. Verder wijzen critici erop dat de mens handelt in een omgeving die beperkingen oplegt, bijvoorbeeld in de vorm van instituties. Keuzevrijheid is gelimiteerd.

Onze actor is een 'homo sociologicus', bij wiens gedrag Webers motivering een rol speelt, die signalen uit de omgeving ontvangt en tijdens interacties betekenis geeft aan situaties, deze betekenis tot uitgangspunt voor zijn handelen neemt en die daarbij gebruik maakt van zijn 'culturele bagage'. 'Motivering' is bij het handelen een belangrijk aspect (zie par. 2.5.6.2 en 2.5.6.3).

Routines worden gebruikt bij het zoeken naar oplossingen voor problemen door de mens uit ons actorperspectief, het uitstippelen van strategieën, de selectie van middelen, de vergaring en interpretatie van informatie et cetera. Routines geven 
actoren aan hoe waar te nemen, hoe over zaken te denken en wat wan hen wordt verwacht bij het handelen.

Hiermee willen wij overigens niet zeggen dat de actor in ons perspectief een 'cultural dope' is. Een dergelijke uitspraak staat op gespannen voet met het interactionisme. Al houden ook volgens het interactionisme de actoren bij handelingen en betekenisgeving wel degelijk rekening met zaken zoals hun eigen daelen (zie Blumer, 1969), dit impliceent nog niet dat zij zilch daardoor volledig laten dirigeren. Het beschreven actorperspectief neemt op het continuüm met voluntarisme en determinisme als de uiteinden, een plaats in die dichter bij het eerste uiteinde ligt dan bij het tweede. Het perspectief is dus evenmin volledig voluntaristisch. Daarmee komen wiil tegemoet aan commentaren van degenen die het voluntaristische karakter van het interactionisme in het verleden hebben bekritiseerd (zie Meltzer et all, 1975).

De actor is zoals gezegd creatief en kan keuzes maken. Niettemin, ook daarbij maakt hij gebruik van routines. Ook voor het proces van betekenisgeving fungeren routines als referentiekader. Ook betekenissen zijn "gekleurd' door routines. Dit alles verleent aan handelingen enige voorspelbaarheid. De voorspelbaarheid ils niet maximaal want routines zijn geen onveranderlijke blauwdrukken die bovendien exact aangeven hoe te handelen, te beoordelen et cetera. Routines kennen een bandbreedte.

De voorspelbaarheid van het verloop van interacties is zo mogelijk nog geringer, zeker wanneer het gaat om interacties in collectiviteiten zoals groepen en organisaties (door Blumer 'joint action' of 'collective action' genoemd). Volgens Blumer (1969) ontstaan dergelijke interacties gedurende een zich vormend proces, waarin afzonderlijke gedragingen van actoren op elkaar worden gericht, aan elkaar worden verbonden en worden aangepast. Het verloop van deze interacties kan volgens hem niet worden verklaard uit houdingen en bedoelingen van afzonderlijke individuen.

In de bestudeerde netwerken waren de actoren veelal managers. Binnen de resource dependence benaderingen (Aldrich en Pfeffer, 1976) is waarborging van het voorbestaan van de eigen organisatie voor managers een fundamenteel belang. Het gaat hun ter harte, het is voor hen een cruciaal doel. Strategieën die zij hanteren om middelen te verkrijgen, zijn voor een groot gedeelte op dit voortbestaan georiënteerd. Indien nu bijvoorbeeld het dienen van een netwerkdoel nadelig is voor het voortbestaan van de eigen organisatie, dan is -uitgaande van het actorperspectief- de verwachting reèel dat managers van participerende organisaties zullen kiezen ten faveure van het laatste, ook al zijn zij lid van het netwerk en is hun keuze niet in het belang van het netwerk.

Uit het streven het voortbestaan van de eigen organisatie te waarborgen, spreekt de geneigdheid van deze actoren om vanuit de positie van hun organisatie de omgeving tegemoet te treden en het belang van hun organisatie te laten prevaleren boven andermans' belangen. De actoren zijn geneigd hun eigen gang te gaan en zich miets gelegen te laten liggen aan de belangen van anderen (laat staan van een netwerk). Deze geneigdheid noemen wij 'individualiteit' en beschouwen wij als het kernonderdeel van de routines van de actoren die wij hebben bestudeerd. Samen met het andere uiterste -Hofstede's (1985) 'collectiviteit'- maakt individualiteit deel uit van een continuüm. 'Collectiviteit' omschrijven wij als de geneigdheid samen met anderen te handelen. Deze geneigdheid kan eveneens tot de routines behoren, maar is bij de managers ondergeschikt aan individualiteit. Collectiviteit treedt op de voorgrond, indien individualiteit daarmee is gebaat.

De geneigdheid de eigen gang te gaan en de belangen van de eigen organisatie te laten prevaleren, kan in een netwerk tot fricties leiden (bijvoorbeeld tussen twee 
actoren onderling of fussen de ene actor en de rest van het netwerk als geheel), wanneer individuele belangen niet overeenkomen.

\subsubsection{Context: structuur (afhankelijkheidsrelaties en patroonsgewijs handelen)}

Om te kunnen handelen zoals zij dat nodig of wenselijk vinden, hebben actoren middelen nodig. Wij spreken dan over 'behoefte aan middelen". Dit geldt niet alleen voor individuen, maar ook voor verzamelingen van individuen zoals organisaties.

\subsubsection{Afhankelijkheid en middelen: handelingsruimte}

Middelen geven actoren de gelegenheid op een beoogde manier te handelen. Deze verschaffen hen 'handelingsruimte'. 'Handelingsruimte' kan letterlijk worden opgevat ('deze vergaderzaal is te klein') of overdrachtelijk ('ik als hulpverlener vind dat ik te weinig ruimte krijg om zelf beslissingen te nemen').

Veelal bevinden middelen zich in de omgeving van de actor, die in resource dependence benaderingen uit andere organisaties bestaat. In deze benaderingen is een middel al hetgeen aan doelbereiking kan bijdragen, zoals regels, personeel, geld, cliënten, diensten, handelingen van derden, deskundigheid of respect. De omgeving legt beperkingen op. Niettemin kunnen individuele actoren en hun organisaties strategische keuzes maken. Een organisatie kan vorm geven aan haar omgeving (Aldrich en Pfeffer, 1976).

De noodzaak middelen te verkrijgen uit de omgeving maakt de organisatie afhankelijk (steun- of hulpbehoevend) van andere actoren die over deze middelen beschikken of toegang tot deze middelen hebben (zie Yuchtman and Seashore, 1967). Een belangrijk streven van een organisatie is te vermijden dat zij van anderen afhankelijk wordt en tegelijkertijd te zorgen dat een andere organisatie van haar afhankelijk wordt (Selznick, 1957; Benson, 1975). Behoefte aan middelen beschouwen wij als de aanleiding tot interactie met degenen die deze middelen heeft of daar toegang toe heeft ( $\mathrm{vgl}$. Homans, 1961). In onze visie interacteren de actoren met anderen wanneer zij concluderen dat zij van hen afhankelijk zijn, wanneer zij niet volledig in hum eigen behoeften kunnen voorzien. Hun conclusies zijn geworteld in hun routines. Tijdens de interacties zullen zij trachten anderen ertoe te bewegen het benodigde middel te verschaffen.

Interacties in netwerken vinden plaats binnen relaties. De relaties zijn afhankelijkheidsrelaties. Een relatie is een verbondenheid tussen actoren, ontstaan uit interacties die zich in het verleden op min of meer dezelfde wijze hebben herhaald (Rademaker, 1978). Relaties ontstaan en worden verbroken. Een verzameling actoren kan onderling verbonden raken (vervlechting), verbondenheid kan weer verdwijnen (ontvlechting).

Relaties zijn dus het product van patroonsgewijze interacties. Tegelijkertijd vormen relaties het kader van dergelijke handelingen (vgl. Giddens, 1979). Dit sluit overigens niet uit dat relaties tevens het kader kunnen zijn van handelingen die niet volgens een patroon verlopen. Niettemin, zonder enige vorm van patroonsgewijze interactie kan van een relatie geen sprake zijn. Zonder relaties bestaat geen netwerk. Een netwerk hebben wij namelijk gedefinieerd in termen van actoren én hun relaties. Patroonsgewijze interacties, relaties en netwerken gaan hand in hand.

Van belang is te vermelden dat wij niet uitgaan van een 'objectief bestaande' afhankelijkheid, noch van een objectief bestaande werkelijkheid in het algemeen. Het gaat in onze studie om de werkelijkheid zoals actoren deze percipiëren. Dit is 
consistent met uitspraken van Aldrich en Pfeffer (1976). Zij stellen dat 'it does seem reasonable to argue that organizational actions will be determined by perceived reality.

Wanneer wij deze gedachtengang die wij ook in het interactionisme aantreffen, doortrekken, dan komen wij tot de volgende conclusie. Indien actoren in een bepaalde situatie tot de bevinding komen dat zij afhankelijk zijn, dan geven zij aan deze situatie de betekenis 'afhankelijkheidssituatie'. Deze betekenis heeft consequenties. Indien bijvoorbeeld twee actoren die beiden met dezelfde, derde actor een relatie hebben, aan deze relatie een verschillende betekenis geven, dan zouden zij ook verschillend gaan handelen.

Indien de betekenis van afhankelijkheid verandert, dan veranderen ook de interacties. Verandering in betekemis hoeft niet te corresponderen met een verandering wan de situatie. Dezelfde, onveranderde situatie kan opnieuw worden gedefinieerd, bijvoorbeeld aan de hand van nieuwe informatie.

\subsubsection{Symbiotische en competitieve afhankelijkheidsrelaties}

In netwerken kan sprake zijn van verschillende soorten relaties. Het verschil wordt bepaald door de aard van de afhankelijkheid (Godfroiij, 1981). Afhankelijkheid kan symbiotisch of competitief zijn (Pfeffer en Novak, 1976). De bij deze vormen van afhankelijkheid behorende relaties hebben dezelfde adjectieven.

Van symbiotische afhankelikheid is sprake wanneer twee of meer actoren elkars steun nodig hebben om de eigen doelen te bereiken en doelbereiking door de ene actor niet nadelig is voor doelbereiking door de andere. Te denken valt aan twee organisaties die leder afzonderlijk niet in staat zijn een dienstenpakket te leveren waaraan een hulpvrager behoefte heeft, maar dit gezamenlijk wél kunnen doen.

Wij spreken van competitieve afhankelijkheild wanneer doelbereiking door de ene actor wèl nadelig is voor doelbereiking door de andere actor. Uitgaande van onze omschrijving van "doel" is van competitieve afhankelijkheid ook sprake, indien de handelwijze van de ene actor nadelig is vool de mogelijkheid van een aindere actor te handelen zoals deze wil. Dit is bijvoorbeeld het geval wanneer twee zorgaanbiedende instellingen aan een en dezelfde klant dezelfde hulp willen verlenen. De klant is hier een middel. Zonder de klant kan de instelling niet doen wat zij wil doen: hulp verlenen. Als de ene instelling de hulp aan deze klant verleent, dan kan de andere dat niet doen. Hulpverlening door de ene beperkt de gelegenheid tot hulpverlening door de andere. De handelingsruimte van de laatstgenoemde actor wordt beperkt door de eerste. Competitie om middelen betreft in feite competitie om handelingsruimte.

Uiteraard is de afhankelijkheid competitiever naarmate doelbereiking door de ene actor nadeliger is voor doelbereiking door de andere. Omdat een actor meerdere doelen kan mastreven, is het mogelijk dat afhankelijkheidsrelaties tussen dezelfde actoren symbiotisch zijn met betrekking tot het ene doel en competitief met betrekking tot het andere doel.

\subsubsection{Afhankelikheidsrelaties en interactievormen}

Symbiotische afhankelijkheidsrelaties en competitieve afhankelijkheidsrelaties vormen samen de uiteinden van een continuüm. De aard van de interacties tussen de betrokken actoren volgen dit continuüm. Wanneer de afhankelijkheidsrelatie tussen alle actorem in een netwerk volledig symbiotisch is, dan zal tussen al deze actoren sprake zijn van samenwerking. Naarmate het andere uiteinde van het continuüm meer in zicht komen zullen de interacties het karakter krijgen van achtereenvolgens coalitievorming, concurrentie en strijd (Godfroij, 1981). 
Indien actoren vinden dat ze over en weer kunnen bijdragen aan elkaars doelbereiking (dat ze voor elkaar van nut kunnen zijn), dan kunnen ze met dat oogmerk trachten hun handelingen op elkaar af te stemmen. Wanneer zij denken dat deze afstemming meer voor- dan nadelen biedt, dan is te verwachten dal ze gaan samenwerken (Godfroij, 1981).

Van samenwerking is sprake indien en voorzover tussen actoren tot een gemeenschappelijk handelingsscenario wordt besloten (Könmen, 198014), volgens welk scenario zij handelen. Coalitievorming is een variant van samenwerking. Echter, de actoren slaan nu de handen ineen om zich samen sterk te maken tegen een derde partij. Bij concurrentie ofwel competitie trachten actoren, met het oog op hun eigen doeleinden, elkaar bij het verkrijgen van middelen de loef af te steken. Bij strijd tenslotte probeert leder van de betrokken actoren te belemmeren dat de ander zijn doelen bereikt (Godfroij, 1981). Zij zitten elkaar dwars, rijden elkaar in de wielen.

Zoals in par. 2.5.2.2 is gezegd, is het de geneigdheid de eigen gang te gaan en de belangen van de eigen organisatie te laten prevaleren, die in een netwerk tot fricties kan leiden, wanneer individuele belangen niet overeenkomen. Collectiviteit, voor zover daarvan sprake is, delft het onderspit. Natuurlijk behoeft zich in een netwerk tussen individuele belangen geen spanning voor te doen. De empirie wijst echter uit dat deze mogelijkheid eerder de uitzondering is dan de regell (Van Raak et al, 1993). Alleen indien individuele belangen compatibel en niet strijdig zijn, kan in relaties collectiviteit voorop staan.

Individualiteit is het kernonderdeel van de routines van de bestudeerde actoren. Omdat routines het uitgangspunt vormen voor het handelen, kunnen relaties en de interacties daarbinnen meer of minder symbiotisch dan wel competitief zijn. Naarmate individuele belangen minder compatibel of meer strijdig zijn, is sprake van verminderde geneigdheid met elkaar te handelen. Samenwerkingsrelaties komen moeizamer of niet tot stand. Wanneer in bestaande samenwerkingsrelaties belangen minder compatibel of strijdig worden, komt de samenwerking onder druk te staan, omdat individualiteit nou eenmaal het primaat heeft boven collectiviteit. In het uiterste geval zullen ontstane samenwerkingsrelaties (vervlechting) uiteen vallen (ontvlechting van samenwerkingsrelaties).

Aan de basis van afhankelijkheidsrelaties, interactles daarbinnen, vervlechting en ontwlechting, ligt dus de verhouding tussen individualiteit en collectiviteit. Deze verhouding maakt het verband zichtbaar dat via het handelen bestaat tussen cultulur (routines, met name individualiteilt) enerzijds en structuur en macht (afhankelijkheidsrelaties) anderzijds. Fig. 2.10 brengt de samenhang tussen de genoemde verschijnselen in beeld. Naarmate het accent op collectiviteit ligt, is de afhankelijkheid symbiotischer. Het gaat dus steeds om de verhouding tussen individualiteit en collectiviteit in relaties tussen actoren. 


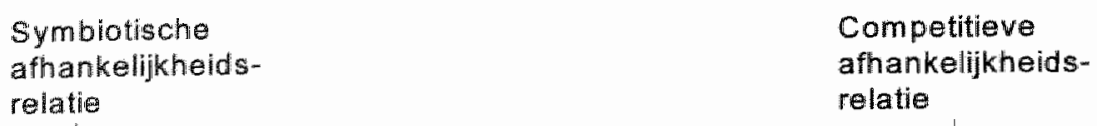

$\begin{array}{ll}\text { Symblotische } & \text { Competitieve } \\ \text { afhankelijkheids- } & \text { afhankelijkheids- } \\ \text { relatie } & \text { relatie }\end{array}$
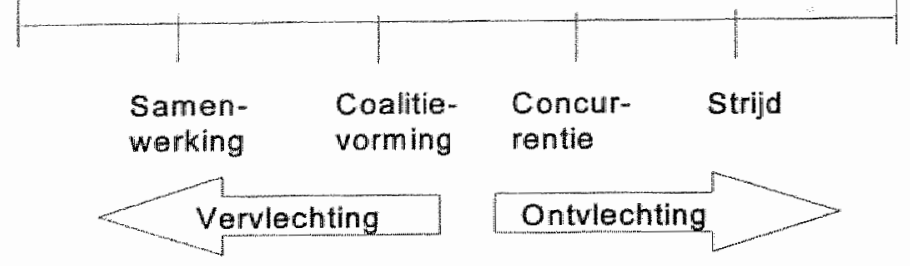

Collectiviteit

Individualiteit

Fig. 2.10 Afhankelikkheidsrelaties en de bijbehorende interactievormen, met routines als onderliggende dimensie

\subsubsection{Posities als schakel tussen systeem en structuur}

Een verzameling afhankelijkheidsrelaties noemen wij 'structuur'. 'Structuur' is niet synoniem aan 'systeem". Bij een systeem gaat het om zowel elementen (in ons geval handelende actoren) als hun relaties. Bij structuur gaat het om de relaties alleen (De Josselin de Jong, 1978). Dat laat onverlet dat actoren in het verschijnsel dat met 'structulur' wordt aangeduid een rol spelen, omdat hun handelen tot de verzameling relaties heeft geleid. Niettemin is de actor naar de zijlijn gemanoeuvreerd.

Met behulp van het begrip "positie' kunnen wij de actor uit de marge terughalen en aldus terugkeren naar 'systeem'. Een 'positie" is een plaats in de structuur die wordt bekleed door een actor. Een positie verbindt meerdere relaties. Het is een knooppunt. Van degene die een positie bekleed, wordt verwacht dat deze op een bepaalde manier handelt (Rademaker, 1978), bijvoorbeeld vastgesteld werk (een verzameling taken ofwel functie) verricht. Taken kunnen over meerdere actoren zijn verdeeld. Verdeling van die taken kan op zichzelf ook een taak zijn. Een andere taak kan zijn te zorgen dat de taken op elkaar worden betrokken (afstemming, coördinatie). lemand die een verzameling taken dient te vervullen noemen wij een functionaris. Een taak betreft datgene wat iemand móet doen, het werk dat moet worden verricht. Het begrip 'bevoegdheid' verwijst naar het recht bepaalde handelingen te verrichten, naar datgene wat iemand màg doen ${ }^{15}$.

Met structuur wordt dus een verzameling relaties bedoeld die het resultaat zijn van patroonsgewijze interacties (zie ook Giddens, 1979 en 198416). Omdat bij deze handelingen regels worden gebruikt, is structuur het resultaat van handelingen volgens

16 Volgens Giddens (1979) is een structuur both medium and outcome of the reproduction of practices". 
regels. Structuur en patroonsgewijs handelen vallen niet samen, structuur en regels evenmin.

"Positie" en "structuur" hebben niet alleen betrekking op relaties tussen individuele actoren. De begrippen betreffen ook relaties tussen verzamelingen van actoren, zoals organen binnen een organisatie of een netwerk, alsmede tussen netwerken die samen een netwerk kunnen vormen. Mintzberg (1979) onderscheidt de organen van een organisatie met behulp van vijf begrippen:

- strategische top ( "strategic apex'): de managers bovenaan de hierrarchie die zijn belast met de algehele verantwoordelijkheid voor de organisatie; zij moeten erop toezien dat de organisatie haar missie vervult;

- lijnmanagement ('middle line"): de managers onder de strategische top, die de top en de werkvloer met elkaar verbinden en gezag uitoefenen over de werkvloer;

- werkvloer ("operating core'): degenen die producten vervaardigen en diensten leveren;

ondersteunende staf ("Support staff): degenen die diensten vertenen (andere dan de diensten van de werkvloer) zoals "research and development' secretarieel en administratief werk;

- technostructuur ('technostructure'): betreft degenen die het werk van anderen moeten standaardiseren (regulariseren) en de organisatie helpen bij de aanpassing aan haar orngeving. Technostructuur en ondersteunende staf worden beide als 'staf' aangeduid.

Een verzameling organen noemt Mintzberg (1979, 1988) een configuratie. Hij onderscheidt de volgende vijf configuraties, waarvan mengvormen ('hybriden') denkbaar zijin:

Eenvoudige structuur (simple structure"): kenmerkend voor een configuratie met deze structuur (zoals "de bakker op de hoek") is dat het onderscheid in functies behorend bij de strategische top, het linmanagement, de ondersteunende star, technostructuur en werkvloer vaag is. De structuur is niet geëlaboreerd, er is nauwelijks sprake van specialisatie. De strategische top is het centrale orgaan, waarbinnen de macht (zie par. 2.5.4) is geconcentreerd. Vanuit de strategische top vindt toezicht plaats op de gebeurtenissen binnen de organisatie.

- Machine bureaucratie ('machine bureaucracy'): deze configuratie heeft de volgende kenmerken: zeer gespecialiseepde, repetitieve taken van de werkvloer. geformaliseende werkprocedures (nadruk op standaardisatie, in dit geval van werkprocessen) en communicatie, verregaande regulering, een uitgebreide staf, hiërarchische niveaus en gecentraliseerde macht. Een voorbeeld is de fietsenfabriek.

Professionele bureaucratie ('professional bureaucracy'): in deze configuratie (bijvoorbeeld het ziekenhulis) bestaat de werkvloer uit hoog opgeleide professionals die de zeggenschap over de eigen werkzaamheden hebben. De macht is derhalve geconcentreerd op de werkvloer. De overeenkomst met de voorgaande configultatie betreft de nadruk op standaardisatie (standaardisatie van vaardigheden, die vooral tijdens de opleiding wordt gerealiseerd) en specialisatie.

- Divisiestructuur ('divisionalized form'): een configuratie met deze structuur (zoals McDonalds) bestaat uit een aantal quasi-autonome eenheden of organisaties (bureaucratieën), die aan elkaar zijn gekoppeld door een centrale besturingsstructuur. Aan standaardisatie (in dit geval standaardisatie van het product) wordt veel aandacht besteed. Binnen elke divisie is de macht geconcentreerd bij het lijnmanagement. 
- Adhocratie ("adhocracy"): deze configuratie komt onder andere voor in de fuchtvaartindustrie en is bij uitstek bedoeld om innovaties tot stand te brengen. Binnen een adhocratie, door Mintzberg ook aangeduid als 'project structure', worden professionals vanuit verschillende disciplines bijeen gebracht in gespecialiseerde 'creative teams'. Deze teams of projectgroepen moeten vocr de beoogde innovaties zorg dragen. Veelal gaat het om tijdelijke teams die een afgebakende opdracht moeten uitvoeren ('task forces'). Afstemming tussen de betrokkenen wordt vooral door overleg gerealiseerd. Kenmerkend voor de adhocratie is verder dat de macht niet is geconcentreerd bij de strategische top. maar is verspreid over de organisatie. In het bijzonder is macht gedelegeerd naar de teams. Afhankelijk van het type configuratie wordt de werkvloer wel ("operating adhocracy') of niet ('administrative adhocracy') tot de adhocratie gerekend. In de 'administrative adhocracy' wordt de werkvloer bijvoorbeeld uitbesteed aan andere organisaties.

Bij Mintzberg hebben deze configuraties betrekking op organisaties, niet op netwerken van organisaties. Zij zijn echter ook bruikbaar voor de bestudering van netwerken (zie Mur-Veeman en Tijssen, 1992).

\subsubsection{Context: macht (asymmetrische afhankelijkheidsrelaties)}

In de relaties als product van patroonsgewijze interacties waarover wij hier spreken, is altijd sprake van macht. Dit is het geval omdat actoren middelen nodig hebben om te kunnen handelen zoals zij dat nodig of wenselijk vinden, en juist met anderen imteracteren om die middelen te verkrijgen. Macht heeft alles met middelen te maken. Degene die over middelen beschikt of toegang tot middelen heeft, heeft macht over degene die daaraan behoefte heeft (Emerson, 1962)17. Van macht kan in meerdere of mindere mate sprake zijn.

Afhankelijkheid is veelal asymmetrisch. Tussen afhankelijke actoren bestaat dan machtsverschil. De ene actor in de afhankelijkheidsrelatie is dominant, de andere is ondergeschikt. Afhankelijkheidsrelaties hoeven in theorie niet altijd asymmetrisch te zijn. Het is denkbaar dat tussen twee actoren in een relatie machtsevenwicht bestaat: beiden hebben dan exact evenveel macht (symmetrisch). Er is nog een tweede type symmetrische relaties: machtsvrije relaties. Daarvan kan naar ons inzicht geen sprake zijn. Symmetrische relaties laten wij verder buiten beschouwing.

De mate van asymmetrische afhankelijkheid wordt bepaald door het belang van de middelen (centraliteit ofwel 'essentiality') voor de actor die de middelen wil hebben, alsmede door de aan- of afwezigheid van alternatieve middelen waarop deze actor een beroep kan doen (substitueerbaarheid ofwel 'substitutability'; Jacobs, 1974).

Afhankelijkheidsrelaties (asymmetrisch, symbiotisch of competitief) zijn niet statisch. Doordat bijvoorbeeld de behoefte aan middelen of het belang van middelen kan wijzigen, is de mogelijkheid tot dynamiek en verandering in de relaties altijd aanwezig.

17 In de literatuur (zie bijwoorbeeld Hanf en Scharpf, 1978) wordt weleens onderscheid gemaaki tussen machtsbronnen en machtsmiddelen. "Machtsbronnen" verwijst dan naar de herkomst wan 'machtsmiddelen'. Wij nemen dit onderscheid niet over, omdat het onderscheid betrekkelijk is. Zo kan het gegeven dat actor $A$ toegang heeft tot een machtsbron, door hem worden gebruikt als middel om actor B te laten handelen zoals actor $A$ dat will. 


\subsubsection{Macht, dwang en gezag}

'Macht' is hier verbonden aan 'relatie", al was thet alleen maar omdat afhankelijkheid van middelen via interacties resulteert in relaties. De onderlinge verbondenheid van macht en relaties was reeds bij Weber zichtbaar. Weber (1976) omschrijft macht als "jede Chance, innerhalb einer soziallen Beziehung den eigenen Willen auch gegen Widerstreben durchzusetzen, gleichviel worauf diese Chance beruht". Macht is een gelegenheid, een kans. Macht kan binnen een rellatie worden uitgeoefend. Machtsuitoefening noemen wij sturing. Macht heeft in deze studie betrekking op handelingsruimte. Bezit van (of toegang tot) middelen maakt het voor de dominante actor, als deze dat will, mogelijk de ondergeschikte actor de gelegenheid te geven of te ontnemen tot handelen, bijvoorbeeld op een manier die de laatste wenselijk of noodzakelijk vindt.

Macht kan worden onderverdeeld in dwang en gezag. Van dwang of gezag kan eveneens in meerdere of mindere mate sprake zijn. Uitgaande van Webers definitie kan de ene actor aan de ander de eigen wil opleggen met of zonder de medewerking van de ander. Dit laatste ('zonder medewerking') is het uitoefenen van dwang. De eerste mogelijkheid is het uitoefenen van gezag. Gezag is macht die als redelijk en juist wordt aanvaard (zie Rademaker, 1978), met andere woorden 'legitieme macht'.

Ook bij macht moet naar ons inzicht aandacht worden besteed aan 'betekenis' en 'routine'. Macht is een verschijnsel dat voor het handelen pas gevolgen heeft, als een actor daaraan op basis van zijn routines de betekenis "macht" heeft gegeven. Deze uitspraak kan worden geillustreerd aan de hand van 'gezag', dat wij hebben omschreven als macht die als redelijk en juist wordt aanvaard. 'Redelijk en juist" zijn beoordelingen en beoordeling is een van de twee kanten van betekenis (zie par. 2.5.1).

Betekenisgeving vanuit routines verdient bij zowel dwang als gezag aandacht in het geval van de dominante actor. Indien de dominante actor zich niet dominant acht, dan zal hij ook niet als zodanig handelen. Deze uitspraak vloeit voort uit het interactionistische standpunt dat betekenis het uitgangspunt voor handelen is. Bij dwang, dat de gedachte oproept aan het gebruik van fysiek of verbaal geweld, doet de betekenis van de relatie met de dominante actor voor de ondergeschikte niet ter zake, omdat de dominante actor zonder medewerking van de ondergeschikte zijn eigen wil kan opleggen. De dominante actor hoeft geen rekening te houden met wat de ondergeschikte wan de gang van zaken vindt.

Anders ligt dit voor gezag. In dat geval is ook de betekenis die de ondergeschikte aan de relatie geeft van belang. Indien deze actor zich niet ondergeschikt acht, dan zal hij ook niet handelen alsof hij ondergeschikt is. Hii zal zich door de actor die zichzelf als dominant beschouwt, niet diens will laten opleggen.

Dit laatste kan ook het geval zijn als een actor zich wèl ondergeschikt acht, maar de handelingen die de dominante actor van hem verwacht -op grond van zijn routinesvolstrekt onaanvaardbaar vindt. Hij zal niet doen wat de dominante actor will, zelfs niet indien hij alleen daardoor de middelen kan krijgen waaraan hij behoefte heeft. De handelingsruimte die de dominante actor biedt, wordt dan niet benut voor de handelingen die hij verlangt.

In deze en andere gevallen waarin degene die zich ondergeschikt acht wordt geconfronteerd met wensen ten aanzien van handelingen die hij niet juist vindt, zal hij een afweging maken. Deze kan ertoe leiden dat de ondergeschikte toch doet wat de dominante will, bijvoorbeeld uit vrees voor straffen of omdat hij op deze manier middelen krijgt waarmee hij handelingen kan verrichten die hij belangrijker vindt. Met betrekking tot het laatste kan worden gedacht aan werknemers die bereid zijn onaangename arbeid te verrichten omdat zij daardoor in staat zijn in hun levensonder- 
houd te voorzien of met hun collega's op te trekken. Het is ook mogelijk dat de ondergeschikte gevolg geeft aan de wensen van de dominante actor, omdat gehoorzamen strookt mel zijn routines. Deze voorbeelden betreffen enkele van de denkbare mogelijkheden.

Het gegeven dat het uiteindelijk de ondergeschikte is die bepaalt of volgens de wensen van de dominante actor wordt gehandeld, geeft aan asymmetrische alhankelijkheid bij gezag (bij dwang valt voor de ondergeschikte niets te bepalen) het karakter van wederkerigheid. De dominante actor en de ondergeschikte hebben bij gezag beiden macht, waardoor eenileder eisen kan stellen. Zo kan de ondergeschikte eisen dat de dominante actor van de middelen waaraan de eerste behoefte heeft, meer beschikbaar stelt.

Deze wederkerige afhankelijkheid leidt ertoe dat de dominante actor en de ondergeschikte actor, vooropgesteld dat zij iets van elkaar willen, onderling tot een vergelijk moeten zien te komen indien de ene de eisen van de ander niet wenst in te willigen of omgekeerd. Zij moeten trachten tot een resultaat te komen dat voor beiden misschien niet optimaal kan zijn, maar toch aanwaardbaar is ("satisficing": Simon, 1957; zie par. 2.5.2.2).

Blijven beiden elkaars wensen onaanvaardbaar winden, dan zal geen van hen doen of toestaan wat de ander wil. De noodzaak te komen tot een vergelijk wordt weergegeven door het begrip 'negotiation': "the process of give-and-take, of diplomacy, of bargaining" (Strauss et al, 1963). Het langs de weg van "megotiation" bereikte vergelijk ("sociale ordle") heeft geen eeuwigheidswaarde. Sprekend over ziekenhuizen wijzen Strauss et al (1963) erop dat contracten, overeenkomsten, verstandhoudingen en regels, die aan de basis liggen van de sociale orde (opgevat als 'concerted action') niet voor altijd gelden. In de organisatie kunnen zich allerlei gebeurtenissen voordoen zoals de komst van een nieuwe actor, invoering van een nieuwe technologie of contractbreuk , die aanleiding zijn tot nieuwe onderhandelingen. Deze op hun beurt resulteren in verandering van de sociale orde. De orde wordt voortdurend gevestigd, vernieuwd, herzien en herroepen. In het geval van gezag is de sociale orde een 'negotiated order'.

In theorie is het mogelijk dat 'dwang' zich voordoet. Dwang is de meest extreme vorm wan macht. Gebruik van geweld hebben wij met betrekking tot de onderzochte netwerken niet waargenomen. Overzicht 2.1 geeft de verschillen weer tussen dwang en gezag.

Ontstaat een 'negotiated order', dan houdt deze veranderingen in de situatie in, naar de wensen van de dominante actor toe. Er vindt een 'pull' (Mintzberg, 1991) plaats, bijvoorbeeld op zich ontwikkelende configuraties, in de richting van de routines van de dominante actor. Overigens zijn Mintzberg's 'pulls' (en "forces') niets anders dan handelingen en interacties gedurende welke actoren vormgeven aan hun situatie.

\subsubsection{Macht en regels}

De kans die macht volgens Weber is, kan op uiteenlopende middelen zin gebaseerd. In principe kan alles aan de actor macht verschaffen. Zo ook regels. Toegang tot financiering bijvoorbeeld is in het Nederlandse stelsel voor de zorgsector in regels vastgelegd. Deze regels kunnen zelf een machtsmiddel zijn. In de gezondheidszorg zijn regels juist een zeer belangrijk machtsmiddel. Gebruik van erkenningsregels heeft er bijvoorbeeld lange tijd voor gezorgd dat thuiszorginstellingen een monopoliepositie konden innemen (zie Massop et al, 1991). Verder worden in systemen zoals organisaties bevoegdheden van actoren vastgelegd. In het geval van superieuren 
wordt afgesproken dat zij macht hebben. Deze afspraken zinn in regels omschreven. Veranderen de gebruikte regells, dan verandert de vastgelegde macht.

Overzicht $2.1 \quad$ Verschillen tussen dwang en gezag als vormen van macht

\begin{tabular}{|c|c|c|}
\hline \multicolumn{3}{|c|}{ Manht (meer-minder: } \\
\hline & (meer-mindery & Gezag (meer-minder) \\
\hline- & $\begin{array}{l}\text { de dominapte actor kan zino whopleggen zonder } \\
\text { medewerking van de ondergeschikte }\end{array}$ & $\begin{array}{l}\text { medewerking van de ondergeschikte is nodig opdat } \\
\text { de dominante actor zin ziri kringt }\end{array}$ \\
\hline - & $\begin{array}{l}\text { de betekenis van de relatie voor de dominante actor } \\
\text { is wan belang, de betekenis voor de ondergeschikte } \\
\text { niet }\end{array}$ & $\begin{array}{l}\text { de betekenis wan de relatie voor de dominante actor } \\
\text { en de ondergeschilete is varh belang }\end{array}$ \\
\hline- & $\begin{array}{l}\text { geen wederkerigheid, de ondergeschikte heeft in de } \\
\text { relatie geen enkele macht }\end{array}$ & $\begin{array}{l}\text { wederkerigheid, de dominante actor em de onderge. } \\
\text { schikte hebben in de retatie beiden mecht }\end{array}$ \\
\hline- & geen 'negotiated order' & $\begin{array}{l}\text { "negotiated order', gericht op een aanaardbare } \\
\text { silualie voor de dominante actor ent de ondergeschik* } \\
\text { te }\end{array}$ \\
\hline
\end{tabular}

\subsubsection{Sturing (machtsuitoefening)}

Actoren in netwerken, dominant of ondergeschikt, zijn geneigd hun afhankelijkheden zodanig te reguleren (Godfroij, 1981) of te modificeren (Blau, 1964; zie Hanf en Scharpf, 1978) dat de door hen gepercipieerde afhankelijkheidssituatie in overeenstemming is met de door hen gewenste situatie (zie ook Mijs, 1987).

\subsubsection{Object van sturing}

Actoren voor wie de gepercipieerde actuele situatie een wenselijke is, zullen trachten deze te handhaven. Actoren daarentegen voor wie deze situatie niet wenselijk is, zullen proberen deze te veranderen. Streven naar handhaving of verandering kan betrekking hebben op de situatie als geheell of op onderdelen daarvan.

Voorstanders van veranderingen zullen trachten regels in te voeren die bij gebruik ervoor zorgen dat handelingen verlopen volgens een patroon dat zij wenselijk of noodzakelijk vinden. Omdat relaties de resultante zijn van patroonsgewijze interacties, leidt gebruik van dergelijke regels ook tot veranderingen in relaties. Tegenstanders van veranderingen zullen trachten de handelingsregels die in gebruik zijn te handhaven en invoering van nieuwe regels te voorkomen. ledere voorstander van verandering is geneigd handelingsregels op te stellen die aansluiten bij de eigen routines. Afhankelijk van hun routines kunnen actoren verschillende regels nastreven. Dit kan leiden tot conflicten (vgl. Burns en Flam, 1987).

Handhaving of verandering van handelingsregels is in onze studie hét object van sturing. Omdat het hier gaat om handelingen binnen asymmetrische, wederkerige afhankelijkheidsrelaties (dwang hebben wij niet waargenomen), is een actor niet zomaar in staat de eigen wensen te verwezenlijken. Indien hij in zijn relatie met een ander bijvoorbeeld een nieuwe handelingsregel wil gebruiken, dan zal die andere met de regel akkoord moeten gaan. Zo niet, dan zal de nieuwe regel niet worden gebruikt. 
Deze gang van zaken is een cruciaal voorbeeld van de wederkerigheid die wij bij onze bespreking van gezag aan de orde hebben gesteld.

Wanneer een regel is geaccepteerd, dan behoeft dat niet voor onbepaalde tijd te zijn. Eenmaal in gebruik kan een regel bijwoorbeeld voor een actor onvoorzien tot onacceptabele afhankelijkheid leiden. De regel kan dan opnieuw ter discussie komen te staan. Dynamiek en verandering voeren ook hier de boventoon.

Gegeven de beschreven afhankelijkheid zal de ene actor de ander ertoe moeten aanzetten te doen wat de eerste wil. Hij moet in zijn interactie met de ander de macht uitoefenen waarover hij beschikt. Hij moet sturen. Interacties waarbinnen wordt gepoogd te sturen noemen wij sturingsinteracties. Alle interacties in deze studie zijn sturingsinteracties. In de betekenis van de situatie ligt voor de actor de aanleiding tot sturing $^{18}$.

Ons baserend op uitspraken van Pröpper en Herweijer (1992) zouden wij sturing ofwel machtsuitoefening kunnen beschouwen als handelingen door actoren om anderen doelgericht zodanig te beïnvloeden, dat zij bereid zijn te handelen conform de wensen van de eersten. Het is deze omschrijving die ons ertoe heeft gebracht sturing als 'machtsuitoefening' te beschouwen. Of anderen daadwerkelijk handelen conform de wensen van actoren en dat bovendien doen ten gevolge van de handelingen van deze actoren, valt buiten de reikwijdte van deze omschrijving. Echter, naar ons inzicht oefenen actoren juist macht uit om te bereiken dat anderen als gevolg daarvan daadwerkelijk doen wat de eersten willen. Bereiken zij dit, dan hebben zij vollgens Pröpper en Herweijer (1992) invloed. Wij reserveren het begrip 'sturing" voor die gevallen waarin blijkt dat actoren deze invloed hebben. Op alle andere gevallen is het begrip 'poging tot sturing" van toepassing (zie verder par. 2.5.5.2).

ledereen die over machtsmiddelen beschikt, kan sturingspogingen ondernemen. Wij gaan er derhalve vanuit dat het in situaties altijd mogelijk is dat meerdere actoren sturingspogingen doen. Dit is al een aanwijzing dat bij onderzoek naar sturing de interactiebenadering de meest geëigende is (zie par. 1.3). Sturingspogingen kunnen zich over en weer voordoen tussen twee of meer actoren. Pogingen tot tegensturing kunnen volgen op sturingspogingen. Dit kan van een netwerk een verschijnsel maken, waarbinnen het bruist van activiteit. Gebaseerd op de typen middelen die een actor macht verschaffen, kunnem de volgende vormen van sturing worden onderscheiden (Pröpper en Herweijer, 1992; Mur-Veeman en Van Raak, 1996):

juridische sturing: sturing op basis van wetten en andere handelingsregels die de overheid heeft ingevoerd (wet- en regelgeving);

- economische sturing: sturing op basis van geld, cliënten, personeel, faciliteiten. informatie et cetera;

- organisatorische sturing: sturing op basis van handelingsregels die voor een netwerk of verzameling netwerken zijn ingevoerd; communicatieve sturing: sturing op basis van uitwisseling van argumenten, overtuigingskracht en door overreding.

18 Behoefte aan middelen wan anderen als aanleiding voor interacties (zie par. 2.5.3.1) is niet iets anders dain deze aanleiding tot sturing. Om situaties te kunnen handhaven of veranderen zijn immer handelingen nodig. Handelingen vereisen altijd middelen. Alles kan een middel zilln. Omdlat in situaties per definitie meerdere actoren zijn betrokken, is altijd de medewerking van anderen nodig om de situatie te wijzigen of in stand te houden. Dit maakt dat het vermogen van een actor tot medewerking aan een van beide opties voor hem een middel is. De inzet van sturingsinteracties is dan het verkrijgen van deze medewerking, dus van hel middel. 
Actoren kunnen bestuurders en/of bestuurden zijn. Een bestuurder zendt stuurders (stuursignalen) uit. Dit zijn alle mogelike (verzamelingen van) tekens die worden gebruikt om de ander te beïnvloeden. Zij kunnen verbaal of nonverbaal zijn. Te denken valt aan woorden, lichaamsbewegingen en gelaatsuitdrukkingen. Sturing en sturingspogingen impliceren altijd een of andere vorm van verbale of nonverbale communicatie. Communicatie kan namelijk.worden omschreven als het overbrengen via een medium van een boodschap door zenders aan ontvangers (Rademaker. 1978).

Een bestuurder (verzender) is degene die een stuurder verzendt ofwel een poging tot sturing doet. Een bestuurde (ontvanger) is degene voor wie de stuurder is bestemd, op wie de poging is gericht. Sturingspogingen kunnen binnen het netwerk plaatsvinden. maar ook vanuit de omgeving. Juist de vraag wie de poging onderneemt cen actor binnen het netwerk of erbuiten) is interessant. Een bestuurde kan op zijn beurt naar de bestuurder een stuurder verzenden. De bestuurde wordt dan de bestuurder en omgekeerd. Wij noemen de werzender een bestuurder en de beoogde ontvanger de bestuurde, ongeacht of een stuurder wel of niet is ontvangen en of een sturingspoging wel of niet is geslaagd.

Een 'stuurder" mag niet worden opgevat als de stimulus die rechtstreeks tot de response 'handelen' leidt. Actoren ontvangen de stuunder, geven er betekenis aan, trekken conclusies over de mogelijke gevolgen wanneer zij al dan niet zouden handelen conform de gepercipieerde inhoud van de stuurder, wegen deze gevolgen af en gaan dan pas over tot handelen (of juist niet).

\subsubsection{Patroon van sturingsinteracties}

Sturing is hier een proces dat verloopt volgens een interactiepatroon van these (stelling), antithese (tegenstelling) en synthese (samengestelde eenheid). De ene actor stelt bijvoorbeeld voor een netwerk op te richten (these), een of meer andere actoren reageren daarop met besprekingen, commentaar, aamvulingen of een tegenvoorstel (antithese), waarna een besluit volgt (synthese, waarbinnen bijvoorbeeld een mengeling van voorstellen en reacties herkenbaar kan zijn), zoals het besluit het netwerk daadwerkelijk op te richten. These en antithese zijn stuurders. De synthese sluit het patroon af, het besluit is de -al dan niet voorlopige- afronding van de sturingsinteracties. De synthese in deze studie zijn uitsluitend besluiten tot oprichting en opheffing van netwerken en besluiten tot invoering of annuleren van handelingsregels. Gedurende processen van vervlechting en ontvlechting kunnen patronen van these, antithese en synthese worden waargenomen.

De oprichting en opheffing van netwerken vinden hun aanzet bij sturing. Het besluit tot bijvoorbeeld de formering van een netwerk omvat namelijk een opdracht. Opdrachten zijn handelingsregels. Met behulp van een stuurder wordt de opdracht aan een actor medegedeeld19. Het is natuurlijk de bedoeling dat de actor de opdracht vervolgens uitvoert. De regel moet bij diens handelen worden gebruikt. Hier eindigt de sturing en begint het handelen volgens regels.

Omdat wij ervan uit giaan dat meerdere actoren stuurders verzenden, staat naar ons inzicht het resultaat van sturingspogingen niet bij voorbaat vast. Het resultaat kan afwijken van hetgeen de bestuurder wenste. Boudon (1981) spreekt van 'spontane effecten". Ook achten wij het resultaat van de sturing niet in zijn geheel herleidbaar tot 
de afzonderlijke sturingspogingen van individuele actoren. Zelfs wanneer een besluit volledig correspondeert met het voorstel van een bepaalde actor, dan nog kan deze synthese niet uitsluitend als resultaat worden beschouwd van de sturingspoging van deze ene actor. Om het voorstel te doen heeft de actor bijvoorbeeld informatie verzameld of zich laten inspireren door anderen "die stuurders verzonden. Ook kan een voorstel zijn veranderd na reacties van anderen. Diverse betrokkenen hebben dan een bijdrage geleverd. Daarom beschouwen wij 'sturing' als resultaat van sturingspogingen van meerdere actoren en in geen geval als resultaat van sturingspogingen door éen actor. Om deze reden zeggen wij niet dat een actor heeft gestuurd, maar een sturingspoging heeft gedaan.

Mensen die met elkaar interacteren verplaatsen zich in gedachten steeds in elkaars omstandigheden Dit is volgens Mead (1934) nodig om elkaars bedoelingen en elkaars vermoedelijke reacties op het komende gedrag te achterhalen. Vertaald naar sturing betekent dit dat een bestuurder zich moet kunnen verplaatsen in de omstandigheden waarin de bestuurde verkeert. Wil zijn paging tot sturing kans van slagen hebben, dan moet hij zien te achterhalen welke betekenis de bestuurde aan de stuurder zal geven. De betekenis van de stuurder voor de bestuurde hoeft niet zonder meer overeen te komen met de betekenis voor de bestuurder, zij kan daarvan afwijken. Zeker wanneer de bestuurder niet is ingewijd in de routines van de bestuurde, bestaat de kans op afwijking. Sturingspogingen kunnen alleen al op grond daarvan mislukken.

\subsubsection{Handelingsregels}

Volgens Blumer (1974) geven actoren elkaar tijdens hun interacties aanwijzingen voor het handelem. Burns en Flam (1987) noemen deze aanwijzingen 'regels'. Het zijn Burns en Flam, van wie wij de uitspraak hebben overgenomen dat bij handelingen regels worden gebruikt. Regels zijn verzamelingen van talige tekens die voorschrijven welke handelingen zijn vereist, verboden of toegestaan (gebaseerd op Ostrom, 1991; Shimanoff, 1980). Zij zijn bedoeld om bij het handelen te worden gebruikt.

Regels die worden gebruikt, geleiden het handelen. Regels behoren tot de taal, kunnen geschreven of ongeschreven Zijn. Zij krijgen betekenis gedurende interacties en worden tijdens interacties gemaakt en veranderd. Regels en hun betekenissen worden tijdens interacties aangeleerd (vgl. Burns en Flam, 1987). Actoren maken bij het handelen keuze uit meerdere van deze aangeleerde regels. Zij verwachten van elkaar dat zij handelen in overeenstemming met de regels.

Strikt genomen handelen actoren niet volgens de regels, maar volgens de betekenis die zil aan deze regels verbinden. Dit is een cruciaal uitgangspunt. Niet een regel op zich, maar de betekenis ervan is voor de actor de basis voor het handelen. Wanneer wij hierna spreken over 'handeien volgens regels' dan bedoelen wij daarmee 'handelen volgens de betekenis van regels'.

Regels geven niet alleen aan hoe moet worden gehandeld, maar ook welke actor in welke positie wát mag of moet doen. Gebruik van handelingsregels leidt tot ontwikkeling van de relaties waarbinnen zij worden gebruikt. Door de handelingen waarbij deze regels worden gebruikt ontstaan en veranderen situaties, relaties
netwerken en configuraties. Taken en bevoegdheden geraken bijvoorbeeld over actoren verdeeld. Zij gaan bepaalde functies vervullen. Tussen de netwerken in een configuratie kunnen afhankelijkheidsrelaties ontstaan, waarbinnen het ene netwerk een dominante of ondergeschikte positie inneemt ten opzichte van het andere, of 
omgekeerd en waarbinnen actoren gaan handelen. Relaties, netwerken en conflguraties kunnen door handelingen weer verdwijnen.

\subsubsection{Regels en routines}

Vergelijking van de definitie van regels met onze uitspraken over routines laat zien hoezeer regels en routines verwant zijn. Desondanks beschouwen wij regels en routines niet als synoniem, om de volgende reden. Regels zijn geworteld in routines en worden ontwikkeld en ingevoerd als gevolg van sturingsinteracties. Ondanks deze worteling zijn regels niet altijd de weerspiegeling van routines van individuele actoren. Regels kunnen het spontane effect ziln van sturingsinteracties, welk effect niet door een individuele bestuurder behoeft te zijn beoogd.

Regels zijn bedoeld om het handelen te vereenvoudigen. Een actor weet dankzij de betekenis van regels ongeveer hoe te handelen in bepaalde omstandigheden. De actor hoeft daardoor geëigende handelwijzen niet steeds opnieuw uil te vinden. Ook maken regels het verloop van interacties voor de betrokken actor enigszins voorspelbaar en beheersbaar. Onzekerheden worden daardioor gereduceerd. Onzekerheden in het bestaan zijn volgens. Burns en Flam (1987) problematisch voor een actor. Reductie van onzekerheid is voor hem belangrijk. Dit geldt bijvoorbeeld voor managers binnen een organisatie, die besluiten moeten nemen met gevolgen voor hun eigen systeem (zie Aldrich en Mindin, 1978). Regels zijn hulpmiddelen, instrumenten voor het handelen. Gebruik van nieuwe regels kan leiden tot veranderingen in routines.

\subsubsection{Regels en volgzaamheid}

Actoren kunnen handelen volgens bepaalde regels ("volgzaamheid"), maar kunnen dit ook nalaten. Volgzaamheid is afhankelijk van drie factoren (Burns en Flam, 1987). Allereerst is daar de betekenis van regels. Regels zijn nooit zó specifiek en eenduidig dat altijd volledig vast staat hoe een actor moet handelen. Regels zijn bovendien in ontwikkelling. Zij raken pas in de loop van de tijd uitgekristalliseerd. Zelfs wanneer regels klaar zijn, is sprake van onduidelijkheden, inconsistenties en tegenstrijdigheden. Verder moeten actoren de betekenis van regels nog aanleren. Bovendien kunnen actoren met verschillende routines andere betekenissen aan een en dezelfde regel geven en is het magelijk dat dezelfde regel woor dezelfde actoren in een andere situatie een andere betekenis krijgt.

Kortom, de betekenis van een en dezelfde regel kan in de tijd, van de ene situatie tot de andere en van de ene actor tot de andere variêren. Er is altijd ruimte voor andere betekenissen. De betekenis van regels is een cruciale factor voor een handelingsverloop. Wordt bijvoorbeeld de betekenis die de wetgever verbindt aan een door hem geformuleerde wet niet gedeeld door de leden van de gemeenschap, wairvoor die wet bedoeld is, dan leidt dit tot verwarring. De leden weten dan niet welke handelingen wolgens de wetgever vereist, toegelaten of verboden zijn. Het is daardoor niet mogelijk het handelen van deze leden te verklaren vanuit de betekenis die de wetgever aan de wet verbindt.

De tweede factor is de motivatie, die aan het gedrag van actoren ten grondslag ligt (zie par. 2.5.2.2). Een actor kan intrinsiek gemotiveerd zijn te handelen conform een regel. De actor is dan overtuigd van het belang te handelen overeenkomstig de regel omdat dit handelen correspondeert met de handelingen die volgens zijn routines wenselijk of noodzakelijk zijn. Een actor zal meer geneigd zijn conform regels te handelen naarmate voorgeschreven handelingen meer met zijn eigen routines overeen stemmen. 
Een actor kan ook extrinsiek gemotiveerd zijn te handelen volgens een regel. Dit gebeurt via beloning (toekenning van middelen) en straf (ontzegging of afneming van middelen). Deze vorm van motivering heeft te maken met de uitoefening van macht.

Intrinsieke motivering kan het resultaat zijn van extrinsieke motivering. Het is mogelijk dat interacties tussen actoren met verschillende routines gaandeweg leiden tot cultuurverandering. Dit is echter niet zonder meer het geval. Zeker ten aanzien van het effect van beloningen en straffen op intrinsiake motivering zijn de meningen in de literatuur verdeeld. Elias (1982) hing de stelling aan dat 'Fremdzwang' leidt tot 'Selbstzwang'. Onderzoekers, geinspireerd door Festinger's 'A theory of cognitive dissonance' (1957; zie Ott, 1989) en Skinner's 'Science and behavior' (1953; zie Ott, 1989) stelden dat door strategieen zoals belonen en straffen gedrag kon worden veranderd. Echter, Ott (1989) wijst erop dat gedragsverandering nog niet hoeft te leiden tot verandering van culturur. Met andere woorden, wanneer routines onveranderd zijn, kan een actor weer in zijn oude gedrag vervallen, zodra beloningen en straffen achterwege blijven.

Routines kunnen in een en dezelfde situatie tegenstrijdige eisen stellen aan actoren. Dit is de derde factor. Het is mogelijk dat een actor een regel volgt in overeenstemming met de ene routine, hoewel deze handelwijze indruist tegen een van zijn andere routines. De actor moet een keuze maken tussen conflicterende opties. Volgens ons actorperspectief is hij tot keuze in staat.

Routines kunnen niet alleen leiden tot 'innerlijke conflicten' bij een individuele actor, maar ook tot conflicten tussen verschillende actoren. Indien actoren in een netwerk bijvoorbeeld starten met interactie, dan hebben zij behoefte aan regels volgens welke de interacties zodanig zullen verlopen, dat hun doelen kunnen worden bereikt. Hun voorkeur gaat uit naar regels die zoveel mogelijk hun eigen routines weerspiegelen. Ze moeten gewenste handelingen en interacties mogelijk maken en ongewenste verhinderen. Wanneer die regels er niet zijn, dan zullen actoren ze gaan ontwikkelen. Echter, indien de routines van de diverse betrokken actoren onderling verschillen, kunnen tijdens de ontwikkeling en toepassing van regels allerlei keuzevraagstukken, discussies, ruzies en conflicten ontstaan.

Conflicten kunnen resulteren in het afbreken van de interactie. Echter, meestal is het resultaat hetgeen Goffman (1959) 'working consensus' noemt: een ad hoc tot stand gebrachte overeenkomst tussen interactiepartners die voorlopig de woortgang van de interactie garandeert. Strauss et al (1963) zouden spreken over een 'negotiated order'. Sociale orde is steeds precair. Er is niet veel nodig om de overeenkomst te verstoren en het proces van onderhandelen opnieuw te doen beginnen.

\subsubsection{Verklaring van handelingen volgens regels}

Het voorgaande toont dat regels in onze optiek belangrijk zijn voor handelingen en daaruit voortvloeiende veranderingen. Echter, uit bijvoorbeeld de opmerking dat regels die niet worden gebruikt, 'dode letters zijn' (zie par. 2.4.2), wordt duidelijk dat regels op zichzelf niet leiden tot veranderingen in structuur, cultuur en macht. Een regel is een instrument. Het is het gebruik tijdens het handelen van dit instrument, dat bijvoorbeeld voor veranderingen zorg draagt, niet het instrument zelf.

Gezien het belang van het gebruik van regels is nader inzicht in de achtergrond daarvan waardevol. Het is daarbij weliswaar noodzakelijk vast te stellen dát volgens regels wordt gehandeld (of niet) "maar dit inzicht alleen is niet toereikend. Om het verloop van handelingen als motor van veranderingen daadwerkelijk te begrijpen, is het noodzakelijk te weten waaróm actoren regels al dan niet gebruiken. 
Interactionistisch onderzoek is 'verstehend' onderzoek. Om handelingen te begrijpen, moet worden gezocht naar de motivering van actoren. Handelen is volgens Weber namelijk gedrag op basis van een motief. Dit geldt evenzeer voor handelingen volgens regels. Bepalend voor handelingen is niet de regel zelf, maar de motivatie van actoren de regel wel of niet te gebruiken. Voor verder inzicht moeten we zoeken naar de diepere betekenis van de handelingsregels voor de actoren. Het gaat erom vast te stellen of de actoren wel of niet gemotiveerd zijn de regels te gebruiken, tegen de achtergrond van de betekenis die de situatie -welke ontstaat bij gebruik van deze regels-voor hen heeft.

Wij bestudeerden de gegevens met behulp van twee verklaringen. De eerste verklaring heeft betrekking op intrinsieke motivatie: actoren handelen wolgens de regels omdat deze handelingen overeenkomen met de handelingen die volgens hun routines wenselijk of noodzakelik zijn. De tweede verklaring betreft extrinsieke motivatie en luidt dat actoren handelen volgens de regels omdat zij dat moeten doen van een dominante actor, die daarvoor de benodigde ruimte verschaft. De twee verklaringen hangen nauw samen. Routines spelen namelijk in beide een rol. Ons standpunt is derhalve dat in de uiteindelijke verkllaring routines van doorslaggevende betekenis zijn.

\subsection{Vierde opbouwfase van de theorie: beschrijving van de relaties tussen concepten}

$\mathrm{Na}$ bovenstaande bespreking kan onze theorie worden 'voltooid'20. Dit gebeurt door de relaties aan te geven tussen de concepten waarmee de bestudeerde verschijnselen worden aangeduid. Op veel plaatsen in par. 2.5 is dit reeds gebeurd.

Het voorgaande vormt het geheel, waarvan de concepten en hun relaties die in het empirische gedeelte van dit verslag aan de orde komen, een deelverzameling zijn (zie Fig. 2.11, gebaseerd op Fig. 2.7). Een conceptueel raamwerk, zoals weergegeven in Fig. 2.11, is op zichzelf al een vereenvoudigde weergave van de werkelijkheid. Niettemin zijn ook daarbinnen meer relaties aan te geven dan in de figuur is gebeurd. Het raamwerk beperkt zich echter tot die relaties die met het oog op onze probleemstelling het meest van belang ziljn.

In Fig. 2.11 worden het verloop van de bestudeerde gebeurtenissen en de relaties tussen de verschijnsellen die met behulp van onze concepten zijn aangeduid, door genummerde pijlen weergegeven. Belangrijk is de handelende actor als element in een systeem. Actoren zijn individuen en verzamelingen van individuen, zoals organisaties of beroepsgroepen. Zij bevinden zich bimnen en buiten een netwerk. De opeenvolging van gebeurtenissen en de veranderingen in de verschijnselen die door de concepten worden aangeduid, verlopen door handelingen van actoren via processen van interpretatie en betekenisgeving.

Het moge duidelijk zijn, dat betekenissen die handelende actoren aan zaken geven een cruciale rol spelen. Zowel regels, structuur, cultuur (routines) als macht kunnen niet los van deze betekenissen worden bezien. Situaties waarin actoren tot de conclusie komen dat zij de ander nodig hebben om hun doelen te kunnen bereiken,

"Voltooid" is hier relatief: eigenlijk is het proces wan conceptualisering nooit klaar. Zelfs wanneer concepten en hun relaties volledig zijn uitgekristalliseerd, dan nog is het proces niet beëindigd: sociale verschijnselen veranderen voorturend. De concepten die op deze verschijnselen betrekking hebben moeten steeds mee veranderen. Zie hoofdstuk 3. 
krijgen de betekenis van afhankelijkheidssituaties. Een en dezelfde structuur als verzameling relaties kan door actoren met verschillende routines verschillende betekenissen krijgen. Actoren beoordelen de betekenis van regels en situaties in termen van wenselijk of onwenselijk vanuit hun routines. Op basis van de beoordeling handelen zij.

In de volgende subparagrafen worden de relaties tussen verschijnselen kort beschreven, aan de hand van de nummering in de figuur. Overzicht 2.2 bevat de concepten, waarmee wij in de empirische hoofdstukken de verschijnselen en hun relaties belichten.

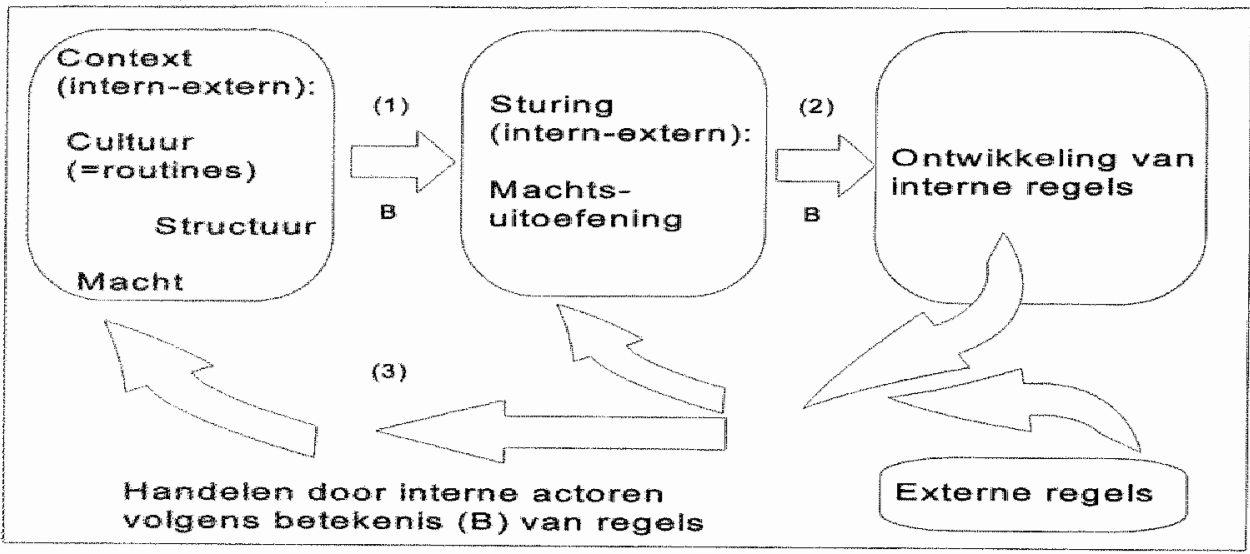

Fig. 2.11 Conceplueel raamwerk mel genummerde relaties

\subsubsection{Eerste relatie tussen verschijnselen}

Actoren beoordelen een situatie (actoren met hun kenmerken, hun afhankelijkheidsrelaties met anderen en de handelingen en interacties binnen deze relaties -macht en structuur) vanuit hun cultuur (routines). Zij kunnen de situatie als wenselijk of onwenselijk beschouwen. Actoren handelen op basis van de betekenis die situaties voor hen hebben. Deze assumptie vormde een van de centrale richtsnoeren voor onze analyses. Actoren geven betekenis vanuit hun routines. Routines, die onder andere de handelwijzen betreffen waaraan men gewend is of die men wenselijk vindt, vormen dus uiteindelijk het uitgangspunt voor het handelen. Dezelfde situatie kan voor verschillende actoren andere betekenissen hebben. Gevolg is dat zij op verschillende wijze zullen handelen. In de betekenis van de situatie ligt de aanleiding voor sturing. 
Overzicht 2.2 Begrippen uit het conceptueel raamwerk, waarmee in de empirische hoofdslukken de werschijnselen en hun relaties worden besproken

\begin{tabular}{|c|c|}
\hline $\begin{array}{l}\text { Hoofid-con- } \\
\text { cept }\end{array}$ & Comcepten \\
\hline Cullutur & 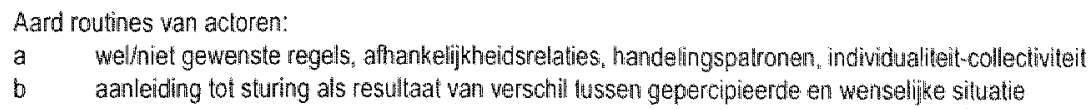 \\
\hline \multirow[t]{6}{*}{ Servolutur } & $\begin{array}{l}\text { Aard afhankelikheidsrelaties tussen actoren: symbiotisch-compeifief, wervlechting-ontulechting van } \\
\text { samenwerkingsrelaties }\end{array}$ \\
\hline & $\begin{array}{l}\text { Aatid (patroonsgewize) handelingen van actoren, die resulteren in siructuur: } \\
\text { a stamenwerking, coalitie, concurrentie, strijd } \\
\text { b negotiated order }\end{array}$ \\
\hline & Aard posities vam actoren, organen en configuraties \\
\hline & Aard taken van actoren \\
\hline & Aard bevoegdheden wan actoren \\
\hline & Aard functies van actoren \\
\hline \multirow[t]{3}{*}{ Macht } & Aard afhankelijkheidsrelaties tussen acloren: asymmetrisch \\
\hline & $\begin{array}{l}\text { Middelen van actoren: } \\
\text { a welgeen bezil, aard en behoefte } \\
\text { b centraliteit en substitueerbaarheid }\end{array}$ \\
\hline & Handelingsrumte van actoren \\
\hline \multirow[t]{3}{*}{ Suring } & $\begin{array}{l}\text { Aard sturingsinteracties van actoren: pogingen tot sturing over en weer door de acitoren die nu cens } \\
\text { bestuurder/werzender waren en dan weer bestuurdelontvanger via these, anithese en synthese }\end{array}$ \\
\hline & Aard sluursignalen \\
\hline & $\begin{array}{l}\text { Sturingswormem: juridische, economische, organisatorische en communicalieve sluring op basis wan } \\
\text { middelen }\end{array}$ \\
\hline \multirow[t]{2}{*}{ Regels } & $\begin{array}{l}\text { Extem ontwikkelde handelingsregels: } \\
\text { a aard } \\
\text { b gebruik }\end{array}$ \\
\hline & $\begin{array}{l}\text { Interne handelingsregels: } \\
\text { a aard } \\
\text { b ontwikkeling } \\
\text { c gebruk }\end{array}$ \\
\hline
\end{tabular}

De beoordeling door actoren kan behelzen dat de situatie moet worden veranderd of juist onveranderd moet blijven. Voorstanders van verandering van de situatie zullen sturingspogingen ondernemen om veranderingen te bewerkstelligen. Tegenstanders van verandering zullen pogingen tot tegensturing ondernemen om verandering te verhinderen. Regels zijn bij uitstek het object van sturing. Zij zijn bedoeld om bij het handelen te worden gebruikt. Regels die worden gebruikt, geleiden het handelen. Regels zijn geworteld in routines, maar reflecteren niet noodzakelijkerwijs de routines 
van individuele actoren. Gebruik van regels is in onze studie synoniem aan handelen volgens regels.

Om te kunnen doen wat zij wenselijk of noodzakelijk vinden (zoals het handhaven of veranderen van de situatie) hebben actoren middelen nodig. De behoefte aan middelen is aanleiding tot interactie met degene die deze middelen heeft of daar loegang toe heeft. Interacties zijn sturingsinteracties 21 .

De actor die middelen bezit of daar toegang toe heeft, heeft macht over degene die aan de middelen behoefte heeft. In de relatie tussen beide is de eerste dominant en de tweede ondergeschikt. Sturing vereist machtsmiddelen. Middelen bieden gelegenheid tot juridische sturing (op basis van wet- en regelgeving), economische sturing (op basis van geld, personeel et cetera), organisatorische sturing (op basis van handelingsregels die voor een netwerk of werzameling van netwerken zijn ingevoerd) of communicatieve sturing (op basis van argumenten, overtuigingskracht en door overreding).

Afhankelijkheid is veelal asymmetrisch (machtsverschil). In de relaties waarover wij spreken is altijd sprake van macht. De mate van asymmetrische afhankelijkheid wordt bepaald door het belang van de middelen (centraliteit ofwel 'essentiality') voor de actor die de middelen wil hebben, alsmede door de aan- of afwezigheid van alternatieve middelen waarop deze actor een beroep kan doen (substitueerbaarheid ofwel "substitutability'; Jacobs, 1974).

Macht heeft betrekking op handelingsruimte. Bezit van (of toegang tot) middelen maakt het voor de dominante actor, als deze dat will, mogelijk de ondergeschikte actor de gelegenheid te geven of te ontnemen tot handelen, bijvoorbeeld op een manier die de laatste wenselijk of noodzakelijk vindt.

Macht heeft voor het handelen pas gevolgen als een actor daaraan op basis van zijn routines de betekenis "macht' heeft gegeven. Indien de dominante actor zich bijvoorbeeld niet dominant acht, dan zal hij ook niet als zodanig handelen. Indien de ondergeschikte zich bijvoorbeeld niet ondergeschikt acht, dan zal hij ook niet handelen alsof hij ondergeschikt is.

Macht is in deze studie gezag. Dit betekent dat medewerking van de ondergeschikte nodig is opdat de dominante actor zijn zin krijgt. Het is uiteindelijk de ondergeschikte die bepaalt of volgens de wensen van de dominante actor wordt gehandeld. De asymmetrische afhankelijkheid is wederkerig. De dominante actor en de ondergeschikte hebben bij gezag beiden macht, waardoor eenieder eisen kan stellen. Dit leidt ertoe dat de dominante actor en de ondergeschikte actor, vooropgestelld dat zij iets van elkaar willen, onderling tot een vergelijk moeten zien te komen indien de ene de eisen van de ander niet wenst in te willigen of omgekeerd. Zij moeten trachten tot een resultaat te komen dat voor beiden misschien niet optimaal kan zijn, maar toch aanvaardbaar is. Het bereikte vergelijk is een 'negotiated order'. Blijven beiden elkaars wensen onaanvaardbaar vinden, dan zal geen van hen doen of toestaan wat de ander wil. Ontstaat een 'negotiated order', dan houdt deze veranderingen in de situatie in, naar de wensen van de dominante actor toe. Er vindt een 'pull' plaats, bijvoorbeeld op zich ontwikkelende configuraties, in de richting van de routines van de dominante actor.

Ondat in situaties per definitie meerdere actoren zijn betrokken, is altijd de medewerking van anderen nodig om de situatie te wijzigen of in stand te houden. Dit maakt dat het vermogen van een actor tot medewerking aan een van beide opties voor hem een middel is. De inzet van unteracties is dan het verkrijgen van deze medewerking, dus van hel middel. Behoefte aan middelen van anderen als aanleiding voor interacties is derhalwe niet iets anders dan de eerder genoemde aanleiding tot
sturing. 


\subsubsection{Tweede relatie tussen verschijnselen}

In situaties zijn het altijd meerdere actoren die tijdens interacties over en weer proberen te sturen. Sturing is altijd het resultaat van sturingspogingen van meerdere actoren. Zij verzenden stuurders. Bestuurders en bestuurden kunnen zich bevinden in de netwerken of de omgeving. Als resultaat van alle sturingspogingen tijdens interacties ('sturingsinteracties', die verlopen volgens een schema van these, antithese en synthese) kunnen in een netwerk nieuwe handelingsregels worden ontwikkeld, van toepassing worden verklaard en weer verdwijnen.

Regels zelf zijn enkel instrumenten ofwel hulpmiddelen voor het handelen. Op zichzelf resulteren zij bijvoorbeeld niet in veranderingen in structuur, cultuur en macht. Zij moeten worden gebruikt. Actoren moeten gemotiveerd zijn om de regels bij het handelen te gebruiken. Er kan sprake zijn van extrinsieke motivatie (machtsverklaring) of intrinsieke motivatie (routineverklaring). In beide gevallen spelen routines een rol. Voor de verklaring van handelingen volgens regels en andere verschijnselen zijn routines uiteindelijk van doorslaggevende betekenis.

\subsubsection{Derde relatie tussen verschijnselen}

Nieuwe handelingsregels leiden pas tot een andere cultuur, structuur of macht, indien actoren volgens (de betekenis van) deze regels handelen. Ontwikkelde regels moeten worden gebruikt. Worden regels gebruikt, dan geleiden zij de handelingen. Worden zij niet gebruikt, dan zijn zij 'dode letters'. Sturingsinteracties zijn eveneens handelingen. Ook daarbij worden regels gebruikt.

Tijdens het gebruik van nieuwe regels ontstaan en veranderen situaties, relaties, netwerken en configuraties. Taken en bevoegdheden geraken bijvoorbeeld over actoren verdeeld. Zij gaan bepaalde functies vervullen. Tussen de netwerken in een configuratie kumnen afhankelijkheidsrelaties ontstaan, waarbinnen het ene netwerk een dominante of ondergeschikte positie inneemt ten opzichte van het andere, of omgekeerd en waarbinnen actoren gaan handelen.

Relaties, netwerken en configuraties kunnen door handelingen weer verdwijnen. Ontstaan relaties, dan is sprake van wervlechting. Vallen relaties uiteen, dan spreken wij van ontvlechting.

Aan de basis van relaties, handelingen en interacties daarbinnen, vervlechting en ontvlechting ligt de verhouding tussen 'individualiteit' en 'collectiviteit'. Birnen de routines van de bestudeerde actoren -vooral managers- heeft individualiteit het primaat boven collectiviteit. Collectiviteit kan alleen voorop staan, wanneer individuele belangen compatibel en niet strijdig zijn. Naarmate individuele belangen minder compatibel of meer strijdig zijn, is sprake van verminderde geneigdheid met elkaar te handelen. Samenwerkingsrelaties komen moeizamer of niet tot stand, bestaande samenwerkingsrelaties komen onder druk te staan.

In het uiterste geval vindt ontvlechting van zulke relaties plaats. Aldus wordt het verband zichtbaar dat via het handelen bestaat tussen cultuur enerzijds en structuur en macht anderzijds.

Structuren en machtsrelaties kunnen veranderen, maar wanneer deze veranderingen niet stroken met de routines (in het bijzonder die van dominante actoren), is de kans groot dat zij niet beklijven. Zij veren dan terug naar de routines. Cultuur is tamelijk stabiel. Daarmee is ook de veranderlijkheid van structuur en macht beperkt, de 
verandentheid van systemen eveneens. Voor zorgvernieuwing werpen routines berristas ap.

\subsubsection{Eerste relatie tussen verschijnselen (bis)}

Veranderingen in structuur of macht (situatie) worden beoordeeld vanuit cultuur (routines). Beoordeling kan weer aanleiding geven tot sturing, et cetera.

\subsection{Slotopmerkingen}

In dit hoofdstuk hebben wij achtereenvolgens via de stapsgewijze selectie wan te bestuderen verschinselen, de presentatie van het conceptueel raamwerk en de beschriving van concepten en hun relaties onze theorie opgebouwd. Dit gebeurde met behulp van empirische gegevens en kennis uit de functionalistische benaderingen van de "social system theory" en het interactionisme. In de opgebouwde theorie ligt bij het interctionisme het primaat.

De benaderingen waaruit wij inzichten hebben benut, kennen behalve overeenkomsten ook verschillen. Niettemin achten wij de gebruikte inzichten verenigbaar. Wij hebben daarvoor een aantal argumenten gegeven. Een daarvan is dat vermenging van inzichten ut verschillende benaderingen reeds gaande is. Integratie is waarneembaar.

Centraat in onze studie van netwerken staat het samenspel van de verschijnselen die wil hebben aangeduid met de begrippen structuur, cultuur, macht, sturing. betekenis, handelen en regels. Dit samenspel zorgt voor dymamiek en veranderingen in de verschijnselen die wij bestuderen, meer in het bijzonder de netwerken.

Aandacht voor betekenissen stelde ons in staat inzichten vanuit verschillende functionalistische benaderingen aaneen te smeden en meerwaarde te geven. Tussen verschijnselen die werden aangeduid met concepten uit de 'social system theory' en handelingen van actoren plaatsten wij 'betekenis'. Daarbij lieten wij ons leiden door de interactionistische gedachte dat actoren handelen op basis van de betekenis die zaken wor hen hebben, en niet op basis van de zaken zelf.

Tot bestuly van dit hoofdstuk merken wij het volgende op. Onze studie is downent met noties ut het interactionisme. Sterker nog, niet alleen de bestudeerde achen geven betekenissen, ook wij als onderzoekers doen dit. Al het onderzoeksmaverid is door ons verzameld, geinterpreteerd en van betekenissen voorzien. Wij gebulkten daarvoor handelingsregels. Deze regels moeten wij beschrijven voordat de bevimugen ten aanzien van de bestudeerde netwerken aan de orde kunnen komen. Deze exercitio word ook wel 'methodologische verantwoording' genoemd en vindt plads in hootosuk 3 . 


\section{Penselen en verf: paradigma en methodologie}

\subsection{Inleiding}

De theorie die wij in het vorige hoofdstuk hebben opgebouwd, hebben wij gepositioneerd in het functionalistische paradigma. Wij legden het primaat bij het interactionisme. 'Theorie' is het ene centrale bestanddeel van een paradigma. Het andere is 'methodologie', dat wij omschrijven als de verzameling regels die bij wetenschappelijk onderzoek binnen een paradigma moeten worden gevolgd. Methodologische regels betreffen het gebruik van concepten, de opzet en uitvoering van een onderzoek, de methoden en technieken die worden gebruikt en de aard van de bewijsvoering.

In dit hoofdstuk beschrijven wij de methodologie van de onderhavige studie. Uiteraard ligt ook daarin het primaat bij het interactionisme. In par. 3.2 gaan wij na in hoeverre het onderzoek waarop de studie is gebaseerd, alsmede de studie zelf, zijn uitgevoerd volgens een aantal methodologische basisregels van het interactionisme volgens Blumer (1969). Wij hebben een 'case study' uitgevoerd. In par. 3.3 beoordelen wij de uitvaering van het onderzoek en de studie aan de hand van de regels uit de 'case study' benadering volgens Yin $(1989,1994)$.

In par. 3.4 bespreken wij de dataverzameling gedurende het onderzoek, waaronder de gebruikte bronnen, methoden en instrumenten. Aldus selecteren wij de penselen en maken wij de verf klaar voor de schildering van het tafereel van netwerken. In par. 3.5 gaan wij in op de technieken die wij in de studie hebben gebruikt voor de analyse van onderzoeksgegevens. In par. 3.6 wordt de gevolgde werkwijze bij de analyses nader toegelicht, met behulp van analyseschema's. Par. 3.7 bevat een aantal slotopmerkingen.

\subsection{Paradigma en methodologie van het interactionisme: beoordeling van het onderzoek en de studie}

Om onderzoek op zijn wetenschappelijke kwaliteit te kunnen beoordelen is een maatstaf nodig. Deze beoordelingsmaatstaf is de methodologie binnen het paradigma waartoe de onderzoeker zijn werk rekent. Volgens Kuhn (1970) zijn mensen wier onderzoek gebaseerd is op gemeenschappelijke paradigma's, gebonden aan dezelfde 
regels voor de wetenschappelike praktijk. Is het paradigma anders, dan is ook de beoordelingsmaatstaf anders. Beoordeling van het werk van een onderzoeker wit het ene paradigma met een maatstaf uit een ander paradigma, zal door die onderzoeker niet als overtuigend worden aanvaard. Voor hem heeft die beoordeling geen waarde, want beoordelingsmaatstaven uit verschillende paradigma"s zijn niet vergelijkbaar (incommensurabel'; Chalmers, 1983).

\subsubsection{Het vraagstuk van de beoordelingsmaatstaf}

Het begrip 'beoordelingsmaatstaf' vooronderstelt dat de regels binnen het paradigma eenduidig zijn. Bij de paradigma's die Kuhn beschrijft is dit niet het geval. Volgens Chalmers (1983) zijn de paradigma's van Kuhn 'niet zo precies dat ze kunnen worden vervangen door een expliciet stel regels (...). Verschillende wetenschapsbeoefenaren of groepen wetenschapsbeoefenaren zouden het paradigma op enigszins verschillende wijzen kunnen interpreteren en toepassen. Gesteld voor dezelfde situatie zullen niet alle wetenschapsbeoefenaren tot dezelfde beslissing komen of dezelfde strategie aanvaarden".

Het is daarom moeilijk te komen to een eenduidige beoordelingsmaatstaf, zelfs binnen én paradigma. Dit geldt al voor wetenschap die is gegrondvest op eerdere wetenschappelijke prestaties, welke door een wetenschappelijke gemeenschap een tijj lang worden erkend als basis voor haar werk. Dergelijke wetenschap, zoals de natuurkunde, noemt Kuhn 'normale wetenschap'. Voor de sociologie als wetenschap geldt het in nog grotere mate, aangezien geen sprake is van een algemeen erkende grondslag (Rademaker, 1978). Binnen thet functionalistische paradigma bijvoorbeeld zijn meerdere methodologieën zichtbaar (zie Burrell en Morgan, 1982). Er is geen sprake van methodologische eenstemmigheid.

Het woord 'interpreteren' in Chalmers' uitspraken laat zien dat wetenschappers aan de beschikbare regels in hun paradigma betekenis moeten geven. Ons baserend op het werk van onder anderen Blumer (1969) hebben wij in par. 2.5.1 gesteld dat een object en diens betekenis niet onlosmakelijk met elkaar zijn verbonden. Betekenissen kunnen veranderen, hetzelfde object kan voor verschillende actoren verschillende betekenissen hebben. Dit geldt ook voor de regels voor de beoordeling van wetenschappelijk onderzoek, de regels voor normale wetenschap niet uitgezonderd. thet is derhalve mogelijk dat voor de beoordeling van een en dezelfde studie door verschillende wetenschappers verschillende maatstaven worden gehanteerd, afhankelijk van de betekenis die de regels van het paradigma voor hen hebben. Degene die onderzoek beoordeelt kan dit alleen doen, uitgaande van de betekenis die hij geeft aan de wetenschappelijke regels die op dat moment worden geacht te gelden.

Betekenissen van de regels kumnen weliswaar variëren, maar omdat deze zijn geworteld in de routines (zie ook par. 2.5.6.1) die wetenschappers gedurende hun opleiding en loopbaan hebben aangeleerd, valt niet te verwachten dat de betekenissen volledig uiteenlopen. Onze uitspraken moeten dan ook niet leiden tot de conclusie dat thet zinloos is de regels te bespreken waaraan de onderhavige studie moet voldoen. Integendeel. Het wetenschappelijk debat is erbij gebaat wanneer die regels worden geexpliciteend. In hoeverre het onderzoek naar het Programma van WVC en de studie die daarop is gebaseerd, wetenschappelijk verantwoord zijn opgezet en uitgevoerd, kan -rekening houdend met bovenstaande uitspraken- alleen worden beoordeeld aan de hand van de regels die gelden binnen het paradigma en de benadering daarbinnen, waartoe beide behoren. 
Hierna bespreken wij de basisregels die wolgens Bumer (1969) metden wor interactionistisch onderzoek. Wij doen dit aan de hand van het verschw tussen toetsend en explorerend onderzoek (zie ook par. 1.4) en tussen 'sensitzing concepts' an 'definitive concepts'. In par. 3.3 krijgt de methodologische beoordeling een specifieker karakter. Daarin staan de regels centraal die Yin $(1989,1994)$ voor case studies hedef geformulleerd.

\subsubsection{Toetsende en explorerende benadering}

Van oudsher wordt in de sociologie gestreefd naar de verklaring en voorspelling van sociale verschijnselen. In een deel van de uitgevoerde studies wordt getracht nauwkeurig gedefinieerde variabelen te onderscheiden en in uitspraken over relaties daartussen vast te leggen onder precies welke omstandigheden zich bepaaide verschijnselen wel of juist niet zullen voordoen (hypothesen). Een variabele is een kenmerk dat elementen (bijvoorbeeld cases) in verschillende mate kunnen bezitten (Segers, 1983). De geschetste werkwijze resulteert in een conceptueel model dat vervolgens, na indicering en operationalisering aan de empirische werkelijkheid dient te worden getoetst. Deze onderzoeksbenadering wordt 'toetsende benadering' genoemd en is ontleend aan de natuurwetenschappen (Swanborn, 1987).

\subsubsection{Toetsen of exploreren}

In onderzoek volgens de 'toetsende benadering' wordt de empirische cyclus eén maal doorlopen. Zaken zoals de werkwijze gedurende het onderzoek, de hypothesen, meetinstrumenten en de onderzoekspopulatie liggen vast voordat het onderzoek begint. Vooraf geformuleerde voorspellingen kunnen gedurende het onderzoek niet worden bijgesteld (Swanborn, 1987).

Onderzoek dat volledig wordt uitgevoerd vanuit een toetsende benadering, is gebaat bij stabiliteit. Variabelen die te onderzoeken verschijnselen aanduiden moeten eenduidig kunnen worden gedefinieerd en al hun relevante dimensies moeten voorafgaand aan empirische toetsing bekend zijn. Alleen dan is het mogelijk hypothesen te formuleren en vervolgens te toetsen. Zouden tijdens een onderzoek bijvoorbeelld aan variabelen nieuwe dimensies moeten worden toegevoegd, dan kunnen de hypothesen op losse schroeven komen te staan. Will de onderzoeker op dat moment vasthouden aan de toetsende benadering, dan is deze genoodzaakt met het onderzoek-inuitvoering te stoppen. Vervolgens dienen definities van variabelen te worden aangepast, moeten nieuwe dimensies worden onderscheiden en nieuwe hypothesen worden opgesteld. Pas dan kan weer met toetsing worden aangevangen. Tijdens dit nieuwe toetsende onderzoek kan wederom blijken dat de definities van variabelen en hun dimensies niet toereikend zijn, et cetera.

Wanneer toetsend onderzoek wordt gedaan naar verschijnselen die zodanig dynamisch zijn dat definities van variabelen voortdurend moeten worden aangepast, omdat niet alle mogelijke ontwikkelingen bij voorbaat kunnen worden ingecalculeerd, dan is adequate uitvoering van toetsend onderzoek een probleem. Dit is nu exact de situatie bij netwerkvorming in de gezondheidszorg. Verschijnselen waarvan de definities en dimensies in variabelenschema's zouden moeten worden vastgelegd, zijn voortdurend aan verandering onderhevig (Mur-Veeman et al 1995).

Indien de sociale werkelijkheid het problematisch maakt de toetsende benadering toe te passen, dan ligt toepassing van een andere onderzoeksbenadering voor de hand. Een benadering is vereist waarbinnen niet wordt gestart met een vooraf 
gespecificeerd theoretisch verklaringsmodel "maar met globale, vage veronderstellingen ten aanzien van de te bestuderen verschijnselen en hun relaties. Uitgaande van dit globale beeld wordt gedurende het onderzoek gestreefd naar verdieping van de inzichten (zie Swanborn, 1987).

Dit is de explorerende benadering zoals Blumer (1969) die beschrijft. Binnen deze benadering wordt bij de bestudering van de empirie niet begonnen met een verzameling scherp geformuleerde hypothesen. De werkwijze en andere zaken van het onderzoek worden niet van tevoren exact vastgelegd en de empirische cyclus wordt herhaalde malen doorlopen. Steeds vindt wisselwerking plaats tussen de ontwikkeling van het conceptuele raamwerk en de empirische waarnemingen. Veronderstellingen worden al doende aangepast, net zolang tot een redelijke 'fit' is verkregien tussen theorie en empirie.

\subsubsection{Exploreren: interpreteren en 'sensitizing concepts'}

Interactionistisch, explorerend onderzoek is interpreterend ('verstehend") onderzoek22. Dit betekent dat getracht wordt te begrijpen waarom actoren handelen en interacteren zoals zij dat doen.

Handelen is zoals wij in par. 2.3.2 hebben gesteld, de motor in de verandering van de bestudeerde verschijnselen. Actoren handelen op basis van betekenissen die verschijnselen voor hen hebben. Het verloop van handelingen kan alleen adequaat worden verklaard, indien de onderzoeker deze betekenissen kent. De betekenissen die de onderzoeker geeft, moeten overeenkomen met de betekenissen die verschijnselen voor de onderzochte personen hebben. Voorwaarde hiervoor is dat de onderzoeker zich verplaatst in de situatie waarin de bestudeerde actoren zich bevinden (Blumer, 1969). Hij moet zich in hun omstandigheden kunnen inleven.

In de explorerende benadering start de onderzoeker met vage begrippen waarmee verschijnselen worden aangeduid ('sensitizing concepts"). 'Sensitizing concepts" richten de aandacht op aspecten van de veranderende sociale werkelijkheid en hun relaties, zonder deze in gedetailleerde definities vast te leggen. De onderzoeker treedt aanvankelijk met globale noties de empirie tegemoet. Hij probeert in de loop van het onderzoek verschijnselen meer en meer te begrijpen. Tijdens zijn tocht door de empirie tracht de onderzoeker de concepten weliswaar aan te scherpen (en meer inzicht te krijgen in de relaties tussen de verschijnselen die met de concepten worden aangeduid), maar deze blijven een "sensitizing karakter' behouden. 'Sensitizing concepts' kunnen namelijk nooit 'definitive concepts' worden, omdat de verschijnselen en hun relaties, alsmede hun betekenis voor de handelende mens, aan verandering onderhevig blijven. Toetsing van een vooraf volledig ontwikkeld theoretisch verklaringsmodel met hypothesen over de onderhavige verschijnselen, heeft derhalve geen plaats binnen dit methodologisch perspectief (voor een verdere discussie: zie Schnabel, 1978).

\subsubsection{Relatief verschil tussen toetsende en explorerende benaderingen}

Toetsing van hypothesen en exploratie zijn niet wederzijds uitsluitend. Dit standpunt is herkenbaar bij Glaser en Strauss (1967). Voor deze interactionisten ligt het primaat in sociologisch onderzoek bij theorie-ontwikkeling. Volgens hen is toetsing belangrijk, maar zij verbinden daaraan een voorwaarde. Zij beschouwen toetsing. 
samen met beschrijving, als onderdeel van de ontwikkeling van een theorie. Toetsing moet ten dienste staan van deze ontwikkeling, zij mag haar niet in de weg staan. De onderzoeker die volgens de interactionistische, explorerende benadering te werk gaat, moet hypothesentoetsing dus niet ten principale afwijzen, maar beoordelen op bruikbaarheid gedurende exploratie.

De explorerende benadering van Blumer en andere interactionisten neemt, doordat 'sensitizing concepts' worden gebruikt, een plaats in tussen een benadering waarbij de onderzoeker geacht wordt zonder enige conceptie vooraf de empirie in te gaan (de ultieme variant van de 'grounded theory' gedachte), en de toetsende benadering, waarin alle concepten tot in detail moeten zijn uitgewerkt voordat de empirie wordt tegemoet getreden.

Verder onderschrijft Blumer methodologische regels die ook in de toetsende benadering worden gehanteerd. Volgens hem is het syrnbolisch interactionisme bedoeld om verifieerbare kennis te vergaren. Het is een empirische wetenschap en voorondersteit evenals andere wetenschappen het bestaan van een empirische wereld. Deze wereld staat tegenover de wetenschapper en de eigenschappen moeten worden blootgelegd door waarneming, studie en analyse. Daarbij concentreren interactionisten zich op de wijze waarop actoren in hun interacties vorm geven aan hun omgeving via processen van betekenisgeving en interpretatie.

Een belangrijk methodologisch verschil met de toetsende benadering betreft de methoden van dataverzameling. Volgens het interactionisme zijn voor bestudering van de empirie kwalitatieve methoden beter geschikt dan kwantitatieve. Er is een voorkeur voor participerende observatie, bij interviews worden intensieve, weinig gestructureerde gesprekken (focused interviews) geprefereerd. Ook wordt veell gebruilk gemaakt van persoonlijke documenten (Van Hoof, 1983). Op de dataverzameling komen wij terug in par. 3.3 en 3.4 .

\subsubsection{Beoordeling van het uitgevoerde onderzoek en de studie}

Terugblikkend op onze werkzaamheden sinds de start van het onderzoek naar het Programma van WVC, kunnen wij concluderen dat wij volgens de explarerende benadering te werk zijn gegaan. Ter beargumentering beschrijven wij op hoofdlijnen de gevolgde werkwijze.

Bij het begin van het onderzoek hebben wij een aantal concepten beschreven en globale veronderstellingen geformuleerd over de relaties tussen empirische verschijnselen. Dit gebeurde met behulp van noties vanuit verschillende theoretische invalshoeken (Tijssen et al, 1991). De concepten waren niet zodanig omschreven, dat vaststond welke dimensies exact konden worden onderscheiden. Het resulterende conceptuele raamwerk fungeerde niet als een toetsbaar model, maar als een vizier waardoor wij als onderzoekers de blik konden richten op verschijnselen waarvan de bestudering in het licht van het onderzoeksdoel relevant was. Met het conceptuele raamwerk bestudeerden wij vooral de wijze waarop de actoren in de netwerken gezamenlijk trachtten vorm te geven aan een nieuwe organisatie van de hulpverlening.

De concepten en hun relaties kregen door bestudering van verzamelde gegevens meer en meer inhoud. Geheel in overeenstemming met de onderzoeksopzet (Tijssen et al, 1991) werden begrippen en veronderstellingen mettertijd aangescherpt en geherformuleerd. Het begrippenapparaat werd aangepast terwijl wij de empirische 
cyclus enkele malen doorliepen. Dit ging voort tot het einde van de studie, waarover wij hier verslag doen. De concepten bleven echter "sensitizing"23.

Reacties van bestudeerde actoren die wij in de loop van het onderzoek ontvingen, toonden dat wij steeds beter aansluiting kregen bij hetgeen volgens hen in hun situatie gaande was ('construct validity'; Yin, 1989), een enkel project daargelaten. Aanvankelijk bestond onder de deelnemers aan de zorgvernieuwingsprojecten in het Programma van WVC scepsis over de wijze waarop wij trachtten inzicht te verkrijgen. De scepsis betrof met name het door ons gebruikte begrip 'formele bevoegdheden' en kwam tot uiting tijdens de tweede conferentie over het Programma van WVC in $1992^{24}$. Volgens ons aanvankelijke conceptuele raamwerk zou het bezit van deze bevoegdheden voor de projectleiders noodzakelijk zijn om de beoogde veranderingen teweeg te brengen. Daaraan lag impliciet de gedachte ten grondslag dat formele bevoegdheden rechtstreeks bepalend zijm voor de manier waarop participanten handelen. Dit is een standpunt met wortels in het structureel functionalisme.

Projectleiders wezen ons erop dat het bezit van deze bevoegdheden niet zonder meer tot de beoogde resultaten zou leiden. Van doorslaggevende betekenis was volgens hen hoe zijzelf te wérk gingen -bevoegdheden of niet- en hoe hun persoonlijke handelwijze door de andere actoren werd gewaardeerd. Naar aanleiding van dergelijke reacties verschoven wij de aandacht van de bevoegdheden van projectleiders naar de wijze waarop zij handelden. Het begrip 'veranderingsmanagement' kreeg een geprononceerde plaats in ons conceptueel raamwerk (zie Van Raak et al, 1993).

Ook al gingen wij vanaf de start te werk volgens het principe van de 'sensitizing concepts'25, het moment -in 1992- waarop het begrip 'veranderingsmanagement' op de voorgrond werd geplaatst markeerde de verandering van een vooral systeemtheoretisch georiënteerd onderzoek naar een onderzoek dat meer naar het interactionisme neigde.

Ondanks deze verandering kreeg bij de veronderstelde relatie tussen verschijnselen en het handelen van actoren in de netwerken die de projecten uitvoerden, het belang van 'betekenis' als 'intermediair' (zie par. 2.2.2) alleen impliciet aandacht. Pas in deze studie komt het interactionistische karakter expliciet tot uiting.

Het bovenstaande laat zien dat wij niet alleen probeerden ons conceptueel raamwerk gaandeweg aan te scherpen, maar dat wij ook trachtten ons in te leven in de situatie waarin de actoren verkeerden. Om inzicht te behouden in hun situatie verzonden wij tussentijds ter becommentariëring schriftelijke weergaven van onze onderzoeksbevindingen naar de netwerken die de projecten uitvoerden.

23 Het is om deze reden dat wij in deze studie niet redeneren in termen wan wariabelen, maar in termen van concepten (begrippen). Het verschil met variabelen is hierin gelegen dat bij concepten geen duidelijke, vaste waarden kunnen worden onderscheiden waarop elementen kunnen scoren (zie Swanborn, 1987).

24 'Leren jongleren. Zorgvernieuwing in de praktijk'. Conferentie op 13.5.1992 in 's-Hertogenbosch.

25 Wij gebruikten deze terminologie overigens niet. Niettemin kwam de gevolgde werkwijze naar haar inhoud bezien overeen met hetgeen Blumer (1969) heeft beschreven. 


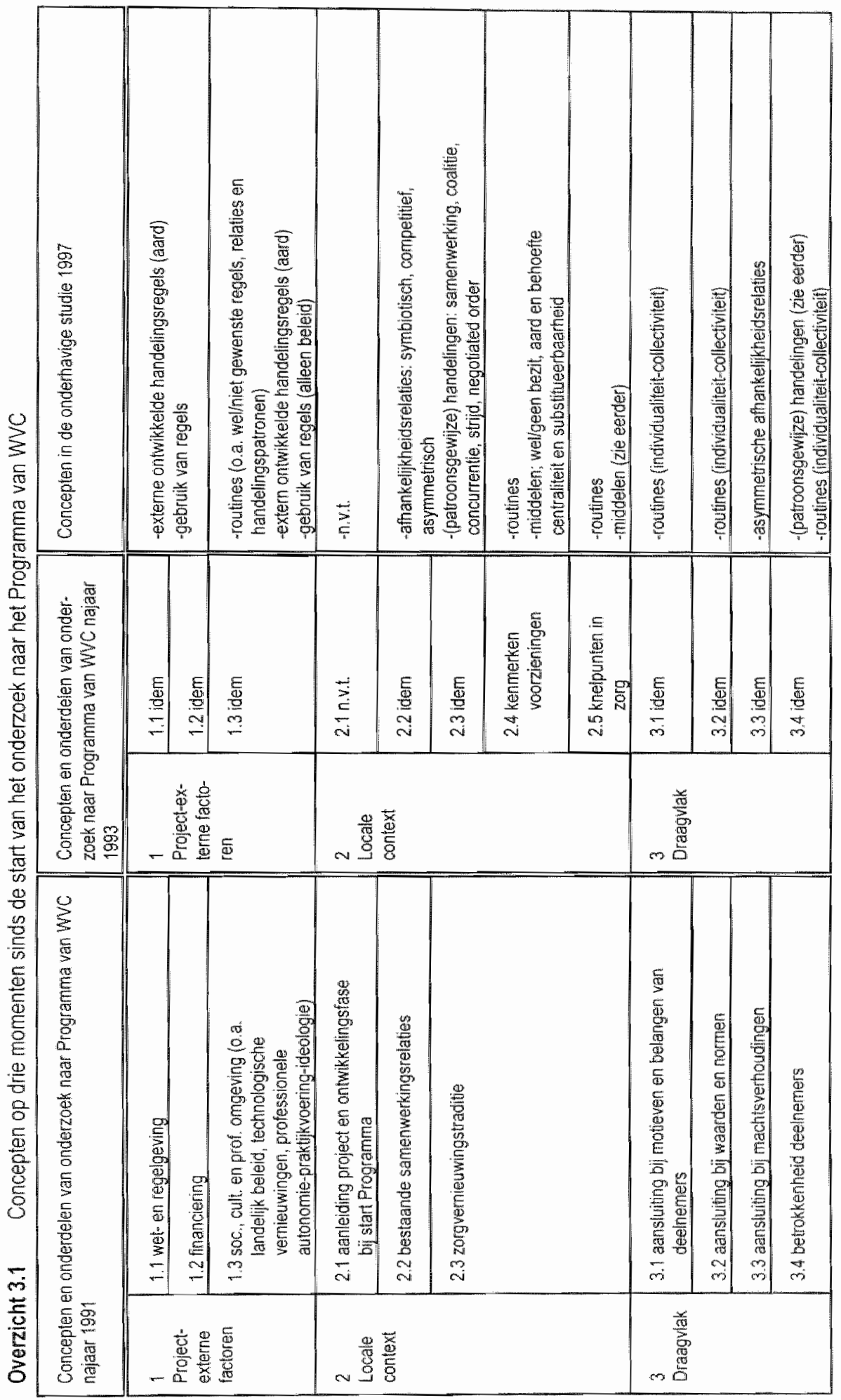




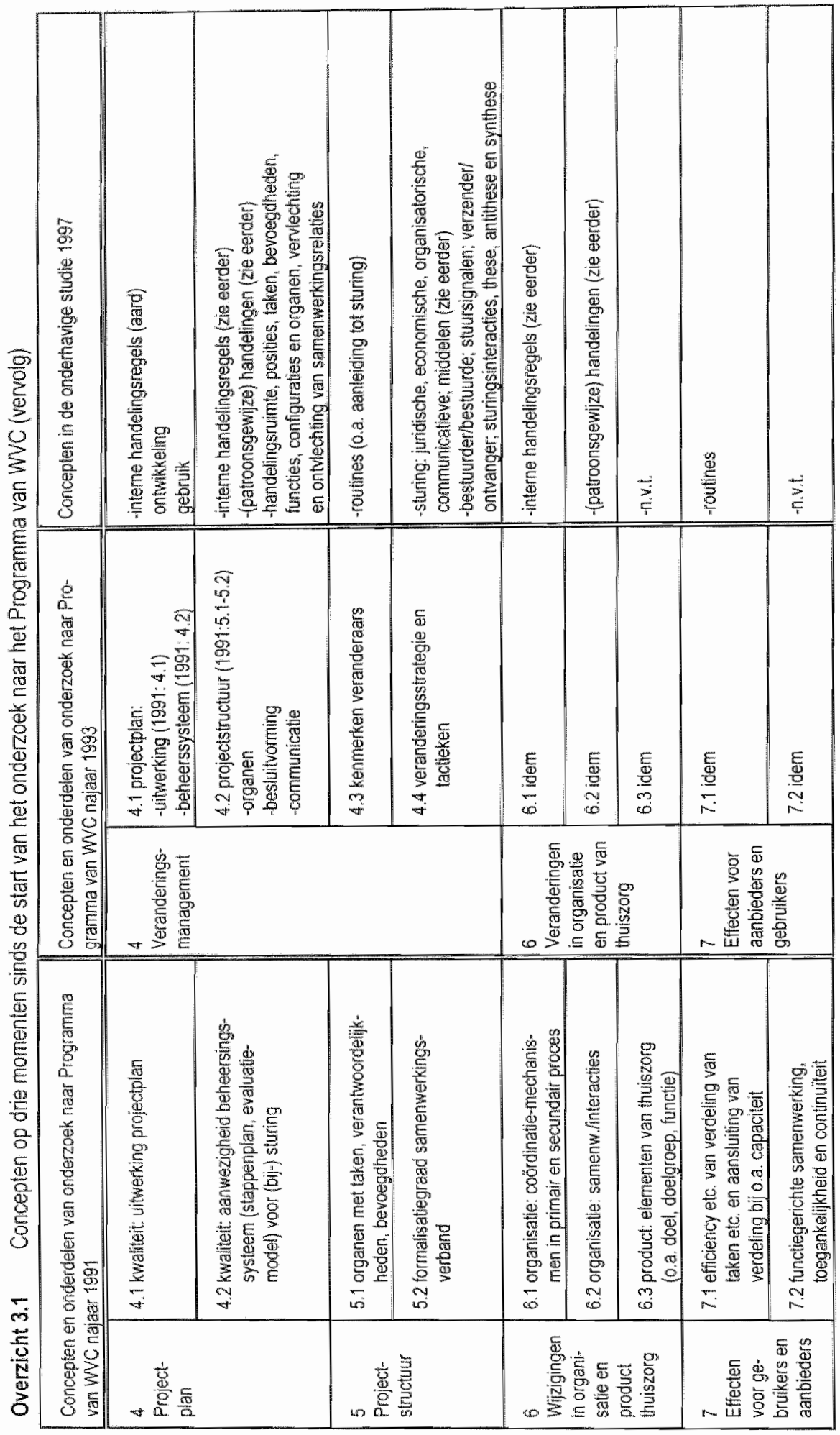


Overzicht 3.1 toont aan de hand van drie momentopnamen op hoofdlinen het conceptualiseringsproces sinds de start van het onderzoek 26

\section{3 'Case study' benadering volgens Yin: beoordeling van het onderzoek en de studie}

Het onderzoek naar thet Programma van WV en de onderhavige studie vormen samen een "case study' waarin wij de regels hebben toegepast die Yin (1989, 1994) heeft geformuleerd. Een case is een object van onderzoek zoals een proces of gebeurtenis. Een gebeurtenis beschouwen wij als het moment waarop een verschijnsel of een verandering daarin zich voordoet. Voorbeelden van cases zijn beleidsprogramma's en zorgvernieuwingsprojecten. Yin (1989) definieert een 'case study' als an empirical inquiry that: investigates a contemporary phenomenon within its real-life context; when the boundaries between phenomenom and context are not clearly evident; and in which multiple sources of evidence are used'.

De "case study" benadering volgens Yin onderscheidt zich met name van andere onderzoeksstrategieën, zoals een experiment of een survey, omdat zij de onderzoeker in staat stelt een variëteit aan databronnen te gebruiken. Dit is een vorm van "triangulatie'. Met 'triangulatie' wordt bedoeld dat dezelfde onderwerpen worden bestudeerd met behulp van gegevens die afkomstig zijn uit verschillende databronnen, die zijn verzameld met verschillende instrumenten, of die zijn bestudeerd door verschillende onderzoekers. 'Triangulatie' is volgens Yin (1994) in case studies het middel bij uitstek om de validiteit van bevindingen te verhogen.

Onze 'case study' ressorteert onder 'explanation building'. Deze variant komt overeen met de wijze waarop interactionisten zaals Blumer (1969) de empirie bestuderen. In beide gevallen wordt gestart met globale concepties, die door confrontatie van ideeën van de onderzoeker met de verzamelde gegevens worden aangescherpt. Volgens Yin kan 'explanation building' worden gebruikt voor explorerend onderzoek en hij verwijst daarbij naar de wijze waarop Glaser en Strauss (1967) te werk zijn gegaan.

Overzicht 3.2 bevat de regels van de 'case study' benadering volgens $V$ in (1989, 1994). Steeds wordt aangegeven in hoeverre de kenmerken van ons onderzoek en onze studie met deze regels overeenkomen. Aldus wordt in éen oogopslag duidelijk in hoeverre wij volgens de regels van Yin hebben gewerkt. De navolgende subparagrafen bevatten een toelichting op de kenmerken in Overzicht 3.2

Niet alle verschijnselen die aan het einde van het onderzoek werden bestudeerd, worden teruggevonden in de rechterkalom van hef averzicht. De begrippen in deze rechterkolom zijn afkamslig uit Overzicht 2.2. Bij de 'sociale, culturele en professionele omgeving (concept 1.3) richt onze studie zich alleen op 'beleid'. De "knelpunten in de zorg' (concept 2.5) beperken zich tot het secundaire proces en het secundair niveau van het primaire proces. 'Product' (concept 6.3) bilift buiten beschouwing, evenals een deel van de effecten voor gebruikers en aanbieders (concept 7.2) 
Overzicht 3.2 Regels van Yin's 'case study' benadering en kenmerken van het onderzoek en de sludie: overeenkomsten en verschillen

\begin{tabular}{|c|c|c|}
\hline \multicolumn{2}{|c|}{ Regeis van de case sudy tonadering } & $\begin{array}{l}\text { Kenmerken } \\
\text { onderzoek } \\
\text { en studie }\end{array}$ \\
\hline A & $\begin{array}{l}\text { ALGEMEEN } \\
\text { Aard van de te selecteren cases: } \\
\text { - focus op contemporaine gebeurtenissen } \\
\text { - vage grenzen tussen case en context } \\
\text { - case bestudeerd binnen eigen context } \\
\text { - geen controle vereist over handelingen en gebeurterissen } \\
\text { Type studie: } \\
\text { - beschrijwend } \\
\text { - verklarend } \\
\text { - 'explanation building' } \\
\text { - paattern-malching' }\end{array}$ & $\begin{array}{l}* \\
* \\
* \\
* \\
* \\
* \\
* \\
* \\
\end{array}$ \\
\hline $\begin{array}{l}2 \\
\text { A } \\
\text { B }\end{array}$ & $\begin{array}{l}\text { 'CASE STUDY DESIGN' } \\
\text { Te formuleren onderzoekswragen: } \\
-\quad \text { wat, hoe, waarom } \\
\text { Te gebruiken soorten designs: } \\
\text { - 'holistic single-case' (1 analyse-eenheid binnen } 1 \text { case) } \\
\text { - 'embedded single-case' (meerdere analyse-eenheden binnen } 1 \text { case) } \\
\text { - 'holistic nultiple-case' (1 analyseweenheid, meerdere cases) } \\
\text { - 'embedded multiple-case' (meerdere analyse-eenheden, meerdere cases) } \\
\text { Overig } \\
\text { - design is niel voltooid bij het begin van de studie } \\
\text { - verschuivingen in hel design zijn onvermijdelijk en onder woorwaarden toegestaan }\end{array}$ & $\begin{array}{c}* \\
- \\
* j- \\
- \\
- \\
* \\
*\end{array}$ \\
\hline 3 & $\begin{array}{l}\text { THEOREE } \\
\text { - Vooral theorefische proposities formuleren } \\
-\quad \text { Rivaliserende verklaringen opstellen }\end{array}$ & $\begin{array}{l}* 1- \\
* / 1\end{array}$ \\
\hline 4 & 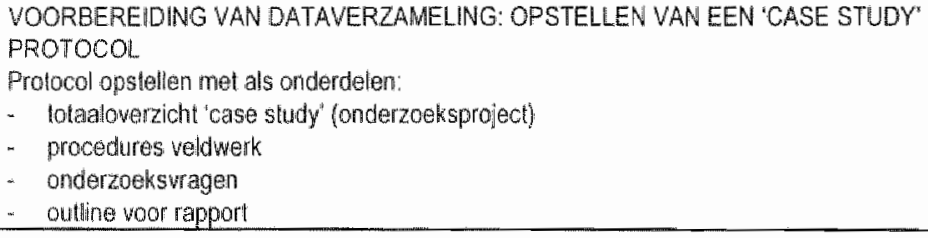 & $\begin{array}{l}: \\
* \\
* \\
\end{array}$ \\
\hline $\begin{array}{l}5 \\
A\end{array}$ & 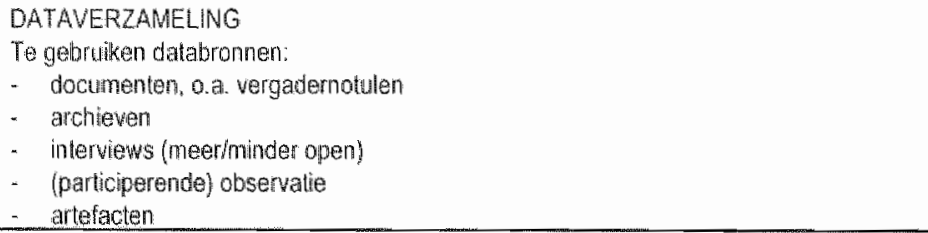 & $\begin{array}{l}\dot{*} \\
* \\
* \\
* \\
- \\
\end{array}$ \\
\hline
\end{tabular}


Overzicht 3.2 Regels van Yin's 'case study' benadering en kenmerken van het onderzoek en de studie: overeenkomsten en verschillen (vervolg)

Regels wan de 'case siudy' benadering

Kenmerken onderzook

en studie

\section{DATAVERZAMELING}

$B$ Te volgen werkwijze bil dataverzameling:

- meerdere bronnen gebruiken in plaals wan één bron

- database creërem

- externe persoon in staat stellen weg wan vragen naar conclusies en omgekeerd te volgen ("chain of evidence')

- in rapportage toereikende citering van relevante delen wan de database

- omstandigheden wan datawerzameling aangeven (0.a. hijd en plaats wan interviews)

- aangeven of dalawerzameling verliep volgens de procedures uit het prolocol

\section{ANALYSE}

A. Te valgen strategieën:

- "pattern-matching"

- 'explanation building'

- 'time-series analysis'

\section{RAPPORTAGE}

A. Te volgen werkwijze:

- in vroeg stadium starten met schrijwer

- concept-teksten laten beoordelen door sleutel-informanten ("review")

- cases bij voorkeur niet anoniem presenteren:

8 VALIDITEIT EN BETROUWBAARHEID

A Begripswalidileit:

- triangulatie

- 'chain of evidence'

- "reviews"

B Interne validiteit:

- 'pattern-matching'

- "explanation building

- "time-series analysis"

- rivaliserende verklaringen

C Externe walliditeit:

- geen statistische, maar analytische generaliseerbartheid

- 'replication'

D Betrouwbaarheid: herhaling van "case study" mogelijk maken door:

- gevolgde procedures documenteren

- weldwerkprotocol gebruiken

- toegankelijkheid databases waarborgen

- 'chain of evidence' presenteren

Kenmerk komt overeen met rege!

Kenmerk komt gedeeltelijk overeen met regel

Kenmerk komt niet owereen met regel 


\subsubsection{Algemene kenmerken}

Het onderzoek liep in de tijd gezien parallel aan de uitvoering van het Programma van WVC. Over ontwikkelingen werden gegevens verzameld terwijl deze zich voordeden. Hoewel in het anderzoek gebruik werd gemaakt van documenten over de voorgeschiedenis van projecten lag het accent op bestudering van contemporaine gebeurtenissen.

Het centrale object van het onderzoek en de onderhavige studie zijn netwerken van actoren. Deze netwerken fungeerden tijdens thet onderzoek in een omgeving, die bestond uit andere actoren zoals organisaties. De grenzen tussen netwerk en omgeving waren vaag, flexibel en dynamisch. De netwerken konden derhalve niet zomaar uit hun omgeving worden gelicht. Zij hadden daarin hun vertakkingen. Dientengevolge konden ziij alleen worden bestudeerd binnen hun eigen context. Een onderzoek, opgezet als een laboratorium-onderzoek, was niet mogelijk. Vanuit het onderzoek bestond geen mogelijkheid controle te houden over de handelingen en gebeurtenissen binnen het Programma en de projecten. Het waren deze kenmerken en omstandigheden die maakten dat uitvoering van een 'case study' de geëigende werkwijze was.

Beantwoording van de onderzoeksvragen vereiste een beschrijving van gebeurtenissen, ontwikkelingen, omstandigheden en resultaten. De beschrijving van omstandigheden diende uiteindelijk als basis voor de opbouw van een verklaring ('explanation building").

\subsection{2 'Case study design'}

Zowel in de studie als gedurende het onderzoek moesten wat-, hoe- en waaromvragen worden beantwoord. De vragen voor het onderzoek waren: "Welke nieuwe organisatievormen ten behoeve van de thuiszorg worden in de praktijk van de projecten opgezet en hoe ('wat'- en 'hoe'-vraag)? Welke factoren belemmeren of bevorderen het tot stand komen van deze nieuwe organisatievormen ('waarom'-vraag)? In hoeverre slaagt men erin met deze nieuwe vormen de kwaliteit van het thuiszorgaanbod te verbeteren ('wat'-vraag)?' (Tijssen et al, 1991).

De vragen voor deze studie zijn vermeld in par. 1.3. De indeling daarvan als 'wat'-, 'hoe'-en 'waarom'-vragen 27 is als volgt:

- 'hoe'-vraag: Door wie, hoe en in welke richting is aan ontwikkeling(en) van/binnen netwerken van instellingen en beroepsbeoefenaren in de thuiszorg sturing gegeven?

- 'waarom'-vragen: Welke omstandigheden (situatie) hebben aanleiding gegeven tot deze sturing? Welke omstandigheden (situatie) hebben al dan niet gelegenheid geboden tot sturing?

- 'wat'-vraag: Tot welke ontwikkelingen van/binnen de netwerken heeft de sturing geleid?

27 We hebben de volgorde van de vier eerste vragen in par. 1.3 gehandhaafd. Bij de indeling hebben wij de vijfde vraag buiten beschouwing gelaten. Deze wordt beantwoord met behulp van de antwoorden op de overige vragen. De aspecien 'wat', "hoe" en "waarom' komen bij die vijfde vraag derhalve gezamenlijk terug. 
Hoewel de projecten uit het Programma van WVC gedurende het orderoek vas: aandacht kregen, dienden de bevindingen over de projecten uheindelik als basis vow beantwoording van de onderzoeksvragen op Programma-nveau. Onze opdrack was namelijk evaluatie van het Programma en niet van de projecten. Het Programma vormde de case en de projecten fungeerden daarbinnen als analyse-eenheden. Mot onderzoek betrof een 'embedded single-case".

Het onderscheid tussen Yin's soorten designs is relatief. De onderhavige sudue richt zich op éen van de onderzochte projecten uit het Programma van WVC: project Intensieve Thuiszorg Zuid-Kennemerland ('project itz'). In deze studie zou het project alls case kunnen worden beschouwd, terwijl het in het onderzoek naar het Programma van WVC als analyse-eenheild binnen de case zou zijn aangeduid. De typering van een design als 'embedded", "single-case' of anderszins is afhankelijk van het niveau waarop bij de analyses en rapportage de nadruk wordt gelegd. Had in het onderzoek het accent gelegen op de afzonderlijke projecten in plaats van op het Programma als geheel, dan waren de projecten de cases geweest en niet het Programma.

De studie naar het project itz beschouwen wij als een 'single-case study". Volgens Y'in (1989) kan een dergelijke studie nuttig zijn voor het uitproberen van een theorie, waarna zij kan dienen als 'prelude' voor verdere case studies. De ondermavige studie heeft die functie (zie par. 1.2). Binnen deze "single-case study" maken wil geen onderscheild tussen de begrippen 'cases' en 'analyse-eenheden'. Wij spreken in alle gevallen over "cases'.

De onderzoekswragen waren opgenomen in een design, dat wij voorafgaand aan het evaluatie-onderzoek hebben opgesteld. Dit onderzoeksdesign was vooraf niet voltooid. In de loop van het onderzoek is het ingevuld. Met behulp van veldwerkprotocollen werd het design tussentijds toegesneden op actuele ontwikkelingen binnen het Programma. Het design bevatte onder meer de onderzoeksvragen en een beknopte beschrijving van de 12 projecten uit het Programma van WVC.

Gezien de complexiteit van de materie waarop case studies zich richten, acht Yin het onvermijdelijk dat een design bij de start van het onderzoek niet is voltooid. Verschuivingen in het onderzoeksdesign zijn dan ook toegestaan. Bij pattern-matching (een varilant waarbij een empirisch waargenomen patroon wordt vergeleken met een of meer voorspelde patronen die vooraf in theoretische proposities zijn vastgelegd) geldt daarbij de volgende regel. Verschuivingen in theoretische oriêntatie zijn gedurende de uitvoering niet geoorloofd. Wanneer blijkt dat dergelijke verschuivingen nodig zijn, dan moet het onderzoek na bijstelling van het design worden hervat met een nieuwe case. Deze variant komt overeen met de toetsende benadering die in par. 3.2 .2 .1 is besproken.

Bij 'explanation building' mag de theoretische orientatie gedurende de bestudering wan één en dezelfde case wél worden aangepast. In deze variant beschouwt Yin (1989) de uiteindelijke verklaring van een verschijnsel het resultaat van een reeks iteraties 28 . Hij voegt daaraan toe: In this sense, the final explanation may not have been fully stipulated at the beginning of a study (...). Rather, the case study evidence is examined, theoretical propositions are revised, and the evidence is examined once again from a new perspective, in this iterative mode: Onze theoretische orientatie is in de loop van de tijd aangepast, zoals wij in par. 3.2.3 hebben geillustreerd. Uit Yin's

Iteraties behelzen het volgende: formulering van een theoretische proposițe; vergelijking daarvan mel bevindingen ower een casie ('initial case'); herziening van de propositie; vergelijking daarvan met andere details van dezelfde case; wederom herziening van de propositie; vergelijking van de herziening met een volgende case, et cetera. 
verdere beschrijvingen valt op te maken dat 'pattern-matching' en 'explanation building' op hetzelfde continuüm kunnen worden geplaatst. Wij hebben voor de toetsende benadering en de explorerende benadering hetzelfde opgemerkt. De analogie is evident.

Voor beide varianten geldt dat de onderzoeker moet zien te voorkomen dat zijn onderzoek verwijderd raakt van het oorspronkelijke aandachtsgebied. Vin adviseert daarom de onderzoeksvragen en -doelen onveranderd te laten. Het oorspronkelijke design van ons onderzoek is tot aan het einde op hoofdlijnen hetzelfde gebleven. Het onderzoeksdoel en de onderzoeksvragen werden niet veranderd. Ook in de onderhavige studie is het onderzoeksdoel ongewijzigd gebleven. Anders ligt dit voor de vraagstelling. De oorspronkelijke onderzoeksvraagstelling vormde het kader, waarbinnen wij de vragen voor de studie hebben geformuleerd. De studie-vragen betreffen een selectie en nadere specificatie van de thematiek in de onderzoeksvragen. Het oorspronkelijke aandachtsgebied bleef echter hetzelfde.

\subsubsection{Theorie}

Het design bevatte voorafgaand aan het onderzoek een aantal, globale theoretische proposities ofwel veronderstellingen. Zij betroffen de randvoorwaarden waaronder zorgvernieuwing in de projecten naar verwachting tot stand kwam. Zo werd verondersteld dat de aanwezigheid van een projectplan met afgebakende, duidelijk omschreven doelstellingen en een nauwkeurig gespecificeerd tijdschema van activiteiten bevorderlijk was voor doelbereiking.

Voor de verklaring van verschijnselen in een 'case study' acht Yin het, ongeacht de variant, waardevol wanneer op theoretisch niveau meerdere verklaringen worden opgesteld, die elkaar uitsluiten ('rivaliserende verklaringen'). Met Rivaliserende verklaringen hebben wij gedurende het onderzoek niet gewerkt. In de onderhavige studie is dat wél gebeurd. Met betrekking tot sturing hebben wij bepaald welk van twee rivaliserende hoofdperspectieven plausibel is: het rationele-actorperspectief, of de integratiebenadering (zie par. 1.3 en hoofdstuk 5). Verder hebben wij in par. 2.5.6.3 ten aanzien van de motivering tot handelen volgens regels twee verklaringen gegeven (de machts- en routineverklaringen; zie ook hoofdstuk 6). Echter, deze zijn niet wederzijds uitsluitend. In beide verklaringen, die gedurende de reeks iteraties zijn geformuleerd, spelen routines namelijk een rol. Beide zijn geen zuivere rivaliserende verklaringen, in de betekenis die Yin daaraan geeft.

\subsubsection{Voorbereiding van dataverzameling: opstellen van een 'case study'
protocol}

Bij Yin is een protocol een handleiding voor dataverzameling gedurende een 'case study. Het dient de volgende zaken te bevatten: een overzicht van de gehele studie (zoals achtergrondinformatie, doelen en onderwerpen van het onderzoek); een beschrijving van de procedures voor veldwerk (zoals informatie over te gebruiken databronnen en te volgen werkwijze om toegang te krijgen tot deze bronnen); de onderzoeksvragen en een aanduiding van de te benutten databronnen; een 'outline' voor de rapportage.

Gedurende het onderzoek vonden enkele afzonderlijke ronden van dataverzameling plaats naast de voortdurende verzameling van documenten. Voor elke ronde 
schreven wij meerdere notities. Daarin werden de veldwerkprocedures beschreven en verantwoord (zoals de planning van interviews, de selectie van respondenten en de te gebruiken meetinstrumenten). Ook werden de onderzoekswragen en -thema's aangegeven die de dataverzameling aanstuurden, alsmede de benodigde databronnen. Kort nadat een veldwerkronde was afgesloten werd een analyseschema opgesteld, evenals een outhine voor de rapportage van de bevindingen. Een notitie met een totaaloverzicht van het onderzoek werd niet opgesteld. Het onderzoek kreeg binnen de hoofdlijnen, die waren aangegeven in het design, namelijk steeds meer vorm en inhoud. Bij het schrijven van notities over bijvoorbeeld de veldwerkprocedures werd steeds teruggegrepen naar eerdere notities waarin het design werd ingevuld.

Voor elke veldwerkronde hanteerden wil dus een handleiding die uit verschillende notities bestond. Deze verschillende protocollen waren niet gebundeld tot éen protocol.

\subsubsection{Dataverzameling}

Van de soorten databrommen die Yin (1989) bruikbaar vindt woor een 'case study' (documenten, archieven, interviews, (participerende) observatie en artefacten) hebben wilj voor het onderzoek en deze studie meerdere benut, met name documenten en interviews. Aan beide wordt in zowel het interactionisme ais in de "case study" benadering belang gehecht. Van de vraaggesprekken maakten wij geluidsopnamen, die wij bij de verslaglegging beluisterden.

Daarnaast hebben wij in het onderzoek gebruik gemaakt van registratieformulieren en lijsten met gesloten vragen voor schriftelijke enquêtes. Een belangrijke methode in het interactionisme, observatie, hebben wij niet zelf toegepast. Artefacten en archiefstukken hebben wij niet verzameld.

Yin beschouwt gegevens uit interviews als een relevante bron. Andere bronnen verschaffen volgens hem bruikbare aanvullende informatie. Uit zijn bespreking van gegevens uit archieven en interviews blijkt dat ook kwantitatieve gegevens kunnen worden geraadpleegd, zij het alleen in combinatie met (en ter aanvulling van) gegevens uit andere bronnen. Registratieformulieren worden door Yin niet genoemd. Op zichzelf achtten wij het benutten van gegevens uit registratieformulieren en schriftelijke enquêtes acceptabel. Gedurende het onderzoek hebben wil deze steeds gebruikl in combinatie met gegevens uit andere bronnen.

Tijdens elke ronde van dataverzameling creëerden wij meerdere databases. Voor gegevens uit schriftelijke enquêtes werden SPSS-bestanden opgebouwd. Data uit registraties en interviews werden opgenomen in computer-tekstbestanden (Word Perfect). Documenten werden, per project gegroepeerd en ingedeeld naar bijvoorbeeld thematiek of tijdsperiode, in archiefkasten opgeslagen.

Over het onderzoek verschenen onder andere drie rapporten. Daarin werd vermeld welke bronnen waren benut, wanneer en bij wie gegevens waren verzameld. Met behulp van bijvoorbeeld informatie over de response op enquêtes werd globaal beschreven in hoeverre de dataverzameling verliep volgens de procedures, zoals beschreven in de veldwerknotities. Bij de onderzoeksthema's die in de rapporten aan bad kwamen, werd steeds aangegeven op welke bronnen de bevindingen waren gebaseerd. Wij gaven bij elke bevinding echter niet aan welk specifiek deel van een bepaaide database aan deze bevinding ten grondslag lag. Op basis van de rapporten konden externe personen alleen op hoofdlijnen de "chain of evidence' volgem. In de navolgende hoofdstukken hebben wij specifieker dan in de onderzoeksrapporten naar relevante databronnen verwezen. De 'chain of evidence' is meer gedetailleerd. Door bij 
de bespreking van de analyses (zie par. 3.5 en 3.6) en bij de bevindingen in de volgende hoofdstukken meerdere malen te verwijzen naar de relatie met de vraagstelling en ons conceptueel raamwerk, hebben wij getracht de lezer in staat te stellen de weg van vraagstelling naar conclusies en omgekeerd te volgen.

\subsubsection{Analyse}

Van de drie belangrijkste technieken ('strategieën') die Yin noemt voor de analyse van gegevens gedurende een 'case study', hebben wij tijdens het onderzoek 'explanation building' en 'time-series analysis' toegepast. Bij de laatste techniek gaat het om de bestudering van opeenvolgende gebeurtenissen en verschijnselen in de tijd. "Pattern-matching' is niet aan de orde geweest.

'Explanation building' hebben wij al toegelicht. 'Time-series analysis' in het onderzoek betrof vooral de beschrijving van ontwikkelingen in de projecten en op Programma-niveau, zoals veranderingen in de organisatie van de hulpverlening. Dit gebeurde met behulp van gegevens over gebeurtenissen. Op de 'time-series anallysis' in de onderhavige studie komen wij terug in par. 3.5.

\subsubsection{Rapportage}

Over het onderzaek hebben wij met behulp van meerdere media verslag gedaan. Wij schreven rapporten, artikelen en papers, hielden voordrachten, verzorgden colleges en brachten tijdens discussiebijeenkomsten onze bevindingen in. De kern van de verslaglegging werd gevormd door twee tussentijdse rapporten en een eindrapport (Tijssen et al, 1991; Van Raak et al, 1992, 1993). Al vroeg na afloop van een dataverzamelingsronde werd gestart met het schrijven van onderdelen van het rapport. Concept-versies van de hoofdstukken met bevindingen werden naar sleutelinformanten (projectleiders en participanten) verzonden met het verzoek de vermelde feiten kritisch te bestuderen en ons van eventuele onjuistheden op de hoogte te stellen ('review). Daarna werden de concept-teksten zo nodig bijgesteld. Tijdens de studie hebben wij geen 'review' toegepast.

In onze rapporten hebben wij de case en zijn onderdelen zoveel mogellijk met naam en toenaam gepresenteerd. Daardoor was de lezer beter in staat de geboden inzichten op hun waarde te beoordelen, bijvoorbeeld door de informatie te combineren met feiten die door derden waren vergaard. Namen van individuele respondenten werden bij de bevindingen niet genoemd om hun privacy zoveel mogelijk te beschermen. Alleen in projectbeschrijvingen maakten wij de identiteit van de belangrijkste informanten bekend: de projectleiders. Dit was onvermijdelijk de beschrijvingen van elk project gedeeltelijk waren gebaseerd op gegevens die door hen waren verstrekt. In de onderhavige studie is op gelijkaardige wijze met anonimiteit omgegaan.

\subsubsection{Validiteit en betrouwbaarheid}

De mogelijkheid die in de definitie van case studies (par. 3.3) werd genoemd om een varieteit aan bronnen te gebruiken, wordt door Yin beschouwd als de unieke kracht
van case studies. Voor validiteit is deze vorm van case studies. Voor validiteit is deze vorm van triangulatie belangrijk. 


\section{Begripswaliditeit}

Yin vermeldt drie technieken (hij noemt deze "tactieken') die zijn bedoeld om de plausibiliteit van bevindingen te vergroten: gelijktijdig meerdere databronnen benutten (triangulatie), een 'chain of evidence" presenteren en teksten laten beoordelen ('review') door sleutelpersonen. Volgens hem zijn conclusies die op basis wan theoretische noties over de empirische werkelijkheid worden getrokken overtuigender en accurater wanneer deze zijn gebaseerd op gegevens uit meerdere bronnen die over een bepaald onderwerp tot dezelfde bevindingen leiden. De beide andere technieken bieden externe personen de gelegenheid uitspraken in rapporten op hun plausibiliteit te beoordelen.

Gedurende het onderzoek zijn de drie technieken in meerdere mate (triangulatie en 'review') of in mindere mate (presentatie van een 'chain of evidence') gebruikt. Tijdens de op het onderzoek gebaseerde studie hanteerden wij de techniek van 'triangulatie' en presentatie van een 'chain of evidence'. Over de 'chain of evidence' en 'review' hebben wij in het voorgaande al gesproken. In de navolgende hoofdstukken is op een aantal plaatsen zichtbaar dat wij triangulatie hebben toegepast, doordat achter bevindingen meerdere (soorten) bronnen zijn vermeld. Door gegevens uit documenten, interviews en registratieformulieren over dezelfde onderwerpen met elkaar te vergelijken, kwamen overeenkomsten en verschillen in de bevindingen aan het licht. Wij waren daardoor beter in staat de plausibiliteit van inzichten, gebaseerd op de diverse bronnen, te beoordelen en vervolgens te besluiten wat wij met de inzichten zouden doen.

\section{Interne validiteit}

Interne validiteit heeft betrekking op causale uitspraken, waarin de relatie wordt gelegd tussen oorzaak en gevolg (verklaring; zie ook par. 3.5.3). Van interne validiteit is volgens Yin sprake, wanneer duidelijk wordt aangetoond dat bepaalde condities leiden tot andere condities. De onderzoeker moet uit zijn gegevens afleiden dat een bepaalde gebeurtenis het gevolg is van een eerdere gebeurtenis. Interne validiteit draait dan om de volgende vragen: is de afleiding correct en zijn alle rivaliserende verklaringen overwogen? Is de bewijslast convergent (komen bevindingen over hetzelfde onderwerp, gebaseerd op gegevens uit meerdere bronmen, met elkaar overeen?) en lijkt deze waterdicht?

Voor deze vorm van validiteit acht Yin 'pattern-matching' en de door ans toegepaste technieken 'explanation building' en 'time-series analysis' van groot belang, alsmede het gebruik van rivaliserende verklaringen.

\section{Externe validiteit}

Externe validiteit betreft de bepaling van het domein waarnaar bevindingen uit een studie kunnen worden gegeneraliseerd. Deze vorm van validiteit heeft bij case studies niets te maken met statistische generaliseerbaarheid, maar met analytische generaliseerbaarheid: "case studies, like experiments, are generalizable to theoretical propositions and not to populations or universes. In this sense, the case study, like the experiment, does not represent a "sample", and the investigator's goal is to expand and generalize theories (analytic generalization) and not to enumerate frequencies (statistical generalization)" (Yin, 1989).

Met het oog op analytische generaliseerbaarheid moeten empirische resultaten van een 'case study' worden vergeleken met theoretische proposities. Komen theorie en empirie overeen, dan moet de exercitie bij een andere case worden herhaald. Voor de selectie van deze case fungeert een verzameling theoretische uitspraken, die aangeven onder welke omstandigheden een bepaald verschijnsel wordt verwacht (of 
juist niet) als uitgangspunt (Yin, 1994). In de geselecteerde case moet van deze omstandigheden sprake zijn.

Leidt de exercitie tot dezelfde conclusies, dan is sprake van 'replication'. De bevindingen winnen aan overtuigingsikracht. Toepassing van de "replication logic" is zowel mogelijk bit 'pattern-matching' als bij 'explanation building'. Volgens Glaser en Strauss (1967) is "replication" door middel van vergelijking 29 thet beste middel om te komen tot valide bevindingen.

In het onderzoek en de studie streefden wij uitsluitend naar analytische generaliseerbaarheid. Tijdens het onderzoek vergeleken wij op meerdere momenten een empirisch patroon dat wij -'bestuurd' vanuit ons conceptueel raamwerk- in een project vaststelden en vervolgens beschreven, met empirische patronen in de andere projecten in het Programma van WVC. Aldus konden wij bepalen of het patroon dat wij waarnamen in het ene project, ook in het andere te zien was.

Ten behoeve van 'replication' gedurende de onderhavige studie hebben wij binnen het project itz een aantal kleinere en grotere cases onderscheiden (zie par. 3.5.3). 'Replication' buiten het kader van het project itz is in deze studie niet aan de orde en laten wij in dit hoofdstuk verder buiten beschouwing. Dergelijke 'replication' is een aandachtspunt voor vervolgonderzoek "waarbij de theorie uit hoofdstuk 2 kan worden gebruikt (zie par. 7.7.2).

Belangrijk is te benadrukken dat het zowel in het onderzoek als in deze studie ging om vergelijking van empirische patronen met 'sensitizing' veronderstellingen. welke langs de weg van 'explanation building' via iteraties werden geformuleerd en aangescherpt. De theoretische patronen die wij hebben beschreven, zijn vanuit de empirie tot stand gekomen en niet onafhankelijk daarvan. Bij Blumer (1969) is dit een belangrijke voorwaarde. Theoretische uitspraken die onafhankelijk van de empirie tot stand zijn gekomen, worden in het interactionisme niet aanvaard.

\section{Betrouwbaarheid}

Bij Yin heeft 'betrouwbaarheid' betrekking op herhaling van een uitgevoerde 'case study" door een andere onderzoeker. Indien deze onderzoeker via exact dezelfde procedures, zoals gehanteerd en beschreven door de eerste onderzoeker(s), tot dezelfde bevindingen komt, is sprake van betrouwbaarheid. De betrouwbaarheid kan dus pas worden beoordeeld, zodra deze exercitie is uitgevoerd.

Een zorgvuldige, stapsgewijze administrering van alle gevolgde procedures is een belangrijke voorwaarde om de betrouwbaarheid te kunnen vaststellen. Zonder een dergelijke administratie is herhaling van de "case study' onmogelijk. Het gebruik van een veldwerkprotocol is daarbij een waardevol hulpmiddel. Verder moeten databases op een zodanige wijze zijn opgebouwd, dat gegevens die daarin zijn opgeslagen probleemloos kunnen worden opgevraagd en kritisch kunnen worden beoordeeld. Tenslotte is de opbouw van een 'chain of evidence' noodzakelijk, opdat een andere onderzoeker de weg tussen onderzoeksvragen en bevindingen via reeds verzamelde gegevens in beide richtingen kan volgen.

Gedurende het onderzoek zijn alle gevolgde procedures gedocumenteerd. Van veel analyses zijn verantwoordingen geschreven. Deze documenten, alsmede exemplaren van alle gebruikte instrumenten voor dataverzameling en de opgebouwde

'Reptication' is bij Glaser en Strauss (1967) een variant van de "vergelijkende analyse", waarvan de grondgedachte reeds door Weber, Durkheim en anderen werd antwikkeld. Vergeilijkende analyse wordt niet alleen toegepast bij exploratie, maar ook bij experimenten en statistische analyses. 
gegevensbestanden, hebben wij bewaard. Veldwerkprotocollen zijn beschikbaar, databases hebben wij toegankelijk gemaakt. Over de 'chain of evidence' hebben wij al gesproken. De "case study" kan worden herhaald.

Yin beperkt zich in zijn bespreking van betrouwbaarheid tot herhaling van de 'case study' als geheel, met behulp van reeds verzamelde gegevens. Daarmee wordt echter de vraag niet beantwoord of bijvoorbeeld herhaalde toepassing van dezelfde methode woor dataverzameling bij dezelfde respondenten op een ander tijdstip zou leiden tot dezelfde bevindingen.

Tijdens de onderhavige studie hebben wij vooral gebruik gemaakt van gegewens uit documenten en interviews. Voor de eerste databron is geen meetinstrument gebruikt, voor de laatste wel. Alle interviews gedurende ons onderzoek vonden plaats op basis van open vragen en themalijsten. Kenmerkend voor deze werkwijze is dat zij niet leidt tot maximale vergelijkbaarheid van gegevens die zijn verzameld tijdens verschillende interviews. Elk interview heeft zijn unieke verloop, ook al zijn dezelfde vragen en thema's aan de orde gesteld. Sommige onderwerpen zullen tijdens het ene interview bijvoorbeeld diepgaand worden besproken en in het andere niet. Verschillende onderzoekers zullen, ook al gebruiken zij dezelfde themalijst, niet dezelfde soorten gegevens verzamelen. Van test-retest betrouwbaarheid, onderzoeker-betrouwbaarheild en instrument-betrouwbaarheid (Segers, 1983) kan niet worden gesproken.

\subsubsection{Beoordeling van het uitgevoerde onderzoek en de studie}

Gezien de aard van het onderzoeksobject (dit was bijvoorbeeld gecompliceerd en kon niet uit de context worden gelicht) lag toepassing van de 'case study' benadering als onderzoeksstrategie voor de hand. Een andere benadering was niet geschikt. Bezien wij het onderzoek naar het Programma van WVC en de onderhavige studie vanuit de 'case study' benadering volgens Y'in, dan komen wij tot de conclusie dat deze veelal zijn uitgevoerd volgens de regels die Yin heeft geformuleerd, in het bijzonder voor de variant van de 'explanation building'. Het voorgaande moge dit illustreren.

$\mathrm{Er}$ zijn minpunten. Observatie is -uitsluitend wegens gebrek aan personele capaciteit binnen de Onderzoeksgroep Zorgvernieuwing- niet door onszelf toegepast, welke methode naast documentstudie en focused interviews belangrijk is bij exploratie. De betrouwbaarheid van de gebruikte instrumenten voor interviews laat te wensen over, ook al is dit probleem inherent aan de gevolgde methode. Hoewel de vragen van de studie zijn geformuleerd binnen het kader van de vragen van het onderzoek, kunnen wij niet zeggen dat de vraagstelling sinds de start van het onderzoek onglewijzigd is gebleven.

\subsection{Dataverzameling gedurende het onderzoek}

In toetsend onderzoek volgen op de ontwikkeling van een conceptueel madel de processen van indicering en operationalisering. Indicering is de benoeming van empirisch waarneembare verschijnselen ('indicatoren') die een theoretische variabele 
vertegenwoordigen ( $\mathrm{vgl}$. Segers, 1983) ${ }^{30}$. Operationalisering wordt doorgaans omschreven als de formulering van instructies voor de indicatoren van variabelen. In deze instructies (ook wel 'operationele definities' genoemd) is aangegeven hoe de waarde van een variabele zal worden vastgesteld. Waarnemingsmethoden worden aangewezen en de onderzoeker krijgt een handgreep aangereikt om te kunnen vaststellen of onderzochte elementen bepaalde eigenschappen bezitten of niet. Operationele definities worden opgenomen in instrumenten voor dataverzameling (Segers, 1983).

Indicering en operationalisering, zoals hier omschreven, verhouden zich slecht met de interactionistische methodologie. Zij kunnen namelijk pas plaatsvinden nadat variabelen volledig zijn gespecificeerd. Zij vereisen 'definitive concepts', terwijl Blumer juist het 'sensitizing' karakter van begrippen benadrukt.

Dit laat onverlet dat ook bij exploratie tussen concepten en dataverzameling een verbinding kan worden gelegd. In het onderzoek vormden de door ons gehanteerde 'sensitizing concepts' de basis voor instrumenten voor dataverzameling. Uitgaande van deze concepten zijn gedurende het onderzoek steeds onderwerpen ('topics'; Yin, 1989) benoemd waarover gegevens moesten worden verzameld. Deze onderwerpen werden opgenomen in instrumenten waarmee wij de empirie tegemoet traden, zoals themalijsten voor vraaggesprekken. Wanneer wij het in het kader van onze 'explanation building' het conceptueel raamwerk veranderden, dan veranderden wij vervolgens ook de onderwerpen en aansluitend de instrumenten voor dataverzameling.

Wij hanteerden geen operationele definities, zoals hierboven omschreven. Een uitzondering waren de schriftelijke enquêtes die wij hebben georganiseerd (zie par. 3.4.1). De daarbij gebruikte instrumenten bestaan voornamelijk uit operationele definities en passen niet in de interactionistische methodologie. Daarom zijn de enquêtegegevens in de onderhavige studie niet gebruikt.

\subsubsection{Methoden en instrumenten voor dataverzameling}

Gedurende het onderzoek zijn op meerdere momenten instrumenten voor dataverzameling vervaardigd en vond een aantal veldwerkronden plaats.

Overzicht 3.3 vat de dataverzameling samen. Vermeld zijn de gehanteerde instrumenten en de methode waartoe zij behoren; een omschrijving van de instrumenten; de veldwerkperiode, de respondenten en response. In de laatste kolom is steeds aangegeven of de gegevens voor de onderhavige studie zijn gebruikt. Het overzicht bevat 11 instrumenten. Het zou te ver voeren hier een exemplaar van al deze instrumenten op te nemen. De bijlage 'Instrumenten voor dataverzameling' bevat een aantal onderdelen van verschillende instrumenten.

Voor de verzameling van documenten is, zoals gezegd, geen afzonderlijk instrument gehanteerd. Deze methode is in Overzicht 3.3. daarom niet vermeld. Documenten werden meestal verstrekt door de projectleiders. De onderzoekers stonden op de verzendlijst voor documenten die aan de orde kwamen tijdens vergaderingen van de strategische top van de projectorganisaties. Daardoor ontvingen wij exemplaren van dezelfde documenten als de projectparticipanten. Periodiek werd

Swanborn (1987, p. 167) noemt een indicator een deelinstrumentje, een item in eem meefinstrument. Hij schakelt indicator en operationele definitie dus gelijk. Segers (1983) doel dit nu eens wét (p.134) en dan weer niet (p. 133) 
gecontroleerd of alle vergaderstukken waren ontvangen, die in de agenda van vergaderingen werden genoemd. Was dit niet het geval, dan werd de projectleider gevraagd ontbrekende dacumenten na te zenden. Dit gebeurde doorgaans ook.

Biij de ontwikkeling van instrumenten zijn zelden vragen uit bestaande instrumenten overgenomen. De ontwikkeling vond plaats na raadpleging van literatuur over de onderwerpen die voor het onderzoek belangrijk waren.

\subsection{2 'Fit' tussen latere concepten en eerder verzamelde data}

Hoewel het opstellen van het conceptueel raamwerk van deze studie deel uitmaakt van het conceptualiseringsproces dat bij de start van het onderzoek is ingezet, komen de concepten uit onderzoek en studie niet helemaal overeen (zie Overzicht 3.1).

Gevalg zou kunnen zijn dat tussen latere concepten en eerder verzamelde data niet altijd sprake is van een 'fit'. In toetsend onderzoek zou hier een validiteitsprobleem bestaan ('meet ik wat ik wil meten?'). In ons explorerend onderzoek echter niet. Door het gebruik van 'sensitizing concepts' als richtinggevers bij het veldwerk en door verzameling van gegevens met behulp van gespreksthema's, open vragen et cetera, zijn de data noch specifiek gekoppeld aan een afgebakend begrip, noch aan afzonderlijke dimensies daarvan. Dit geldt eens temeer voor de gegevens in de verzamelde documenten.

Wij hebben de beschikbare geglevens onderzocht en willen het volgende benadrukken. Gegevens zijn niet terzijde geschoven wanneer wij vaststelden dat hun kenmerken niet konden worden verenigd met de inhoud van het conceptueel raamwerk. Haddlen wij dit wel gedaan, dan was een onaanvaardbare vertekening van de inzichten opgetreden. Wij gingen anders te werk. Kwamen empirie en theorie niet overeen, dan stelden wij via iteraties het conceptueel raamwerk bij. Uit de verantwoording van de werkzaamheden tot dusverre moge duidelijk zijn dat deze werkwijze in overeenstemming is met de interactionistische methodologie. Niet alle facetten van het conceptueel raamwerk konden steeds volledig met de empirie worden vergelleken. Lacunes in de beschikbare gegevens komen op meerdere plaatsen nog aan de orde.

\subsubsection{Bruikbaarheid van de verzamelde gegevens voor de studie}

Het achterwege laten van obserwaties gedurende ons onderzoek lijkt in eerste instantie een probleem te zijn. Observatie is namelijk de methode bij uitstek voor het waarnemen van interacties tussen actoren (zie Segers, 1983). Interacties waren in thet onderzoek en de studie belangrijke verschijnselen.

De door ons toegepaste combinatie van drie methoden wan dataverzameling beschouwen wij als een oplossing van dit probleem. Onderdeel van de documenten die wij hebben verzameld, zijn notulen van vergaderingen binnen netwerken. De meeste zijn meer dan besluitenlijsten. In het grootste deel wordt verslag gedaan wan interacties en andere zaken die voor deze studie van belang zijn. De notulen werden tijciens een volgende vergadering besproken en -al dan niet na tekstuele wijziging-door de participanten vastgesteld. De weergave van verschijnselen werd door de betrokkenen zelf gecontrolleerd. 
Overzicht 3.3 Dataverzameling gedurende het onderzoek

\begin{tabular}{|c|c|c|c|c|c|c|}
\hline \multicolumn{2}{|c|}{$\begin{array}{l}\text { Haaminstrumenl woor } \\
\text { dataverzameling (metho- } \\
\text { de) }\end{array}$} & \multirow{2}{*}{ 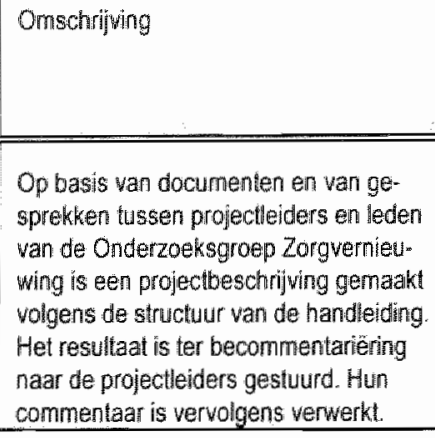 } & \multirow{2}{*}{$\begin{array}{l}\begin{array}{l}\text { Veldwerk- } \\
\text { periode }\end{array} \\
\begin{array}{l}\text { jan+dec } \\
1990\end{array}\end{array}$} & \multirow{2}{*}{$\begin{array}{l}\begin{array}{l}\text { Respon- } \\
\text { denten } \\
\text { (aantal) }\end{array} \\
\text { Projectlei- } \\
\text { ders (12) }\end{array}$} & \multirow{2}{*}{$\begin{array}{l}\begin{array}{l}\text { Respom- } \\
\text { se } \\
\text { perc. } \\
\text { (aantal) }\end{array} \\
\begin{array}{l}100 \% \\
(12)\end{array}\end{array}$} & \multirow{2}{*}{$\begin{array}{l}\text { Data ge- } \\
\text { bruikt in } \\
\text { studie }\end{array}$} \\
\hline 1 & $\begin{array}{l}\text { "Handieiding voor } \\
\text { het structureren } \\
\text { van innovatien pro- } \\
\text { jecten zorgaan- } \\
\text { bod' (registratie) }\end{array}$ & & & & & \\
\hline 2 & $\begin{array}{l}\text { 'Registratieformu- } \\
\text { lieren mei/juni } \\
1990 \text { (registratie) }\end{array}$ & $\begin{array}{l}\text { Het instrument bestaat uit open wragen } \\
\text { en is ter invulling naar de projectleiders } \\
\text { verzonden. }\end{array}$ & $\begin{array}{l}\text { jun-dec } \\
1990\end{array}$ & $\begin{array}{l}\text { Projectlei- } \\
\text { ders }(12)\end{array}$ & $\begin{array}{l}100 \% \\
(12)\end{array}$ & ja \\
\hline 3 & $\begin{array}{l}\text { 'Enquête partici- } \\
\text { parten najaar } \\
1990 \text { ' (schriftelijke } \\
\text { enquête) }\end{array}$ & $\begin{array}{l}\text { Het instrument bevat naast open vragen } \\
\text { veelal gesloteri vragen. Het is ter invul- } \\
\text { ling verzonden naar de directeuren wan } \\
\text { instellingen die formeel op de participan- } \\
\text { lenlijst van de projecten stonden. }\end{array}$ & $\begin{array}{l}\text { okt-dec } \\
1990\end{array}$ & $\begin{array}{l}\text { Directeu- } \\
\text { ren partici- } \\
\text { perende } \\
\text { instelling- } \\
\text { en (125) }\end{array}$ & $\begin{array}{l}84 \% \\
(105)\end{array}$ & nee \\
\hline 4 & $\begin{array}{l}\text { "Themalijst inter- } \\
\text { views directeuren } \\
\text { gezinszorg en } \\
\text { kruiswerk najaar } \\
1990 \text { (focused } \\
\text { interviews) }\end{array}$ & $\begin{array}{l}\text { Het instrument beval uitsiluitend open } \\
\text { wragen en is gebruikt tijdens open inter- } \\
\text { views. Bij de vragen zijn mel behulp van } \\
\text { sleutelwoorden relevante onderwerpen } \\
\text { genoleerd. Deze sleutelwoorden stelden } \\
\text { de interwiewer in staat le bepalen of } \\
\text { tijdens het interview de belangrijkste } \\
\text { thema's aan de orde kwamen. Elk inter- } \\
\text { view is gewoerd door een lid van de } \\
\text { Onderzoeksgroep Zorgvermieuwing. }\end{array}$ & $\begin{array}{l}\text { sep-nov } \\
1990\end{array}$ & $\begin{array}{l}\text { Directeu- } \\
\text { ren ge- } \\
\text { zinszorg } \\
\text { en krüls- } \\
\text { werk (25): }\end{array}$ & $\begin{array}{l}100 \% \\
(25)\end{array}$ & ja \\
\hline 5 & $\begin{array}{l}\text { "Themallitst inteil" } \\
\text { views projectle:- } \\
\text { ders najaar } 1990 " \\
\text { (focused inter- } \\
\text { views) }\end{array}$ & Zie omschrijuing bij instrumeni 4 & $\begin{array}{l}\text { sep-nov } \\
4990\end{array}$ & $\begin{array}{l}\text { Project- } \\
\text { leiders } \\
\left(11^{*}\right)\end{array}$ & $\begin{array}{l}100 \% \\
(11 \%)\end{array}$ & $\Pi a$ \\
\hline
\end{tabular}




\section{Overzicht 3.3 Dataverzameling gedurende het onderzoek (vervolg)}

\begin{tabular}{|c|c|c|c|c|c|c|}
\hline \multicolumn{2}{|c|}{$\begin{array}{l}\text { Naam instrument voor } \\
\text { datawerameling (metho- } \\
\text { de) }\end{array}$} & \multirow{2}{*}{$\begin{array}{l}\text { Omschrijving } \\
\text { Het instrument is naar de projecteiders } \\
\text { gezonden. Het beval een aantal formulie- } \\
\text { ren met een vaste structuur: rijen en } \\
\text { kolommen waarim de projectleiders over in } \\
\text { de kolommen aangegexen onderwerpen } \\
\text { gegevens dienden in te vullen. }\end{array}$} & \multirow{2}{*}{$\begin{array}{l}\text { Veld- } \\
\text { werkperi- } \\
\text { ode } \\
\\
\begin{array}{l}\text { okt-dec } \\
1991\end{array}\end{array}$} & \multirow{2}{*}{$\begin{array}{l}\text { Respon- } \\
\text { denten } \\
\text { (aantal) }\end{array}$} & \multirow{2}{*}{$\begin{array}{l}\begin{array}{l}\text { Response } \\
\text { perc. } \\
\text { (aantal) }\end{array} \\
100 \% \\
(12)\end{array}$} & \multirow{2}{*}{$\begin{array}{l}\text { Datage } \\
\text { bruikt in } \\
\text { studie }\end{array}$} \\
\hline 6 & $\begin{array}{l}\text { "Woortgangsregis- } \\
\text { tratie projecten } \\
\text { periode najaar } \\
1990 \text { - } 1.4 \text { oktober } \\
1991 \text { ' (registratie) }\end{array}$ & & & & & \\
\hline 7 & $\begin{array}{l}\text { "Vragenlijst inter- } \\
\text { wews projectlei- } \\
\text { ders najaar 1991' } \\
\text { (focused inter- } \\
\text { views) }\end{array}$ & Zie omschrijving bij instrument 5 . & now 1891 & $\begin{array}{l}\text { Projectlei- } \\
\text { ders }(12)\end{array}$ & $\begin{array}{l}100 \% \\
(12)\end{array}$ & 间 \\
\hline 8 & $\begin{array}{l}\text { "Voontgangsragis" } \\
\text { tratie projecten } \\
\text { najaar } 1992 \text { (re- } \\
\text { gistratie) }\end{array}$ & Zie omschrijving bij instrument 6 . & $\begin{array}{l}\text { ok } 1992 \\
- \\
\text { jan } 1993\end{array}$ & $\begin{array}{l}\text { Projectiel. } \\
\text { ders (12) }\end{array}$ & $\begin{array}{l}100 \% \\
(12)\end{array}$ & ja \\
\hline 9 & $\begin{array}{l}\text { 'Themalist inter- } \\
\text { views projectlei- } \\
\text { ders najaar } 1992 \\
\text { (focused inter- } \\
\text { views) }\end{array}$ & Zie omschrijuving bij instrument 5 . & $\begin{array}{l}\text { nov } \$ 992 \\
-j a n \\
1993\end{array}$ & $\begin{array}{l}\text { Project- } \\
\text { leiders } \\
\text { (12) }\end{array}$ & $\begin{array}{l}100 \% \\
(12)\end{array}$ & ja \\
\hline 10 & $\begin{array}{l}\text { 'Enquête partici- } \\
\text { panten najaar } \\
1992 \text { (schriftelij)- } \\
\text { ke enquêle) }\end{array}$ & Zie ornschrijving biil instrument 3 . & $\begin{array}{l}\text { mov } 1992 \\
\text { - jan } \\
\text { J993 }\end{array}$ & $\begin{array}{l}\text { Directeu- } \\
\text { ren parti- } \\
\text { ciperende } \\
\text { instelling- } \\
\text { en (114) }\end{array}$ & $\begin{array}{l}71 \% \\
(81)\end{array}$ & nee \\
\hline 11 & $\begin{array}{l}\text { "Enquête huipver- } \\
\text { leners januari } \\
1993 \text { ' (schrifttelij- } \\
\text { ke enquête) }\end{array}$ & $\begin{array}{l}\text { Het instrument bewat naast open vragen } \\
\text { veelal gesloten vragen. Het is ler inwulling } \\
\text { verzonden naar hulpverleners en naar } \\
\text { personen met overzicht over de organis al- } \\
\text { tie van de gehele zorgwerlening. }\end{array}$ & $\begin{array}{l}\text { jan-mrt } \\
1993\end{array}$ & $\begin{array}{l}\text { Huipwerle- } \\
\text { ners an } \\
\text { algenene } \\
\text { coördina- } \\
\text { toren } \\
(170)\end{array}$ & $\begin{array}{l}73 \% \\
(124)\end{array}$ & nee \\
\hline
\end{tabular}

Tijdens genoemde veldwerkperiode fungleerde éen respondent tijdeliik als projectleider van twe projecten.

Verder beschikken wij over evaluatierapporten van processen en gebeurtenissen binnen netwerken, door leden van de netwerken zelf geschreven. Onder hen waren de personen (projectleiders) die door hun positie in de netwerken de gebeurtenissen op alle niveaus van de netwerken konden aanschouwen. In de genoemde evaluatierapporten zijn dergelijke aangelegenheden, zoals interacties, meermaals weergegeven. Wij hebben dus niet zelf geobserveerd, maar hebben gebruik gemaakt van schriftelijke verslagen van observaties door derden. Via hen konden wij waarnemen. Zij waren onze ogen en oren.

Hoe bruikbaar de verzamelde documenten op zichzelf ook mogen zijn, gebruik daarvan alleen achtten wij niet toereikend om het gewenste inzicht te krijgen. Daarom hebben wij tevens gegevens benut uit interviews met sleutelpersonen. Tijdens deze interviews is bijvoorbeeld ingegaan op de interacties tussen leden van de netwerken. 
Wellicht zijn dergelijke interviews minder dan observaties geschikt voor het vastleggen van interacties. Ze zijn daarvoor echter niet ongeschikt (Segers, 1983). In de registratieformulieren die wij meerdere malen ter invulling naar de projectleiders hebben verzonden, kwamen onderwerpen zoals interacties eveneens aan de orde.

Gebruik van gegevens over observaties door de projectparticipanten zelf had een voordeel, dat in het licht van onze methodologie van belang is. De drie beschreven bronnen zijn verzamelingen uitspraken van de betrokken actoren (zie ook par. 3.5.1). De observaties die door deze uitspraken worden weergegeven betreffen niet alleen feitelijke beschrijvingen van bijvoorbeeld interacties, maar ook beoordelingen daarvan. Met andere woorden, de uitspraken reflecteren de betekenis die verschijnselen voor de actoren zelf hadden. Wij kregen aldus inzicht in de intermediair tussen verschijnselen en handelingen (zie par. 3.2.3). Niet in alle gevallen overigens waren gegevens beschikbaar om de betekenissen voor de actoren op te sporen. Wij gaven als onderzoekers dlan zelf betekenis. In de navolgende hoofdstukken is beargumenteerd in hoeverre wij de door ons gegeven betekenis toepasselijk achten.

De uitspraken van de actoren waren tenslotte ook van belang om de aard van routimes van actoren te kunnen bepalen. Routines -een van de kernverschijnselen in onze studie- worden zichtbaar in handelingen (vgl. Schein, 1988; Peterson, 1985; Blumer, 1969; Glaser en Strauss, 196731). De weergave van handelingen en interacties in de reeds besproken uitspraken, gaf ons dus gelegenheid routines van de bestudeerde actoren te identificeren. Tot handelingen behoort ook het gebruik van taal zelf (taalhandelingen ofwel 'speech acts'; zie Austin, 1976). Uitspraken die werden gedaan tijdens vergaderingen en interviews, waarin actoren bijvoorbeeld situaties beoordeelden, verschaften -naast een beeld van betekenissen- ook inzicht in routines. Uitspraken die handelingen en interacties beschrijven en uitspraken als handelingen zelf, boden ons een tweeledige mogelijkheid de routines van actoren in kaart te brengen.

\subsection{Gebruikte analysetechnieken}

Aan alle analyses die wij voor deze studie hebben uitgevoerd "ligt de techniek van de 'time-series analysis' ten grondslag. Opdat de techniek kon worden toegepast moesten de data over het project itz worden verwerkt tot analyseerbare eenheden. Dit hebben wij gedaan met behulp wan een techniek, ontleend aan Denzin (1989): 'bracketing'. Ten behoeve van de plausibiliteit van theoretische uitspraken hebben wij de 'replication'-techniek gehanteerd. In het navolgende bespreken wij deze analysetechnieken.

Als hulpmiddel bij de analyse van de gegevens diende een aantal schema's. Zij boden ons een ordeningskader voor de grote hoeveelheid gegevens waarover wij beschikken, alsmede een controlemiddel voor onze redeneringen. Deze schema's worden, in de varm van figuren, in par. 3.6 gepresenteerd.

Schema 3.1 toont, geordend naar de vragen van onze studie, de vindplaatsen van de bevindingen naar aanleiding van de analyses. 
In hoofdstuk 4 worden de veranderingen met betrekking tot netwerken beschreven in termen van structuur, macht en cultuur ('wat'-vraag; zie par. 3.3.2). In hoofdstuk 5 beschrijven wij hoe de veranderingen gebeurden, via handelingen volgens de regels die gedurende sturingsinteracties zijn ontstaan ('hoe'-vraag). Daarmee wordt de eerste aanzet gedaan tot de verklaring van verschijnselen.

In hoofdstuk 6 belichten wij de aanleiding tot sturing en gaan wij dieper in op de sturing door actorem. De bespreking reikt tot aan het product van sturing (handelingsregels). De verklaring wordt verder opgebouwd ('waarom'-vragen). Het inzicht dat resulteerde uit de analyse van de 'brackets' is in hoofdstuk 7 gebruikt voor de beantwoording van de vragen uit de probleemstelling.

Door middel van Wordperfect (versie 6.1) hebben wij de te analyseren data verwerkt en in overzichten ingedeeld. Gebruik van computerprogrammatuur voor de analyse van kwantitatieve of kwalitatieve gegevens, zoals SPSS en Kwalitan, kwam niet in aanmerking. Dergelijke programmatuur zou alleen zijn gebruikt om data te ordenen en in te delen. Wij konden met Word Perfect op eenvoudige wijze hetzelfde doen.

\section{Wat:}

netwerken en veranderingen

in structulur, macht en cultuur

Hoe:

veranderingen door handelingen volgens regels, als product van sturingsinteracties

Waarom:

van aanleiding van sturing tot product (handelingsregels)

Opbrengst:

inzicht in processen

Gebruk inzicht:

beantwoording van de vragen

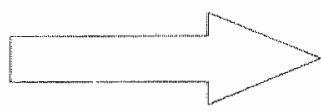

Hoofdstuk 4

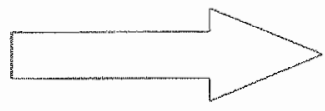

Hoofdstuk 5

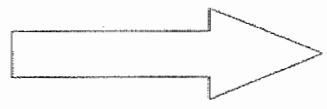

Hoofdstuk 6

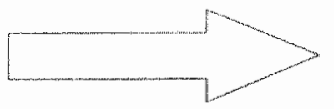

Hootdstuk 4, 5, 6

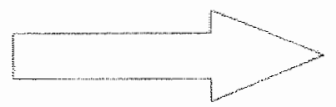

Hoofdstuk 7

Schema 3.1 Totaaloverzicht: analyses en de vindplaats van bevindingen 


\subsection{1 'Bracketing'}

De techniek van 'bracketing' (Denzin, 1989), die wij aanstonds illustreren, wordt toegepast bij de analyse van uitspraken in teksten en verhalen (zoals persoonlijke getuigenissen van actoren), die inzicht geven in verschijnselen. Teksten of verhalen worden uiteengerafeld, van de onderdelen (uitspraken) wordt de betekenis bepaald, bij voorkeur de betekenis voor de actor in kwestie. Vervolgens wordt nagegaan welke kenmerken van het bestudeerde verschijnsel de betekenissen weergeven. Samenvoeging van 'brackets' tot een verzameling en schikking van de 'brackets' daarbinnen (door Denzin aangeduid als 'construction') levert tenslotte een totaalbeeld op van het verschijnsel. Dit beeld wordt door de onderzoeker beschreven.

De gegevens in onze databestanden zijn -met uitzondering van een aantal tekeningen (organogrammen)- uitspraken in teksten: schriftelijke weergaven van vraaggesprekken, registratieformulieren die door bestudeerde actoren zijn ingevuld, documenten zoals vergadernotulen, beleidsplannen en protocollen. Ten aanzien van de handelingsregels bijvoorbeeld hebben wij de beschikking over schriftelijke voorstellen voor de organisatie van betrekkingen tussen actoren (schriftelijke regels), alsmede over regels die tijdens vergaderingen zijn uitgesproken en in notulen zijn vastgelegd (mondelinge regels, op schrift gesteld). Om de gegevens uit al deze teksten geschikt te maken voor analyse hebben wij de bracketing-techniek toegepast.

Bestuurd vanuit onze concepten hebben wij de verzameling data uiteengerafeld. Wij hebben de resulterende data-eenheden ingedeeld naar de verschijnselen die wij met behulp van het conceptueel raamwerk bestudeerden 32 . Aan concepten zoals 'afhankelijkheidsrelaties' konden wij aldus empirisch inhoud geven. De verschijnselen die met dit concept werden aangeduid, konden met hun variëteit in de sociale werkelijkheid zichtbaar worden gemaakt. De eenheden die tijdens de uiteenrafeling ontstonden, zijn 'brackets'. Dit konden individuele uitspraken zijn, maar ook een aantal uitspraken bijeen. In een aantal gevallen vonden wij het nodig de inhoud van omvangrijke 'brackets' compact weer te geven. Daartoe hebben wij samenvattingen gemaakt. In de terminologie van Denzin (1989) hebben wij in die gevallen 'thin descriptions' vervaardigd van 'thick descriptions'.

Overzicht 3.4 bevat, ingedeeld bij de concepten uit Overzicht 2.2, een korte aanduiding van de data waarop wij de 'bracketing' techniek hebben toegepast. Om inzage te bieden in de manier waarop wij bij de analyses te werk zijn gegaan, is in Overzicht 3.5 een illustratie opgenomen van de resultaten van de uiteenrafeling van gegevens. De illustratie heeft betrekking op de case van de psychogeriatrische patiënten (pg-patiënten) die in hoofdstuk 6 wordt beschreven. In het overzicht zijn uitspraken van actoren als 'brackets' ingedeeld bij de categorieën these, antithese en synthese. Aangegeven is de vergadering tijdens welke de uitspraken zijn gedaan (netwerk en datum), het kader van de uitspraken en de gegevensbron ('D' verwijst naar de databron -zie bijlagen- 'documenten'). De opmerkingen die wij gedurende de analyses hebben gemaakt, zijn in cursief weergegeven.

32 De inzĭchten die deze werkwijze opleverde, werden zo nodig gebruikt on hel canceptueel raanmerk aan te scherpen, waarna eventueel herindeling van de data plaatswond. 


\subsection{2 'Time-series analysis'}

'Time-series analysis' ( $Y$ in, 1989) houdt in dat analyseerbare data-eenheden ('brackets', ingedeeld bij concepten) in een chronologische volgorde worden geplaatst. om bestudering van opeenvolgende gebeurtenissen en verschijnselen in de tijd mogelijk te maken. In Overzicht 3.5 is deze werkwijze voor de case van de psychogeriatrische patiënten herkenbaar.

Met behulp van de genoemde techniek hebben wij de basis gelegd voor de beantwoording van de 'wat'-, 'hoe'- en 'waarom'-vragen (zie par. 3.3.2). Een voorbeeld is de werkwijze voor hoofdstuk 4. Wij belichten daarin twee opeenvolgingen van gebeurtenissen. In beide gaat het om processen van vervlechting en ontvlechting van samenwerkingsrelaties. De eerste opeenvolging betreft de opkomst en opheffing van netwerken met hun handelingsregels. De tweede heeft betrekking op de ontwikkeling. invoering en teniet verklaring van modellen voor de organisatie van de hulpverlening. Elk model bestond uit een verzameling handelingsregels die voor de organisatie van de hulpverlening moesten worden gebruikt.

\subsection{3 'Replication'}

Om daadwerkelijk te kunnen begrijpen waarom verschijnselen zich voordoen, moet de onderzoeker -in navolging van Blumer (1969)- ervan uitgaan dat niet een verschijnsel op zichzelf van belang is voor de verklaring van handelingen, maar de betekenis daarvan voor de actor. Vervolgens moet hij laten zien dat die betekenis aanleiding is geweest voor de handelingen.

Of de betekenis een actor er daadwerkelijk toe heeft aangezet op een bepaalde manier te handelen, kon in de studie niet worden vastgesteld. Hume's uitspraak dat een verband tussen oorzaak en gevolg niet empirisch waarneembaar is (zie Segers en Hagenaars, 1980), is hier zeker van toepassing. Datgene wat zich in het hoofd van de actoren afspeelt, is de black box van deze studie. Blumer's stelling is in ons geval derhalve een assumptie.

Om toch inzicht te kunnen krijgen in de relatie tussen betekenissen en handelingen zijn wij de analyses gestart met de volgende redenering over de relatie tussen oorzaken en gevolg. De onderzoeker moet aantonen dat hij waarnam dat het verschijnsel $X$ (in zijn interpretatie de oorzaak van $Y$ ), in tijd bezien aan $Y$ is vooraf gegaan. Gaat $X$ niet vooraf aan $Y$, dan kan $X$ niet de oorzaak zijn (Segers en Hagenaars, 1980).

Nu kan deze waarneming een incident zijn. Volgens Yin (1989) is in case studies een verklaring overtuigender, indien het veronderstelde patroon tussen $X$ en $Y$ dat in het ene geval empirisch is waargenomen, ook in andere gevallen wordt geconstateerd. Er is dan sprake van 'replication'. 'Replication' hebben wij allereerst nagestreefd bij het patroon tussen regels en handelingen (zie hoofdstuk 5). In essentie gaat het hier om een eerste aanzet tot verklaring van veranderingen in structuur, cultuur en macht vanuit handelingen door actoren ('hoe'-vraag). Vervolgens probeerden wij ook tot 'replication' te komen bij de verdieping van deze verklaring: het vraagstuk van de motivering tot handelen volgens de regels ('waarom'-vragen; zie hoofdstuk 6). Hoofdstuk 5 en 6 tonen dat van 'replication' daadwerkelijk sprake is geweest. 


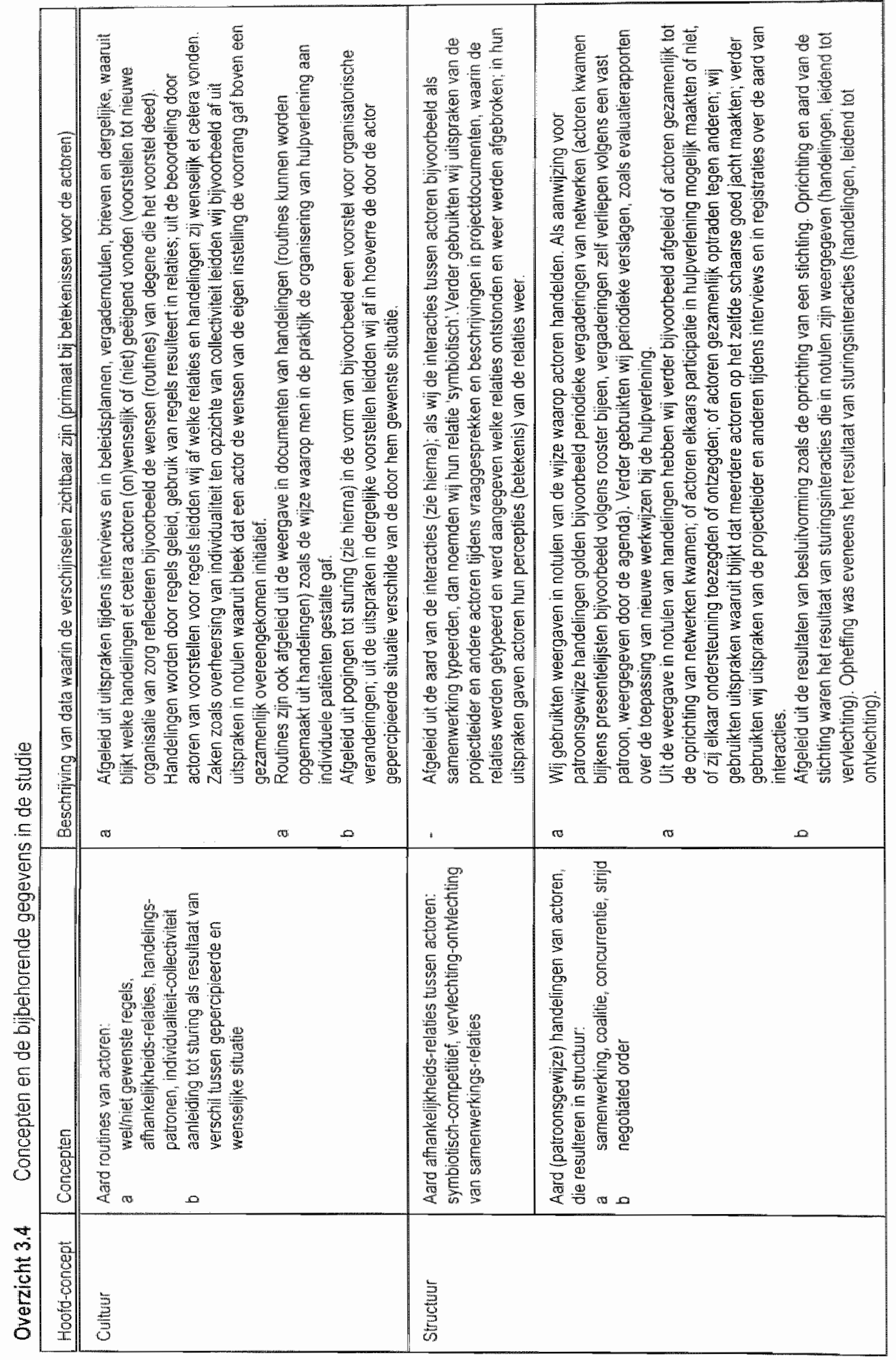




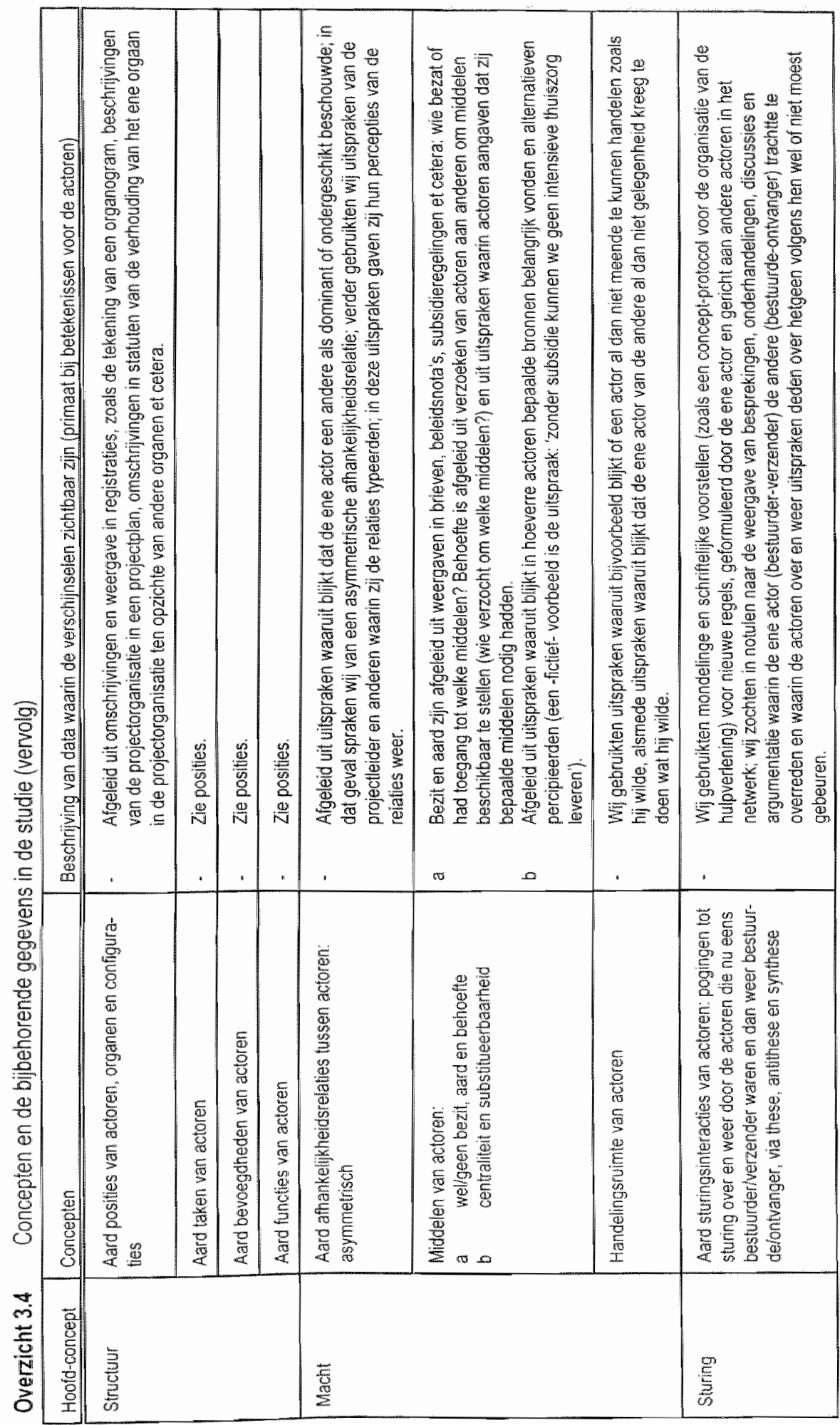




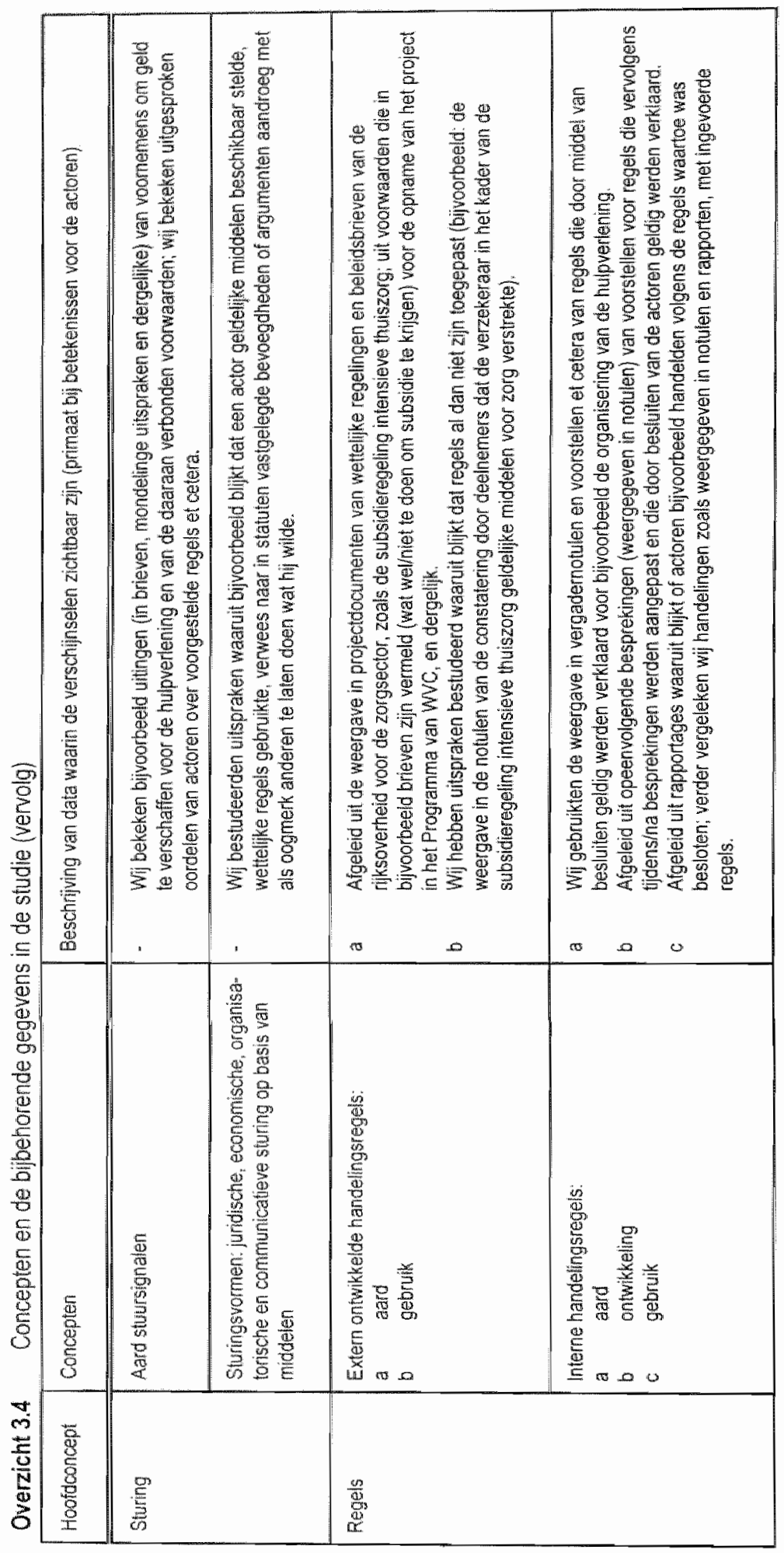




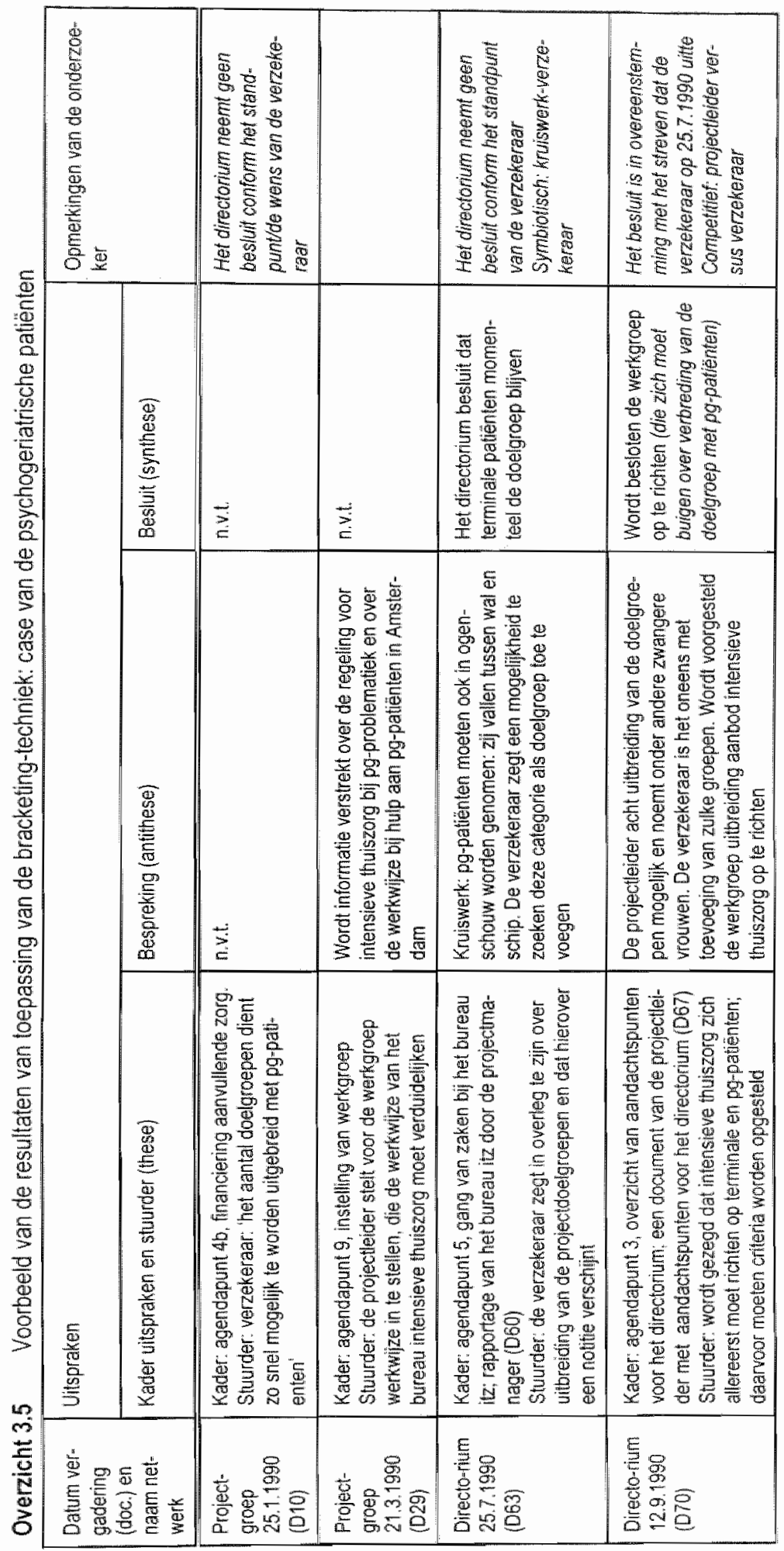


Geheel conform hel gestelde in par. 2.2 .2 gingen wij niet uit van een stimulusresponse schema waarin $X$ rechistreeks leidt tot $Y$ (in dit geval handelingen), maar een sichema waarin $X$ eerst door de actor moet worden waargenomen en van betekenis moet worden voorzien, op basis van welke betekenis de actor vervolgens handelt.

\subsubsection{Regels en handelingen: 'kleinere' cases}

Handelingsregels zijn bedoeld om bij het handelen te worden gebruikt, zo leerde ons de literatuur. Regels die worden gebruikt, geleiden het handelen. Tijdens een eerste, globale inspectie van de gegevens kregen wij de indruk dat regels inderdaad handelingen geleidden. Wij besloten de gegevens systematischer te analyseren om te zien in hoeverre deze veronderstelling juist was. Omdat sturingsinteracties ook handelingen zijn, bezagen wij of bij sturing eveneens regels werden gebruikt. Elke invoering van een regel of verzameling regels is te beschouwen als een case, met behulp waarvan 'replication' kan worden nagestreefd.

Gedurende de analyses onderzochten wij of de invoering van een regel $(X)$, zoals een opdracht, in tijd bezien vooraf ging aan handelingen $(Y)$ waarop de regel betrekking had. Was dit niet het geval, dan was het maar de vraag of de regel bij het handelen was gebruikt. Als aanwijzingen voor gebeurtenis $X$ gebruikten wij besluiten over de invoering van regels in vergadernotulen. Een voorbeeld is het besluit een netwerk op te richten. Dit besluit houdt een opdracht in. Als aanwijzingen voor gebeurtenis $Y$ in dit voorbeeld gebruikten wij documenten waarin de datum was vermeld waarop het netwerk voor het eerst bijeen kwam. Deze en andere handelingen, zoals weergegeven in bijvoorbeeld vergadernotulen, vergeleken wij steeds met de betekenis van de ingevoerde regels. Kwamen handelingen $Y$ en de betekenis van regel $X$ overeen en ging $X$ in tijd vooraf aan $Y$, dan was dit een eerste aanwijzing dat volgens de regels werd gehandeld.

Daarmee is nog niet gezegd dat de regels daadwerkelijk werden gebruikt. Wellicht waren de actoren niet op de hoogte van de regells en berustte de overeenstemming tussen regels en handelingen op toeval. Als wij konden vaststellen dat actoren, die conform de betekenis van regel $X$ handelden, voorafgaand aan de handelingen $Y$ op de hoogte waren van de regel, dan was de uitspraak plausibeler dat de regel het handelen had geleid 33 .

\subsubsection{Motivering tot handelen volgens regels: "grotere' cases}

In hoofdstuk 5 wordt duidelijk dat het veronderstelde patroon tussen (de betekenis van) regels en daarop volgende handelingen niet in elke case werd aangetroffen. Soms werd regel $X$ niet gevolgd door handelingen $Y$ conform de regel. Soms vond $Y$ al plaats voordat $X$ was ingevoerd en gaf $X$ enkel de gevestigde praktijk weer. Niettemin, in de meeste gevallen werd het veronderstelde patroon tussen $X$ en $Y$ waargenomen. In toetsend onderzoek zou een dergelijke bevinding geen aanleiding hoeven te zijn om

Voor de oprichting en vergaderingen wan netwerken is deze redenering in elk geval plausibel. Van eem aantal netwerken staat vast dat zij voor de eerste maal bijeen kwamen ( $Y$ ) nadat was besloten tot oprichting (invoering van handelingsregel $X$ ). Daarna vergaderden zij wolgens rooster (een verzameling handelingsregels) of kwamen zij weer bijeen nadat daarvoor tijdens de vergadering een afspraak was gemaakt. Deze handelingsregels stonden in de notulen en in de uitnodigingsbriewen voor vergaderingen die naar de leden werden verzonden. Zij konden derhalve op meerdere manieren van de regels kennis hebben genomen. Wij gaan ervan uit dat dit het geval was en gewen daarvoor in het betreffende hoofdlstuk argumenten. Het is verre van aannemelijk dat de actoren in de netwerken steeds bijeen waren gekomen op de data en tijden waarop de vergaderingen werden gehouden, wanneer dergelijke regels miet waren geformuleerd en aan hen waren medegedeeld. 
een theoretische uitspraak over samenhang tussen $X$ en $Y$ als gefalsificeerd te beschouwen. Samenhang behoeft in de sociale wetenschappen niet perfect te zilin. maar mag een stochastisch karakter hebben. Het is in toetsend onderzoek niet noodzakelijk dat voor alle bestudeerde gevallen geldt dat $\gamma$ zich voordoet wanneer vooraf van $X$ sprake is (Segers en Hagenaars, 1980 ).

In bovenstaande bevindingen zagen wilj weliswaar ondersteuning voor de theoretisch veronderstelde funcitie van regels voor handelingen en daaruit voortvloeiende veranderingen, maar wanneer wij met de analyses op dit punt waren gestopt, dan zouden onze bevindingen tekort hebben geschoten. Wij zouden de indruk kunnen wekken dat regels op zichzelf, als een stimulus, bepallend waren woor handelingen. Dat zou ten onrechte zijn. Regels zijn namelijk instrumenten, die moeten worden gebruikt. Wij stelden ons niet tevreden met de genoemde bevindingen alleen en zagen in de uitzonderingen op het beschreven patroon juist aanleiding tot verdere analyses. Wij wilden de achtergrond van het gebruik van regels belichten. Om het verloop van handelingen als motor van veranderingen daadwerkelijk te begrijpen, moesten wij niet blijven stilstaan bij het gebruik van regels op zichzelf.

Wij besloten derhalve niet na te gaan of bij afwijkingen op het patroon wellicht regels in het geding waren, die tot dan buiten beschouwing waren gebleven. Wij besloten na te gaan wat de actoren ertoe drééf regels al dan niet te gebruiken. Bepalend voor handelingen was, maar wij veronderstelden, niet de regel zelf, maar de motivatie van actoren om regels wel of niet te gebruiken. Voor verder inzicht moesten we zoeken naar de diepere betekenis van de handelingsregels voor de actoren. Het ging er om vast te stellen of de actoren wel of niet gemotiveerd waren de regels te gebruiken, tegen de achtergrond van de betekenis die de situatie welke zau ontstaan blj gebruilk van deze regels- voor hen had. Juist door dit onderdeel van de analyses konden wij recht doen aan het 'verstehend' karakter van interactionistisch onderzoek.

De ervaringen met het gebruik van regels $s_{n}$ zoals beschreven in hoofdstuk 5 , gaven aan dat wij voor de motivering in twee richtingen moesten zoeken. We hadden in een meerderheid van de gevallen geconstateerd dat werd gehandeld volgens regiels die door een dominante actor waren ingevoerd. Dit was voor ons aanleiding de aandacht te richten op extrinsieke motivering (machtsverklaring). Echter, de dominante actoren die de regels hadden ingevoerd "handelden meestal conform de eigen regels. Het was niet logisch te stellen dat bij dit gebruik van de regels extrinsieke motivatie een rol speelde. In deze gevallen bleek dat de regels weergaven wat reeds de praktijk of de gewoonte was. Dit wees erop dat wil voor het achterhalen wan de motivering tot gebruik van regels de aandacht ook moesten richten op de routineverklaring (intrinsieke motivatie).

Om het beoogde inzicht te verwerven selecteerden wij binnen het project itz drie cases (zie par. 3.6.3), die 'groter' ofwel veelomvattender waren ${ }^{34}$ dan de cases uit de voorgaande subparagraaf. Uitgangspunt voor de cases was de situatie, waaronder asymmetrische afhankelijkheidsrelaties 35 , zoals waargenomen door de betrokken actoren. In elke case gingen wij na of actoren gemotiveerd waren te handelen volgens de regels omdat zij dat moesten doen van een actor die zij-voorafgaand aan de betreffende thandelingen- als dominante beschouwden (machtsverklaring), of omdat zij dat zelf wenselijk of noodzakelijk vonden (routineverklaring).

35 Omdat in de relaties in deze studie altijd sprake is van machtsverschil, waren geen cases denkbaar zonder asymmetrische relatie tussen actoren. 
Fig. 3.1 geeft de plaats van de beide verklaringen in de analyses weer. Door in de casebeschrijvingen het chronologisch verloop van sturingsinteracties te beschrijven vanaf de aanleiding woor sturing tot aan de resultaten (regels die bij het handelen moesten worden gebruikt), wordt de verklaring plausibel gemaakt die wij allengs voor de gebeurtenissen geven. Het patroon dat wij in de eerste case waarnamen trachtten wij met het oog op 'replication' vervolgens in de twee andere cases te ontdekken.

\subsubsection{Beoordeling van de analyses vanuit interactionistisch perspectief}

De analyse van het gebruik van regels was de eerste stap naar de daadwerkelijke interactionistische verklaring. Het was een noodzakelijke stap, ook in een interactionistische studie. Per slot van rekening zegt Blumer (1969) zelf dat actoren elkaar tijdens interacties voor het handelen aanwijzingen geven. Deze aanwijzingen hebben wij in par. 2.5.6 regels genoemd.

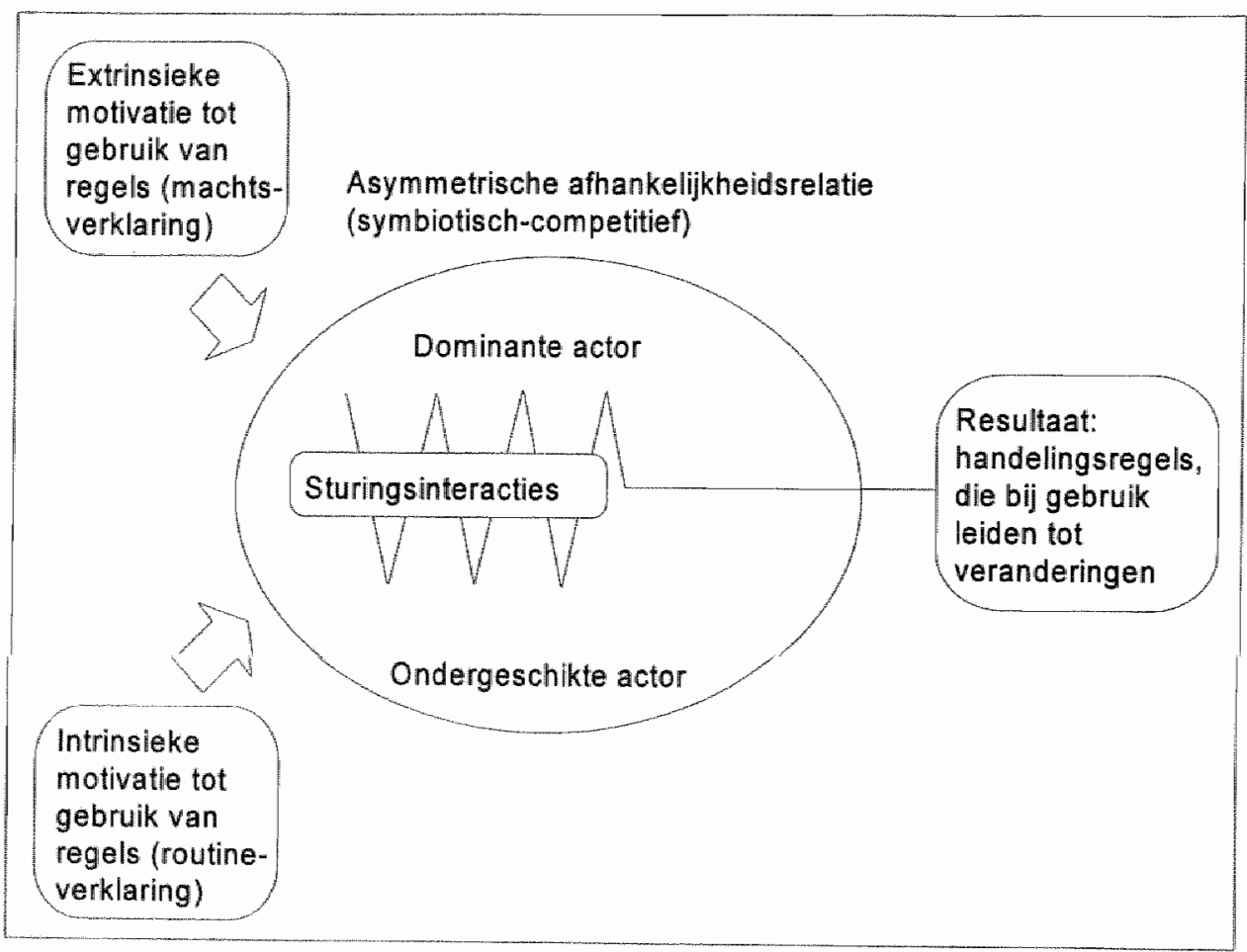

Fig. 3.1 Plaats van de machts- en routineverklaring in de analyses van de drie 'grotere' cases

De stap, hoe noodzakelijk ook, leidde op zichzelf echter onvoldoende tot verklaring. Want hoe belangrijk regels voor het verloop van handelingen en de daaruit voortvloeiende veranderingen ook zijn, een analyse alleen van de relatie tussen regel $X$ en handelingen $Y$ is niet toereikend om het handelen als motor daadwerkelijk te begrijpen. Dat 'betekenis" als intermediair tussen $X$ en $Y$ is toegevoegd, doet aan deze conclusie niets af. Voor meer inzicht moesten wij ons richten op de achtergrond van het 
gebruik van regels. Dit gebeurde in de analyse van de drie grotere cases, de tweede en laatste stap naar verklaring.

Wanneer wij na de eerste stap waren gestopt, dan zouden de analyses alleen hebben laten zien dat de regels meestal werden gebruikt. Op zichzelf is dit een belangrijke ondersteuning van de uitspraken in hoofdstuk 2 over de relatie tussen regels en handelingen. Echter, wat de actor er daadwerkelijk toe had gebracht de regels al dan niet te gebruiken, zou dan versluierd zijn gebleven. Bovendien zouden wij wellicht de verdenking op ons hebben geladen dat wij, ondanks de toevoeging van betekenis als intermediair, bij de definitieve verklaring volgens een stimulus-response schema te werk waren gegaan. Wij zouden dan de indruk wekken dat wij bij de verklaring zijn uitgegaan van redeneringen zoals deze: "in de perceptie van de actor zegt de regel dat hij handeling A moet verrichten, dus doet hij dat'. Dit zou de indruk wekken dat de regel -ondanks de toevoeging van 'betekenis'- alsnog als de stimulus zou moeten worden opgevat, waarop het handelen als rechtstreekse response volgt.

Het belang van de gevolgde werkwijze gedurende de eerste stap mag overigens niet worden onderschat. Wij hebben bijvoorbeeld getracht de mogelijkheid uit te sluiten dat een actor het verschijnsel 'regels' niet heeft waargenomen. 'Regels' bleven niet als een abstractie zweven boven of buiten de empirische werkelijkheid van de actoren. Zoals Blumer het heeft voorgeschreven, hebben wij de regels bestudeerd ais een concreet verschijnsel, midden in de situatie waarin de actoren verkeerden. Aldus konden wij de regels veel dichterbij de actoren brengen dan mogelijk was geweest, indien wij alleen hadden gekeken naar samenhang tussen $X$ en $Y$, volgens de regells van de statistiek ${ }^{36}$.

\subsection{Nadere toelichting op de uitgevoerde analyses}

De 'time-series' analyses die wij hebben uitgevoerd om de wat-, hoe- en waaromvragen te kunnen beantwoorden, worden hier per type vraag verder toegelicht.

\subsubsection{Wat-vraag: netwerken en veranderingen in structuur, macht en cultuur}

Voor de beantwoording van de 'wat"-vraag geven wij in hoofdstuk 4 op hoofdlijnen de ontwikkelingen weer met betrekking tot de netwerken en organisatiemodellen voor de zorgverlening als verzamelingen van handelingsregels. Wij beginnen daar met de beschrijving van veranderingen in structuur en macht en eindigen met de veranderingen in cultuur.

De veranderingen in structuur en macht hebben wij op de volgende manier inzichtelijk gemaakt. De perioden tussen de oprichting en opheffing van de netwerken,

36 Er was woor ons geen mogelijkheid de relatie tussen regels, betekenissen en handelingen op een andere manier in beeld te brengen dan wij hebben gedaan. Een wellicht beter alternatief obserwaties door onszelf van alle situaties waarin regels werden ingevoerd en van de daaropvolgende handelingen- zou gedurende het onderzoek onvitvoerbaar zijn geweest. Zoals wij in par. 3.3 .9 hebben gezegd liet de beschilkbare personele capaciteit niet toe gedurende het onderzoek observaties te doen. Interviews, waarin na afloop van gebeurtenissen naar het gebruik van regels wordt gevraagd, houden al te zeer het risico in dat het handelen door de respondent achteraf wordt gerationaliseerd (zie Weick, 1969). Alternatieve, sociologische methoden zijn ons niet bekend. De gekozen werkwijze beschouwen wij als de 'next best option'. 
alsmede tussen de invoering en teniet verklaring van de organisatiemodellen (vervlechting en ontvlechting) zijn met behulp van vierkanten op een tijdbalk aangeduid (zie Fig. 3.2). De linkerzijden van de vierkanten corresponderen met de oprichtings- of invoeringsdatum, de rechterzijden met de datum van opheffing of teniet verklaring. Deze data zijn vastgesteld met behulp van uitspraken ('brackets') in notulen van de vergaderingen.

De netwerken en de veranderingen daarin beschrijven wij met behulp van Mintzberg's (1979) configuraties. Deze zijn bruikbaar voor de bestudering van netwerken (zie Mur-Veeman en Tijssen, 1992). Fig. 3.3 toont de wijze waarop wij de netwerken als configuraties grafisch weergeven. Wij gingen na in hoeverre de kenmerken van de projectorganisatie, tot uiting komend in de 'brackets', overeenkomsten vertoonden met de configuratie-beschrijvingen van Mintzberg.

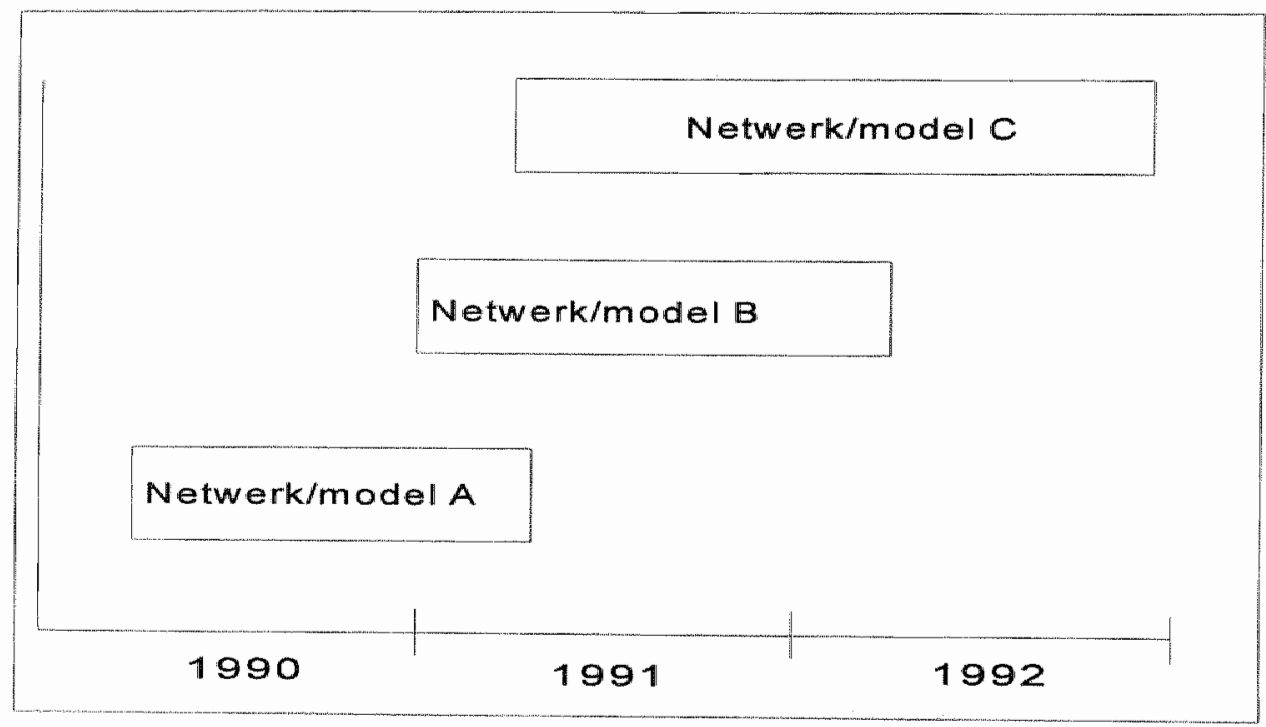

Fig. 3.2 Weergave van processen betreffende netwerken en organisatiemodellen voor de zorgverlening

Een soortgelijke werkwijze volgden wij bij de beschrijving van de organisatiemodellen voor de zorgverlening. Fig. 3.4 fungeerde daarbij als hulpmiddel. Wij gebruikten voor de beschrijving de volgende indeling in fasen van het primaire proces (Van Raak et al, 1993):

- aanmelding van zorguragen;

- voorbereiding van de zorgverlening: intake, indicatiestelling, zorgtoewijzing, opstellen van een hulpplan;

uitvoering van de zorgverlening;

evaluatie van de zorgverlening. 


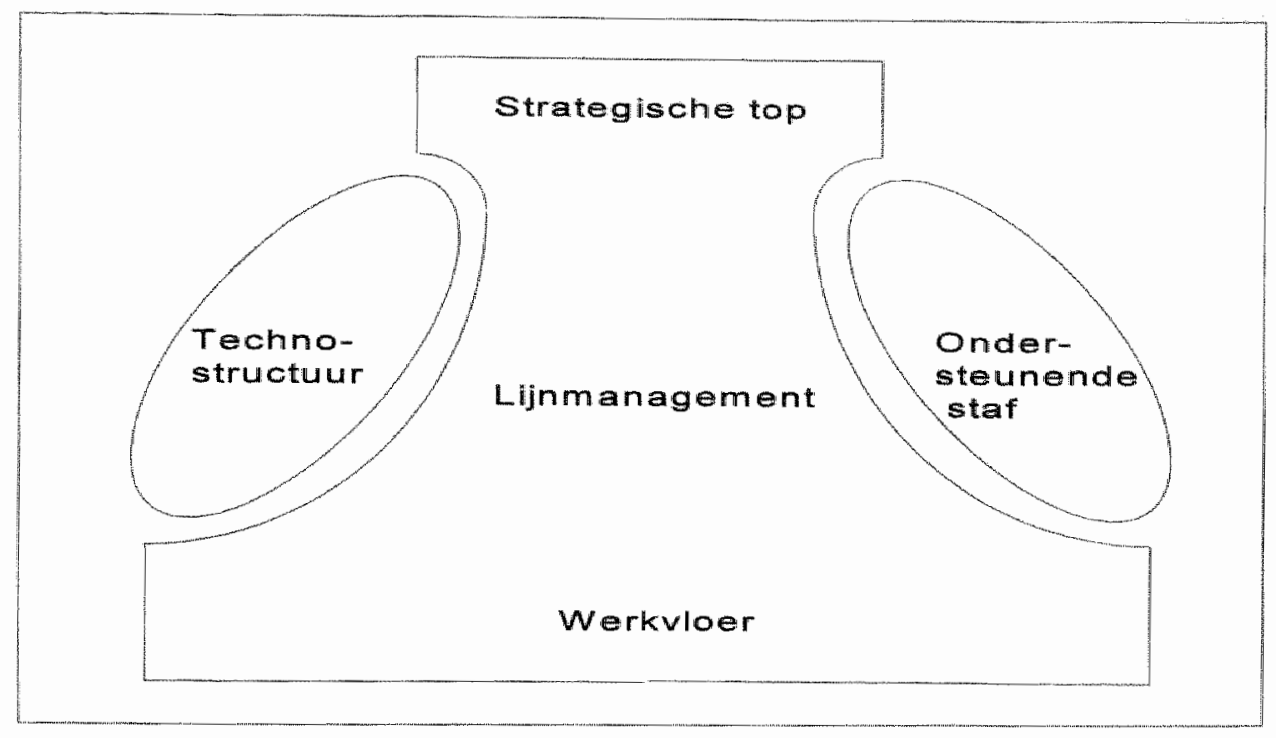

Fig. 3.3 Netwerken, weergegeven als configuraties volgens Mintzberg (1979)

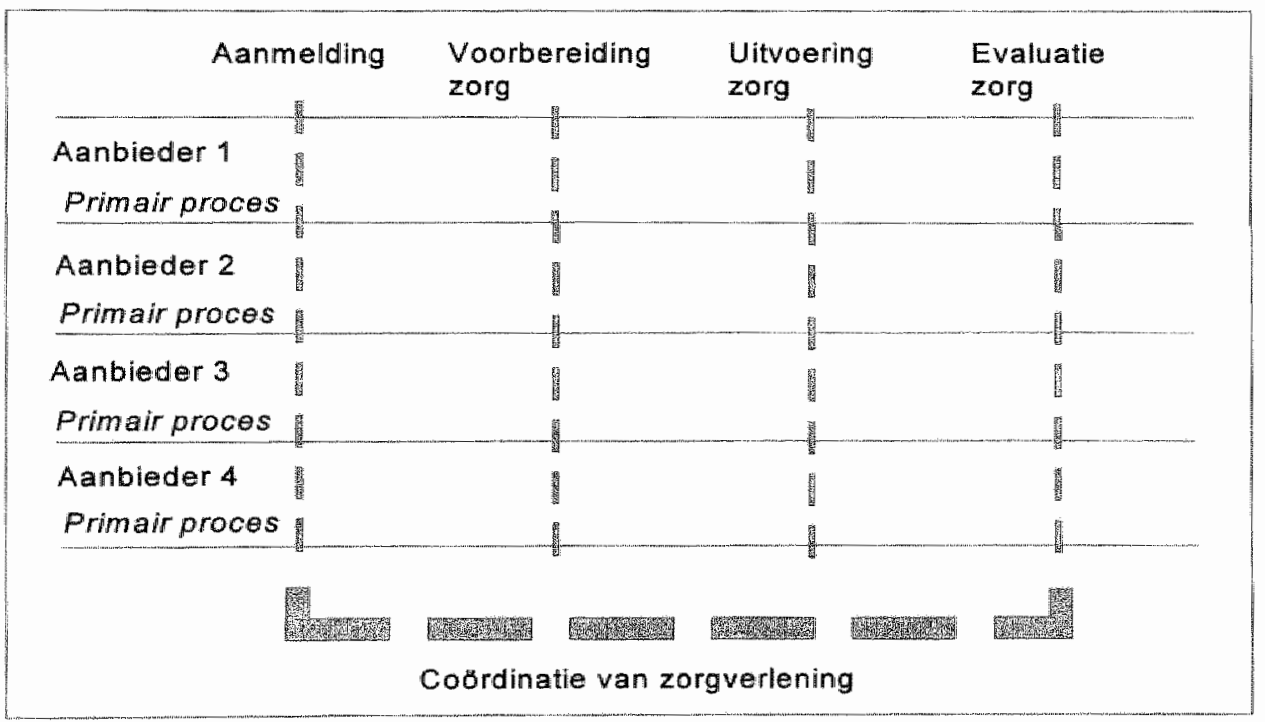

Fig. 3.4 Weergave van de organisatiemodellen voor zorgverlening aan de hand van vier fasen van het primaire proces 
Ter ondersteuning van de beschrijving van veranderingen in cultuur (routines) maakten wij gebruik van Fig. 3.5. Aan de basis van de processen van vervlechting en ontvlechting ligt de verhouding tussen individualiteit en collectiviteit binnen de relaties tussen actoren (zie par. 2.5.3.3). In de 'brackets' zochten wij naar aanwijzingen voor deze verhouding.

\subsubsection{Hoe-vraag: veranderingen door handelingen volgens regels, als product van sturingsinteracties}

In hoofdstuk 5 gaat de aandacht uit naar sturingsinteracties tussen bestuurders en bestuurden, alsmede naar de producten van deze interacties (regels). Naar wij veronderstelden leidden deze producten bij gebruik tot de veranderingen, die in hoofdstuk 4 zijn beschreven.

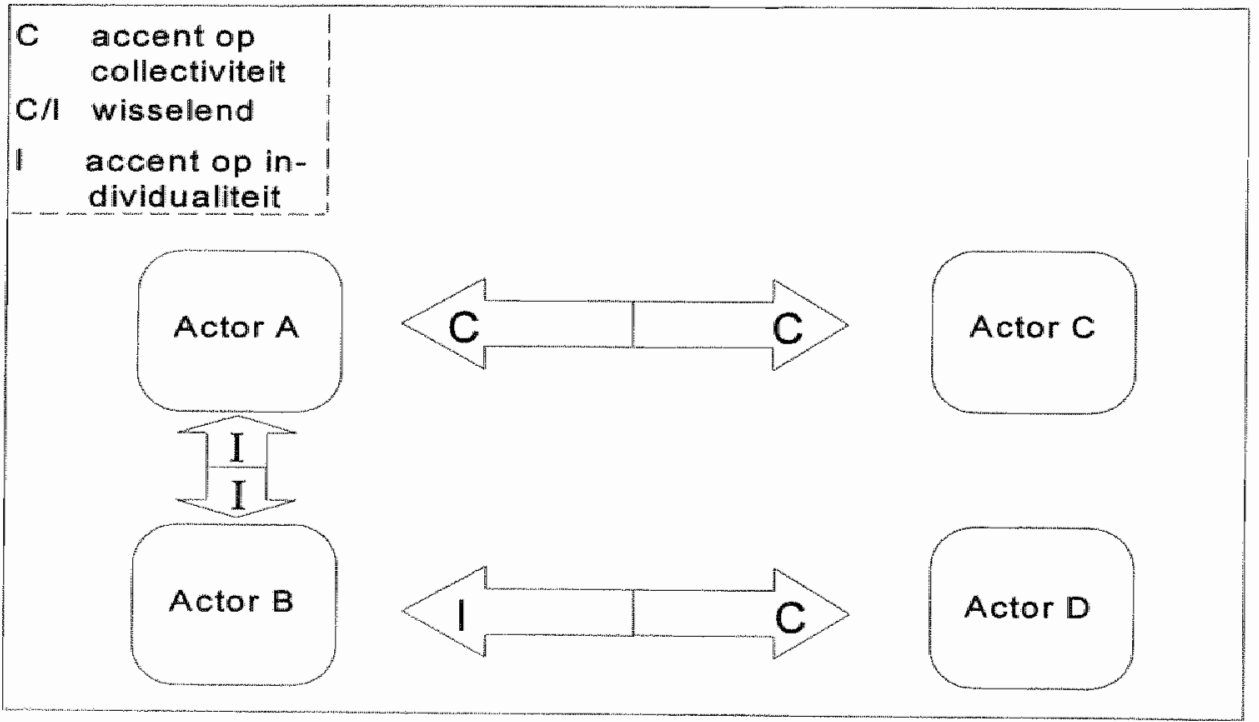

Fig. 3.5 Weergave van de verhouding tussen individualiteit en collectiviteit binnen relaties tussen actoren

De 'time-series' analyse die wij aangaande de sturingsinteracties hebben uitgevoerd, lichten wij toe aan de hand van het verschijnsel 'handelingsregels'. Zoals in hoofdstuk 5 nog blijkt werden regeis, die uiteindelijk werden ingevoerd, gedurende het project itz geformuleerd door werkgroepen of individuele actoren. Zij legden hun voorstellen (these) voor aan degenen die over invoering moesten besluiten. Deze actoren gaven daarop een reactie: zij bespraken de voorstellen, gaven commentaar, formuleerden aanvullingen of deden een tegenvoorstel (antithese). De interacties werden afgerond met een bes/uit tot aanvaarding van voorstellen (synthese).

Van deze sturingsinteracties doen de vergadernotulen verslag. Daarin worden (bijvorbeeld onder het agendapunt 'mededelingen') ook sturingsinteracties beschreven 
die buiten de vergadering hadden plaatsgevonden, zoals overleg met actoren in de omgeving. Verder werden documenten voor bespreking geagendeerd, zoals voorstellen voor handelingsregels (nota's en rapporten) en brieven met reacties op voorstellien. Voor de analyse hebben wij ons vooral in de vergadernotulen en de bijbehorende vergaderstukken verdiept, aangevuld met gegevens uit vraaggesprekken en registratieformulieren.

Uitspraken tijdens vergaderingen die in de notulen zijn vermeld, hebben wij van elkaar onderscheiden op basis van het agendapunt en -daarbinnen- het onderwerp waarop zij betrekking hadden. Vervolgens deelden wij de ontstane 'brackets' in bij de drie genoemde categorieenn: these (voorstel), antithese (reactie) en synthese (besluit) 37 .

Een opeenvolging van these, antithese en synthese deed zich niet altijd voor tijdens een en dezelfde vergadering. Meerdere malen strekte dit patroon, dat wij in Fig. 3.6 hebben weergegeven, zich uit over een aantal vergaderingen. Het beschreven patroon is zichtbaar in ontwikkelingen met betrekking tot de handelingsregels voor de arganisatie van de verlening van intensieve thuiszorg, alsmede betreffende de regels van netwerken. Bij de oprichting en opheffing van netwerken zelf kon het patroon van these, antithese en synthese eveneens worden waargenomen, zij het in een relatief kleiner aantal gevallen.

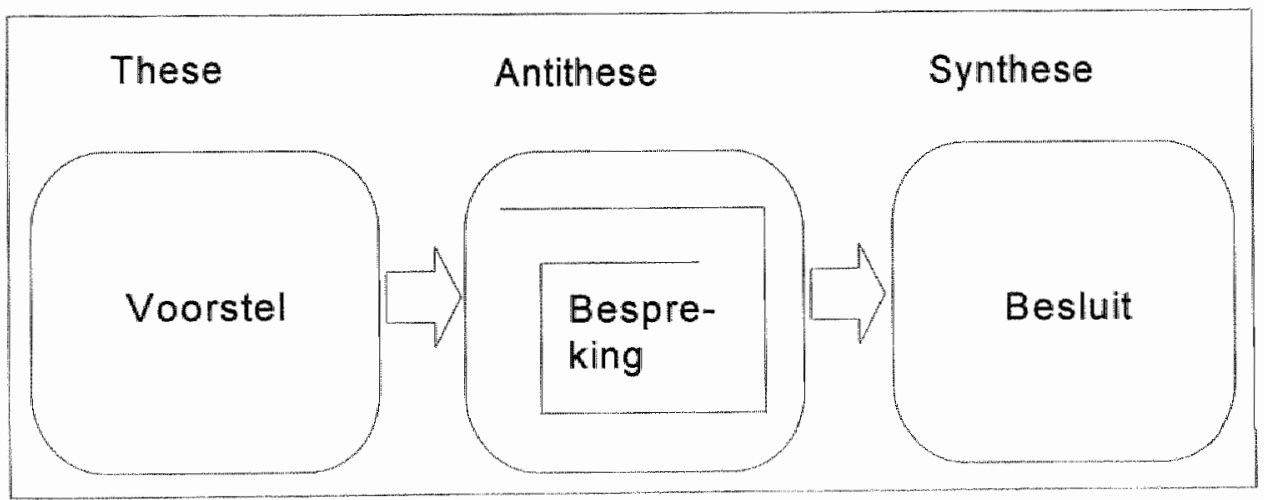

Fig. 3.6 Weergave van sturingsinteracties volgens een patroon van these, antithese en synthese

Actoren binnen de projectorganisatie onderhielden relaties met elkaar en met actoren buiten de projectorganisatie. Binnen die relaties werden stuurders verzonden. Relaties en interacties tussen actoren als bestuurders en bestuurden binnen en buiten netwerken vormden een kluwen. Onze gegevens reflecteren dit kluwen. Om het te ontwarren hebben wij de diverse relaties tussen actoren met behulp van 'brackets' ondergebracht bij vier afhankelijkheidscirkels (Fig. 3.7).

De cirkels dekken samen het geheel van afhankelijkheidsrelaties, waarover wij in de volgende hoofdstukken spreken. Om onderscheid tussen de cirkels te kunnen maken is allereerst het criterium gebruikt dat sprake moest zijn van asymmetrische 
afhankelijkheid tussen actoren entof netwerken, welke afhankelijkheid door betrokkenen werd gepercipieerd. Vervolgens werd bezien wie meer of minder dominant dan wel ondergeschikt was.

De eerste cirkel betreft actoren en netwerken die in de afhankelijkheidsrelaties de meest ondergeschikte positie innamen. De actoren en netwerken in de daarop volgende cirkels namen steeds een dominante positie in ten opzichte van degenen in de voorgaande cirkels. Ook tussen de cirkels zijn derhalve afhankelijkheidsrelaties waarneembaar. De eerste twee cirkels bevatten actoren en netwerken die tot de projectorganisatie behoorden ('projectintern'). De andere cirkels bevatten actoren in de omgeving van de projectorganisatie ("projectextern").

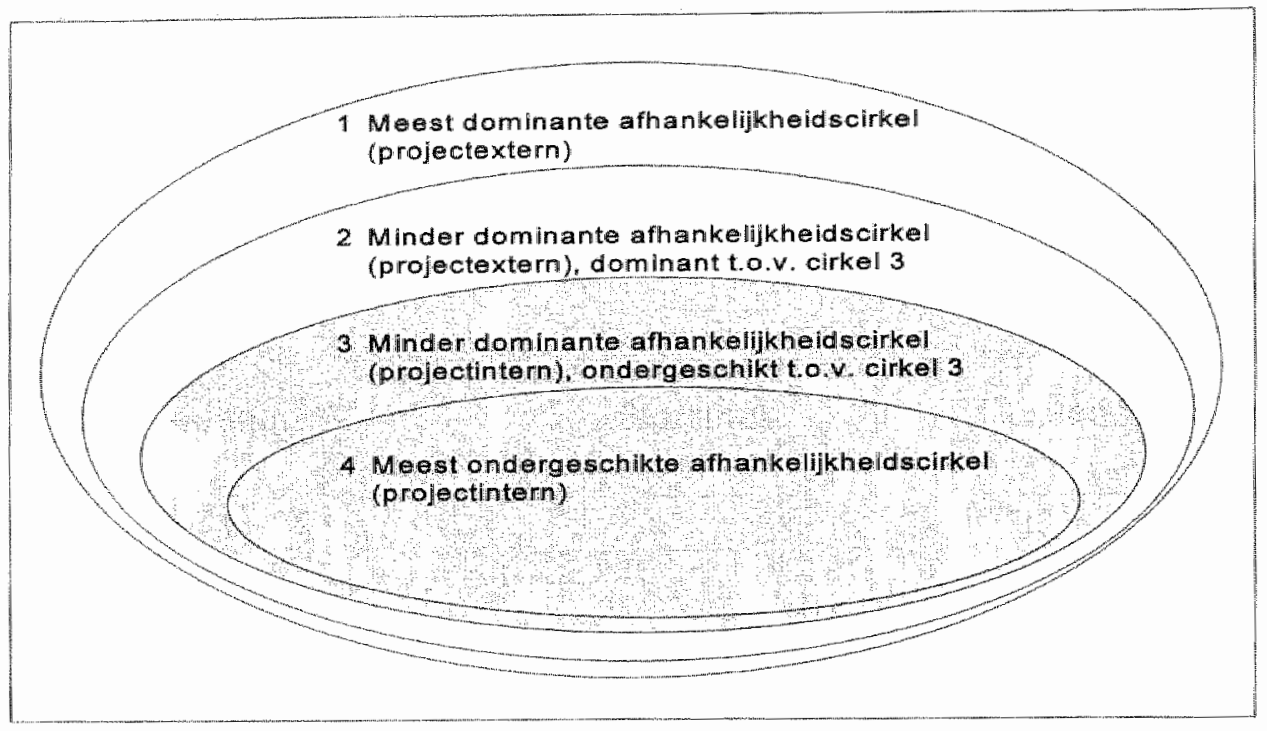

Fig. 3.7 Weergave valn vier afhankelijkheidscirkels

Vergaderingen waren in alle geledingen van de projectorganisatie een veel voorkomende wijze van interacteren. Wij beschouwen deze daardoor in onze studie als belangrijkste interacties. Actoren (individuen of organisaties) noemen wij 'projectextern' indien zij niet op de deelnemerslijsten stonden van vergaderingen binnen de projectorganisatie (zie par. 2.3.3). Zij zijn 'projectintern' (eerste of tweede cirkel), indien zij wél op de deelnemerslijsten stonden en herhaaldelijk aan de vergaderingen hebben deelgenomen.

Natuurlijk namen de organisaties waartoe een lid van de projectorganisatie behoorde niet als geheel aan de genoemde interacties deel. Zij waren vertegenwoordigd. Daarom hebben wij deze organisaties zelf ingedeeld bij de derde cirkel en hun vertegenwoordigers bij de eerste of tweede cirkel. Daarbij gold als voorwaarde dat de organisaties binnen de afhankelijkheidsrelatie met de projectorganisatie een dominante positie hadden. De organisaties die ten opzichte van de projectorganisatie en de derde cirkel een dominante positie innamen en waarvan een of meer leden weliswaar interacteerden met leden uit de projectorganisatie, maar niet door deelname aan vergaderingen binnen het project, hebben wij ondergebracht bij de vierde cirkel. Deze 
exercitie leidde ertoe dat de derde cirkel bestond uit zorgaanbiedende instellingen (inclusief de beroepsgroep huisartsen) en de zorgverzekeraar. De vierde cirkel kende één actor: het Ministerie van WVC.

Cirkels zijn begrensd: de grens van de ene afhankelijkheidscirkel wordt gevormd door een andere afhankelijkheidscirkel. Via de afhankelijk-heidsrelaties tussen de vier cirkels worden het microniveau (projectorganisatie en haar actoren), mesoniveau (actoren in de regionale omgeving van de projectorganisatie) en het macroniveau (op landelijk niveau opererende actoren) met elkaar verbonden. Datgene wat gebeurt op het niveau van de gehele samenleving, kan met behulp van 'gepercipieerde afhankelijkheden' worden verbonden met het niveau van de individuele actor. Aldus wordt de 'micro-macro gap' overbrugd, een vraagstuk dat in de sociologie herhaalde malen inzet is geweest van discussie tussen interactionisten en systeemtheoretici (zie Rademaker, 1978).

\subsubsection{Waarom-vraag: (aanleiding tot) sturing}

In hoofdstuk 6 gaan wij dieper op de sturingsinteracties in, alsmede op de aanleiding daarvam. De producten van sturingsinteracties komen weliswaar aan de orde, maar daarop ligt niet het accent. Om de beoogde inzichten te verwerven, hebben wij tussen en binnen de afhankelijkheidscirkels drie 'grotere' cases afgebakend (zie par. 3.5.3.2). Zij zijin door ons uit de data over het project itz gesneden. Daarvoor zijn de volgende criteria gebruikt. De cases moesten inzicht geven in:

- de aanleiding tot, aard en verloop van sturingsinteracties tussen actoren binnen asymmetrische afhankelijkheidsrelaties, ingedeeld bij de vier afhankelijkheidscirkels;

- de resultaten van de sturingsinteracties op het niveau van het secundaire proces en het secundaire niveau van het primaire proces;

- de relevantie van macht en routines bij de verklaring van gebeurtenissen (extrinsieke en intrinsieke motivatie).

De cases vormen een uitsnede gedurende processen. Kenmerkend voor processen is dat zij doorlopen; hun absolute begin- en eindpunt kunnen niet worden geïdentificeerd. Aanduiding van een begin- en eindpunt heeft derhalve een zeker willekeurig karakter. De afbakening van de cases impliceert daardoor een constructie. Verder leidden lacunes in de gegevens ertoe dat het aantal bruikbare cases beperkt was. Beide omstandigheden hebben ongetwijfeld geleid tot selectiviteit, waardoor bijvoorbeeid generalisering van de bevindingen naar de totale denkbare populatie cases niet mogelijk is. Indien de onderzoeker streeft naar statistische generaliseerbaarheid van bevindingen, dan is dit een probleem. Wij streven echter naar analytische generaliseerbaarheid (zie par. 3.3.8), waardoor het probleem niet geldt. Integendeel, selectiviteit, uitgaande van theoretische uitspraken, is juist de basis van 'replication' (zie Yin, 1994).

Het beoogde inzicht hebben wij verworven door de analyse en weergave van opeenvolgende gebeurtenissen. Fig. 3.8 laat zien op welke wijze wij de opeenvolging van gebeurtenissen van de aanleiding tot het resultaat van sturing in beeld brengen. Een soortgelijke figuur wordt gebruikt voor de weergave van opeenvolgingen van gebeurtenissen in hoofdstuk 5. 


\subsection{Slotopmerkingen}

In dit hoofdstuk hebben wij beschreven langs welke weg wij tot de inzichten zijh gekomen. Wij beschreven de uitvoering van de studie en het onderzoek dat daaraan ten grondslag lag, en beoordeelden de uitvoering aan de hand van methodologische regels van Blumer en Yin. Uitzonderingen daargelaten verliep een en ander volgens deze regels.

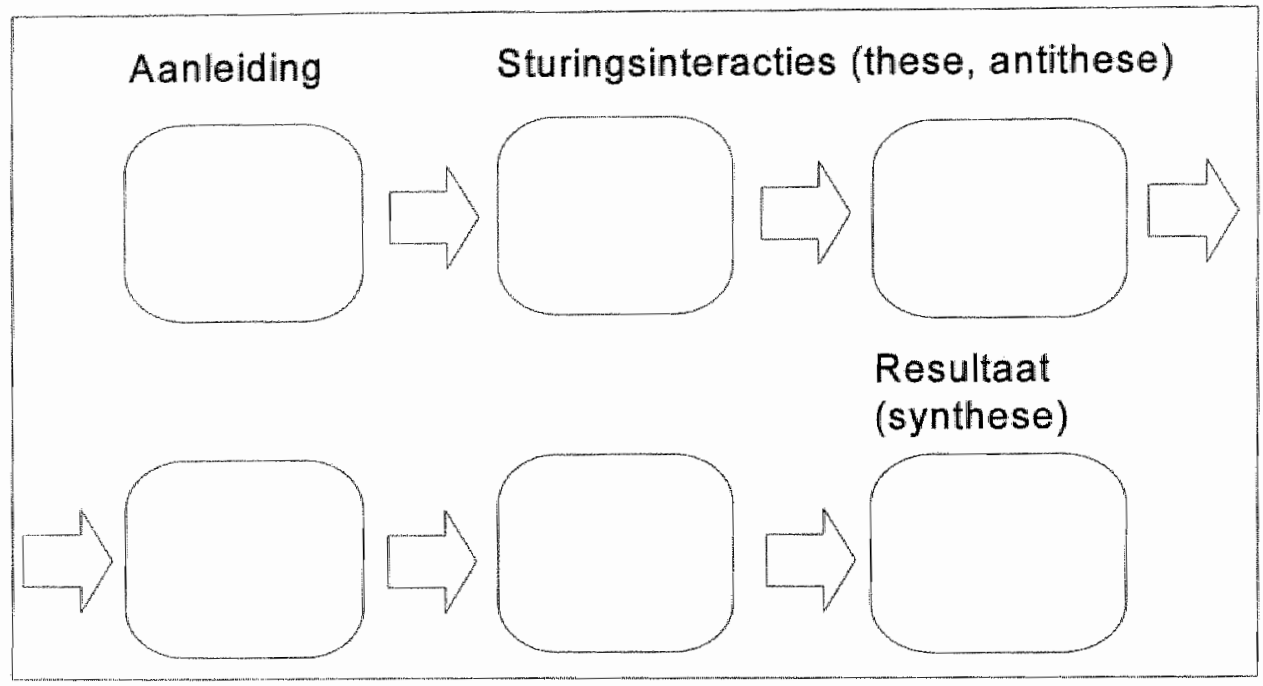

Fig. 3.8 Weergave van opeenvolging van gebeurtenissen van de aanleiding van sturingsinteracties tot het resultaat

Met behulp van de resultaten van onze werkwijze presenteren wij in de navolgende hoofdstukken een totaalbeeld van de verschijnselen die wij bestudeerden, in het bijzonder de netwerken. Tot dit totaalbeeld behoren de ontwikkelingen die de verschijnselen hebben doorgemaakt. Aldus wordt recht gedaan aan hun dynamische, veranderlijke karakter.

Het beeld zou niet compleet zijn, wanneer aan de handelende mens daarin een geprononceerde plaats zou zijn onthouden. Daarom stelden wij ons steeds de vraag wat de verschijnselen die door ons zijn geselecteerd en van een label zijn voorzien, betekenden voor de actoren in de netwerken en hoe zij met deze betekenissen in hun handelingen en interacties omgingen. Wij laten hen in de volgende hoofdstukken ook meerdere malen aan het woord en hebben daarbij steeds gekozen voor citaten die exemplarisch waren voor onze bevindingen. 


\section{Houtskoolschetsen: verandering- en in structuur, macht en cultuur}

\subsection{Inleiding}

In hoofdstuk 2 hebben wij het ontstaan van onze theorie beschreven. Wij stelden dat gaandeweg een 'fit' ontstond tussen theorie en empirie, door de empirische cyclus meerdere malen te doorlopen. Het moment is gekomen te laten zien dat van een "fit" sprake is. Vanaf nu gaan wij met behulp van empirische gegevens over het project Intensieve Thuiszorg Zuid-Kennemerland ('project itz') tonen dat veranderingen in de bestudeerde verschijnselen daadwerkelijk verliepen volgens Fig. 2.11 uit hoofdstuk 2 . In die figuur hebben wij de hoofdconcepten uit de theorie en hun relaties weergegeven.

Wij beginnen met een aantal houtskoolschetsen. In dit hoofdstuk beschrijven wij de veranderingen in structuur, macht en cultuur, die gedurende de projectperiode plaatsvonden. In de daarop volgende hoofdstukken brengen wij de verflagen aan. In hoofdstuk 5 laten wij zien dat de veranderingen plaatsvonden door handelingen volgens regels, die via sturingsinteracties tot stand zijn gekomen. De verklaring van de handelingen, waarvoor de aanzet in hoofdstuk 5 is gedaan, gaan wij in hoofdstuk 6 uitbouwen. Dit doen wij door ons te richten op de motivering voor handelingen. Om de anonimiteit van actoren zoveel mogelijk te waarborgen duiden wij hen -bij citaten in cursief- aan met de naam van het type voorziening waartoe zij behoren.

De gegevens voor de drie hoofdstukken zijn afkomstig uit vergadernotulen en andere documenten, uit vraaggesprekken en registratieformulieren. De gebruikte bronnen zijn vermeld in de bijlagen. Door middel van cijfers, voorafgaand door de letter " $V$ ' (vraaggesprekken), ' $D$ " (documenten) of 'R" (registratieformulieren) wordt naar deze bronnen verwezen. Met behulp van de geanalyseerde gegevens beantwoorden wij in hoofdstuk 7 uiteindelijk de 'wat'-vraag: 'Tot welke ontwikkelingen van/binnen de netwerken heeft de sturing geleid? (zie par. 1.3 en 3.6.1).

In het onderhavige hoofdstuk schetsen wij de veranderingen met betrekking tot zowel het secundaire proces als het secundaire niveau van het primaire proces. De uitvoering van de zorgverlening zelf (het resterende deel van het primaire proces) komt niet aan de orde. Fig. 4.1 toont op welk gedeelte van het conceptueel raamwerk wij ons hier richten. In par. 4.2 geven wij de startsituatie weer van het project itz. In par. 4.3 en 4.4 beschrijven wij de veranderingen in structuur en macht, in par. 4.5 en 4.6 de veranderingen in cultuur. Aldus typeren wij de netwerken op meerdere momenten, hetgeen bij uitstek de doelstelling achter onze "wat'-vraag is. Par. 4.7 bevat een aantal 
slotopmerkingen. Bij de beschrijvingen worden analyseschema's uit par. 3.6 als hulpmiddel gebruikt.

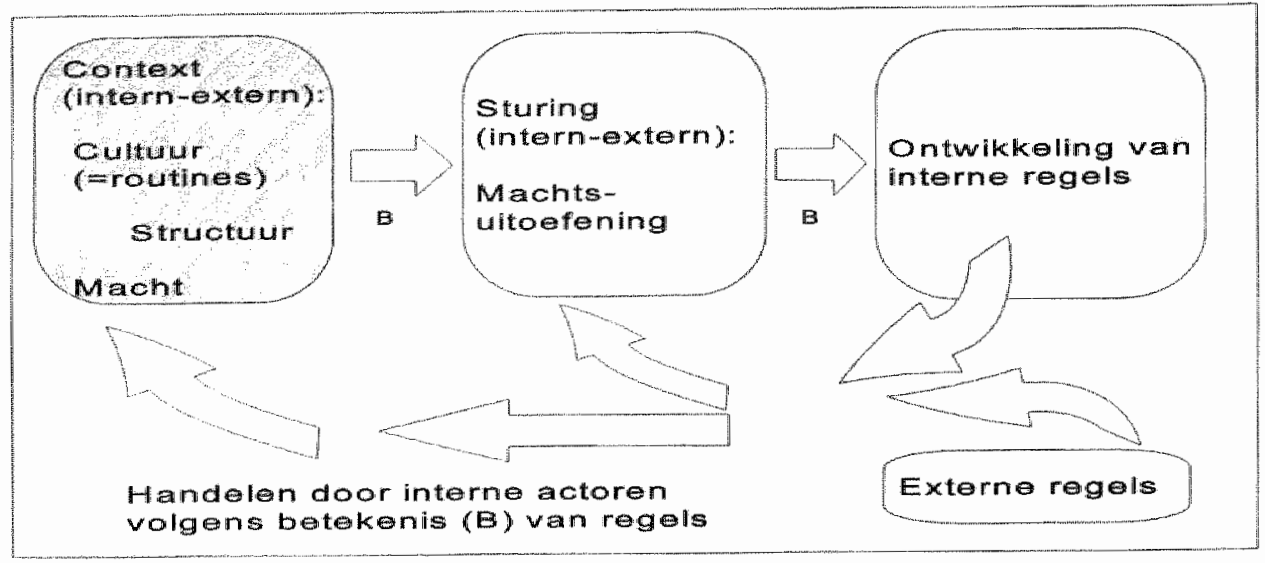

Fig. 4.1 Besproken gedeelte (gearceerd) van het conceptueel raamwerk

De ontwikkelingen waarover wij hierna spreken, waren geen papieren veranderingen. Zoals in hoofdstuk 5 wordt besproken, functioneerden de netwerken daadwerkelijk. De situaties bestonden, zowel in de perceptie van de betrokken actoren als in onze eigen perceptie.

\subsection{Startsituatie van het project}

Bij aanvang van het Programma van WVC participeerden in het project itz meerdere zorgaanbieders (kruiswerk, gezinszorg, huisartsen, algjemeen maatschappelijk werk -'amw'). Zij beoogden verlening van intensieve thuiszorg ('itz') te organiseren voor terminale patiënten en psychogeriatrische patiënten (pg-patiënten) in de regio. Genoemde zorgaanbieders, inclusief de beroepsgroep huisartsen noemen wij 'instellingen' of 'zorgverlenende instellingen'. Aan een aantal projectvergaderingen nam de vertegenwoordiger van de zorgverzekeraar deel. Verder werd een projectleider aangesteld die afkomstig was uit een organisatie in de regio die ondersteuning bood bij de uitvoering van zorgvernieuwingsprojecten. Deze organisatie noemen wij de "regionale ondersteunende organisatie". Uit de regio was nog een tweede project opgenomen in het Programma van WVC. Dit project duiden wij aan als 'het andere project in de regio'.

Intensieve thuiszorg is zorg die wordt verleend in aanvulling op de reguliere zorg van de instellingen. Voor de verkrijging van financiële middelen voor de aanvullende hulp deden de instellingen een beroep op het regionale ziekenfonds (hierna aangeduid als de 'zorgverzekeraar'38). 


\section{Overzicht 4.1 Passages uit het projectplan van het project itz}

ZORGVERNIEUWINGSPROJECT INTENSIEVE THUISZORG ZUID-KENNEMERLAND.

\section{Voorgeschiedenis en kern}

Een werkgroep van huisartsen, kruiswerk en gezinsverzorging in Zuid-Kennemerland heeft in 1988 en 1989 voorstellen aan het regionale ziekenfonds voorgelegd voor een project terminale thuiszong (...). Het regionale ziekentonds zag weel goeds in de voorstellen, maar vond de aanvankelike opzet te duul" woor de beperkte doelgroep. Het ziekenfonds wilde een bredere opzet en nam met het oog daarop zitting in de werkgroep (...). De leden wan de projectgroep zijn tot het volgende voorstel gekamen. Er komt een zorgvernieuwingsproject intensieve thuiszorg in Zuid-Kennemerland. Dit houdt hoofdzakeligk in, dat een gllabaal model voor het gecoördineerd verlenem van intensieve thuiszorg wordt uiligeprobeerd door het geleidelijk aan van toepassing te verklaren op meer, on moeilijker: doelgroepen, te beginnen met terminale patiënten. Het regionale ziekenfonds betaalt de uitvoerende kosten van het project voor verzekerden bij het ziekenfonds. Voor de kosten van het overallprojectleiderschap wordt een financieel beroep gedaan op het Mimisterie van WVC, in het kader van de zorgvernieuwingsprojecten van dat departement. In maart 1990 is het voorstel ter besluitvorming hoegezonden aan de besturen van de betrokken organisaties. Deze hebben op hun beurt de ondernemingsraden geraadpleegd. Deze week is wan alle organisaties nu ook formeel bekend geworden, dat zij akkoord zijn (...).

\section{Situatie-analyse}

(...) Zuid-Kennemerland is enorm (ook dubbel) vergrijsd en ontgroend; kampt met een grote doorstromingsproblematiek in de ouderenzorg; heeft zojuist een reductie van $30 \%$ van het aantal bedden in algemene ziekenhuizen achter de rugi, theeft een in vergelijking met de rest van Nederland hoog niveau van zorgconsumptie, waarbij niettemin een schrijnende schaarste wordt ervaren, m.n. op het terrein van de ouderenzorg. Verleggen van de grenzen van de thuiszorg, inhoudelijk, en organisatorisch en financieel, is tegen deze achtergrond een must (...).

3. De doelstellingen van het project

De doelstellingen van het project zijn:

a het uitproberen en invoeren vam een model woor het gecoördineerd werlenen van intensieve thuiszorg door huisartsen. kruiswerk, gezinswerzorging en amw, en wel door het model geleidelijk aan van toepassing te verklaren op meer, en moelijker, doelgroepen; (...)

b. het komen tot protocollen voor de zorgverlening aan de betreffende (doel)graepen patiënten (...) het doen convergeren van (...) de ontwikkelingen in Zuid-Kennemerland met betrekking tot de intensieve thuiszorg (.) naar éen organisatorisch, inhoudelijk en financieel model voor thuiszorg (..).

4. De hoofdlijnen van hell ad 3.abedoelde model

Het onder 3.a. bedoelde model ziet er globaal gezien als volgt uit:

- alle aanwragen voor intensieve thuiszorg worden via de reguliere zorg ingediend bij het Bureau Intensieve Thuiszorg Zuid-Kennemerland

aan het hoofd van hel bureau staat de projectmanager: een vaste, daarvoor vrijgestelde huisarts uit Zuid-Kennemertand, die onder toezicht wan het directorium van de op te richten Stichting Intensiewe Thuiszorg werkt. 


\section{Overzicht 4.1 Passages uit het projectplan van het project itz (vervolg)}

ZORGVERNIEUWINGSPROJECT INTENSIEVE THUISZORG

25-04-1990

ZUID-KENNEMERLAND.

4. De hoofdlinen van hel ad 3.a bedoelde model (vervolg)

* in aanwezigheid van de projectmanager stellen de betrokken disciplines (de eigen huisarts van de patlënt, wijkverpleging, gezinszorg, amw) de indicatie voor intensieve thuiszorg; de projectmanager beoordeelt m.b.t. terminale patiënten in hoeverre aan de indicatievoorwaarden is voldalan.

onder leiding van de projectmanager stellen de direct betrokken hulpwerleners een hulpplan op; bil het hulpplan wordl $0 . \mathrm{lW}$. de projectmanager een kostenraming, een "begroting" opgesteld en voor akkoord ondertekend; levens wordt een zorgcoördinator (één van de direct betrokkenen) aangewezen.

onder leiding van de zorgcoürdinator wordt tot uitvoering wan het hulpplan overgegaan.

de projectmanager en de zorgcoördinator houden contact met elkaar over het verloop wan de zorg, onder meer om tot wijziging van het hulpplan te kunnen komen als dat nodig is

de projectmanager zorgt voor een goede registratie, voor het opstellen van het definitieve kostenoverzicht en voor uitbetaling van de geleverde aanvullende zorg.

\section{Beheersworm}

De participanten (...) richten een Stichting Intensieve Thuiszorg Zuid-Kennemerland op. De stichting kent een bestuur en een directorium. Beleidsvoorbereidende en uitvoerende taken worden gedelegeerd aan het directorium. (...) Het 'Bureau Intensieve Thuiszorg Zuid-Kennemerland' ressorteert onder het directorium. De projectmanager is in dienst wan de stichting (...). Hij is verantwoording schuldig aan het directorium. Een verfegenwoordiger van het Ziekenfonds, de eerste en grootste financier van aanvullende thuiszorg in het kader wan het project intensieve thuiszorg, zal de vergaderingen van het directorium bijwonen. De stichting zal zich laten bijstaan door een overall-projectheider voor het hele project intensieve thuiszorg. Deze wordt ingehuurd (...) op voorwaarde dat de financiering daarwan rond komt, en dat de projectleider inhoudellijk onder de Stichting functioneert.

\section{6. financiering}

Het regionale ziekenfonds is bereid tot financiering van de coördinatiefunctie van het Bureau Intensieve Thuiszorg Zuid-Kennemerland en wan de variabele kosten van aanvullende zorg voor verzekenden bij het ziekenfonds (...). Voor de bekostiging van de projectleider wordt een beroep gedaan op het Ministerie van WVC. in het kader van de zorgvernieuwingsprojecten van dat Ministerie (...).

\section{Participanten en looptijd}

De participanten in de Stichting Intensiewe Thuiszorg Zuid-Kennemerland em de deenemers aan het project Intensieve Thuiszorg zijn: de kruisvereniging; de stedeljke gezinsverzorging; de regionale huisantsenvereniging; het algemeen maatschappelijk werk; de regionale gezinszorg. De looptijd van het project is de periode van 01-05-1990 tot 01-01-1993(...)

8. Globaal overzicht van activiteiten

(...)

Om de projectondersteuning te financieren werd het project aangemeld voor opname in het Programma Zorgvernieuwingsprojecten Thuiszorg van het Ministerie van WVC (D36). Opdat het project in aanmerking kwam voor opname in het Programma van WVC moesten de participanten onder meer een projectplan opstellen, dat informatie bevatte over cle aanleiding tot het project, de doelstellingen, doelgroepen, activiteiten die de participanten wilden ondernemen, en andere zaken. Het diende ter goedkeuring naar WVC te worden verzonden. Goedkeuring zou leidlen tot verstrekking door het Ministerie van subsidie voor projectondersteuning.

Het definitieve projectplan (D20) werd op 25.4.1990 ingediend. WV keurde het plan goed en besloot tot verlening van subsidie (D57). Om duidelijk te maken wat het 
project volgens de participanten moest behelzen, hebben wij in Overzicht 4.1 een aantal passages opgenomen uit het goedgekeurde projectplan ${ }^{39}$.

De datum waarop het besluit tot subsidiëring van projectondersteuning werd genomen, werd in het kader van het Programma van WVC beschouwd als het startmoment van het project ${ }^{40}$.

\subsection{Veranderingen in structuur en macht: vervlechting en ontvlechting op het niveau van de projectorganisatie}

De ontwikkelingen gedurende de projectperiode werden gekenmerkt door processen van verviechting en ontvlechting. Actoren kwamen vanuit organisaties in de omgeving samen en gingen weer uiteen, netwerken kwamen op en verdwenen weer, afhankelijkheidsrelaties tussen individuen en verzamelingen van individuen, alsmede (patroonsgewijze) handelingen binnen deze relaties, ontstonden en werden weer verbroken.

Deze twee processen betekenden voor de regio een herstructurering en veranderingen in machtsverhoudingen. Beide processen beschrijven wij hierna met behulp van de volgende begrippen die wij in hoofdstuk 2 (zie Overzicht 2.2) onder de hoofdconcepten 'structuur' en 'macht'41 hebben vermeld42: relaties, posities, organen en configuraties, (patroonsgewijze) handelingen, taken, functies en bevorgdheden. Ten aanzien van de handelingen beperken wij ons hier tot de vaststelling dat deze plaatsvonden. Daarop gaan wij in hoofdstuk 5 dieper in. Verder gebruiken wij het begrip 'handelingsregels".

De netwerken voerden het geheel van handelingen uit, dat wij het 'project itz' hebben genoemd en waarvan het projectplan een aantal bevat. Gezamenlijk vormden de netwerken die op enig moment het project uitvoerden, de 'projectorganisatie'.

In Fig. 4.2 is weergegeven welke netwerken gedurende de projectperiode zijn opgericht en opgeheven ${ }^{43}$. Voor de netwerken werden regels opgesteld en ingevoerd, die door de leden bij hun handelingen moesten worden gebruikt. Meestal gebeurde dit ook (zie hoofdstuk 5).

39. De namen van de betrokken organisaties hebben wij in Overzicht 4.1 vervangen door de naam van hun woorziening (cursief).

40 Dit moment is niet zonder meer het 'echte' startmoment. Het gaal hier om een moment in een proces dat zich al voltrok. Zo was al sprake van de projectgroep itz voordat het project was opgenomen in het Programma.

4. Onder de noemer 'macht' schaarden wij in Overzicht 3.4 ook middelen, die handelingsruimte verschaffen. Middelen en handelingsruimte komen na dit hoofdstuk aan de orde.

42 Omdat wij in dit hoofdstuk hautskoolschetsen presenteren, hebben wil de diepgang van die beschrijwingen begrensd. Ten aanzien wan de relaties beperken wij ons lot typering in termen van asymmetrische afhankelijkheid. Het onderscheid tussen symbiotische en competitieve relaties komt in hoofdstuk 6 aan de orde. Hetzelfde geldt voor het onderscheid in de vormen wan handelingen (samerwerking, coalilie, concurrentie, strijd, "negotiated order").

43. De opkomst en verdwijning van metwerken en hun handelingsregels in de praktijk volgdien in de tijd bezien op besiluiten, die werden genomen door de strategische top van de projectorganisatie (zie hoofdstuk 5). Voor de bepaling van de momenten var opkomst en verdwijning is gebruik gemaakt van gegevens aver deze besluiten. 


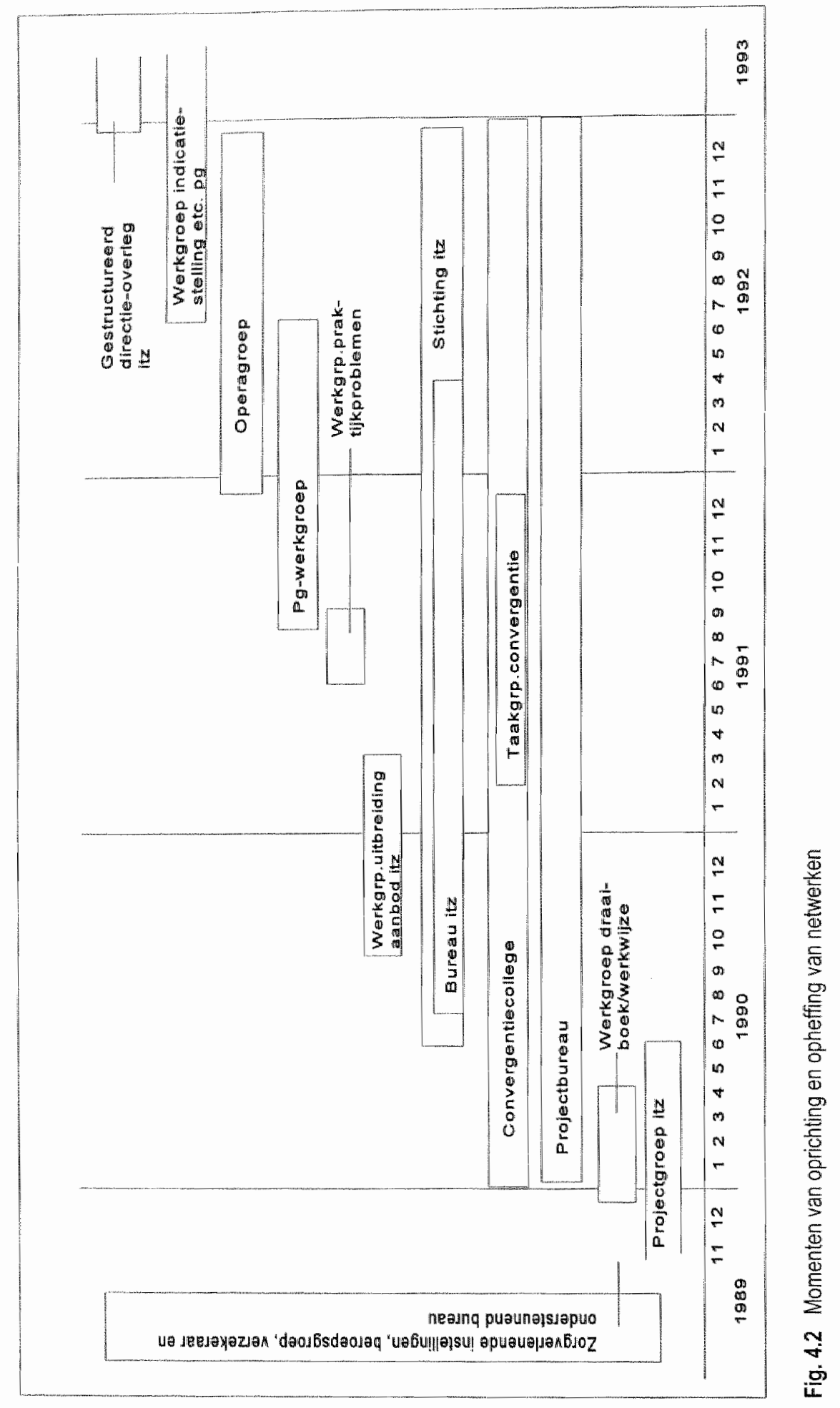




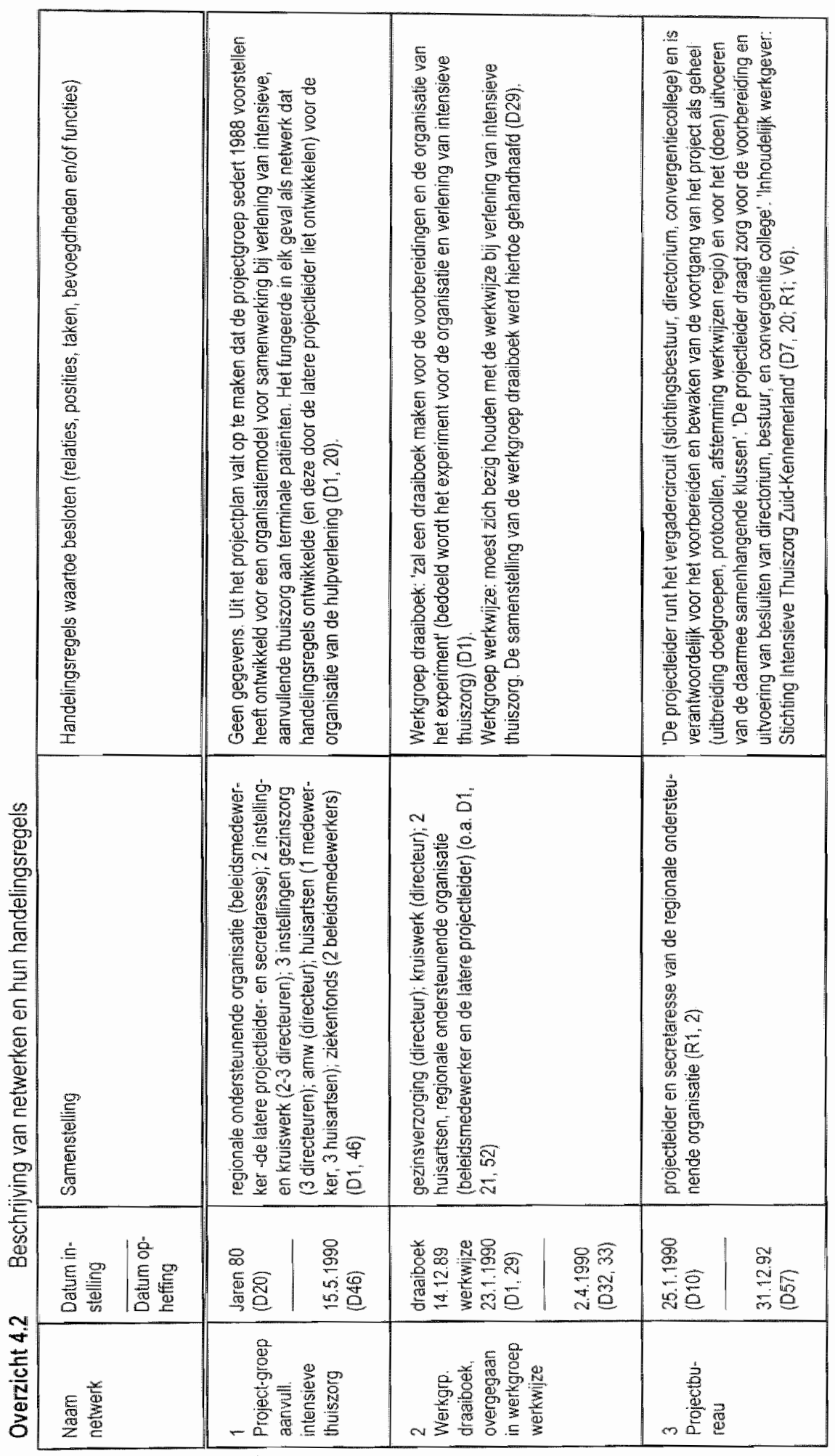




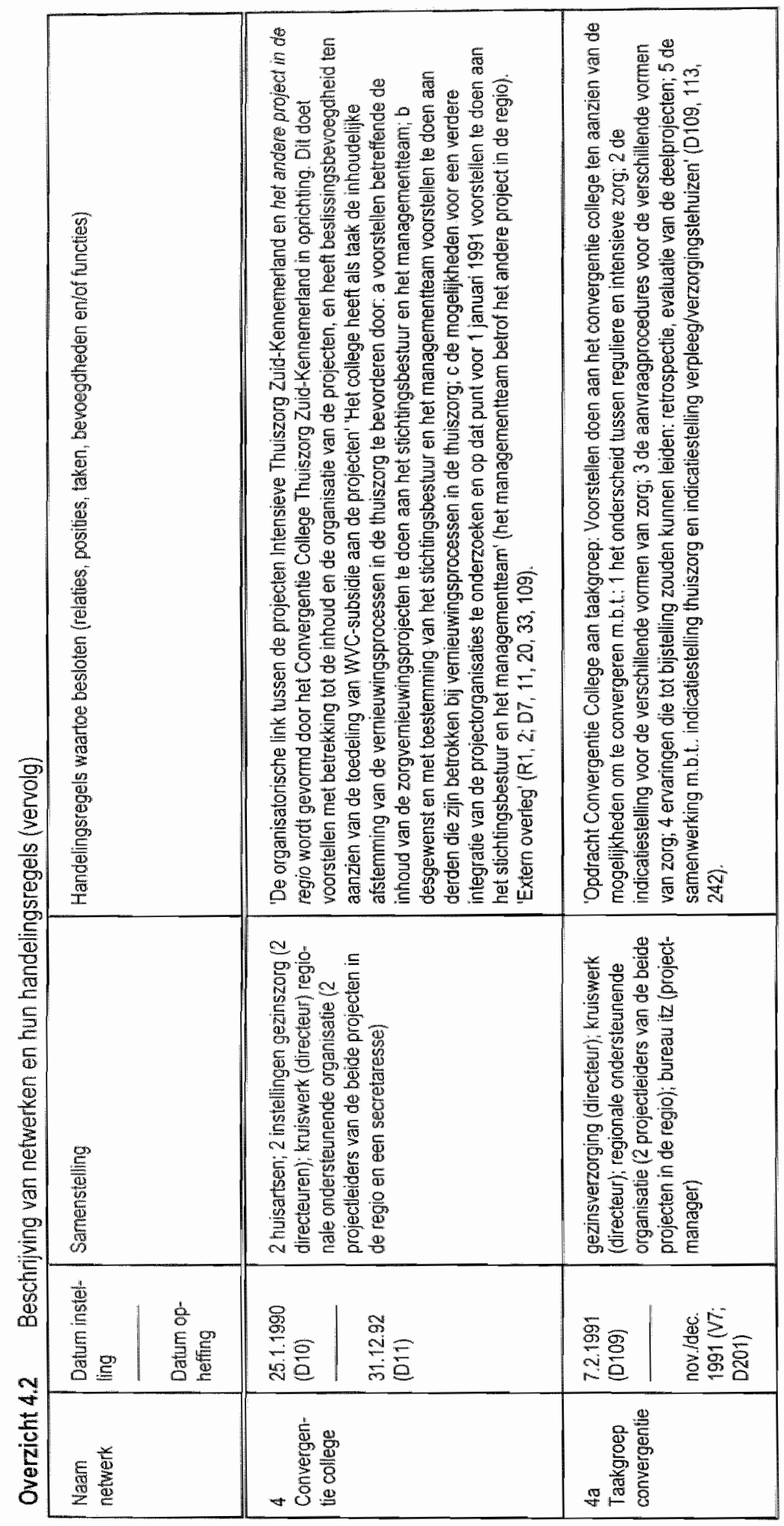




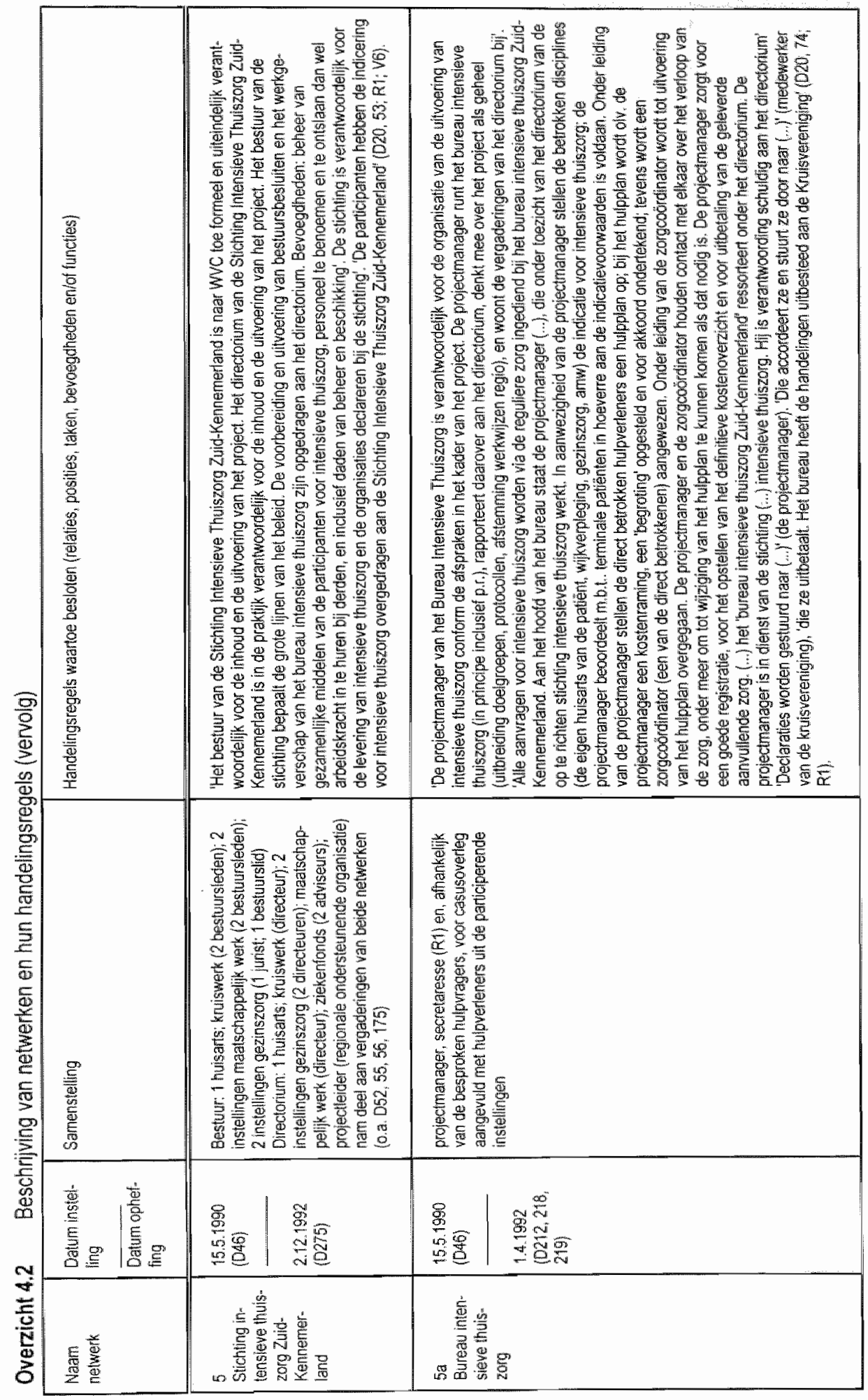




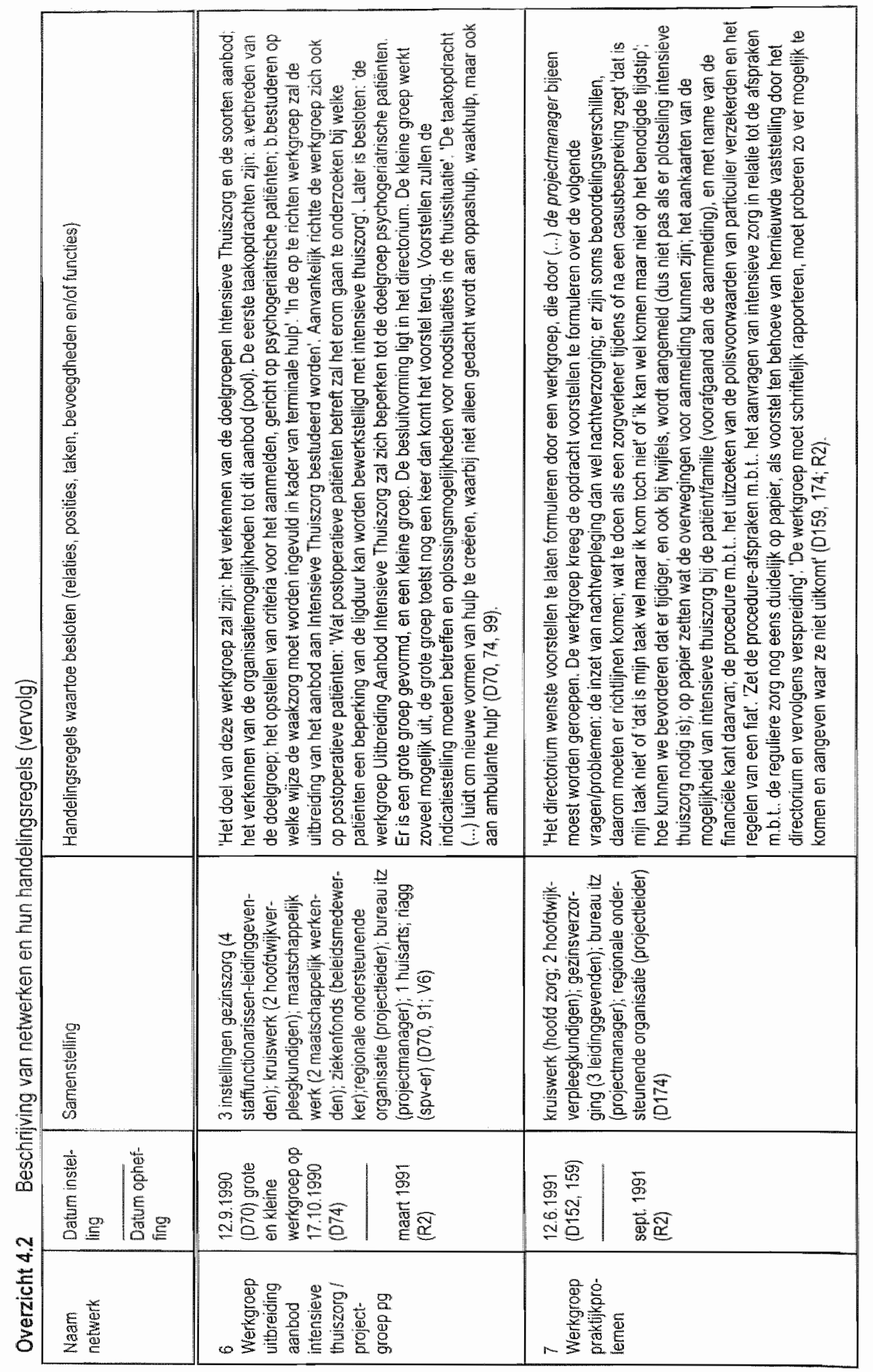




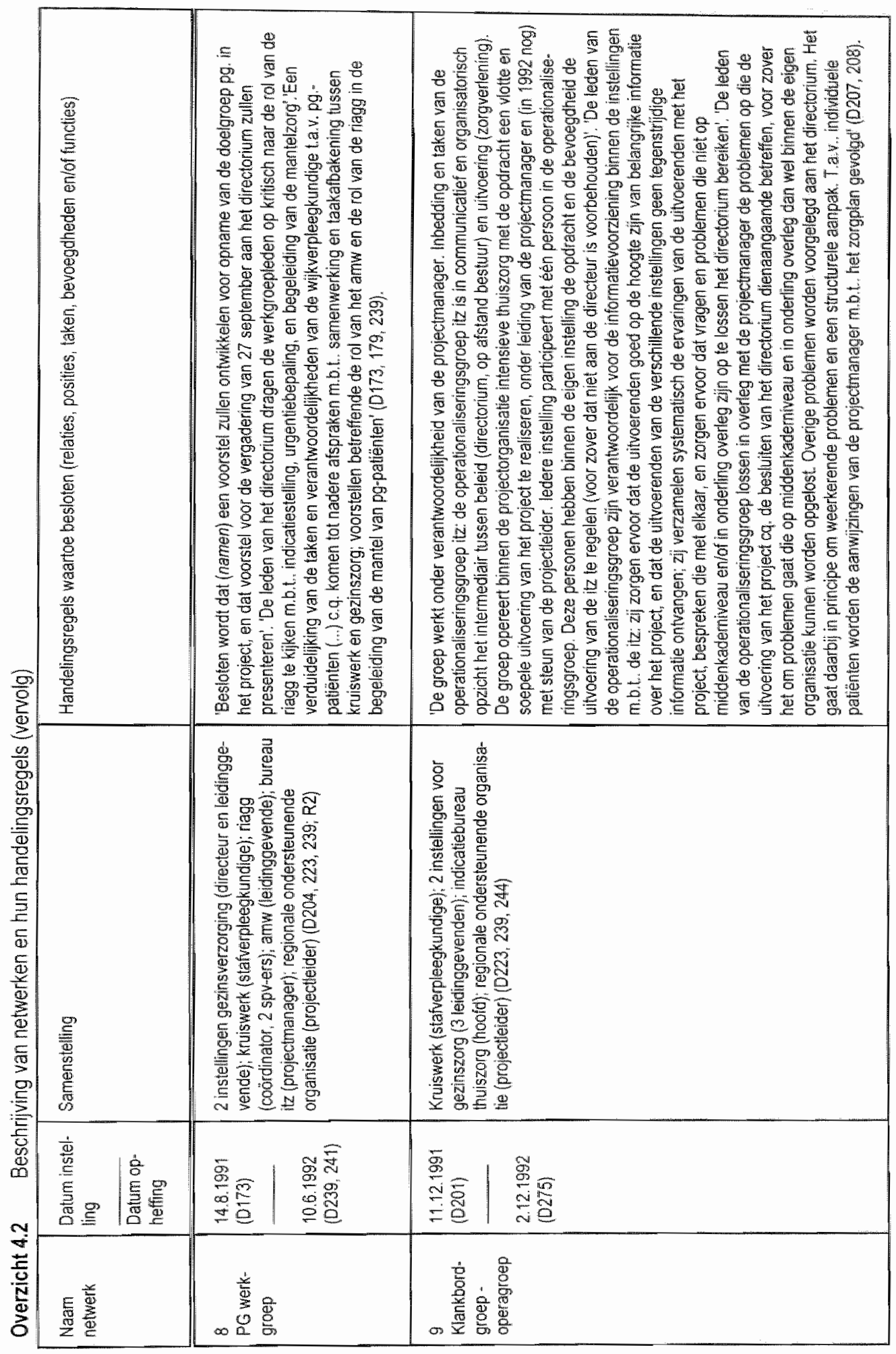




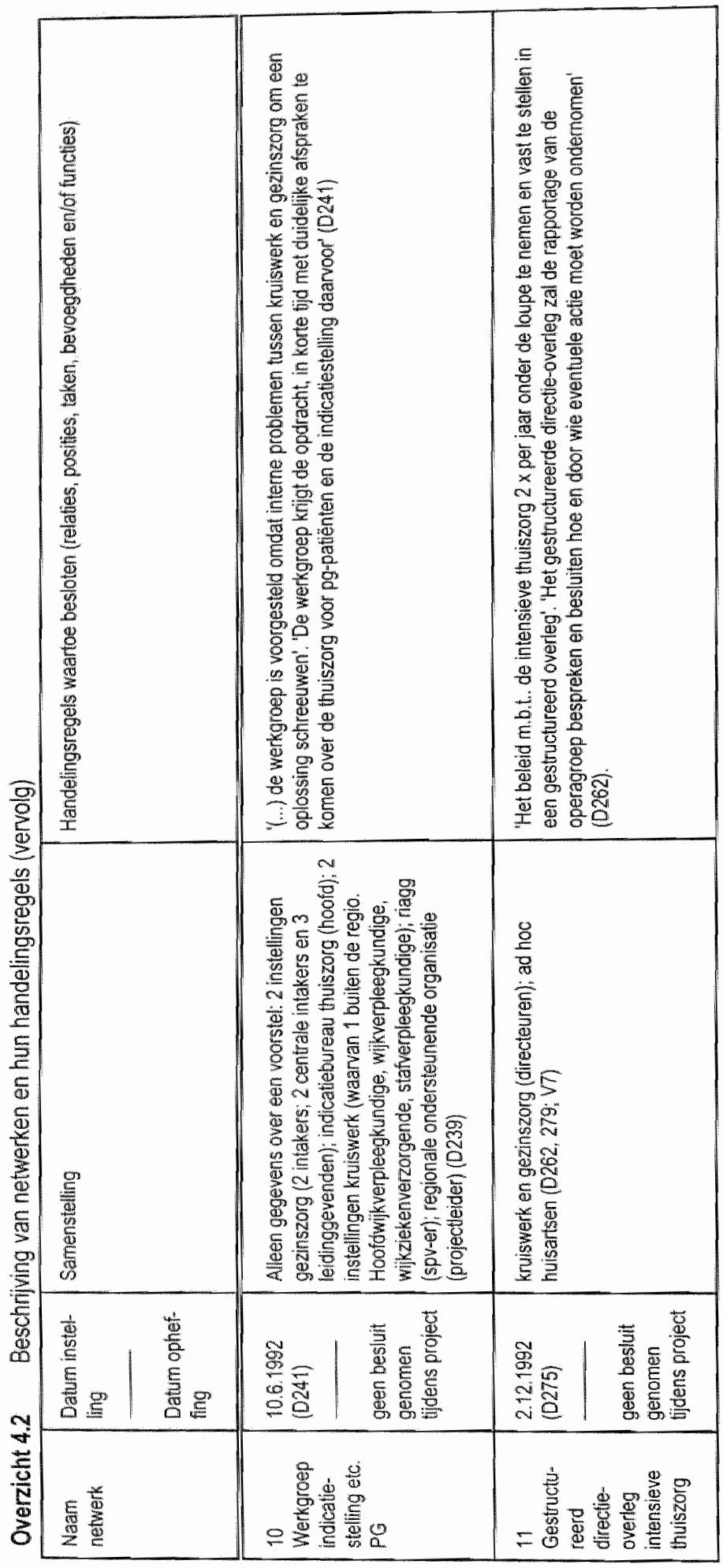


Door de handelingen waarbij deze regels werden gebruikt geraakten taken en bevoegdheden over de netwerken in de projectorganisatie verdeeld en gingen actoren binnen de projectorganisatie bepaalde functies vervullen. Tussen de netwerken ontstonden afhankelijkheidsrelaties, waarbinnen het ene netwerk een dominante of ondergeschikte positie innam ten opzichte van het andere "of omgekeerd en waarbinnen actoren patroonsgewijs gingen handelen. Relaties en netwerken werdwenen door handelingen weer.

Overzicht 4.2 bevat per netwerk een toelichting, zoals de samenstelling en een beknopte weergave van de geldende handelingsregels ${ }^{44}$.

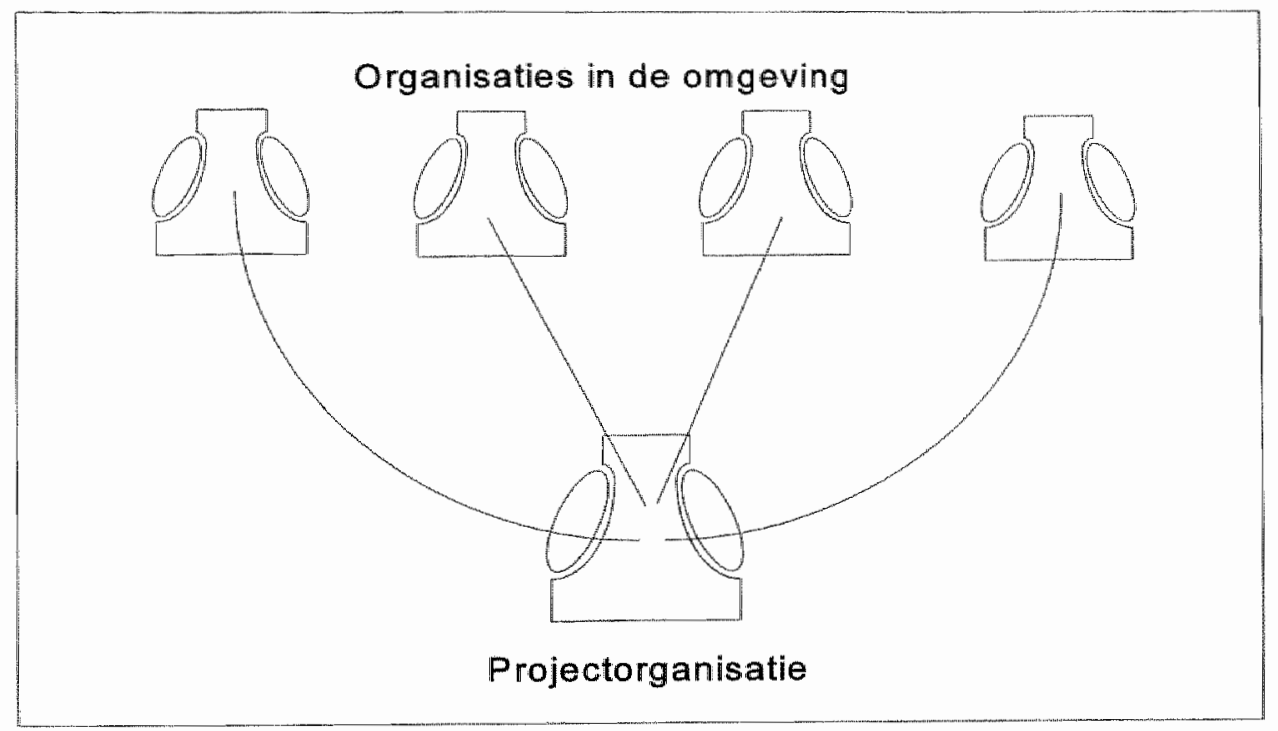

Fig. 4.3 Groepering in de projectorganisatie van actoren uit organisaties in de omgeving

De netwerken in de projectorganisatie bestonden uit vertegenwoordigers van organisaties. Zij werden vanuit hun organisaties opnieuw gegroepeerd (Fig. 4.3). Een aantal van hen werd tegelijkertijd of volgtijdelijk lid van meerdere netwerken. De leden kwamen periodiek bijeen om te vergaderen. Voor de weergave van de projectorganisatie op meerdere momenten hebben wij gebruik gemaakt van de figuurtjes waarmee Mintzberg (1988) 'zijn' configuraties aanduidt.

Voor zover het binnen de beschikbare ruimte mogelight is, bevat Overzicht 4.2 (alsmede Overzicht 4.3) de letterijke weergave van handelingsregels uit de projectdocumenten en andere databronnen (te herkennen aan de aanhalingstekens). In een aantal gevallen waren de regels in projectdocumenten zodanig uitgebreid, dat een samervatting noodzakelijk was. Voor deze samenvatting werd, indien beschikbaar, gebruik gemaakt van beknopte beschrijvingen die de projectleider op ons verzoek tijdens interviews en in registrafieformulieren heeft gegeven. Aldus werd in elk gewal de betekenis wan regels weergegewen, zoals die gold voor een van de actoren uil de projectorganisatie. Vanwege het belang dat wij aan 'betekenis' hebben gehecht, was deze werkwijze methodologisch gezien noodzakelijk. In andere gewallen moesten wij zélf een samenvatting maken. 


\subsubsection{De eerste configuratie: de eenvoudige structuur}

Het allereerste netwerk in de reeks van netwerken die zouden opkomen en verdwijnen was de 'projectgroep aanvullende/intensieve thuiszorg" ("projectgroep itz'). Uit het projectplan blijkt dat dit netwerk in de jaren tachtig is ontstaan als een werkgroep van huisartsen, kruiswerk en gezinsverzorging. Zij werd nog woor de start van het Programma van WVC aangevuld met vertegenwoordigers van de zorgverzekeraar, het amw en de regionale ondersteunende organisatie. Een van de beleidsmedewerkers van de laatstgenoemde organisatie werd in 1990 de projectleider.

De oprichting van de projectgroep itz beschouwen wij als de eerste vorm van vervlechting van relaties tussen de actoren die later het project uitvoerden. De projectorganisatie vormde zich tot haar eerste configuratie (Fig. 4.4). Deze toonde gelijkenis met Mintzberg's 'eenvoudige structuur'. Kenmerkend daarvoor is dat het onderscheid in functies behorend bij de strategische top, het lijnmanagement, de ondersteunende staf, de technostructuur en de werkvloer (zie par. 2.5.3.4) vaag is. De strategische top is het centrale orgaan, waarbinnen de macht is geconcentreerd. Van daaruit vindt supervisie plaats over de gebeurtenissen binnen de organisatie.

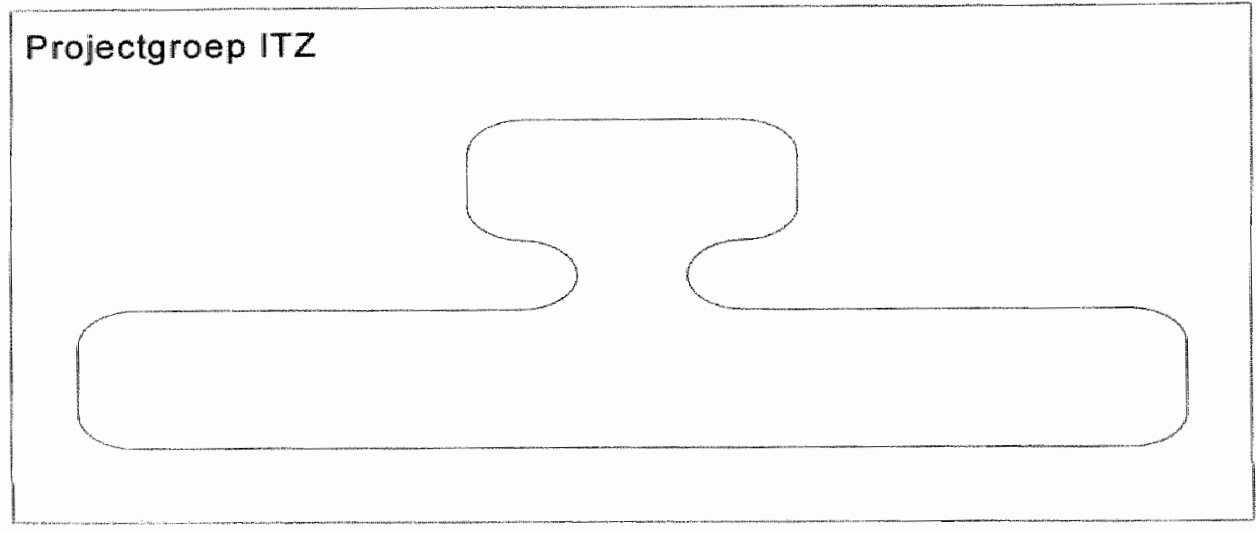

Fig. 4.4 Configuratie wóór 1990: eenvoudige structuur

De projectorganisatie aan het einde van de jaren tachtig was een eenvoudige versie van deze configuratie. Zij bestond uit één netwerk, waarbinnen de leden de functie van strategische top en staf vervulden. Dit orgaan vervaardigde de eerste versies van het projectplan, gedurende besluitvorming in onderling overleg tussen de leden.

Van een strikt onderscheid in bevoegdheden of taken was nog geen sprake. Wel kende de projectgroep een voorzitter (een vertegenwoordiger van het kruiswerk), als 'primus inter pares'. Verder lag voor de vertegenwoordigers van de regionale ondersteunende organisatie het accent op de uitvoering van administratieve en secretariële taken. Zo werden notulen en andere vergaderstukken door hen geschreven. Meer dan de overige leden vervulden zij functies die niet alleen behoren tot de ondersteunende staf, maar ook tot de technostructuur. Een van de conceptversies van het projectplan (D6), geschreven door de latere projectleider, bevatte namelijk werkprocedures (een vorm van standaardisatie). De eerste contouren van een 
asymmetrische afhankelijkheidsrelatie werden zichtbaar, waarin de vertegenwoordigers van de regionale ondersteunende organisatie allengs een ondergeschikte positie zouden gaan innemen ten opzichte van de vertegenwoordigers van de zorgverlenende instellingen.

Mintzberg's functies, die behoren bij het lijnmanagement en de werkvloer, werden vooralsnog niet vervuld. Producten ten behoeve van de hulpverlening werden nog niet gemaakt, er viel derhalve geen leiding te geven aan de levering daarvan. Met name door het ontbreken van de werkvioer-functie week de configuratie af van de eenvoudige structuur in haar zuivere vorm. In dit opzicht liet de configuratie zien een adhocratie-in-wording te zijn.

\subsubsection{De tweede configuratie: de hybride adhocratie}

De vervlechting en de ontwikkeling van de projectorganisatie zette zich voort, toen door de instellingen en huisartsen die waren vertegenwoordigd in de projectgroep, de werkgroep draaiboekiwerkwijze werd opgericht, gevolgd door onder andere het convergentiecollege en de Stichting Intensieve Thuiszorg Zuid-Kennemerland ('stichting itz'). De projectorganisatie ontwikkelde zich tot haar tweede configuratie: Mintzberg's adhocratie (Fig. 4.5).

De adhocratie is bij uitstek bedoeld om innovaties tot stand te brengen, in dit geval vernieuwingen in de organisatie van zorg. Binnen een adhocratie, door Mintzberg ook aangeduid als 'project structure', worden professionals vanuit verschilende disciplines bijeen gebracht in 'creative teams'. Deze teams of projectgroepen moeten voor de beoogde innovaties zorg dragen. Veelal gaat het om tijdelijke teams die een afgebakende opdracht moeten uitvoeren ('task forces").

Afstemming tussen de betrokkenen wordt vooral door overleg gerealiseerd. Kenmerkend voor de adhocratie is verder dat de macht niet is geconcentreerd bij de strategische top, maar is verspreid over de organisatie. In het bijzonder is macht gedelegeerd naar de teams.

Het onderscheid tussen strategische top, lijnmanagement en staf (technostructuur en ondersteunende staf) is niet scherp. Afhankelijk van het type configuratie word de werkvloer wel ('operating adhocracy') of niet ("administrative adhocracy') tot de adhocratie gerekend. In de 'administrative adhocracy' wordt de werkvloer bijvoorbeeld uitbesteed aan andere organisaties.

Uitgaande van de handelingsregels die na besluiten in de projectorganisatie werden ingevoerd en waaruit de functies, relaties en posities, alsmede de verdeling van taken en bevoegdheden duidelijk warden 45 , hebben wij de netwerken in de tweede configuratie getypeerd. Zoals nog blijkt leerde een vergelijking met de genoemde kenmerken dat sprake was van een hybride, 'administrative adhocracy'. 


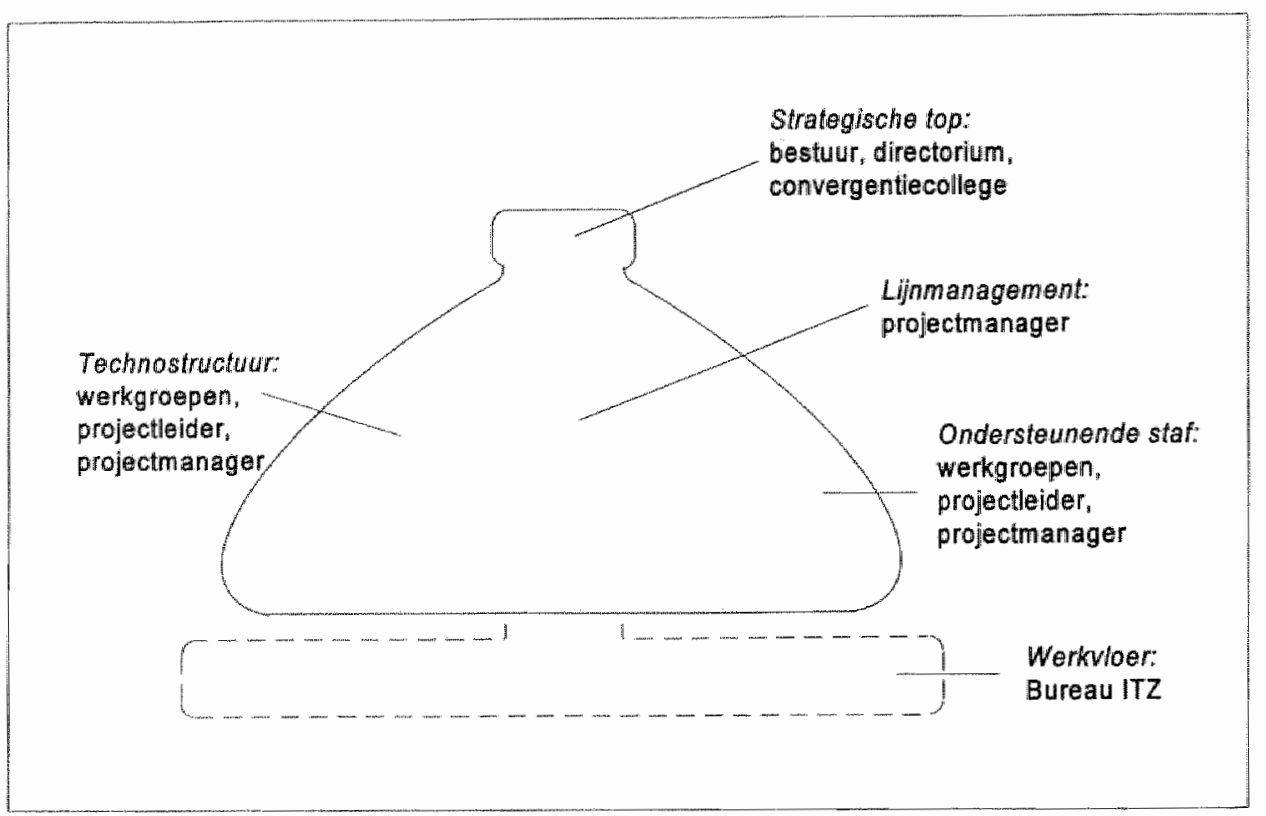

Fig. 4.5 Configuratie 1990-1992: hybride adhocratie

\section{Strategische top}

De stichting itz, die het project moest uitvoeren en onder andere bevoegd was de middelen voor de verlening van intensieve thuiszorg te beheren (D20), bestond uit een bestuur en een directorium. Beide netwerken waren samengesteld uit vertegenwoordigers (bestuursleden resp. directeuren, met uitzondering van de vertegenwoordigers van de huisartsen) van de participerende instellingen. Een beleidsmedewerker van de zorgverzekeraar nam als adviseur deel aan de directoriumvergaderingen. Het bestuur van de stichting itz werd geacht de grote lijnen van het beleid te bepalen. Het directorium moest bestuursbesluiten voorbereiden en (doen) uitvoeren (R1).

Het bestuur en directorium van de stichting itz kunnen wij samen met het convergentiecollege de strategische top van de projectorganisatie noemen. Zij moesten besluiten nemen over de toedeling van de geldelijke middelen die de stichting itz beheerde, en over te ondernemen projectactiviteiten, zoals de invoering van een organisatiemodel voor de verlening van intensieve thuiszorg (zie par. 4.4). In de praktijk was het vooral het directorium dat dergelijke besluiten nam. Een deel46 van hun handelingsregels, alsmede die van projectmanager en projectleider, waren opgenomen in schriftelijke overeenkomsten of statuten. Voor de overige netwerken was dit niet het geval. Volgens deze regels was de macht in de projectorganisatie bij het bestuur en het directorium geconcentreerd. 
Het convergentiecollege werd ingesteld opdat regionale ontwikkelingen in de hulpwerlening op elkaar konden worden betrokken (D11). Dit college moest onder andere afstemming realiseren tussen het project itz en het andere project in de regio. Het was samengesteld uit vertegenwoordigers van de projectorganisaties van beide projecten.

\section{Technostructuur en ondersteunende staf}

De stichting itz en het convergentiecollege werden bij de uitwoening van hun taken ondersteund door een projectleider ${ }^{47}$, een secretaresse en een aantal tijdelijke werkgroepen ('task forces") die met verschillende namen werden aangeduid ('werkgroep', 'projectgroep', 'klankbordgroep', 'operagroep' of 'taakgroep'). De werkgroepen fungeerden als 'creative teams' en bestonden meestal uit professionals (vooral hulpverleners met uiteenlopende disciplinaire achtergronden, zoals wijkverpleging en maatschappelijk werk), die beschikbaar werden gesteld door de verschillende participerende organisaties. Zij moesten in onderling overleg tijdens vergaderingen hun werk doen.

De projectleider en de secretaresse waren afkomstig van de regionale ondersteunende organisatie. Getweeën vormden zij het 'projectbureau". Het projectbureau en de werkgroepen werkten in opdracht van het directorium, het bestuur of het convergentiecollege.

Nu eens kregen werkgroepen de taak nieuwe zorgproducten te ontwikkelen. In die gevallen kunnen zij de ondersteunende staf worden genoemd. Dan weer dienden zij handelingsregels te ontwikkelen voor de organisatie van de zorgverlening, die bijvoorbeeld in een protocol werden ondergebracht, zoals de handleiding intensieve thuiszorg voor terminale patiënten $(\mathrm{D} 223)^{48}$. Protocollen zijn bedoeld om werkprocessen te standaardiseren. De werkgroepen fungeerden in die gevallen als instrumentenmakerijen en zouden door Mintzberg (1979) met het begrip "technostructuur" zijn aangeduid. De functies van technostructuur en ondersteunende staf liepen voor meerdere werkgroepen dus in elkaar over. Dit geldt voor de taakgroep convergentie, de werkgroep uitbreiding aanbod intensieve thuiszorg, de werkgroep praktijkproblemen en de operagroep.

Tot de taken van de ondersteunende staf behoren 'research and development'activiteiten. De werkgroepen voerden dergelijke taken uit wanneer zij beleidsondersteunende informatie verzamelden, bijvoorbeeld over beschikbare (aanbieders van) zorgproducten voor pg-patiënten in de regio. Zij brachten dan als een team van landmeters de regionale en nationale amgeving van het project in kaart en deden van hun bevindingen verslag aan de strategische top, in het bijzonder aan het directorium. Het was de bedoeling dat het directorium met behulp van de informatie van de werkgroepen besluiten nam over het projectbeleid, welke besluiten verwolgens ter goedkeuring aan het bestuur moesten worden voorgelegd.

De projectleider kreeg soortgelijke opdrachten als de werkgroepen, werd (evenals de projectmanager, zile hierna) geacht deel uit te maken van werkgroepen en moest ervoor zorgen dat vergaderingen plaatsvonden, dat opdrachten van netwerken werden uitgevoerd en dat verzamelde informatie op de beoogde plaatsen terecht kwam. Ook 
de functie van de projectleider kan met behulp van de begrippen "ondersteunende staf en 'technostructuur worden getypeerd.

Tussen de staforganen van de projectorganisatie en de organen in de strategische top was sprake van een asymmetrische afhankelijkheidsrelatie. Daarin namen de laatstgenoemde organen een dominante positie in ten opzichte van de eerste (zie ook hoofdstuk 5). Het was voor het eerst in de regia dat tussen interorganisationele netwerken onderling een asymmetrische afhankelijkheidsrelatie was gecreeerd. Aan de vervulling van staffuncties waren geen bevoegdheden verbonden.

\section{Lijnmanagement}

$\mathrm{Na}$ de stichting itz richtten de participanten gezamenlijk het Bureau Intensieve thuiszorg ("bureau itz') op, van waaruit de verlening van intensieve thuiszorg aan de doelgroepen van het project moest worden georganiseerd. Het ressorteerde onder de stichting itz. Hoofd van het bureau was de projectmanager (niet te verwarren met de projectleider). Deze trad in dienst bij de stichting itz, in casu bij het directorium, dat bevoegd was het werkgeverschap te vervullen (D56).

Doordat de projectmanager een aantal malen opdracht kreeg deel te nemen aan werkgroepen (het directorium formuleerde daartoe handelingsregels), diende deze functies te vervulten die door Mintzberg zijn toebedeeld aan de technostructuur en de ondersteunende staf. Voor het overige handelde de projectmanager als lijnmanager. door leiding te geven aan de organisatie van de verlening van intensieve thuiszorg. Deze functionaris was onder andere bevoegd hulpverleners uit de participerende organisaties voor casusoverleg bijeen te roepen (D20) (zie par. 4.4). Daarmee was een asymmetrische afhankelijkheidsrelatie gecreëerd tussen projectmanager en hulpverleners. De relatie kende geen precedent. Het was nog niet voorgekomen dat een functionaris buiten de instellingen zeggenschap kreeg over de hulpverleners van deze organisaties.

De functie van één werkgroep -de operagroep- lag op de grens van de functies van de technostructuur en de ondersteunende staf enerzijds en van het lijnmanagement anderzijds. De operagroep moest structurele knelpunten in de hulpverlening zien op te lossen (D208), niet alleen door informatie te verzamelen of handelingsregels te ontwikkelen, maar ook door zélf in te grijpen in de praktijk van hulpverlening. Zij diende op te treden als een team van mecaniciens dat de eigen instrumenten gebruikte. Het was de bedoeling dat alleen mecaniciens deelnamen die in de eigen instelling de verlening van intensieve thuiszorg mochten regelen. Met andere woorden, zij moesten binnen de eigen organisatie lijnmanagers zijn.

De instelling van de operagroep leidde binnen de projectorganisatie niet tot een verdere invulling van het lijnmanagement voor de uitvoering van de intensieve thuiszorg. Hoewel (uitgaande van de omschrijving van hun functie in de projectdocumenten) de individuele leden well degelijk een dergelijke functie hadden, beperkte deze $z i c h$ tot de eigen organisatie. Noch individueel, noch als groep konden zij volgens de regels in elkaars organisatie als lijnmanagers optreden.

\section{Werkwloer}

Het bureau itz noemen wij de werkvloer. Behalve de projectmanager en een secretaresse bestond dit netwerk uit hulpverleners van de participerende instellingen. Zij werden per hulpsituatie bijeengeroepen. De samenstelling kon van casus tot casus variëren. Op deze manier ontstonden casusteams die elk het karakter hadden van 'task forces'. Na beëindiging van de hulpverlening aan de betreffende vrager gingen de leden uiteen. 
Verlening van intensieve thuiszorg behoorde niet tot de producten van de werkvloer van de projectorganisatie, maar was een zaak van de zorgverlenende instellingen zélf. Niettemin werden door het bureau itz producten vervaardigd. Onder leiding van de projectmanager stelden de hulpverleners ten behoeve van de organisatie van de intensieve thuiszorg aan individuele patiënten bijwoorbeeld de indicatie. Ook werden hulpplannen opgesteld 49 .

\section{Hybride adhocracy}

De beschreven functies waren miet altijd scherp onderscheiden. Zo hebben wij aangegeven dat werkgroepen taken kregen die zowel bij de techmostructuur als de ondersteumende staf behoren. Verder waren de meeste netwerken werkgroepen, die vooral als tijdelijke 'task forces' en als 'creative teams' moesten opereren. In zulke opzichten komt de configuratie zoals wij die waarnamen overeen met de beschrijving van de adhocratie door Mintzberg.

Anders dan in de adhocracy in haar zuivere vorm echter werd de macht niet gedelegeerd naar de professionals in de 'creative teams'. Bestuur en directorium van de stichting itz hadden de zeggenschap over projectaangelegenheden. Het was bijwoorbeeld aan deze netwerken te besluiten welke regels voor de organisatie van de hulpverlening werden ingevoerd, niet aan de teams. De configuratie had daarmee het karakter van een hybride. Zij was een combinatie van de adhocratie en de eenvoudige structuur.

Omdat in de configuratie sprake was van een werkvloer die producten maakte, zouden wij kunnen spreken van een 'operating adhocracy'. Echter, de producten reikten niet zover dat zij de gehele hulpverlening aan intensieve thuiszorg-patiënten omvatten. Degenen die daadwerkelijk de hulp verleenden, behoorden tot de werkvloer van de participerende organisaties. Daarmee hield de configuratie het midden tussen de 'administrative adhocracy' en de 'operating adhocracy'.

\subsubsection{De derde configuratie: terug naar de eenvoudige structuur}

Eind 1992 waren de meeste netwerken verdwenen. De projectorganisatie ontwikkelde zich weer in de richting van haar oorspronkelijke vorm: de eenvoudige structuur (Fig. 4.6).

De stichting itz werd eind 1992 opgeheven. In de platats kwam een 'gestructureerd directie-overleg intensieve thuiszorg' tussen de directeuren van kruiswerk en gezinszorg, waaraan ap ad hoc basis een vertegenwoordiger van de huisartsen zou worden toegevoegd. Het amw participeerde hierin niet. Van dit overleg is alleen bekend dat het diende om het beleid met betrekking tot intensieve thuiszorg in de regio te bezien en vast te stellen. Het convergentiecollege en het projectbureau bestonden tot het einde van 1992. Het bureau itz was reeds per 1.4.1992 opgeheven, de datum

49 Hoewel in beide de werkafispraken en de taakverdeling tussen hulpverleners worden vastgelegd (Van Raak et al, 1993), is een hulpplan niet hetzeifde als een protocol. Een hulpplan is bedoeld voor gebruilk bij één patiënt. Een protocol daarentegen is bedoeld voor de zorg aan een gehele patientencategorie. Met een protocol wordt beoogd de hulpverlening aan de doelgroepen te standaardiseren. Het opstellen van protocollen is daarom de taak van de technostructuur en miet van de werkvloer. Anders dam bij protocollen wordt in het hulpplan de zorg op maat gesneden van de individuele hulpvrager. Van standaardisatie is geen sprake. 
waarop de toenmalige (tweede ${ }^{50}$ ) projectmanager met ontslag ging. Afgesproken werd dat de functies van de projectmanager en het bureau itz voortaan werden vervuld door leden van een aantal afzonderlijke participerende instellingen, zoals het kruiswerk en de gezinsverzorging.

\section{Directie-overleg}

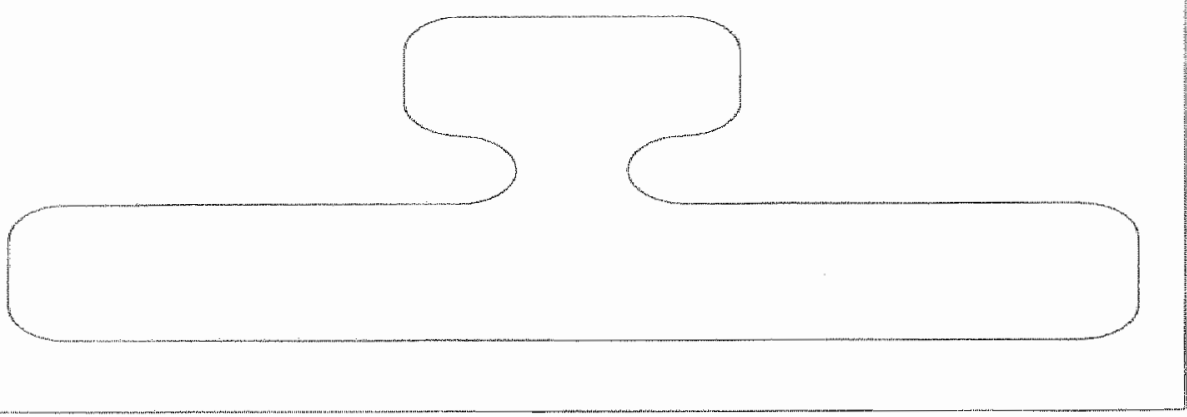

Fig. 4.6 Configuratie eind 1992: terug naar de eenvoudige structuur

In de tussentijd waren de meeste opgerichte werkgroepen uiteen gegaan. De twee resterende werkgroepen, de operagroep en de 'werkgroep indicatiestelling etc. pg', kregen van het directorium de opdracht van hun werkzaamheden en bevindingen verslag te doen aan de afzonderlijke directies die in de projectorganisatie participeerden. De operagroep werd aan het einde van het project opgeheven. Over het lot van de 'werkgroep indicatiestelling etc. pg' zijn geen gegevens beschikbaar.

Deze veranderingen betekenen dat aan het einde van de projectperiode van lijnmanagement en een werkvloer geen sprake meer was. Tot de ondersteunende staf en de technositructuur kon hooguit nog de 'werkgroep indicatiestelling etc. pg' worden gerekend, voor zover die nog bestond. De aanduiding 'strategische top' betrof voortaan het directeurenoverleg, een netwerk waarvan handelingsregels niet langer in statuten van een rechtspersoon of in een schriftelijke overeenkomst waren vastgelegd. Relaties, asymmetrisch en anderszins, waren afgebroken, actoren waren teruggegaan naar hun eigen organisaties in de omgeving, de ontvlechting was vergaand. De eenvoudige structuur die ontstond was feitelijk een desintegrerende adhocratie.

\subsection{Veranderingen in structuur en macht: vervlechting en ontvlechting in de organisatie van intensieve thuiszorg}

De processen die wij tot dusverre hebben beschreven betroffen zowel het secundaire proces als het secundaire niveau van het primaire proces. 
Het project was met name bedoeld voor innovaties in het laatstgenoemde proces. Invoering van het organisatiemodel voor de hulpverlening dat in het projectplan werd omschreven, vormde de primaire bestaansreden van de projectorganisatie. Dit model had alleen betrekking op de verlening van intensieve thuiszorg door meerdere instellingen gezamenlijk (multidisciplinaire zorg). De organisatie van de reguliere zorg van de afzonderlijke instellingen, waarop de intensieve thuiszorg een aanvulling moest zijn, diende niet te worden veranderd.

Een beschrijving van de veranderingen op het organisatorische niveau van de hulpverlening verschaft meer inzicht in hetgeen de leden van de projectorganisatie trachtten te realiseren. Modellen zoals het model in het projectplan bestaan uit een of meerdere verzamelingen van regels, die bij de organisatie van de hulpverlening moeten worden gebruikt. De veranderingen die wij bespreken, hebben betrekking op de invoering en de teniet verklaring van dergelijke verzamelingen.

Gedurende de projectperiode zijn meerdere verzamelingen van zulke regels ingevoerd en toegepast. Handelingen kregen bij gebruik daarvan een patroonmatig karakter. Fig. 4.7 toont de momenten waarop door het directorium besluiten $\mathbf{z} i j n$ genomen over de invoering of teniet verklaring van verzamelingen regels. Tussen haakjes staat de auteur vermeld van het document waarin deze regels zijn te vinden.

De regels kunnen worden gegroepeerd tot niet één model, maar tot twee opeenvolgende modellen (Overzicht 4.3). Beide omvatten alle fasen van het hulpverleningsproces (zie par. 3.6.1): aanmelding van de zorg; voorbereiding van de zorgverlening; uitvoering; evaluatie ${ }^{51}$. Geciteerde regels zijn te herkennen aan aanhalingstekens.

Onze weergave van de modellen sluit aan bij de informatie die de projectleider op ons verzaek heeft verstrekt (R3). Beide werden ook door de projectleider als afzonderlijke modellen beschouwd (V7). De betekenis die wij aan de verzamelingen regels geven, komt dus overeen met de betekenis die de modellen voor deze functionaris hadden.

Binnen de modellen stond een aantal instrumenten centraal, die moesten worden gebruikt tijdens het primaire proces: 'meldpunt" (aanmelding); 'multidisciplinaire casusbespreking', 'zorgcoördinator' en 'zorgplan' (voorbereiding en uitvoering); "logboek' (evaluatie). Wiij hebben anvoldoende gegevens om te kunnen bepalen of werd gehandeld volgens alle handelingsregels die in de modellen zijn opgenomen. Anders ligt het voor de instrumenten. Wij weten dat deze in de praktijk werden gebruikt. Dit hebben wij afgeleid uit projectdocumenten zoals interne evaluatierapporten (D19252, 274).

51 Het overzicht bevat niet alle regels die zijn geformuleerd. De ruimte was te beperki om werzamelingen van regeis zoals een handleiding in hun wolledige omvang weer te geven.

52 In dit rapport wordt bijvoorbeeld gesteld dat in de periode juli 1990 - julli 1991 bij hel bureau itz 197 personen zijn aangemeld, 126 patiènten in zorg zijn genomen en 115 casusbesprekingen zijn gehouden. Aan 37 patienten was zorg verleend zonder casusbespreking. Er werden 115 logboeken uitgereikt. Daarvan werden 54 ingewuld geretoumeerd, waarwan 47 met avaluatieformulieren, ingevuld door hulpverleners. 


\subsubsection{Eerste model: vervlechting van relaties tussen hulpverleners}

Gebruik wan het eerste model betekende vervlechting van relaties tussen hulpverleners uit verschillende instellingen. Fig. 4.8 geeft de wijze weer waarop de hulpverlening in het algemeen was georganiseerd voorafgaand aan de invoering van het madel.

Elke zorgaanbiedende instelling regelde in principe afzonderlijk de organisatie van de eigen hulpwerlening. In de figuur is dit met behulp van ononderbroken ellipsen per fase van het primaire proces aangegeven. Dit blijkt uit documenten zoals jaarverslagen en beleidsplannen van de participerende instellingen, alsmede uit interviews met directeuren van de zorgverlenende instellingen (zoals $\mathrm{V} 3$ ).

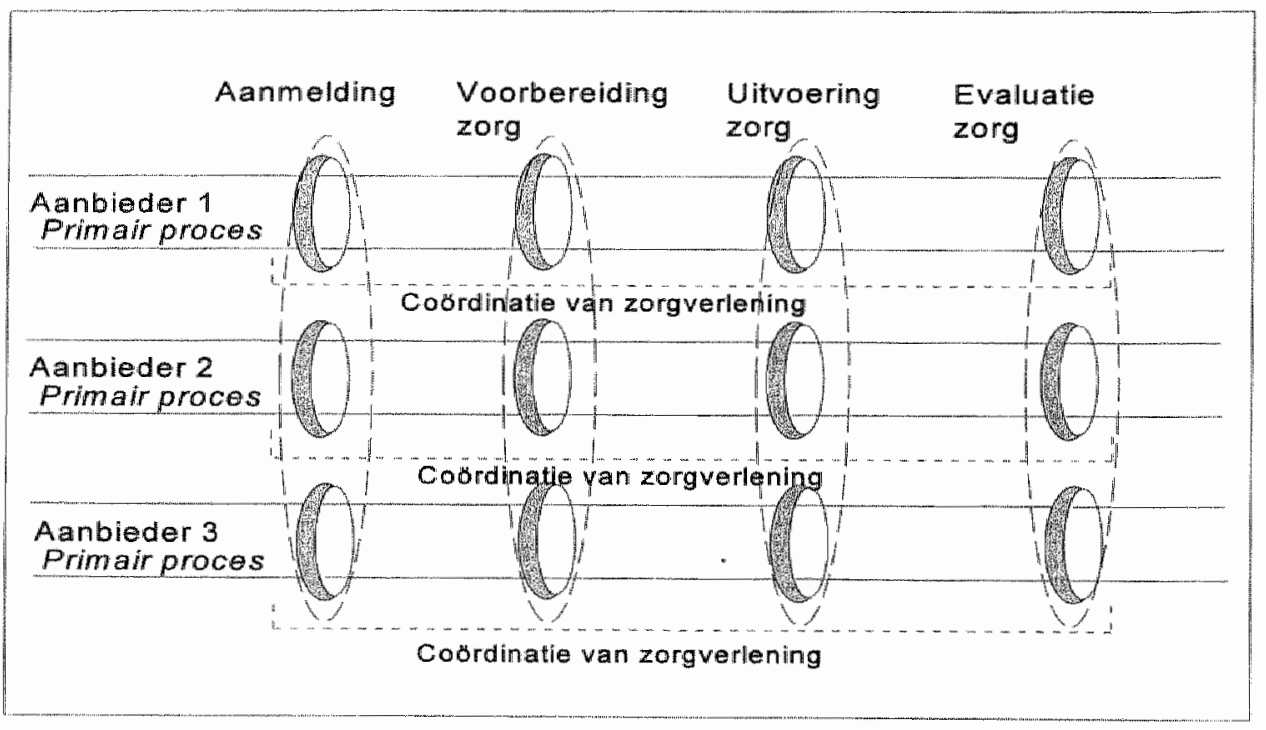

Fig. 4.8 Organisatie van de hulpverlening voorafgaand aan de invoering van het eerste model

Daarmee is overigens niet gezegd dat bijvoorbeeld nooit afstemming plaatsvond tussen hulpverleners uit verschillende instellingen die bij dezelfde vrager waren betrokken. Dit kwam wel degelijk voor. Zo werden in meerdere organisaties multidisciplinaire casusbesprekingen gehouden (zie par. 4.6). Daarom hebben wiij in Fig. 4.8 bij de fasen van de zorgverlening met behulp van stippellijnen schakels getekend tussen verschillende aanbieders.

Het eerste model (1.7.1990 - 31.3.1992) betrof aanvankelijk uitsluitend de terminale patiënten. Later werd het ook van toepassing verklaard op pg-patiënten. Intensieve thuiszorg aan terminale patiënten was uitsluitend een zaak van huisartsen. gezinszorg en kruiswerk. In de zorgverlening aan pg-patiënten participeerde ook het amw, zij het incidenteel. 


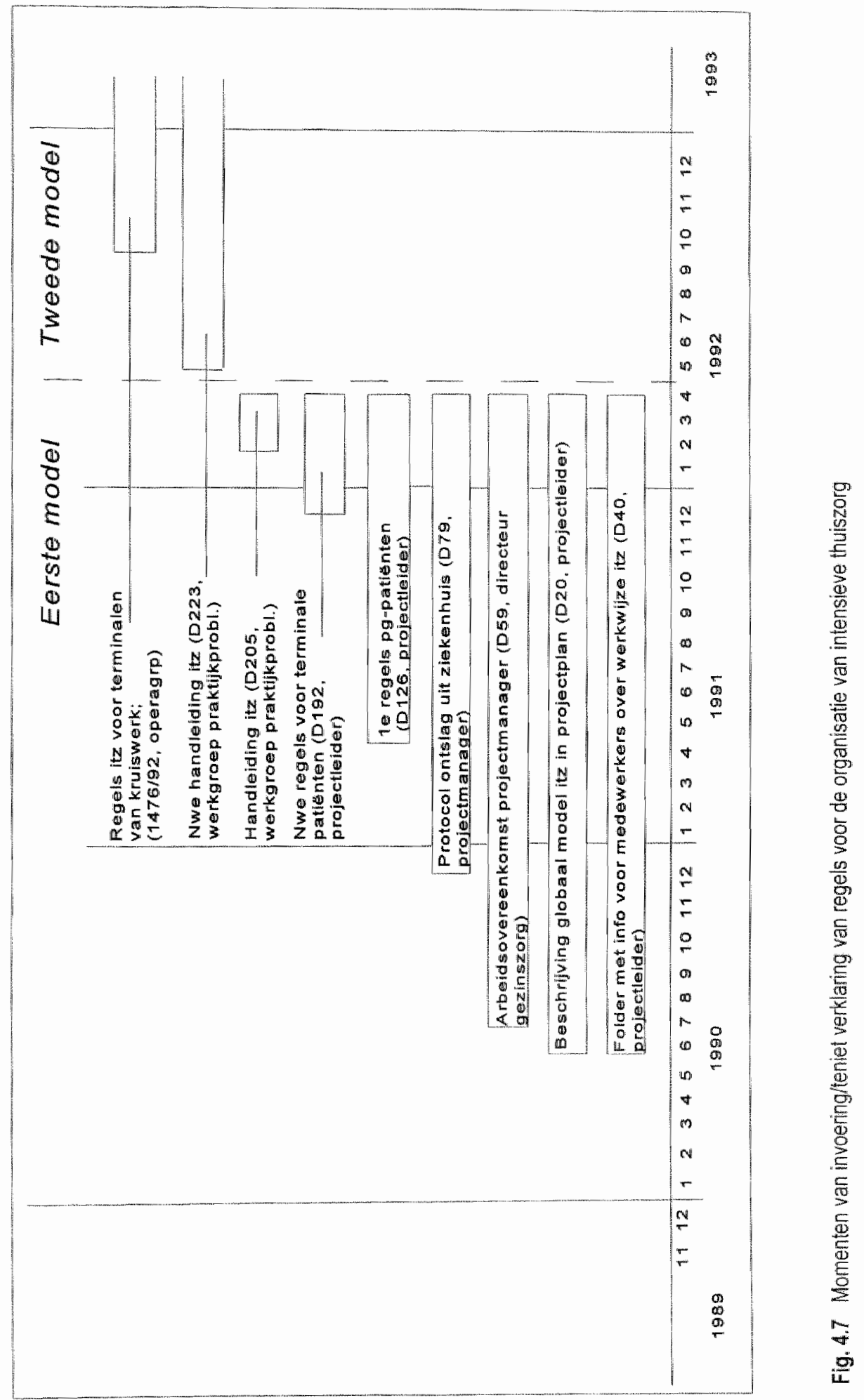




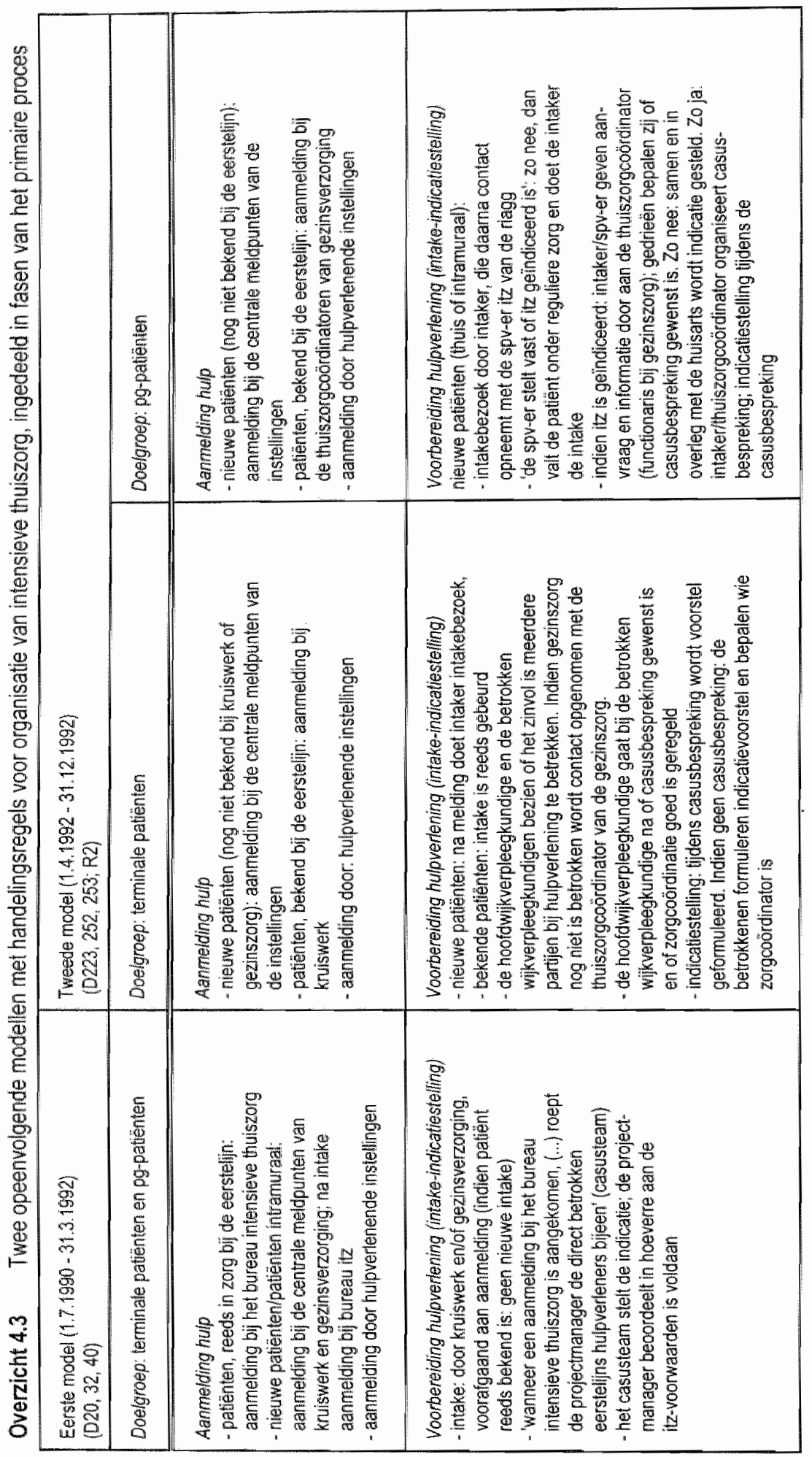




\begin{tabular}{|c|c|c|c|}
\hline & 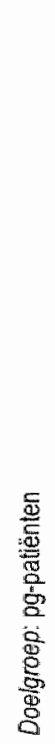 & 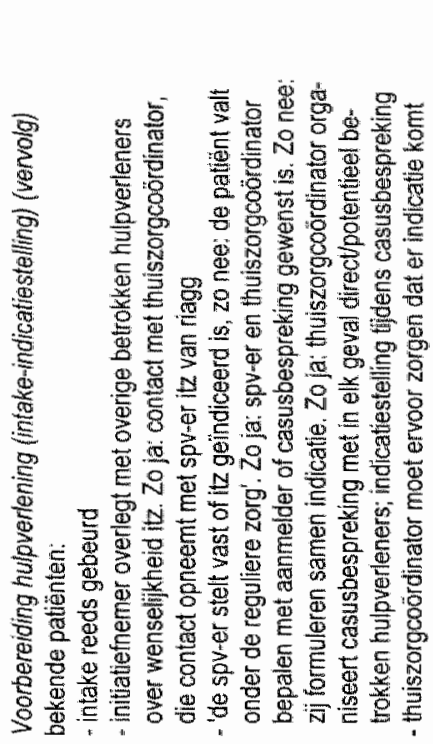 & 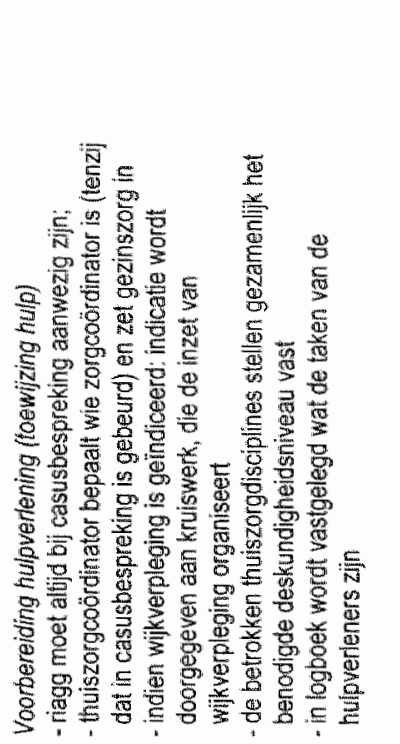 \\
\hline 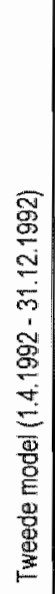 & 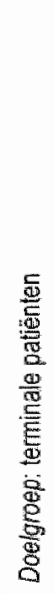 & 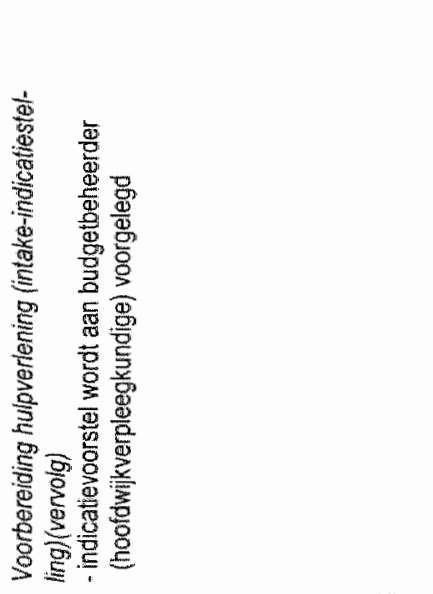 & 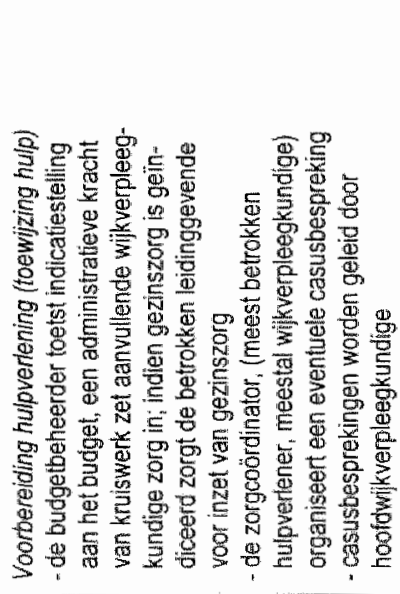 \\
\hline 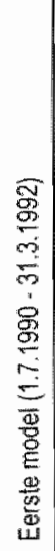 & 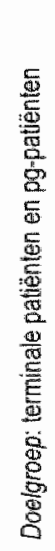 & 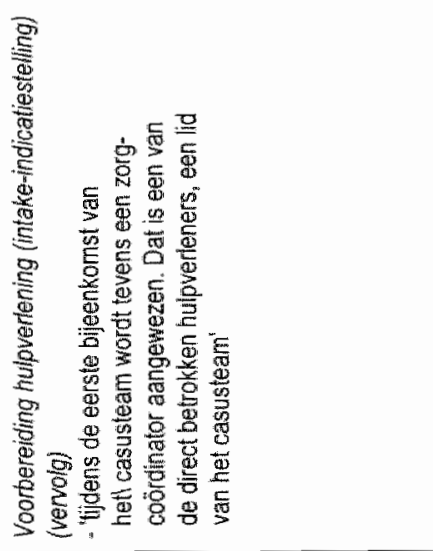 & 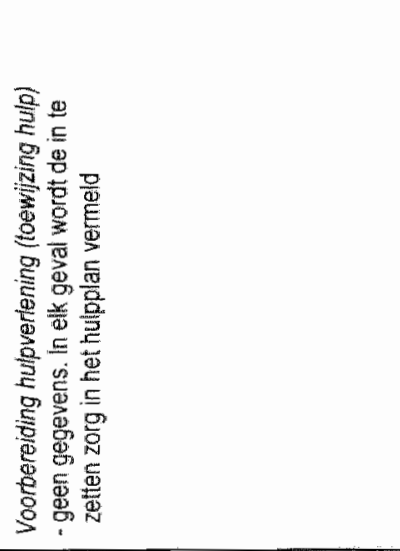 \\
\hline
\end{tabular}




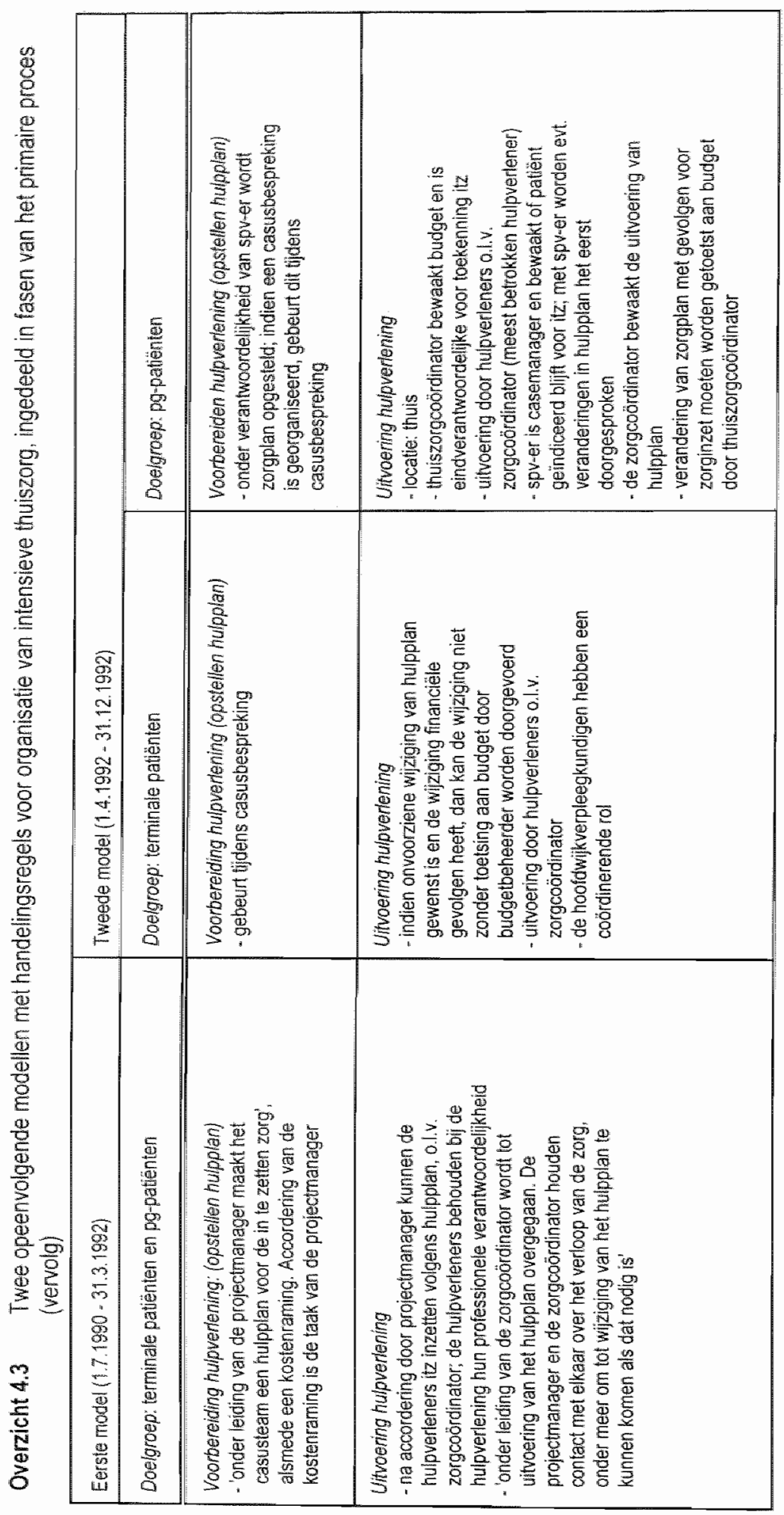




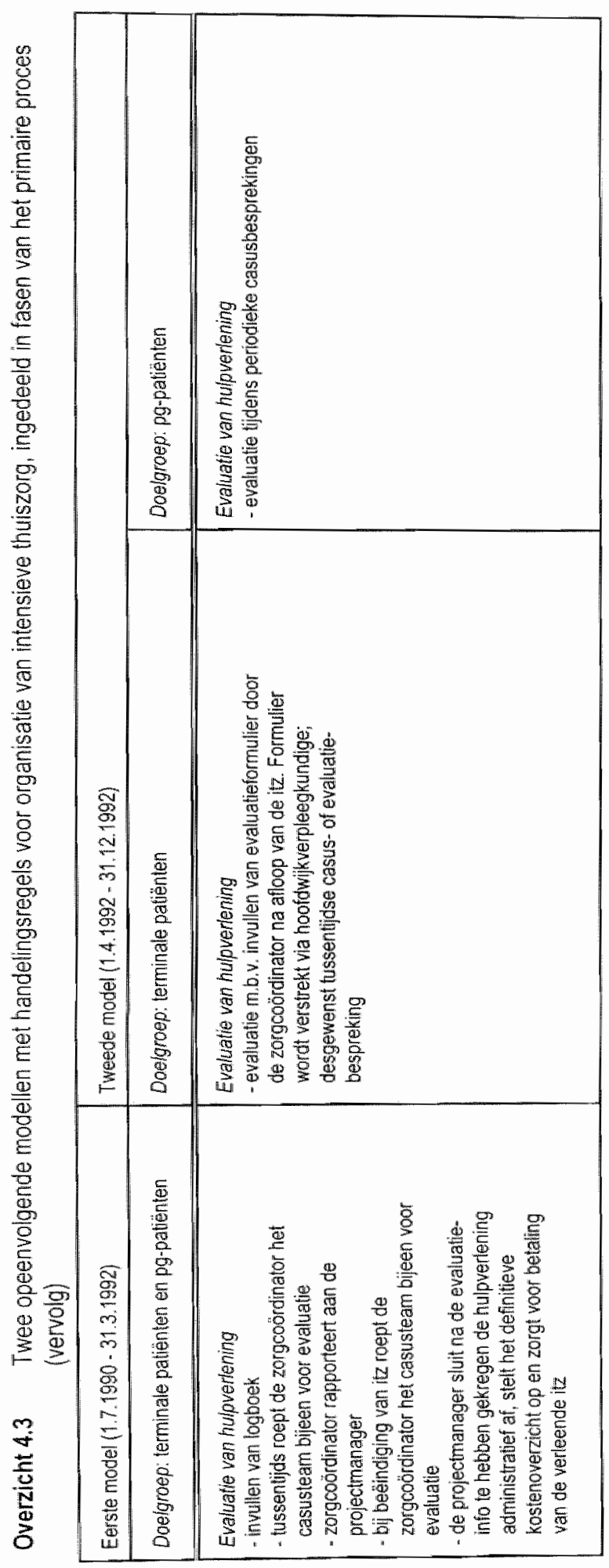


Gebruik van het model betekende in alle fasen van de hulpverlening een organisatorische verandering. Door de formering van multidisciplinaire casusteams die onder leiding van de projectmanager de indicatie moesten stellen, hulpplannen moesten vervaardigen voor patiënten die bij het bureau itz werden aangemeld, en de verleende hulp moesten evalueren, werden per fase schakels gelegd tussen de hulpverlenende instellingen (zie de ellipsen in Fig. 4.9). Dit gebeurde door het bureau itz, dat een positie had buiten de zorgaanbiedende instellingen. Anders dan in de reguliere zorg was de coördinatie van het gehele proces geen zaak van elke afzonderlijke instelling, maar van de projectmanager.

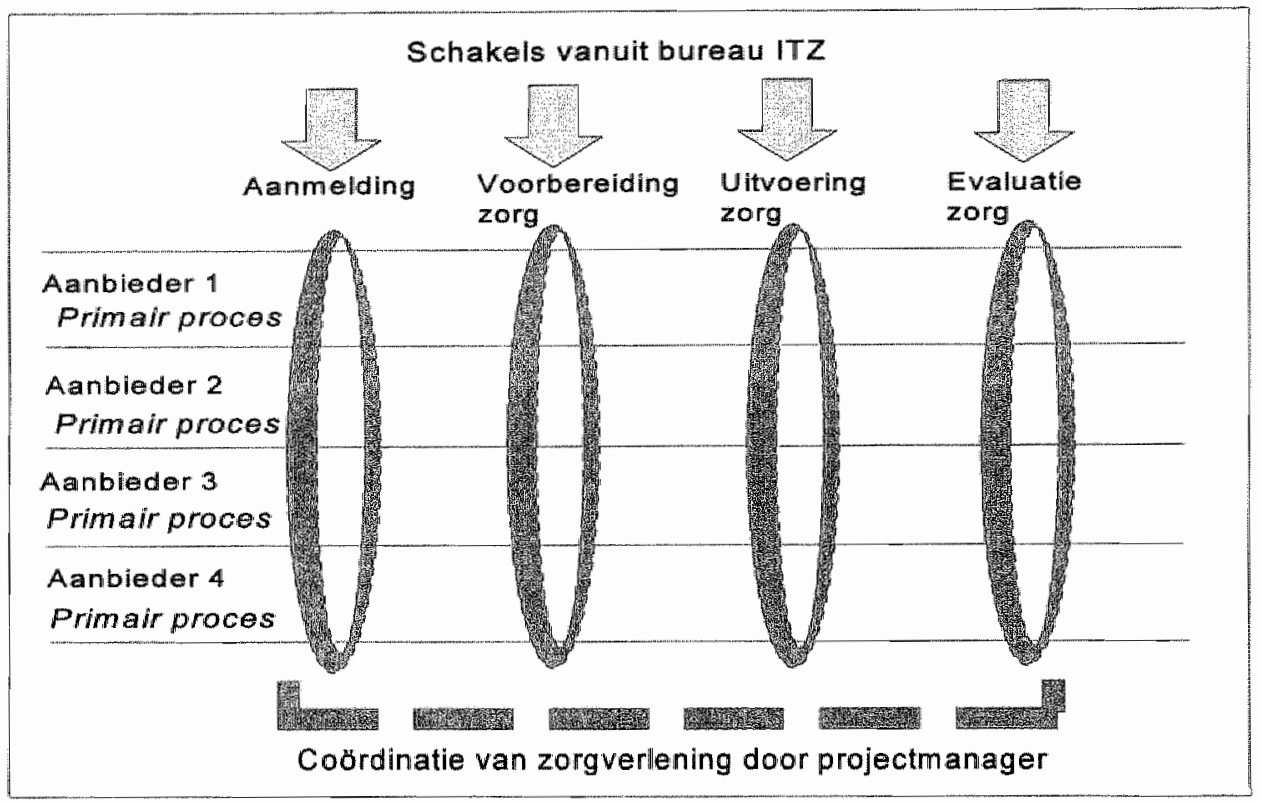

Fig. 4.9 Eerste model: organisatie van de hulpverlening vanuit het bureau itz

\subsubsection{Tweede model: ontvlechting van relaties tussen hulpverleners}

Het eerste model werd met ingang van 1.4.1992 vervangen door het tweede, dat in elk geval tot het einde van het project werd gebruikt. Hulpverlening was vooral een zaak van huisartsen, gezinszorg en kruiswerk en -ten behoeve van pg-patiënten-van de riagg. Inschakeling van het amw gebeurde wederom incidenteel, was van tijdelijke aard en beperkte zich tot de pg-patiënten.

Het belangrijkste verschil tussen de modeilen was resp. de aan- en afwezigheid van de projectmanager en het bureau itz. Per genoemde datum had de projectmanager ontslag genomen. Het directorium besloot daarop het bureau itz op te heffen en de taken over te hevelen naar meerdere participerende instellingen.

Het tweede model had vanaf de invoering betrekking op terminale patiënten en pg-patiënten. Volgens dit model moest de vervaardiging van producten zoals hulpplannen voortaan gebeuren onder de leiding en coördinatie van het kruiswerk 
alleen (terminale zorg), of van de gezinswerzorging en de riagg ${ }^{53}$ gezamenlijk (zorg aan pg-patiënten). Kruiswerk en gezinszorg werden in hel tweede model bovendien de budgetverantwoordelijken voor de aan hen 'toegewezen' doelgroep in hun werkgebied (terminale patiënten voor de regionale kruisvereniging; pg-patiënten in de stad voor de stedelijke gezinszorg; pg-patienten in de regio voor de regionale gezinszorg). Beheer van dit budget was oorspronkelijk de taak van de stichting itz. De projectmanager moest, toen het eerste model nog van kracht was, de betaling van de verleende intensieve thuiszorg regelen.

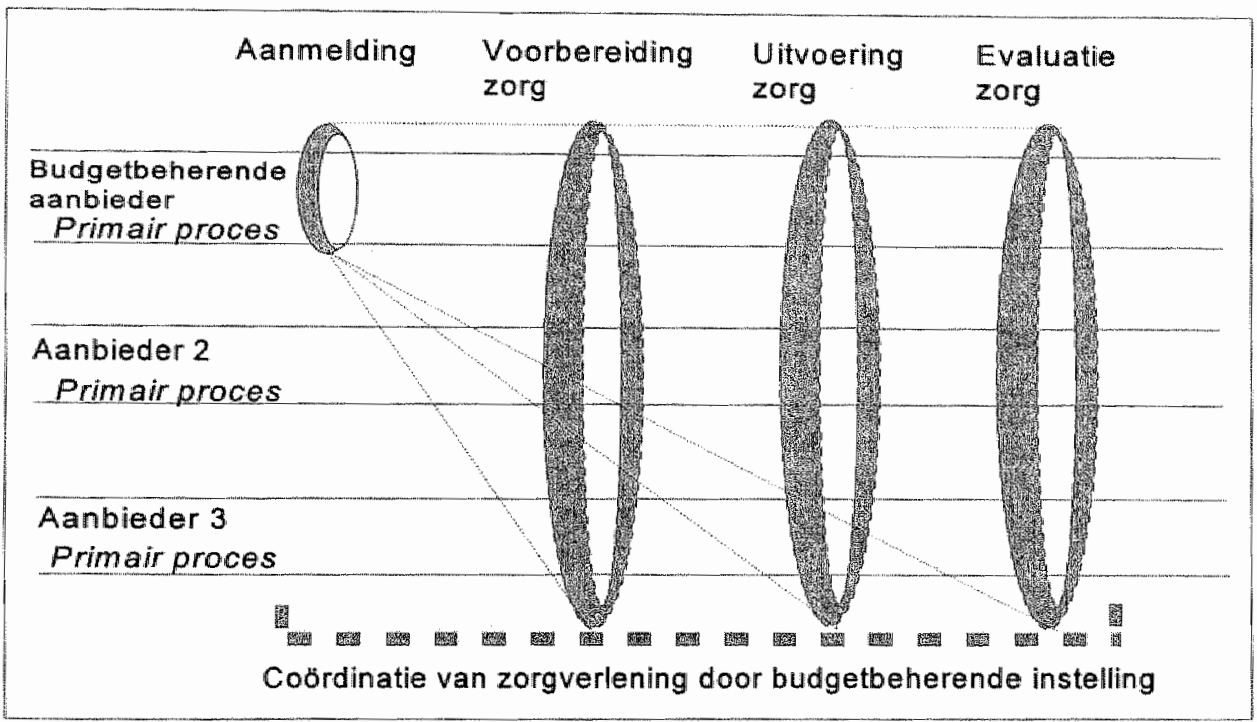

Fig. 4.10 Tweede model: organisatie van de hulpverlening vanuit de budigetbeherende instelling

Invoering van het tweede model impliceerde ontwlechting: de projectmanager en het bureau itz als extern bindmiddel tussen de afzonderlijke hulpverleners waren verdwenen, de coördinatie en leiding over alle fasen van de hulpverlening was evenals bij de reguliere zorg in handen van zorgaanbiedende instellingen zelf. De ontvlechting was echter niet volledig. Weliswaar werd de intensieve thuiszorg aan elk van de onderscheiden doelgroepen georganiseerd vanuit de instelling die het budget daarvoor beheerde, maar dit betekende niet dat de hulp ook uitsluitend vanuit deze organisatie werd verleend. Hulpverlening kon nog steeds multidisciplinair zijn. In die gevallen bleven casusbesprekingen tussen vertegenwoordigers van verschillende instellingen bestaan. Schakels in de diverse fasen werden nog steeds gelegd, zij het voortaan vanuit de budgetbeherende instelling (Fig. 4.10). 


\subsection{Veranderingen in cultuur: vervlechting en ontvlechting op het niveau van de projectorganisatie}

In de navolgende houtskoolschetsen beschrijwen wij de processen wan vervechting en ontwlechting vanuit het perspectief van cultuur. Will concentreren ons op de routines van zorgaanbieders en laten de aanleiding tot sturing, die wij in Overzicht 2.2 eveneens onder cultuur hebben geschaard, achterwege. Daarop komen wij in hoofdstuk 6 terug.

De werkwijze voor par. 4.5 en 4.6 is als volgt. Wij beginnen met de theoretische noties die voor beide paragrafen glelden. Vervolgens bieden wij in elke paragraaf afzonderlijk een korte analyse van de veranderingen in cultuur. Daama dragen will het empirisch materiaal aan "waarop onze bevindingen zijn gebaseerd. Wij sluiten elke paragraaf af met een beschouwing van de analyseresultaten. We laten de betrokken actoren op meerdere plaatsen zelf aan het woord54. Het gaat in onze studie namelijk primair om de betekenissen die zij hebben gegeven aan situaties. Naar aanieiding van deze betekenissen hebben wij zelf betekenis gegeven, met behulp van het conceptueel raamwerk.

in deze paragraaf bekijken wij de veranderingen in cultuur op het niveau van de projectorganisatie. Wij richten ons op de projectgroep itz, de stichting itz en het gestructureerd directie-overleg itz. Anders dan de overige netwerken (zoals werkgroepen en het convergentiecollege) ontstonden deze na elkaar én vloeiden zij in elkaar over. Zij zijn derhalve zeer geschikt als middel om routines in relatie tot de processen van vervlechting en ontvlechting van het begin tot het einde van de projectperiode te laten zien. Het accent komt aldus op het secundaire proces te liggen. In par. 4.6 concentreren wij ons op de cultuurveranderingen op het secundaire niveau van het primaire proces, met betrekking tot de modellen voor de organisatie van de intensieve thuiszorg.

De -unteractionistische- assumpties (zie par. 3.5.3) zijn dat actoren handelen op basis van de betekenis die situaties voor hen hebben. Zij geven deze betekenis vanuit hun routines. Routines, die onder andere de handelwijzen betreffen waaraan men gewend is of die men wenselijk vindt, vormen het uitgangspunt voor het handelen. Deze assumpties liggen aian de basis van de volgende theoretische uitspraken.

Routines zijn tamelijk stabiel. Indien veranderingen in situaties niet stroken met de routines (in het bijzonder die van dominante actoren), is de kans groot dat zij niet beklijven. Veranderlijkheid van patronen van handelingen door actoren in hun onderlinge relaties is daardoor beperkt, de veranderlijkheid van systemen eveneens.

Aan de basis van vervlechting en ontvlechting ligt de verhouding tussen "individualiteit" en 'collectiviteit'. De eerste betreft de geneigdheid de eigen gang te gaan en de belangen van de eigen organisatie te laten prevaleren, de tweede de geneigdheid samen met anderen te handelen. Binnen de routines van managers heeft individualiteit het primaat boven collectiviteit. Collectiviteit kan alleen voorop staan, wanneer individuele belangen compatibel en niet strijdig zijn. Naarmate individuele belangen minder compatibel of meer strijdig zijn, is sprake van verminderde geneigdheid met elkaar te handelen. Samenwerkingsrelaties komen moeizamer of niet tot stand, bestaande samenwerkingsrelaties komen onder druk te staan. In het uiterste geval vindt ontvlechting van samenwerkingsrelaties plaats. Aldus wordt het verband 
zichtbaar dat -via het handelen-bestaat tussen culturur enerzijds en structuur en macht (afhankelijkheidsrelaties) anderzijds.

Wij laten in deze en de volgende paragraaf zien dat de theoretische uitspraken plausibel zijn. Startpunt voor de analyses was de vraag in hoeverre relaties tussen actoren en de handelwijzen daarbinnen niet alleen gedurende het project, maar ook en vooral aan het einde daarvan overeen stemden met de routines die vooratgaand aan het project reeds aanwezig waren. De cultuurverandering tijdens de projectperiode beschouwden wij als geringer, naarmate de genoemde relaties en handelwijzen aan het eind van 1992 meer overeen kwamen met de routines die voor het project reeds bestonden. Omdat routines zichtbaar worden in het handelen en in de daanit voortkomende relaties, zijn wij in de gegevens nagegaan welke relaties en handelwijzen reeds voorafgaand aan de projectperiode waarneembaar waren.

Daarnaast analyseerden wij uitspraken van actoren, waarin hun oordeel over relaties en handelingen daarbinnen (situaties) als wenselijk of niet tot uiting kwam. Ook langs deze weg kregen wij inzicht in routines. Op dezelfde wijze brachten wij bestaande relaties en het oordeel daarover gedurende de verdere projectperiode in kaart.

Wij zochten steeds naar de verhouding tussen 'individualiteit' en 'collectiviteit'. Individualiteit is volgens onze theorie namelijk het kernonderdeel van de routines van de bestudeerde actoren (vooral managers). Tegelijkertijd moest ten behoeve van het project collectiviteit voorop staan. Participanten moesten bijvoorbeeld gezamenlijk beleid maken, met elkaar de hulpverlening organiseren en samen de geldelijke middelen voor intensieve thuiszorg beheren. Indien sprake was van een kloof tussen de nagestreefde zorgvernieuwing en de routines van actoren, dan zou deze bij uitstek in dit opzicht tot uiting moeten komen.

De navolgende beschrijving toont dat op het niveau van het secundaire proces uiteindelijk geen sprake is geweest van cultuurveranderingen. Ongewijzigd bleef in het bijzonder de verhouding tussen individualiteit en collectiviteit in de relaties van de aanbieders. Veranderingen in structuur en macht deden zich gedurende de projectperiode wel degelijk voor, maar zij ontwikkelden zich uiteindelijk terug in de richting van de oude, onveranderde routimes.

\subsubsection{Situatie in het secundaire proces tot medio 1990}

Zoals reeds is aanglegeven was de projectgroep itz in de periode waarin het Programma van WVC werd uitgevoerd, geen nieuw verschijnsel. Zij bestond al in de jaren tachtig. Aanvankelijk was zij een werkgroep van kruiswerk, gezinszorg en huisartsen. Nadien woegde het amw zich bij de anderen (D20).

Drie van de vier soorten zorgaanbiedende voorzieningen die later in de stichting itz zouden participeren, onderhielden op directie-niveau derhalve al jarenlang relaties waarbinnen werd overlegd. Het bestaan van de projectgroep itz het eerste netwerk dat wij als projectorganisatie hebben aangemerkt- lijkt daardoor niet te kunnen worden beschouwd als een verandering ten opzichte van reeds ontwikkelde relaties en handelingspatronen daarbinnen. Zoals nog bijkt, is het beeld genuanceerder.

De projectgroep itz was niet de enige mogelijkheid tot overleg op het niveau van het secundaire proces. Er waren nog andere relaties waarbinnen dergelijk overleg plaatsvond. Fig. 4.11 toont de relaties tussen de actoren die in de loop van de jaren tachtig tot medio 1990 (toen het project itz was opgenomen in het Programma van WVC) naast de projectgroep itz waren ontstaan, alsmede de verhouding tussen individualiteit en collectiviteit. 
Het primaat lag duidelijk bij de relaties tussen kruiswerk en gezinszorg. Daarom hebben wij ons in de weergave van de relaties van amw en huisartsen beperkt tot relaties die zij met kruiswerk of gezinszorg hadden. Eventuele onderlinge relaties tussen het amw en de huisartsen zijn buiten beschouwing gelaten. In de rest van par. 4.5 en in par. 4.6 is hetzelfde gebeurd.

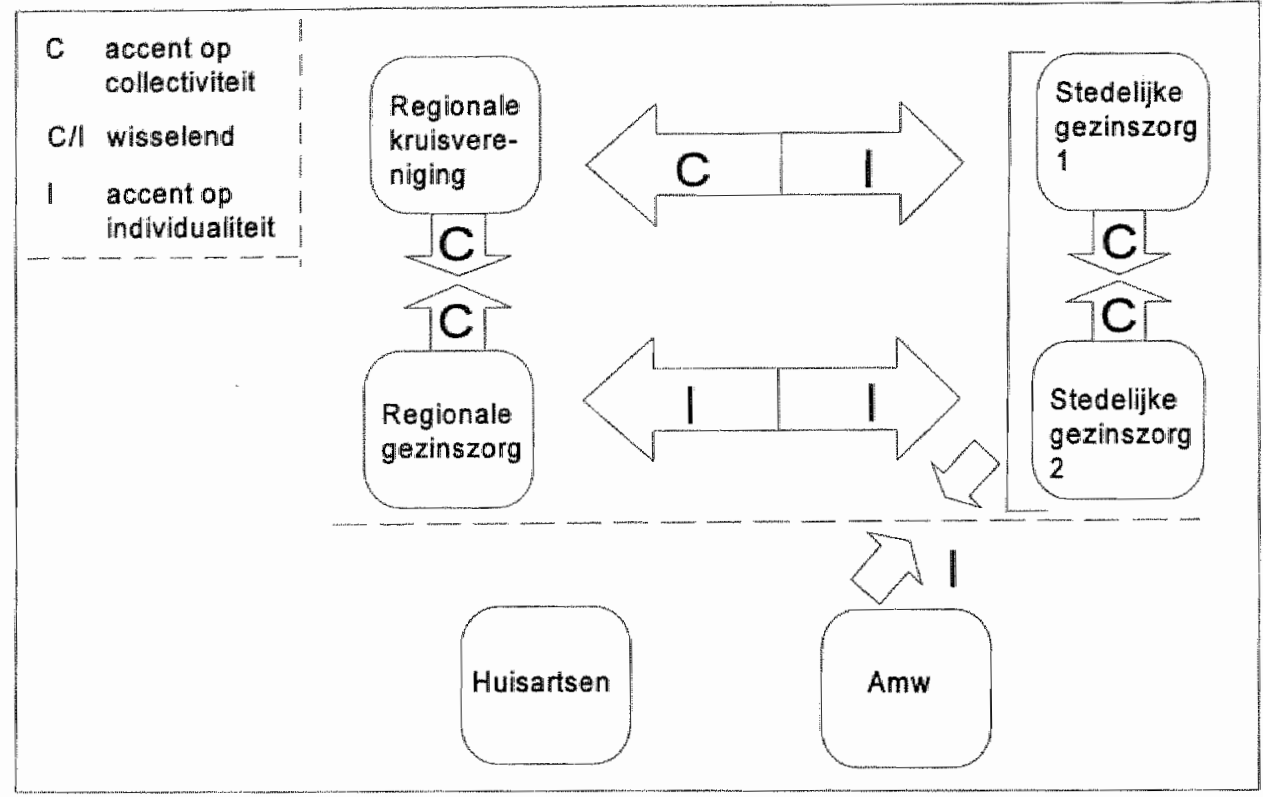

Fig. 4.11 Bestaande relaties tussen zorgverlenende participanten buiten de projectgroep itz, tot medio 1990, en typering van de verhouding tussen individualiteit en collectiviteit (secundair proces)

Fig. 4.11 laat verder zien dat in de relatie tussen kruiswerk en gezinszorg in het gedeelte van Zuid-Kennemerland buiten de stad (het 'buitengebied') voor beiden het accent lag op collectiviteit. Dat gold ook voor de twee stedelijke instellingen voor gezinszorg onderling. Tussen de gezinszorg in stad en regio daarentegen overheerste individualiteit. Verder was de relatie tussen kruiswerk en gezinszorg in de stad een moeizame, waarin de instellingen elkaar nu eens aantrokken en dan weer afstootten. Enerzijds lag het accent op collectiviteit, anderzijds was dit niet het geval.

We presenteren eerst het empirisch materiaal waarop het beeld in de figuur is gebaseerd. Daarna bepalen wij in hoeverre van cultuurverandering sprake was.

De beroepsgroep huisartsen was volgens onze gegevens geen overlegpartner op het niveau van het secundaire proces in relaties buiten de projectgroep itz. Het amw participeerde, in tegenstelling tot de huisartsen, nog in het andere project in de regio, dat parallel aan het project itz tot stand was gekomen en eveneens in het Programma van WVC was opgenomen (V1). Binnen de projectorganisatie daarvan lag het primaat bij de relatie tussen kruiswerk en gezinszorg; in de relatie tussen amw en beide andere voorzieningen overheerste de geneigdheid van kruiswerk en gezinszorg om zich op elkaar te oriënteren (zie Tijssen et al, 1991, Van Raak et al, 1992, 1993). Anders dan bij de huisartsen was participatie van het amw in de projectgroep itz van recente datum. 
De directeuren van de stedelijke instellingen voor gezinszorg streefden naar éen regionale thuiszorgorganisatie waarin kruiswerk en gezinszorg zouden kunnen fuseren. Aan het amw of de huisartsen was daarin vooralsnog geen plaats toebedacht. Najaar 1990 zouden over de thuiszorgorganisatie besprekingen plaatsvinden met de kruisvereniging en de regionale gezinszorg. Of deze besprekingen spoedig resultaat zouden opleveren, was volgens hen zeer de vraag. Zo had het kruiswerk ${ }^{55}$ aangegeven pas per 1.1.1992 over fusie te willen praten. Wat ook de uitkomst zou zijn, de stedelijke instellingen voor gezinszorg zouden doorgaan met de plannen tot samengaan. Reeds waren zij bezig met onderling overleg om de besturing door het management binnen hun beider organisaties te uniformeren (V2).

Het kruiswerk stond positief tegenover het plan voor één regionale thuiszorgorganisatie, maar toonde tegelijkertijd terughoudendheid. De directeur had tegen de stedelijke instellingen voor gezinszorg gezegd: 'zodra jullie de bestuurlijke intentie ${ }^{56}$ uitspreken, dan zijn wij bereid vanaf het begin in de besprekingen te participeren. Zolang jullie het niet over deze intentie eens zijn, hou ons er dan buiten' (V5).

Volgens de directeur van de regionale gezinszorg vond afstemming tussen haar instelling en de stedelijke gezinszorg incidenteel plaats. Zij was weliswaar betrokken bij de besprekingen over fusie tot één regionale thuiszorginstelling, maar gaf er de voorkeur aan dat eerst de stedelijke instellingen woor gezinszorg zouden samengaan. Haar instelling stond er niet om te springen met beide één geheel te vormen en vond één organisatie voor kruiswerk en gezinszorg voor de gehele regio (stad en buitengebied) veel te groot. Samenvoeging van kruiswerk en gezinszorg in het buitengebied daarentegen vond zij wél van belang. De relatie van haar instelling met het kruiswerk was volgens haar anders dan met de stedelijke gezinszorg. Er bestond al in de jaren tachtig periodiek zorg-en beleidsoverleg tussen haar instelling en het kruiswerk in het buitengebied. Intensivering van de samenwerking tussen het kruiswerk en de regionale gezinszorg werd waardevol gevonden, bleef aandacht krijgen en was opgenomen in een beleidsplan ( $/ 23)$.

\subsubsection{Situatie in het secundaire proces tot eind 1992}

Ook al participeerden de huisartsen al jaren in de projectgroep itz, dan nog betekende het bestaan van dit netwerk een afwijking van de gangbare relaties en handelwijzen van kruiswerk en gezinszorg. Zelfs binnen het kader van het Programma van WVC oriënteerden kruiswerk en gezinszorg zich namelijk op elkaar. De huisartsen en het amw waren buitenstaanders. De directeur van het kruiswerk gaf medio 1992 kernachtig weer welke samenwerkingsrelaties deze van belang achtte (D243): 'het kruiswerk geeft prioriteit aan de samenwerking tussen kruiswerk en gezinszorg'.

De samenwerking op het niveau van het secundaire proces tussen kruiswerk en gezinszorg in het buitengebied was goed (V6). In de stad daarentegen verliep dit proces, door de betrokkenen aangeduid als 'het integratieproces', gedurende de gehele projectperiode moeizaam (R2, 3). De partijen trokken elkaar aan, maar stootten elkaar ook af. 'We zijn niet in alle opzichten samenwerkingsgericht; we zijn sterk disciplinegericht (...). Het gaat bij de integratie tussen kruiswerk en gezinszorg om drie 
instellingen met eer eigen ontwikkeling en cultuur die zich moeten ombouwen fot ển organisatie. Dit betekent dat men alle stenen opnieuw moet opnemen, bekijken. schoonmaken en anders neerleggen' (V2).

Samenwerking tussen stad en regio was een probleem. De directeur van de regionale gezinszorg behield gedurende de gehele projectperiode bezwaren tegen integratie tot éen thuiszorgorganisatie (V7). De projectleider zei daarover: "het is dat er een regionale kruiswereniging is voor geheel Zuid-Kennemerland, want anders zouden stad en buitengebied net zo gescheiden zijn geweest als vroeger. De regionale gezinszorg wil niet fuseren met de stedelijke gezinszorg omdat ze in de stedelijke instellingen voor gezinszorg geen vertrouwen heeft' (V6).

Voor de moeizame samenwerking in de regio als geheel waren met name deze bezwaren illustratief. Zij kwamen ook tot uiting gedurende de besprekingen in de projectgroep itz, die werden afgesloten met de oprichting van de stichting itz. Tijdens de projectgroepvergadering van 20.4.1990 (D37) zei de directeur van de regionale gezinszorg dat de stichting itz moest toewerken naar opheffing van zichzelf. Zij wenste een artikel in deze trant in de statuten te laten opnemen. Besloten werd deze wens niet te honoreren. Het argument was dat sprake was van aparte aanvullende financiering van gezamenlijke zorgvernieuwing. Daarvoor was een eigen beheersorgaan, in casu de stichting itz, noodzakelijk (V7). De directeur legde zich bij dit besluit neer. Echter, zij ondersteunde de oprichting van de stichting itz niet van harte: 'Er zijn participanten die willen dat het project een aanzet is om tot een instelling te groeien (...). Ik daarentegen zie het project als een mogelijkheid tot verbetering van de samenwerking maar niet als een stap naar één grote organisatie' (V/3). Realisering van één instelling was niet in het belang van de regionalle gezinszorg.

In 1992 werd besloten dat de stichting itz werd opgeheven (D275). De stichting itz als afzonderlijk beheersorgaan was eind 1992 niet langer nodig. Met de zorgverzekeraar was inmiddels overeengekomen dat de instellingen voor kruiswerk en gezinnszorg voortaan buidgethouders voor intensieve thuiszorg zouden zijn (D267). De relaties konden worden ontvlochten.

In de plaats van de stichting kwam het 'gestructureerd directie-overleg itz'. Dit was primair een overleg van kruiswerk en gezinszorg, waarbinnen zij de magelijkheden tot onderlinge samenwerking verder konden exploreren. Op ad hoc-basis moest dit overleg worden aangevuld met de huisartsen, hetgeen in 1992 niet is gebeurd. Het andere zorgvernieuwingsproject uit het Programma van WVC in de regio, waarin het amw participeerde, was eind 1992 stopgezet, de projectorganisatie was ontbonden (Van Raak et al, 1993).

Het amw kwam voor participatie in het directie-overleg niet in aanmerking. Hel feit dat de handelingsregels voor het directie-overleg niet in statuten van een stichting of een andere rechtspersoon waren vastgelegd (zie par. 4.3.3), laat zien dat stad en regio nog niet dichter bij een gezamenlijke thuiszorgorganisatie waren gekomen. Het directieoverleg was derhalve illustratief voor de relaties en de verhouding tussen individualiteit en collectiviteit, die wij in Fig. 4.11 al hebben weergegeven. Sterker nog, bestaande relaties met het amw waren beëindigd. Het feit dat in het directie-overleg de huisartsen alleen op ad hoc basis zouden deelnemen en het amw al hellemaal niet, geeft aan hoezeer de projectgroep itz een afwijking van het gangbare is geweest. 


\subsubsection{Beschouwing van vervlechting en ontvlechting in de projectorganisatie: geen cultuurverandering}

De beschreven gang van zaken kan op twee manieren worden geïnterpreteerd. Volgens de eerste belandden de participanten via de projectgroep itz, de stichting itz en het directie-overleg itz driemaal in een nieuwe situatie. In deze interpretatie zou geen sprake zijn van een terugkeer naar oude handelwijzen en zouden routines zijn veranderd.

Volgens de tweede interpretatie keerden de betrokkenen met de oprichting van het directie-overleg terug naar de situatie die bestond tot 1990. In deze interpretatie zouden de participanter na opheffing van de stichting itz zijn teruggevallen op hun oude vertrouwde handelwijzen binnen relaties die al jaren bestonden. De afwijking van de oude routines zou zijn teniet gedaan, oprichting van de stichting itz zou als een rimpel in de vijver moeten worden beschouwd.

Wij opteren voor de tweede interpretatie. Vanaf het begin van het Programma van WVC lag in Zuid-Kennemerland het accent op de relatie tussen de instellingen woor kruiswerk en gezinszorg. Binnen deze -moeizame- relatie bleven zij zoeken naar mogelijkheden voor integratie tussen hun instellingen in stad en buitengebied. Huisartsen en armw vielen buiten hun beeld.

Oude neigingen en standpunten bleven bestaan, wegen die jaren geleden waren ingleslagen en die buiten de gezamenlijke stichting itz van kruiswerk, gezinszorg, amw en huisartsen om liepen, werden nog steeds gevolgd. Het beeld dat wij in Fig. 4.11 hebben weergegeven, was nog actueel, zij het dat de relatie tussen gezinszarg en amw niet meer bestond. Verder waren de stedelijke instellingen voort gezinszorg inmiddels gefuseerd. Echter, ook dit laatste stemt overeen met de intenties die zij reeds hadden geuit. Fusie strookte met de geneigdheid tot collectiviteit binnen hun onderlinge relatie, die in de jaren tachtig all zichtbaar was. Fig. 4.12 geeft de situatie eind 1992 weer, die gold voor de reguliere zorg en de intensieve thuiszorg.

Uitgaande van de aard van de projectgroep itz en de stichting itz mogen beide worden beschouwd als een vernieuwing die sterk afweek van de routines. Een projectgroep die werd vervangen door een afzonderlijke rechtspersoon, niet alleen van het kruiswerk en gezinszorg, maar ook van het amw en de huisartsen, kende geen precedent. Voor het eerst zou door hen samen beleid worden gemaakt op een deel van het terrein van de hulpverlening. Voor het eerst zouden zij samen gelden voor hulpverlening gaan beheren. Voor het eerst zou volledige collectiviteit het primaat hebben boven individualiteit of gedeeltelijke collectiviteit.

Het bleek een doodlopende weg. De vernieuwing beklijfo niet. Collectiviteit kende haar grenzen en was beperkt tot enkele van de participerende instellingen. De oude routines van de directeuren bleven onveranderd, individuele belangen van een aantal actoren waren niet compatibel en zelfs strijdig. Oprichting van de projectgroep itz en de stichting itz was een afwijking van vertrouwde handelingspatronen, een afwijking die in 1992 werd gecorrigeerd. De configuratie die aanvankelijk geleek op de eenvoudige structuur en vervolgens een hybride adhocratie werd, veranderde opnieuw in de richting van de eenvoudige structuur. Actoren, van wie wij na dit hoofdstuk nog laten zien dat zij dominant waren, oefenden in hun handelingen een zodanige trekkrach ${ }^{57}$ uit op de configuratie, dat deze zich ontwikkelde in de richting die overeenkwam met hun routines. 


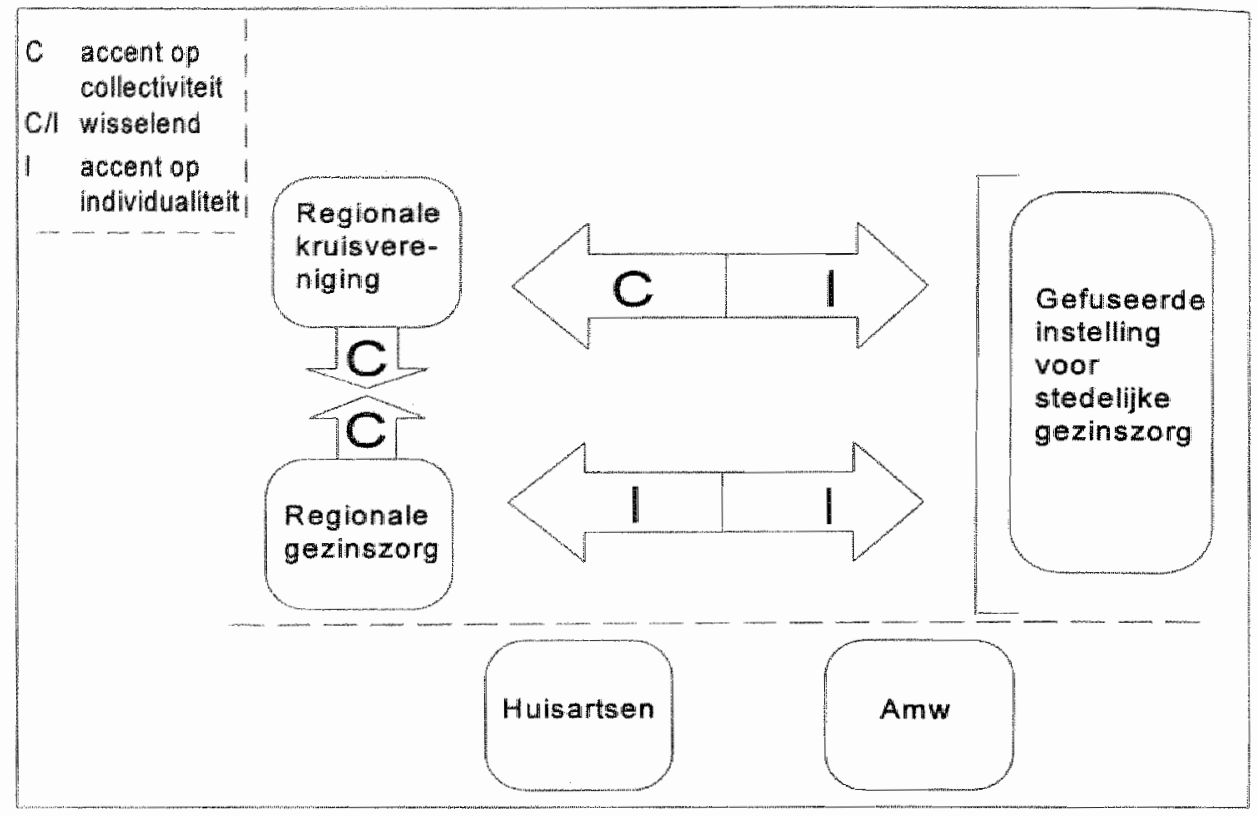

Fig. 4.12 Bestaande relaties tussen de zorgverlenende participanten eind 1992 en typering van de verhouding lussen individualiteil en collectiviteit (secundair proces)

\subsection{Veranderingen in cultuur: vervlechting en ontvlechting in de organisatie van intensieve thuiszorg}

In de navolgende beschrijving over cultuur en de organisatie van intensieve thuiszorg richten wij ons op de instrumenten uit de organisatiemodellen die wij in par. 4.4. hebben besproken. Zij zijn een goed referentiepunt ten opzichte waarvan eventuele cultuurverandering tijdens de processen van vervlechting en ontvlechting zichtbaar kan worden gemaakt. De beschikbare gegevens noopten tot een concentratie op drie instrumenten: meldpunt, multidisciplinaire casusteambespreking en projectmanager.

Duidelijk zal worden dat, anders dan in het secundair proces, op het niveau van de organisatie van de hulpverlening wel degelijk sprake was van cultuurverandering. Deze verandering had betrekking op het instrument van de multidisciplinaire casusteambespreking. De verhouding tussen individualiteit en collectiviteit bij het gebruik wan dit instrument ontwikkelde zich in de richting van collectiviteit. Eind 1992 was het instrument nog in gebruik.

\subsubsection{Situatie op het secundaire niveau van het primaire proces tot medio 1990}

Fig. 4.13 toont de relaties tussen de actoren en de verhouding tussen individualiteit en collectiviteit tot het midden van 1990. Onze beschrijving naar aanleiding van deze figuur laat zien dat, anders dan bij het secundaire proces, thet 
amw, de huisartsen, kruiswerk en gezinszorg gezamenlijk overlegden. Niettemin lag ook in de organisatie van de hulpverlening het accent op de relaties tussen kruiswerk en gezinszorg.

Het kruiswerk had de gehele projectregio als werkgebied voor de hulpverlening. De werkgebieden voor de instellingen van gezinszorg waren strikt gescheiden. Hulpverieners van de stedelijke gezinszorg verleenden geen diensten in het buitengebied (het werkgebied van de regionale gezinszorg) en omgekeerd.

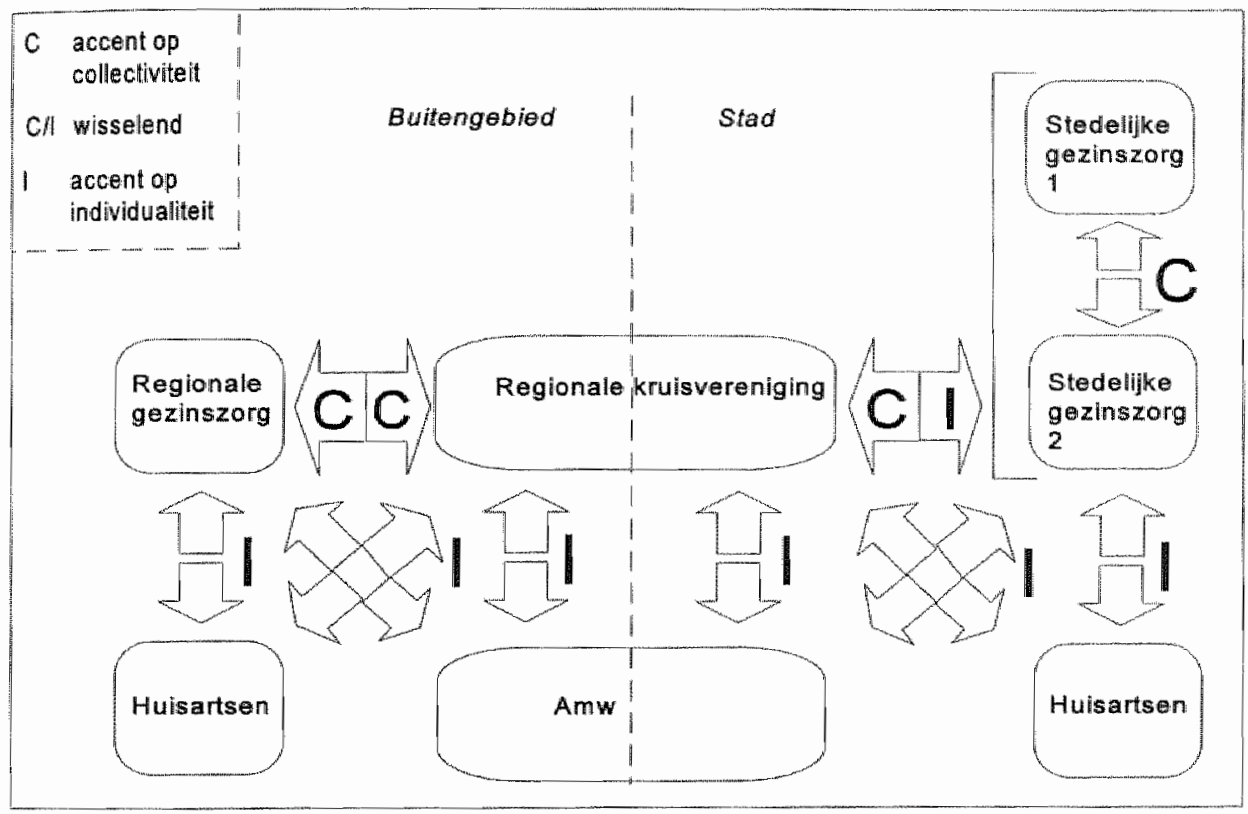

Fig. 4.13 Bestaande relaties tussen zorgverlenende participanten tol medio 1990 en typering van de werhouding tussen individu-aliteil en collectiviteit (secundair niveau van primair proces)

Voor de diverse voorzieningen in het buitengebied overheerste alleen in de relatie tussen kruiswerk en gezinszorg onderling collectiviteit. De verhouding tussen individualiteit en collectiviteit in de betrekkingen tussen kruiswerk en gezinszorg in de stad varieerde. In het voornemen tot samenwerking van kruiswerk en gezinszorg in de stad lag het primaat bij collectiviteit. In de uitvoering van dit voornemen overheerste echter individualiteit. Tussen de stedelijke instellingen voor gezinszorg onderling stond collectiviteit voorop.

In het buitengebied vond over de hulpverlening periodiek overleg plaats tussen kruiswerk, gezinszorg en andere voorzieningen. Elke gemeente kende een eerstelijnssamenwerkingsoverleg (ELSO) tussen hulpverleners uit alle disciplines die zorg boden in de thuissituatie, inclusief huisartsen en amw $(V 1,3)$. Ondanks het bestaan van dit overleg voerde de relatie tussen gezinszorg en kruiswerk onderling de boventoon. Van oktober 1988 tot april 1989 hadden zij met gezamenlijke intake geëxperimenteerd. Sinds eind 1989 vond tussen hulpverleners uit beide instellingen eenmaal per twee weken zorgoverleg plaats, met aansluitend cliëntenbesprekingen. Tijdens deze besprekingen werd bepaald welke taken moesten worden verricht en door 
wie: gezinswerzorging of wijkverpleging (V3). Afstemming van deze aard op de werkvloer tussen de gezinszorg en voorzieningen, andere dan het kruiswerk, gebeurde incidenteel. Het ELSO was daarvoor geen instrument (V3).

Het stedelijk gedeelte van het werkgebied van het project itz kende geen ELSO. Er bestond weliswaar een stedelijk eerstelijnsberaad (dat later werd opgevolgd door het andere project in de regio; V2), maar van gezamenlijke afstemming in de hulpverlening aan individuele vragers tussen kruiswerk "gezinszorg, amw en huisartsen was eventuele incidenten daargelaten-geen sprake. Ook hier betrof afstemming op de werkvloer vooral het kruiswerk en de gezinszorg. Zil hadden voor de stad een "project gezamenlijke thuiszorg" opgezet, dat onderdeell werd van het andere zorgvernieuwingsproject in de regio, en waarmee werd beoogd een gezamenlijk indicatiebureau voor de thuiszorg in te richten en gecoördineerde zorg in de wijken te verlenen. Met deze zorgverlening was van september 1988 tot april 1989 in twee wijken geëxperimenteerd $(\mathrm{V} 1,2,5)$.

\section{Meldpunt}

Een van de resultaten van het experiment met gezamenlijke intake in het buitengebied was dat in 1989 een centraal meldpunt was opgezet voor alle nieuwe aanvragen die voor het kruiswerk en de regionale gezinszorg samen waren bestemd $(\sqrt{3}, 5)$. De directeur van de regionale gezinszorg was zeer te spreken over dit initiatief en hechtte daaraan groot belang: 'Ik heb het liefst dat aanmelding in het kader van het project via mijn meldpunt verloopt en niet via een apart meldpunt; zo is namelijk sprake van drie meldpunten (... $)^{58}$. Voor het publiek is het duidelijker als mijn meldpunt een eigen positie blijft behouden (...). Dit meldpunt moet zo goed mogelijk worden uitgebouwd want het betreft een goede werkwijze (V3)'. De directeur van het kruiswerk wenste in elk geval één meldpunt voor de stad, maar ze prefereerde eigenlijk één meldpunt voor de gehele regio (V5).

Najaar 1990 waren kruiswerk en gezinszorg in de stad bezig met elkaar een meldpunt op te richten in het kader van het 'project gezamenlijke thuiszorg' $(\mathrm{V} 2,5)$. Wellicht konden andere werksoorten zoals huisartsen en het amw mettertijd in dit project participeren, maar zover was het nog niet.

\section{Multidisciplinaire casusteambespreking}

De regionale gezinszorg werkte al jarenlang met casusteambesprekingen (V3), zij het alleen binnen de eigen werksoort. Gezamenlijke casusteambesprekingen van kruiswerk, gezinszorg, huisartsen en amw waren woor zover bekend nog niet voorgekomen $(\mathrm{V} 1,5)$. Ervaringen met casusteambesprekingen van kruiswerk en de regionale gezinszorg onderling waren nog jong en dateerden van het experiment met gezamenlijke intake. Deze intake vond plaats in het meldpunt dat kruiswerk en gezinszorg in het buitengebied hadden opgezet, bij vragen die voor beide instellingen waren bestemd. Na de intake ging de gezamenlijke zorgvraag naar een multidisciplinair team van zorgverleners, die de zorg in onderlinge bespreking op elkaar moesten afstemmen $(\mathrm{V} 3,5)$.

Met betrekking tot het 'project gezamenlijke thuiszorg' was door de stedelijke gezinszorginstellingen en het kruiswerk afgesproken dat op termijn in alle wijken van de

De respondent bedoelt het meldpunt in het kader van het project itz, het meldpunt dat in de stad werd opgericht in het kader van het zogenaande 'project gezamenlijke thuiszorg' en het meldpunt van de regionale gezinszorg. 
stad teams van hulpverleners (eerst van kruiswerk en gezinszorg. later ook van werksoorten als thet amw) moesten worden geformeerd. Zoals in het experiment binnen twee wijken was gebeurd, moest elk team in onderling overleg de zorgverlening organiseren en uitvoeren (V2). Medio 1990 bestonden deze teams nog niet (V4).

\section{Projectmanager}

Ook al was deze beperkt, in het buitengebied hadden de participanten meer ervaring met de twee besproken instrumenten dan in de stad. Anders lag dit voor het instrument 'projectmanager'. Dit instrument was een idee van de huisartsen (D20) en was voor kruiswerk en gezinszorg in buitengebied én stad een nieuw verschijnsel. Een coördinerende functionaris die vanuit een organisatie buiten de zorgverlenende instellingen (in casu het bureau itz) het werk van hulpverleners uit meer dan één werksoort moest aansturen, was er nog nooit geweest. De verwerking van aanmeldingen en het houden van casusteambesprekingen waren zaken die de instellingen alleen of eventueel onder gezamenlijke coördinatie uitvoerden. Door de introductie van het instrument 'projectmanager' zou deze coördinatie hen uit handen worden genomen. Bovendien werd aan de organisatie van de hulpverlening een schakel toegevoegd.

De regionale gezinszorg en het kruiswerk (van de stedelijke gezinszorg is het oordeel niet bekend) bekeken het instrument 'projectmanager' met scepsis. De directeur van de eerstgenoemde instelling zei op 8.10.1990: 'Om nieuwe ontwikkelingen te ondersteunen is samenwerking steeds relevanter. Toch lijken mieuwe ontwikkelingen vooral een stuk extra werk op te leveren en daar zit men niet op te wachten. Dit merk ik ook bij de betrokken leidinggevenden. Zij moeten nu overleggen met de projectmanager. lets dergelijks was voorheen niet nodig (...). Men had met het kruiswerk al zo'n goed overleg; nu komt er overleg met de projectmanager en de huisartsen bij' (V3) 59 .

De directeur van het kruiswerk oordeelde als volgt: 'De werkwijze is ook voor de wijkverpleegkundige veranderd. Normaal moest de wijkverpleegkundige bij een aanvraag overleggen met de directe leidinggevende; nu gaat er een melding naar het bureau intensieve thuiszorg, vervolgens wordt overlegd (...). De wijkverpleegkundige had voorheen de bevoegdheid zelf te bepalen wat nodig was'60. In het geval van hulpvragen die de inzet van meerdere disciplines noodzakelijk maakte, nam de wijkwerpleegkundige in het algemeen 'zelf contact op met een andere instelling om te proberen een afspraak te regelen". Het kruiswerk vertoonde ook de neiging aan deze werkwijze vast te houden: 'Men heeft er altijd profijt van gehad dat men zo direct was georganiseerd. Dit moet zo blijven"61 (V5).

59 Opvallendi is dai het amw niet wordt genoend, hoewel deze instelling volgens het projectplan in de verlening wan intensieve thuiszorg maest participeren.

De respondent noemt de projectmanager hier niet met name. Echter, het bureau itz werd geleid door de projectmanager. Ook was het de projectmanager die de hulpverleners voor overleg bijeenriep. De kanttekeningen van deze respondent moeten derhalve ook de projectmanager hebben betroffen.

De scepsis die hier doorklinkt theeft geen betrekking op de afstemming ussen kruiswerk en gezinszorg in hel buitengebied, bijvoorbeeld gedurende casusteambesprekingen. Er zijn geen aanwijzingen dat deze afstemming moeizaam verliep. De geciteerde uitspraken richten zich op hel gehele eerste model voor de organisatie van de intensieve thuiszorg. waarin het bureau itz dat werd geleid door de projectmanager, een centrale plaats had. 


\subsubsection{Situatie op het secundaire niveau van het primaire proces tot eind 1992}

Ook al waren de instrumenten "meldpunt" en "multidisciplinaire casusteambespreking' bekend bij participanten voordat het Programma van WWC van start ging. het waren nog geen vanzelfsprekendheden. Het derde instrument, de "projectmanager", was zo mogelik nog nieuwer.

Het eerste model voor de organisatie van intensieve thuiszorg bevatte niet alleen nieuwe instrumenten, het werd bovendien ingevoerd terwijl de regionale gezinszorg voor de werkvloer wilde vasthouden aan de strikte scheiding van stad en buitengebied (V3) en de instellingen voor kruiswerk en gezinszorg in de stad trachtten onderling tot afstemming te komen in alle fasen van de hulpverlening. Deze pogingen verliepen uiterst problematisch en kenmerkten zich ook op het secundaire niveau van het primaire proces door onderlinge aantrekking en afstoting.

Eind 1991 was een patstelling bereikt. "Tussen kruiswerk en gezinszorg in de stad bestaat competitie en rancune op alle niveaus (...). Het kruiswerk vraagt zich af of het met de gezinszorg nog well lets samen wil" (V6). Ook al wilde men samen aan de slag. individuele belangen bleken moeilijk verenigbaar. Er waren 'grote verschillen tussen het kruiswerk en de gezinszorg: organisatorisch (wie stelt prioriteiten, wie organiseent de zorg), inhoudelijk (meningsverschilen over taakafbakening en samenwerking), in "gezeglikheid" van de uitvoerenden (grote verschillen tussen de wijkverpleegkundigen onderling in taakopvatting en plooibaarheid)' (R2). De onderlinge samenwerking tussen kruiswerk en gezinszorg in de stad was vastgelopen, samenwerking op de werkvloer met andere voorzieningen stond op thet tweede plan. Realisering van één regionaal organisatiemodel voor de gezamenlike verlening van intensieve thuiszorg door kruiswerk, gezinszorg, huisartsen én amw met een centrale coördinerende positie van het bureau itz leek verder weg dan ooit.

Het was onder deze omstandigheden dat het bureau itz werd opgeheven. Het tweede model voor de organisatie van intensieve thuiszorg werd ingevoerd, het instrument 'projectmanager' werd daarin niet gebruikt. De taken van de projectmanager werden verdeeld over leidinggevenden van de instellingen voor kruiswerk en gezinszorg. Beide andere instrumenten werden gehandhaafd.

Echter, samen met het bureau itz verdween het ene centrale meldpunt van het project. Aanmeldingen moesten voortaan plaatsvinden bij de meldpunten van de instellingen die voorafgaand aan invoering van het eerste model al bestonden of in oprichting waren. De casusteambesprekingen werden vanaf nu georganiseerd door leden van participerende voorzieningen (zie par. 4.4).

Fig. 4.14 toont de situatie aan het einde van 1992, zoals deze gold voor reguliere zorg en intensieve thuiszorg. Het verschill met de situatie tot medio 1990 was dat de stedelijke gezinszorginstellingen inmiddels waren gefuseerd en dat casusteambesprekingen met huisartsen in het kader van intensieve thuiszorg meer dan voorheen plaatsvonden (R3). Het amw had enige tijd aan deze besprekingen deelgenomen, maan deed dit eind 1992 niet meer. Voor het amw resteerde alleen relaties met kruiswerk en gezinszorg in het buitengebied in het kader van de ELSO's, voor zover deze nog bestonden 62 . Het andere zorgvernieuwingsproject in de regio, dat gold als voortzetting van het stedelijk eerstelijnsberaad, was eind 1992 namelijk stopgezet (Van Raak et al, 1993). Voor de rest kwamen beide situaties overeen. 


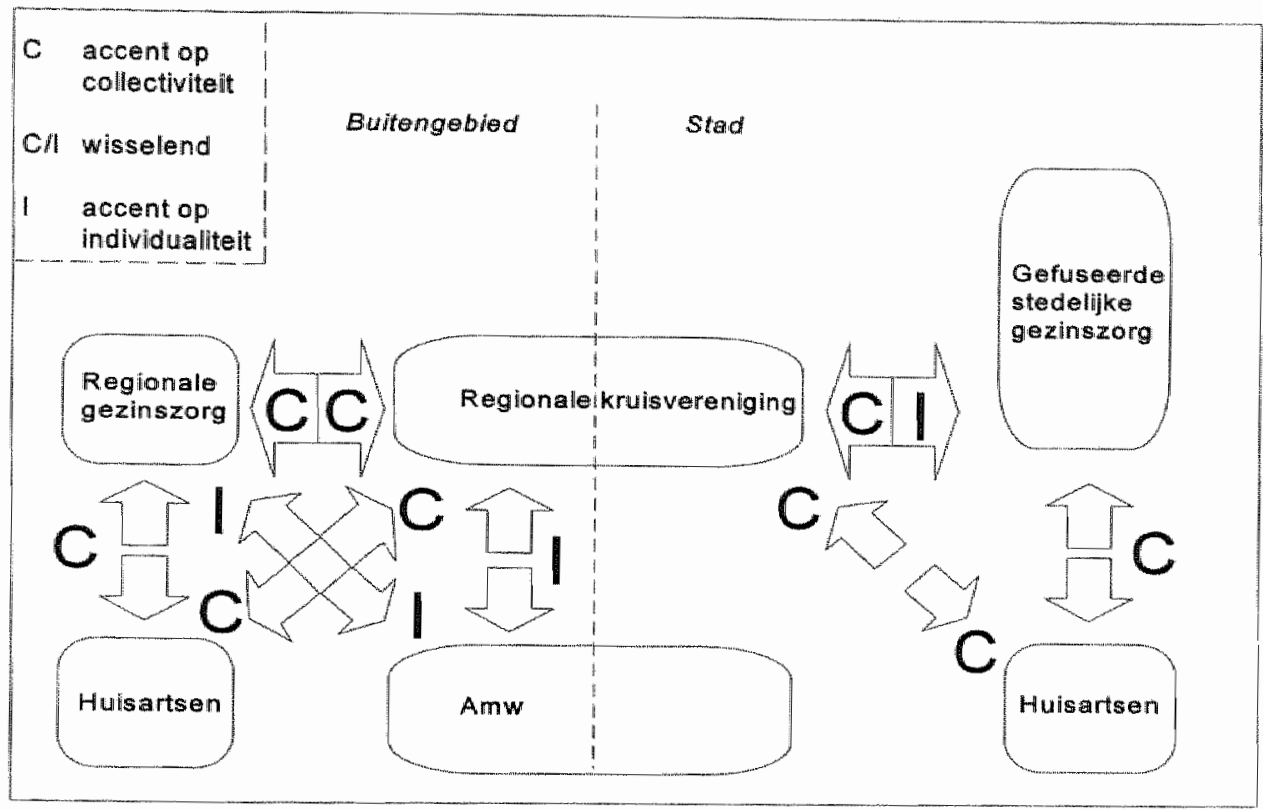

Fig. 4.14 Bestaande relaties tussen zorgverlenende participanten eind 1992 en typering van de verhouding tussen individualiteit en collectiviteit (secundair niweau van primair proces)

\subsubsection{Beschouwing van vervlechting en ontvlechting in de organisatie van de hulpverlening: wel cultuurverandering}

Het onderscheid tussen het eerste model voor de organisatie van intensieve thuiszorg en de routines van de participanten was groot. Integratie tussen kruiswerk en gezinszorg alleen al betekende een ingrijpende wijziging van handelwijzen die men belangrijk vond, waaraan men gewend was en waaraan men geneigd was vast te houden. Daarenboven zou bij intensieve thuiszorg nog moeten worden samengewerkt met de huisartsen én het amw, hetgeen ook al niel de gewoonte was. Tenslotte moesten daarbij nieuwe instrumenten worden gebruikt waarvan één -'projectmanager'niet werd aanvaard 63 . Het eerste model voor intensieve thuiszorg was gefundeerd op de noodzaak van collectiviteit in de relaties tussen alle vier participerende voorzieningen. in de praktijk echter was deze collectiviteit niet zichtbaar. Individuele belangen waren onvoldoende compatibel.

In dit licht beziem zou het vreemd kunnen worden genoeirnd dat de participanten akkoord gingen mel het eerste model. We moeten echter niet vergeten dat de actoren zich door de regionalie situatie in de hulpveriening, zoals beschreven in hat projectplan, genoodzaakt voliden te zoeken naar mogelijkheden voor multidisciplinaire hulpverlening. Tijdens de vergadering van de projectgroep itz op 14.12.1989 (D1) werd het eerste model aangeduid als thet 'zeer experimentele experiment". Deze aanduiding maakt duidelijk wat de status ervan was. Het model bood de magelijkheid met onderlinge samenwerking te oefenen. 
De invoering van het tweede model betekende een verandering, zij het in de richting van de oude routines. Vergeliking van het tweede model met onze eerdere bespreking van de instrumenten 'meldpunt' en 'casusteambespreking' toont dat hel model goed aansloot bij de wijze waarop de regionale gezinszorg en het kruiswerk in het buitengebied geneigd waren te werken. Ook in de beschrijving van het stedelijke "project gezamenlijke thuiszorg", dat in 1990 nog in de kinderschoenen stond, herkennen wij het tweede model. Verdeling van de taken van de projectmanager over de instellingen van kruiswerk en gezinszorg strookte met de routines die in de uitspraken van de respondenten in 1990 tot uiting komen. Vervanging van het ene centrale meldpunt door de afzonderlijke meldpunten van stad en buitengebied correspondeerde met de woorkeuren die de directeur van de regionale gezinszorg in 1990 uitsprak.

Anders dan bij het secundair proces was geen sprake van een volledige terugkeer naar de aloude situatie vóór 1990: "wat de itz betreft kan worden gesteld dat het aanvankelijke model is verlaten en is aangepast aan de reguliere werkwijzen met. nadrukkelijke pogingen tot behoud van enkele zorgvernieuwende intenties/verworventieden, zoals de casusbespreking" (R3). De instrumenten 'casusteambespreking' en 'meldpunt' bleven gespaard.

Dit zou kunnen impliceren dat cultuurverandering had plaatsgevonden. De projectleider zei dit ook letterlijk: "Bij de hulpverleners heeft een verandering van cultuur plaatsgevonden gedurende het gebruik van de procedures voor intensieve thuiszorg (...). De weerstand bestond vooral en het meest tegen dat ene speciale bureau specifiek voor intensieve thuiszorg dat los stond van de overige voorzieningen" (V7).

Er zijn aanwijzingen dat voor de casusteambesprekingen gedurende de projectperiode inderdaad van cultuurverandering sprake was, hoewel wij de kiem daarvoor al vinden in de periode voor 1990. De casusteambespreking bleken gaandeweg op de steun van de hulpverleners te kunnen rekenen. Het voeren van dergelijke besprekingen was allengs onderdeel gaan uitmaken van de routines van de hulpverleners. Volgens een projectintern evaluatierapport (D192) ervaarden de hulpverleners het reeds in 1991 als zinvol in gezamenlijk overleg een hulpplan op te stellen. Het kostte de projectmanager volgens het rapport zelden moeite de hulpverleners rond de tafel te krijgen. Eind 1992 was het beeld gelijkaardig. Dit blijkt uit een schriftelijke enquête van de projectleider in 199264. Van de ondervraagde hulpverleners vond $75 \%$ een casusbespreking in zorgsituaties waarbij meer dan één discipline was betrokken, altijd zinvol.

Gegevens ontbreken om eventuele cultuurwerandering met betrekking tot 'meldpunt' te kunnen bepalen.

64 Aan 105 huisartsen, 143 wijkwerpleegkundigen, 37 leden van de gezinszorg, 11 leden van de riagg en 14 intakers van de centrale meldpunten werd een schriftelijke wragenlijst voorgelegd. In totaal werden 94 ingevulde enquêteformulieren geretourneerd. De responsepercentages waren resp. 20 , $30,30,100$ en 57. Van de bevindingen werd verslag gedaan in het rapport "Evaluatie van de intensieve thuiszorg mel bijzondere aandacht voor de werkwijze" (D274). Naar aanleiding van deze lage responsepercentages werd in het verslag opgemerkt dat van de aangeschrevenen een groot deel niet of incidenteel met intensieve thuiszorg in aanraking was gekomen. 


\subsection{Slotopmerkingen}

In dit hoofdstuk hebben wij aan de hand van houtskoolschetsen ontwikkelingen laten zien in de projectorganisatie en in de organisatie van de vertening van intensieve thuiszorg. In deze schetsen wordt een proces van vervlechting en ontvlechting zichtbaar. De projectorganisatie, die vanuit de projectgroep itz ontstond en meer en meer vorm kreeg met de oprichting van de stichting itz, het bureau itz, het projectbureau en werkgroepen (vervlechting van relaties), viel later uiteen. Parallel aan deze ontwikkeling werden functies voor de organisatie van de hulpverlening eerst aan de projectorganisatie toegekend en vervolgens daaraan onttrokken.

Oude vertrouwde routines bleken hardnekkig. Ontwikkelingen die voorafgaand aan het Programma van WVC waren ingezet, gingen gedurende het project itz voort. Als het om samenwerking ging, dan keken kruiswerk en gezinszorg met het ene oog naar het gemeenschappelijk belang en met het andere oog naar het eigen belang. Zeker op het niveau van de strategische top van de instellingen waren de routines niet veranderd. Ten bate van het project moest het accent liggen op collectiviteit in alle relaties tussen de participanten, terwijl het accent veelal lag op individualiteit. Dit werd vervolgens zichtbaar in de onderlinge afhankelijkheidsrelaties en de handelingen daarbinnen (structuur en macht). Met de oprichting van de stichting itz en van het bureau itz leek verandering te komen in de geneigdheid te handelen als vanouds, maar dat ging uiteindelijk niet door. De kenmerken van structuur en macht weken een tweetal jaren af van de routines, maar veerden uiteindelijk naar de oude routines terug.

De gegevens benadrukken de relevantie van de theoretische uitspraak dat structuren en machtsrelaties kunnen veranderen, maar dat deze veranderingen niet beklijven wanneer de cultuur onveranderd blifft. Tevens tonen zij hoezeer cultuur stabiel kan zijn. Daarmee is ook de veranderbaarheid van structuur en macht beperkt.

Volgens onze theorie ontstaan veranderingen in structuur, macht en cultuur door handelingen waarbij regels worden gebruikt. Handelingen zijn de motor in de processen van vervlechting en ontvlechting die wij in dit hoofdstuk hebben besproken. De motor bekijken wij in hoofdstuk 5 nader. 



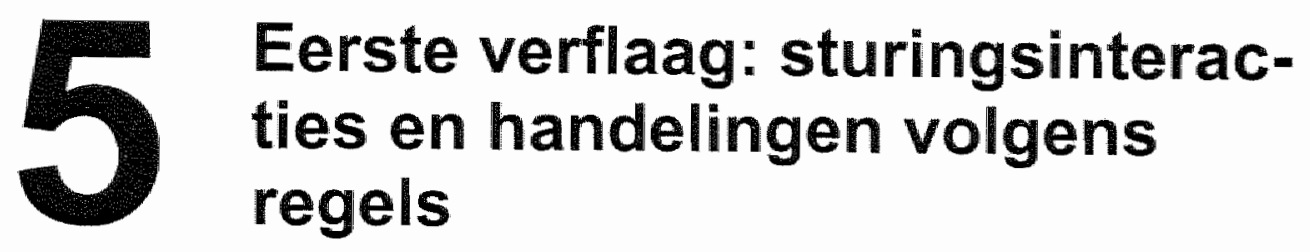

\subsection{Inleiding}

De houtskoolschetsen in hoofdstuk 4 lieten zien wat gedurende de projectperiode ten aanzien van structuur, macht en cultuur is gewijzigd. Ontvlechting van relaties volgde op vervlechting, een aantal routines veranderde. De veranderingen vonden plaats in een bestaande context van actoren die in onderlinge relaties reeds met elkaar interacteerden.

Handelingen beschouwen wij als de motor in deze ontwikkelingen. Volgens het conceptueel raamwerk zijn de genoemde veranderingen het resultaat van handelingen die verliepen volgens (de betekenis van) regels die werden geformuleerd en ingevoerd. Deze regels op hun beurt ontstonden, werden van toepassing verklaard en verdwenen weer gedurende sturingsinteracties tussen actoren. Gezien het belang van handelingen in het algemeen en sturingsinteracties in het bijzonder, wilden wij weten op welke manier dit alles gebeurde, door de volgende 'hoe-vraag' te beantwoorden: 'door wie, hoe en in welke richting is aan ontwikkeling(en) van/binnen netwerken van instellingen en beroepsbeoefenaren in de thuiszorg sturing gegeven?' (zie par. 1.3 en 3.6.2).

In dit hoofdstuk presenteren wij de empirische onderbouwing van bovenstaande en nog volgende theoretische uitspraken. Wij laten zien dat meerdere actoren aan de sturing hebben bijgedragen, wie dat zijn geweest, waar zij zich bevonden (binnen of buiten een netwerk ${ }^{65}$ ) en hoe sturing gebeurde. Wij brengen aldus op het doek de eerste verflaag aan. De richting van de ontwikkelingen (vervlechting en ontvlechting) is in hoofdstuk 4 al besproken.

In par. 5.2 beschrijven wij de sturingsinteracties. Omdat de ontwikkelingen die zijn genoemd in de 'hoe-vraag' het resultaat zijn van handelingen volgens regels, laten wij in par. 5.3 zien of werd gehandeld in overeenstemming met de (betekenis van) de regels die werden ingevoerd, en of deze regels werden gebruikt. Externe regels laten wij vooralsnog buiten beschouwing (zie hoofdstuk 6). Sturingsinteracties zijn ook 
handelingen. In par. 5.4 bespreken wij in hoeverre daarbij eveneens regels werden gebruikt. Par. 5.5 bevat een aanlal slotopmerkingen. Citaten zijn herkenbaar aan aanhalings- en sluitingstekens. Actoren hebben wij aangeduid met de naam van hun voorziening. Bij de beschrijvingen gebruiken wij de analyseschema's uit par. 3.6.

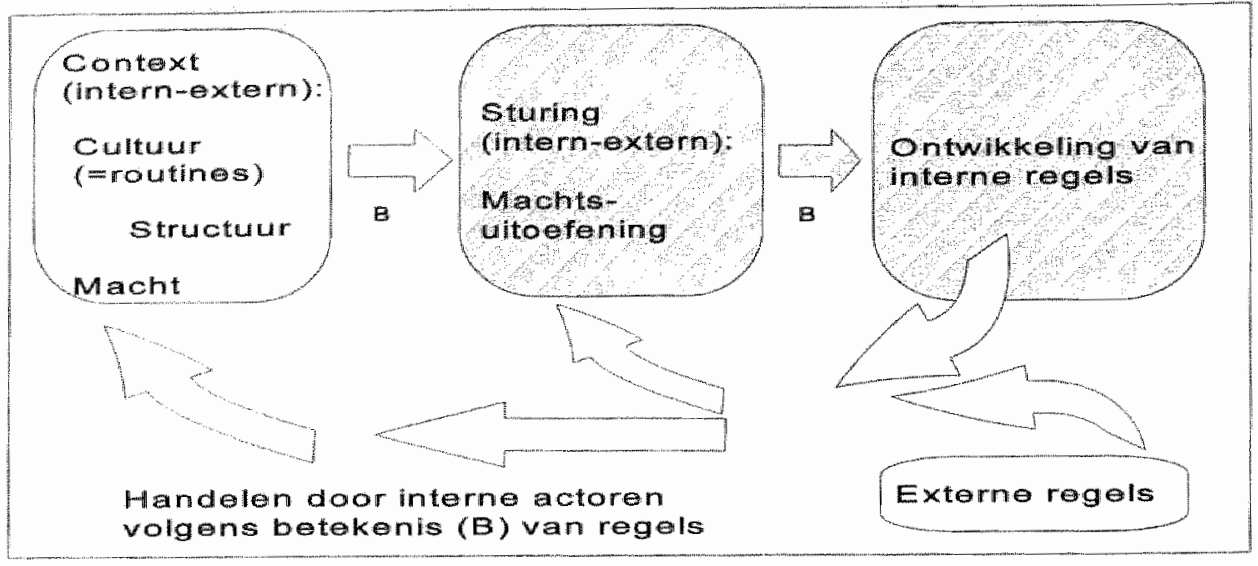

Fig. 5.1 Besproken gedeelte van het conceptueel raamwerk (gearceerd)

\subsection{Sturingsinteracties}

In deze paragraaf beschrijven wij de sturing (doelgerichte beïnvloeding) die plaatsvond. Wii maken daarbij gebruik van de volgende concepten (zie Overzicht 2.2): handelingsregels (aard en ontwikkeling66); aard van de sturingsinteracties (these, antithese en synthese); pogingen tot sturing ${ }^{67}$ over en weer door de actoren die bestuurder/verzender of bestuurde/ontvanger kunnen zijn; aard van de stuursignalen.

Wij beginnen met een weergave van de theoretische uitspraken uit hoofdstuk 2 . Vervolgens geven wij aan welke patronen wij waarnamen, die wij dan bespreken. Fig. 5.1 laat zien op welk gedeelte van het conceptueel raamwerk wij ons hier richten.

Regels die bij het handelen moeten worden gebruikt, zijn in onze studie hét object van sturing. Omdat tot de handelingsregels bijvoorbeeld ook opdrachten behoren een netwerk te formeren, daarin zitting te nemen of een netwerk uiteen te doen gaan, vinden de oprichting en opheffing van netwerken hun aanzet bij sturing. Sturing is in onze theorie een proces dat verloopt volgens een interactiepatroon van these, antithese en synthese. De ene actor stelt bijvorbeeld voor een netwerk op te richten (these), een of meer andere actoren reageren daarop met besprekingen, commentaar, aanvullingen of een tegenvoorstel (antithese), waarna een besluit volgt (synthese)

67 Overzicht 2.2 bevat ook een onderscheid in wormen van sturing, zoals juridische sturing. Deze komen in hoofdstuk 6 aan de orde. 
zoals het besluit het netwerk daadwerkelijk op te richten 68 . Fig. 5.2 geeft dit patroon weer.

These en antithese zijn stuurders, die worden verzonden om anderen doelgericht te beïnvloeden. Stuurders kunnen verbaal of nonverbaal zijn. Onze gegevens noopten ons tot concentratie op verbale stuurders. Deze kunnen schriftelijk zijn (zoals uitspraken in brieven en nota's) of mondeling (zoals uitspraken tijdens vergaderingen, vastgelegd in notulen). De synthese sluit het patroon af, het besluit is -al dan niet vaorlopig- de afronding van de sturingsinteracties. De synthese in deze studie zijn uitsluitend besluiten tot oprichting en opheffing van netwerken en tot invoering of annulering van handelingsregels.

Het besluit tot bijvoorbeeld de formering van een netwerk is een opdracht, een handelingsregel. Met behulp van een stuurder wordt deze aan een actor medegedeeld69. Het is natuurlijk de bedoeling dat de actor de opdracht vervolgens uitvoert. De regel moet bij diens handelen worden gebruikt. Hier eindigt de sturing en begint het handelen volgens regels (zie par. 5.3).

Gedurende processen van vervlechting en ontvlechting kunnen steeds patronen van these, antithese en synthese worden waargenomen. Zij lopen als een rode draad door deze processen.

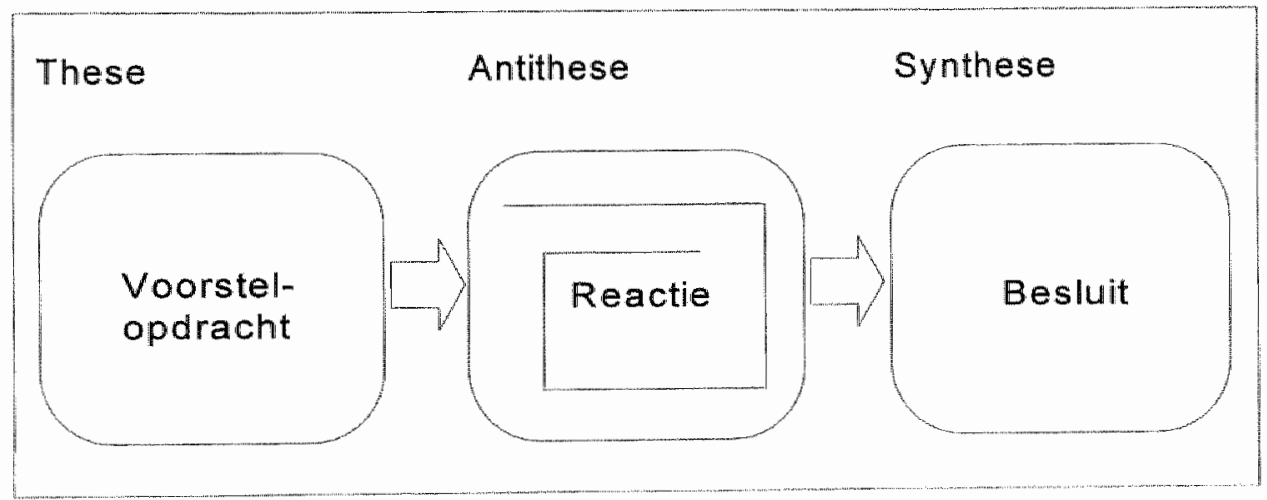

Fig. 5.2 Siuringsinteracties volgens een schema van these, antithese en synthese

In de theorie gaan wij ervan uit dat niet één, maar meerdere actoren sturingspogingen doen. De pogingen kunnen binnen het netwerk plaatsvinden, maar ook vanuit de omgeving. Actoren kunnen bestuurders of bestuurden zijn. Omdat meerdere actoren stuurders verzenden, beschouwen wij 'sturing' in geen geval als resultaat van sturingspogingen door éen actor. Daarom zeggen wij niet dat een actor heeft gestuurd, maar een sturingspoging heeft gedaan.

68 Het bestult behoeft in de tijd bezien niet rechtstreeks aan te sluiten op de genoemde these en antithese. Tussen theise, antithese en synthese kunnen tijdsintervallen voorkomen. These en antithese kunnen meerdere malen voorkomen, voordat hel besluit wordit genomen.

Een regel wordl geformuleerd opdat deze bil het handielen wordt gebruikt. Mededeling van een regel aan actoren karn derhalwe worden beschouwd als een poging tof doelgerichte beinvloeding. Dit maakt van de regel zelf geen stuurder. De stuurder transporteert hier de regel. Ook al hebben stuurder en regel raakwlakken (beide zijn talig), zij zijn niet synoniem. 
Wij namen het patroon van these, artithese en synthese in de gegevens waar, toen wij met behulp van de vervaardigde 'brackets' (zie par. 3.5.1) gebeurtenissen betreffende netwerken en regels op een tijdbalk plaatsten en vervolgens bestudeerden ('time-series analysis'). Vooral interacties tijdens vergaderingen in de projectorganisatie, waarvan de notulen verslag doen, gaven inzicht in dit patroon.

Vergaderingen kwamen weliswaar in alle geledingen van de projectorganisatie voor (zie par. 3.6.2), maar zij waren niet de enige interactievorm. Door bestuurders werden bijvoorbeeld brieven verzonden en buiten vergaderingen in de projectorganisatie vond overleg plaats. Een deel van dergellike gebeurtenissen werd echter weer tijdens vergaderingen besproken, bijvoorbeeld onder het agendapunt 'mededelingen' 70 . om deze reden hebben wij ons voor dit hoofdstuk verdiept in vergadernotulen en in de bijbehorende vergaderstukken.

\subsubsection{Patronen van these, antithese en synthese: vervlechting en ontvlechting in de projectorganisatie}

In deze subparagraaf belichten wij het patroon van these, antithese en synthese bij de oprichting en opheffing van netwerken in de projectorganisatie. Het gaat hier dus vooral om gebeurtenissen (zie par. 3.5.3.1) op het niveau van het secundaire proces. Bij de oprichting van netwerken werden tegelijkertijd handelingsregels voor de leden ervan geformuleerd. Toen de netwerken ophielden te bestaan, werden deze regels ongeldig. Omdat de ontwikkelingen aangaande de netwerken en hun handelingsregels gelijktijdig verliepen, behandelen wij deze samen.

Het nemen van besluiten over netwerken en handelingsregels was de taak van de strategische top (zie par. 4.3.2). In de praktijk werden zij vooral genomen door het directorium of zijn voorganger, de projectgroep itz. Handelingsregels werden bijvoorbeeld pas van kracht na hun besluiten. Daarom bestudeerden wij met name de sturingspogingen die plaatsvonden binnen of vanuit beide netwerken, en de stuurders die op deze twee waren gericht. Overzicht 5.1 en 5.2 laten per netwerk zien welke projectdocumenten de thesen, antithesen en synthesen bevatten voor de oprichting resp. opheffing van netwerken en wie de bestuurders en bestuurden zijn ${ }^{71}$. De documenten in het eerstgenoemde overzicht bevatten ook informatie over de invoering van handelingsregels in de periode van oprichting. Voor een beeld van deze en andere regels verwijzen wij naar Overzicht 4.2 .

De gebeurtenissen hebben wij uit data over lopende processen gelicht. Aangezien de overzichten 'dwarsdoorsneden' uit processen bevatten, mag niet worden geconcludeerd dat alle bestuurders en bestuurden zijn vermeld. Zo kunnen aan een voorstel stuurders (thesen, antithesen) vooraf zijn gegaan. In Overzicht 5.1 is dit ter illustratie meerdere malen alangegeven.

70 Vanzeltsprekend is niet elk gesprek dat plaatsvond 'in de wandelgangen', elke toevallige, informete bespreking et cetera in vergaderingen aan de orde geweest. Van de interacties die plaatswonden buiten de vergaderingen om, hebben wij een deelverzameling in de notulen aangetroffen.

71 De gegevens zijn niet zodanig gedetailleerd dat altijd duidelijk is wie de individuele besturders en bestuurden waren. Met name bij de "antithese" is dit het geval. Tenzij de gegevens specificatie mogelijk maaklen, is als bestuurder of bestuurde een netwerk als geheel genoemd. De bestaansperiode van de netwerken is in Overzicht 5.1 en 5.2 berekend vanaf de datum waarop tot oprichting werd besloten en niet vanaf de datum waarop het netwerk operationeel was (zie Overzicht 5.3). 


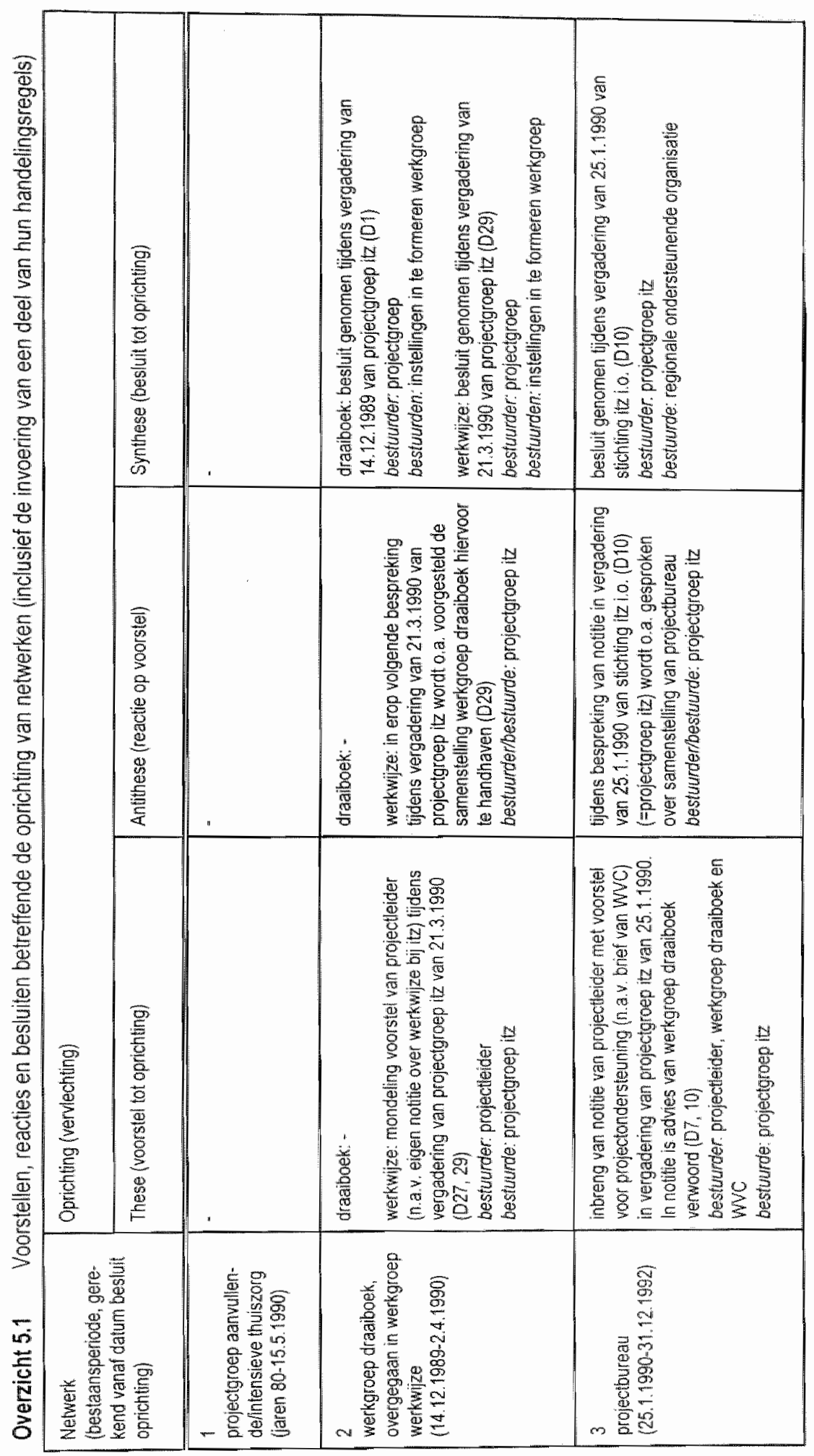




\begin{tabular}{|c|c|c|c|c|}
\hline 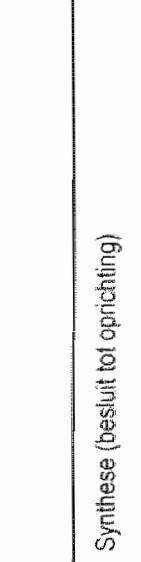 & 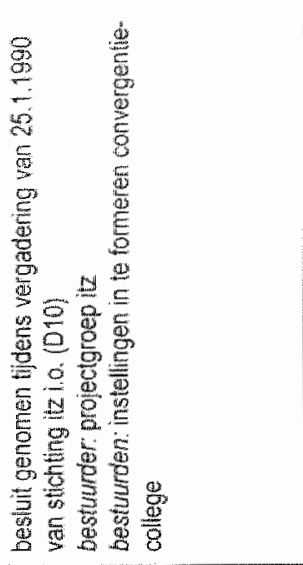 & 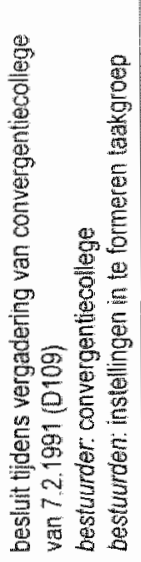 & 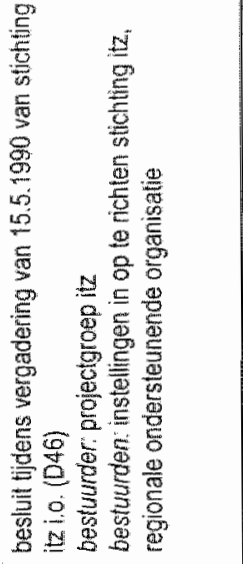 & 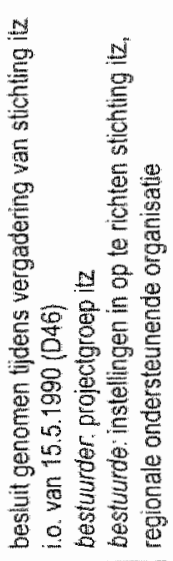 \\
\hline 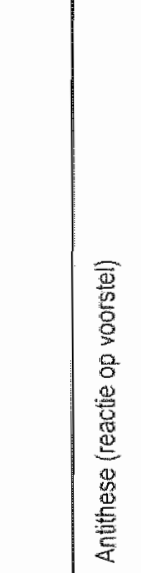 & 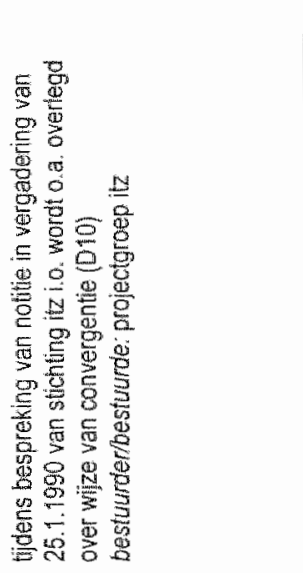 & 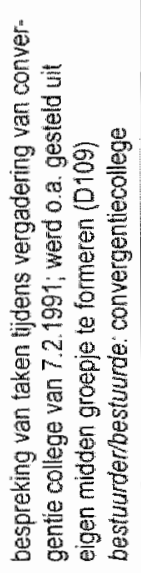 & 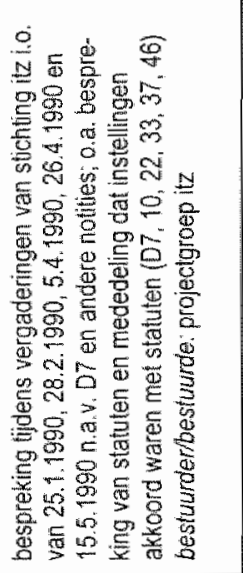 & 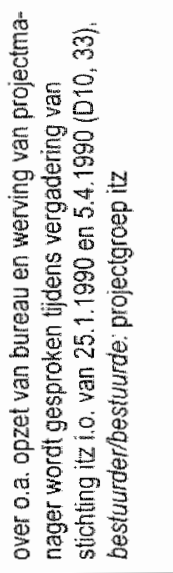 \\
\hline 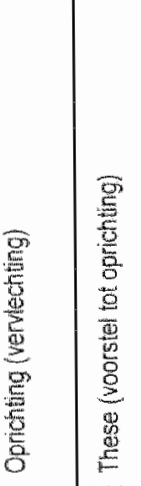 & 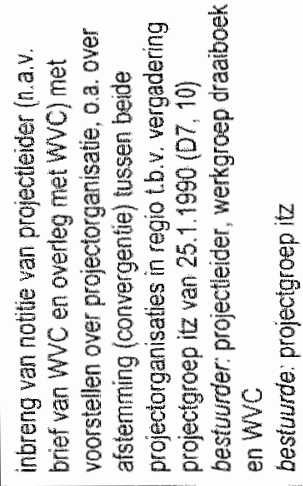 & 4 & 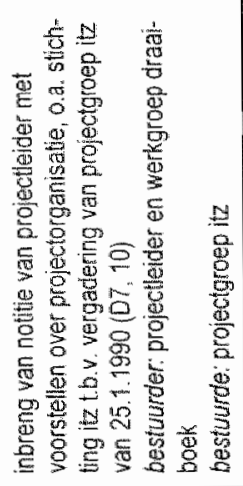 & 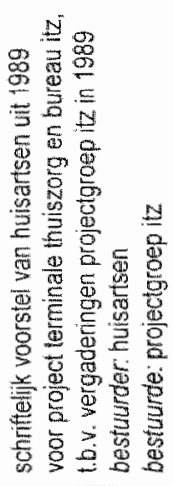 \\
\hline 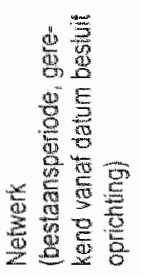 & 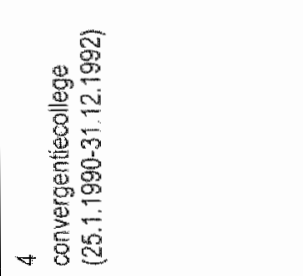 & 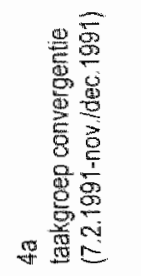 & 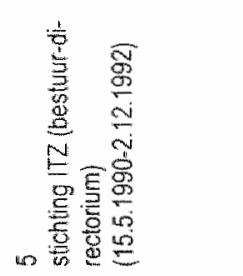 & 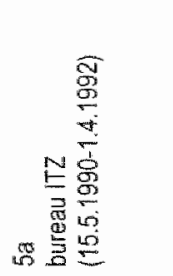 \\
\hline
\end{tabular}




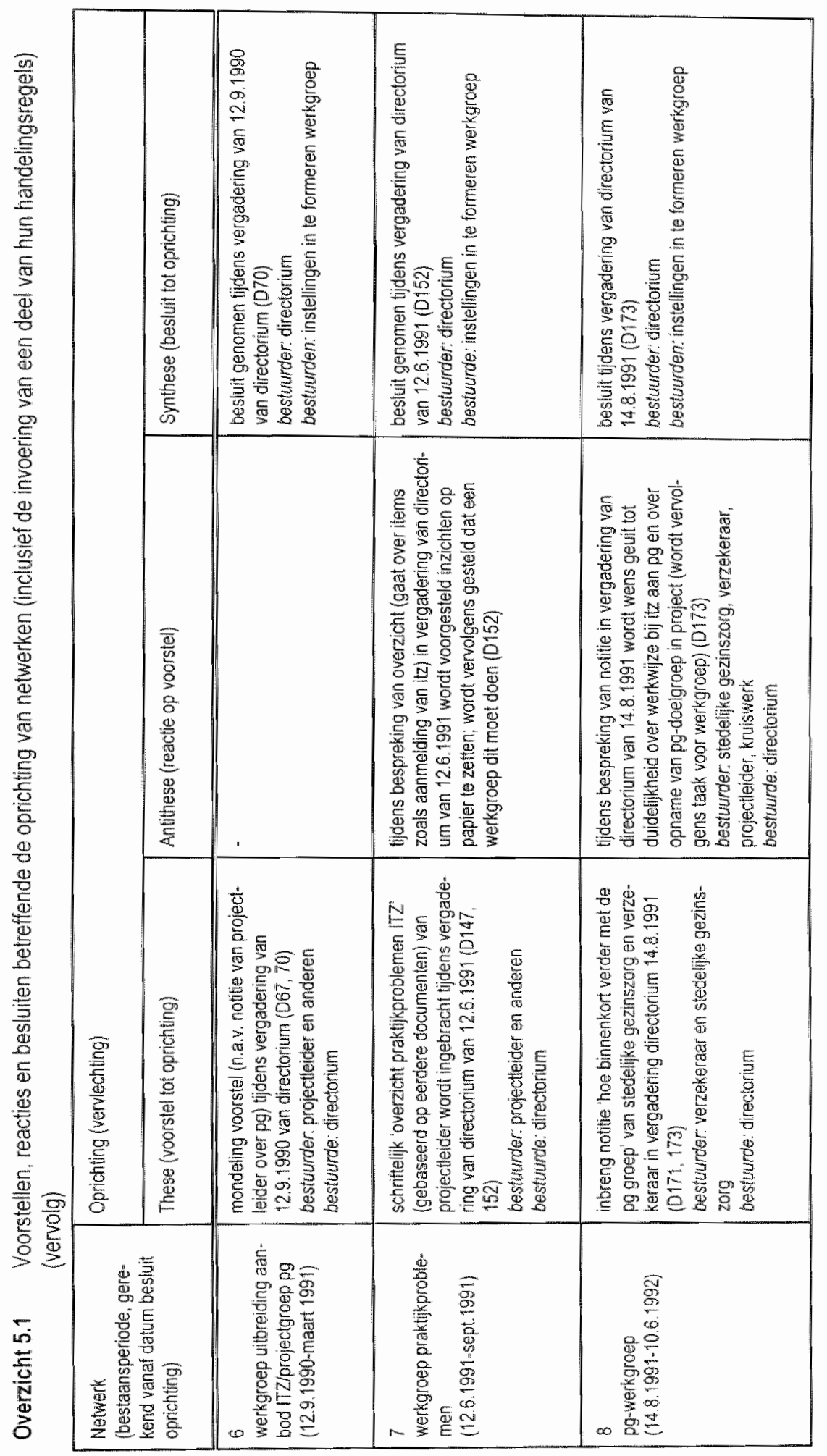




\begin{tabular}{|c|c|c|c|c|}
\hline 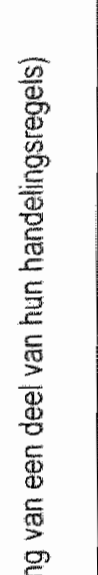 & 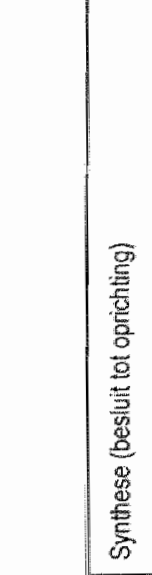 & 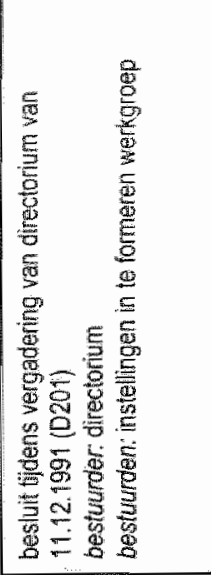 & 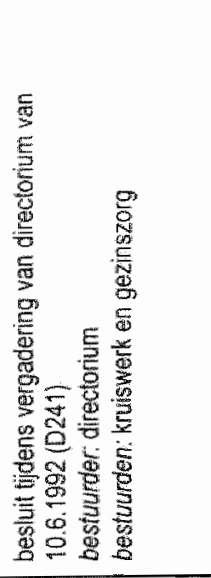 & 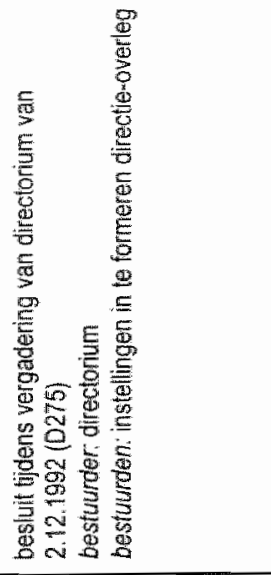 \\
\hline 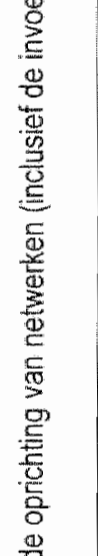 & 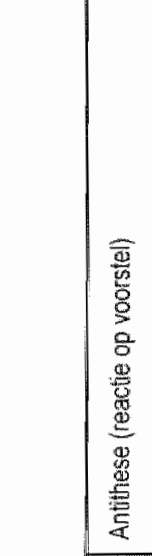 & 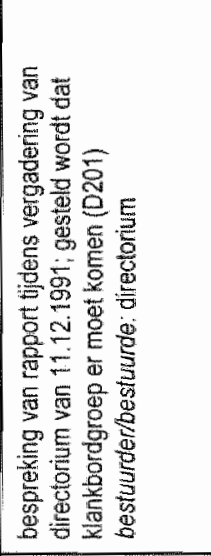 & 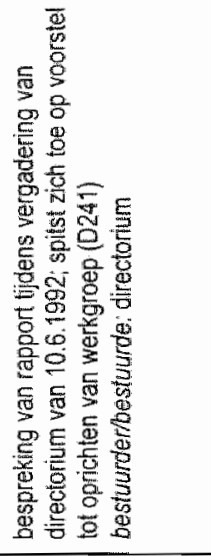 & 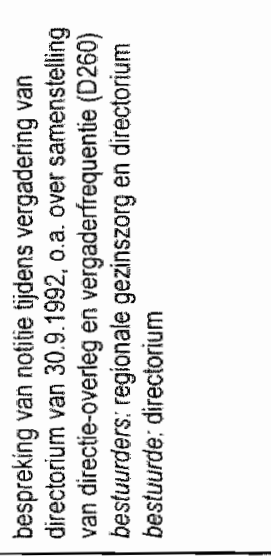 \\
\hline 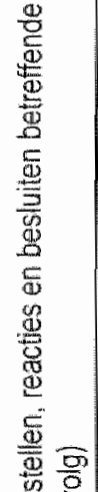 & 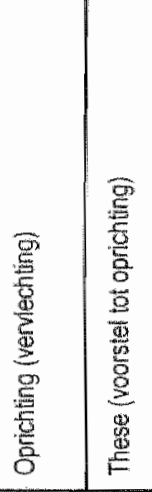 & 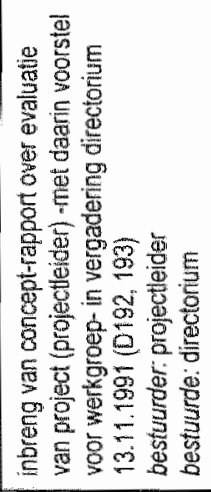 & 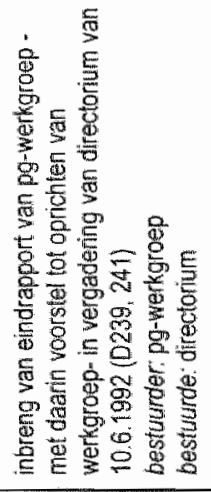 & 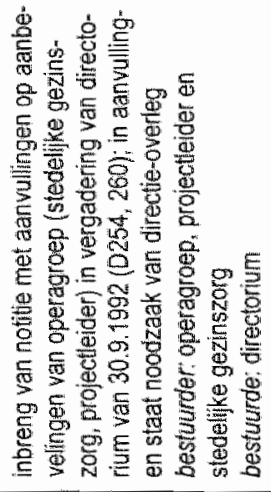 \\
\hline $\begin{array}{l}\frac{8}{9} \\
= \\
\frac{5}{5} \\
\frac{5}{0} \\
\frac{5}{0}\end{array}$ & 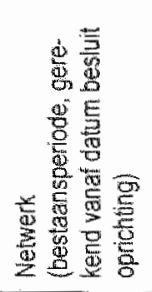 & 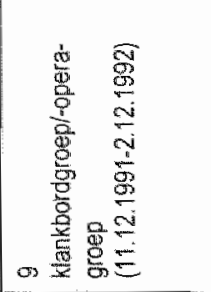 & 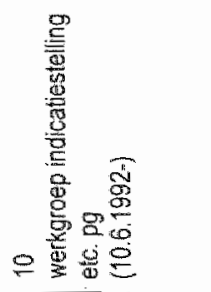 & 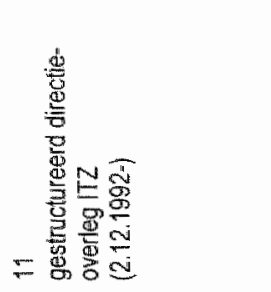 \\
\hline
\end{tabular}




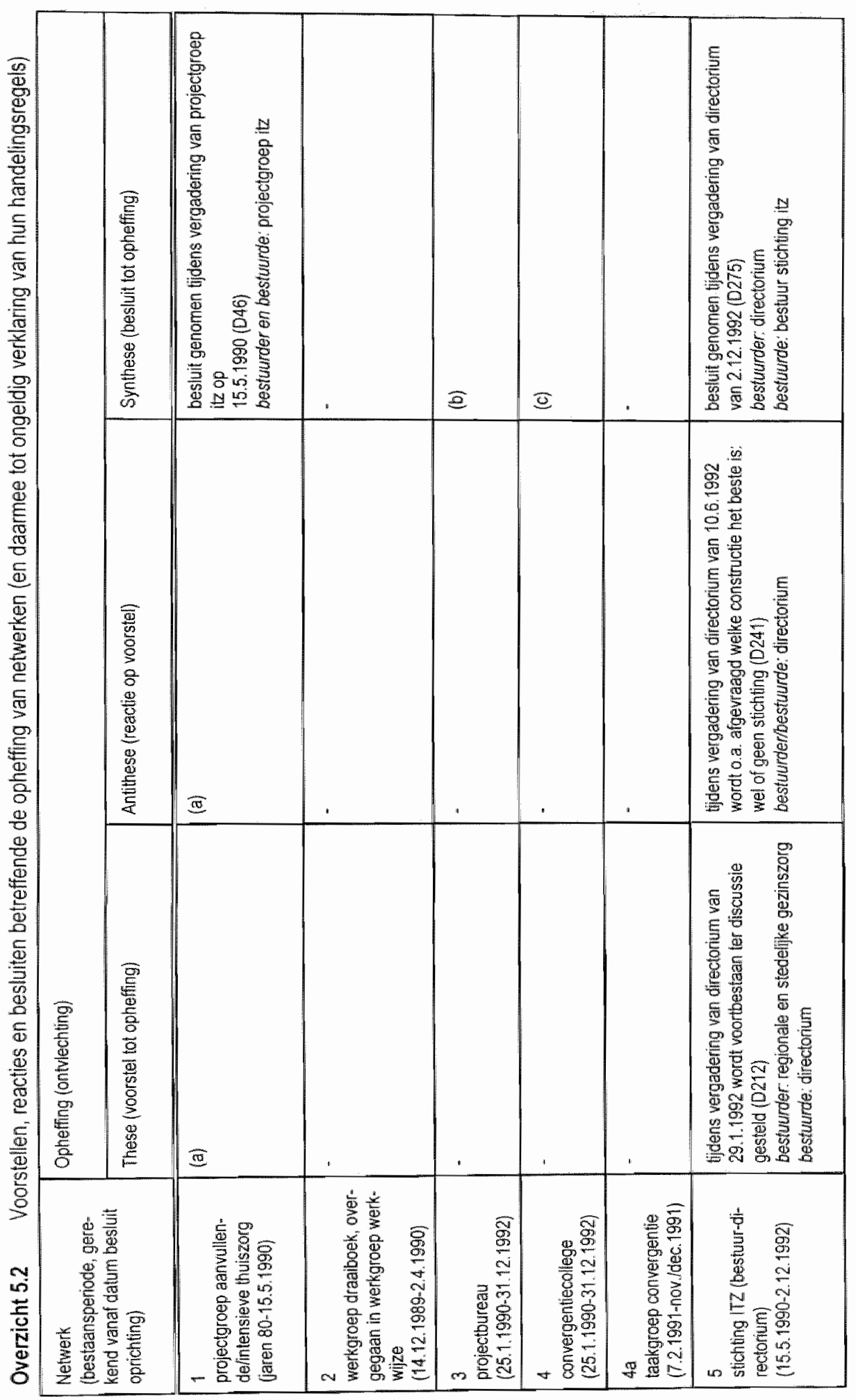




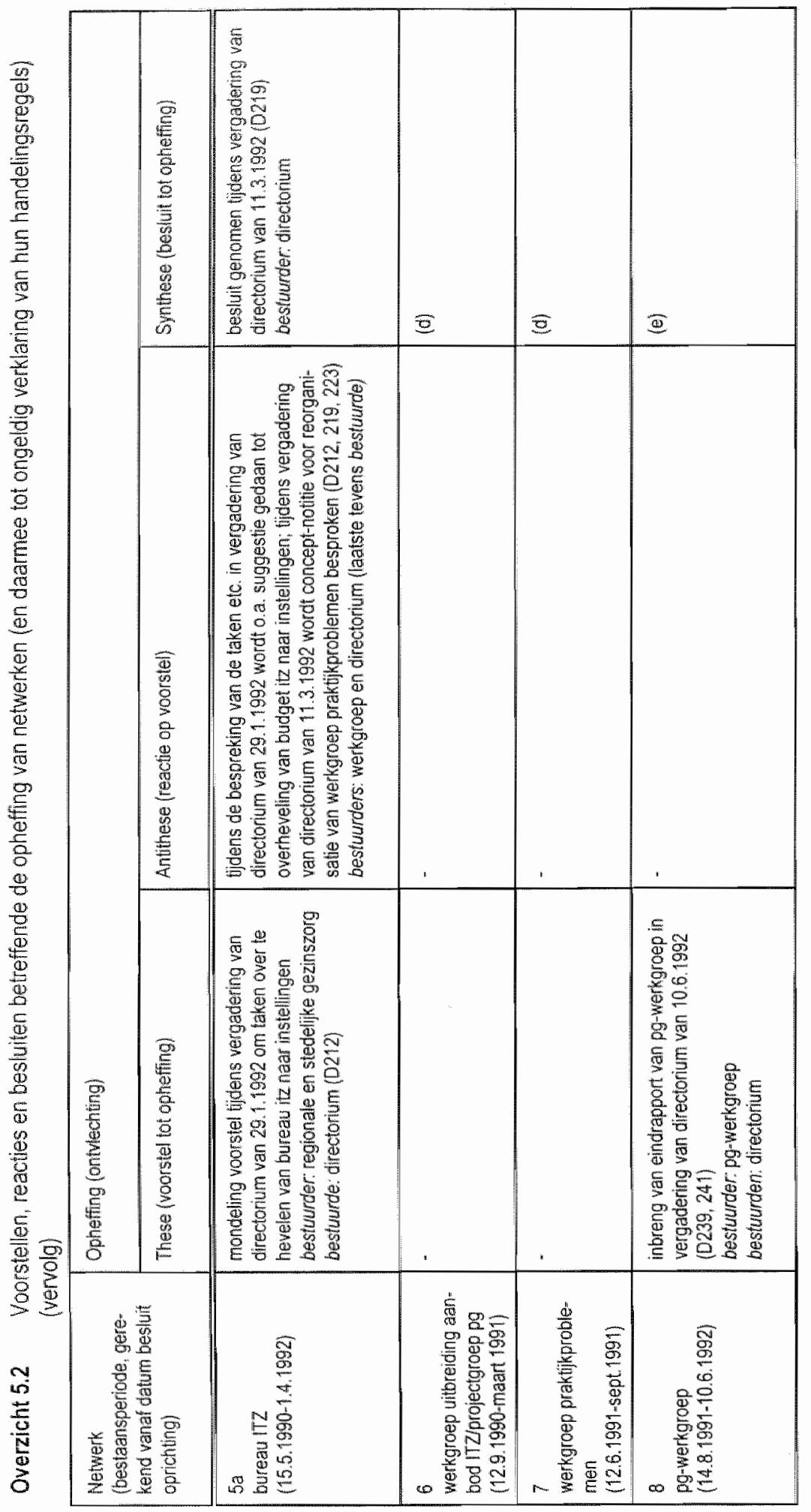




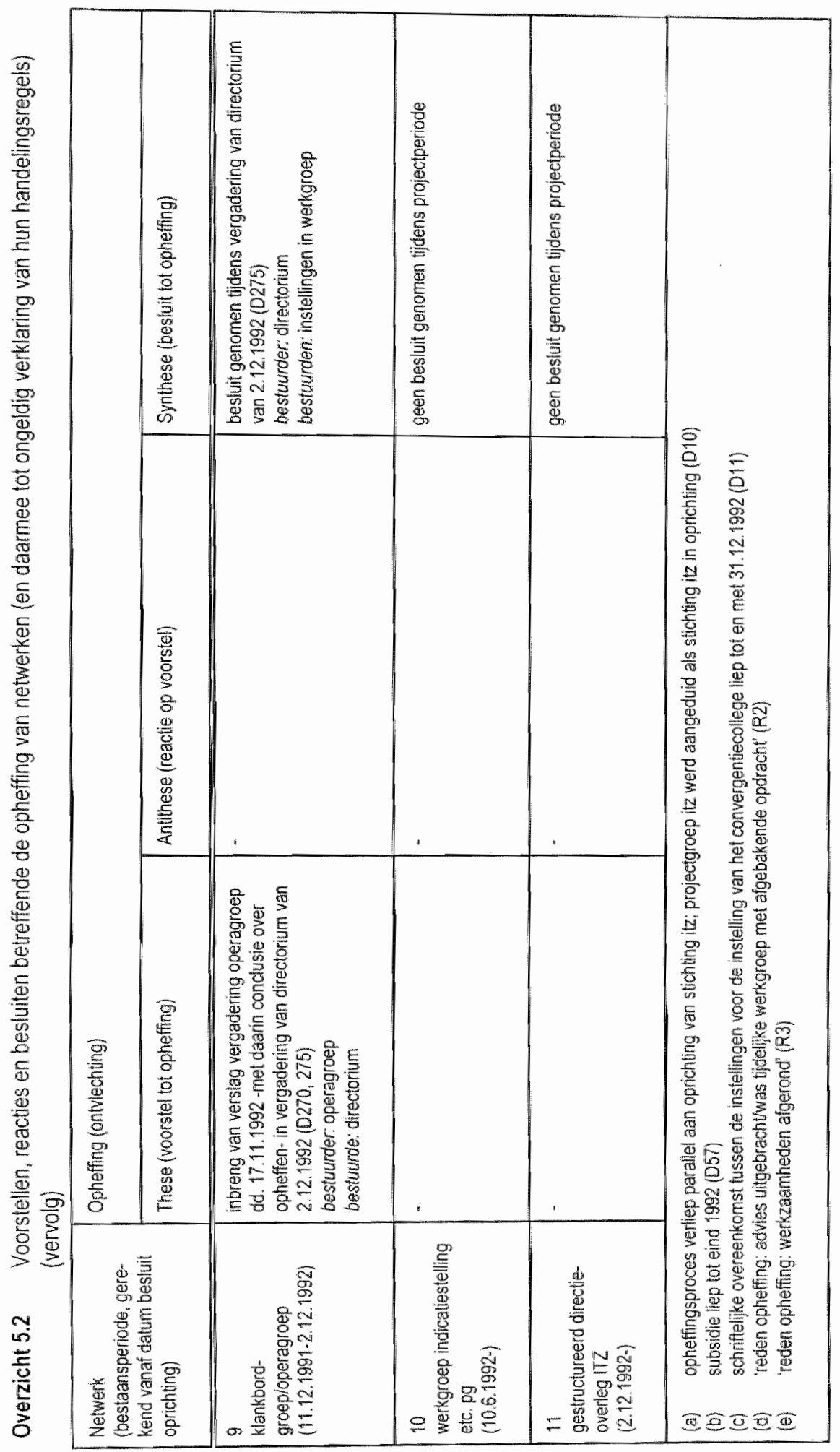


Daarom kan degene die het voorstel deed niet zonder meer als enige bestuurder worden beschouwd. Een voorbeeld is de werkgroep 'indicatiestelling etc. pg", die werd geformeerd om zich te buigen over handelingsregels voor de organisatie van hulpveriening aan psychogeriatrische patiënten. Tot de oprichting werd besloten tijdens de directoriumvergadering van 10.6.1992 (D241) na de bespreking van een rapport van de pg-werkgroep, waarin het voorstel tot oprichting werd gedaan (D239).

Het besluit volgde rechtstreeks op het voorstel van de pg-werkgroep, maar werd genomen nadat tijdens eerdere vergaderingen al besprekingen waren gevoerd over de organisatie van de hulpverlening aan deze doelgroep van het project.

Overzichten 5.1 en 5.2 tonen dat het patroon vooral zichtbaar is bij de oprichting van netwerken en minder bij de opheffing ervan. Dit geldt in het bijzonder voor de werkgroepen. Bijna alle waren opgericht om opdrachten uit te voeren met een tijdelijk karakter, zoais het schrijven van een protocol. Zij hielden automatisch op te bestaan zodra hun opdracht was vervuld. In de aard van hun opdracht, die tot stand was gekomen volgens het patroon van these, antithese en synthese, lag het besluit voor hun opheffing besloten.

Wijzigingen in de concept-statuten van de stichting itz (verslag vergadering projectgroep itz 28.2.1990)

"Artikel 4, punt 1b. Wijziging: "Deze diensten worden verleend vanuit de participanten en in harmonie met de gebruikelijke dienstwerlening van de participanten. Punt $1 \mathrm{c}$ : Dit punt wordt geschrapt.

Artikel 6, punt 1: Toevoeging "Het bestuur bestaat uit leden die worden aangewezen en benoemd door de participanten.

Artikel 7: Gehandhaafd blijven de aandachtsstrepen:

overijiden

onder curatele stelling

opzegging van het bestuurslidmaatschap door het bestuurslid

vervanging van hel bestuurslid door de participant of participanten door wie het

bestuurstid is aangewezen

uittreding uit de stichting van de participant of participanten door wie het bestuurslid is aangewezen.

De overige aandachtsstrepen worden geschrapt

Artikel 9, punt 1: Schrappen van zin "Beleidsplannen kunnen tussentijds door het bestuur worden gewijzigd". Extra punt: het bestuur draagt de voorbereiding en uitvoering van

bestuursbesluten op aan het directorium'.

Wij volstaan met één voorbeeld van de tot stand koming van handelingsregels volgens het patroon. Voor de vergadering van de projectgroep itz van 28.2.1990 (D22) was de bespreking van de concept-statuten van de stichting itz geagendeerd. Dit concept ofwel voorstel (these) voor de statuten was geschreven door de projectleider. Tijdens de bespreking reageerden de deelnemers aan de vergadering op het concept (antithese). Deze reacties hielden in dat de statuten op een aantal plaatsen moesten worden aangepast (zie kader). De leden van het directorium schoten gaten in het voorstel, waarna de gaten werden opgevuld met nieuwe handelingsregels.

In de vergaderingen van 26.4.1990 en 15.5.1990 (D37, 46) werden de aangepaste concept-statuten (these) wederom besproken en bijgesteld (antithese), met in achtneming van de reacties vanuit de participerende instellingen, aan wie de concept-statuten inmiddels ter becommentariëring waren voorgelegd. Nadat was 
vastgesteld dat de instellingen instemden met de statuten, werd op 15.5.1990 besloten dat deze van kracht zouden worden (synthese).

\subsubsection{Patronen van these, antithese en synthese: vervlechting en ontvlechting in de organisatie van de hulpverlening}

De bespreking van de invoering en ongeldig verklaring van de twee organisatiemodellen voor de verlening van intensieve thuiszorg (het secundaire niveau van het primaire proces: zie par. 4.4) houden wij kort. De ontwikkelingen aangaande het bureau itz (de pijler van het eerste model), zoals weergegeven in Overzicht 5.1 en 5.2 , illustreert namelijk dat wij het patroon van these, antithese en synthese hebben waargenomen.

Met het besluit van het directorium om per 1.4.1990 het bureau itz op te heffen, werd tevens een eind gemaakt aan die geldigheid van alle regels die onderdeel uitmaakten van het eerste model. Intussen was het sein gegeven tot de ontwikkeling van de regels voor het tweede model. Fig. 4.7 uit het vorige hoofdstuk geeft de perioden weer van de invoering tot en met de teniet verklaring van de verzamelingen van regels die deel uitmaakten van de twee modellen.

Wijzigingen in de tekst van de tweede concept-handleiding voor intensieve thuiszorg aan terminale patiënten (verslag directoriumvergadering 15.1.1992)

"De tekst op blz 4 punt e (gang van zaken tijdens de casusbespreking) wordt: De direct betrokken hulpverleners maken een probleeminventarisatie. Op basis daarvan stellen de aanwezigen onder leiding van de projectmanager de doelstelling en, gemeten aan de hand van objectieve criteria, het zorgplan vast. Vervolgens worden er afspraken gemaakt $m$.b.t. de operationalisering van het zorgplan. De projectmanager leidt de bijeenkomst en bewaakt de financiële aspecten. De direct betrokken hulpverleners .... etc.

$B \mid z .6$ ad b: uitbreiding van de zorg vervangen door onvoorziene verandering van het zorgaanbod

$\mathrm{Blz}$. 6 ad $\mathrm{b}$ laatste aandachtsstreepje: wijzigen en aanvullen conform hetgeen het directorium 11 december heeft besloten m.b.t. de evaluatievragen voor de mantel.

voor het overige wordt het concept ongewijzigd vastgesteld".

De handleiding voor de verlening van intensieve thuiszorg aan terminale patiënten is een goed voorbeeld van de gang van zaken tijdens de sturingsinteracties die werden afgesloten met de invoering en ongeldig verklaring van de regels. De werkgroep praktijkproblemen schreef van de handleiding drie opeenvolgende versies en legde deze telkens voor aan het directorium (these). Gedurende vier vergaderingen werden de versies besproken. De deelnemers aan de vergadering deden wijzigingsvoorstellen (antithese; zie kader). Deze werden door de werkgroep praktijkproblemen verwerkt, waarna de aangepaste versie opnieuw als voorstel ter bespreking werd geagendeerd (these). De tweede versie werd op 15.1.1992 geldig verklaard (synthese). In dezelfde maand echter werd besloten het bureau itz op te heffen. Er diende een nieuwe handleiding te worden geschreven. Dit was de derde versie, die door het directorium op 16.3.1992 werd vastgesteld (synthese). 


\subsubsection{Bestuurders en bestuurden}

Uit het voorgaande valt op te maken dat diverse actoren gedurende de processen van vervlechting en ontvlechting stuurders hebben verzonden, die waren bestemd voor uiteenlopende bestuurden. Bestuurders en bestuurden hebben wij ondergebracht bij vier cirkels. De indelingscriteria zijm vermeld in par. 3.6.2.

De eerste cirkel betreft actoren en netwerken die in de afhankelijkheidsrelaties de meest ondergeschikte positie innamen. De actoren en netwerken in de daarop volgende cirkels namen steeds een dominante positie in ten opzichte van degenen in de voorgaande cirkels. De eerste twee cirkels bevatten de actoren die tot de projectorganisatie behoorden ('projectintern'), de andere cirkels de actoren in de omgeving van de projectorganisatie ('projectextern'). De cirkels zijn als volgt samengesteld:

- eerste cirkel (projectintern): technostructuur, ondersteunende staf, lijnmanagement en werkvloer (projectleider, projectmanager en werkgroepen);

- tweede cirkel (projectintern): strategische top (directorium, bestuur en convergentiecollege);

derde cirkel (projectextern): zorgverzekeraar en hulpverlenende instellingen; vierde cirkel (projectextern): Ministerie van WVC.

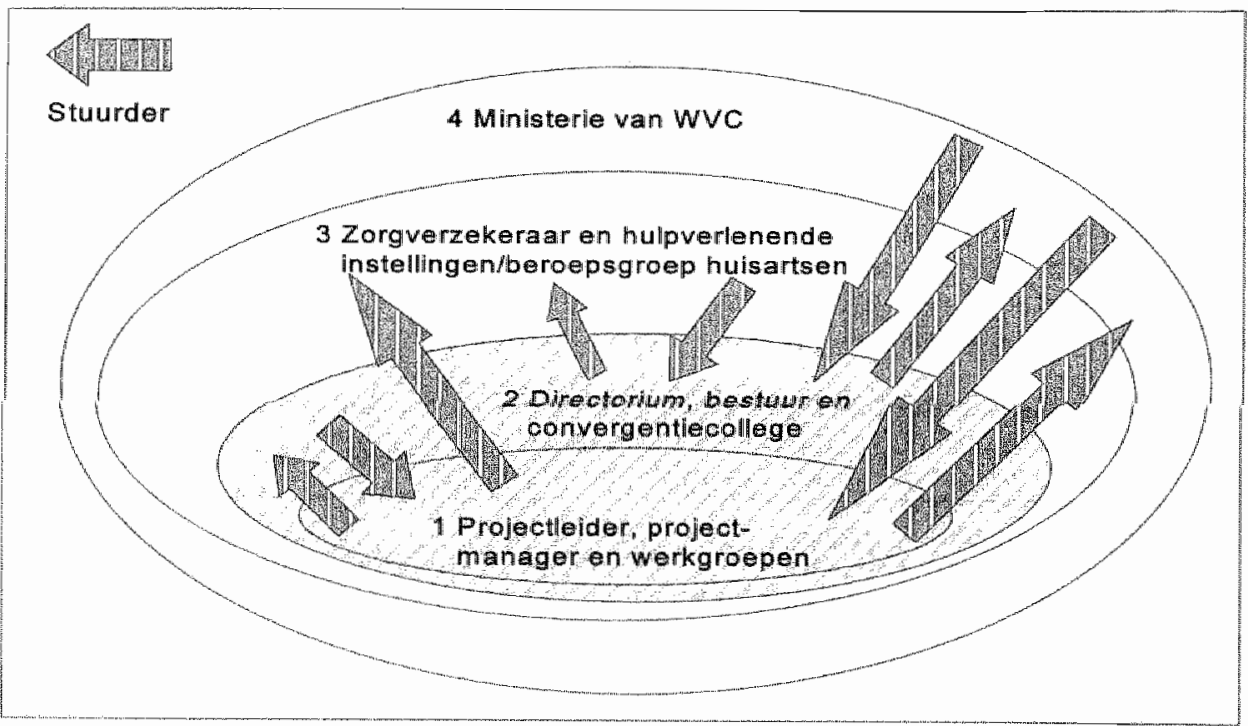

Fig. 5.3 Bestuurders en bestuurden in vier afhankelijkheidscirkels

Fig. 5.3 geeft aan welke actoren in de sturingsinteracties bestuurders en bestuurden waren, op basis van gegevens over verzonden stuurders. In hoofdstuk 6 gaan wij op een aantal van deze interacties dieper in. Met het oog op de beantwoording van de 'hoe-vraag' kunnen wij hier volstaan met een weergave op hoofdlijnen aan de hand van een aantal voorbeelden. 


\section{Eerste cirkel}

De werkgroepen, alsmede de projectleider en de projectmanager, maakten voorstellen voor bespreking door de strategische top van de projectorganisatie, zoals de handleiding voor de organisatie van de intensieve thuiszorg aan terminale patiënten (D223). Deze voorstellen waren stuurders, hetgeen hen tot bestuurders maakte. Tevens waren zij bestuurden. De opdracht voor het schrijven van de voorstellen was namelijk door de strategische top verstrekt. De strategische top verzond naar hen voor dit doel stuurders in de vorm van uitspraken tijdens vergaderingen die door de projectleider en de projectmanager (zij waren lid van de werkgroepen) werden bijgewoond.

Gedurende vergaderingen kregen de projectleider en de projectmanager ook opdrachten te horen werkgroepen bijeen te roepen, bestaande uit vertegenwoordigers van de participerende instellingen (D174). Daartoe moesten zij deze instellingen benaderen. In de vorm van bijvoorbeeld brieven verzonden zij stuurders naar deze instellingen. Zo stuurde de projectleider een brief aan de instellingen met het verzoek mede te delen wie aan de operagroep zouden deelnemen (D208). Zij waren dan bestuurders, de instellingen bestuurden.

\section{Tweede en derde cirkel}

De strategische top bestond uit vertegenwoordigers van de zorgaanbiedende instellingen. De concept-statuten van de stichting itz werden door de vertegenwoordigers in de projectgroep als voorstel (een stuurder als these) ter goedkeuring aan hun eigen organisatie voorgelegd. Namens hun instellingen spraken de leden van de projectgroep itz in mei 1990 uit dat zij akkoord waren met de statuten, waarna de projectgroep itz besloot dat de stichting kon worden opgericht (D46). Strategische top en instellingen waren hier bestuurders resp. bestuurden en vice versa.

Tussen de zorgverzekeraar en vertegenwoordigers van het directorium hebben gedurende het project meerdere malen besprekingen plaatsgevonden. Een voorbeeld is het overleg dat op 25.11.1991 plaatsvond over de financiering van intensieve thuiszorg (D198). Tijdens dit overleg trachtten de deelnemers tot overeenstemming te komen over de hoogte van het budget. Zij spraken hun standpunten uit en beargumenteerden deze. $Z_{i j}$ verzonden dus naar elkaar stuurders. Zij waren bestuurders en bestuurden, verzenders en ontvangers.

\section{Vierde cirkel}

Het Ministerie van WVC trad op als bestuurder, toen de projectparticipanten verzochten het project op te nemen in het Programma Zorgvernileuwingsprojecten Thuiszorg. WWC verbond daaraan voorwaarden en verwoordde deze in brieven. In zijn brief van 21.12.1989 (D2) meldde WV bijvoorbeeld dat het projectplan moest worden herzien voordat opname kon plaatsvinden.

Een van de voorwaarden was dat afstemming werd gerealiseerd tussen de projectorganisaties van het project itz en het andere project in de regio. Om tot overeenstemming te komen over de wijze waarop deze afstemming moest worden bereikt, wond vervolgens overleg plaats tussen ambtenaren van het departement en vertegenwoordigers van de projectorganisaties (projectleiders en leden van de strategische top) (D1,57). Tijdens dit overleg zetten de deeinemers over en weer hun visies uiteen. Degenen die door WVC werden bestuurd, traden hierbij tegelijkertijd op als bestuurders van de ambtenaren. 


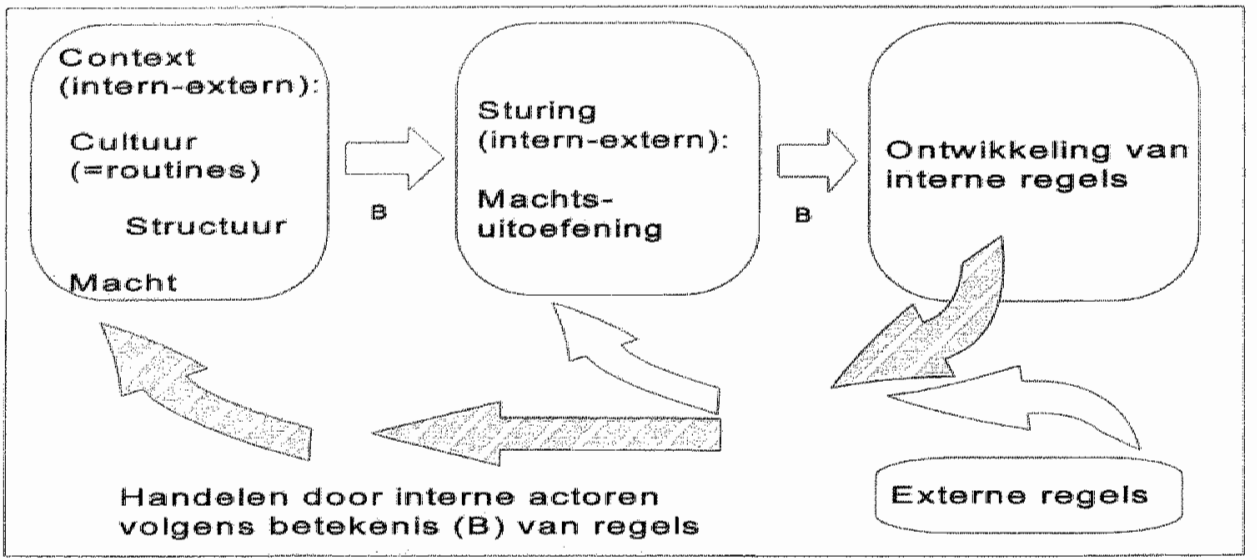

Fig. 5.4 Besproken gedeelte van het conceptueel raarnwerk (gearceerd)

\subsection{Handelen volgens (de betekenis van) projectinterne regels}

In deze paragraaf belichten wij de handelingen en het gebruik daarbij van regels. Wij richten ons op de regels die binnen de projectorganisatie (eerste en tweede cirkel) zijn ontwikkeld en ingevoerd (zie Overzicht 2.2). Aldus krijgen wij zicht op het grootste gedeelte van alle regels, de daarmee corresponderende handelingen en de daaruit voortvloeiende relaties. Ook de actoren uit de derde en vierde cirkel zijn belangrijk geweest bij de ontwikkeling en invoering van regels. Zij keren in hoofdstuk 6 in ons blikweld terug.

De valgende bespreking concentreert zich op het gearceerde gedeelte van het conceptueel raamwerk in Fig. 5.4, en wordt stap voor stap opgebouwd. Zijdelings komen routines aan bod. We tonen eerst dat veranderingen in structuur en macht plaatsvonden door patroonsgewijze handelingen (par. 5.3.1). Vervolgens laten wij zien dat vrijwel altijd werd gehandeld in overeenstemming met de ingevoerde regels. Bovendien zijn er sterke aanwijzingen dat deze regels werden gebruikt. Het waren in die gevallen handelingen volgens régels die leidden tot veranderingen. We maken daarbij onderscheid tussen regels voor de oprichting en opheffing van netwerken (par. 5.3.2) en voor thandelingen binnen en tussen netwerken (par. 5.3.3). Wij bespreken niet het gebruik van de regels voor de organisatie van de hulpverlening. Daarover hebben wij in par. 4.4. reeds opmerkingen gemaakt. De aandacht gaat uit naar het secundaire proces.

Gebruik van regels hebben wij vastgesteld op de wijze die in par. 3.5.3.1 is beschreven. Wii gaan uit van de assumptie dat actoren niet handelen volgens de regels zelf, maar volgens de betekenis die deze voor hen hebben. Ten behoeve van de leesbaarheid gebruiken wij veelal formuleringen zoals 'handelingen volgens regels", in plaats van bijvoorbeeld 'handelingen volgens de betekenis van regels".

Methodologisch gezien is het van belang dat wij de handelingsregels bestuderen als een concreet verschijnsel, mididen in de situatie waarin de actoren verkeerden (zie 
par. 3.5.3.3). Dit betekent onder meer dat moet worden aangetoond dat de handelingsregels zijn waargenomen door de actoren, voor wie zij zijn bestemd.

Om te beginnen hebben wij dit gedaan voor de algemene regel, die wij in par. 5.3.2.1 bespreken. Deze regel was in elk geval bekend bij de leden van de strategische top. Als lid van de voormalige projectgroep itz bespraken zil bijvoorbeeld de conceptstichtingsstatuten en de overeenkomst voor het convergentiecollege, waarin deze regel tot uiting komt. Ook de projectleider, die deelnam aan de vergaderingen van de strategische top, kende de regel. Zij heeft deze bijvoorbeeld op ons verzoek weergegeven in de registratieformulieren die wij haar toezonden. Het is de betekenis die zij aan de regel gaf, waarvan wij hier uitgaan. Omdat de projectleider, met uitzondering van het bureau itz, deelnam aan de vergaderingen van alle netwerken in de eerste en tweede cirkel, is tenminste een gedeelte van de actoren in elk van deze netwerken van de algemene regel op de hoogte geweest en gaf minstens een gedeelte aan de algemene regel de betekenis die wij hebben verwoord.

Deze redenering betreft eveneens de regels voor de oprichting van netwerken 72. Niet alleen de projectleider, maar ook de projectmanager nam deel aan de vergaderingen in de eerste en tweede cirkel. Beiden hebben de besluiten tot oprichting tijdens de vergaderingen van de tweede cirkel gehoord of konden nadien door lezing van de notulen daarvan kennis nemen. Op dezelfde wijze konden zij vernemen welke regels de netwerken moesten gebruiken. De meeste regels werden namelijk gelijktijdig met het bes/uit tot oprichting geformuleerd.

Voorzover bekend waren het de projectleider en de projectmanager die de netwerken, na de opdracht van de strategische top te hebben vernomen, voor het eerst bijeenriepen en hen van de besluiten op de hoogte stelden ${ }^{73}$. Zij waren de koeriers van de strategische top, werden lid van de op te richten netwerken en informeerden de andere netwerkieden over de voor hen geldende handelingsregels. Zij verwoordden daarbij de regels zoals zij dachten dat deze luidden. In een aantal gevallen gebeurde dit met behulp van brieven en notities, die zij hadden geschreven. Aldus gaven de projectleider en de projectmanager de betekenis weer die de regels voor hen hadden. Vervolgens namen zij zelf deel aan de interacties in de netwerken, met -naar wij veronderstellen; zie par. 3.5.3-genoemde betekenis ais uitgangspunt.

Zoals nog blijkt, is het beeld van de opheffing van netwerken diffuser.

73 Bekend is dat in elk geval de werkgroep draaiboek-werkwijze, de taakgroep convergentie, het directorium, het bestuur, de werkgroep praktikproblemen en de operagroep bijeen zijn geroepen door de projectleider en/of door haar van de besluiten van de strategische top op de hoogte zijn gesteld. De pg-werkgraep is bijeengeroepen door de projectmanager (D29, 50,64, 113, 120, 173, $\$ 74,208$ ). Zinsneden uit de brief die de projectleider op 26.8.1991 naar de leden van de werkgroep praktijkproblemen verzond, illustreren hoe werkgroepteden op de hoogte werden gesteld van de algemene regel en opdrachten van de strategische top: Zowel in de hoofdenvergadering van de kruisverenging als in de vorige vergadering van de werkgroep is gebleken, dat jullie behoefte hebben aan werduidelijking van de opdracht van de werkgroep (...). Ik zal proberen die diuidelijkheid te verschaffen (...). Het bestuur beslist over de grote lijinen van het project. De richtilinen voor de dagelijkse gang van zaken worden door het directorium wastgesteld (...). De projectmanager (...) moet werken binnen de richtlinen die door het directorium zijn vastgesteld (..). Jullie kregen de opdracht woorstellen te formuleren (...)" (D174). 


\subsubsection{Veranderingen door patroonsgewijze handelingen}

Volgens de theorie in hoofdstuk 2 ontstaan veranderingen in structuur, cultuur en macht door handelingen. In hoofdstuk 4 hebben wij laten zien dat gedurende de vervlechting en ontvlechting nagenoeg geen veranderingen in cultuur ontstonden. Analyse van de achtergrond van cultuurverandering is dan weinig zinvol. Daarom richten wij de aandacht hier op structuur en macht.

De belangrijkste empirische ondersteuning voor de theoretische uitspraak over de rol van handelingen in structuur- en machtsveranderingen vinden wij in het verschijnsel 'vergadering'. Vergaderingen kwamen in de projectorganisatie regelmatig voor. Tabel 5.1 bevat voor de netwerken informatie over het aantal vergaderingen dat gedurende de projectperiode tenminste heeft plaatsgevonden. Niet altijd is het totale aantal vergaderingen per netwerk bekend. Het projectbureau en het bureau itz zijn buiten beschouwing gelaten. Er zijn minstens 71 vergaderingen gehouden.

Tabel 5.1 Aantal wergaderingen per netwerk in de projectperiode (1990-1992)

\begin{tabular}{|c|c|}
\hline Netwerk & Aantal vergaderingen \\
\hline projectoroep itz & 7 \\
\hline werkgroep draaboek-werkwize & $\geq 2$ \\
\hline convergentiecollege & 5 \\
\hline taakgroep convergentie & 6 \\
\hline bestuur stichting itz & 5 \\
\hline directorium stichting ilz & 26 \\
\hline werkgroep uitbreiding aanbod itz/projectgroep pg & 6 \\
\hline werkgroep praktijkproblemen & 6 \\
\hline pg-werkgroep & 10 \\
\hline Klankbondgrosp-operagroep & $>2$ \\
\hline werkgroep indicatiestelling elc. pg. & 21 \\
\hline gestruchureerd directie-oventeg itz & 0 \\
\hline Tolaal & $\geq 74$ \\
\hline
\end{tabular}

Doordat in tenminste tien gevallen tussen de betrokken actoren herhaaldelijk twee of meer- vergaderingen plaatsvonden ${ }^{74}$, waren deze gevallen per definitie netwerken. Een netwerk bestaat namelijk uit een aantal actoren die onderling relaties hebben en daarbinnen handelen. Relaties zijn volgens de theorie ontstaan uit interacties die zich in het verleden op min of meer dezelfde wijze hebben herhaald. Zij zijn het product van patroonsgewijze interacties.

Herhaaldelijk plaatsvindende vergaderingen zijn bij uitstek voorbeelden van dergelijke interacties. De eerste vergadering van de netwerken mag derhalve de start worden genoemd van het ontstaan van een nieuwe verzameling relaties en daarmee

74 Van de werkgroep draaiboek-werkwijze en de operagroep is bekend dalt zij tenminste tweemaal bijeen kwamen. 
van een verandering in structuur en macht (vervlechting). De laatste vergadering betekende de beëindiging van de relaties en impliceerde opnieuw veranderingen in structuur en macht (ontvlechting). In hoeverre dit alles niet alleen gold voor structuur, maar ook voor macht, zal aanstonds duidelijk worden.

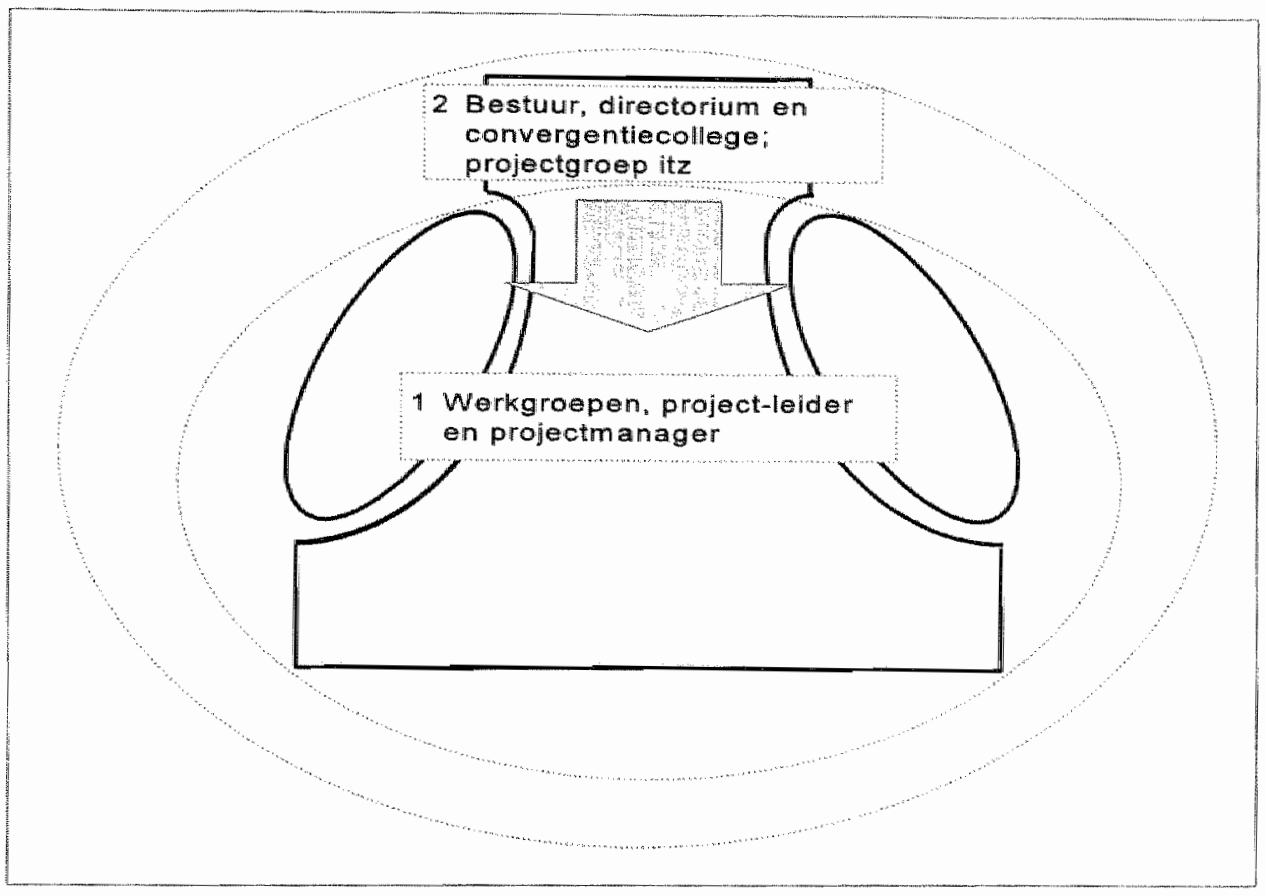

Fig. 5.5 Relatie tussen tweede en eerste cirkel: beleidsbepalers en uitwoerders

\subsubsection{Veranderingen door handelingen volgens regels: oprichting en opheffing van netwerken}

Onze theorie beperkt zich niet tot de uitspraak dat de genoemde veranderingen plaatsvinden tijdens handelingen zonder meer. Bij deze handelingen worden regels gebruikt. Voor deze uitspraken dragen wij hierna de empirische argumenten aan.

\subsubsection{Algemene regel: beleidsbepalers en uitvoerders}

Met het ontstaan van de tweede configuratie van de projectorganisatie (zie par. 4.3.2) kregen niet alleen relaties binnen netwerken verder vorm, maar ook daartussen. Onder de netwerken die de strategische top vormden en de overige netwerken tekende zich meer en meer een asymmetrische afhankelijkheidsrelatie af fussen dominanten en ondergeschikten 75 . Deze situatie werd vervolgens vastgelegd in de statuten van de 
stichting itz, die op 30.5.1990 van kracht werden. Daarin domineerden de volgende handelingsregels. Bestuur en directorium moesten het beleid voor de inhoud en uitwoering van het project bepalen en erop toezien dat dit beleid werd uitgevoerd; voor de uitwoering kon het directorium anderen inschakelen; het directorium moest besluitvorming van het bestuur voorbereiden en ervoor zorgen dat bestuursbesluiten werden uitgevoerd (D20, 53; R1; V6).

Volgens de handelingsregels die zijn opgenomen in de overeenkomst voor de oprichting van het convergentiecollege (D11), had ook dit netwerk beleidsbepalende taken. Samen met het bestuur en het directorium maakte het convergentiecollege deel uit van de tweede cirkel (zie Fig. 5.3).

Kort en goed hielden de weergegeven regels in dat de tweede cirkel bepaalde wat moest gebeuren en dat anderen het bepaalde moesten uitvoeren (Fig. 5.5). Deze 'anderen" behoorden tot de eerste cirkel. Wij noemen dit de 'algemene regel', die door de strategische top zelf was ingevoerd. Er werd afgesproken dat de tweede cirkel zeggenschap had over actoren in de eerste cirkel. Nakomen van deze afspraak zou impliceren dat de daarin neergelegde asymmetrische afhankelijkheidsrelatie in de handelingen werd bevestigd en bestendigd. Met andere woorden, gebruik van de algemene regel zou ertoe leiden dat de tweede cirkel niet alleen op papier, maar ook in de praktijk dominant was ten opzichte van de ondergeschikte eerste cirkel.

Met het oog op de vaststelling van veranderingen, zowel in structuur als in macht, was het belangrijk na te gaan of de actoren in de eerste cirkel zich inderdaad iets gelegen lieten liggen aan de algemene regel. Wij keken daartoe of de eerste cirkel zich hield aan de regels (opdrachten en anderszins) die door de tweede cirkel werden ingevoerd. Was dit het geval, dan beschouwden wij het als aanwijzing dat zij zich aan de algemene regel conformeerden. We beginnen de verslaglegging met de regels voor de oprichting en opheffing van netwerken. In par. 5.3.3 kijken wij naar de regels die golden voor de handelingen binnen en tussen de netwerken. De gegevens laten zien dat de algemene regel door de eerste cirkel inderdaad werd gebruikt. Om de analyse van het gebruik van regels af te ronden zijn wij nagegaan na of de tweede cirkel zelf rekening hield met de regels die het had opgesteld 76 .

\subsubsection{Gebruik van regels voor de oprichting en opheffing van de netwerken}

Analyse van de gebeurtenissen bij de oprichting van netwerken bracht ons tot de volgende conclusie. De tweede cirkel gaf opdrachten tot oprichting en de eerste cirkel voerde de opdrachten uit. Veranderingen in structuur en macht, in de vorm van de tot stand koming van netwerken die vervolgens onderling afhankelijkheidsrelaties opbouwden, vonden plaats door handelingen waarbij de algemene regel en de verleende opdrachten als leidraad werden genomen.

Als het moment waarop een netwerk operationeel was, beschouwen wij de datum van de eerste bijeenkomst van het netwerk. Overzicht 5.3 laat zien dat minstens negen van de 13 netwerken (de stichting itz kende twee netwerken: bestuur en directorium) die na de projectgroep itz tot stand kwamen, voor de eerste keer bijeenkwamen nadat

het directorium en dle projectleider en projectmanager, die als vertegenwoordigers van hun netwerken meerdere malen met het directorium vergaderden. Juist door deze herhaalde interacties kunnen wij spreken van een asymmetrische afhankelijkheidsrelatie. 
door de tweede cirkel het besluit tot oprichting was genomen. Directorium en convergentiecollege riepen feitelijk zichzelf in het leven, doordat een aantal van hun leden deelnam aan de besluitvorming in de projectgroep itz tot oprichting.

Meerdere malen volgde een besluit tot oprichting nadat daartoe al een schriftelijk voorstel was opgesteld door een of meer van de leden van het later opgerichte netwerk. Dit was bijvoorbeeld het geval bij de operagroep (zie Overzicht 5.1). Betrokkenen waren dus al van zins het netwerk op te richten. Niettemin vond ook dan de eerste bijeenkomst pas plaats nadat de strategische top met oprichting instemde. Voor zover bekend kwamen netwerken dus niet tot stand voordat de tweede cirkel daarmee akkoord ging. $\mathrm{Er}$ is eén uitzondering: de werkgroep uitbreiding aanbod itz. De leden daarvan formeerden uit hun midden zelf een grote en een kleine werkgroep. zonder daarvoor besluiten van de strategische top af te wachten (D74). De werkgroep als geheel kwam echter pas voor het eerst bijeen nadat de tweede cirkel tot oprichting had besloten. Verder is één geval bekend waarbij een netwerk niet tol stand kwam hoewel de tweede cirkel daartoe had besloten. Op 15.1.1992 nam het directorium het besluit dat een werkgroep moest worden opgericht die zich zou buigen over de vorming van een pool van hulpverleners (D207). In 1992 is deze werkgroep niet bijeen gekomen.

Overzicht 5.3 Bes luiten tot oprichting van netwerken en daium van eerste bijeenkonst

\begin{tabular}{|c|c|c|}
\hline Netwerk & Datum besluit to oprichting $(x)$ & Datum eerste bijeenkomsi $(Y)$ \\
\hline $\begin{array}{l}\text { werkgroep draaiboek resp. } \\
\text { werkwize }\end{array}$ & $\begin{array}{l}\text { 14.12.1989 resp. } 23.1 .1990 \text { (D1, } \\
\text { 29) }\end{array}$ & geen gegevens \\
\hline projectbureau & $25.1 .1990(\mathrm{D} 10)$ & $\begin{array}{l}\text { grensgeval: er was al projectondersteuning wóó } X \text {, } \\
\text { maar deze handelingen werden niet als zodanig } \\
\text { benoemd (D1) }\end{array}$ \\
\hline convergentie-college & $25.1 .1990(010)$ & $30.1 .1990(\mathrm{D} 13)$ \\
\hline $\begin{array}{l}\text { stichting itz (bestuyr-directo- } \\
\text { rium) }\end{array}$ & $15.5 .1990(\mathrm{D} 4 \mathrm{~B})$ & $\begin{array}{l}\text { directorium: } 5.6 .1990(\mathrm{D} 56) \\
\text { bestur: } 13.8: 1990 \text { (D64, } 109)\end{array}$ \\
\hline bureau itz & $15.5 .1990(046)$ & $\begin{array}{l}\text { projectmanager werd per } 1.7 .1990 \text { aangesteld en na dat } \\
\text { moment was netwerk operationeel (D56) }\end{array}$ \\
\hline $\begin{array}{l}\text { werkgroep uitbreiding aan- } \\
\text { bod it? }\end{array}$ & $12.9 .1990(\mathrm{D} 7 \mathrm{D})$ & na $17.10 .1990(D 74)$ \\
\hline takgroep comvergentie & $7.2 .1991(0109)$ & $27.3 .1991(\mathrm{D} 120)$ \\
\hline werkgroep praktijkproblemen & $12.6 .1994(\mathrm{D} 152,159)$ & na 12.6 .1991 (D174) \\
\hline pg-werkgroep & $14.8 .1991(\mathrm{D} 173)$ & $\operatorname{ma} 14.8 .1991(\mathrm{D} 204)$ \\
\hline operagroep & $11.121991(\mathrm{D} 201)$ & na 20.1.1992(0208) \\
\hline $\begin{array}{l}\text { werkgroep indicatiestelling } \\
\text { elc pg }\end{array}$ & $10.6 .1992(0241)$ & geen gegevens \\
\hline $\begin{array}{l}\text { gestructureerd directie-over- } \\
\text { legizz }\end{array}$ & $2.12 .1992(D 275)$ & $\begin{array}{l}\text { op } 3.12 .1992 \text { bestond netwerk nog niet; oprichting was } \\
\text { plan voor } 1993 \text { (V7) }\end{array}$ \\
\hline
\end{tabular}


Op grond van deze bevindingen én van het feit dat besluiten tot oprichting door leden yan de latere netwerken werden waargenomen aleer zil woor het eersi bijeenkwamen, noemen wij de uitspraak plausibel, dat de regels voor de oprichting van netwerken werden gebruikt. De actoren in de eerste cirkel gaven gehoor aan de opdrachten van de strategische top, die volgens de algemene regel waarvan minstens een deel van elke werkgroep op de hoogte was, zeggenschap had over hun werk. Door hun handelingen bekrachtigden zij de asymmetrie in de relatie met de strategische tap. Filg. 5.6 brengt het verloop van de gebeurtenissen in beeld.

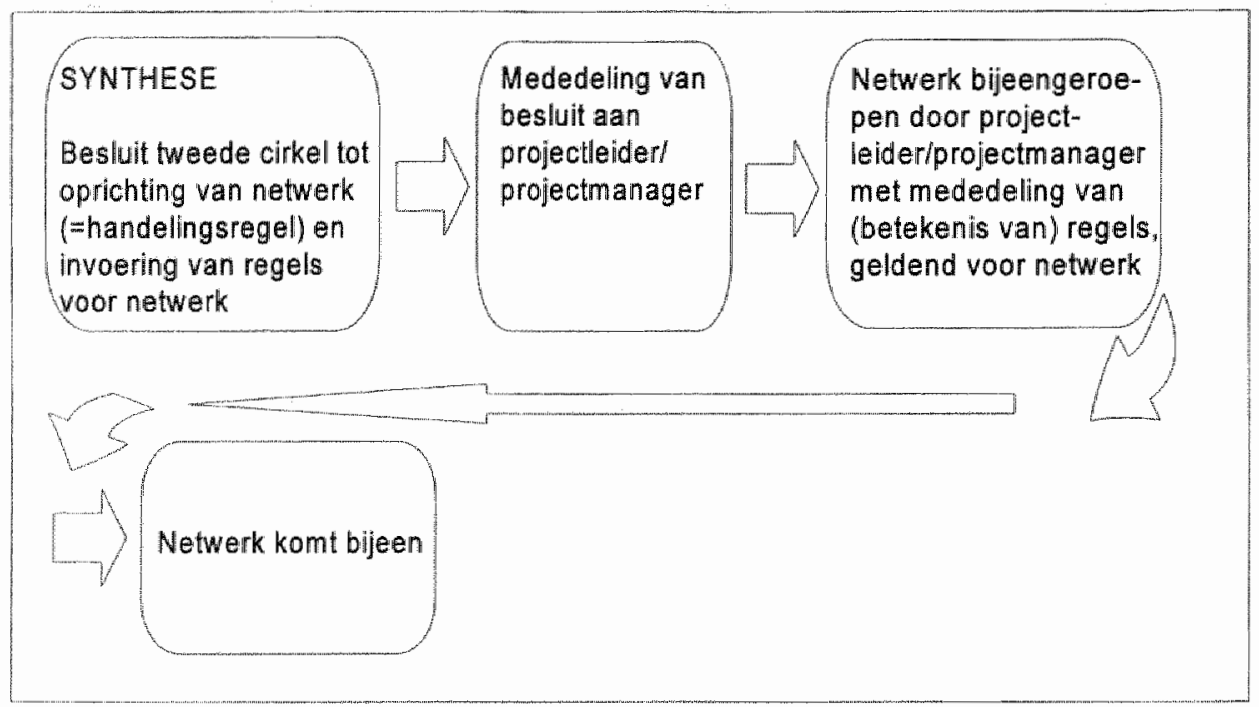

Fig. 5.6 Verloop van gebeurtenissen na besluit door tweede cirkel

Nadat was besloten tot oprichting vergaderden de netwerken volgens rooster (een verzameling handelingsregels) of kwamen zij weer bijeen nadat daarvoor tijdens de vergadering een afspraak was gemaakt. Juist het gebruik van zulke regels maakt, aangezien dit tot herhaalde interacties leidde, dat wij van netwerken mogen spreken. Deze handelingsregels stonden in de notulen en in de uitnodigingsbrieven voor vergaderingen die naar de leden werden verzonden (zoals D16, 47, 50, 56, 64, 104 . 120, 123). Zil konden dus op meerdere manieren van de regels kennis hebben genomen. Het is niet aannemelijk dat de actoren in de netwerken steeds bijeen waren gekomen op de data en tijden waarop de vergaderingen werden gehouden, wanneer dergelijke regels niet waren geformuleerd en miet aan hen waren medegedieeld. 
Overzicht 5.4 Ingevoerde handelingsregels en handelingen van de werkgroepen na invoering

\begin{tabular}{|c|c|c|}
\hline Wekgroep & $\begin{array}{l}\text { Dalum invoering eersle hande- } \\
\text { lingsregel }(X)\end{array}$ & Handelingen na invoering wan regel (M) \\
\hline $\begin{array}{l}\text { werkgroep draaiboek- } \\
\text { werkwijze }\end{array}$ & $\begin{array}{l}\text { draaboek: } \\
\text { 14.12.1989: werkgroep moet } \\
\text { draaiboek maken voor de woor- } \\
\text { bereiding en organisatie van } \\
\text { hel projeci (D1) } \\
\text { werkwijze: } \\
\text { 21.3.1990: werkgroep moet } \\
\text { zich met werkwijze bil werlening } \\
\text { wan itz bezig houden (D29) }\end{array}$ & $\begin{array}{l}\text {-draaiboek: } \\
\text { 25.1.1990: concept-raamwerk draaiboek gereed; op } \\
\text { 21.3.1990 werd definitieve draaboek door project- } \\
\text { groep itz vaslgesteld (D9) } \\
\text {-werkwijze: } \\
\text { 2.4.1990 notitie met verduidelijking van werkwilze } \\
\text { bu verlening wan itz (D32) }\end{array}$ \\
\hline taakgroep convergentie & $\begin{array}{l}\text { 7.2.1991 opdracht tot uitwerken } \\
\text { van vijf onderwerpen waarop } \\
\text { convergentie nodig werd ge- } \\
\text { acht, 0.a. indicatiestelling, on- } \\
\text { derscheid aanwullende en regiv- } \\
\text { liere hulp, aanwraagprocedure } \\
\text { voor itz (D109) }\end{array}$ & 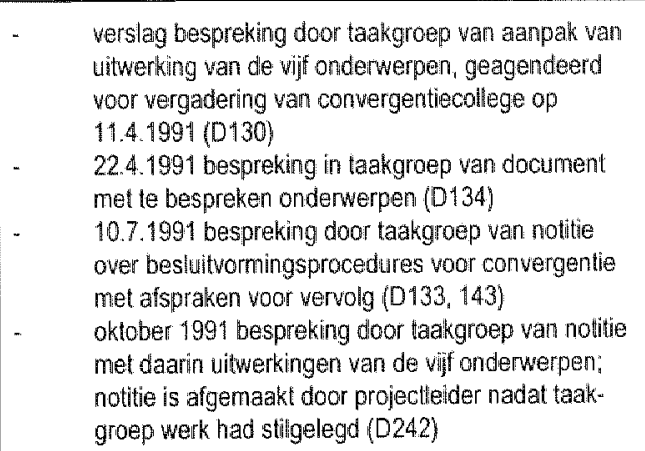 \\
\hline $\begin{array}{l}\text { werkgroep uilbreiding aan- } \\
\text { bod ITZ }\end{array}$ & $\begin{array}{l}\text { 129:1990: de werkgroep moet } \\
\text { onder andere criteria opstellen } \\
\text { voor aanmelding van hulpura- } \\
\text { gen; ze moest doelgroepen en } \\
\text { aanbod verkennen alsmede } \\
\text { van organisatie van aanbod } \\
\text { (o.a. poolvorming) (D70) }\end{array}$ & 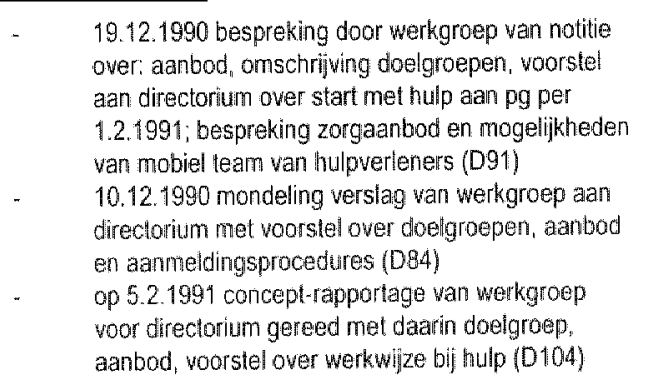 \\
\hline $\begin{array}{l}\text { werkgroep praklijkproble- } \\
\text { men }\end{array}$ & $\begin{array}{l}\text { 12.6.1991: werkgroep moel } \\
\text { voorstellen formuleren ower } \\
\text { bijvoorbeeld inzel van nacht- } \\
\text { verpleging, procedure voor } \\
\text { aanmelding en aanuragen van } \\
\text { itz (D159) }\end{array}$ & 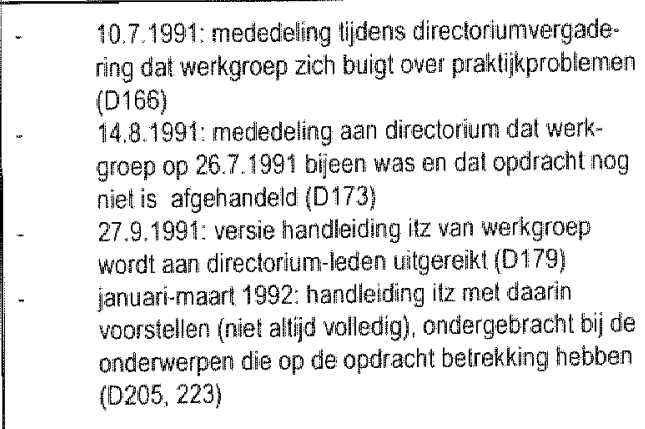 \\
\hline
\end{tabular}


Overzicht 5.4 Ingevoerde handelingsregels en handelingen van de werkgroepen na invoering (vervolg)

\begin{tabular}{|c|c|c|}
\hline Werkgroap & $\begin{array}{l}\text { Datum invoering eerste hande- } \\
\text { lingsragel }(x)\end{array}$ & Handelingen na inwoering van regel $(Y)$ \\
\hline pg-werkgroep & $\begin{array}{l}\text { 14.8.1991: werkgroep moet } \\
\text { voorstel ontwikketen woor op- } \\
\text { name van pg-doelgroep in pro- } \\
\text { ject (0173) }\end{array}$ & 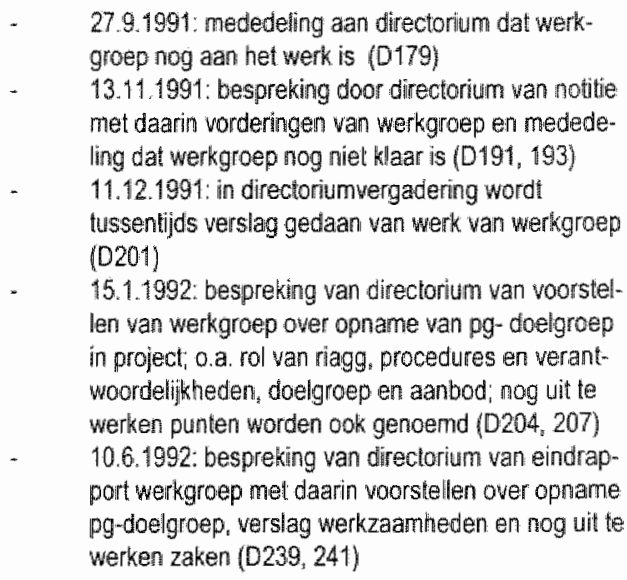 \\
\hline $\begin{array}{l}\text { klankbordgroep/ } \\
\text { operagroep }\end{array}$ & $\begin{array}{l}\text { 15.1.1992: de werkgroep moet } \\
\text { werken aan de oplossing wan } \\
\text { problemen in de uitvoering van } \\
\text { de itz (D207) }\end{array}$ & 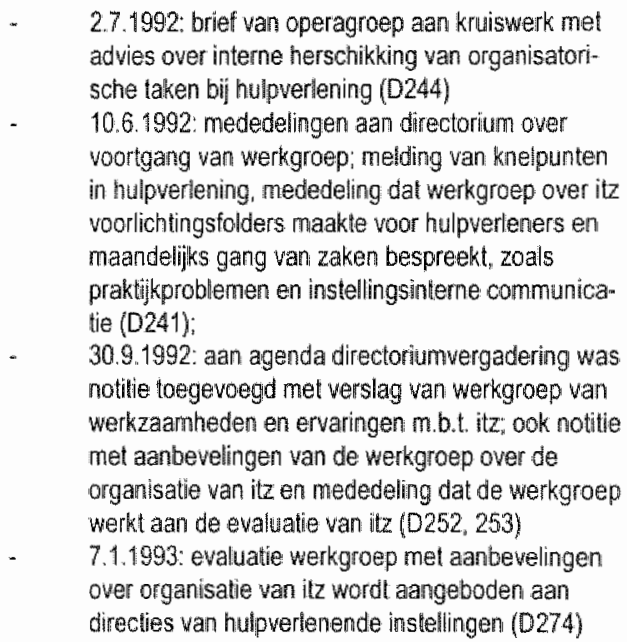 \\
\hline $\begin{array}{l}\text { werkgroep indiciatiestelling } \\
\text { atc. pg }\end{array}$ & $\begin{array}{l}\text { 10.6.1992; de werkgroep moet } \\
\text { aispraken formuleren over ver- } \\
\text { lening van Ihuiszorg voor pg- } \\
\text { paitenten (D241) }\end{array}$ & $\begin{array}{l}\text { okt-nov. 1992: werkgraep schrift concept-protocol } \\
\text { over indicatiestelling en zorgtoewijzing (D269) } \\
2.12 .1992 \text { : mededeling aan directorium dat verdere } \\
\text { witvoering van opdracht in voorbereiding is en dat } \\
\text { werkgroep in december zail rapporteren aan de } \\
\text { directies van dle instellingen (D275) } \\
21.12 .1992 \text { : brief van projectleider aan directoriurn: } \\
\text { aanbieding van rapportage van werkgraep indicatie- } \\
\text { stelling etc. pg (0278) }\end{array}$ \\
\hline
\end{tabular}


Over de besluiten tot de opheffing van netwerken sinds 30.5 .1990 en de daaropvolgende gebeurtenissen, kunnen wij kort zijn. Alleen voor de projectgroep itz, de stichting itz, het bureau itz en de operagroep zijn dergelijke besluiten bekend. Het bureau itz was sinds het vertrek van de projectmanager, kort nadat het besluit tot opheffing was genomen, volgens de projectleider niet langer operationeel (V7). Tijdens de vergadering van de projectgroep itz op 15.5 .1990 stelde de voorzitter dat de projectgroep op die dag voor het laatst bijeen was. Of het directorium, het bestuur en de operagroep nog bijeen zijn geweest na de datum waarop zij opgeheven werden verklaard (dus feitelijk in 1993), is onbekend.

\subsubsection{Veranderingen door handelingen volgens regels: handelingen binnen en tussen de eerste en tweede cirkel}

Op zichzelf kan een analyse van de oprichting en opheffing van netwerken volstaan, om uitspraken te kunnen doen over veranderingen in structuur en macht. De analyse tot dusverre laat namelijk zien dat bijvoorbeeld relaties ontstonden, als product van patroonsgewijze interacties volgens regels tussen actoren. Echter, zonder nader inzicht in de aard van de handelingen die zich binnen de relaties afspeelden en de rol van regels daarbij, blijven de analyseresultaten tamelijk leeg.

In de rest van de paragraaf bespreken wij deze handelingen en de rol van regels daarbij. Aldus krijgen de relaties tussen de actoren en de handelingen daarbinnen meer inhoud.

De gegevens over de handelingen van de werkgroepen na hun oprichting laten zien dat zij de regels gebruikten, die de strategische top had ingevoerd. Zij gehoorzaamden wederom aan degenen die volgens de algemene regel de dominante partij waren. Andere actoren handelden meestal, maar niet altijd volgens de geldende regels. De constatering dat de werkgroepen opnieuw gehoorzaamden aan de strategische top en dat andere actoren niet altijd volgens de regels handelden, was voor ons aanleiding de achtergrond van het gebruik van regels te belichten. Wij bestudeerden de motivering van actoren om regels te gebruiken -of niet (zie par. 3.5.3.2). Het resultaat van deze analyses wordt in hoofdstuk 6 beschreven.

\section{Werkgroepen}

Overzicht 5.4 toont per werkgroep de datum waarop de eerste regels zijn ingevoerd (met de projectleider en projectmanager als koeriers), alsmede een beschrijving van deze regels en van alle handelingen van de werkgroepleden waarvan onze gegevens verslag doen. Voor vier werkgroepen werden de regels na invoering aangescherpt: de taakgroep convergentie, werkgroep uitbreiding aanbod itz, pgwerkgroep, operagroep 77 . Zo werd op 20.1 .1992 (D208) besloten dat de operagroep een soepele uitvoering van de verlening van intensieve thuiszorg moest regelen, leden van de organisaties moest informeren over het project, informatie moest vergaren over knelpunten en het directorium van deze informatie op de hoogte moest stellen. Deze regels waren een aanvulling op de eerste handelingsregel, die op 15.1.1992 voor de operagroep van kracht werd.

De handelingen volgden steeds op de invoering van de eerste regels en voorzover kon worden vastgesteld- op de mededeling daarvan aan de netwerkleden. 
De overeenkomsten tussen de omschriving van de regels en de handelingen zijn meestal evident. Dit zijn voor ons de aanwijzingen dat de opdrachten leidraad waren woor hun werk.

De werkgroepen voerden alleen handelingen wit die overeenkwamen met de betekenis, die de regels hadiden naam het inzicht van een van de leden -de projectleider ${ }^{78}$, ook al voltooiden zij bijvoorbeeld niet altijd hun werk en gaf het directorium op 13.2.1991 aan dat het ontevreden was met het product van de werkgroep uitbreiding aanbod itz (D112).

\section{Projectleider van het projectbureau}

Voor de projectleider als lid van het projectbureau hebben wij een soortgeilike analyse verricht. In de vergadernotulen van de projectgroep itz, het directorium, het convergentiecollege en het bestuur hebben wij 59 opdrachten aangetroffen, die door de projectleider moest worden uitgevoerd, eventueel met anderen. Wij lieten hierbij de opdrachten aan de werkgroepen, waarvan de projectleider deel uitmaakte, buiten beschouwing.

De opdrachten aan de projectleider werden verleend tijdens vergaderingen die $z i j$ bijwoonde. Zij betroffen de inventarisatie van knelpunten in de hulpverlening, van zorgpraducten en tarieven; het beleggen van bijeenkomsten, bijvoorbeeld met de verzekeraar; het schrijven van brieven, voorstellen met handelingsregels "pr-materiaal " begrotingen en evaluaties; de verstrekking van informatie aan derden. zoals gemeenten.

In 36 gevallen kondlen wij vaststellen dat de opdracht in tijd werd gevolgd door handelingen van de projectleider, die met de opdracht overeen stemden (61\%) In de overige 23 gevallen ontbraken gegevens om een conclusie te kunnen trekken. Een opdracht die met het oog op de vervlechting van relaties in de strategische top van belang was, en die wij niet in de documenten hebben aangetroffen, betrof de statuten die de projectleider in overleg met anderen zoals de notaris heeft opgesteld. Bekend is overigens wél dat aan de projectleider opdracht tot bijstelling van de statuten is verstrekt. De projectleider heeft vervolgens de opdracht uitgevoerd.

Deze gegevens wekken de indruk dat de projectleider voornamelijk handelde na daartoe opdracht te hebben gekregen. Echter, de projectleider heeft ook werk gedaan warover blijkens de documenten geen besluit is genomen. Tijdens vergaderingen van de strategische top vertelde zij over ontwikkelingen en situaties buiten het vergaderend netwerk en mengde zij zich in discussies tussen de leden. Ook zwengelde zij besprekingen aan door bijvoorbeeld discussiestukken en andere documenten die zij op eigen initiatief had geschreven, te agenderen of ter vergadering voorstellen te formuleren. Het is ook voorgekomen dat de projectleider handelingen van deelnemers aan de directoriumvergaderingen beoordeelde en van kritische kanttekeningen voorzag. Dit zou tot de conclusie kunnen leiden dat de projectleider in tegenstelling tot de werkgroepen, ook buiten de regels om te werk ging.

In het begin van 1990 zijn de volgende handelingsregels voor de projectleider geformuleerd: "de projectleider is verantwoordelijk voor het verloop van het project als zodanig. De projectleider runt het vergadercircuit (stichtingsbestuur, directorium, convergentiecollege) en is verantwoordelijk voor het voorbereiden en bewaken van de voortgang van het project alls geheel (uitbreiding doelgroepen, protocollen, afstemming werkwijzen regio) en voor het (doen) uitvoeren van de daarmee samenhangende 
klussen. De projectleider draagt zorg voor de voorbereiding en uitvoering van besluiten wan directorium, bestuur, en convergentie college (DT, 20; R1; VG) . De formulering van deze regels maakt zeer uiteenlopende betekenissen mogelijk. Uitgaande van de meest ruime betekenis kan worden geconcludeerd dat de projectleider volgens de regels handelde. De beschreven handelingen passen namelijk bij deze betekenis.

Hoewel niet alleen de projectleider, maar ook de leden van het directorium op de hoogte waren van deze regels ${ }^{79}$. gaven zij daaraan niet allen dezelfde betekenis. Saillant is bovendien dat de gegevens op dit punt de interactionistische uitspraak ondersteunen dat actoren handelen op basis van de betekenis die zaken voor hen hebben. De regels waren dezelfde, hun betekenis verschilde.

Uitspraken van de directeur van de regionale gezinszorg op 8.10 .1990 (V3) tonen dat de projectleider in de perceptie van deze respondent in haar werk verder moest gaan (en ging) dan bijwoorbeeld het schrijven van notities: 'lk vind het jammer dat (projectleider) wegens zwangerschapsverlof is weggevallen; (projectleider) voegde iets aan het project toe. (Projectleider) speelde een belangrijke rol bij de voortgang en ontwikkeling van het project".

Over het werk van de projectleider zei de directeur van het kruiswerk op 9.10.1990 daarentegen: 'De ondersteuning vanuit (de regionale ondersteunende organisatie) werkte bevorderend; het helpt best als je iemand hebt die de stukken maakt' (V5). Stukken maken was hetgeen de projectleider volgens deze directeur moest doen. Meer niet.

Gezien de handelingen indertijd van de directeur van het kruiswerk is het aannemelijk dat deze betekenis het uitgangspunt was voor haar interacties met de projectleider. Toen de projectleider conform de ruime betekenis anders werkte dan volgens de directeur de bedoeling was, werd zij door de laatste op de vingers getikt ${ }^{80}$. De projectleider zei hierover: 'Tot augustus 1990 heb ik sterk aan het project getrokken. De directeur van het kruiswerk floot mij terug omdat ik te eigengereid bezig zou zijn' (V6).

Met betrekking tot de opdrachten die de strategische top verstrekte kunnen wij concluderen dat de regels de leidraad waren voor het werk van de projectleider. Voor het overige is dit de vraag, tenzij wij uitgaan van een ruime betekenis van de handellingsregels die begin 1990 voor de projectleider waren geformuleerd. Niet het feit dăt de projectleider wellicht handelde volgens een ruime betekenis van deze regels, was voor ons interessant, maar de achtergrond daarvan.

Uitspraken van de projectleider wijzen erop, dat zijzelf meer wenste te zijn dan uitvoerder van andermans opdrachten: "na mijn zwangerschapsverlof vond ik dat ik niet kon werken zoals ik wilde; ik vond dat ik werd beschouwd als een veredelde secretaresse van het directorium (V6)'. Hier vangen wij een glimp op van de routines van de projectleider. De beschreven handelingen, die alleen met de regels overeenkomen als wij een ruime betekenis hanteren, passen bij deze routines. Er leek

79 Dat de projectleider bekend was met deze regels staat vast (zij heeft deze op ons verzoek zelf omscheven; R1). Voor de leden van het directorium ligt dit voor de hand. Een deel vari de regels voor de projectleider is opgenomen in de overeenkomst die de stichting itz aanging vioor de oprichting van het convergentiecollege. Andere stukken, besproken gedurende directoriumvergaderingen, bevatten eveneens dergelitke regels (zoals D53).

80 Waarschijnlijk vond de ingreep van de directeur van het kruiswerk plaats in augustus of september van 1990. De betekenis 'stukken maken' die deze gaff, hebben wij pas op 9 oktober wan dat jaar vastgestelid. Hoewel de tijdstippen van $X$ en $Y$ dicht bij elkaar liggen, kunnen wij hier niet met zekerheid stellen dal de genoernde betekenis al gold vóor de ingreep. 
bij de projectleider sprake te zijn van intrinsieke motivatie om te handelen volgens de ruime betekenis.

\section{Projectmanager van het bureau itz}

De hoofdtaak van de projectmanager was de organisatie van de verlening van intensieve thuiszorg vanuit het bureau itz. De projectmanager voerde deze taak uit. Dit gebeurde nadat de regels dienaangaande waren ingevoerd. Wij beschouwen hen als leidraad. Daarnaast kreeg de projectmanager opdrachten van de strategische top tijdens vergaderingen die deze functionaris bijwoonde. Door lacunes in de beschikbare gegevens kan niet worden vastgesteld in hoeverre door de projectmanager werd gehandeld conform al deze opdrachten.

De notulen van de vergaderingen van de strategische top (in casu het directorium) bevatten 28 opdrachten aan de projectmanager. In 10 gevallen kon worden bepaald of de projectmanager wel of niet handelde volgens opdracht. Steeds was het eerste het geval. Zo werd in de directoriumvergadering van 10.4.1991 het voorstel besproken dat de projectmanager in opdracht van het directorium had geschreven over de wijze van verantwoording van de projectmanager aan het directorium. Het voorstel betrof maandelijkse rapportages aan het directorium over de gang van zaken bij de verlening van intensieve thuiszorg (D125). Sindsdien heeft de projectmanager periodiek gerapporteerd. Aan de projectmanager is in hoofdstuk 6 een aparte case gewijd 81 .

\section{Convergentiecollege}

Uit de beschrijving van de interacties tot dusverre wordt duidelijk dat de strategische top tijdens zijn vergaderingen de koers bepaalde voor de opzet en uitvoering van het project. De top werkte aldus conform zijn eigen algemene regel. Nadat de projectgroep itz was vervangen door de stichting itz, was het directorium bij uitstek het netwerk dat bij de dagelijkse gang van zaken de besluiten nam. Echter, er waren nog twee andere netwerken die wij tot de tweede cirkel hebben gerekend: het convergentiecollege en het bestuur.

Het convergentiecollege moest volgens de gesloten overeenkomst (D11) onder andere besluiten nemen over de toekenning van geldelijke middelen voor projectondersteuning die beschikbaar werden gesteld door WVC en voorstellen doen aan het stichtingsbestuur over de inhoud van het project. Het convergentiecollege werd opgericht nadat de handelingsregels voor dit netwerk waren vastgesteld door de projectgroep itz. Leden van het latere college maakten tijdens die gebeurtenis deel uit van de projectgroep itz.

Het convergentiecollege handelde veelal anders dan de regels voorschreven. Het heeft zich namelijk vooral bezig gehouden met discussie en uitwisseling van ideeën. Vanaf het moment dat in het projectplan de verdeling van de door WVC beschikbaar gestelde geldelijke middelen over het project itz en het andere project in de regio was neergelegd (D20), heeft het convergentiecollege de regel die op de verdeling betrekking had, niet meer toegepast. Wèl besloot het in april 1991 de raming van de jaarlijkse kosten in het projectplan vast te stellen als de begroting vaor 1990, 1991 en 1992 (D130). Daarmee handelde het echter volgens de regels die golden voor het bestuur. Voorzover bekend heeft het bestuur nooit gereageend op dit besluit van het

81 Met betrekking tot de projectleider is voor hoofdstuk 6 geen case geselecteerd. Een dergelike case zou geen waarde hebben toegevoegd aan de inzichten die wij hier hebben weergegeven. Een afzonderlijke case voor de werkgroepen zou weliswaar relevant zijn geweest, maar kon wegens lacunes in de gegevens niet worden geselecteerd. 
convergentiecollege. Het hield geen rekening met deze beslissing en nam zélf besluiten over de vaststelling van begrotingen.

Het feit dat het convergentiecollege zich veelal niet hield aan de eigen regels, was in het geheel van de handelingen en regels die wij hebben bestudeerd, uitzonderlijk. De achtergrond daarvan vonden wij voldoende interessant om daaraan in hoofdstuk 6 een aparte case te wijden.

\section{Bestuur en directorium}

Bestuur en directorium handelden meestal overeenkomstig de opgestelde regels. Ongetwijfeld waren beide netwerken bekend met deze regels: hun leden hadden die zelf mee opgesteld. Ook de besturen van instellingen, waaruit leden naar het stichtingsbestuur werden afgevaardigd, droegen bij aan de formulering. De regels sloten aan bij de praktijk die in de projectgroep itz als voorganger van de stichting itz reeds was gegroeid. Er zijn aanwijzingen dat de handelingsregels in de statuten weerspiegelden wat de leden van bestuur en directorium toch al deden en reeds wilden doen $^{82}$. Dit wijst erop dat intrinsieke motivatie bij het gebruik van de regels een rol speelde (zie hoofdstuk 6) (z3. $^{8}$.

Het bestuur stelde zich meerdere malen op als de partij die over het projectbeleid de beslissingen nam $(D 160,213)$. Het directorium legde ten behoeve van besluitvorming door het bestuur concept-begrotingen, concept-beleidsplannen en andere voorstellen aan dit netwerk voor. Het directorium op zijn beurt liet zich 'voeden' door stuurders van de projectleider, projectmanager, werkgroepen of andere actoren. Directorium en bestuur handelden in deze gevallen conform de regels, zoals vermeld in de statuten.

Bij besluitvorming over projectaangelegenheden kan onderscheid worden gemaakt tussen organisatorische en financiële zaken. Met betrekking tot organisatorische aangelegenheden zoals de invoering van het tweede model voor verlening van intensieve thuiszorg (zie par. 4.4.2), besloot het bestuur in overeenstemming met de voorstellen van het directorium. Het gaf te kennen zilch geheel te kunnen vinden in de ideeën van dit netwerk (D213\%.

Ten aanzien van financiële zaken daarentegen legde het bestuur voorstellen van het directorium meerdere malen terzijde, nadat het had aangegeven zich daarin niet te kunnen vinden (D160). Dit gebeurde voor het eerst toen hel directorium aan het bestuur verzocht mandaat te verstrekken voor de afwikkeling van de begroting (D105). Het bestuur zei het verzoek niet te honoreren omdat het vond dat uitsluitend het bestuur een begroting kon vaststellen. Het bestuur gaf dus een bepaalde betekenis aan zijn eigen taken en handelde dienovereenkomstig.

Het directorium heeft zichzelf een aantal malen begeven buiten de kaders die door de regels waren aangegeven. Het betreft organisatorische zaken. Meerdere malen werden handelingsregels voor de organisatie van de hulpverlening door het directorium ingevoerd zonder dat het bestuur daartoe had besloten.

Er zijn geen gegevens die erop wijzen dat het bestuur bezwaar maakte tegen deze gang van zaken, hoewel het daarvan op de hoogte was. Tijdens bestuursvergaderingen vormden mededelingen over de voortgang in het project namelijk een vast

82 Met andere woorden, handelingen $Y$ vonden al plaats, voordat regel $X$ werd ingevoerd. Toch is het niet uitgesloten dat $X$-na invoering- de handelingen geleidde. Handelingen ' $Y$ gingen namelijk na invoering van $X$ voort op de manier die in de regel was aangegeven.

83 Of extrinsieke motivatie een rol speelde valt natuurlijk te betwijfelen, aangezien deze actoren zelf de regeis invoerden en miet een actor aan wie zij ondergeschikt waren. 
onderdeel. Deze mededelingen werden gedaan door de projectleider en de voorzitter van het directorium. Wij richten ons op de inhoud van Fig. 4.7 in hoofdstuk 4. Van de verzamelingen van handelingsregels in de figuur zijn alleen de regels aan het bestuur voorgelegd (D213), welke zijn gebundeld in de laatste versie van de handieiding itz (D223). Aangezien dit document het uiteindelijke tweede model voor de organisatie van de hulpverlening betrof, kunnen wij concluderen dat het bestuur alleen in actie kwam bij de 'grote' organisatorische veranderingen ${ }^{84}$. Voor het overige besloot het directorium.

\subsection{Sturingsinteracties volgens regels}

Volgens de theorie zijn ook sturingsinteracties handelingen, waarbij regels worden gebruikt.

Het feit diat de actoren in de eerste cirkel bij hun handelingen de regels moesten gebruiken die door de tweede cirkel waren ingevoerd, impliceert dat ook de sturingsinteracties volgens regels dienden te verlopen. Opdrachten van het directorium om voorstellen te formuleren hielden namelijk in dat de eerste cirkel stuurders (bijvoorbeeld in de vorm van een rapport) moest verzenden, gericht aan de strategische top. Ook het gegeven dat het directorium volgens de regels besluitvorming van het bestuur moest voorbereiden, kan op deze wijze worden geïnterpreteerd. Wie de stuurders diende te verzenden en wie dienaanglaande besluiten moest nemen, was met behulp van regels vastgelegd. Fig. 5.7 geeft de opeenvolging van gebeurtenissen weer voor het proces van vervlechting, toegespitst op de werkgroepen ${ }^{85}$.

De reeks gebeurtenissen in de figuur (van sturingsinteracties via handelingen volgens regels en wederom sturingsinteracties, leidend tot het besluit tot invoering van regels en het gebruik van die regels), die wordt afgesloten met veranderingen in structuur, (cultuur) en macht, is -gezien de voorgaande beschrijvingen- vrijwel geheel regelgeleid.

Fig. 5.8 toont het verloop aan de hand van ons conceptueel raamwerk. De sturingsinteracties volgens regels zijn gearceerd. Het verloop is het aggregaat van gebeurtenissen voor, tijdens en na vergaderingen als patroonsgewijze interacties. Het verloop zelf kan een typerend patroon van interacties worden genoemd.

De strategische top ging akkoord met de inhoud van een aantal documenten die volgens de werkwijze in Fig. 5.7 aan hem werden voorgelegd. Echter, de invoering van handelingsregels en de oprichting et cetera van netwerken geschiedde niet omdat het directorium zich verplicht voelde voorstellen dienaanglaande van de projectieider, projectmanager of werkgroepen te aanvaarden. Uit de handelingen van het directorium blijkt duidelijk dat dit netwerk zich de mogellijkheid voorbehield voorstellen aan te (doen) passen of terzijde te schuiven. De strategische top bepaalde wat gebeurde.

In het laatste vraaggesprek dat wij met de projectleider hielden, zei deze hierover het volgende: 'ik vind dat je doen en laten als projectleider weinig invloed heeft op het verloop in het project. Dwingen helpt niet en is dus niet op zijn plaats. Wèl: afdwingen

De regels in de folder voor medewerkers (D40) en het projectplan (D20) zijn buiten beschouwing gelaten. De besluiten daarover zijn namelijk genomen door de projectgroep itz. De regels in de arbeidsovereenkomst met de projectmanager (D59) konden door het directorium worden ingevoerd zonder fiat van het bestuur, omdat de werkgeversfunctie naar het directorium was gedelegeerd.

85 Dezelfde opeenvolging geldt voor de projectleider en de projectmanager afzonderlijk, zij het dat de derde en wierde gebeurtenis dan buiten beschouwing blijven en in de vijfde gebeurtenis 'netwerk' moet worden vervangen door 'projectleider' of 'projectmanager'. 
dat de participanten een oplossing vinden voor een probleem. I $\mathrm{k}$ was in het begin nogal drammerig; later heb ik geleerd bij weerstand te vragen waarvoor de participanten bang zijn en vervolgens te accepteren dat soms andere zaken voorrang genieten bij de participanten. Overtuigen is wel van belang" (V7).

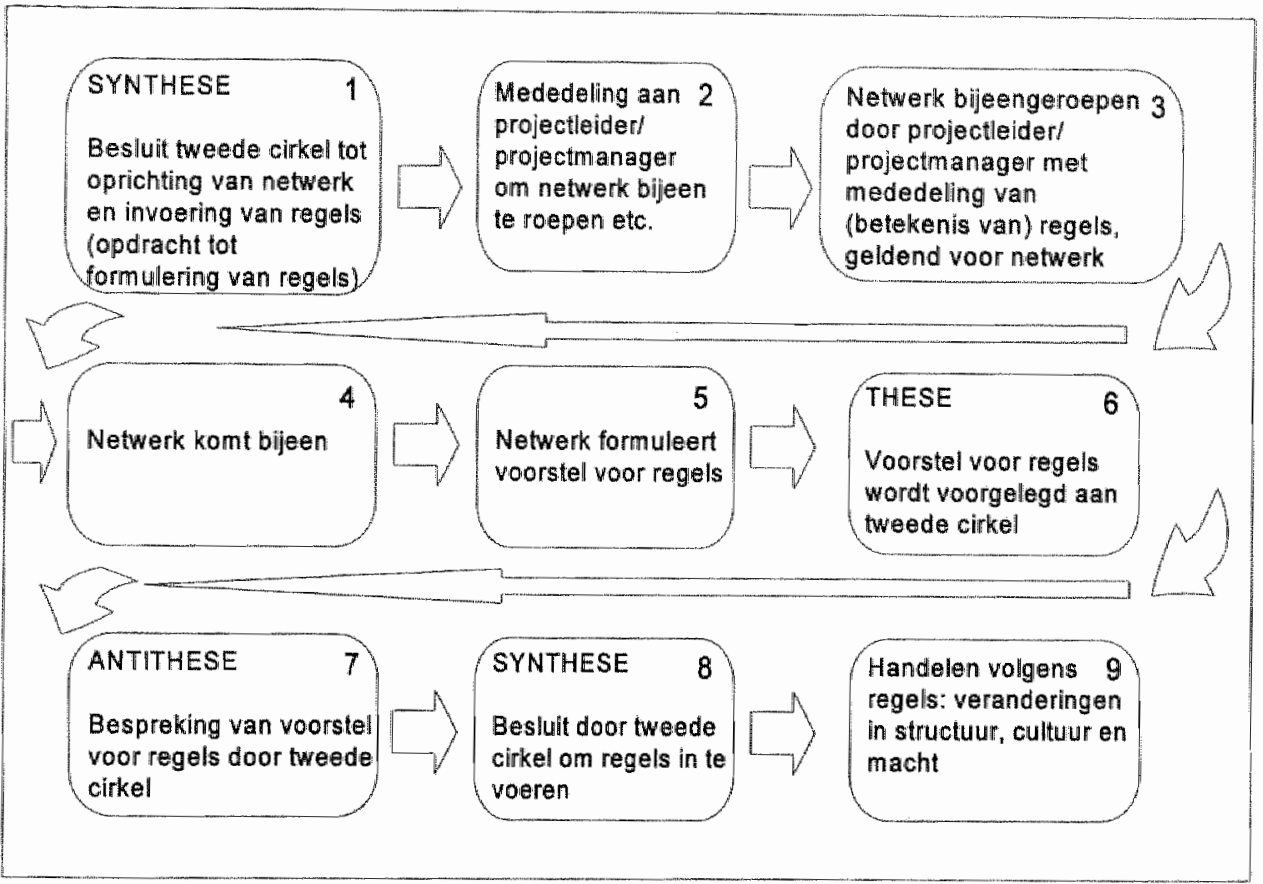

Fig, 5.7 Sturingsinteracties volgens regels: gebeurtenissen na besluiten door de tweedle cirkel tot en met veranderingen in structuur, macht en cultuur

En toch... onderschatte de projectleider haar bijdrage aan de besluitvorming door het directorium niet? Alleen of samen met anderen zorgde zij ervoor dat vergaderstukken werden geschreven en dat uitnodigingen voor vergaderingen werden verzonden, zodat vergaderingen konden plaatsvinden. De projectleider faciliteerde niet alleen het besluitvormingsproces. Zij kaderde discussies en daarop volgende besluiten in door (in overleg met de voorzitter) de agenda voor vergaderingen op te stellen en gedurende vergaderingen vragen te stellen en notities van haarzelf en anderen voor te leggen, waarover vervolgens werd gediscussieerd.

Wij kunnen niet concluderen dat de stuurders van de projectleider rechtstreeks (volgens een stimulus-response schema) leidden tot directoriumbesluiten overeenkomstig de inhoud van de stuurder. Wij kunnen wél concluderen dat de route waarlangs het directorium slingerend, hollend, vertragend of anderszins zijn weg in de besluitvorming zocht, mede door de projectleider stukje bij beetje werd uitgezet. 


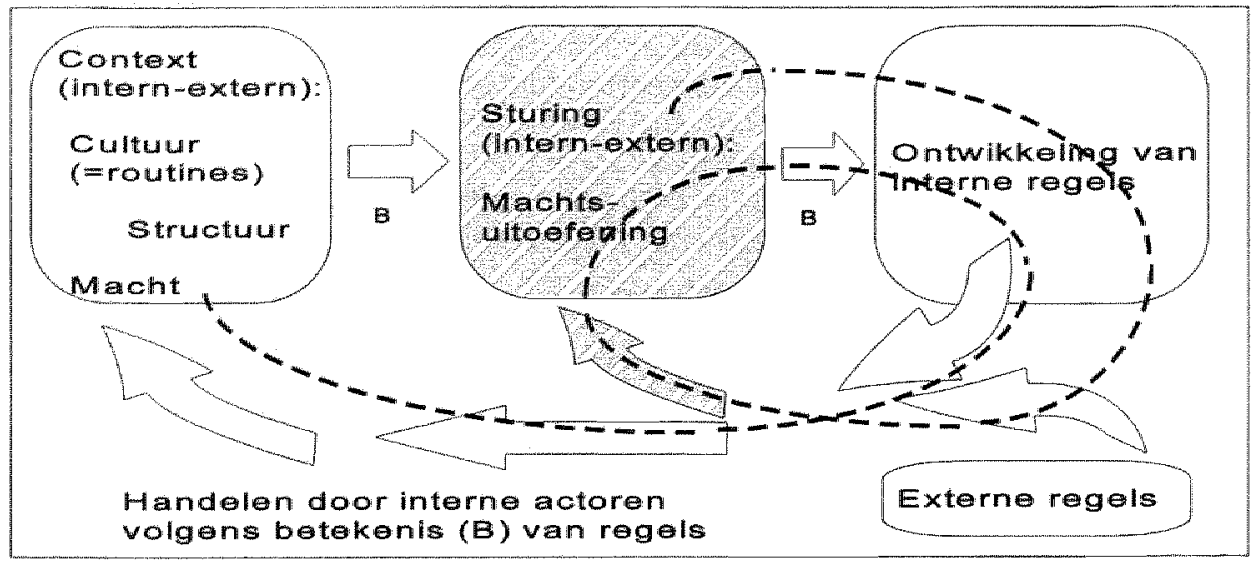

Fig. 5.8 Veranderingen in structuur, macht en cultutur via sturingsinteracties en handelingen, beide volgens de betekenis van regels

\subsection{Slotopmerkingen}

In dit hoofdstuk hebben wij over het project itz empirisch materiaal gepresenteerd, waarmee wij niet alleen lieten zien dat de geconstateerde veranderingen in structuur en macht het resultaat waren van handelingen van actoren, maar ook welke handelingen dat waren. Het ging daarbij om de oprichting en opheffing van netwerken, en om de handelingen en interacties die plaatsvonden binnen en tussen deze netwerken. Omdat in cultuur nagenoeg geen veranderingen waren opgetreden, waren wij genoodzaakt ons te concentreren op veranderingen in structuur en macht.

Bij het grootste deel van de handelingen werden de regels gebruikt, die voor de projectorganisatie waren ingevoerd ${ }^{86}$. Handelingsregels werden ingevoerd en teniet verklaard gedurende sturingsinteracties die verliepen volgens patronen van these, antithese en synthese. Wij hebben laten zien dat stuurders niet werden verzonden door één, maar door meerdere actoren. Onze conclusie is dat voor de bestudering van het gekozen object de interactiebenadering de geëigende is. Anders dan bij het rivaliserende rationele-actorperspectief (zie par. 1.3) wordt daarin gesteld dat sturing door meer dan één actor plaatsvindt.

Her en der vingen wij tijdens de analyses een glimp op van de achtergrond van het gebruik van regels. Deze glimp maakte het voor ons eens te meer duidelijk dat het niet voldoende zou zijn alleen aandacht te schenken aan de toepassing van handelingsregels, om het verloop van handelingen én de daaruit voortvloeiende veranderingen te begrijpen. Voor een interactionistische verklaring van de gebeurtenissen was het van belang achter de regels te kijken, naar de motivering tot gebruik ervan. Dit gebeurt in hoofdstuk 6. 


\section{Tweede verflaag: sturing en haar aanleiding}

\subsection{Inleiding}

In hoofdstuk 4 is beschreven welke veranderingen plaatsvonden in termen van structuur, cultuur en macht. Deze veranderingen gebeurden in een bestaande context ofwel situatie. Handelingen van actoren volgens (de betekenis van) regels zijn in de theorie de motor in de beschreven veranderingsprocessen. Om de motor te leren kennen was het derhalve van belang het gebruik van regels te beschrijven. Dit deden wij in hoofdstuk 5 . Bespreking van handelingen volgens regels was een noodzakelijke, maar op zichzelf onvoldoende stap om te begrijpen wat gaande was. Het was nodig te zoeken naar de diepere betekenis van de handelingsregels voor de actoren. Het ging erom vast te stellen of de actoren wel of niet gemotiveerd waren de regels te gebruiken, tegen de achtergrond van de betekenis die de situatie -welke zou ontstaan bij gebruik van deze regels- voor hen had. Dat gebeurt in dit hoofdstuk, aan de hand van de navolgende theoretische uitspraken.

Volgens de theorie die wij hebben opgebouwd wordt een situatie door actoren waargenomen en door hen vanuit hun cultuur (routines) beoordeeld. Actoren kunnen een situatie als wenselijk of onwenselijk beschouwen. $Z_{i j}$ handelen op basis van de betekenis die situaties voor hen hebben. Omdat zij betekenis geven vanuit hun routines, vormen deze uiteindelijk het uitgangspunt voor het handelen. Dezelfde situatie kan voor verschillende actoren andere betekenissen hebben. Gevolg is dat zij op verschillende wijze zullen handelen. Routines kennen een bandbreedte.

In de betekenis van de situatie ligt de aanleiding voor sturing. De beoordeling door actoren kan behelzen dat de situatie moet worden veranderd of juist onveranderd moet blijen. Voorstanders van verandering van de situatie zullen sturingspogingen ondernemen om veranderingen te bewerkstelligen. Tegenstanders van verandering zullen pogingen tot tegensturing ondernemen.

Handelingsregels zijm bij uitstek het object van sturing. Regels zijn enkel instrumenten ofwel hulpmiddelen om het handelen te geleiden. Op zichzelf resulteren zij bijvoorbeeld niet in veranderingen in structuur, cultuur en macht. Zij moeten worden gebruikt. Actoren moeten gemotiveerd zijn om de regels bij het handelen te gebruiken. Er kan sprake zijn van extrinsieke motivatie (machtsverklaring) of intrinsieke motivatie (routineverklaring). 
Om te kunnen doen wat zij wenselijk of noodzakelijk vinden (zoals het veranderen of handhaven van de situatie) hebben actoren middelen nodig. Zij hebben behoefte aan middelen. Deze behoefte is aanleiding tot interactie met degene die deze middelen heeft of daar toegang toe heeft ${ }^{87}$.

De actor die de middelen bezit of daar toegang toe heeft, heeft macht over degene die aan de middelen behoefte heeft. In de afhankelijkheidsrelatie tussen beiden is de eerste dominant en de tweede ondergeschikt. Macht heeft betrekking op handelingsruimte. Bezit van (of toegang tot) middelen maakt het voor de dominante actor, als deze dat wil, mogelijk de ondergeschikte actor de gelegenheid te geven of te ontnemen tot handelen, bijvoorbeeld op een manier die de laatste wenselijk of noodzakelijk vindt. Sturing vereist machtsmiddelen.

Middelen bieden gelegenheid tot juridische, economische, organisatorische of communicatieve sturing. Afhankelijkheid is veelal asymmetrisch (machtsverschil). In de relaties waarover wij spreken is altijd sprake van macht. De mate van asymmetrische afhankelijkheid wordt bepaald door het belang van de middelen (centraliteit) voor de actor die de middelen wil hebben, alsmede door de aan- of afwezigheid van alternatieve middelen waarop deze actor een beroep kan doen (substitueerbaarheid). Macht heeft voor het handelen pas gevolgen als een actor daaraan op basis van zijn routines de betekenis 'macht' heeft gegeven. Indien de dominante actor zich bijvoorbeeld niet dominant acht, dan zal hij ook niet als zodanig handelen. Indien de ondergeschikte zich bijwoorbeeld niet ondergeschikt acht, dan zal hij ook niet handelen alsof hij ondergeschikt is.

Macht is in deze studie gezag. Dit betekent dat medewerking van de ondergeschikte nodig is opdat de dominante actor zijn zin krijgt. De asymmetrische afhankelijkheid is wederkerig. De dominante actor en de ondergeschikte hebben beiden macht, waardoor eenieder eisen kan stellen. Dit leidt ertoe dat de dominante actor en de ondergeschikte, vooropgesteld dat zij iets van ellkaar willen, onderling tot een vergelijk moeten zien te komen indien de ene de eisen van de ander niet wenst in te willigen of omgekeerd. Zij moeten trachten tot een resultaat te komen dat voor beiden misschien niet optimaal kan zijn, maar toch aanvaardbaar is. Het bereikte vergelijk is een 'negotiated order'. Blijven beiden elkaars wensen onaanvaardbaar vinden, dan zal geen van hen doen of toestaan wat de ander wil.

Ontstaat een 'negotiated order', dan houdt deze veranderingen in de situatie in, naar de wensen van de dominante actor toe. Er vindt een "pull' plaats, bijwoorbeeld op zich ontwikkelende configuraties, in de richting van de routines van de dominante actor.

In dit hoofdstuk tonen wij het empirische fundament van de theoretische uitspraken. Dit gebeurt niet voor elke uitspraak. Onze theorie bevat een veronderstelling over de rol van betekenissen als aanleiding voor het handelen, die wij niet volledig met empirisch materiaal kunnen staven. De veronderstelling is een assumptie, die wij als uitgangspunt voor onze redeneringen hanteren (zie par. 3.5.3 en 5.3.3).

Wij starten de bespreking met de aanleiding tot sturing. Vervolgens gaan wij dieper in op de sturing zelf. Wij brengen de tweede -en laatste- verflaag aan op het

87 Behoefte aan middelen van anderen als aanleiding voor interacties is miet iets anders dan de reeds genoemde aanleiding tot sturing. Om situaties te kunnen handhaven of veranderen zijn immer handelingien nodig. Handelingen vereisen altijd middelen. Alles kan een middel zijn. Orndat in situaties per definitie meerdere actoren zijn betrokken, is altijd de medewerking van anderen modig om de situatie te wijzigen of in stand te houden. Dit maakt dat het vermogen wan een actor tof medewerking aan een van beide opties voor hem een middel is. De inzet van sturingsinteracties is dan het verkrijgen van deze medewerking, dus van het middel. 
doek en geven een antwoord op de "waarom'-vragen (zie par. 1.3 en 3.6.3): "Welke omstandigheden (situatie) hebben aanleiding gegeven tot deze sturing?' 'Welke omstandigheden (situatie) hebben al dan niet gelegenheid geboden tot sturing?". Ook in dit hoofdstuk laten wij de betrokkenen meerdere malen aan het woord.

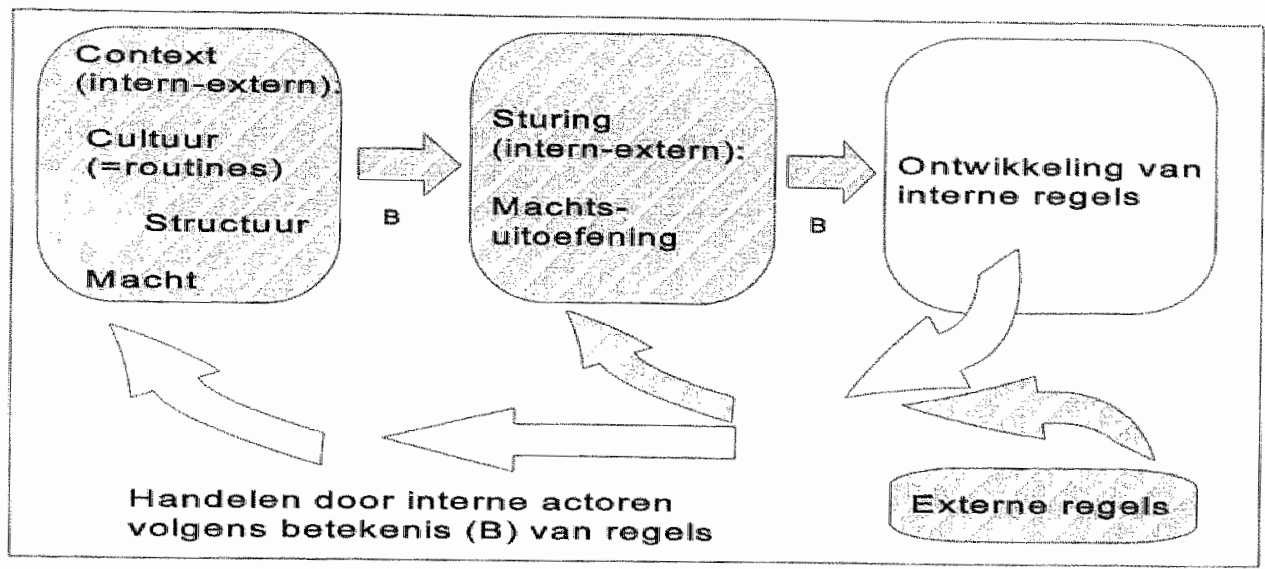

Fig. 6.1 Besproken gedeelte (gearceerd) van het conceplueel raamwerk

De bespreking heeft betrekking op het gedeelte van het conceptueel raamwerk van de aanleiding van sturing tot het resultaat van sturing -'interne' handelingsregels(Fig. 6.1). De interne regels zelf en het gebruik daarvan, evenals de daaruit voortvloeiende veranderingen in de context, beschrijven wij terloops. Zij zijn in Fig. 6.1 dan ook niet gearceerd. Zij kwamen aan de orde in hoofdstuk 4 en 5 . De regels uit de omgeving van de netwerken ('externe regels') -zij bleven tot dusverre buiten beschouwing- bezien wij daarentegen wel.

Bij de externe regels ging het om wettelijke regelingen die door actoren uit de clerde en vierde cirkel voor sturingsdoeleinden werden gebruikt, zoals de subsidieregels voor intensieve thuiszorg. Evenals interne actoren deden externe actoren voorstellen voor handelingsregels die waren bestemd voor gebruik door de leden van de projectorganisatie. Om hun voorstellen kracht bij te zetten maakten de externe actoren gebruik van genoemde wettelijke regelingen. Opdat wij niet alleen een dieper inzicht verkrijgen in de gebeurtenissen, maar ook een breder inzicht, is het van belang zowel interne als externe actoren (derde en vierde cirkel) in onze beschouwingen te betrekken. De laatsten bleven in par. 5.3 en 5.4 buiten beeld, maar keren in dit hoofdstuk in het blikveld terug.

Onze analyse richtte zich op drie cases binnen vier afhankelijkheidscirkels (zie par. 3.6.2). Omdat op de kenmerken van regels als het resultaat van sturingsinteracties hier niet het accent ligt, worden in de cases vanuit een beschrijving van de aanleiding en de sturing zijdelings aandacht besteed aan de processen van vervlechting en ontvlechting op het secundaire niveau (ontstaan en verdwijning van netwerken) en op hef secundaire niveau van het primaire proces (ontstaan en verdwijning van de modellen voor de verlening van intensieve thuiszorg).

Bij de analyses gingen wij te werk, zoals beschreven in par. 3.5.3.3. Wij analyseerden de empirische gegevens over elke case met behulp van schema's uit par. 
3.6 en de volgende concepten (zie Overzicht 2.2): al dan niet gewenste regels, relaties en handelingspatronen; aanleiding tot sturing (routines); aard van de afhankelijkheidsrelaties (asymmetrisch, symbiotisch-competitief); aard van de handelingen (samenwerking, coalitie, competitie, strijd, 'negotiated order'); behoefte aan middelen, aard en bezit van middelen, centraliteit en substitueerbaarheid; handelingsruimte (structuur en macht): juridische, economische, organisatorische en communicatieve sturing; aard en gebruik van extern ontwikkelde handelingsregels ${ }^{88}$.

Fig. 6.2 geeft weer wat wij ten aanzien van de cases hebben geanalyseerd. Met betrekking tot actoren uit de eerste cirkel beperken de cases zicht tot de projectmanager en één werkgroep -de operagroep-. Voor de andere actoren uit deze cirkel was het niet zinvol of niet mogelijk een afzonderlijke case te selecteren (zie ook par. 5.3.3).

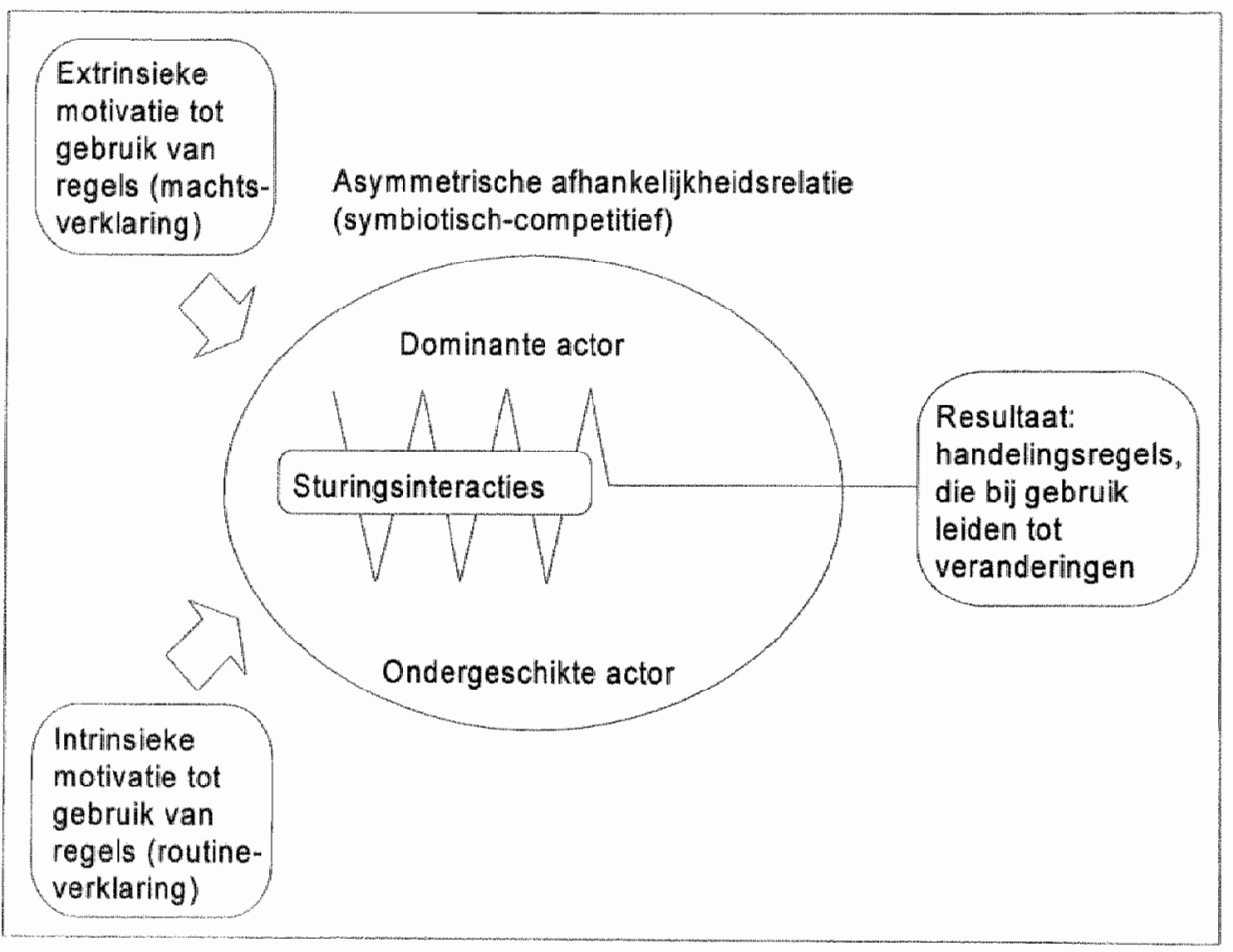

Fig. 6.2 Analyses van de drie cases

In par. 6.2 beschrijven wij de algemene aanleiding tot de uitvoering van het project itz, in par. $6.3,6.4$ en 6.5 de drie cases. De bespreking van elke case kent de volgende opzet. Eerst geven wij op hoofdlijnen het verloop van gebeurtenissen weer aan de hand van de concepten. Vervolgens presenteren wij de empirische gegevens waarop de weergave is gebaseerd. Elke bespreking wordt afgesloten met een korte 
beschouwing vanuit de machts- en routineverklaring. Par. 6.6 bevat een aantal slotopmerkingen.

\subsection{Algemene aanleiding tot de uitvoering van het project itz}

Wij beginnen met de beschrijving van de situatie voor de aanvang van het project. De algemene aanleiding tot de sturingsinteracties in de drie cases moet hier worden gezocht. Uit de gegevens blijkt dat de participanten in het project samenwerking noodzakelijk achtten om zowel zorginhoudelijke als financiële redenen (D20; R1; V2, 3 , 5).

De situatie in de hulpverlening die de participanten in het project voor 1990 waarnamen, vonden zij onwenselijk. Deze betekenis wordt onder meer zichtbaar in het definitieve projectplan (zie Overzicht 4.1), in de eerdere versies daarvan en in een beleidsnota van het amw uit september 1989 (V1). Mede door vermindering van de intramurale capaciteit werd in toenemende mate een beroep gedaan op aanbieders van thuiszorg. De hulpverlening schoot tekort, de aanbieders konden de vraag naar thuiszorg (met name onder de ouderen) niet aan. Geconstateerd was dat in de regio behoefte bestond aan multidisciplinaire, gecoördineerde zorg: "Consumenten en verzekeraars zullen van de leveranciers van zorg steeds nadrukkelijker een veelomvattend zorgaanbod verlangen, waarbij zorg op maat, aanvullende zorg en gecoördineerd verlopende zorg via een enkel adres vanzelfsprekend zijn: de "markt" vereist een nauwe samenwerking' (R1).

Tussen de aanbieders ontbraken echter de relaties die de beoogde samenwerking tussen disciplines en verlening van gecoördineerde zorg mogelijk maakten. De zorgverlenende instellingen wilden deze situatie veranderen. Door uitvoering van het gezamenlijke project itz wensten zij een multidisciplinair samenwerkingsmodel in te voeren. Met andere woorden, zij wilden onderling nieuwe afhankelijkheidsrelaties opbouwen.

Aan deze wens lag tevens de behoefte aan geldelijke middelen ten grondslag. De participanten gaven dit duidelijk te kennen. Om te kunnen blijven doen wat zij nodig achtten (hulp verlenen) hadden de instellingen extra financiering nodig. De beschikbare geldelijke middelen stonden namelijk onder druk. Door deel te nemen aan de uitvoering van het project trachtten zij aanvullende financiering te verkrijgen (zie verder par. 6.5): 'De motieven89 zijn: samenwerking en geldbronnen aanboren. Mijn instelling zit overigens minder krap dan andere instellingen. Onze bijdrage is ten dele te beschouwen als een stuk solidariteit maar niet helemaal. Het aantal hulpvragen neemt toe, de financiële middelen blijven gelijk. Bij andere instellingen zijn de financiële mogelijkheden al beperkt. Dit kan voor mijn instelling echter ook gaan gelden. Wij kunnen aan de grenzen van het budget komen. Het structureel aanspreken van financiële bronnen is dan van belang (...). Afstemmen en samenwerking is belangrijk; een ander motief om aan het project deel te nemen is het gezamenlijk verkrijgen van extra financiering" (V3).

De waargenomen situatie werd niet plotskliaps als onwenselijk beschouwd. De noodzaak tot verandering werd gaandeweg gevoeld: 'Pas toen er sprake was van bezuinigingen in de intramurale zorg, en ontwikkelingen extramuraal, was de bodem een beetje rijp. Op het moment dat mensen zomaar opgenomen kunnen worden is de 
vraag naar thuiszorg niet relevant. De tijd was dus nog niet rijp voor het project itz; men moest aan de nieuwe ontwikkelingen wennen (...). De huisartsen waren absoluut niet bereid tot enig contact met welke instelling dan ook. Later hebben ze zich verenigd zodat ze iets minder individualist waren, en nu zijn ze bereid in een werkgroep te gaan zitten. Dit is nogal een omsichakeling. Voordat het project itz bestaansgrond had moesten dus nogal omschakelingen plaatsvinden' (V5).

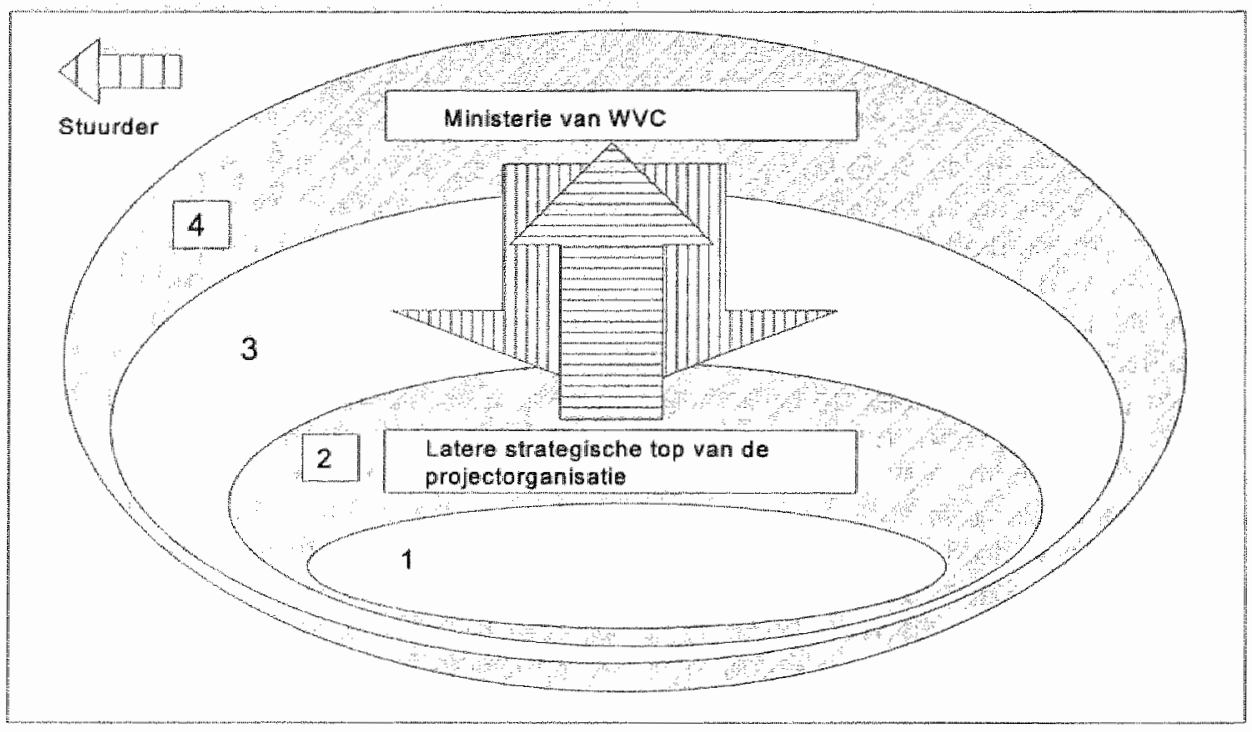

Fig. 6.3 Case van het convergentiecollege: sturingsinteracties tussen de vierde en de tweede afhankelijkheidscirkel

Niet alleen de hulpverlenende instellingen, maar ook de zorgverzekeraar en het Ministerie van WVC onderschreven de wenselijkheid van uitvoering van het project (D20, 57). Dit wekt onder meer de indruk dat de onderlinge afhankelijkheden tussen de betrokkenen symbiotisch waren. De cases laten een genuanceerder beeld zien.

\subsection{De case van het convergentiecollege}

De eerste case betreft de oprichting van het convergentiecollege en heeft betrekking op het secundaire proces. Het gaat hierbij om de interacties tussen het Ministerie van WVC (vierde afhankelijkheidscirkel90) en de vertegenwoordigers van de instellingen in de projectgroep itz. Uit de projectgroep werd medio 1990 de strategische

90 Wij hebben het Ministerie van WVC ondergebracht bij de vierde afhankelijkheidscirket. Dit impliceent dat niet aleen de projectorganisatie, maar ook actoren in de derde afhankelikheidscirkel de ondergeschikten zijn in een asymmettrische afhankelijkheidsrelatie met deze partij. Omdal de rijksoverheid in de gezondheidszorg algemeen bekend staal als degene die wettelijke regelingen maakt waaraan verzekeraars en zorgverlenende instellingen zich moeten houden, winden wil] het niet nodig deze indeling te beargumenteren. 
top wan de projectorganisatie geformeerd (tweede cirkel). In Fig. 6.3 hebben wij de cirkels gearceerd, waarop de case zich concentreent.

\subsubsection{Weergave van de gebeurtenissen aan de hand van de concepten}

In de navolgende procesbeschrijving laten wij zien dat de behoefte aan geld voor projectondersteuning de aanleiding kan worden genoemd voor de participanten om met het Ministerie van WVC in interactie te treden. Dit geld diende hen de ruimte te verschaffen te kunnen doen wat zij nodig wonden: uitvoering van het project itz. Door een beroep te doen op het Ministerie creëerden zij een afhankelijkheidsrelatie waarin zij] de ondergeschikten waren en het Ministerie de dominante actor.

De subsidie die WVC kon verlenen was beschikbaar in het kader van het (beleids)Programma Zorgvernieuwingsprojecten Thuiszorg. De subsidie was een machtsmiddel, een middel om sturingspogingen te kunnen doen. Het Ministerie maakte van deze mogelijkheid gebruik door aan de verstrekking van subsidie voorwaarden te stellen. WVC formuleerde handelingsregels waaraan de participanten zich moesten houden en maakte daarvan melding in een brief (communicatieve sturing).

Het Ministerie wilde onder andere dat de organisatie van het project itz en van het andere project in de regio werden samengevoegd. Bij zijh sturingspogingen maakte het tevens gebruik van de regelgeving die het Ministerie voor het eigen beleidsprogramma had ingevoerd (economische en juridische sturing met behulp van externe regels).

De participanten onderkenden dat zij voor financiering van de projectondersteuning van het departement afhankelijk waren. Verkrijging van geld voor projectondersteuning was voor hen belangrijk (centraliteit), alternatieven waren niet voorhanden (substitueerbaarheid).

De participanten handelden conform een gedeelte van de handelingsiregels die WVC opstelde, nadat WVC deze had medegedeeld. Niettemin kon het Ministerie niet volstaan met verzending van één stuurder om al zijn wensen gerealiseerd te zien. De participanten gingen met de regels over de samenvoeging van de projectorganisaties namelijk niet akikoord. Zij verhieven deze regels niet tot handelingsregels woor intern gebruik ${ }^{11}$. Zij beoordeelden deze regels en de situatie die bij gebruik daarvan zou ontstaan als onwenselijk en wilden de situatie die inmiddels ontstond (twee afzonderlijke projectorganisaties) handhaven.

$\mathrm{Na}$ overleg met ambtenaren van het Ministerie (sturing en tegensturing) werden voor de projectorganisaties handelingsregels ingevoerd die de participanten aanvaardbaar vonden ('negotiated order') en die door gebruik resulteerden in de formering van het convergentiecollege. Relaties op het niveau van het secundaire proces tussen de twee projectorganisaties raakten daardoor in bepaalde mate vervlochten. Fig. 6.4 vat het verloop van de gebeurtenissen samen.

91 Het was de strategische top van de projectorganisatie die besloot over invoring varl handelingsregels woor de projectparticipanten. Deze werkwijze maakte wan extern getomuleerde handelingsregels. bedoeld voor gebruk door de participanten, in de praktik woorstellem voor besluitvorming. 


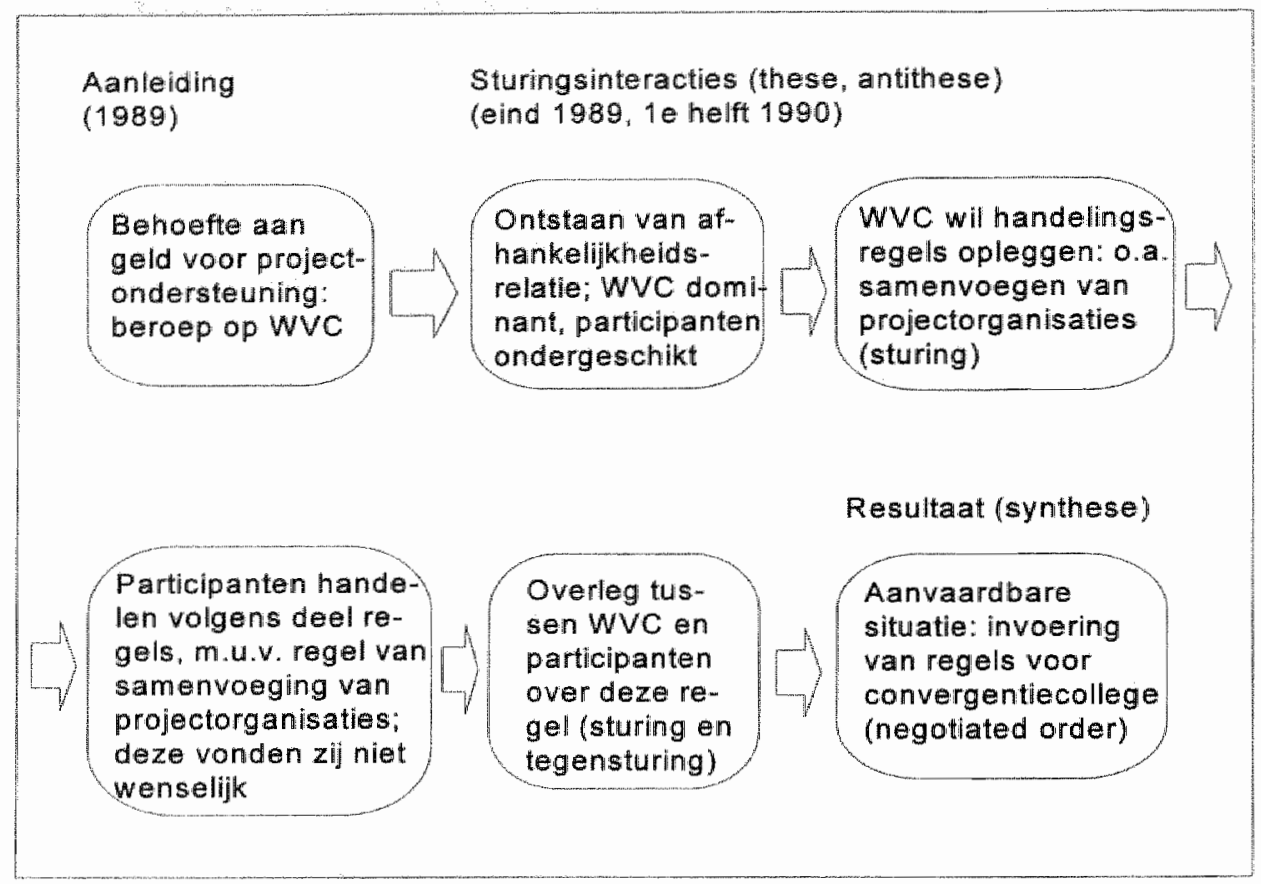

Fig. 6.4 Verloop van gebeurtenissen in de case wan het convergentie-college

\subsubsection{Empirische gegevens over het verloop van de gebeurtenissen}

De participamten vonden dat zij bij de uitvoering van het project itz ondersteuning nodíg hadden. Zij besloten eind 1989 voor de financiering daarvan een beroep te doen op het Ministerie van WVC, dat in het kader van het Programma Zorgvernieuwingsprojecten Thuiszorg subsidie kon verstrekken (D2). Met name voor het amw en de stedelijke gezinszorg was deze subsidie van belang (V1, 2). De mogelijkheden voor financiering van de verandering van de organisatie van de hulpverlening uit de eigen middelen waren schaars en financieringsmogelijkheden, andere dan in het kader van het Programma van WVC, waren niet voorhanden. 'Een zorgvernieuwingsproject gericht op integratie kost ontzettend veel geld en dan nog zitten we binnen de organisaties vreselijk knijp. Alle inspanningen voor het project moeten we uit de huidige mogelijkheden halen (...). De hele ontwikkelingscapaciteit die je in huis hebt is minimaal en alleen maar ingesteld op de dagelijkse voortgang van de zaak en niet op dit soort gigantische processen. Je moet in staat gesteld worden om daarvoor extra capaciteit en kwaliteit in huis te halen' (V2).

WVC was bereid de projectondersteuning te financieren maar verbond daaraan voorwaarden. Om in het Programma te kunnen worden opgenomen en subsidie voor projectondersteuning te krijgen, diende het project te voldoen aan zes algemene bepalingen (zie par. 1.2.3) die voor elk project in het Programma golden (WVC, 1989).

De participanten handelden in overeenstemming met deze bepalingen, zij het niet volledig. De doelstelling van de latere stichting itz, zoals vastgelegd in de statuten, kan 
worden beschouwd als een intentieverklaring van de participanten 92 (eerste bepaling): er werd een projectplan ingediend waarin de door WVC genoemde onderwerpen -met uitzondering van de beoordelingscriteria voor de projectresultaten-waren opgenomen (tweede bepaling); over de wijze waarop met exploitatieglevolgen zou worden omgegaan was overeenstemming bereikt (derde bepaling); aan WW werden in 1991 en 1992 voortgangsrapportages uitgebracht (vierde bepaling); de participanten verleenden medewerking aan het evaluatieonderzoek dat wij hebben uitgevoerd (vijfde bepaling); een projectleider werd aangesteld, die deelnam aan het Overlegorgaan Zorgwernieuwing Thuiszorg (zesde bepaling). Dit alles volgde in tijd bezien op de formulering van de bepalingen door WVC (D20,57, 92, 236, 280).

De participanten lieten in woord en gebaar merken dat zij rekening hielden met de algemene bepalingen van een partij van wie zij zich voor de financiering van projectondersteuning afhankelijk achtten. Dat zij zich afhankelijk beschouwden blijkt in onze gegevens voor het eerst uit de notulen van de vergadering van de projectgroep itz wan 5.4.1990, voordat conform vier bepalingen werd gehandeld. Tijdens deze vergadering werd voorgesteld tegemoet te komen aan wensen die WVC had geuit om te voorkomen dat definitieve goedkeuring van het projectplan door het Ministerie uitbleef (D33). Hieruit mag echter niet worden geconcludeerd dat de participanten gewoonweg gehoorzaamden aan WVC. De navolgende gebeurtenissen laten zien dat een dengelijke conclusie onjuist zou zijn. Zij hebben betrekking op aanwijzingen die WNC specifiek voor het project itz had geformuleerd, naast de algemene bepalingen.

In zijn brief van 21.12.1989 (D2) deelde WVC aan de participanten mede dat het projectvoorstel dat zij eind 1989 hadden ingediend niet kon worden goedgekeurd en dat een herzien voorstel moest worden ingediend, indien de participanten wensten dat het project werd opgenomen in het Programma van WVC. In het herziene voorstel moesten de aanwijzingen zijn verwerkt, die ambtenaren van het departement tijdens overleg met de participanten op 21.12.1989 hadden verstrekt. Deze aanwijzingen (door de projectleider aangeduid als 'de eisen van (WVC') hielden in dat de participanten garanties moesten verstrekken voor de integratie van het project itz en het andere project in de regio. Voor het departement moest duidelijk zijn dat er na drie jaar éen organisatie zou zijn ontstaan voor beide projecten (D7). Wij noemen deze aanwijzingen de "integratieregel'93.

In de projectgroepvergadering van 25.1 .1990 werd een schriftelijk voorstel besproken met daarin vier modellen voor de organisatie van het project itz en het andere project in de regio. Deze modellen waren blijkens de notulen door de werkgroep draaiboek geformuleerd naar aanleiding van de eisen van WVC (D9, 10).

Een van de modellen ('model $A^{\text {') }}$ ) behelsde dat beide betrokken projectorganisaties een intentieverklaring of overeenkomst zouden ondertekenen, waarin zou worden geregeld hoe de afstemming tussen de projecten zou worden georganiseerd bijvoorbeeld door de oprichting van een gezamenlijk orgaan. Besloten werd dit model te nemen en te streven naar een nader te bepalen vorm van een geïtegreerde projectorganisatie, waarvoor de mogelijkheden moesten worden onderzocht.

92 Volgens de allgemene voonwaarden moest ook hel ziekenhuis een intentieverklaring ondertekenen. Ziekenhuizen participeerden echter niet in het project.

93 Wij betwijfelen nief dal de actoren op de hoogte waren van de bepalingen en de integratieregel wan WWC. Wij beschikken over duplicaten wan de brieven van WVC waarin de bepalingen zijn wermeld en die naar de projectparticipanten zijn verzonden, alsmede over notulen van vergaderingen in de projectorganisatie waarin aan de brieven en de integratieregel door de deetnemers werd gerefereerd. 
De projectleider zond op 13.3.1990 een brief naar WVC, waarin zij de bestuiten van de projectgroep itz beschreef (D24). Op 5.4.1990 werd medegedeeld dat WVC akkoord ging met de constructie waartoe de projectgroep itz had besloten (D33). Onderdeel van deze constructie was de oprichting van hel gezamenlijk orgaan voor beide projectorganisaties. Het werd inmiddels 'convergentiecollege' genoemd94.

Vervolgens werd het defiritieve projectplan naar WVC verzonden, met daarin de genoemde constructie (D20, 36). Als bijlage werd een kopie toegevoegd van de overeenkomst voor de oprichting van het convergentiecollege die de participanten in beide projecten waren aangegaan. In de overeenkomst stond onder meer de volgende taak van het college: "de mogelijkheden voor een verdere integratie van de projectorganisaties te onderzoeken en op dat punt voor 1 januari 1991 voorstellen te doen' aan de beide projectorganisaties (DM1). WVC besloot daarop het project itz op te nemen in het Programma en deelde dit mede in zijn brief van 25.6.1990 (D57).

Tussen het uiteindelijke resultaat van de beschreven sturingsinteracties betreffende de integratieregel tussen WVC en de participanten en de aanvankelijke opstelling van de betrokkenen bestaat verschil. WVC wilde eind 1989 garanties voor de inhoudelijke integratie van het project itz en het andere project in de regio. Het moest voor het departement duidelijk zijn dat na drie jaar één organisatie voor de projecten zou zijn ontstaan. De participanten daarentegen vonden éen organisatie voor beide projecten niet wenselijk 95 . Dit blijkt wel uit de volgende uitspraken van de projectleider over het convergentiecollege: "WVC wilde dat er voor de thuiszorg één projectorganisatie voor geheel Zuid-Kennemerland zou komen. Dit was dan ook de taak van het college volgens WWC. Komen tot én "projectorganisatie" is echter niet zinnig; een superbestuur zou alleen maar meer werk en meer onduidelijkheden opleveren. Daarom: is besloten alleen te komen tot inhoudelijke afstemming' (V6). 'De participanten vonden het convergentiecollege waanzin' (VT).

De participanten kwamen aan de integratieregel van het Ministerie tegemoet door te besluiten het convergentiecollege op te richten. Ook al vonden zij dat ze rekening moesten houden met de wensen van het Ministerie, dit leidde er niet toe dat de participanten valledig conform de regel handelden. Tegelijkertijd bleek ook het oorspronkelijke standpunt van WVC niet onwrikbaar. WVC 'eiste aanvankelijk integratie van de projectorganisaties (...) als garantie voor het bereiken van inhoudelijke integratie van de projecten, maar nam later genoegen met onze voorstellen voor het convergentiecolleges (D120).

In de stukken waarmee WV witeindelijk akkoord ging wordt geen garantie gegeven dat na drie jaar één organisatie voor beide projecten in de regio zou zijn ontstaan. Weliswarar werd in het definitieve projectplan als doelstelling opgenomen de ontwikkelingen in de regilo te doen convergeren naar één model, maar nergens in het plan of de bijlagen wondt gesteld dàt er na drie jaar één organisatie zou zijin. Oprichting wan het convergentiecollege moet worden beschouwd als een resultaat dat voor de participanten en het Ministerie aanvaardbaar was, maar niet optimaal.

Dit orglaan was overigens in januari 1990 reeds voor het eerst bijeen gekomen, voordat WVC met de constructie akkoord ging.

95 Deze beoordeling hebbem wij niet geregistreerd voordat het overleg met WVC over de projectopzet plaatsvond. Dat de beoordeling voorafging aam de beschreven gebeurtenissen, is derhalve een veronderstelling. In haar brief van 21.3.1991 (D120) aan de taakgroep convergentie schriff de projectleider: "we moesten eigenlijk al in 1990 de mogelijkheden voor een verdere integratie van de projectorganisiaties onderzoeken. Ik heb dat steeds opgevat als een loze belofte'. Tenzij het hier gaat om een rationalisatie achteraf (zie Weick, 1969), toont deze uilspraak dat de veronderstelling plausibel is. 
Het convergentiecollege kwam een aantal malen bijeen, maar bleef vooral een orgaan waarbinnen vertegenwoordigers van beide projectorganisaties met elkaar van gedachten wisselden. Eén organisatie voor beide projecten is uiteindelijk nooit opgezet (V7). Dat dit niet zou gebeuren, lieten de participanten in hun brief van 15.4.1991 aan WVC (D131) al blijken: 'Gelet op de reeds ingebouwde garanties voor de inhoudelijke afstemming van de deelprojecten zou het zinloos, zelfs contra-productief zijn om tijd en energie te steken in een formele integratie van de projectorganisaties, die immers van een totaal verschillende orde zijn (...) Een zinnig bestuurlijk geïntegreerd model bedenken zou geen eenvoudige opgave zijn, en is gelukkig ook niet nodig. Gezien de worderingen en bestaande garanties op het punt van de inhoudelijke convergentie van de deelprojecten nemen wij aan. dat convergentie binnen de huidige structuur voldoende is gewaarborgd'.

WVC heeft niet gereageerd op deze brief (V6). Het Ministerie liet de zaak rusten en dreigde bijvoorbeeld niet de subsidie in te trekken.

\subsubsection{Reflectie op de gebeurtenissen vanuit de machts-en routineverklaring}

Belichten wij de case vanuit de machts- en routineverklaring, dan kan worden geconcludeerd dat de participanten zich in hun afhankelijkheidsrelatie met WVC ondergeschikt achtten. Vervolgens handelden zij zoals de dominante actor wilde en met behulp van zes algemene bepalingen (handelingsregels) had voorgeschreven.

Het gegeven dat de participanten ten aanzien van één handelingsregel (de integratieregel) van dit patroon afweken, zou in sociaal wetenschappelijk, toetsend onderzoek geen aanleiding hoeven te zijn om de machtsverklaring als gefalsificeerd te beschouwen (zie par. 3.5.3.2). Wij vonden een dergelijke redenering niet bevredigend. Wij wilden inzicht krijgen in de achtergrond van het gegeven dat niet volgens deze regel van de dominante actor werd gehandeld. Juist dan konden wij recht doen aan het 'verstehend' karakter van interactionistisch onderzoek.

Het ging hier om een regel die de ondergeschikte partij onwenselijk vond. De projectparticipanten wilden geen samenvoeging van de projectorganisaties en werkten daaraan niet mee. Deze gang van zaken komt overeen met de routines, die in de brief aan WVC van 15.4.1991 tot uiting komen (D131), hetgeen erop wijst dat de routineverklaring eveneens plausibel is.

De participanten kregen van WVC de gelegenheid zich aan de eis te onttrekken. WVC trad niet op, als dominante actor gaf het Ministerie hen de handelingsruimte te doen wat zijzelf wilden. Deze ruimte was niet onbegrensd: ook al wilden zij dat eigenijik niet, de participanten richtten een convergentiecollege op. De verandering van de situatie ging derhalve hoe dan ook in de richting die de dominante partij wenselijk vond. Deze constatering, die met het oog op zorgvernieuwing belangrijk is, geldt ook voor de navolgende cases.

\subsection{De case van de stichting itz}

In de tweede case staan gebeurtenissen centraal aangaande de stichting itz, op het niveau van het secundair proces en het secundaire niveau van het primaire proces. Wij starten met een beschrijving van de sturingsinteracties tussen de hulpverlenende instellingen (derde cirkel), welke werden afgesloten met de oprichting van de stichting 
itz. Van deze stichting behoorden het bestuur en het directorium tot de strategische top (tweede cirkel).

Vervolgens beschrijven wij de sturingsinteracties tussen leden van de eerste cirkel (vooral de projectmanager van het bureau itz) en van de tweede (het directorium) en derde cirkel, nadat de stichting itz was opgericht. In Fig. 6.5 zijn de cirkels gearceerd waarop de case betrekking heeft.

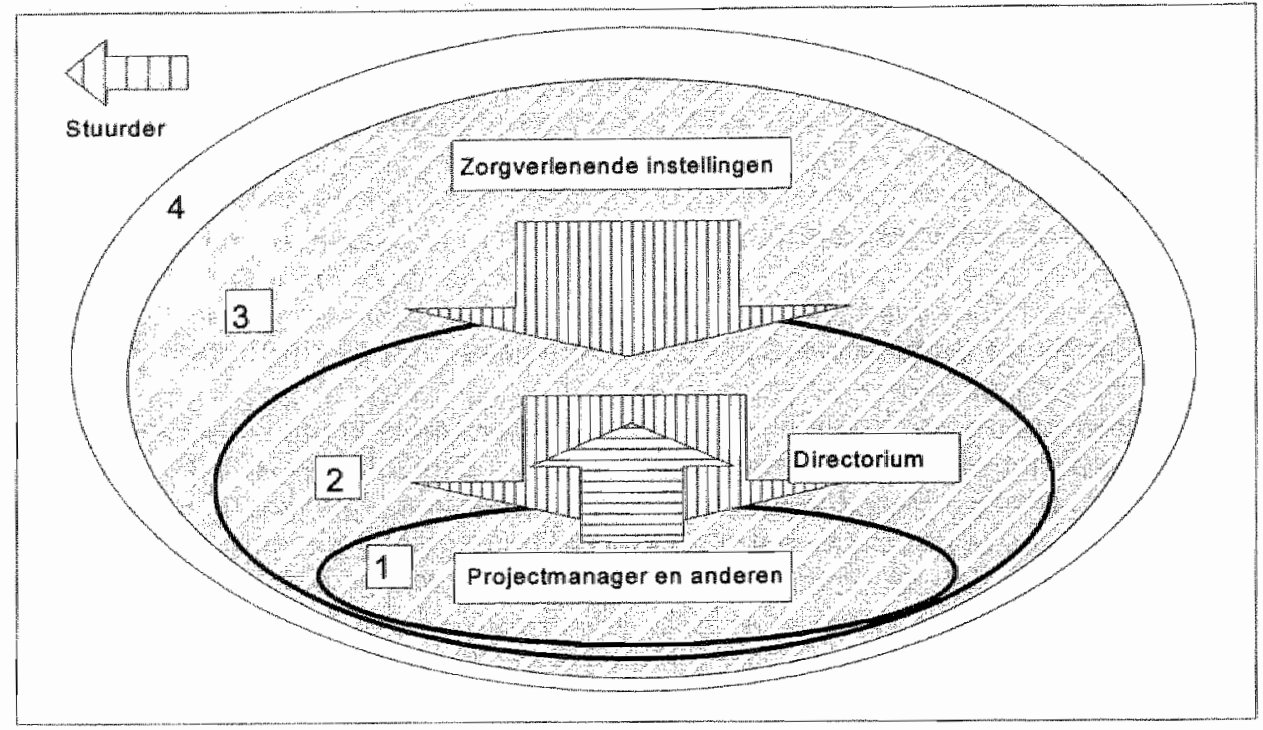

Fig. 6.5 Case van de stichting itz: sturingsinteracties tussen de derde en tweede athankelijkheidscirkel enerzijds en de eerste cirkel anderzijds

\subsubsection{Weergave van de gebeurtenissen aan de hand van de concepten}

Als onderdeel van de nieuwe, onderlinge afhankelijkheidsrelaties die de participanten door de uitvoering van het project itz wilden opbouwen (zie par. 6.2, ook voor de aanleiding), werd medio 1990 de stichting itz opgericht. Met de oprichting werd een afhankelijkheidsrelatie gecreëerd tussen de zorgverlenende instellingen en de projectorganisatie, waarin de eerstgenoemden de dominante partij waren en de laatstgenoemde de ondergeschikte.

Als het ging om het beleid voor de organisatie en uitvoering van de hulpverlening in hun regio, achitten de instellingen het ongewenst indien zij de ondergeschikte partij zouden worden ten opzichte van een gezamenlijke organisatie. De inzet was handelingsruimte voor de instellingen en de projectorganisatie. Uit de sturingsinteracties voor en na de oprichting van de stichting itz blijkt dat de instellingen geneigd waren hun bestaande handelingsruimte tenminste te behouden. Dit was kenmerkend voor hun routines.

De handelingsruimte waarover de thuiszorgorganisaties beschikten was toegekend door het Ministerie van WVC, met behulp van wettelijke erkenningsvoorwaarden. Erkenning was belangrijk. Niet-erkende organisaties bleven verstoken 
van reguliere financiering door het Ministerie. Het Ministerie van WVC had in de loenmalige erkenningsvoonwaarden voor het kruiswerk vastgelegd dat per werkgebied éen kruiswerkorganisatie was toegestaan. Werkgebieden van erkende instellingen voor gezinszorg mochten elkaar alleen overlappen. indien zij onderling een taakverdeling waren overeengekomen. De erkenningsvoorwaarden leverden voor de thuiszorgorganisaties monopolieposities op. Zij waren alleenheerser geworden op een eigen, begrensd werkterrein (Massop et al, 1991; LVT, z.j.).

In de handelingsregels die deel uitmaakten van de statuten van de stichting itz werd de handelingsruimte van de instellingen en de stichting itz vastgelegd en kreeg de dominantie van de instellingen ten opzichte van de projectorganisatio een wettelijke basis, die mogelijkheden bood tot juridische en organisatorische sturing. Zowel de instellingen als de leden van het latere directorium vonden de situatie die zou ontstaan bij gebruik van deze regells wenselijk (routines). De directoriumleden hadden de regels zelf mee opgesteld. Kenmerkend voor deze situatie was dat de instellingen in hun relaties mel de projectorganisatie de zeggenschap behielden over hun eigen handelingsruimte en zeggenschap kregen over de ruimte van de stichting itz. Uitzonderingen daargelaten onderhielden de actoren in de derde cirkel een symbiotische afhankelijkheidsrelatie met de actoren in de latere tweede cirkel.

Andere leden van de projectorganisatie daarentegen, die behoorden tot de eerste cirkel, vonden de beschreven situatie onwenselijk. De afhankelijkheidsrelatie tussen de Iweede en derde cirkel enerzijds en de eerste cirkel anderzijds was asymmetrisch én competitief. De competitie ging om handelingsruimte. Leden van de eerste cirkel -in het bijzonder de projectmanager-waren niet tevreden met de ruimte waarover zij van de instellingen de beschikking hadden gekregen. Zij wilden meer. Wij beschouwen deze betekenis als de aanleiding tot de pogingen die zij ondernamen de situatie te veranderen. Zij deden met dit oogmerk aan het directorium schriftelijke voorstellen voor andere handelingsregels (communicatieve sturing).

Door de behoefte van de leden van de eerste cirkel aan handelingsruimte werd het bezit van deze ruimte voor de instellingen en hun directeuren een machtsmiddel. De behoefte kwam tot uiting in twee kwesties: de poolvorming en de onderhandelingsruimte van de projectmanager. De instellingen waren volgens de statuten de enigen die extra handelingsruimte konden verschaffen (centraliteit en substitueerbaarheid). Zij wilden dit echter niet doen. Honorering van de wensen van de eerste cirkel zou ten koste gaan van hun eigen handelingsruimte. Pogingen tot tegensturing volgden op sturingspogingen. De directeuren van de instellingen in het directorium vormden een coalitie tegen de betrokken leden van de eerste cirkel. Zij trachtten te voorkomen dat dezen hun doel bereikten (strijd).

De betrokken leden van de eerste cirkel verioren uiteindelijk het pleit. Hun handelingsruimte werd niet vergroot. Zij vonden de situatie echter niet aanvaardbaar en legden in 1992 hun werkzaamheden neer. Er kwam voor hen geen vergelijk, van een 'megotiated order' was uiteindelijk geen sprake. De directeuren konden aan leden van de eerste cirkel weliswaar handelingsruimte ontzeggen, maar zij bereikten niet dat deze leden de situatie die voor hen onwenselijk was blijend aanvaardden en voort gingen met handelingen conform de regels van de directeuren. In het geval van de projectmanager was dit voor de directeuren overigens geen onoverkomelijk probleem. $\mathrm{Zij}$ beschikten over een alternatief voor de inzet van de projectmanager (substitueerbaarheid). Fig. 6.6 geeft in hoofdlijnen de opeenvolging weer van de gebeurtenissen. 
Aanleiding (1989)
Sturingsinteracties (these, antithese) (1990-1992)

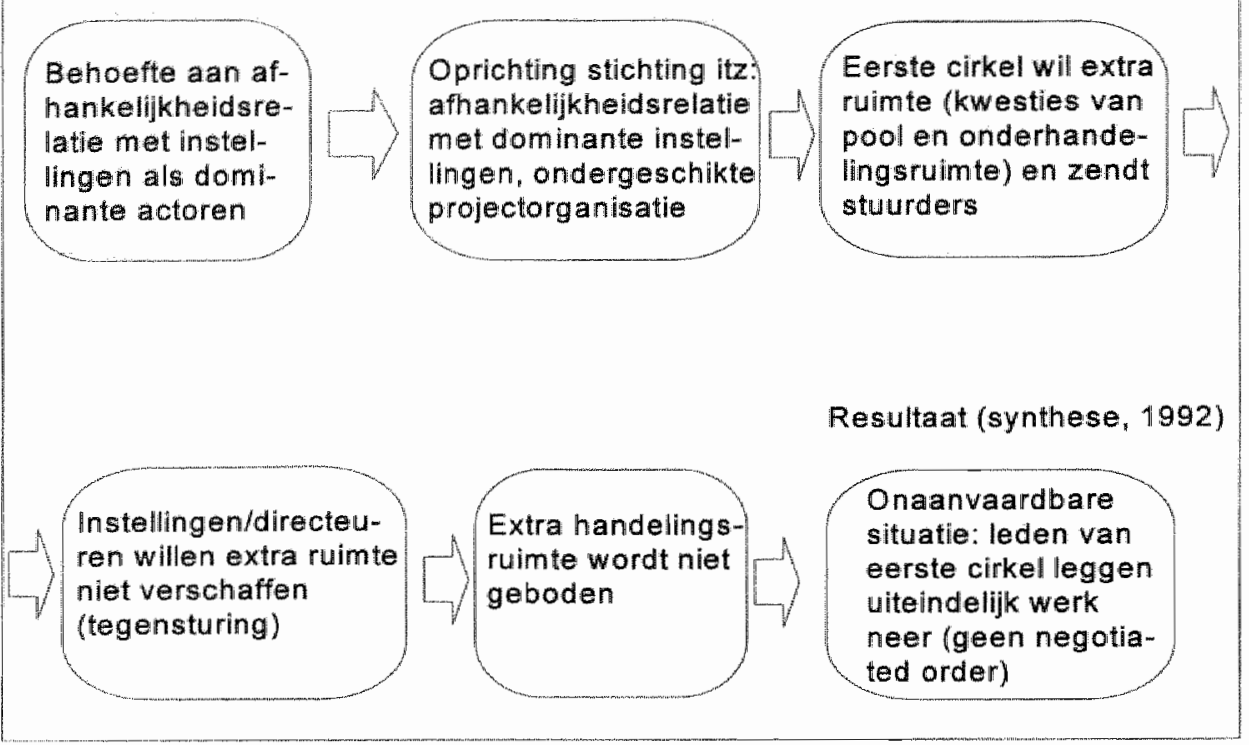

Fig. 6.6 Verloop van gebeurtenissen in de case van de stichting itz

\subsubsection{Empirische gegevens over het verloop van de gebeurtenissen}

Reeds in januari 1990 kregen de instellingen door hun vertegenwoordigers in de projectgroep itz de gelegenheid sturingspogingen te doen bij de vormgeving van de organisatie van het project. De leden van de projectgroep itz besloten dat voorstellen voor de vormgeving van het project itz en de stappen die tijdens de vormgeving dienden te worden genomen, voor advies moesten worden verzonden naar de ondernemingsraden en besturen van de instellingen. Op dlat moment was de afhankelijkheidsrelatie tussen de projectorganisatie en de instellingen al zichtbaar, die uiteindelijk werd vastgelegd in de statuten van de stichting itz.

Ook besloten zij dat de concept-statuten van de stichting itz aan de instellingsbesturen moest worden voorgelegd, ten behoeve van besluitvorming. De besturen gaven na ontvangst daarvan aan welke wijzigingen zij in de statuten aangebracht wensten te zien. Deze wijzigingen werden in de projectgroep itz besproken en vervolgens in de statuten verwerkt. Dit proces ging voort totdat de besturen en de directeuren zich in de statuten kon vinden. Op 31.5.1990 werd de stichting itz opgericht, ook al werd dit niet door iedereen van harte ondersteund (zie par. 4.5.2) (D1, 10, 19, 29,37).

De instellingen kregen van hun directeuren de medewerking om de handelingsregels in de uiteindelijke stichtingsstatuten op hun eigen wensen af te stemmen. De directeuren trachtten nadrukkelijk daarvoor gelegenheid te bieden. Zo uitte de directeur van het kruiswerk op 21.3.1990 in de vergadering van de projectgroep itz bezwaar tegen het feit dat voor het op te richten directorium reeds vergaderingen waren 
gepland, terwij de besluitvorming van de besturen over de stichtingsstatuten nog niet rond was. Op het bezwaar werd door andere projectgroepleden gereageerd met de uitspraak dat formele zaken inderdaad pas konden worden gedaan nadat de besluitvorming door de instellingsbesturen was afgerond, maar dat voorbereidingen alvast konden worden getroffen (D29).

De stichting itz werd pas een feit nadat de instellingen met de bijgestelde statuten en met de oprichting akkoord gingen. Daaruit concluderen wij dat de stichtingsstatuten uiteindelijk de relatie tussen instellingen en stichting itz weergaven die de instellingen wenselijk vonden. Anders was de stichting gewoonweg niet opgericht.

De sturingsinteracties hadden regels tot resultaat, die bij gebruik aan de instellingen ruimte zouden bieden voor de verlening van intensieve thuiszorg, naast de ruimte die zij al hadden voor de reguliere zorg. De besturen hadden de medewerking wan hun directeuren benut om deze ruimte te creëren.

Dit blijkt uit de volgende wijziging in de concept-statuten. Tijdens de vergadering van 28.2.1990 werd in de conceptversie van artikel 4 bij de beschrijving van de wijze waarop de stichting itz haar doel trachtte te verwezenlijken, de zinsnede 'door (...) deze dienstverlening in harmonie met de gebruikelijke dienstverlening van de participanten te organiseren' gewijzigd in 'deze diensten worden verleend vanuit de participanten en in harmonie met de gebruikelijke dienstverlening van de participanten"96. De verlening van intensieve thuiszorg moest niet alleen harmoniëren met de wijze waarop de instellingen gewend waren hulp te verlenen, maar de intensieve thuiszorg moest door de participanten zelf worden geleverd. Daarenboven werd in de concept-statuten opgenomen dat de hulpverlening door de stichting itz alleen aanvullend mocht zijn op de zorg die de instellingen al leverdien (D15, 19).

Verder hadden de instellingen langs de weg van de statuten voor zichzelf posities gereserveerd in het bestuur en het directorium van de stichting itz. Aldus kregen zij via hun vertegenwoordigers een stem in het beleid van de stichting itz. Dat was met opzet gedaan. In de vergadering van 26.4.1990 van de projectgroep itz zei de vertegenwoordiger van de regionale gezinszorginstelling dat haar bestuur de voorwaarde had gesteld dat de instelling een plaats kreeg in het bestuur van de stichting itz. Daarop werd gereageerd met de uitspraak dat de formulering van de statuten onder andere dit als oogmerk had (D37, 51). De stichting itz op haar beurt kreeg geen stem in het beleid van de afzonderlijke instellingen. De handelingsruimte van de stichting itz was daarmee afgebakend. De instellingen mochten deze ruimte betreden, andersom mocht dit niet. Door de statutaire handelingsregels werd de stichting itz langs meerdere kanten ondergeschikt gemaakt aan de instellingen.

De gegevens maken duidelijk dat deze situatie de instemming had van de directeuren, met uitzondering van de directeur van de regionale gezinszorg, voor wie de oprichting van de stichting itz een verandering was die te vergaand was (V3). Er waren in de projectorganisatie meer leden die niet tevreden waren met de situatie, zij het om een andere reden. Zij behoorden tot de eerste cirkel. Er zijn meerdere kwesties geweest waarbij actoren uit de eerste cirkel stuurders verzonden om de situatie te veranderen. Doorvoering van de verandering zou ertoe hebben geleid dat de stichting itz de handelingsruimte van de instellingen kon betreden. Wij bespreken twee kwesties. Beide betreffen de projectmanager van het bureau itz.

Behalve de projectmanager behoorde de operagroep tot degenen die ontevreden waren met de situatie. De operagroep was ingesteld om te fungeren als schakel tussen 
het directorium en hulpverleners uit de instellingen en werd eind 1992 opgeheven (V6). De operagroep wenste meer te doen dan de directeuren toestonden, achtte de situatie zoals zij deze waarnam niet aanvaardbaar en wond dat zij haar werk moest beëindigen. 'De operationaliseringsgroep wordt opgeheven want de leden vinden dat ze met betrekking tot intensieve thuiszorg zelf geen beleid kunnen formuleren. Het voorste! was dat de hoofden zorg een beleidsoverleg moeten vormen. De directeuren waren hierop tegen; zij willen dat aan hen wordt gerapporteerd waarna zij zelf bekijken wat te doen valt. De directeuren willen nadrukkelijk alle touwtjes in handen hebben' (V7).

\subsubsection{De kwestie van de (onderhandelings)ruimte van de projectmanager}

Gedurende de projectperiode zijn twee opeenvolgende projectmanagers werkzaam geweest. De eerste projectmanager nam in december 1990 ontslag ${ }^{97}$ en werd in januari 1991 opgevolgd. De relatie tussen de stichting itz en de projectmanagers was met behulp van een arbeidsovereenkomst van een juridische basis voorzien. Het ging om een relatie tussen een dominante actor (het directorium als werkgever namens de stichting itz) en een ondergeschikte actor (de projectmanager als werknemer) (D59, 84, 99).

Door de avereenkomst te ondertekenen moet iedere projectmanager van de aard van de relatie, zoals wij die hebben weergegeven, op de hoogte zijn geweest. De overeenkomst werd ondertekend voordat de projectmanager met de werkzaamheden begon. Niettemin bieden de gegevens geen inzicht in het machtsmiddel, waarop de asymmetrische afhankelijkheidsrelatie uiteindelijk was gebaseerd. Was het salaris? Ging het om de mogelijkheid een baan te krijgen en het eigen beroep uit te oefenen? Het is niet bekend.

Vast staat dat de eerste projectmanager en zijn opvolger in een aantal gevallen handelden conform de opdrachten die de werkgever verstrekte (zie par. 5.3.3). Zij handelden als ondergeschikte. De manier waarop de relatie was vastgelegd bood de stichting itz gelegenheid tot juridische, economische en organisatorische sturing. Voor zover bekend heeft het directorium niet getracht sturing te geven aan het werk van de projectmanager door te verwijzen naar de arbeidsovereenkomst en hebben de projectmanagers de aard van de relatie niet ter discussie gesteld.

Kennelijk vonden zij de relatie op zichzelf aanvaardbaar en deden zij (tot een nog te bespreken moment) wat de werkgever verlangde, zonder dat deze een beroep moest doen op de beschikbare mogelijkheden tot sturing (afgezien van communicatieve sturing bij de verstrekking van opdrachten).

De handelingsruimte die door de directeuren werd geboden, was in de perceptie van zowel de eerste projectmanager als zijn opvolger echter te klein. Zij trachtten deze te vergroten. De eerste poging vond plaats tijdens de directoriumvergadering van 14.11.1990. De toenmalige projectmanager legde aan de directeuren een notitie voor over "de onderhandelingsruimte projectmanager' (D78, 80). Daarin werd voorgesteld dat de projectmanager voortaan zorg zou inkopen bij de zorgaanbiedende organisaties, inclusief particuliere instellingen.

Honorering van deze wensen zou er niet alleen toe hebben geleid dat de projectmanager voortaan de ruimte kon betreden die voordien was voorbehouden aan de instellingen, maar ook dat deze functionaris in die ruimte werk zou doen, dat tot dan door de instellingen zëlf was gedaan. Zij hadden altijd zelf bepaald hoe de zorg werd 
ingezet en welke hulpverleners moesten worden ingeschakeld. Het directorium besloot dat dit aandachtspunt zou blijven liggen tot de volgende vergadening en is niet meer op de notitie terug gekomen. Het wilde de wensen van de projectmanager niet honoreren en dit gebeurde ook niet (V7). De handelingsruimte van de instellingen werd niet aangetast. De situatie die voor de projectmanager onwenselijk was werd niet veranderd in een situatie die voor het directorium onwenselijk was.

\subsubsection{De kwestie van de poolvorming}

Het vraagstuk van de handelingsruimte van de projectmanager kwam terug in de tweede kwestie. Deze betrof de vorming van een gezamenlijke pool van hulpverleners, van waaruit de projectmanager de inzet van intensieve thuiszorg kon regelen. Volgens de voorstellen moest de pool ressorteren onder het bureau itz. De projectmanager diende de bevaegdheid te krijgen de leden van de pool voor de hulpverlening in te zetten, indien de personele capaciteit wan de instellingen te gering was om intensieve thuiszorg te kunnen bieden.

Het eerste voorstel over de vorming van een pool was afkomstig van de vertegenwoordiger van de huisartsen in de projectgroep itz, die in juli 1990 werd aangesteld als de eerste projectmanager van het bureau itz. Het voorstel werd door hem in april 1990 aan de projectgroep itz voorgelegd, nadat hij had geconstateerd dat de instellingen (in het bijzonder de stedelijke gezinszorg) een tekort hadden aan menskracht. Door dit tekort zou het volgens hem niet mogelijk zijn snel le reageren op een hulpwraag, zodra medio 1990 mel de verlening van intensieve thuiszorg zou zijn gestart (V6, 7; D37). Vorming van een pool onder het gezag van de projectmanager werd door hem als de oplossing voor dit probleem beschouwd.

De meningen in de projectgroep itz waren verdeeld. De directeur van de regionalle gezinszorg bijvoorbeeld reageerde op de ideeën met de uitspraak dat haar organisatie het capaciteitsprobleem zou kunnen opvanglen: 'er hoeft in aanvang geen nieuwe pool te worden gestart" (D33, 37). Ondanks deze afkeurende reactie besloot het directorium in september 1990 de 'werkgroep uitbreiding aanbod intensieve thuiszorg' in te stellen, die onder andere de taak kreeg de magelijkheden tot de organisatie van een pool te werkennen. De werkgroep adviseerde in december 1990 de pool tot stand te brengen. Het directorium nam geen besluit. Hoewel het tekort aan menskracht en de kwestie van de poolvorming vervolgens tot november 1991 meerdere malen aan de orde kwamen, werden over beide onderwerpen geen beslissingen genomen (D70, 84, 117, 179, 193, 196).

In december 1991 veranderde dit. Tijdens de bespreking van een rapport van de projectleider over de gang van zaken bij de verlening van intensieve thuiszorg. onderschreef het directorium de noodzaak van poolvorming om de capaciteitsproblemen te omzeilen. We moeten een gedifferentieerd zorgaanbod ontwikkelen; de mensen 98 worden gezamenlijk en nadrukkelijk ten behoeve van intensieve thuiszorg geworven. maar komen in dienst bij de afzonderlike instellingen; de mogelijkheden voor een nauwere samenwerking op het punt van de organisatie van de zorginzet zullen worden bestudeerd; de organisaties pakken het bovenstaande samen buiten de vergaderingen van het directorium om op, het directorium houdt de vinger aan de pols; kruiswerk en gezinszorg gaan met prioriteit proberen een pool te vormen van verplegenden, ziekenverzorgenden, verzorgenden, helpenden, oppashulpen et cetera 
ten behoeve van nacht- en dagverpleging, nacht- en dagverzorging et cetera" (D192, $201)$.

Duidelijk is dat de instellingsdirecteuren de poolvorming in eigen hand wilden houden. Ten aanzien van de vraag wie het gezag moest voeren over de leden van de pool, hielden zij zich vooralsnog op de vlakte. Niettemin was de indruk gewekt dat de directeuren werk gingen maken wan de poolvorming.

Maar toen gebeurde het volgende. De directeur van de kruisvereniging zei op 15.1.1992 weliswaar dat een pool nodig was, maar plaatste vervolgens "vraagtekens bij de prioriteit van de poolvorming voor ziln instelling: het vraagt een flinke investering van de instellingen (...), de vraag betreft vooral de gezinszorg. Hij stelt voor dat de gezinszorg met de poolvorming aan de slag galat. Het direcitorium besloot daarop dat een werkgroep aan het werk moest gaan om verder inhoud te geven aan de voorstellen over poolvorming, die onder andere door de werkgroep uitbreiding aanbod itz waren gedaan.

De directeur van de kruisvereniging zel vervolgens dat zijn instelling niet zou participeren in deze werkgroep. De stichting itz mocht wat hem betrof overgaan tot de werving van verpleegkundigen, die bij de kruisvereniging in dienst konden komen (D207). Het kruiswerk deed een stap terug.

Twee weken later besloot het directorium dat de pool er moest komen (D212). Nadat gedurende bijna twee jaar definitieve beslissingen over de kwestie vooruit waren geschoven, werd door het directorium een besluit genomen dat er uiteindelijk toe hadden kunnem leiden dat de handelingsruimte van de instellingen werd betreden door de stichting itz. Dit zou het geval zijn geweest als de projectmanager zeggenschap had gekregen over de pool zoals volgens de voorstellen de bedoelling was (V7).

In maart 1992 werd bekend gemaakt dat de instellingen die zouden participeren in de werkgroep, elkaar nog niet hadden gesproken over de poolvorming (D218). Dit is het laatste dat wij over de kwestie hebben vernomen. De pool is niet gevormd. De wensen van de projectmanager werden wederom niet gehonoreerd. De handelingsruimte van de instellingen bleef uiteindelijk ook in deze kwestie intact. Ook konden zij binnen die ruimte blijven handelen zoals zij wilden.

\subsubsection{Ontslag van de projectmanager}

In de beide besproken kwesties trok de projectmanager aan het kortste eind. De directeuren als vertegenwoordigers van de instellingen waren niet alleen op papier de dominante partij. Ook in de praktijk gedroegen zij zich als zodanig, en met succes. Vooral kruiswerk en gezinszorg toonden zilch volgens de projectleider machtig (V7).

De directeuren gingen besluitvorming uit de weg of namen besluiten die zil vervolgens niet uitvoerden. Uitvoering van de bestuiten was wellicht in het belang van de stichting itz, maar niet in het belang van de instellingen. De directeuren verkozen het bellang van de eigen instelling te dienem. Dit wordt zichtbaar in uitspraken van de projectleider: "In het directorium was bestoten een gezamenlijke pool van hulpverleners op te zetten. De gezinszorg zou als trekker fungeren. Dit is instellings-intern gesaboteerd; de gezamenlijke pool is er niet gekomen. (...) De dubbele loyaliteit van de directeuren in het directorium was een probleem. Zij hebben duidelijk twee petten op en die blijken verschillend te zijn. Voorbeeld: het directorium besluit tot de vorming van een pool van hulpwerleners, vervolgens doen de instellingen er niets aan" (V7).

Een jaar eerder had de projectleider de verwachting uitgesproken dat de instellingen de zeggenschap over de inzet van hulpverleners nooit uit handen zouden geven: "zelfs al zouden ze daartoe bereid zijn, en dat zijn ze niet, dan zouden de 
instellingen ruzie krijgen over wie deze bevoegdheid mag hebben: elke instelling zou dan willen dat iemand uit de eigen gelederen deze bevoegdheid zou krijgen' (v6).

Ook al trokken de directeuren en hum instellingen in de kwesties aan het langste eind, dat betekende niet dat de projectmanager zich bij de gang van zaken neerlegde en woortging te doen wat haar werkgever had opgedragen. In januari 1992 nam zil ontslag. Onvrede met de situatie, die zij in haar eigen optiek niet kon veranderen, was de aanleiding. De situatie was voor haar niet langer aanvaardbaar. Tijdens de vergadering van het directorium van 15.1 .1992 wordt deze stap door haar als volgt uitgelegd: 'De functie geeft haar geen bevrediging. Zij werkt noch als arts noch als manager van een project: ze heeft weinig kunnen bijdragen, er ligt te veel bij de instellingen. Het project schiet niet hard op, er wordt weinig extra's geleverd, het gaat allemaal heel langzaam en heel moeizaam. Gezien haar leeftijd moet ze bovendien haast maken met het omzien maar een andere werkkring" (D207).

De projectmanager vergeleek haar wensen met de betekenis die de situatie voor haar had, concludeerde dat beide onverenigbaar waren en hakte vervolgens de knoop door: zij stapte op.

De handelingen van het directorium na de ontslagname van de projectmanager en de bijbehorende besluiten van het stichtingsbestuur (D213) bevestigden de aanspraken van de instellingen op hun eigen handelingsruimte, die in de statuten tot uiting kwamen.

De situatie in de hulpverlening maakte directoriumbesluiten nodig. De bevoegdheden waarover het bureau itz in de oorspronkelijke vorm beschikte, voldeden niet langer om te kunnen omgaan met de capaciteitsproblematiek bij de verlening van intensieve thuiszorg. De problematiek vereiste orwel dat de bevoegdheden van de projectmanager werden uitgebreid tot de inzet van menskracht uit de pool, ofwel dat de instellingen intern naar oplossingen voor de capaciteitsproblemen zouden zoeken (V7).

De directeuren beslotem het bureau itz op te heffen en stelden geen nieuwe projectmanager aan. Hieruit blijkt dat zij de menskracht van een projectmanager niet onontbeerlijk vonden voor die verlening van zorg. De taken van de projectmanager werden overgenomen door leden van kruiswerk en gezinszorg (zie par. 4.4.2), de bevoegdheid tot het inzetten van menskracht bleef in handen van deze instellingen. In de perceptie van de projectleider zou uitbreiding van de bevoegdheden van de projectmanager 'te ver vooruitlopen op de eventuele toekomstige samenwerking tussen de instellingen' (V7). Met andere woorden, de situatie die zou ontstaan met de uitbreiding van de bevoegdheden van de projectmanager, kwam niet overeen met de situatie die de leden van het directorium op dat moment wenselijk vonden.

\subsubsection{Reflectie op de gebeurtenissen vanuit de machts-en routineverklaring}

Tijdens de reeks gebeurtenissen die werd afgesloten met de oprichting van de stichting itz toonden de directeuren zich ondergeschikt aan hun eigen instellingen. Bij de formulering van de stichtingsstatuten gaven zij gehoor aan de wensen van hun bestuur. De gegevens wijzen erop dat de directeuren deze handelwijze wenselijk vonden. Zij dienden uit eigener beweging de belangen van hun insteling. De uitspraak in par. 6.4.2 van de projectleider aver de dubbele loyaliteit van de directeuren is daarvoor illustratief. De machts-en routineverklaring lopen hier duidelijk door elkaar.

Na de oprichting van de stichting itz was het directorium op papier de dominante partij in een asymmetrische afhankelikheidsrelatie mel de projectmanager. Het gedroeg zich ook als zodanig. Het gaf opdrachten. De opeenvolgende projectmanagers 
wisten, voordat zij hun functie gingen vervullen, dat zij de ondergeschikten waren. Vervolgens voerden $z i j$-voor zover valt na te gaan; zie par. 5.3.3-opdrachten wan hett directorium uit. Zij gedroegen zich als ondergeschikten. Dit wijst erop dat de machtsverklaring plausibel is.

Echter, uiteindelijk besloot de -tweede- projectmanager niet langer te doen wat het directorium wilde. Zij nam ontslag, nadat zij had geoordeeld dat de instellingen haar niet de ruimte zouden geven te doen wat zijzelf wenselijk of noodzakelijk achtte. Ook al drong zij daarop aan, de situatie werd door het directorium niet conform haar wensen aangepast. De situatie was voor haar niet langer aanvaardbaar en zij vertrok. De machtsverklaring is plausibel tot het moment waarop de projectmanager ontslag nam. Juist op dat moment laat de routineverklaring haar relevantie zien.

\subsection{De case van de organisatie van itz aan pg-patiënten}

De laatste case die wij beschrijven heeft vooral betrekking op het secundaire niveau van het primaire proces. In deze case gaat de aandacht uit naar de sturingsinteracties tussen de zorgverzekeraar (derde cirkel) en de projectorganisatie (tweede cirkel; het directorium) (Fig. 6.7). Het thema is de organisatie van de verlening van intensieve thuiszorg aan psychogeriatrische patiënten (pg-patiënten).

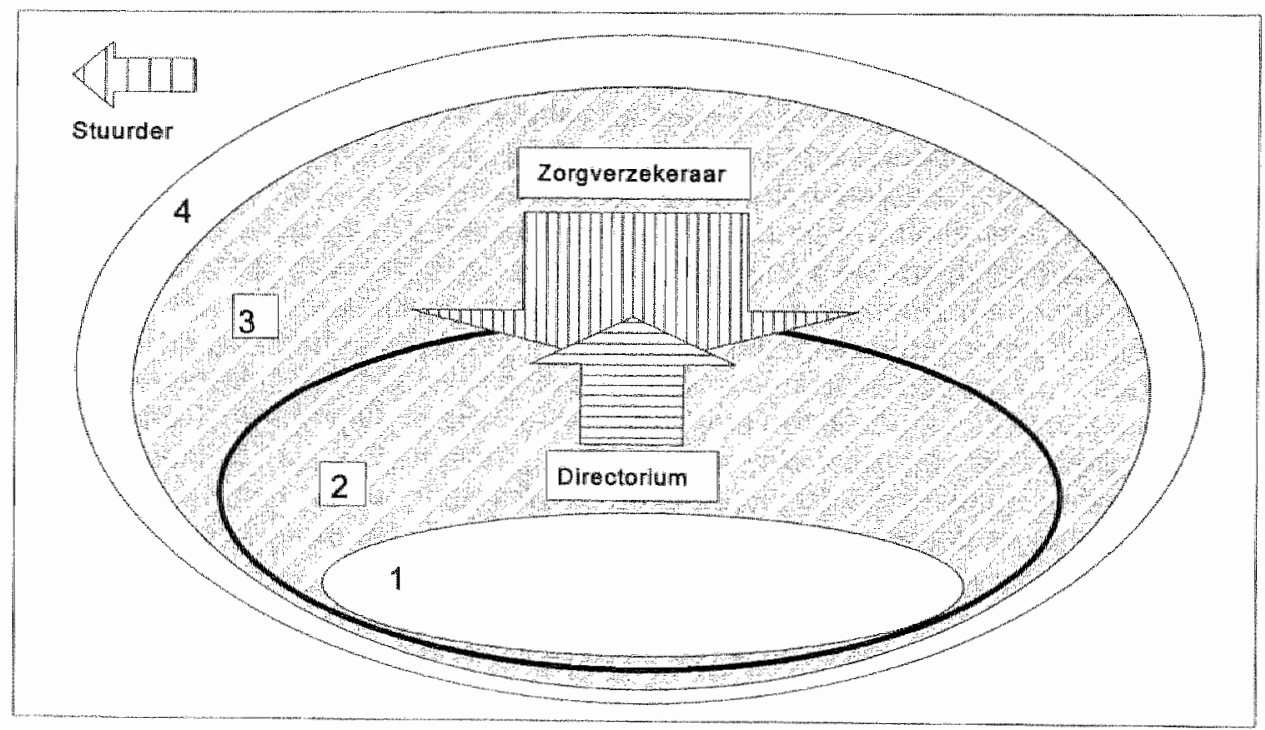

Fig. 6.7 Case van de pg-patiënten: sturingsinteracties tussen de derde en tweede cirkel

\subsubsection{Weergave van de gebeurtenissen aan de hand van de concepten}

De deelnemers aan het project en de zorgverzekeraar vonden de situatie in de hulpveriening aan pg-patiënten, zoals zij die percipieerden, niet aanvaardbaar (routines; zie par. 6.2). Zij vonden het voorafgaand aan de start van het Programma 
van WVC reeds van belang deze situatie te veranderen. Gedurende de gehele projectperiode werd verlening van hulp in aanvulling op de reguliere zorg van de instellingen (intensieve thuiszorg) noodzakelijk geacht.

Om aanvullende zorg te kunnen verlenen, deden de leden van het latere directorium reeds vóór 1990 een beroep op de financiële middelen die de zorgverzekeraar beschikbaar kon stellen. Financiering van aanvullende thuiszorg was ingekaderd binnen de 'regeling subsidiëring ziekenfondsraad intensieve thuiszorg' (Ziekenfondsraad, 1991). Regionale verbindingskantoren, waaronder het ziekenfonds dat bij het project betrokken was, waren de uitvoerders van de regeling. Zij waren de ondergeschikte partij in een asymmetrische afhankelijkheidsrelatie met de ziekenfondsraad.

Voor goedkeuring van de regeling was de Ziekenfondsraad afhankelijk van het Ministerie van WVC. Door de keuze van de projectparticipanten voor levering van intensieve thuiszorg en de dlaarop volgende aanvraag van subsidie in het kader van genoemde regeling (D18), werd in één slag een afhankelijkheidsrelatie gecreëerd tussen de tweede, derde en vierde cirkel.

Financiële bijdragen van de verzekeraar waren fundamenteel. Alleen de middelen uit de subsidieregeling konden aan de instellingen de ruimte verschaffen de zorg te verlenen die zij noodzakelijk wonden. Alternatieve middelen waren niet beschikbaar, zonder de middelen van de verzekeraar kon intensieve thuiszorg niet worden verleend (centraliteit en substitueerbaarheid). Gezien de doelstellingen in het projectplan (D20), zou het project in dat geval geen bestaansgrond hebben gehad. Door hun behoefte aan financiering en doordat zij de verzekeraar verzochten geldelijke middelen te verschaffen, creëerden de participanten met deze partij een asymmetrische afhankelijkheidsrelatie, waarin zijzelf de ondergeschikten waren.

Voor het teweeg brengen van verandering waren de verzekeraar en de instellingen wederkerig afhankelijk. Zonder de geldelijke middelen van de verzekeraar was aanvullende hulpverlening onmogelijk. Echter, zonder de medewerking van de instellingen -voor kruiswerk en gezinszorg- kon de verzekeraar niet zorgen voor verbetering van de hulp aan een categorie van hun verzekerden: de pg-patiënten. Deze instellingen in het project waren namelijk de enigen in de regio die de vereiste hulp konden verlenen, alternatieve zorgaanbieders waren niet aanwezig (R1). De diensten die zij konden verlenen, de menskracht die zij voor intensieve thuiszorg konden inzetten, vormden daardoor voor de instellingen een machtsmiddel. Ook al was de verzekeraar dominant, de participanten aan het project waren niet verstoken van macht.

Met betrekking tot het oogmerk van de verandering (invoering van handelingsregels die bij gebruik zouden leiden tot hulpverlening aan pg-patiënten, welke in de perceptie van de betrokkenen kwalitatief beter was) waren de relaties tussen de betrokkenen in deze case symbiotisch. Alle partijen gaven dezelfde betekenis aan de situatie: deze was onwenselijk en moest worden veranderd. Met het oog op verandering deden zij onderling meerdere malen pagingen elkaar ertoe te bewegen te doen wat over en weer wensellik werd geacht.

Gedurende de onderlinge interacties deden de betrokkenen voorstellen en reageerden zij op elkaars voorstellen (communicatieve sturing). De verzekeraar trachtte daarnaast zijn wensen te verwezenlijken door gebruik te maken van de wettelijke mogelijkheden die de subsidieregeling intensieve thuiszorg hem bood om aan de zorgverlenende instellingen in het project gelden voor intensieve thuiszorg beschikbaar te stellen of te ontzeggen (juridische en economische sturing, met gebruik making van externe regels). 
Over de aard van de veranderingen en de handelingsruimte die daarvoor beschikbaar moest zijn, verschilden de inzichten. De relatie tussen de verzekeraar en het directorium was dienaangaande competilief. De competitie ging mettertijd over in strijd. Daarin wormden de leden van het directorium een coalitie tegen de verzekeraar. Hoewel de instellingen de geldelike middelen van de verzekeraar nodig hadden, conformeerden hun directeuren zich niet zonder slag of stoot aan de wensen van het ziekenfonds.

Birnen de asymmetrische relatie slaagde de verzekeraar er niet zonder meer in zijn wensen aan het directorium op te leggen. In tegendeel, op het hoogtepunt van de strijd die allengs ontstond. werd een patstelling bereikt. De wensen van de partjen werden over en weer onaanvaardbaar gewonden. Echter, met betrekking tot het oogmerk van de verandering zelf was gedurende het gehele proces de relatie tussen de verzekeraar en de leden van de projectorganisatie symbiotisch gebleven. Betrokkenen trachtten met hernieuwde inzet de patstelling te doorbreken. Dit gebeurde, waarna in 1992 een situatie werd gecreeerd, die door de verzekeraar en de leden van de projectorganisatie -met uitzondering van het amw- werd aanvaard (negotiated order').

Inzet van de interacties binnen de competitieve afhankelijkheidsrelatie was ook in deze case handelingsruimte. Die geldelijke middelen die de verzekeraar voor de verlening van intensieve thuiszorg beschikbaar wilde stellen, waren in de perceptie van de directeuren ontoereikend (de kwestie van de financiering). De verzekeraar stelde aan de verstrekking van geldelijke middelen bovendien voowwaarden, waarmee een deel van het directorium het oneens was. Deze voorwaarden betroffen handelingsregels (externe regels) voor de organisatie van de intensieve thuiszorg, die bij gebruik door de projectparticipanten ertoe zouden leiden dat de riagg aan de hulpverlening zou deelnemen en het amw niet (de kwestie van de organisatie).

De huisartsen en het amw wonden de situatie waartoe het gebruik van deze regels zou leiden onwenselijk (routhes). Van het kruiswerk is het standpunt niet geheel duidelijk. Wel hebben wij vastgesteld dat deze werksoort, evenals de gezinszorg, prioriteit gaf aan de afstemming in de hulpverlening tussen kruiswerk en gezinszorg (zie par. 4.5.2). De regionale gezinszorg toonde zich in de gegevens sceptisch over de betrokkenheid van het amw bij de hulpverlening. De directeur van deze instelling betwijfelde of het amw meenwaarde kon geven aan de hulpverlening. Deelname van het riagg kwam overeen met de wensen van de regionale en stedelije gezinszorg (routines).

Toen de verzekeraar met het directorium overeenstemming bereikte over de ormang van de financiering (de verzekeraar zegde meer middelen toe dan voorheen). waarbij de verzekeraiar onverminderd vasthield aan zijn wensen betreffende deelname van amw en riagg, legden de voorstanders van betrokkenheid van het amw bij de hulpwerlening zich bij de situatie neer. De pg-patiënten werden als doelgroep opgenomen in het project, maar het amw beeindigde zijn projectparticipatie. In Fig. 6.8 zijn de gebeurtenissen schematisch weergegeven.

\subsubsection{Empirische gegevens over het verloop van de gebeurtenissen}

De volgende uitspraken van leden van het directorium laten zien dat zij aan hun positie in de beschreven athankelikheidsrelatie met de verzekeraar dezelfde betekenis 
gaven als wij99. Zij beschouwden zich afhankelijk van de gelden van de verzekeraar. Over de voorbereiding van het project zei een directeur: "daarmee was men al een jaar of vijf bezig. Er kwam pas echt een doorbraak op het moment dat de financier, het ziekenfonds, er zich mee ging bemoeien. (...) Toen het ziekenfonds daar ${ }^{100}$ lucht van kreeg, dit hebben ze snel opgepikt en ze hebben ook risico"s willen lopen, zijn ze zich ermee gaan bemoeien en hebben ze toezeggingen gedaan. Het ziekenfonds stak zijn nek uit: voordat de zaken beklonken waren was de toezegging al rond 101 . Vanaf dat moment kwam de zaak in een stroomversnelling' (V2).

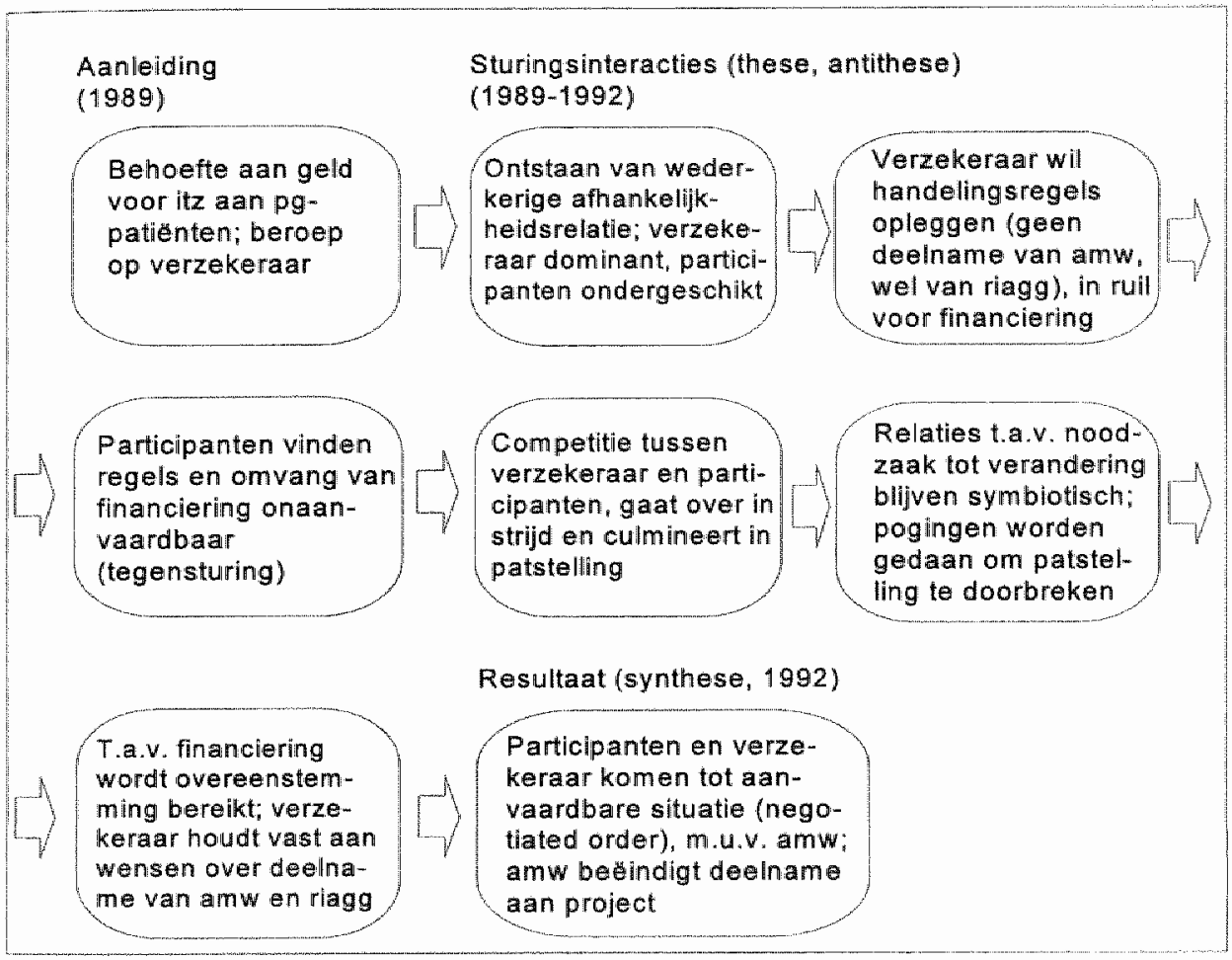

Fig. 6.8 Verloop van gebeurtenissen in de case van de pg-patiènten

Andere directoriumleden deden de volgende uitspraken. "Het voorspoedig verloop van het project is vooral het gevolg van de lange voorbereidingstijd. Het plan lag klaar; toen financiering door het ziekenfonds mogelijk werd kon men zo starten' (V3). 'Het knelpunt bij het project itz was: (...). Daardoor ontstond vertraging; bovendien was de financiering niet rond. Dit laatste gaf veel problemen (wat kan wel/niet gedeclareerd

Deze betekenis is nitet vastgesteld voordat de handelingen zich voltrokken. Er is een kans op rationalisatie achteraf.

100 De respondent doell hier op de subsidlieregeing intensieve thuiszorg, welke voorafgaand aan thet project in voorbereiding was.

101 Hel gaat orn de toezegging dat verlening van intensieve thuiszorg zou worden gefinancierd. 
worden?). Zonder de nieuwe mogelijkheden van de ziekenfondsraad 102 was het niet gelukt' (V5).

Niet alleen aan het begin van het project beschouwden de leden van het latere directorium zich als de ondergeschikte partij. Ook nadien was dit het geval (D74, 125). Geld van de verzekeraar moest aanbieders de ruimte bieden hulp te verlenen zoals zij dat wilden. Dit werd in de directoriumvergadering van 10.4.1991, toen de financiering van de deeiname van het amw aan de hulpverlening uit het budget voor intensieve thuiszorg werd besproken, tegen de vertegenwoordiger van de verzekeraar letterlijk gezegd: 'geef ons de ruimte ook amw in te zetten binnen de f. 1.400,- per patiënt per week voor het experiment met pg-patiënten' (D125).

Het projectplan voorzag nadrukkelijk in de mogelijkheid de doelgroepen van het project uit te breiden. Daarin werd nog niet gesproken over mogelijkheid van uitbreiding met pg-patiënten. In januari 1990 oordeelde de zorgverzekeraar dat pg-patiënten zo spoedig mogelijk als doelgroep van het project moesten worden opgenomen (D10). Ook vanuit het directorium was de noodzaak geuit tot opname. Volgens de directeur van het kruiswerk vielen pg-patiënten in de hulpverlening vaak tussen wal en schip (D63). Niettemin honoreerde het directorium niet onmiddellijk de wens van de verzekeraar om pg-patiënten als doelgroep in het project op te nemen. Het duurde circa anderhalf jaar voordat aan deze groep aanvullende hulp werd verleend, aanvankelijk op experimentele basis.

In de projectperiode is het vraagstuk van hulp aan pg-patiënten tijdens 25 vergaderingen van het directorium en zijn voorganger besproken. Uit deze besprekingen blijkt dat de betrokken actoren het lang niet altijd eens waren over een passende financiering en organisatie van de hulp. Pas toen overeenstemming tussen actoren in deze beide kwesties in zicht was, werd gestart met de hulpverlening.

\subsubsection{De kwestie van de financiering}

De verzekeraar deed bij monde van zijn vertegenwoordiger een aantal budgetvoorstellen aan het directorium, waarbij hij handelingsruimte bood die door dit netwerk als te beperkt werd ervaren. Het directorium trachtte de ruimte meerdere malen te vergroten door tegenvoorstellen te doen. De verzekeraar op zijn beurt stuurde aan op beperking van de ruimte (D18, 34, 84, 112, 118, 125, 137, 138, 173, 196, 198, 211 . $213,215,216,218-220,237,259,260,268,272,275)$.

In de competitie om handelingsruimte tussen verzekeraar en directorium was de aandacht geconcentreerd op de grens tussen reguliere financiering en aanvullende financiering. Standpunt van de verzekeraar was dat aan pg-patiënten eerst alle beschikbare reguliere hulp (uitgedrukt in uren) moest worden verleend, voordat uren aanvullende hulp konden worden gefinancierd. Voor de zorgaanbiedende instellingen betekende dit dat het aantal aanvullend te financieren zorguren kleiner was, naarmate het aantal reguliere uren groter was.

Tegen deze achtergrond moet het streven van de aanbiedende instellingen worden begrepen om bij de begrenzing van het aantal uren reguliere zorg de lat lager te leggen dan de verzekeraar wenste. Hoe minder zorguren uit de eigen instellingsbudgetten (regulier) moesten worden gefinancierd, des te beter. Met name voor de stedelijke gezinszorg was dit belangrijk, aangezien bij uitstek deze instelling kampte met budgetproblemen (V7). 
De competitie met de verzekeraar is in het geval van het amw zeer duidelijk geweest. Het amw zei te willen participeren in de hulpverlening aan pg-patienten onder de voonwaarde dat al zijn hulp aanvullend zou worden gefinancierd. Als reden werd opgegeven dat het voor deze instelling om een nieuw hulpaanbod ging (D137, 138). De verzekeraar wilde de voorwaarde niet aanvaarden. De gemeenten waren de financiers van het amw. De verzekeraar gaf in april 1991 bij monde van zijn vertegenwoordiger te kennen dat hij weigerde te betalen voor hulp die volgens hem voor rekening van de gemeenten moest komen (D125).

Het gehelle directorium betuigde aanvankelijk steun aan het amw en de opstelling van de verzekeraar werd betuttelend genoemd (D125). De relatie tussen verzekeraar en directorium verslechterde. De gegevens uit vergadernotulen laten zien dat het directorium en de verzekeraar zich op het punt van de financiering terugtrokken op hun stellingen. Beide partijen willden een ander resultaat dan over en weer aanvaardbaar werd gevonden. De standpunten lagen uiteen en de brug daartussen werd niet geslagen. "De financier is ruimhartig van start gegaan, maar is al snel begonnen de duimschroeven wat aan te draaien. Directoriumvergaderingen lijken soms in hoofdzaak bestemd voor discussies met (naam verzekeraar) (...) 'De financier zit erg op de centen (...). Discussies over aspecten met financiële implicaties vergden enorm veel energie in het directorium en zijn niet goed voor de creativiteit/de fut' (R2). 'Bij aanvang was het project voor alle participanten belangrijk. Nu dreigt het gevaar dat de participanten het bijltie erbij neergooien als de problemen in de financiering en de zorgverlening niet worden opgellost' (V6).

Het was in deze periode dat de directoriumleden het noodzakelijk wonden onderling van gedachten te wisselen over de relatie met de verzekeraar. De projectleider organiseerde daartoe op 5.6.1991 een bezinningsdag met als doel, in afwezigheid van de vertegenwoordiger van de verzekeraar tot een standpunt te komen over de grems tussen reguliere en aanvullende zorg.

Tijdens deze bezinningsdag bleken de individuele visies op de passende grens uiteen te lopen. De stedelijke gezinszorg prefereerde een grens die anderen niet redelijk vonden naar de verzekeraar toe (D148). Uiteindelijk kwamen de deelnemers tot de conclusie dat alle hulp die uitsteeg boven acht uur per week als aanvullend moest worden beschauwd. Besloten werd deze conclusie als voorstel aan de verzekeraar voor te leggen en daaraan gekoppeld de bereidheid uit te spreken de pg-patiemten als doelgroep op te nemen in het project. Indien de beschikbare itz-gelden ontoereikend waren om het voorstel volledig te honoreren, zo bepaalde het directorium tevens, dan zou de verzekeraar het budget moeten verschaffen, dat wél beschikbaar was (D148, 196).

Het directorium gaf hiermee aan bereid te zijn samen met de verzekeraar te zoeken naar een haalbare oplossing van de kwestie van de financiering. De verzekeraar ging op de handreiking in. Hoewel hij stelde niet in staat te zijn het voorstel volledig te honoreren (D164), drukte de verzekeraar in november 1991 het directorium op het hart dat hij niets anders had willen doen dan de betrokkenen te stimuleren samen zo snel mogelijk goede hulpverlening voor de pg-patiënten te ontwikkelen: 'de situatie van de pg-patienten maant tot spoed. Het directorium is weinig voortvarend geweest. De gang van zaken is misschien wat verwarrend geweest, maar het resultaat is toch maar dal de partijen aanstaande vrijdag allemaal bij elkaar zitten' (D193).

Met deze woorden maakte de vertegenwoordiger wan de verzekeraar duidelijk het belangrijk te vinden dat de partijen gezamenlijk een oplossing vonden voor de problematiek in de hulpverlening aan pg-patiënten, een oplassing die de verzekeraar urgent vond. Tevens wordt zichtbaar dat de verzekeraar zich afhankelijk wist van de 
medewerking wan de instellingen in het directorium, om pg-patiënten betere zorg te kunnen bieden. Het ging daarbij om kruiswerk en gezinszorg 103.

Ten aamzien van aanwullende financiering van diensten van het armw had de verzekeraar intussen schoorvoetend aangegeven dat, indien uit een experiment bleek dat de inbreng van het amw meerwaarde had in de hulpverlening aan pg-patiënten, deze financiering voor hem bespreekbaar was. De verzekeraar deed echter geen harde belofte dat financiering van het amw na afloop van het experiment zou plaatswinden. Daarover zou nog overleg moeten plaatsvinden. De verzekeraar ging vooralsnog niet verder dan de toezegging dat hij zou trachten financiering van het amw te regelen, indien meerwaarde was vastgesteld (D125). Het experiment werd vervolgens opgezet en uitgevoerd, waarbij het amw de kosten van zijn inbreng voor eigen rekening nam (D152, 173, 193).

De zorgverzekeraar onderbouwde in juli 1991 zijn standpunt over het budgetvoorstel, dat het directorium tijdens de bezinningsdag had ontwikkeld, door te stellem dat het voorstel niet verenigbaar was met de geldende subsidieregels van de ziekenfondsraad (D164). De externe regels werden hier strikt toegepast. Een maand later zegde de verzekeraar toe dat hij de subsidieregels niet streng zou hanteren, indien de riagg een rol in de hulpverlening aan pg-patiënten kreeg (D173). De externe regels zouden in dit geval soepel worden toegepast.

Dit leidt ons tot de volgende conclusie. De zorgverzekeraar fungeerde niet enkel als doorgeefluik van subsidie voor intensieve thuiszorg. Door de regels afwisselend streng en soepel te hanteren trachtte de verzekeraar te bewerkstelligen dat gebeurde wat hij wenselijk vond. Door in het eerste geval de subsidieregels strikt toe te passen kon worden voorkomen dat het directorium de handelingsruimte kreeg die de verzekeraar onwenselijk vond. Door in het tweede geval de regels soepel toe te passen trachtte de verzekeraar te bereikem dat de riagg een plaats kreeg in de organisatie van de hulpverlening, hetgeen zijn wens was (zie par. 6.5.2.2).

Pas nadat beide partijen hadden getoond dat zij toenadering zochten en een reeks vergaderingen had plaatsgevonden, waarbij de inspanningen waren gericht op het bereiken van overeenstemming, werd het besluit genomen tot opname van de pgpatiënten als doelgroep. Dit gebeurde in november 1991 (D198). De projectleider rekende op een goede afloop van de kwestie: 'De relatie met (naam verzekeraar) was een tijdje slecht, maar is nu beter. (Naam verzekeraar) heeft recentelijk zijn opstelling herzien' (...) (Naam verzekeraar) is nu wat soepeler, de klankbordgroep ${ }^{104}$ kan aan de sfeer gaan werken, dus het komt allemaal wel op de pootjes terecht' (V6). 'Met betrekking tot intensieve thuiszorg wordt geen energie meer besteed aan een discussie over regulier-aanvullend $(\ldots)$. Er is een modus gevonden hoewel het budget soms als wat krap wordt ervaren, vooral voor pg' (V7).

Van belang is het woord waarmee de projectleider hier de bereikte overeenstemming aanduidt: 'modus'. Het drukt uit dat verzekeraar en directorium uiteindelijk bereid waren te komen tot een -in hun perceptie- redelijke, aanvaardbare handelingsruimte voor het directorium, niet langer tot een optimale.

Nadat het directorium had besloten de pg-patiënten als doelgroep van het project op te nemen, gingen discussies met de zorgverzekeraar over de hoogte van budgetten voor intensieve thuiszorg voort. Het karakter was echter anders: een patstelling zou

103 Dat de zorgverzekeraar deelname van het amw niet belangrijk vond is inmiddels duidelijk. Het oordeel van de verzekeraar over de inbreng van huisartsen is niet bekend. 
zich niet meer voordoen, het accent bleef liggen op pogingen met elkaar tot overeenstemming te komen.

\subsubsection{De kwestie van de organisatie}

Aan de opstelling van de verzekeraar ten opzichte het amw lag in onze waarneming niet alleen de kwestie van de financiering ten grondslag. De verzekeraar was niet overtuigd van de noodzaak het amw een plaats te geven in de organisatie van intensieve thuiszorg aan pg-patiënten. Of de diensten van het amw een meerwaarde gaven aan de hulpverlening aan pg-patiënten, stond voor de verzekeraar niet vast en moest uit het genoemde experiment blijken.

Toen het experiment was beëindigd, drong het amw bij de verzekeraar aan op afspraken over de financiering van zijn deelname aan de aanvullende hulpverlening aan pg-patiënten. Deze afspraken werden niet gemaakt. Inzet van amw-hulp werd door de verzekeraar niet aanvuliend gefinancierd. De verzekeraar wenste niet het amw, maar de riagg een plaats te geven in de hulpverlening aan pg-patiënten en hield gedurende de gehele projectperiode aan dit standpunt vast. In de optiek van de verzekeraar moest de riagg de aanmelding en indicatiestelling coördineren (D173, 193, 211).

Niet alleen voor de zorgverzekeraar bestond een organisatorisch vraagstuk. Voor het directorium was het problematisch een adequaat aanbod voor pg-patienten te formuleren, een categorie pg-patiënten te vinden die voor intensieve thuiszorg in aanmerking moest komen en een passende organisatievorm te vinden. De situatie in de hulpverlening aan pg-patiënten was ongewenst, maar vooralsnog kon niemand aanvaardbare voorstellen voor de organisatie van de hulpverlening aandragen. Werkgroepen worstelden met de ontwikkeling van handelingsregels. Resultaten van hun inspanningen waren voor het directorium niet altijd naar wens.

De projectleider gaf de problemen als volgt weer: 'Met betrekking tot de doelgroep pg-patiënten zijn er visies en opties verkend. Voortvarende besluitvorming kwam er eerst niet: we zagen niet hoe we de zorg van die groep organisatorisch, personeel en financieel vorm zouden moeten geven. Door de vingeroefeningen met een kleine groep 105 zijn we toch wat meer grip op het onderwerp gaan krijgen' (V6). Geleidelijk aan werden de problemen opgelost. Het directorium kreeg in augustus 1991 zicht op een verzameling handelingsregels dat hem welgevallig was (D173). In de tijd dat werd besloten tot opname van de pg-patiènten als doeigroep van het project, ging de organisatie die het directorium wenselijk vond op papier vorm krijgen.

In het bijzonder over de plaats van riagg en amw zijn in het directorium meerdere discussie gevoerd (D193). Niet alleen de deelname van de riagg, maar ook de deelname van het anw -participant van het eerste uur-kende voor-en tegenstanders in het directorium $(\mathrm{D} 125,173,207)$. Hoewel het directorium in de kwestie van de financiering steun had betuigd aan het amw, is ons gebleken dat deze steun niet door iedereen van harte werd gegeven. De directeur van de regionale gezinszorg toonde reeds in 1990 scepsis over het belang van het amw voor de hulpverlening aan de doelgroepen van het project: "Het amw moet nog aantonen wat zijn belang kan zijn. Ik werkte zelf acht jaar bij het amw. Ik weet er veel van en denk dus dat het belang van het amw voor het project vaak overtrokken wordt' (V3). De directeuren van de stedelijke gezinszorg gaven in hetzelfde jaar te kennen dat zij aan afstemming met het amw lagere prioriteit hechtten dan aan afstemming met het kruiswerk (V2).

Daamee wordt het reeds genoemde experiment bedoeld, waarin hef amw woor eigen rekening participeerde. 
De riagg kreeg van het directorium in de organisatie van de hulpverlening de plaats die de verzekeraar aan deze instelling wilde toekennen. Het amw werd buitenspel geplaatst en beëindigde zijn participatie in het project (D218). Voor de instellingen voor gezinszorg strookte de wens van de verzekeraar aangaande deelname van het amw en de riagg bij de hulpverlening aan pg-patiënten uiteindelijk met de eigen wensen. Eind 1992 zei de projectleider: 'De gezinszorg zag niets in inschakeling van het amw omdat de vraag uiteindelijk toch bij de riagg terecht zou komen: waarom dan niet meteen met de riagg in zee gaan?' (V7). De twijfels die met name de directeur van de regionale gezinszorg in 1990 had geuit over de betrokkenheid van het amw. waren mettertijd uitgegroeid tot weerstand tegen deelname van het amw. Wat de overige directoriumleden ertoe bewoog de wensen van de verzekeraar over de deelname van amw en riagg uiteindelijk in te willigen, is niet bekend.

\subsubsection{Reflectie op de gebeurtenissen vanuit de machts- en routineverklaring}

Gedurende het proces dat wij hebben beschreven besloot het directorium dat de pg-patiënten als doelgroep in het project zouden worden opgenomen. De wens van de verzekeraar werd uiteindelijk vervuld. Aangezien de verzekeraar de dominante partij was, zou dit gegeven kunnen worden uitgelegd als een argument ten gunste van de geldigheid van de machtsverklaring.

De vertegenwoordiger van de verzekeraar deed aan het directorium in de loop van de case 14 verzoeken en voorstellen (D10,63, 74, 84, 112, 125, 137, 166, 173, $193,196,218)^{106}$. Deze betroffen handelingsregels ten behoeve van overleg met de verzekeraar of anderen; formulering, onderbouwing en aanpassing van directoriumvoorstellen aan de verzekeraar; beantwoording van vragen van de verzekeraar. Stuurders hadden ook betrekking op de experimentele en definitieve opname van de doelgroep pg-patiënten en de organisatorische en financiële randvoorwaarden daarvoor.

In tien gevallen nam het directorium besluiten conform de inhoud van de stuurder (nadát deze blijkens de vergadernotulen waren verzonden), in vier gevallen deed het directorium dat niet. Het directorium als ondergeschikte partij liet dus zien in zijn handelingen wel degelijk rekening te houden met stuurders van de dominante partij, de verzekeraar. Deze gegevens wijzen erop dat de machtsverklaring in bepaalde mate plausibel is.

Echter, de routineverklaring lijkt minstens evenzeer relevant te zijn. Bij vier van de genoemde tien besluiten strookte het besluit reeds met wensen die directoriumleden bij eerdere gelegenheden hadden geuit. De besluiten kwamen overeen met hun routines. Bovendien moet niet worden vergeten dat de wens tot vormgeving van de organisatie voor hulpverlening aan pg-patiënten correspondeerde met de routines van verzekeraar én directorium.

Een beschouwing vanuit de routineverklaring lijkt op het eerste gezicht een inconsistentie op te leveren. Verandering van de situatie vond pas na ruim anderhalf jaar plaats, hoewel dit volgens de dominante én ondergeschikte partijen urgent was. De gevoelde noodzaak tot verandering was op zichzelf klaarblijkelijk onvoldoende voorwaarde voor verandering. Andere routines, die betrekking hadden op de gewenste 
handelingsruimte en handelingsregels (de kwesties van de financiering en de organisatie) stonden aanvankelijk in de weg.

Pas toen, uitgaande van deze routines, voor de betrokkenen een aanvaardbare situatie in het verschiet lag (hier manifesteert zich de bandbreedte van routines; zie par. 2.5.2.2) werd tot verandering overgegaan. De case maakt duidelijk dat verschillende routines kunnen resulteren in tegengestelde eisen aan het handelen van een en dezelfde actor.

\subsection{Slotopmerkingen}

In dit hoofdstuk hebben wij drie cases beschreven, die duidelijk maken welke omstandigheden in het project itz volgens ons aanleiding en gelegenheid hebben gegeven tot sturing. De analyses onderstrepen dat de aanleiding tot sturing moet worden gezocht in de betekenis die een situatie voor actoren heeft. Indien bijvoorbeeld actoren een situatie als onwenselijk beschouwen, zullen zij trachten anderen ertoe te bewegen mee te werken aan verandering. Om daadwerkelijk te kunnen aansturen op verandering van de situatie is macht belangrijk. Middelen waaraan behoefte bestaat bieden de bezitter ervan de mogelijkheid te trachten anderen ertoe te bewegen mee te werken aan de veranderingen die de bezitter welgevallig zijn.

Macht alleen is echter niet voldoende. Routines zijn eveneens van belang. Indien de beoogde verandering onverenigbaar is met de routines van de actoren wier medewerking wordt verlangd, dan is realisering van de verandering een probleem. In ons abject van studie is namelijk sprake van macht in de vorm vam gezag. Bij gezag hebben de dominante en ondergeschikte actoren allen macht. Gevolg is dat de uiteindelijke verandering veelal een 'negotiated order' is, een compromis tussen de wensen van de betrokkenen als resultaat van een reeks sturingsinteracties.

Desondanks laten de cases zien dat de uiteindelijke veranderingen in de richting gingen die de machtige actor wenselijk vond. Machtige actoren waren WVC, de verzekeraar en het directorium. De projectparticipanten richtten bijvoorbeeld een convergentiecollege op, hoewel zij dat niet wilden. Ook al was dit college een zwakke afspiegeling van hetgeen WVC wenste (integratie van twee projectorganisaties), de verandering kwam wel degelijk tegemoet aan de wens van de machtige partij107.

Kijkend naar de empirische bevindingen uit hoofdstuk 4, 5 en 6 , valien de volgende zaken op. V'eranderingen van situaties strookten eerder met de routines van dominante actoren dan met die van ondergeschikten. Dominantie was binnen de cases voornamellijk gebaseerd op het bezit van of de toegang tot financiële middelen, vastgelegd in wettelijke regels. Ondergeschikten bezaten dergelijke middelen niet. Zij hadden echter een middel waarvan het belang niet mag worden onderschat: het vermogen tot communicatie. De beschrijving in par. 5.4 van de bijdragen van de projectleider in de besluitvorming over projectaangelegenheden, is hiervoor illustratief.

Het ultieme middel van de ondergeschikten was natuurlijk de menskracht die zij konden leveren ten behoeve van de veranderingen die de dominante actor wenselijk vond. Toch was dit middel lang niet voor alle ondergeschikten een machtsmiddel. De

107 Dergelijke bevindingen zijn gebaseerd op alle drie de cases die, uitgaande van de selectiecriteria (zie par 3.6.3) overeenkomen, en die, binnen het kader dat de criteria vormen, bezien naar hun onderwerp en de aard wan de betrokken actoren, verschillen. De bevindingen uit de eerste case komen op hoofdlijnen overeen met die uit de tweede en derde case. Wij concluderen dal sprake is van 'replication' (Yin, 1989; zile par. 3.5.3). 
menskracht wan het amw en de projectmanager was voor de verzekeraar en de directeuren van kruiswerk en gezinszorg niet onmisbaar bij de verlening van intensieve thuiszorg. Anders lag dit voor de menskracht die kruiswerk en gezinszorg konden leveren. Van de instellingen in het directorium waren zij het machtigst. Zonder hun inzet was verlening van intensieve thuiszorg onmogelijk. De verzekeraar, die als dominante partij de zorgverlening aan pg-patiënten wilde verbeteren, was voor de verwezenlijking van dit streven afhankelijk van de inzet van deze organisaties.

De empirische hoofdstukken leren ons verder dat voor het object van studie een bespreking van de relatie tussen macht en regels enerzijds en het handelen wan actoren anderzijds, door wellke handelingen structuur ontstaat, in termen van stimulusresponse niet valide is. Het is bijvoorbeeld niet voldoende een regel te formuleren, om bepaalde handelingen teweeg te brengen.

Niet alleen moet tussen het handelen en andere verschijnselen de betekenis voor de actor worden geplaatst. Ook moet de situatie op enig moment worden beschouwd als het resultaat van handelingen en interacties (sturing en tegensturing) volgens patronen van these, antithese, synthese, aangezwengeld vanuit routines. De relaties tussen actoren binnen en buiten netwerken en de patroonsgewijze handelingen in deze relaties, vormen gezamenlijk een 'negotiated order', gerealiseerd tussen actoren in wier handelingen routines zichtbaar worden.

Macht is belangrijk om regels voor het handelen in te voeren (of te schrappen) en handelingsruimte te verschaffen (of te begrenzen). Regels doen ter zake alls ondersteuning en leidraad voor het handelen. Of die regels worden gebruikt en of de ruimte wordt benut, heeft te maken met de motivatie van actoren. Het belang van routines bij die motivatie mag niet worden onderschat. Routines doordrenken alles wat met handelen te maken heeft. Routines zijn weerbarstig. Zulke bevindingen hebben grote implicaties voor zorgvernieuwing. Zo kan de weerbarstigheid van routines van dominante en geschikte actoren zorgvernieuwing in de weg staan. Deze en andere implicaties bespreken wij in hoofdstuk 7 . 


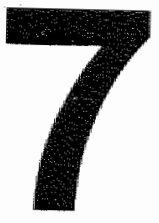

\section{Het tafereel gevernist en bekeken: conclusies en discussie}

\subsection{Inleiding}

Met het aanbrengen van de tweede verflaag hebben wij in hoofdstuk 6 het schildenwerk beëindigd. In dit hoofdstuk brengen wij de vernislaag aan en bekijken wij het resultaat vanaf een afstand.

Met behulp van de vragen uit hoofdstuk 1 gaan wij in par. 7.2 tot en met 7.6 na wat het schilderij van het project Intensieve Thuiszorg Zuid-Kennemerland ons over de netwerken onthult. Bij de beantwoording van de vragen maken wij gebruik van de concepten uit het conceptueel raamwerk. Het zal duidelijk worden dat het noodzakelijk is vanuit een interactiebenadering te werk te gaan, om besturing in het kader van zorgvernieuwing te kunnen begrijpen. Het rationele-actorperspectief, als rivaliserende benadering (zie par. 1.3 en 3.3.3), achten wij daarvoor niet bruikbaar. Ter afsluiting van het onderhavige verslag bediscussiëren wij in par. 7.7 de uitgevoerde studie.

\subsection{Sturing van en binnen netwerken}

De eerste vraag die wij tijdens de studie wilden beantwoorden is: door wie, hoe en in welke richting is aan ontwikkeling(en) van/binnen netwerken van instellingen en beroepsbeoefenaren in de thuiszorg sturing gegeven? Netwerken beschouwen wij als systemen, als verzamelingen van actoren en van de afhankelijkheidsrelaties, waarbinnen zij handelen en interacteren.

Actoren handelen op basis van de betekenis die verschijnselen voor hen hebben. Vanuit hun routines beoordelen zij situaties als wenselijk of onwenselijk. Om te kunnen handelen zoals zij dat gewenst of noodzakelijk achten (hetgeen in hun routines ligt besloten), hebben zij middelen nodig zoals geld, personeel en informatie. Het beeld dat uit de gegevens is opgekomen, laat het volgende zien. 


\subsubsection{Richting van ontwikkelingen}

Opbouw en afbraak van relaties en netwerken -vervlechting en ontvlechting-waren de meest kenmerkende richtingen waarin ontwikkelingen betreffende het project itz gingen.

De ontwikkelingen waren het resultaat van handelingen volgens regels. Regels, vooropgesteld dat zij worden gebruikt, geleiden het handelen. Zij zijn instrumenten die niet op zichzelf, maar bij toepassing tijdens het handelen resulteren in veranderingen in structuur, macht en/of cultuur.

Het project itz maakte van medio 1990 tot eind 1992 deel uit van het Programma Zorgvernieuwingsprojecten Thuiszorg van WVC. Het werd uitgevoerd door hulpverlenende instellingen, ondersteund door een projectleider en met bijdragen van de zorgverzekeraar, om in aanvulling op de reguliere zorgverlening aan thuiswonende, terminale en psychogeriatrische patiënten thuiszorg te bieden. Deze aanvullende, intensieve thuiszorg moest worden verleend in samenwerking tussen kruiswerk, gezinszorg, huisartsen, amw en riagg.

Ter realisering van het doel werden actoren uit de omgeving samengebracht in netwerken die tijdens de projectperiode werden opgericht en weer opgeheven. De omgeving bestond uit organisaties. De verzameling netwerken die op enig moment het project itz uitvoerde, noemden wij de projectorganisatie. De ontwikkeling van netwerken betrof de opbouw en verandering van deze projectorganisatie en haar organen. Netwerken werden opgericht en weer opgeheven (zie verder par. 7.5).

De ontwikkelingen binnen netwerken betroffen de formulering, verandering. invoering en teniet verklaring van handelingsregels. Deze ontwikkelingen verliepen parallel aan de vervlechting en ontvlechting van de projectorganisatie. De regels waren bedoeld voor gebruik tijdens handellingen en interacties binnen en tussen de organen in de projectorganisatie (secundair proces) en in de organisatie van de verlening van intensieve thuiszorg (secundaire niveau van het primaire proces).

Voor de projectorganisatie waren bijvoorbeeld statutaire handelingsregels ingevoerd ten behoeve van de stichting itz. Daarin was onder andere vastgelegd dat bestuur en directorium van de stichting verantwoordelijk waren voor de inhoud en uitvoering van het project itz. Bestuur en directorium maakten deel uit van de strategische top van de projectorganisatie. De statuten werden buiten werking gesteld toen de stichting itz werd opgeheven.

Voor de organisatie van de hulpverlening waren de belangrijkste regels opgenomen in twee opeenvolgende organisatiemodellen. De modellen waren bedoeld om in de organisatie van de verlening van intensieve thuiszorg afstemming teweeg te brengen tussen hulpverleners uit verschillende instellingen (zie par. 7.5).

Op zichzelf was de beschrijving van de richtingen, waarin de ontwikkelingen gingen, waardevol om een eerste inzicht te krijgen in de gebeurtenissen. Belangwekkender met het oog op de mogelijkheden tot zorgvernieuwing was echter het inzicht in hetgeen op de achtergrond van deze ontwikkelingen aanwezig was: de routines van de betrokken actoren. Daarop komen wij in par. 7.5 terug.

\subsubsection{Bestuurders}

De gebeurtenissen gedurende het project itz laten zien dat de aan de orde zijnde zorgvernieuwing niet kan worden begrepen vanuit een rationele-actorperspectief. Een interactiebenadering is vereist. 
De situatie op enig moment was niet het resultaat van de rechtstreekse inwilliging van de wensen van éen actor, maar een 'negotiated order'. De ontwikkelingen kunnen nilet worden toegeschreven aan de pogingen van één actor om de anderen doelgericht te beinvloeden (sturing). Er wonden sturingsinteracties plaats tussen meerdere betrokkenen. Gebruikte handelingsregels waren het product van deze interacties.

De projectleider, projectmanager, werkgroepen, instellingen, besturen, directeuren, vertegenwoordigers van de zorgverzekeraar en het Ministerie van WVG, zij allen hebben getracht elkaar zodanig te beïnvloeden dat de een deed wat de ander wilde. Zij gaven elkaar voor het handelen aanwilzingen (regels). Binnen een kluwen van relaties droegen zili -gedurende onderlinge interacties van sturing en tegensturing-allen bij aan de ontwikkelingen die zich hebben voltrokken.

De bestudeerde sturingsinteracties vonden grotendeels plaats tijdens vergaderingen binnen de projectorganisatie. Ook vanuit de omgeving van de projectorganisatie werden sturingspogingen gedaan. De belangrijkste actoren in deze omgeving waren de hulpverllenende instellingen (inclusief de beroepsgroep huisartsen), de zorgverzekeraar en het Ministerie van WVC.

De sturingspagingen van de instellingen hebben wij zichtbaar gemaakt bij de oprichting van de stichting itz. De handelingen van de verzekeraar als bestuurder hebben wij belicht bij de ontwikkeling van organisatorische arrangementen voor de hulpverlening aan pg-patiënten. Het Ministerie manifesteerde zich als bestuurder vooral bij aanvang van het Programma van WVC, op het vlak van de vormgeving van de projectorganisatie.

De zorgverzekeraar en WNC waren machtige bestuurders. Zij waren degenen die door de verstrekking van gelden gedurende de jaren 1990, 1991 en 1992 uitvoering wan het project in de beschreven vorm mogelijk maakten. Met de geldelijke middelen waarover zij beschikten konden de verzekeraar en WV de handelingsruimte verschaffen of ontnemen, die de projectdeelnemers nodig hadden om intensieve thuiszorg aan de doelgroepen te kunnen bieden.

Het is niet plausibel te stellen dat aanvullende thuiszorg was verleend wanneer de zorgverzekeraar geen geldelijke middelen had verschaft die beschikbaar waren in het kader van de regelling van de ziekenfondsraad voor subsidiëring van intensieve thuiszorg. Zonder de verlening van intensieve thuiszorg had het project geen bestaansgrond gehad. Het valt evenzeer te betwijfelen of van een projectbureau sprake was geweest indien WVC in het kader van het Programma Zorgvernieuwingsprojecten Thuiszorg aan de participanten geen subsidie woor projectondersteuning had verleend.

De gelden die WVC voor projectondersteuning beschikbaar stelde, maakte de weg vrij voor het aanstellen van een functionaris, wier rol bij de gebeurtenissen niet mag worden onderschat. Samen met de projectmanager en de werkgroepen heeft de projectleider door haar voorstellen de route uitgezet waarlangs de besluitvorming door de strategische top van de projectorganisatie plaatsvond. De projectleider zorgde ervoor dat vergaderingen konden plaatsvinden. Zij kaderde discussies en besluiten in, door de agenda op te stellen en gedurende vergaderingen vragen te stellen en ten behoeve van discussie notities van haarzelf en anderen voor te leggen.

WVC en de zorgverzekeraar maakten gebruik van de middelen waarover zij beschikten om te trachten de strategische top van de projectorganisatie ertoe te bewegen te doen wat zij beoogden. De strategische top hield terdege rekening met de: wensen van deze actoren, maar deed niet zonder meer wat beiden wilden. De verzekeraar bijvoorbeeld moest de modige moeite doen om de medewerking van de top te verkrijgen. 
Alles overziend komen wij tot de conclusie dat de zorgverlenende instellingen die waren vertegenwoordigd in het directorium, en de zorgverzekeraar de belangrijkste bestuurders waren. Het directorium was binnen de projectorganisatie het centrale orgaan, het gezagscentrum. Het waren in het bijzonder de vertegenwoordigers van kruiswerk en gezinszorg in dit netwerk, die met de verzekeraar de richting van de ontwikkellingen bepaalden. Vooral zij waren in staat de organisatie op het niveau van het secundaire proces en het secundaire niveau van het primaire proces conform de eigen routines vorm te geven. De wederwaardigheden van het Ministerie en de verzekeraar in hun relaties met de vertegenwoordigers van de instellingen illustreren hoe belangrijk het concept van 'negotiated order' is om vanuit een interactiebenadering te begrijpen hoe zorgvernieuwing tot stand komt (zie verder par. 7.4).

\subsubsection{Wijze van sturing}

De sturingsinteracties verliepen volgens een patroon van these (voorstel), antithese (commentaar, bespreking) en synthese (besluit). Binnen de projectorganisatie kregen de projectleider en projectmanager van de strategische top -vooral het directorium- opdrachten (handelingsregels) netwerken te formeren. Zij waren dan bestuurden ofwel ontvangers van stuursignalen.

De meeste opgerichte netwerken waren werkgroepen. Zij waren voornamelijk samengesteld uit vertegenwoordigers van zorgverlenende instellingen. Samen met de projectleider en de projectmanager deden zii mondelinge en schriftelijke voorstellen voor handelingsregels, die waren bestemd voor gebruik tijdens het secundair proces en op het secundaire niveau van het primaire proces. Dit gebeurde in opdracht van de strategische top, waaraan de voorstellen vervolgens werden voorgelegd. De leden van de strategische top gaven commentaar op de voorstellen of formuleerden aanvullingen, waarna de voorstellen werden bijgesteld en opnieuw werden voorgelegd.

De strategische top besloot of handelingsregels werden ingevoerd of teniet verklaard. Ingevoerde regels werden gewoonlijk gebruikt. Gebruik resulteerde bijvoorbeeld in het ontstaan, de verandering en verdwijning van relaties en netwerken.

Hoewel in een aantal gevallen in het uiteindelijk besluit de aard van de stuurder van een bepaalde actor kan worden herkend, kan dit besluit niet zonder meer tot deze afzonderlijke stuurder worden herleid. Een aantal voorstellen werd bijvoorbeeld gedaan nadat door de strategische top was bepaald dat een voorstel nodig was. In een deel van de voorstellen zijn onderdelen van eerdere voorstellen opgenomen. Aan zulke voorstellen gingen voorstellen en besprekingen vooraf.

Een 'stuurder' zoals een voorstel was geen stimulus die rechtstreeks leidde tot de response 'besluit'. Stuurders gedurende het project waren signalen die in de tijd werden gevolgd door een proces van interpretatie en betekenisgeving gedurende handelingen en interacties. Een stuurder werd object van bespreking. Actoren ontvingen de stuurder, verwoordden hun conclusies, anderen reageerden, enzovoorts. Bestuurden verzonden stuurders naar bestuurders en omgekeerd. Bestuurders werden bestuurden, bestuurden werden bestuurders. 


\subsection{Aanleiding tot sturing}

De tweede vraag van deze studie is: welke omstandigheden (situatie) hebben aanleiding gegeven tot deze sturing? De aanleiding hebben wij gezocht en gevonden in de ontevredenheid met de bestaande situatie of de toekomstige situatie, zoals gepercipieerd door de betrokken actoren. Gedurende processen kan voor sturing meerdere malen van een aanleiding sprake zijn.

De aanleiding tot het project itz lag in het ongenoegen van de participanten over de hulpverlening aan bepaalde categorieën zorgvragers, in casu thuiswonende terminale en pg-patiënten. Tussen hulpverlenende instanties ontbraken relaties die nodig werden geacht voor goede hulpverlening. De wijze van hulpverlening aan terminale en pg-patiënten en de manier waarop deze hulp was georganiseerd, zoals de participanten deze waarnamen, verschilden van hetgeen zij wenselijk of noodzakelijk wonden. Deze moesten worden veranderd. Dàt de waargenomen situatie moest worden veranderd, stond woor allen vast. Wèlke de nieuwe situatie moest worden, daarover was men het niet altijd eens. Routines verschilden.

Beoordeling van een situatie ging vooraf aan de sturingspogingen van de individuele actoren die erop waren gericht de situatie met de eigen routines in overeenstemming te houden of te brengen. Meer bepaald wensten actoren handelingsregels die bij gebruik leidden tot de afhankelijkheidsrelaties, handelingen en interacties waarin hun eigen routines werden weerspiegeld. Echter, omdat de routines van actoren niet altjjd overeenkwamen namen interacties niet alleen de vorm aan van samenwerking, maar ook van competitie en strijd.

De case van de pg-patiënten is een goede illustratie van hetgeen wij hebben geconstateerd. Verzekeraar en directorium vonden het beiden belangrijk dat de situatie in de hulpverlening aan pg-patiënten werd verbeterd. In dit opzicht was hun onderlinge relatie symbiotisch. Bij de verwezenlijking van de gewenste situatie was enige tijd geen sprake van een symbiotische relatie. Voorstellen voor organisatorische arrangementen voor de hulpverlening aan pg-patiënten en de financiering daarvan leverden discussie op tussen voor- en tegenstanders.

Voor de hulpverlening hadden de instellingen geldelijke middelen van de zorgverzekeraar nodig. Geld was onontbeerlijk voor de realisering van het initiatief; alternatieven voor de gelden van de verzekeraar waren niet voorhanden (centraliteit, geen substitueerbaarheid). Geld kon aan de instellingen de handelingsruimte verschaffen waarbinnen zij conform hun routines hulp konden verlenen. De behoefte aan geld maakte dat zij ondergeschikt werden aan de zorgverzekeraar. Er ontstond een asymmetrische afhankelijkheidsrelatie waarbinnen de verzekeraar de dominante partij was.

De vertegenwoordigers van de hulpverlenende instellingen in het directorium stelden zich ten doel deze gelden te verkrijgen door een beroep te doen op de middelen die de verzekeraar kon verstrekken in het kader van de subsidieregeling intensieve thuiszorg. Zij wilden echter meer middelen dan de verzekeraar bereid was te verschaffen. Tegelijkerijid stelde de verzekeraar eisen aan de organisatie van de hulpverlening die een deel van het directorium niet aanvaardbaar vond.

In de optiek van de verzekeraar moesten de handelingsregels voor de organisatie van de hulpverlening zodanig zijn, dat de riagg een centrale functie kon vervullen. Anderen betwijfelden of aan de riagg een dergelijke functie moest worden toegekend. Tegelijkertijd vond de verzekeraar deelname van het amw niet wenselijk, een deel van het directorium daarentegen wel. Tussen de zorgverzekeraar en het directorium werd de relatie competitief. 
Directorium en verzekeraar namen standpunten in die over en weer als onwernselijk werden beoordeeld, hetgeen aanleiding was tot verdere sturingsinteracties. Tijdens deze interacties trachtte iedere actor aanvankelijk tot een resultaat te komen dat optimaal overeenkwam met zijn wensen, maar voor de ander niet aanvaardbaar was. Directorium en verzekeraar leverden strijd en het resultaat was een patstelling. Deze werd pas doorbroken toen actoren zich bereid toonden een suboptimaal resultaat te aanvaarden. Een 'negotiated order' ontstond.

\subsection{Gelegenheid tot sturing}

Voor sturing is niet alleen een aanleiding nodig. Sturing moet ook mogelijk zijn. Omstandigheden (situatie) kunnen al dan niet gelegenheid bieden tot sturing. Daarop heeft de derde vraag van onze studie betrekking.

Genoemde omstandigheden betreffen de aanwezigheid van asymmetrische afhankelijkheidsrelaties tussen een dominante en ondergeschikte actor en de handelingen daarbinnen. De asymmetrie vindt haar oorsprong in de behoefte van de ene actor aan de middelen die een andere actor kan verschaffen. Macht is gebaseerd op het bezit van of toegang tot zulke middelen. Macht is per definitie van belang voor sturing. Sturing is namelijk machtsuitoefening.

Macht was gezag in ons object van studie. Dit betekent dat in de asymmetrische afhankelijkheidsrelaties zowel de dominante als de ondergeschikte actor macht hebben. Het is uiteindelijk de ondergeschikte die bepaalt of volgens de wensen van de dominante actor wordt gehandeld. Er is sprake van wederkerigheid. Dit kenmerk van de afhankelijkheidsrelaties heeft tot gevolg dat een nieuwe situatie alleen als 'negotiated order' tot stand kan komen.

\subsubsection{Macht en (de betekenis van) middelen}

De analyses laten zien dat het bezit van middelen op zich onvoldoende is voor sturing. Niet een middel zelf verschaft macht, maar de betekenis die dit middel heeft voor actoren. Verder moet van het bezit van middelen zolang als nodig gebruik worden gemaakt ten behoeve van sturingspogingen.

In par. 7.2.2 hebben wij de verzekeraar, kruiswerk en gezinszorg de belangrijkste bestuurders genoemd. Deze conclusie is op het volgende gebaseerd. De gegevens leren dat kruiswerk en gezinszorg alle middelen bezaten die anderen nodig hadden (behalve voldoende geld). Dankzij de erkenning door het Ministerie van WVC beschikten zij over een eigen taakdomein en waren zij verzekerd van een regulier budget. Het Ministerie had van hen monopolisten gemaakt, het had hen macht verschaft.

Kruiswerk en gezinszorg beschikten over de menskracht die voor de realisering van de projectdoelen nodig was. Zonder hun inbreng zou intensieve thuiszorg niet kunnen worden geleverd. Het personeel dat voor deze zorg moest worden ingezet, was vooral van hen afkomstig. Zelfs het merendeel van de leden van de werkgroepen in de projectorganisatie behoorde tot de genoemde instellingen. De verzekeraar wist dat zonder de inzet van kruiswerk en gezinszorg intensieve thuiszorg een utopie zou zijn. Alternatieve aanbieders in de regio waren niet aanwezig (centraliteit, geen substitueerbaarheid). 
Hoe anders was dit voor het amw en de projectmanager. Hel amw wenste deel te nemen aan de verlening van intensieve thuiszorg en wilde daarvoor van de verzekeraar subsidiegelden ontvangen. Anderen echter, in het bijzonder de gezinszorg en de verzekeraar, twijfelden aan de meerwaarde van deelname door hel amw. Omdat zijn inbreng voor deze partjen niet de betekenis 'meenwaarde' had, kon het amw daarmee geen macht uitoefenen. Zijn eventuele inbreng was bijwoorbeeld geen machtsmiddel om de verzekeraar te kunnen aanzetten tot financiering.

De projectmanager bevond zich in een soortgelijke situatie. Het middel bij uitstek waarover zij beschikte was haar eigen inzet. Ook deze inzet was echter niet onmisbaar. De instellingen lieten met de invoering van het tweede model voor intensieve thuiszorg zien, dat zij van oordeel waren zonder de inbreng van de projectmanager het benodigde werk te kunnen doen. De lotgevallen van het amw en de projectmanager onderstrepen onze uitspraak dat niet een middel zelf macht verschaft, maar de bettekenis die dit middel heeft. In hoeverre de inzet van menskracht voor de projectleider en de werkgroepen een machtsmiddel is geweest, kan niet worden bepaald.

De interacties tussen WVC en de strategische top van de projectorganisatie laten zien dat het bezit van een middel waaraan behoefte bestaat, op zichzelf onvoldoende is om te doen gebeuren wat de bezitter van het middel will. Het middel moet zo lang als nodig voor pogingen tot sturing worden ingezet.

De participanten in het project itz waren voor financiering van de projectondersteuning van WVC afhankelik. Het Ministerie had met de subsidie die het in het kader van het Programma van WVC voor projectondersteuning kon verlenen, een middel in handen waarmee het kon trachten te sturen.

Oogmerk van sturing door WVC was de samenvoeging van twee projectorganisaties in Zuid-Kennemerland. Het Ministerie formuleerde dienaangaande eisen voor de strategische top van de projectorganisatie (handelingsregels). De strategische top wond samenvoeging ongewenst, maar achtte het noodzakelijk aan de eisen van WVC tegemoet te komen. Het zegde toe een convergentiecollege op te richten en de mogelijkheden tot samenvoeging van de projectorganisaties te onderzoeken. WNC ging akkoord en verleende subsidie.

Het college werd opgericht, aan samenvoeging van de projectorganisaties werd echter niet gewerkt. Dit was bij WVC bekend, mar het Ministerie drong niet verder aan. Het dreigde bijvoorbeeld niet de subsidieverleming te staken wanneer samenvoeging langer uitbleef. Natuurlijk is het zeer de vraag of samenvoeging van de projectorganisaties was gerealiseerd indien WVC ook na oprichting van het convergentiecollege had getracht te sturen. WVC heeft dat echter in het geheel niet gedaan. Het benutte in de case van het convergentiecollege zijn eigen subsidie niet langer als machtsmiddel. Nadat het convergentiecollege was opgericht gaf het Ministerie de strategische top de ruimte te handelen zoals deze wilde.

Ook de case van de pg-patiènten illustreert dat het bezit van machtsmiddelen niet automatisch leidt tot het gewenste resultaat. De verzekeraar moest meerdere malen sturingspogingen doen om zijn wensen gehonoreerd te krijgen. Verder maakt de case het karakter van wederkerigheid zichtbaar binnen asymmetrische relaties.

De verzekeraar bleek een partij van een geheel ander kaliber dan WVC. De eerstgenoemde maakte gebruik van zijn machtsmiddelen (subsidie voor intensieve thuiszorg) om sturingspogingen te doen zolang hij dat nodig achtte om zijn wensen gerealiseerd te zien. Verzekeraar en directorium, machtige partijen, gaven zich over en weer niet zomaar gewonnen (zie par. 7.3).

De verzekeraar kon schermen met de subsidie om gedaan te krijgen wat hij wilde. De instellingen op hun beurt konden schermen met de inzet wan menskracht 
(hulpverleners), zonder welke levering van intensieve thuiszorg feitelijk onmogelijk was. Tussen de verzekeraar en de instellingen hebben zich heftige gevechten afgespeeld. Zij hielden elkaar in een houdgreep. Anders dan WVC gaf de verzekeraar de leden van de strategische top niet zomaar de ruimte te doen wat zij wilden.

Uiteindelijk kregen de verzekeraar, kruiswerk en gezinszorg hetgeen zij wensten. Kruiswerk en gezinszorg kregen in aanvaardbare mate de itz-gelden waaraan zij behoefte hadden. De zorgverzekeraar kreeg een organisatorisch arrangement voor intensieve thuiszorg, waarin aan het amw een plaats werd onthouden en aan het riagg een plaats werd gegeven, conform de wensen van de verzekeraar (zie par. 7.3).

\subsubsection{Macht en routines}

Uit het gegeven dat pogingen tot sturing door een dominante actor niet zonder meer hebben geleid tot het beoogde handelen, blijkt dat actoren gemotiveerd moeten zijn te handelen conform de regels (opdrachten, eisen van WVC of anderszins) -in dit geval de regels van de dominante actor.

Motivering kan intrinsiek of extrinsiek zijn. Wanneer intrinsieke motivatie ontbreekt, leidt extrinsieke motivatie in situaties van gezag uiteindelijk niet tot het beoogde resultaat. In de case van het convergentiecollege bleek dit duidelijk. De functie van regels -geleiding van handelingen-gaat teloor. De regels zijn dode letters.

Onze analyses laten zien dat het handelen van actoren, dominant of ondergeschikt, alleen kan worden begrepen door gelijktijdig een beroep te doen op twee verklaringen: de machtsverklaring (extrinsieke motivatie) en de routineverklaring (intrinsieke motivatie). De verklaringen zijn niet wederzijds uitsluitend, routines spelen in beide een rol. Zoals gezegd bijvoorbeeld verschaft een middel zelf geen macht, maar de betekenis die dit middiel voor actoren heeft. Betekenissen worden gegeven vanuit routines.

De voorbeelden in dit hoofdstuk tonen dat het door de dominante actor gewenste handelen aanvaardbaar moet zijn voor de ondergeschikte. Is dat niet het geval, dan werkt de laatste uiteindelijk niet mee. Wat de dominante actor wil, gebeurt niet. Blijven standpunten van dominante en ondergeschikte onverzoenlijk, dan resteert een patstelling. Deze patstelling kan alleen worden doorbroken indien de betrokkenen bereid zijn te komen tot een suboptimale, doch voor hen aanvaardbare situatie ("negotiated order").

\subsubsection{Sturingsvormen}

Alle actoren die waren betrokken bij de ontwikkelingen, bedienden zich bij hun pogingen tot beïnvloeding van argumenten, suggesties, discussiepunten en dergelijke. Pogingen tot communicatieve sturing kwamen het meeste voor. Ook al kunnen bijvoorbeeld communicatieve vaardigheden als middel worden beschouwd, de asymmetrie in de afhankelijkheidsrelaties was vooral gebaseerd op het bezit van of toegang tot geldelijke middelen en op handelingsruimte die met behulp van juridische regels (zoals erkenningsvoorwaarden en stichtingsstatuten) waren vastgelegd.

Geldelijke middelen stelden het Ministerie van WVC en de verzekeraar in staat tot economische sturing. De beschikbaarheid van deze middelen was (en is) in de Nederlandse gezondheidszorg grotendeels verankerd in wettelijke regels, zoals de 
subsidieregeling voor intensieve thuiszorg en de subsidieregels in het kader van het Programma van WVC. Deze regels verschaften mogelijkheden tot juridische sturing.

Ook de hulpwerlenende instellingen konden beide sturingsvormen toepassen. Zij konden personeel uit hun eigen organisatie beschikbaar stellen voor de projectorganisatie en voor de uitwoering van de hulp die vanuit het bureau itz werd georganiseerd. Deze hulpverlening geschiedde in aanvulling op de reguliere hulp van de participerende instellingen, conform hetgeen was bepaald in de wettelijke statuten van de stichting itz. Daarin was onder andere vastgelegd dat het bestuur de bevoegdheid voor werving en ontslag van personeel had gedelegeerd aan het directorium. Deze regels in de statuten boden het directorium vervolgens gelegenheid tot organisatorische sturing. Het belang van mogelijkheden tot organisatorische sturing hebben wij overigens niet kunnen vaststellen. Wij kwamen daarvan geen voorbeelien tegen.

De overige actoren en netwerken konden zich bedienen van communicatieve sturing en economische sturing op basis van hun eigen menskracht. In het geval van de projectmanager was deze menskracht in 1992 geen machtsmiddel (zie par. 7.4.1). Voor de projectleider en de werkgroepen is dit miet bekend.

De gecombineerde mogellikheid van juridische en economische sturing is in het geval van het project itz belangrijk gebleken. Degenen die beide vormen konden toepassen en dat ook daadwerkelijk deden (de verzekeraar, kruiswerk en gezinszorg) bleken ontwikkelingen naar hun hand te kunnen zetten. Ook al was communicatie bijwoorbeeld voor de projectleider een brukbaar middel om besluitvorming door de strategische top te geleiden, het was op zichzelf een onvoldoende krachitig middel om beoogde veranderingen teweeg te brengen.

Uiteindelijk was het niet de projectleider die bepaalde wat gebeurde, mar de strategische top. Communicatieve sturing kon in het project itz alleen in combinatie met de twee andere sturingsvormen daadwerkelijk wruchten afwerpen.

\subsection{Ontwikkelingen van en binnen netwerken}

Ons antwoord op de vierde vraag -tot welke ontwikkelingen van/binnen de netwerken heeft de sturing geleid? - is in par. 7.2 al ten dele gegeven. Dit anwoord werken wij hier uit. De projectorganisatie groeide allengs uit tot een netwerk van netwerken en kromp vervolgens weer ineen. De aard van de zich ontwikkelende projectorganisatie op meerdere momenten tijdens het vervlechtings- en ontvlechtingsproces hebben wij getypeerd in termen van structuur, macht en cultuur.

De beschrijwing van de veranderingen in structuur en macht overstijgt niet het niveau van de casuistiek. wanneer wij 'cultuur' buiten beschouwing laten. Juist door structuur en macht te bezien in relatie tot routines, wordt de beschrijving interessant. Pas dan blijkt namelijk dat veranderingen in structuur en macht niet beklijvem, wanneer zij afwijken van de routines van dominante actoren.

Machtige actoren trekken de vorm van de zich ontwikkelende configuraties naar zich toe. Hun handelingen betekenen een 'pull' op de configuratie naar een vorm die overeenkomt met hun routines. Dit geldt het duidelijkst voor de zorgverzekeraar, kruiswerk en gezinszorg. Het geldt echter ook voor WNC. Ook all trad WWC niet op toen bleek dat de projectparticipanten niet werkten aan de samenvoeging van twee projectorganisaties, de participanten richtten wél het convergentiecollege op, hoewell zij dat eigenlijk niet wilden. De verandering wan de situatie ging derhalve hou dan ook in de richting die WNC als dominante partij wenselijk vond. Zelfs het feit dat het 
convergentiecollege doorgaans naliet te doen wat de regels voorschreven, doet hieraan niets af.

\subsubsection{Structuur en macht}

Voor de typering met betrekking tot structuur en macht hebben wij begrippen van Mintzberg (1988) gebruikt. De ontwikkelingen die wij in par. 7.2 .1 schetsten, hadden hun oorsprong in de projectgroep itz , een netwerk dat bij de start van het Programma van WVC reeds bestond.

De projectorganisatie op dat moment kan worden getypeerd als een eenvoudige structuur. Zij werd gekenmerkt door een vaag onderscheid tussen functies die behoren tot de werkvloer, ondersteunende staf, technostructuur, lijnmanagement en strategische top. De projectorganisatie was nauwelijks geëlaboreerd. Van gescheiden organen waartussen vervolgens afhankelijkheidsrelaties waren gecreeerd, was geen sprake. Wél waren de eerste contouren zichtbaar van een asymmetrische afhankelijkheidsrelatie, waarin de leden van het latere projectbureau allengs een ondergeschikte positie gingen innemen ten opzichte van de vertegenwoordigers van de zorgverlenende instellingen.

Vanuit deze configuratie ontwikkelde de projectorganisatie zich gedurende de haridelingen van de betrokkenen gaandeweg in de richting van een adhocratie. Een projectbureau (projectleider en secretaresse) en werkgroepen werden ingesteld. Zij vervulden de functie van ondersteunende staf en technostructuur. Een van hun taken was de formulering van voorstellen voor veranderingen.

Verder werd de stichting itz opgericht. Deze bestond uit een directorium en een bestuur, die samen met het convergentiecollege de functie van strategische top vervulden. Genoemde netwerken waren bevoegd besluiten te nemen over de richting van vernieuwingen en de besteding van middelen. Onder de stichting itz ressorteerde een netwerk dat de functie had van werkvloer: het bureau itz. Aan het hoofd daarvan stond de projectmanager, die als lijnmanager fungeerde en zorgde voor de organisatie van intensieve thuiszorg vanuit het bureau itz. De uitvoering van de zorg gebeurde door de hulpverleners uit de participerende instellingen.

De ontstane adhocratie had een hybride karakter. Het was een combinatie van de eenvoudige structuur en de adhocratie. Anders dan in een zuivere adhocratie was de macht namelijk niet verspreid over de projectorganisatie. De strategische top bleef in de projectorganisatie dominant.

De hybride adhocratie werd naar het einde van de programmaperiode toe onttakeld. De projectorganisatie ontwikkelde zich tot een eenvoudige structuur, ditmaal in de vorm wan een directeurenoverleg. Actoren die uit de omgeving afkomstig waren en gezamenlijk de projectorganisatie vormden, keerden terug naar de omgeving. Hun onderlinge afhankelijkheidsrelaties verdwenen.

Voor de organisatie van de verlening van intensieve thuiszorg werden twee opeenvolgende modellen ingevoerd. Met de modellen werd afstemming beoogd tussen hulpwerleners van kruiswerk, gezinszorg, amw, huisartsen en -op een later momentriagg. De handelingsregels in deze modellen betroffen onder andere de alanmelding, intake, indlicatiestelling, zorgcoördinatie en het opstellen van hulpplannen. Er werd onder meer gebruik gemaakt van multidisciplinaire casusteambesprekingen.

In het eerste model werd afstemming gerealiseerd onder leiding van de projectmanager van het bureau itz. Dit bureau functioneerde als orgaan buiten de zorgaanbiedende instellingen. Het tweede model -ingevoerd in april 1992- had dezelfde 
afstemming tot doel. Anders dan in het eerste model werd afstemming teweeg gebracht door de afzonderlijke instellingen voor kruiswerk en gezinszorg. Het bureau itz en de projectmanager waren uit het tweede model gelaten. De organisatie van de hulpverlening werd, zoals in de reguliere zorg de gewoonte was, voortaan vanuit de instellingen zelf geregell.

\subsubsection{Cultuur}

Het is niet vreemd dat de strategische top in de hybride adhocratie dominant was en bleef. Dit strookte met de routines van de leden van dit orgaan. Zij waren geneigd hun handellingsruimte te behouden en zo mogelijk te vergroten om te kunnen blijven bepalen wat in de hulpverlening gebeurde. Vanuit het perspectief van routines worden ook de ontwikkelingen van vervlechting en ontvlechting begrijpelijk.

Vanaf het begin van het Programma van WVC lag het accent in de onderlinge relaties tussen de hulpverlenende instellingen op individualiteit. De bestudeerde actoren waren geneigd de belangen van hun eigen organisatie te laten prevaleren boven andermans belangen. Dit was het kernbestanddeel van hun routines. Verdert concentreerden kruiswerk en gezinszorg zich op de opbouw van hun onderlinge relaties, zij het vanuit de positie en belangen van hun eigen organisaties. De opbouw van relaties met huisartsen en amw genoot voor deze machtige actoren lage prioriteit.

De stichting itz als samenwerkingsverband van kruiswerk, gezinszorg, amw ên huisartsen kende geen precedent. Oprichting van een dergelijke rechtspersoon week af van de routines van kruiswerk en gezinszorg.

De beschreven routines van kruiswerk en gezinszorg veranderden gedurende de Programmaperiode niet. Zij bleven zich op elkaar oriënteren, vanuit hun eigen posities. De stichting itz, als 'zeer experimenteel experiment' van kruiswerk, gezinszorg èn andere werksoorten, werd eind 1992 opgeheven. Kruiswerk en gezinszorg bleven doende met elkaar relaties op te bouwen en lieten het amw en de huisartsen aan de zijlijn staan. De stichting itz als vernieuwing beklitifde niet.

Aan hetgeen wij hier beknopt weergaven hebben wij een belangrijk inzicht ontleend. Het is niet toevallig dat vervlechting en ontvlechting zich op de beschreven wijze hebben voorgedaan. Vervlechting in de vorm van de stichting itz strookte aanvankelijk met het streven samenwerkingsrelaties tussen verschillende voorzleningen op te bouwen. De oprichting van de stichting itz bood de kans met de mogelijkheden voor multidisciplinaire samenwerking te experimenteren. De noodzaak voor dergelijke samenwerking werd in de loop van de jaren tachtig gevoeld.

Het experiment bleek echter verstrekkender te zijn dan kruiswerk en gezinszorg wilden. Voortbestaan van de stichting itz was niet verenigbaar met hun onveranderde routines. De configuratie van de projectorganisatie veerde eind 1992 naar de routines van kruiswerk en gezinszorg, ontvlechting was een feit. Het ging niet om willekeurige actoren. Zoals gezegd waren kruiswerk en gezinszorg machtig. Zij waren machtiger dan andere hulpverlenende instellingen. Als dominante actoren zorgden zij ervoor dat de configuratie van de projectorganisatie zich ontwikkelde naar een worm die overeenkwam met hun routines.

Gedreven door eigenbelang, dat niet langer kon worden verenigd met de collectiviteit die voor de stichting itz de enige bestaansgrond was, braken de actoren zelf hun onderlinge relaties af. De adhocratie viel in stukken uiteen, een eenvoudige structuur bleef over. 
Het onderscheid tussen het eerste model voor de organisatie van intensieve thuiszorg en de routines van de participanten was groot. Integratie tussen kruiswerk en gezinszorg alleen al betekende een ingrijpende wijziging van handelwijzen die men belangrijk vond, waaraan men gewend was en waaraan men geneigd was vast te houden. Daarenboven zou bij intensieve thuiszorg nog moeten worden samengewerkt met de huisartsen én het amw, hetgeen ook al niet de gewoonte was. Tenslotte moesten daarbij nieuwe instrumenten worden gebruikt waarvan één -'projectmanager'niet werd aanvaard.

Het eerste model voor intensieve thuiszorg was gefundleerd op de noodzaak van collectiviteit in de relaties tussen alle participerende voorzieningen. In de praktijk echter was deze collectiviteit niet zichtbaar. Individuele belangen waren onvoldoende compatibel.

De invoering van het tweede model betekende een verandering in de richting van de oudie routines. Het model sloot goed aan bij de wijze waarop gezinszorg en kruiswerk geneigd waren te werken. Verdeling van de taken van de projectmanager over de instellingen van kruiswerk en gezinszorg strookte met de routines die reeds in 1990 tot uiting kwamen. Oude routines bleken ook in de organisatie van de hulpverlening hardnekkig.

Echter, anders dan bij het secundair proces was in de organisatie van de hulpverlening geen sprake van een volledige terugkeer naar de aloude situatie vóór 1990. Het instrument 'multidisciplinaire casusteambesprekingen' werd in het eerste en tweede model gehandhaafd. Hoewell wij de kiem voor dit instrument al vinden in de periode voor 1990, werd het pas in de projectperiode regelmatig gebruikt. Hulpverleners gaven aan casusteambesprekingen belangrijk te vinden. Gebruik van dit instrument strookte met hun routines die in de loop van het project waren veranderd.

\subsection{Sturing naar beoogde thuiszorg}

De studie laat eens te meer zien dat macht belangrijk is om regels voor het handelen in te voeren (of te schrappen) en handelingsruimte te verschaffen (of te begrenzen). Regels doen ter zake als leidraad voor het handelen, indien zij worden gebruikt. Of regels worden gebruikt, heeft te maken met de motivatie van actoren.

Het belang van routines bij die motivatie, in het bijzonder de routines van machtige actoren, mag niet worden onderschat. De relevantie van betekenissen die door actoren vanuit hun routines aan situaties wordt gegeven, evenmin. Een actor is bijvoorbeeld pas machtig, indien hij over een middel beschikt dat in de perceptie van een andere actor onontbeerlijk is. Hij kan op basis van dit middel sturingspogingen doen.

De gecombineerde mogelijkheid van juridische en economische sturing is belangrijk. Degenen die beide vormen kunnen toepassen en dat ook daadwerkellijk doen, zijn in staat ontwikkelingen naar hun hand te zetten. Hieruit mag niet worden afgeleid dat mogelijkheden tot communicatieve sturing onbelangrijk zijn. Per definitie impliceren sturing en sturingspogingen namelijk altijd een of andere vorm van verbale of nonverbale communicatie. Verder bevat de case van de pg-patiënten aanwijzingen dat zelfs een machtige bestuurder als de verzekeraar genoodzaakt was de inzet van 
juridische en economische sturingsmiddelen vergezeld te doen gaan van argumentatie en discussie, voordat de eigen wensen werden vervuld ${ }^{108}$.

Routines zijn weerbarstig en doordrenken al hetgeen met handelen te maken heeft, inclusief de veranderingen door handelingen in structuur, cultuur en macht. Deze veranderingen komen niet tot stand op basis van sturing door eén actor, maar van sturingsinteracties. Meerdere actoren dragen aan veranderingen bij, de situatie op enig moment is een 'negotiated order'.

Deze bevindingen hebben grote implicaties voor zorgvernieuwing. Zo kan de weerbarstigheid van routines van machtige actoren veranderingen in de weg staan. Zorgvernieuwing wordt in Nederland belangrijk gevonden (Mur-Veeman et al, 1994). Wij achten het zinvol met onze studie een bijdrage te leveren aan de discussie over de mogelijkheden tot zorgvernieuwing.

Op basis van de bevindingen hebben wij een reeks beleidsaanbevelingen geformuleerd. Aldus wordt de vijfde en laatste vraag van de studie beantwoord: door wie, hoe en onder welke omstandigheden (in welke context) is het mogelijk zodanig sturing te verrichten, dat zich netwerken ontwikkelen die door een of meerdere actoren beoogde thuiszorg leveren?

Wij richten de aandacht bij de beantwoording op het secundair proces en het secundaire niveau van het primaire proces. Thuiszorg als product blijft buiten beschouwing. Ook met de vraag wat goede thuiszorg is, houden wij ons niet bezig. Goede thuiszorg is wat actoren goede thuiszorg vinden. Wat de een goed vindt, kan in de perceptie van de ander slecht zijn. Betekenissen liggen nooit vast, de betekenis van goede thuiszorg evenmin.

\subsubsection{Kennis van routines en betekenissen als uitgangspunt voor sturing}

De uitspraak over wat goede thuiszorg is, brengt ons tot het hart van een kwestie die wij herhaaldelijk zijn tegengekomen, zowel in het onderzoek naar het Programma van WVC als tijdens andere onderzoeken. Actoren in de zorgvernieuwingsprojecten die wij hebben onderzocht, waren nogal eens geneigd datgene wat zij vanuit hun routines zelf als goede thuiszorg zagen, tot standaard te verheffen. Meer dan eens waren initiatiefnemers van vernieuwingen, zoals projectleiders, blind voor de betekenissen die andere actoren op basis van hún routines aan een voorgesteld initiatief gaven. Vervolgens konden zij niet begrijpen waarom anderen niet wilden meewerken aan de door hen geopperde veranderingen: de actoren wilden toch goede thuiszorg en met het voorstel werd toch goede thuiszorg nagestreefd?

Dat routines en daarbij aansluitende betekenissen kunnen variëren van actor tot actor is een belangrijk gegeven, omdat actoren handelen op basis van de betekenis die een situatie voor hen heeft. Kennis van routines van anderen moet het uitgangspunt zijn bij sturingspogingen. De bestuurder heeft de medewerking van anderen namelijk nodig. Juist door nadrukkelijk rekening te houden met hun routines, krijgt een bestuurder beter inzicht in de betekenissen die nagestreefde vernieuwingen voor hen kunnen hebben, en in de realiseerbaarheid van de vernieuwingen. In de navolgende aanbevelingen staan betekenissen en routines dan aok voorop.

108 Wij kunnen owerigens miet bewijzen dat zonder deze communicatie overeenstemming was uitgeblewen. 


\subsubsection{Aanbevelingen}

Veelal is bij zorgvernieuwingsprojecten sprake van een bestuurder die als initiator of kartrekker optreedt. Bij de formulering van de aanbevelingen hebben wij ons verplaatst in de positie van deze bestuurders. Hierna wordt stap voor stap aangegeven hoe zij te werk moeten gaan.

\subsubsection{Voorbereiding van de vernieuwing}

De bestuurder dient te beginnen met een globaal concept van de vernieuwing die hij noodzakelijk acht. Vervolgens moet hij bezien welke actoren bij een vernieuwing betrokken (zullen) zijn en hun routines inventariseren. Het gaat daarbij om routines die met het globale concept in verband kunnen worden gebracht. Het globale concept is hier niet meer dan een hulpmiddel voor de inventarisatie. Zonder dit concept is de speurtocht naar routines richtingloos, tijdrovend en naar verwachting niet efficiënt.

Daarna moet met hetzelfde concept als referentiepunt worden vastgesteld wie van de betrokkenen machtig zijn. Machtige actoren zijn degenen die over middelen beschikken, welke voor anderen belangrijk zijn en waarvoor geen alternatieven aanwezig zijn. In de praktijk gaat het vooral om geldelijke middelen, die handelingsruimte kunnen verschaffen. Met de mogelijkheid dat 'wie betaalt, bepaalt', moet bij zorgwernieuwing terdege rekening worden gehouden.

Wellicht is de bestuurder zelf een machtige actor. Dit moet hem er niet van weerhouden de macht te bepalen van anderen, omdat veranderingen nu eenmaal het resultaat van handelingen van meerdere actoren en niet van één actor.

\subsubsection{Voorstellen voor vernieuwing}

Wanneer de bestuurder een verzameling handelingsregels voorstelt, die bij gebruik resulteren in een systeem met een bepaalde structuur (bijvoorbeeld een projectorganisatie of een organisatiemodel voor afstemming in de uitvoering van de hulpverlening), dan dient hij terdege rekening te houden met de routines van machtige actoren. Naarmate het voorstel verder afwijkt van hetgeen deze actoren wenselijk of noodzakelijk vinden, neemt de realiseerbaarheid af.

Ook machtsverschillen tussen actoren moeten zichtbaar worden gemaakt. Een hulpmiddel daarbij zijn de vier afhankelijkheidscirkels, die wij hebben onderscheiden en waartussen relaties bestaan. De binnenste cirkel (projectinterne werkgroepen en anderen) was het meest ondergeschikt, de buitenste cirkel (het Ministerie van WVC als projectexterne actor) was -gezien de beschikbare economische en juridische machtsmiddelen- in potentie het meest dominant. Afhankelijk van de situatie kan sprake zijn van meer of minder cirkels. Actoren moeten worden ingedeeld bij deze cirkels.

Vervolgens moet worden gezocht naar vernieuwingen, die aanvaardbaar zijn voor de actoren in de buitenste cirkel. Blijkt op voorhand al dat een vernieuwing voor de actoren in de buitenste cirkel volstrekt onaanvaardbaar is en dat zij tijdens sturingsinteracties niet kunnen worden verleid tot een ander standpunt, dan ligt het voor de hand te streven naar een alternatief dat wél aanvaardbaar is. Aldus kan worden voorkomen dat de dominante actor zal weigeren de ruimte te verschaffen die voor uitvoering van het initiatief nodig is. Vervolgens moet worden bezien of de vernieuwing aanvaardbaar is binnen de volgende cirkel (van buiten naar binnen), en zo voort.

Idealiter zijn alle cirkels 'gelijkgeschakeld', woordat wordt gestart met het initiatief. Deze ideaaltypische situatie zal echter eerder uitzondering dan regel zijn. Een 
alternatieve werkwijze is te kiezen woor vernieuwingen waarbij zo min mogelijk afhankelijkheidscirkels van belang zijn.

Omdat de beschikbaarheid van geldelijke middelen in de Nederlandse gezondheidszorg voor thet grootste gedeelte is verankerd in wet- en regelgeving, is het belangrijk vast the stellen of een voorstel voor zorgvemieuwing past binnen de geldende wettelijke regels, die door de actor in de buitenste athankelijkheidscirkell zijn ingevoerd. De hier beschreven werkwijze lijkt een vanzelfsprekendheid, maar is het in de praktijk lang niet altijd. Dat bleek duidelijk gedurende het Programma van WVC. Meerdere malen zijn wij bijvoorbeeld initiatieven tegengekomen, waarvoor financiering en uitvoering volgens de geldende regels niet mogelijk bleek "en welke vervolgens geen doorgang vonden.

Alternatieve mogelijkheden voor zorgvernieuwing zijn belangrik. Wanneer een bestuurder de keus heeft tussen meerdere alternatieven die evenzeer kunnen bijdragen aan de door hem beoogde vernieuwing, dan ligt het voor de hand te kiezen voor het alternatief dat het meeste aansluit bij de routines van de machtige actoren.

Ook al is de bestuurder zelf een machtige actor, dan nog kan hij niet zonder meer doen wat hij wil. Hij moet rekening houden met de wensen van ondergeschikten, omdat het hier gaat om afhankelijkheden binnen asymmetrische gezagsrellaties die wederkerig zijn, en waarbij ondergeschikten eveneens macht hebben. Ook voor een dominante actor geldt dat indien voor vernieuwingen meerdere alternatieven bruikbaar zijn, deze moet kiezen voor het alternatief dat het meeste aansluit bij de routines van anderen, in dit geval ondergeschikte actoren.

\subsubsection{Motivering wan betrokken actoren tot gebruik van de regels}

Actoren moeten gemotiveerd zijn de voorgestelde regels te gebruiken. Intrinsieke motivatie heeft het primaat boven extrinsieke motivatie. Om een beroep te kunnen doen op intrinsieke motivering is kennis van de routines van netwerkleden evenzeer noodzakelijk. Bestuurders moeten bijvoorbeeld weten wat de wensen en behoeften van actoren zijn opdat zij hen met argumenten die daarbij aansluiten kunnen "verleiden' tot participatie.

Kennis van routines is ook in het volgende opzicht van belang. De bestuurder kan van de kennis gebruik maken om te trachten stuurders te verzenden met behulp van taal, die het beste aansluit bij de routines van de actoren en dermalve het meest geschikte vehikel is om boodschappen over te brengen.

Gezien het interactieve karakter van zorgvernieuwing, het belang wan intrinsieke motivatie en van medewerking van ondergeschiktem, geniet een participatieve bestuursstijl de voorkeur boven een autoritaire bestuursstijl.

Voor extrinsieke motivatie zijn machtsmiddelen nodig. Wat een machtsmiddel is, wordt bepaald door de actoren zelf. Zij geven aan zaken in hun omgeving bijvoorbeeld de betekenis 'belangrijk middel'. Degene die weet dat hetgeen hij bezit waardevol is voor de ander, kan met de inzet daarvan trachten te sturen. Een bestuurder moet dus nagaan over welke belangrijke middelen hij beschikt. Ook daarvoor is kennis van de routines van andere actoren vereist.

Twee actoren met belangrijk sturingsvermogen zijn de zorgverzekeraar en de rijksoverheid. Zij beschikken over een middel dat voor de participanten in zorgvernieuwing waardevol is en waarvoor zij veelal geen alternatieven kunnen vinden: geld. Het bezit van geld als fundamenteel machtsmiddel leidt echter niet automatisch tot sturing. Evenmin is een eenmalige stuurder zonder meer voldoende. Zoals aangegeven, zijn ondergeschikten niet verstoken van macht. Zil kunnen aan de vervulling van de wensen 
van een dominante actor hun medewerking verlenen of weigeren. De dominante actor is afhankelijk wan hun bereidheid tot medewerking.

Deze bereidheid is niet vanzelfsprekend aanwezig. Ook al lijken zij nog zo machtig, indien de genoemde bestuurders kartrekker willen zijn bij zorgvernieuwing, dan moeten zij ervan uitgaan dat zij meerdere inspanningen moeten doen om hun wensen gehonoreerd te zien. Wellicht moeten zil rekening houden met een aankomende "negotiated order" en moeten zij op voorhand bereid zijn een suboptimaal resultaat te aanvaarden. Een goed verloop van een reeks sturingsinteracties vergt stuurmanskunst met behulp van een melange van juridische, economische en communicatieve sturing, die is toegesneden op de situatie. Daarvoor is het noodzakelikk dat ook bestuurders zoals de verzekeraar en de rijksoverheid, de door hen waargenomen situatie analyseren. Ook zij moeten de aard leren kennen van de situatie zoals de anderen die percipiëren. Ook zij moeten de routines leren kennen en kunnen bepalen wat zijzelf en andere actoren belangrijk, wenselijk enzovoorts vinden.

Het is een voordeel dat routines niet zodanig specifiek zijn, dat exact vast ligt welke situaties en regels wenselijk of onwenselijk zijn. Routines kennen een bandbreedte. Met betrekking tot situaties omvatten zij een continuüm, dat van 'ideale situatie' vila 'aanvaardbare situatie" loopt tot 'onaanvaardbare situatie". Juist dit gegeven, dat aansluit bij inzichten in de onderhandelingsliteratuur (zie bijvoorbeeld Mastenbroek, 1992), biedt aan bestuurders de mogelijkheid tot het realiseren van een "negotiated order", in situaties waarbij de betrokkenen dragers zijn van verschillende routines. Door bij actoren met werschillende routines actief te zoeken maar het punt op het continuüm waar voor hen allen het aanvaardbare ligt, stellen bestuurders zichzelf in staat een haalbare vemieuwing te vinden.

Tevens is het een voordeel dat betekenissen van verschijnselen niet onwrikbaar vast liggen. Betekenissen kunnen bijvoorbeeld veranderen "wanneer de context van een vernieuwing in de perceptie van de actor anders wordt. Door een vernieuwing, die een actor op zichzelf als onwenselijk beoordeelt, in een andere context te plaatsen, kan de bestuurder bijdragen tot verandering van de betekenis. Besturing is dan manipulatie van betekenissen. Indien een actor het bijvoorbeeld niet wenselijk vindt mee te werken aan de opzet van een gemeenschappelijk coördinatiepunt, omdat een dergelijk initiatief niet strookt met zijn visie op een goede organisatie van de hulpverlening, dan is het zeer wel mogelijk dat hij alsnog meewerkt, wanneer de bestuurder hem duidelijk kan maken dat medewerking de weg effent naar extra financiering.

De veranderlijkheid van betekenissen heeft ook nadelen. Hetgeen vandaag als aanvaardbaar wordt beschouwd, kan morgen de betekenis 'onaanvaardbaar' krijgen. Oindat zij zijn gebaseerd op betekenissen, kan de richting van handelingen niet exact worden voorspeld. Toch is voorspelling niet volledig uitgesloten. Het aantal mogelijke betekenissen is in theorie weliswaar oneindig, maar actoren leren gedurende hun leven betekenissen en routines aan, bijvoorbeeld tijdens beroepsopleidingen. Bestuurders mogen ervan uitgaan dat een deel van de betekenissen die aan situaties (zullen) worden gegeven, raakvlakken vertonen met routines en betekenissen die de actor reeds heeft aangeleerd. Dit biedt bestuurders de gelegenheid te bepalen binnen welke ruime marges een betekenis die aan een situatie wordt gegeven, zich naar verwachting zal bevinden. Daarmee ontstaat de gelegenheid het daarop volgende handelen binnen even zo rume marges te voorspellen. Aan het voorkomen van bepaalde handelingen kunnen zij kansen toekennen. Met behulp daarvan kunnen zij anticiperen op dat wat komen gaat.

Verregaand gespecificeerd kunnen voorspellingen echter niet zijn, temeer daar niet alleen handelingen, maar ook interacties plaatsvinden. Tijdens interacties reageren 
actoren op elkaars handelen. Zij kunnen daardoor gaan afwijken van de voorspelde koers. De voorspelling door de bestuurders kan op losse schroeven komen te staan. Een incrementele benadering van zorgvernieuwing is derhalve noodzakelijk. Deze benadering biedt expliciet de gelegenheid om bij elke stap in het veranderingsproces still te staan bij de ontstane situatie en vervolgens zo nodig van koers te veranderen.

\subsubsection{Invulling van de structuur en functioneren van het systeem}

Ervan uitgaande dat de bestuurder erin slaagt de voorgestelde handelingsregels voor bijvoorbeeld de organisatie van de hulpverlening geaccepteerd te krijgen, moet de aandacht uitgaan naar degenen die de regels moeten gebruiken. Acceptatie en gebruik van regels kumnen twee verschillende zaken zijn. Een systeem ontstaat, bestaat en functioneert door de handelingen van de actoren die daarvan deel uitmaken. Posities in de structuur op papier moeten in de praktijk worden ingevuld.

Idealiter kan de bestuurder zelf kiezen wie welke posities bekleedt. Wanneer een systeem wordt opgebouwd, dan moeten leden worden geselecteerd die de gewenste routines reeds bezitten ('preselection'; zie Merton, 1957). Routines zijn namelijk weerbarstig. Verandering van ongewenste routines tot gewenste routines, ofwel socialisering (Van Maanen, 1976), verloopt moeizaam en is een tijdrovend proces.

In de praktijk zal de keuzevrijheid begrensd zijn. Niettemin dienen ook in dat geval alle mogelijkheden tot 'preselection' te zijn benut, voordat de bestuurder overgaat tot socialisering van actoren die niet de gewenste routines bezitten. Is socialisering onvermijdelijk, dan heeft intrinsieke motivering de voorkeur boven extrinsieke motivering. Aan het effect van de laatste vorm wordt in de literatuur namelijk getwijfeld (Ott, 1989).

Wanneer tijdens het functioneren van het systeem blijkt dat bepaalde leden -tegen de aanvankelijke verwachtingen in- geen dragers zijn van de gewenste routines, dan geniet vervanging door anderen de voorkeur boven socialisering van de zittende leden. Het spreekt voor zich dat deze anderen dragers moeten zijn van de gewenste routines. Dit alles geldt ook wanneer bestaande systemen moeten worden veranderd.

\subsection{Discussie}

Wanneer wij het geschilderde tafereel van een afstand bekijken en daarbij letten op de gebruikte theorie en methodologie als de twee bestanddelen van het functionalistische paradigma waarbinnen wij de studie hebben uitgevoerd, dan komen wij tot de volgende conclusies.

\subsubsection{Theorie}

De werkwijze die wij bij de opbouw van het conceptueel raamwerk hebben gevolgd, kenmerkt zich door de combinering van inzichten uit de 'social system theory' en het interactionisme. De combinatie kwam tot uiting in de aandacht voor de betekenis van verschijnselen voor actoren, voor hun routines als uiteindelijke basis van het handelen, de plaats die wij aan handelingsregels hebben toegekend bij veranderingen gedurende handelingen en interacties in structuur, cultuur en macht, et cetera.

De werkwijze heeft ons de inzichten verschaft die wij in dit hoofdstuk beknopt hebben weergegeven. Belangrijk nu is aan te geven in welke opzichten wij hebben 
bijgedragen aan wetenschappelijke theorie-ontwikkeling. Daaraan voorafgaand gaan wij na of de uitspraken in hoofdstuk 2 samen een theorie zijn.

\subsubsection{Wel of geen theorie}

De verzameling uitspraken over verschijnselen en hun relaties die wij in hoofdstuk 2 met behulp van hel conceptueel raamwerk hebben gepresenteerd, noemen wij een theorie. Dat roept wellicht de vraag op in hoeverre het passend is deze benaming te gebruiken. Volgens Swanborn (1987) is een theorie een stelsel van uitspraken die dienen om beschrijvingen, voorspellingen en verklaringen van de werkelijkheid mogelijk te maken. Deze omschrijving is algemeen. Op grond daarvan kan aan tal van uitsprakenstelsels de naam 'theorie' worden gegeven.

Om te kunnen bepalen of een uitsprakenstelsel theorie mag worden genoemd of niet, zijn meerdere criteria denkbaar. De maatstaf bij uitstek is dat uitspraken weerlegbaar moeten zijn. Dit vereist niet alleen dat zij bijvoorbeeld eenduidig zijn, maar ook dat zij informatief zijn. In de uitspraken moet worden aangegeven welke gebeurtenissen zich onder welke omstandigheden al of niet zullen voordoen. Uitspraken zijn informatiever naarmate, gegeven bepaalde omstandigheden, meer mogelijke gebeurtenissen worden uitgesloten.

Bezien vanuit dit criterium bestaat tussen een stelsel dat 'theorie' mag worden genoemd en een stelsel dat die naam niet mag dragen, geen absoluut onderscheid. Een uitspraak kan meer of minder informatief zijn, omstandigheden en gebeurtenissen kunnen in een uitspraak meer of minder gespecificeerd worden aangeduid. Nemen wij 'volledig ongespecificeerd' en 'volledig gespecificeerd' als de twee uiteinden van een continuüm, dan komen wij tot de volgende conclusie. Wij deden in hoofdstuk 2 uitspraken over de omstandigheden waaronder bepaalde verschijnselen zich (zullen) voordoen. Zo moge duidelijk zijn dat in onze optiek een actor bijvoorbeeld sturingspogingen zal doen, indien handhaving van een situatie door hem niet als wenselijk wordt beschouwd.

Echter, wij gaven niet aan welke kenmerken deze situatie exact moet hebben en hoe de sturingspogingen er precies moeten uitzien. Dit was niet het geval omdat wij onze uitspraken niet specifieker konden maken, maar omdat wij deze niet specifieker wilden maken. De reden ligt in het begrip 'betekenis'. Betekenissen die door de actor vanuit routines aan verschijnselen worden gegeven, beschouwen wij als het uitgangspunt voor het handelen. Betekenissen kleven niet aan verschijnselen vast. $Z$ ij zijn veranderlijk. Verschillende actoren kunnen aan een en hetzelfde verschijnsel verschillende betekenissen geven. Ook kan hetzelfde verschijnsel voor dezelfde actor in een andere context een andere betekenis krijgen. Is de betekenis anders, dan is het uitgangspunt voor handelingen anders. Handelingen zullen ook anders zijn.

Vanwege de veranderlijkheid van betekenissen achtten wij het niet zinvol in onze theoretische uitspraken exact aan te geven wanneer zich welk verschijnsel zal voordoen. Dergelijke uitspraken zijn weliswaar informatief, maar leverden voor de studie geen bruikbare inzichten op.

Niettemin is voorspelling niet geheel uitgesloten. De aanwezigheid van routines verleent aan handelingen enige voorspelbaarheid. Zo kan kennis van routines worden benut om in te schatten welke betekenis situaties voor actoren hebben. Hoewel het aantal betekenissen in theorie oneindig is, zal dit in de praktijk niet het geval zijn. Echter, dit alles geldt voorzover het gaat om handelen van individuele actoren. Een deel van de handelingen bestaat uit interacties. Daarvan staat het verloop lang niet altijd op voorhand vast. Ook daardoor is de voorspelbaarheid beperkt van de verschijnselen waarover wij hier spreken. 
Al deze overwegingen brengen ons tot de conclusie dat ons stelsel van uitspraken een theorie kan worden genoemd, met als kanttekening dat de uitspraken, naar hun mate van specificiteit bezien, een positie innemen tussen de beide uiteinden vam het continuüm. Of de theorie informatief is met betrekking tot het gehanteerde perspectief op besturing, komt in par. 7.7 .1 .2 nog aan de orde.

\subsubsection{Bijdragen aan wetenschappelijke theorie-ontwikkeling}

Over het algemeen zijn de uitspraken in onze theorie gebaseerd op literatuur met een gevestigde status. De meeste zijn dan ook genoegzaam bekend. Niettemin bevat de theorie wel degelijk een nieuw element. Deze betreft de relaties tussen regels enerzijds en cultuur, structuur en macht anderzijds. De uilspraken aangaande deze relatiles (zoals over veranderingen in de laatste drie verschijnselen door gebruik van handelingsregels en over de ral van betekenissen daarbij) vormen een aanscherping van bestaande inzichten uit de literatuur over netwerken in de gezondheidszorg.

Voorts is van belang op het volgende te wijzen. In de theorie zijn wij verder gegaan met de integratie van inzichten uit verschillende functionalistische benaderingen (welke integratie reeds zichtbaar was) en bouwden wij voort op bestaande kennis. Aldus hebben wij getracht bij te dragen aan de wetenschappelijke ontwikkelling die inmiddels plaatsvond.

Genoemde voortgaande integratie is noodzakelijk voor een duidelijker inzicht in de verschijnselen waarover het hier gaat. Onze studie laat zien dat de "social system theory' en het interactionisme complementair kunnen zijn en dat tekortkomingen van de ene benadering vanuit de andere benadering kunnen worden gecompenseerd. Door systeemtheoretische inzichten 109 te gebruiken wordt bijvoorbeeld legemoet gekomen aan de kritiek dat binnen het interactionisme aan het verschijnsel 'structuur' te weinig aandacht wordt besteed. Omgekeerd maakt de toevoeging van interactionistische kennis de aanpak mogelijk van het veelgenoemde probleem, dat bij studies naar systeemontwikkelingen onvoldoende rekening wordt gehouden met de vormgevende rol van betekenisvolle handelingen van actoren.

Wij hebben geconstateerd dat niet alleen wij, maar ook andere auteurs deze integratie noodzakelijk vinden. Zelfs in een discipline als bestuurlijke informatiekunde, warin van oudsher de systeembenadering overheerste, is een verschuiving in oriëntatie waarneembaar. Meer en meer wordt de wens geuit te komen tol een theoretische benadering van informatiesystemen, die rekening houdt met de kenmerken van actoren en hun interacties. lltustratief hiervoor is het pleidooi van Gazendam (1997) vaor de ontwikkeling en het gebruik van multi-actor modellen ter verklaring van de 'sociale en organisatorische werkelijkheid'.

Het pleidooi van Gazendam brengt ons bij het laatste aspect van de bijdragen van de studie in theoretisch opzicht. De analyses van gegevens over het project itz leididen tot tal van aanwijzingen dat van de twee rivaliserende theoretische perspectieven op sturing, het rationele-actorperspectief en de interactiebenadering, de eerste niet bruikbaar is bij de bestudering van het onderhavige object. Doordat wij vervolgens op theoretisch niveau kozen ten faveure van de interactiebenadering, wordt aangaande

109 Wij zijn ons ervan bewust dat wij in hoofdstuk 2 een basale weergawe hebben geboden varn de bestaande systeemthearetische inzichten. Wij hebben ons tot deze weergave beperkt, omdat voor ans hel primaat lag bij het interactionisme. Een van de consequenties is dat systeemtheoretische begrippen zoals 'intrinsieke besturing', welke momenteel in de belangstelling staan wan divarse auteuirs (zoals De Leeuw. 1994) en waarwan de inhoud trouwens herkenbaar is in beschrijwingen in hoofdstuk 4 tot en met 6 , niel zin opgenomen. 
een essentieal verschijnsel sturing- voldaan aan het criterium dat een theorie informatief moet zijn. Uitgesloten wordt namelijk dat het rivaliserende perspectief van toepassing is.

\subsubsection{Methodologie}

Kern van de gevolgde methodologische werkwijze was het gebruik van een conceptueel raamwerk met 'sensitizing concepts', dat langs meerdere iteraties op de empirie werd afgestemd. Bij de onderbouwing wan theoretische uitspraken met behulp van empirische gegevens hebben wij waar mogelijk nauwgezet de regels van Yin gevolgd. Dit alles bleek een goede wijze om met de veranderlijke, complexe onderzoeksmaterie om te gaan.

Ter afronding van de discussie gaan wij in op de empirische onderbouwing en de generaliseerbaarheid van de studie-resultaten.

\subsubsection{Empirische onderbouwing (bewijswoering)}

Kritiek op case studies concentreert zich veelal op de kwaliteit van de bewijsvoering (zie Yin, 1989). Door bijvoorbeeld uitvoerige beschrijvingen te geven van de data waarop onze bevindingen zijn gebaseerd en door de begrenzing van onze bewijslast expliciet aan te geven, hebben wij getracht het wetenschappelijk forum in staat te stellen te bepalen in hoeverre onze uitspraken plausibel zijn. Aldus trachtten wij te vermijden dat de bewijsvoering summier en ondoorgrondelijk werd.

Zoals elke andere kent onze studie een aantal punten waarbij kritische kanttekeningen kunnen worden geplaatst.

De interactionistische uitspraak dat betekenissen het uitgangspunt zijn voor handelingen, was in de studie een assumptie. Of bepaalde betekenissen actoren ertoe hebben aangezet op een bepaalde manier te handelen, kon niet worden waargenomen. Wij konden deze uitspraak niet volledig empirisch onderbouwen. Datgene wat zich in het hoofd van de actoren afspeelde, was een black box en viel per definitie buiten de reikwijdte van de onderhavige, sociologische studie.

Verder hebben wij tijdens het onderzoek voor de studie geen observaties verricht, vanwege gebrek aan personele capaciteit. Observatie is een waardevolle methode voor de waarneming van interacties. Wij hebben gebruik gemaakt van observaties door derden en, waar mogelijk, bevindingen gecontroleerd met behulp van gegevens uit andere bronnen (triangulatie). Aldus hebben wij getracht, conform de regels van de 'case study' benadering volgens Yin, de validiteit van de bevindingen te vergroten.

Niettemin blijft het mogelijk dat eigen observaties ons in staat hadden gesteld interacties scherper in beeld te krijgen dan nu is gebeurd. Eigenhandig verrichte observaties hadden wellicht kunnen leiden tot meer diepgaande beschrijvingen van het verschijnsel dat zichtbaar wordt in het handelen en dat wij 'routines' hebben genoemd. Gesproken in termen van onze metafoor zou het gebruik van een andere penseel mogelijk tot een meer verfijnde schildering hebben geleid.

\subsubsection{Generaliseerbaarheid}

Onze bevindingen hebben betrekking op het project Intensieve Thuiszorg ZuidKennemerland, dat in de beginjaren van het huidige decennium een van de vele zorgvernieuwingsprojecten in Nederland was (Nivel et al, 1991). Wij kunnen de getrokken conclusies niet langs statistische weg generaliseren naar de totale populatie 
van zorgwernieuwingsprojecten. Dit is geen probleem, omdat wil streefden naar analytische generaliseerbaarheid, via 'repilication'.

Echter, ook deze vorm van generaliseerbaarheid heeft hier grenzen. De patronen tussen verschijnselen die wij met behulp van cases hebben vastgesteld, betroffen hetgeen binnen het kader van dit ene project gebeurde. Dit is nog geen garantie dat "replication" magelijk is aan de hand van gegevens over cases büten het project itz.

Toch zijn de verworven inzichten voldoende interessant om in vervolgonderzoek analytische generaliseerbaarheid buiten het project itz na te streven, temeer daar rapporten over andere projecten -zowel binnen het Programma van WVC als daarbuiten- laten zien dat het project itz geen uniek geval is (zie Tijssen et al, 1991; Van Raak et al, 1992, 1993; Van Raak en Mur-Veeman, 1994, 1995, 1997). De rapporten bevatten meer dan eens aanwijzingen dat de inzichten uit deze studie ook voor andere, soortgellike projecten gelden.

Wij beschouwen de theorie die wij met behulp van gevestigde inzichten uit de literatuur en empirische gegevens hebben opgebouwd als een prototype, dat door herhaalde confrontatie van theoretische uitspraken met empirische gegevens tijdens de onderhavige studie een eerste maal is beproefd. Het kan als uitgangspunt dienen voor vervolgonderzoek en moet tijdens dit onderzoek verder op zijn merites worden beoordeeld. Juist omdat de theorie een prototype is, was de beperking wan onze analyses tot één project (dat bovendien overeenkomsten vertoont met andere projecten) geen bezwaar.

In het vervolganderzoek zou de aandacht met name moeten uitgaan naar de rol van routines bij zorgvernieuwing. Kennis die wij hebben verworven tijdens onderzoek naar het interorganisationele samemwerkingsproject 'Wijkzorg voor Ouderen en Gehandicapten in Maastricht" (Van Raak en Mur-Veeman, 1994, 1995 en 1997) sterkt ons in de gedachte dat het verschijnsel van de routines niet alleen van belang is geweest tijdens het Zuid-Kennemerlandse project ${ }^{110}$.

Voor ons vervolgonderzoek is verwerving van verder inzicht in routines de grootste uitdaging, gezien het geconstateerde fundamentele belang daarvan voor het handelen van actoren. Zonder inzicht in routines kan door wetenschappers niet worden doorgrond wat de betekenis van situaties is voor actoren. Het uitgangspunt van

110 In de toop van het onderzoek naar dit Maastrichtse project verstiekten wij op besis van de analyse wan empirische gegevens tussentijdse adviezem aan de projectleiding over de besturing van vernieuwingen in Maastricht. De gegewens werden onder meer werkregen via obserwalte door de onderzoeker tijdens vergaderingen. Uitglangspunt woor de adviezen was de geconslatearde noodzaak van de bereidwillige medewerking van autonome zorgaanbiedende instelingen voor het welslagen van het project. Een wan de adviezen betrof de vormgeving van de projectorganisatie. Aanwankelijk overwoog de projectleiding aan de participanten een voorstel te doen dat voorzag in gecentraliseerde besluitvorming door een afzonderlijk orgaan. Wij adviseerden daarvan af te zien, omdat de participanten daarmee naar onze verwachting miel akkoord zouden gaan. Naar ons inzicht strookte een dergelijk woorstel niet met hun routines. Wil adviseercten de projectorganisatie zodanig vorm te geven, dat werd tegemoet gekomen aan de geneigdheid wan de participantan de besluitvorming over de richting van vernieuwingen in eigen hand le houden. Deze geneigidheid was kenmerkend voor hun routines. De projectleiding deed conform ons advies een voorstel, dat na bespreking unaniem werd aanvaard en vervoigens werd geimplementeerd. Tijdens de bespreking werd door de participanten duidelijk gemaakt dat de voorgestelde projectorganisatie de best haalbare optie was en dat zij een eventueel model dat voorzag in een centraal besturend orgaain, niet zouden hebben geaccepteerd. De projectorganisatie is inmiddels sinds het najaar van 1995 operationeel en de participanten waren anno 1997 tevreden over het functioneren ervan (Van Raak en Mur-Veeman, 1997). 
handelingen blift dan onbekend. Het handelen zelf kan niet worden begrepen, de resultaten daarvan evenmin.

Ook actoren die sturing willen geven aan veranderingen kunnen met inzicht in routines hun voordeel doen. Zonder dit inzicht kunnen handelingen van actoren bijvoorbeeld in geen enkele mate worden voorspeld en kunnen projectleiders en andere veranderaars niet adequaat anticiperen op komende gebeurtenissen of inspelen op lopende processen. Sturing van zorgvernieuwing in de thuiszorg is voor hen dan een onmogelijke opdracht. 


\section{Zorgvernieuwing: een kwestie van routine. Samenvatting}

\section{$1 \quad$ Inleiding}

Van 1990 tot 1993 evalueerde de Onderzoeksgroep Zorgvernieuwing van de huidige vakgroep Beleid, Economie en Organisatie van de Zorg (BEOZ) van de Universiteit Maastricht een van de beleidsprogramma's van het Ministerie van WVC. Het ging om het 'Programma Zorgvernieuwingsprojecten Thuiszorg' (1990-1992). Dit Programma omvatte twaalf locale en regionale interorganisationele samenwerkingsprojecten, welke waren gericht op verandering en verbetering van de thuiszorg ('zorgvernieuwing'). Zorgvernieuwing werd (en wordt) noodzakelijk geacht om in de behoeften van de zorgvragers te kunnen voorzien.

De initiatieven werden uitgevoerd door beroepsbeoefenaren, (vertegenwoordigers van) zorgverlenende instellingen en organisaties die bij de zorgverlening waren betrokken, zoals de zorgverzekeraar. Zij vormden netwerken, die werden ondersteund door een projectleider. Voor de ondersteuning ontvingen de projectparticipanten subsidie van WVC. Een netwerk is een verzameling actoren en hun relaties, waarbinnen handelen en interacties plaatsvinden (systeem). Actoren zijn (verzamelingen van) individuen. De verzameling netwerken (zoals een toporgaan, werkgroepen en een projectbureau) die een project uitvoerde, fungeerde als projectorganisatie.

Tijdens het evaluatie-onderzoek werd over het Programma van WVC een grote hoeveelheid gegevens verzameld. Na afloop van het onderzoek werd een deel daarvan diepgaand bestudeerd, ten behoeve van de onderhavige studie.

Het bestudeerde gedeelte van de gegevens betreft een van de twaalf projecten uit het Programma van WVC: het project Intensieve Thuiszorg Zuid-Kennemerland ('project itz'). Doel van dit project was de invoering van een model voor de verlening van intensieve thuiszorg aan terminale en psychogeriatrische patiërten, met als uitgangspunt de noden van de patiënt; de ontwikkeling van zorgprotocollen; convergentie van ontwikkelingen en projecten in de regio. Intensieve thuiszorg (zorg in aanvulling op de reguliere zorgverlening) moest worden verleend in samenwerking tussen kruiswerk, gezinszorg, huisartsen, amw en riagg.

De volgende paragrafen bevatten een samenvatting van de studie. Aan de orde komen het doel en de vraagstelling (par. 2), het conceptueel raamwerk (par. 3), de gevolgde onderzoeksbenadering (par. 4) en de beantwoording van de studie-vragen (par. 5). Par. 6 bevat een aantal slotopmerkingen.

\section{Doel en vraagstelling}

Object van studie was de ontwikkeling wan (en de ontwikkelingen binnen) netwerken van actoren in de thuiszorg. Het centrale doel van de studie was verwerwing van verdere kennis over dit object. Daartoe werd een theorie ontwikkeld, met behulp van inzichten uit de literatuur en empirische gegevens. Verder diende de studie 
praktische handvaten te bieden voor de sturing (doelgerichte beïnvloeding) van ontwikkelingen aangaande netwerken in de thuiszorg. Voor de studie werden vijf vragen geformuleerd:

1 Door wie, hoe en in welke richting is aan ontwikkeling(en) van/binnen netwerken van instellingen en beroepsbeoefenaren in de thuiszorg sturing gegeven?

2 Welke omstandigheden (situatie) hebben aanleiding gegeven tot deze sturing?

3 Welke omstandigheden (situatie) hebben al dan niet gelegenheid geboden tot sturing?

4 Tot welke ontwikkelingen vam/binnen de netwerken heeft de sturing geleid?

5 Door wie, hoe en onder welke omstandigheden (in welke context) is het mogelijk zodanig sturing te verrichten, dat zich netwerken ontwikkelen die door een of meerdere actoren beoogde thuiszorg leveren?

\section{Conceptueel raamwerk}

De studie is uitgevoerd binnen het functionalistische paradigma (Burrell en Morgan, 1982). Bij de beantwoording van de vragen is een conceptueel raamwerk gebruikt, dat is opgebouwd met behulp van inzichten uit de 'social system theory' en het interactionisme. Het primaat lag bij het interactionisme. De hoofdconcepten in het raamwerk zijn:

- cultuur (routines, die bijvoorbeeld handelingspatronen betreffen waaraan de actoren gewend zijn of die zij wenselijk vinden, alsmede (on)gewenste regels en relaties; betekenissen als aanleiding tot sturing);

- structuur (posities, taken, bevoegdheden, functies, organen, configuraties; symbiotische en competitieve afhankelijkheidsrelaties; handelingen en interacties, zoals samenwerking: 'negotiated order'; vervlechting en ontvlechting);

- macht (gezag; asymmetrische afhankelijkheidsrelaties; machtsmiddelen);

- sturing (interacties volgens een patroon van these, antithese en synthese: stuurders; bestuurders en bestuurden; juridische, economische en communicatieve vormen van sturing);

- handelingsregels (voorschriften, bedoeld om handelingen te gelleiden; extrinsieke en intrinsieke motivatie tot het gebruik van regels).

Een van de fundamentele uitgangspunten in het conceptueel raamwerk is dat ontwikkelingen van/binnen netwerken het product zijn van handelingen door actoren. Handelingen (inclusief interacties) zijn de motor in deze ontwikkelingen. Bij handelingen worden regels gebruikt.

Aan de studie ligt een actorperspectief ten grondslag, dat ervan uitgaat dat actoren situaties percipiëren en daaraan -vanuit hun routines- betekenis geven. Op basis van betekenissen handelen zij. Routines zijn uiteindelijk het uitgangspunt voor het handelen. Zij nemen in het conceptueel raamwerk een centrale plaats in.

Actoren handelen doelgericht en kunnen in het licht daarvan een situatie als wenselijk of onwenselijk beoordelen. In deze betekenis van de situatie ligt de aanieiding tot sturing. De beoordeling door actoren kan behelzen dat de situatie moet worden veranderd of juist onveranderd moet blijven. Voorstanders van verandering bijvoorbeeld zullen pogingen tot sturing ondernemen om veranderingen te bewerkstelligen.

Om te kunnen doen wat zij wenselijk of noodzakelijk vinden (zoals het handhaven of veranderen van de situatie) hebben actoren middelen nodig. De actor die deze middelen bezit of daar toegang toe heeft, heeft macht over degene die aan de 
middelen behoefte heeft. In de relatie tussen beide is de eerste dominant en de tweede ondergeschikt. Macht kan worden gebruikt om sturingspogingen te doen.

Macht is in deze studie gezag. Dit impliceert dat medewerking van de ondergeschikte nodig is opdat de dominante actor zijn zin krijgt. De dominante actor on de ondergeschikte hebben beiden macht, waardoor eenieder eisen kan stellen. Dit leidt er veelal toe dat de dominante actor en de ondergeschikte actor onderling moeten zien te komen tot een resultaat dat voor beiden niet optimaal, maar aanvaardbaar is ('negotiated order'). Ontstaat een 'negotiated order', dan houdt deze veranderingen in de situatie in, naar de wensen van de dominante actor toe. Er vindt een 'pull' plaats, bijwoorbeeld op zich ontwikkelende configuraties, in de richting van de routines van de dominante actor.

Sturing gebeurt door actoren tijdens interacties. Ontwikkelingen zijn niet het resultaat van sturingspogingen door één actor, maar door meerdere actoren. Sturing vindt plaats binnen een bestaande situatie (relaties en handelingen daarbinnen) die grenzen stelt aan het handelen, maar daartoe tevens mogeljkheden biedi.

Regels zijn bij uitstek het object van sturing. Zij zijn bedoeld om het handelen te geleiden. Als resultaat van sturingspogingen kunnen nieuwe handelingsregels worden ontwikkeld, van toepassing worden verklaard en weer verdwijnen.

Regels moeten worden gebruikt, opdat zij handelingen kunnen geleiden. Actoren moeten gemotiveerd zijn om de regels bij het handelen toe te passen. Er kan sprake zijn van extrinsieke motivatie (machtsverklaring) of intrinsieke motivatie (routineverklaring). In beide gevallen spelen routines een rol. Voor de verklaring van handelingen volgens regels en andere werschijnselen zijn routines uiteindelijk van doorslaggevende betekenis.

Tijdens het gebruik van regels ontstaan en veranderen relaties, netwerken en configuraties et cetera. Ontstaan relaties, dan is sprake van vervlechting. Vallen relaties uiteen, dan wordt gesproken vain ontvlechting.

Structuren en machtsrelaties kunnen veranderen, maar wanneer deze veranderingen nilet stroken met de routines (in het bijzonder die van dominante actoren), is de kans groot dat zij niet beklijven. Zij veren dan terug naar de roulines. Cultuur is tamelijk stabiel. Daarmee is ook de veranderlijkheid van structuur en macht beperkt, evenals de veranderijkheid van systemen. Voor zorgvernieuwing werpen routines derhalwe barrières op.

Veranderingen in structuur of macht (situatie) worden beoordeeld vanuit routines. Beoordeling kan weer aanleiding geven tot sturingspogingen, et cetera. Het samenspel van de verschijnselen die met de begrippen structuur, cultuur, macht, sturing. betekenis, handelen en regels worden aangeduid, zorgt voor dynamiek en veranderingen wan en binnen netwerken. Routines nemen in dit samenspel een essentiële plaats in. Routines doordrenken alle verschijnselen waar het hier on gaat.

\section{Onderzoeksbenadering}

Het evaluatie-onderzoek naar het Programma van WV en de daarop gebaseerde, onderhavige studie, vormen een 'case study'. Deze is uitgevoerd volgens de interactionistische, explorerende benadering. Het gaat om de 'case study' strategie, welke door Yin (1989) "explanation building' wordt genoemd. Kern van de explorerende benadering is dat niet wordt begonnen met scherp geformuleerde hypothesen, maar met vage veronderstellingen. Begripsomschrijwingen zijn globaal ("sensitizing concepts") en worden met behulp van empirische gegevens aangescherpt. De onderzoeker tracht 
gedurende zijn onderzoek of studie verschijnselen allengs meer en meer te begrijpen. In het bijzonder gaat het erom, dat de onderzoeker achterhaalt welke motieven aan handelingen van actoren ten grondslag liggen ('verstehen").

Bij de explorerende benadering wordt de empirische cyclus herhaalde malen doorlopen. Veronderstellingen worden al doende aangepast, net zolang tot een redelijke 'fit' is verkregen tussen theorie en empirie. Het weergegeven conceptueel raamwerk is langs deze weg tot stand gekomen.

Ten behoeve van de studie is gebruik gemaakt van gegevens uit interviews, registratieformulieren en documenten zoals brieven en vergadernotulen. De gegevens zijn geanalyseerd met behulp van de volgende technieken:

- 'bracketing' (uiteenrafeling van teksten; bepaling van de betekenissen van de tekstonderdelen ofwel data-eenheden; nagaan welke kenmerken van de bestudeerde verschijnselen door de betekenissen worden weergegeven);

'time-series analysis' (plaatsing van data-eenheden in een chronologische volgorde, opdat opeenvolgende gebeurtenissen en verschijnselen in de tijd kunnen worden bestudeerd)

- 'replication' met behulp van een aantal onderscheiden cases (vergelijking van empirische bevindingen betreffende een case met theoretische proposities; komen theorie en empirie overeen, dan moet de exercitie bij een andere case worden herhaald; leidt deze exercitie tot dezelfde conclusies, dan is sprake van 'replication' ofwel analytische generalisatie).

\section{Beantwoording van de studie-vragen}

Met behulp van de inzichten uit de analyses zijn de onderzoeksvragen als volgt beantwoord.

Vraag 1 Door wie, hoe en in welke richting is aar ontwikkeling(en) van/binnen netwerken van instellingen en beroepsbeoefenaren in de thuiszorg sturing gegeven?

De meest kenmerkende richtingen van de bestudeerde ontwikkelingen waren de opbouw en afbraak van relaties en netwerken -vervlechting en ontvlechting. De ontwikkeling van netwerken betrof de bouw en verandering van de projectorganisatie en haar organen (strategische top, staf, werkvloer en lijnmanagement). Netwerken werden opgericht en weer opgeheven.

De ontwikkelingen binnen netwerken betroffen de formulering, verandering, invoering en teniet verklaring van handelingsregels. Deze ontwikkelingen verliepen parallel aan de vervlechting en ontvlechting van de projectorganisatie. De regels waren bedoeld voor gebruik in de projectorganisatie en bij de organisatie van de hulpverlening (secundair proces en secundair niveau van het primair proces). Gebruik resulteerde onder meer in de geschetste ontwikkelingen van netwerken.

De diverse ontwikkelingen kunnen niet worden toegeschreven aan de pogingen van één actor om de anderen doelgericht te beïnvloeden. Er vonden sturingsinteracties plaats tussen meerdere betrokkenen. Gebruikte handelingsregels waren het product van deze interacties. De situatie op enig moment was niet het resultaat van de rechtstreekse inwilliging van de wensen van éẻn actor, maar een "negotiated order".

Alle betrokken actoren hebben sturingspogingen ondernomen, veelal tijdens vergaderingen. In de praktijk bleken het kruiswerk, de gezinszorg en de zorgverzekeraar de belangrijkste bestuurders te zijn. Vooral zij bepaalden de richting van de 
ontwikkelingen. Met name zij waren in staat de organisatie op het niveau van het secundaire proces en het secundaire niveau van het primaire proces conform de eigen wensen vorm te geven.

De sturingsinteracties verliepen volgens een patroon van these (voorstel), antithese (commentaar, bespreking) en synthese (besluit). Binnen de projectorganisatie kregen werkgroepen en anderen opdrachten van de strategische top. Zij waren dan bestuurden ofwel ontvangers van stuursignalen. Een opdracht kon bijvoorbeeld de ontwikkeling van een protocol zijn, met daarin handelingsregels voor de organisatie van de zorgverlening. Het ontwikkelde protocol werd voorgelegd aan de strategische top, die na bespreking besloot over invoering van het protocol.

Meer in het algemeen was de strategische top het orgaan dat bepaalde of ontwikkelde handelingsregels geldig dan wel ongeldig werden. Ingevoerde regels werden gewoonlijk gebruikt.

\section{Vraag 2 Welke omstandigheden (situatie) hebben aanleiding gegeven tot deze sturing?}

De aanleiding tot het project lag in de ontevredenheid van de participanten over de hulpverlening aan bepaalde categorieën zorgvragers, in casu thuiswonende terminale en psychogeriatrische patiënten. Tussen hulpverlenende instanties ontbraken relaties die nodig werden geacht voor goede hulpverlening aan deze doelgroepen.

Dàt de waargenomen situatie moest worden veranderd, stond voor allen vast. Wèlke de nieuwe situatie moest worden, daarover was men het niet altijd eens. Routines verschilden. Dit was bijvoorbeeld het geval bij de hulpverlening aan psychogeriatrische patiënten. Verzekeraar en zorgaanbiedende instellingen waren thet lange tijd oneens over de wijze waarop de hulp aan deze doelgroep moest worden georganiseerd en over de financiële randvoorwaarden voor zorgverlening. Over en weer werden voorstellen gedaan, beoordeeld en bekritiseerd. Het ene voorstel werd aanleiding tot het andere, pogingen tot tegensturing volgden op sturingspogingen. Pas toen voor de betrokkenen een aanvaardbare situatie in het verschiet lag, werd besloten tot hulpverlening aan de genoemde doelgroep.

\section{Vraag 3 Welke omstandigheden (situatie) hebben al dan niet gelegenheid geboden tot sturing?}

Voor sturing is macht nodig. Macht is gebaseerd op middelen. Louter het bezit van middelen is echter niet voldoende voor sturing. Niet een middel zelf verschaft macht, maar de betekenis die dit middel heeft voor actoren. Een middel moet bijvoorbeeld belangrijk worden geacht. Verder moeten machtsmiddelen worden gebruikt.

De eerdere uitspraak dat het kruiswerk, de gezinszorg en de zorgverzekeraar de belangrijkste bestuurders waren, is op het volgende gebaseerd. Dankzij de erkenning door het Ministerie van WVC beschikten kruiswerk en gezinszorg over een eigen taakdomein en waren zij verzekerd van een regulier budget. Het Ministerie had van hen monopolisten gemaakt ${ }_{\text {n }}$ het had hen macht verschaft. Verder hadden kruiswerk en gezinszorg de beschikking over de menskracht die voor de realisering van het projectdoel nodig was. Zonder hun inbreng zou intensieve thuiszorg niet kurnen worden geleverd. Alternatieve aanbieders in de regio waren niet aanwezig, de verzekeraar was van kruiswerk en gezinszorg afhankelijk voor goede zorgverlening aan zijn verzekerden. 
Op zijn beurt had de verzekeraar toegang tot de geldelijke middelen voor zorgverlening. waarvan kruiswerk en gezinszorg afhankelik waren. Zonder deze middelen konden zij geen zorg verienen.

Met behulp van de machtsmiddelen waarover zij beschikten konden de drie genoemde partijen onderling proberen de situatie in de hulpveriening conform hun wensen vorm te geven. Het lukte hen een situatie te creëren, die voor hen aanvaardbaar was. Andere betrokkenen, zoals het amw, slaagden daar niet in. Zij hadden geen middelen waaraan kruiswerk, gezinszorg en de verzekeraar behoefte hadden. Zij hadden geen macht.

De macht wan kruiswerk, gezinszorg en verzekeraar was gebaseerd op thet bezill van middelen die mogelijkheden boden tot economische en juridische sturing. Het Ministerie van WVC bezat eveneens middelen die konden dienen voor dergelijke sturing. Zo kon WVC subsidie verschaffen voor projectondersteuning. Aan verstrekking van deze subsidie had het Ministerie een aantal eisen verbonden, waaraan de projectdeelnemers zich niet wensten te conformeren. WVC gebruikte zijn machtsmiddelen echter niet om de deelnemers ertoe te bewegen volledig te doen wat het Ministerie wilde.

De gecombineerde mogelijkheid van juridische en economische sturing is in het geval van het project itz belangrijk gebleken. Degenen die beide vormen konden toepassen en dat ook daadwerkelijk deden (de verzekeraar, kruiswerk en gezinszorg). konden ontwikkelingen naar hun hand zetten. Communicatie was op zichzelf een onvoldoende krachtig middel om beoogde veranderingen teweeg te kunnen brengem. Communicatieve sturing kon alleen in combinatie met de twee andere sturingsvormen viuchten afwerpen.

Vraag 4 Tot welke ontwikkelingen van/binnen de netwerken heeft de sturing geleid?

De sturingsinteracties resulteerden in vervlechting en ontvlechting van relaties (structuur en macht). De projectorganisatie groeide allengs uit tot een netwerk van netwerken en kromp vervolgens weer ineen. Structuur en machtsrelaties kregen andere kenmerken, regels veranderden. De configuratie die bij aanvang van het project bestond (de projectorganisatie als een 'eenvoudige structuur') ontwikkelde zich tot een adhocratie, die vervolgens desintegreerde.

De beschrijving van veranderingen in stuctuur en macht moet in relatie worden gebracht met routines. Juist dan wordt de beschrijving interessant. Gebleken is namelijk dat machtige actoren de vorm van de zich ontwikkelende configuraties naar zich toe trokken. Hun handelingen betekenden een 'pull' op de configuratie naar een vorm die overeenkwam met hun routines. Dit gold het duidelijkst voor de zorgverzekeraar, kruiswerk en gezinszorg. Op het niveau van het secundair proces veranderden de routines van met name kruiswerk en gezinszorg gedurende het project niel. De adhocratie die ontstond, betekende een afwijking van hun routines. Deze afwijking werd tegen het einde van het project door de genoemde instellingen "gecorrigeerd", de configuratie veerde naar hun routines terug.

Vraag 5 Door wie, hoe en onder welke omstandigheden (in welke context) is het mogelijk zodanig sturing te verrichten, dat zich netwerken ontwikkelen die door een of meerdere actoren beoogde thuiszorg leveren?

Op grond van de bevindingen die hierboven op hoofdlijnen zijn weergegeven, is de vijfde vraag beantwoord. Wij hebben een aantal aanbevelingen geformuleerd, met als leidraad het geconstateerde, fundamentele belang van routines bij veranderingen. Een van de vereisten bij zorgvernieuwing is het volgende. Bestuurders moeten serieus. 
rekening houden met de routines van dominante en ondergeschikte actoren, wanneer zij haalbare voorstellen tot veranderingen willen formuleren. Kennis van routines en betekenissen die actoren vanuit hun routines aan situaties geven, is daarvoor een absolute noodzaak.

\section{Slotopmerkingen}

De uitgevoerde studie kende een aantal sterke en minder sterke punten. Aan de creditzijde staan de gecombineerde toepassing van inzichten uit het interactionisme en de systeembenaderingen, alsmede de gevolgde explorerende onderzoeksbenadering.

Aan de debetzijde staat het volgende. De beschikbare personele capaciteit stond niet toe dat wij gedurende het onderzoek zelf observaties verrichtten, hoewel deze waardevol zijn voor de waarneming van interacties. Wij konden -naast interviewgegevens- enkel gebruik maken van data uit observaties door derden. Wellicht hadden eigenhandig verrichte observaties kunnen leiden tot meer gedetailleerde beschrijvingen van onderzochte verschijnselen.

De bevindingen waarover verslag is gedaan, hebben betrekking op één project. De verworven inzichten bieden interessante aanknopingspunten voor vervolgonderzoek naar andere zorgvernieuwingsprojecten. Daarbij kan de ontwikkelde theorie -een prototype dat tijdens de analyse van gegevens over het project itz is opgebouwd en een eerste maal is beproefd- worden gebruikt. De aandacht zal dan met name moeten uitgaan naar de rol van routines bij zorgvernieuwing. 



\section{Health care innovation: a matter of routine. Summary}

\section{Introduction}

This study concerns the 'Project Intensive Home Care Zuid-Kennemerland'. Together with eleven other local or regional health care innovation projects, the project was adopted by the 'National Home Care Program' (1990-1992). This policy program was initiated by the Dutch Ministry of Health. The program was evaluated by the Research Group Health Care Innovation, Department of Health Organisation. Policy and Economics of the Universiteit Maastricht. Main purpose of the projects was to improve the organization of care provision to patients in their home settings.

The projects were executed by networks of care providing organizations, professionals "and others. In the study, networks and collections of networks were considered systems. In the case of the 'Project Intensive Home Care ZuidKennemerland', the networks consisted of general practitioners and representatives of the district nursing institution, the insurance company, home help and welfare work agencies.

\section{Characteristics of the study}

Purpose of the study was to analyze developments concerning the networks, such as the relations coming about. In particular, we wanted to understand how and under which conditions these developments occurred, and to establish how in practice such developments can be steered. For this, we developed a theory. 'Steering' (making other people do what one wants them to do) was among the main concepts of the theoretical framework we used. The other basic concepts were 'culture', 'routines', 'structure', 'power", 'meaning', and 'rules' guiding 'actions' and 'interactions'. Routines among others concern the way individuals are used to act or want to act. Routines do not change easily. Power is based on the possession of means.

The study is located in the functionalist paradigm. We built the theoretical framework using insights from (symbolic) interactionism and social system theory. Emphasis was on interactionism. One of the main propositions was that the developments we analyzed were the result of rule-guided actions and interactions between interdependent actors, who entered into relations with each other. It was assumed that actions and interactions, in turn, were based on routines and the meanings the actors gave to the situations they faced. Interactions were considered 'steering interactions', during which actors tried to establish or maintain a situation that corresponded to their routines. For steering purposes, power was needed.

The design underlying the study was explorative, the study was executed according to the principles of the case study approach by Yin. Data sources were interviews, documents and information collected with the aid of registration forms. One of the techniques used to analyze the data was "time-series analysis". 


\section{Results of the study}

Characteristic of the developments in the project being studied was that disintegration followed integration. During rule-guided actions and interactions by the participants who tried to steer developments, relations and networks were first established, and then severed. The situation at the end of the project, described in terms of structures and power relations, resembled the situation prior to the start of the project. Also, the characteristics of both situations corresponded to the habits, preferences et cetera of powerful actors, in particular of the district nursing institution and the home help agencies. During the project their routines virtually remained unchanged. Clearly, if routines of powerful actors do not change, innovations ultimately will not last.

It was obvious that, for steering, both juridical and economic means such as ample financial resources were required. The mere possession of both types of means, however, was not a sufficient requirement for success. For example, only powerful actors who actually used their means for steering purposes were able to persuade others to act in accordance with their wishes, and could pull developing relations and networks towards a shape that was in line with their routines.

Routines are an important phenomenon in the field of home care innovation. Actors who try to steer developments in home care delivery must take the routines of powerful actors into account, if they want to pursue feasible changes. Knowledge of these routines is indispensable. 


\section{Begrippenlijst}

Aamvillende, intensieve thuiszorg

Thuiszorg die het beschikbare reguliere aanbod van de eerstelijn te boven gaat.

\section{Actoren}

Individuen en verzamelingen van individuen, zoals organisaties en beroepsgroepen.

\section{Adhocratie}

Configuratie, bedoeld om innovaties tot stand te brengen. Binnen een adhocratie worden professionals vanuit verschillende disciplimes bijeen gebracht in gespecialiseerde "creative teams" of projectgroepen die voor de beoogde innovaties zorg moeten dragen. Veelal gaat het om tijdelijke teams die een: afgebakende opdracht moeten uitvoeren ("task forces"). Afstemming tussen de betrokkenen wordt vooral door overleg gerealiseerd. De macht is niet geconcentreerd bili de strategische top, maar is werspreid over de organisatie. In het bijzonder is macht gedelegeerd naar de teams. Afhankelijk van het type configuratie wordt de werkvloer wel ('operating adhocracy") of niet ('administrative adhocracy') tot de adhocratie gerekend. In de "administrative adhocracy' wordit de werkvloer bijvoorbeeld uitbesteed aan andere organisaties.

\section{Afhankeligktsend}

Van afhankelijkheid is sprake wanneer een actor steun- of hulpbehoevend is van anderen. Afhankelijkheid kan symbiotisch, competitief en asymmetrisch zijm.

\section{Afstemming (coördinatie)}

Verdeelde taken op elkaal betrekken.

Analyrische generaliseerbaarheid

"Case studies, like experiments, are generalizable to theoretical propositions and not to populations or universes. In this sense, the case study, like the experiment, does not repiresent a "sample", and the investigator's goal is to expand and generalize theories (analytic generalization) and not to enumerate frequencies (statistical generalization)'.

\section{Antithese}

Zie these, antithese, symthese.

\section{Asymmetrische afhankelijkheid}

Vorm waarbij tussen afhankelike actoren machtswerschil bestaat, als resultaat van de behoefte aan middelen. De ene actor is dominant, de andere is ondergeschikt. De mate van asymmetrische aflnankelijkheid wordt bepaald door het belang van de middelen (centralitelt ofwel "essentiality) woor de actor die de middelen wil hebben, alsmede door de aan- of afwezigheid van alternatieve middelen waarop deze actor een beroep kan doen (substitueerbaarheid ofwel "substitutability").

Behoefte aan middelem

Het nodig hebber van middelen om te kunnen handelen zoals nodig of wenselijk wordt gevonden.

\section{Belang}

Datgene wat iemand ter harie gaat.

\section{Bestuurder en besturide}

Een bestuurder (verzender) is degene die een stuurder verzendt ofwel een poging tot sturing doet. Een bestuurde (ontvanger) is degene voor wie de stuurder is bestemd, op wie de poging is gericht. Een bestuurde kan op zijn beurt naar de bestuurder een stuurder verzenden. De bestuurde wordt dan de bestuunder en omgekeerd. Wij noemen de verzender een besfuurder en de beoogde ontwanger de bestuurde, angeacht of een stuurder wel of niet is ontvangen en of een sturingspoging wel of niet is geslaagd. 


\section{Betekenis}

Mentaal beeld (beschrijvende kant van betekenis'). Actoren kunnen het mentaal beeld beoordelen (beoordelende kant van 'betekenis'). Het beeld op zichzelf krijgt in dal geval ook betekenis, bijvoorbeeld goed of slecht, gewenst of ongewenst, gunstig of ongunstig.

\section{Bevoegaheid}

Het recht bepaalde handelingen te verrichten.

\section{Brackoting}

Techniek die wordt toegepast bij de analyse van uitspraken in teksten en werhalen (zoals persooniijke getuigenissen van actoren), die inzicht geven in verschijnselen. Teksten of verhalen worden uiteengerafeld, van de onderdelen (uitspraken) wordt de betekeris bepaald, bij voorkeur de betekenis voor de actor in kwestie. Vervolgens wordt nagegaan welke kenmerken van het bestudeerde verschijnsel de betekenissen wergeven. Samervoeging van 'brackets' tot een verzameling en schikking van de "brackets" daarbinnen ("construction") levert tenslatte een beeld op van het verschilinsel. Dit beeld wordt door de onderzoeker beschreven.

\section{Case}

Een object van onderzoek zoals een proces of gebeurtenis. Voorbeelden van cases zijn beleidsprogramma's, zorgvernieuwingsprojecten en de invoering van handelingsregels.

\section{Case study}

'An empirical inquiry that: investigates a contemporary phenomenon within its real-life context; when the boundaries between phenomenon and context are not clearly evident; and in which multiple sources of evidence are used".

\section{Centraliteit}

Zie asymmetrische afhankelijkheid.

\section{Conmunicatio}

Het overbrengen via een medium van een boodschap door zenders aan ontvangers.

\section{Coaltitievorming}

Een variant van samenwerking. De actoren slaan de handen ineen om zich samen sterk te maken tegen een derde partij.

\section{Colkectiviteit}

De geneigdheid wan actoren samen met anderen te handelen. Deze geneigdheid kan tot de routines behoren, maar is bil de bestudeerde actoren (weelal managers) ondergeschikt aan 'individualiteit. Collectiviteit treedt op de voorgrond, indien individualiteit daarmee is gebaat.

Competitie (concurrentie)

Bij deze interactievorm trachten actoren, met het oog op de eigen doeleinden, elkaar bij het verkrijgen van middelen de loef af te steken. Compelitie om middelen is competitie om handelingsruimte.

\section{Competitieve alhankelijkheid}

Vom waarbij doelbeneiking door de ene actor nadelig is voor doelbereiking door de andere actor, of waarbil de thandelwijze ven de ene actor nadelig is voor de mogelijkheild van een andere actor te handelen zoals deze wil.

\section{Complexe zorgyragen}

Patienten met complexe (meervoudige) zargvragen zijn personen die zorg nodig hebben die vanuil meerdere disciplines gezamentijk of gelijktijdig wordt verleend.

\section{Concurrentie}

Zie competitive.

\section{Configuratie}

Verzameling organen. 


\section{'Construction'}

Samenwoeging wan 'brackets' tot een verzameling en schikking van de 'brackets' daarbinnen.

\section{Coördinatie}

Alstemming.

\section{Cuntutir}

Een collectief cognitief systeem dat richting geeft aan het handelen. In deze studie is cultuur synonient aan routines.

Definitie (betekenis) van de situatie

verzameling betekenissen, door de actor toegekend aan elementen wan de situatie.

\section{Divisiestructuus}

Een configuratie mel deze structuur bestaat uif een aantal quasi-autonome eenheden of organisaties, die aan elkaar zijn gekoppeld door een centrale besturingsstructuur. Aan standaardlsatie van het produch wordt veel aandacht besteed. Binnen elke divisie is de macht geconcentreerd bij het lijinmanagement.

\section{Doel}

Datgene wat wordt nagestreefd. Een doel is in deze studie niet datgene wat ter 'definitieve afsiuiting" van een reeks handelingen wordt nagestreetd (geen statisch 'einddloel"). Verder is "doel' hier geplaatst in her kader van het handelen zelf. Het begrip 'doel' betreft allereerst de door de actor als wenselijk of noodzakelijk beschouwde regeils, handelingspatronen en afhankelijkheidsrelaties met andere actoren. Deze patronen en relaties zijn veranderlijk, hetgeen aan 'doel' een dynamische dimensie geeft. Doelen kunnen veranderen. Actoren hebben voor hun handelingen middelen nodig. De verwerving van middelen is in deze studie eveneens onderdeel van 'doel'. Dat een actor met zijn handelingen "ilets' wil bereiken, sluiten wij niet uit. Dat 'iets' betreft hier vooral handhaving of verandiering van situaties en de verwerving of hef bezit van middelen.

\section{Dwang}

Vorm van macht waarbij de ene actor aan de ander de eigen wil oplegt zonder de medewerking van de ander.

\section{Eenvoudige structur}

Bij een configuratie met deze structuur is het onderscheid in functies behorend bij de strategische top, het lijnmanagement, de ondersteunende staf, technostructuur en werkvloer vaag. De structuur is niet geëlaboreerd, er is nauwelijks sprake van specialisatie. De strategische top is het centrale orgaan. waarbinnen de macht is geconcentreerd. Vanuit de strategische top vindt toezicht plaats op de gebeurtenissen binnen de organisatie.

\section{Enkelvoudige zorgvragen}

Patiènten met 'enkelvoudige' zorgviagen zịn personen die relatief eenvoudige zorg, hulp en medische behandeling nodig hebben en die meestal vanuit eén discipline worden geholpen.

\section{Explanation butilding}

Case study benadering die overeenkomt met de explorerende onderzoeksbenadering van de interactionisten. In beide benaderingen wordt gestart met globale concepties, die door confrontatie van ideeën van de onderzoeker met de verzamelde gegevens worden aangescherpt. Bil 'explanation building' is de uiteindelije verklaring vam een verschijnsel het resultaat van een reeks iteraties. 'In this sense, the final explanation may not have been fully stipulated at the beginning of a study (...). Rather, the case study evidence is examined, theoretical propositions are revised, and the evidence is examined once again from a new perspective, in this iterative mode:

\section{Explorerende onderzoeksbenadering}

In onderzoek volgens deze, interactionistische, benadering wordt niet begonnen met scherp geformuleende hypothesen, maar met vage veronderstellingen en vage begrippen waarmee verschijnselen worden aangeduid ('sensitizing concepts'). De werkwijze bij hel onderzoek en andere zaken worden niet van tevoren vastgelegd en de empirische cyclus wordt herhaalde malen doorlopen. Veronderstellingen worden al doende aangepast, net zolang tot een redelijke 'ffic' is verkregen tussen theorie en empirie. De onderzoeker probeert in de loop van het onderzoek verschijnselen meer en meer 
te begrijpen. Tijdens zijn tocht door de empirie trachi de onderzoeker de concepten weliswaar aan te scherpen (en meer inzicht te krijgen in de relaties tussen de verschijnselen die met de concepten worden alangeduid), maar deze bljven een 'sensitizing karakter' behouden. Toetsing van een vooraf ontwikkeld theorelisch verklaringsmodel met hypothesen over de onderhavige verschijnselen, heeft geen plaats binnen deze benadering.

\section{Extrinsieke motivering tot handelen}

Een actor kan extrinsiek gemotiveerd zijn te handelen volgens een regel. Dit gebeurt via beloning (loekenning van middelen) en straf (ontzegging of afneming wan middelen). Deze varm van motiwering heeft te maken met de uitoefening van macht.

\section{Functie}

Verzameling taken.

\section{Functionaris}

Actor die een verzameling taken dient te vervullen.

\section{Gebeurtenis}

Het moment waarop een verschijnsel of een verandering daarin zich voordoet.

\section{Gezag}

Vorm van macht, waarbij de ene actor aan de ander de eigen wil oplegt met de medewerking van de ander. Gezag is macht die als redelijk en juist wordt aanvaard: legitiene macht. Bij gezag is in de asymmetrische afhankelijkheidsrelatie sprake van wederkerigheid.

\section{Handelen}

Gedrag op basis van een motief. Aan het handelen kunnen meerdere motieven ten grondslag liggen. Handelingen (waarloe interacties behoren) kunnen patroonsgewijs verlopen of incidenten zijn.

\section{Handelingsregels}

Verzamelingen van talige tekens die voorschriven welke handelingen zijn vereisl, verboden of loegestaan. Zij zifn bedoeld om bij het handelen te worden gebruikt en worden geformuleerd en in gebruik genomen om de thandelingen en interacties van actoren op een bepaalde manier te laten werlopen. Worden zij bij handelingen gebruikt, dan geleiden regels het handelen. 'Handelen volgens regels' is in deze siudie geijk aan 'gebruik van regels'. Niet een regel op zich, maar de betekenis ervan is voor de actor de basis voor thet thandelen. "Handellen volgens regels' is in deze studie synoniem aan 'handelen volgens de betekenis van regels'. Een actor kan handelen volgens bepaalde regels, maar kan dit ook nalaten. Een actor kan intrinsiek of extrinsiek gemotiveerd zijn te handelen conform een regel.

\section{Handelingsrumte}

De gelegenheid (letterlijk of overdrachtelijk) op een beoogde manier te handelen.

\section{Individualiteit}

De geneigdheid van actoren om vanult de eigen pasitie van hun organisatie de omgewing tegemoet te treden en het belang van de eigen organisatie te laten prevaleren boven andermans' belangen. De actoren zijn geneigd hun eigen gang te gaan en zich niets gelegen te laten liggen aan de belangen varn anderen (laat staan van een netwerk). Deze geneigdheid is het kemonderdeel van de routtines van dle bestudeerde actoren.

\section{Informatie}

Signalen.

Intensieve thuiszorg (itz)

Zie aanvullende thuiszorg.

\section{Interactiebenadering}

Perspectief op sturing, zichtbaar in modellen waarin wordt verondersteld dat door meer dan één actor of door alle actoren wordt gestuund. 


\section{interacties}

"Samenhandeling". Deelverzameling van handelingen. Interacties waarbinnen wordt gepoogd te sturen zijn sturingsinteracties. Alle inferacties in deze studie zijn sturingsinteracties.

\section{Intern en extern}

Intern: binnen het bestudeerde netwerk. Extern: buiten het besitudeerde netwerk en de bestudeerde verzameling van netwerken die het project itz uitvoerden (projectorganisatie).

\section{Interpretatie}

Een proces gedurende welke betekenissen worden gebruikt en herzien als instrumenten woor de geleiding en wormgeving van handelen. Betekenisgeving is onderdeel van interpretatie.

\section{Intrinsieke motivering to handelen}

Een actor kan intrinsiek gemotiveend zijn te handelen conform een regel. De actor is dan overtuigd van het belang te handelen overeentkomstig de regel omdat dit handelen correspondeert met de handelingen die wolgens zijn routines wenselijk of noodzakelijk zijn. Een actor zail meer geneigd zijn conform regels te handelen naarmalte voorgeschreven handelingen meer met zinn eigen routines overeen stemmen.

\section{Lijmanagement}

De managers onder de strategische top. die de top en de werkvloer met elkaar verbinden en gezag uitoefenen over de werkvloer.

\section{Machine bureaucratie}

Een configuratie met de volgende kenmerker: zeer gespecialiseerde, repetitieve taken wan de werkvloer, geformaliseerde werkprocedures (nadruk op standaardisatie van werkprocessen) en communicatie. verregaande regulering, een uitgebreide staf, hierarchische niveaus en gecentraliseerde macht.

\section{Macht}

"Jede Chance, innerhalb einer sozialen Beziehung den eigenen Willen auch gegen Widerstrebert durchzusetzen, gleichwiel worauf diese Chance beruht'. Macht is het vermogen naar eigen wens te handelen, ook bij weerstand van anderen. Uitoefening van macht is sturing. Degene die over middelen beschikt of toegang tot middelen heeft, heeft macht over degene die daaraan behoefte heeft. Van macht kan in meerdere of mindere mate sprake zijm. Macht kan binnen een relatie worden uilgeoefend an heeft betrekking op handelingsruimte. Bezit van (of toegang tot) middelen maakt het voor de dominante actor, als deze dat wil, mogelijk de ondergeschikte actor de gelegenheid te geven of te ontmemen tot handelen, bijwoorbeeld op een manier die de laatste wenselijk of noodzakelijk vindt. Macht kan worden onderverdeeld in dwang en gezag.

\section{Machtsuitvoering}

Zie sturing.

\section{Meervoundige zorgwragen}

Zle complexe zorgvragen.

\section{Methodologie}

De verzameling regeis die bij wetenschappelijk onderzoek binnen een paradigma moeten worden gevolgd. Methodologische regels belreffen het gebruik wan concepten, de opzet en uitvoering van aen onderzoek, de methoden en technieken die worden gebruikt en de aard van de bewijswoering.

\section{Middel}

Al hetgeen aan doelbereiking kan bijdragen, zoals regels, personeel, geld, cliënten, diensten, handelingen van derden, deskundigheid of respect.

\section{Moderne thuiszorg}

Thuiszorg, verleend vanuit meerdere disciplines gezamenlijk of gelijktijdig aan patienten mel meervoudige, complexe zorgvragen, die voorneen meestal een beroep deden op intramurale voorzieningen.

\section{Motief}

Beweegreden voor het handelen. 
Negotated order

Bij asymmetristhe afhankelijkheidsrelaties, gebaseerd op gezag, is de sociale orde hel resultaat van 'negotiation' tussen de actoren (the process of give-and-take, of diplomacy, of bargaining"). De sociale orde, opgevat als 'concerted action', wordt door hen voortdurend gevestigd, vernieuwd, herzien en herroepen. In de sociale orde kunnen zich gebeurtenissen woordoen die aarleiding zinn tot nieuwe onderhandelingen. Deze kenmerken maken van de sociale orde een 'negotiated order'.

\section{Netwerk}

Verzameling wan actoren en hun relaties. Binnen deze relaties vinden handelingen en interacties plaats. Een verzameling van netwerken kan ook een netwerk zijn. Een netwerk is een systeem.

\section{Ondersteunende staf}

Verzameling actoren die diensten verlenen (andere dan de diensten van de werkwloer) zoals 'resiearch and development', secretarieel en administratief werk.

\section{Ontulechting}

Verdwijnen van onderlinge verbondenheid (relaties) tussen actoren.

\section{Ontwikkeling}

Vorming, ontstaan. Ontwikkelingen doen zich voor tijdens processen en kunnen meerdere richtingen ulitgaan. Ook kunnen zij van richting veranderen.

\section{Organisatie}

Organiseren: verdeling wan taken en afstemming (coördinatie) van deze taken. Organisatie: doelrealiserend samenwerkingsverband, zoals een instelling.

\section{Paradigma}

Fundamentele voorstelling van het object binnen een wetenschap. Deze voorstelling dient om te bepalen wat bestudeerd behoort te worden, welke vragen er moeten worden gesteld, hoe deze moeten worden gesteld en weike regels moeten worden toegepast om verkregen antwoorden te interpreteren. Het paradigma is de meest omwattende eenheid van consensus binnen een gemeenschap welke dient om de ene wetenschappelikke (sub)gemeenschap van de anderen te onderscheiden. Het paradigma brengt die vaorbeelden, theorieên, methoden en technieken onder èen gezichtspunt bij elkaar, definieert deze onderdelen en regelt de betrekkingen ertussen.

\section{Participanton}

Deelnemende actoren.

Patroonsgewize handelingen

Herhaalde handelingen.

\section{Pattern-matching}

Onderzoeksbenadering waarbij een empirisch waargenomen patroon wordt vergeleken met een of meer voorspelde patronen die vooraf in theoretische proposities zijn vastgelegd.

\section{Percipieren}

Betekenisvol waarnemen.

\section{Positio}

Een plaats in de structuur die wordt bekleed door een actor. Een positie verbindt meerdere relaties. Het is een knooppunt. Van degene die een positie bekleed, wordt werwacht dat deze op een bepaalde manier handelt.

\section{Primair proces}

Opeenvolging van handelinglen en interacties tijdens de uitvoering van de hulpverlening. De organisatie van de uitvoering wordt aangeduid als het secundaire niveau.

\section{Proces}

Opeenvolging van handelingen en interacties, gedurende welke bijvoorbeeld een netwerk tot ontwikkeling komt. Kenmerkend voor een proces is dat van een begin- of eindpunt geen sprake is. 


\section{Professionele bureaucratie}

In deze configuratie bestaat de werkvoer uil hoog opgeleide professionals die de zeggenschap over de eigen werkzaamheden hebben. De macht is derhalwe geconcentreerd op de werkvoer. Nadruk op standaardisatie van vaardigheden, die vooral tijcens de opleiding wordt gerealiseerd, en specialisatie.

\section{Project}

Een samenhangend geheel van handelingen die binnen een begrensde tijd moeten worden uitgevoerd.

\section{Projectleider}

Functionaris die moet zorgen dat bij de uitwoering van het project de inspamingen van participanten op elkaar worden afgestemd en dat voortgang wordt geboekt.

\section{Projectorganisatie}

De verzameling netwerken die het project uitvoert.

\section{Protocol (onderzoek)}

Handleiding voor dataverzameling gedurende een case study die de volgende zaken dient te bevatten: een overzicht van de gehele studie (zoals achtergrondinformatie, onderzoeksdoelen en -onderwerpen); een beschrijving van de procedures voor veldwerk (zoals informatie over te gebruiken databronnen en te volgen werkwijze om toegang te krijgen tot deze broninen); de onderzoeksvragen en een abnduiding wan de daarvoor te benttten databronnen; een "outtine" woar de rapportage.

\section{Protocol (zorg)}

Document, waarin rondom concrete patiëntencategorieën werkatspraken en een taakverdeling lusser: hulpverleners zijn vastgelegd. Het onderscheidt zich wan een zorgplan dat zich richt op de individuele patiënt.

\section{Rationele-actorperspectief}

Perspectief op sturing, zichtbaar in modellen waarin wordt uitgegaan van sturing door éen actor.

\section{Regels}

Regels zijn in deze studie synoniem aan handelingsregels.

\section{Relatie}

En verbondenheid tussen actoren, ontstaan uit interacties die zich in het verleden op min of meer dezelfde wijze hebben herhaald. Relaties zijn het product van patroonsgewijze interacties. Relaties zijn afhankellikheidsrelaties.

\section{Replication wan "replication". De bevindingen winnem aan overtuigingskracht. \\ Rivaliserende verklaringen \\ Verklaringen voor een en hetzelfde verschijnsel, die elkaar ultsluiten.}

Met het oog op analytische generaliseerbaarheid moeten empirische resultaten wan een case study worden vergeieken met theoretische proposities. Komen theorie en empirie overeen, dan moet de exeritie bij een andere case worden herhaald. Leidt deze exercitie tot dezelfde conchusies, dan is sprake

\section{Routines}

Geven handelingspatronen weer die actoren werselijk of noodzakelijk vinden of waaraan zij gewend zijm. Routines vormen het beoordelingskader voor (de betekenis van) handelingen en situaties. Actoren handelen, stellen handelingsregels op en creëren tijdens interacties betekenissen vanuit routines die zij hebben verinnerlijkt. Routines zijn het uitgangspunt bij handelingen en kunnen veranderen tijdens handelingen en interacties. Routines worden ook zichtbaar in het handelen en in relaties als hel product van handelingen. Routines en cultutur zijn in deze studie synoniem. Routines zijn geen onveranderlijke blauwdrukken die exact aangeven hoe te handelen, te beoordelen et cetera. Routines kenner een bandbreedte. Zie ook cultuur. 


\section{Secundair proces}

Opeenvolging van handelingen en interacties gedurende welke randvoorwaarden voor hulpverlening worden gecreètd, zoals besturlikge en financiêle kaders.

\section{Sensitizing concepts}

Vage begrippen die de aandacht richten op aspecten van de veranderende sociale werkelijkheid en hun relaties, zonder dat deze in gedetailleerde definities zijn vastgelegd. 'Sensitizing concepts' kunnen nooit 'definitive concepts' worden, ondat de verschilnselen en hum relaties, alsmede hun betekenis voor de handelende mens, aan verandering onderhevig blijven.

\section{Situatie, omstandigheden, context}

Actoren en hun afhankelljkheidsrelaties met anderen binnen of buiten een netwerk en handelingen en interacties binnen die relaties. Tol de situatie behoren ook de kenmerken wan actoren, zoals de kennis van roulines.

\section{Standaardiseren}

Regulariseren.

\section{Strategio}

De weg die actoren, op basis van de betekenis die zili aan informakie geven, uitstippelen om doelen te bere相en.

\section{Strategische top}

De managers bowenaan de hiërarchie die zijn belast met de algehele verantwoordelijkheid voor de organisatie; zij moeten erop toezien dat de organisatie haar missie verwult.

\section{Structuur}

Verzameling afhankelikheidsrelaties tussen actoren als product van patraonsgewijze interacties.

\section{Strijd}

De ene actor probeert te belemmeren dal de ander zijn doelen bereikt.

\section{Sturing (machtsuitoefening) en pogingen tot sturing}

Handelingen door actoren om anderen doelgericht zodanig te beïnwoeden, dat zij niet alleen bereid zijn te hanclelen conform de wensen van de eersten, maar dit ook daadwerkelijk doen. Doen anderen dit, dan hebben de actoren die de eersitgenoemde handelingen uitvoerden, invloed. Wij reserveren thet begrip 'sturing' voor die gevallen waarin blijkt dlat actor deze invloed hebben. Op alle andere gevallen is het begrip 'poging tot sturing' van toepassing. Sturing is het resultaat van sturingspogingen van meerdere actoren en in geen geval het resultaat van sturingspogingen door éen actor. Om deze reden zeggen wij wiet dat oen actor heeft gestuurd, maar een sturingspoging heeft gedaan. Zie ook these, antithese. synthese.

\section{Sturingsvormen}

Gebaseerd op de typen middelen die een actor macht verschaffen. kunnen de volgende vormen van sturing wardern onderscheiden:

- juridische sturing: sturing op basis van wetten en andere handelingsregels die de overheid heeft ingevoerd (wet- en regelgeving);

economische sturing: sturing op basis van geld, clientten, personeel, faciliteiten, informatie el cetera: organisatorische sturing: sturing op basis van handelingsregels die voor een netwerk of werzameling meiwerken zijn ingevoerd;

communicatieve sturing: sturing op basis van uitwisseling van argumenten, overtuigingskracht en door overreding.

\section{Stuurders (stuursignalen)}

Alle mogelije (verzamelingen van) tekens die worden gebruikt om de ander te beinvloeden. Zij kunnen verbaal of non-verbaal ziin. Te denken walt aan woorden. lichaamsbewegingen en gelaatsuitcinukkingen. Sturing en sturingspogingen impliceren altijd een of andere vorm van werbale of non-verbate communicatie. 


\section{Substitueerbaarheid}

Zie asymmetrische afhankelijkheid.

\section{Symbiotische afhankelifkheid}

Vorm waarbij twee of meer actoren elkaars steun nodig hebben om de eigen doeler te bereiken en coebereiking door de ene actor niet nadelig is voor doebereiking door de andere.

\section{Synthese}

Zie these, antithese, synthese.

\section{Systeem}

Zie netwerk.

Taak

Vastgesteld werk. Datgene wat een actor moet doen.

\section{Technostructuur}

Verzameling actoren die het werk wan anderen moeten standaardiseren en de organisatte helipen bili die aanpassing aan haar omgeving. Technostructuur en ondersteunende staf zijn beide "stafi".

\section{Theorie}

Stelsel van uitspraken dat dient om beschrijwingen, voorsjellingen en verklaringen van de werkelikheid mogelijk te maken. Theoretische uitspraken die onafhankelijk van de ampirie tot stand zijn gekomen., worden in het interactionisme niet aanvaard.

These, antithese, syrthese

Sturing is een proces dat verloopt volgens een interactiepatroon van these (stelling), antithese (tegenstelling) en synthese (samengestelde eenheid). De ene actor stelt bijvoorbeeid voor een netwerk op te richten (these), een of meer andere actoren reageren daarop met besprekingen, commentaar, aanvullingen of een tegenvoorstel (antithese), waama een besluit volgt (synthese, waarbinnen bijvoorbeeld een mengeling van voorstellen en reacties herkenbaar kan zijn), zoals het besluit het newwerk daadwerkelijk op te richten. These en antithese zijn stuurders. De synthese sluit het patroon af, het besilitit is de -al dan niet voorlopige- afronding van de sturingsinteracties. Die synthese in deze studie zijn uitsluitend besluiten tot oprichting en opheffing van netwerken en besluiten tot inwoering of annuleren van handelingsregels. Gedurende processen van vervlechting en antvlechting kunnen patronen van these, antithese en synthese worden waargenomen.

\section{Thuiszorg}

Georganiseerde gezondheidszorg en dienstverlening in de eigen woon. en leefsituatie van de hulpvrager. afgestemd op de individuele behoeften van het cliëntsysteem. Het doel van de thuiszorg is mensen, die door gebrek en/of ziekte afhankelijk zijn van de hulp van anderen thuis te ondersteunen, verzorgen, verplegen en/of behandelen, tot zil of hun directe omgeving daarloe zelf in staat zijn. Tevens wordit beargd dat mensen zo lang mogelijk in de eigen leefomgeving kunnen bliwen.

Time-series analysis

Bestudering van opeenvolgende gebeurtenissen en verschijnselen in de lijd. Analyseerbare datai eenheden (in deze studie "brackets", ingedeeld bij concepten) worden daartoe in een chronologische volgorde geplaatst.

\section{Toetsende benadering}

In onderzoek volgens de toetsende benadering wordt de empirische cyclus eenmalig doorlopen. Zaken zoals de werkwilze, hypothesen, meetinstrumenten en de populatie liggen vast voordat hel onderzoek beginf. Vooraf geformuleerde vaorspellingen kunnen gedurende het onderzoek niet worden bijgesteld.

\section{Traditionele thusiszorg}

Zorg aan patiënten met enkelvoudige zorgvragen, verstrekt door instellingen en beroepsbeoefenaren uit de eerstelin (eerste echelon, met name huisartsen, kruiswerk, gezinswerzorging en maatschappelijk werk) met jeder hun eigen, min of meer exclusieve taakdomein. 
Triangutatie

Techniek in de case study benadering warbij dezelfde onderwerpen worden bestudeerd met behulp yan gegevens die afkomstig zijn uit verschillende databronnen, die zijn verzameld met verschillencie instrumenten, of die zijm bestudeerd door werschillende onderzoekers. 'Triangulatie' is in case studies hét middel bif uitstek orr de validitelt van bevindingen te verhogen.

\section{Vorklaring}

Causale uitspraak waarin de relatie wordt gelegd tussen oorzaak en gevolg. In het interactionisme worden verschijnselen als de sociale orde ('concerted action') gezien als resultai van handelingen en interacties van actoren. Om deze handelingen te begrijpen moet de motivering worden achterhaald (verstehen", interpreteren), alsmede de betekenis die verschijnselen woor de actoren hebben. Deze betekenissen zijn het uitgangspunt woor handelingen.

\section{Vervlechting}

Het onderling verbonden raken wan een verzameling actoren.

\section{Wederkerigheid}

Wederzijdse afhankelijkheid. Bij gezag is in de asymmetrische afhankelijkheidsrelatie sprake van wederkerigheid. Het is uiteindelijk de ondergeschikte die bepaalt of volgens de wensen van de dominante actor wordt gehandeld. De dominante actor en de ondergeschikte hebben beiden macht, waardoor eenieder eisen kan stellen.

\section{Werkwoer}

Verzameling actoren die producten vervaardigen en diensten leveren.

\section{Zorgcircuits}

Netwerken van organisaties en limulpwerleners die samenwerkingsrelaties aangaan om eem samenhangend zorgaanbod te kunnen leveren.

\section{Zorgvernieuwing}

Handelingen, gericht op verandering en verbeterimg van de thuiszorg.

\section{Zorgvernieuwingsproject}

Een samenhangend geheel van handelingen die binmen een begrensde tijd zijn gericht op het creëren wan duidelijk gespecificeerde nieuwe én betere organisatievolmen ten behoeve van de thuiszorg.

\section{Zorgvraag}

Gevite behoufte adm hulp en diensten

\section{Zorg}

Hulp, diensten. In deze studie zijn zorg, hulp en diensten synoniem 


\section{Literatuur}

Adriaansens, H.P.M. (1983), 'Algemene sociologie'. 's-Gravenhage, WUGA-Uitgeverij B.V.

Aldrich, H.E., and Pfeffer, J. (1976), "Enwironments of organizations". In: Annua! Review of Sociology, 2 : 79-105.

Aldrich, H. and Mindlin, S. (1978), 'Uncertainty and dependence: two perspectives on environment". in: Karpik, L. (ed.), Organization and environment. Theory, issues and reality. Sage Studies in Intemational Sociology 12. London, Sage Publications Litd.

Andriessen, J.H.T.H. (1989), 'Organisaties en hun relaties. Over het analyseren van interorganisationele netwerken'. Tilburg, IVA.

Astley, W. Graham, and Van de Ven, A.H. (1983), "Cientral perspectives and debates in organizational theory". Administrative Science Quarterly, 28: 245-273.

Austin, J.L. (1976), "How to do things with words". Oxford Oxford Universily Press.

Becker, H. (1973), 'Outsiders. Studies in the sociology of deviance'. New York etc., The Free Press.

Benson, J. (1975). 'The interorganizational network as a political economy'. In: Administrative Science Quarterly, 20: 229-249.

Berns, E. (1981), 'Denken in Parijs. Taal en Lacan, Foucault, Althusser, Derrida'. Alphen a/d Rijn/Brussel, Samson Uitgeverij (2e druk).

Blau, P.M. (1964), "Exchange and power in social life'. New York, John Wiley \& Sons.

Btumer, H. (1969), 'Symbolic Interactionism, Perspective and Method'. Englewood Cliffs, N.J., PrenticeHall.

Blumer. H. (1974), 'Symbolisch interactionisme. Perspectief en methode'. Meppel, Boom.

Boudon, R. (1981), "De logica van het sociale". Alphen a/d Rijn/Brussel, Samson Uitgeverij.

Boudon, R. (1986). 'Theories of social change. A critical appraisal'. Cambridge "Polity Press.

Burns, T. Baumgartner, T., and DeVilie, P. (1985), 'Studies in cybernetics: 10'. New York etc., Gordon and Breach Science Publishers.

Burns, T.R., and Flarn, H. (1987), 'The shaping of social organizations. Social rule system theory with applications'. London etc., Sage Publications.

Burrell, G., and Morgan, $G_{\text {. }}(1982)$ " "Sociological paradigms and organisational analysis. Elements of the soiciology of corporate life". London etc. Heinemann Educational Books Lid.

Chalmers, A.F. (1983), "Wat heet wetenschap? Over aard en status varn de wetenschap en haa" methoden". Meppel, Boom (2e, herziene druk).

Child. $\Perp$. (1972), "Organization structure, ervironment, and performance - the role of strategic choice'. In: Sociology, 6: 1-22.

Collins, R. (1988), 'Theoretical sociology'. San Diego etc., Harcourt Brace Jovanowich Publishers, Inc.

Denzin, IN.K. (1989), "Interpretive interactionism". Newbury Park etc., Sage Publications

Dietz, J.L.G. (1996), 'Introductie tot DEMO, van informatietechnologie naar organisaliextechnologie'. Alphen a/d Rijn/Zaventem, Samson Bedrijfsinformatie.

Doorn, J. van, en Lammers, C. (1976), Moderne sociologie. Een systematische inleiding: Utrecht Het Spectrum (14e druk).

Eco, U. (1975), 'Looking for a logic of culture' In: Sebeok "T.A. (ed). The Tell-Tale Sign. A survey of semiotics. Lisse. The Peter De Ridder Press.

Elials, N. (1982) "Het civilisatieproces. Sociogenefische en psychogenetische onderzoekingen". Utrecht/Antwerpen, Het Spectrum. 
Eilemers, d.E. (1983) 'Functionele analyse'. In: Rademaker, L., en Bergman, H. (red.), Sociologische stromingen. Utrecht. Het Specirum/ Intermediair (3e druk).

Emerson, R. (1962), 'Power-dependence relations'. In; American Sociological Review, 27:31-41.

Fine, G.A. (1990), "Symbolic Interactionism in the post-Blumerian age". In: Ritzer, G. (ed), Frontiers of social theory: the new syntheses. New York etc. Columbia University Press.

Fine, G.A. (1993), The sad demise, mysterious disapperance, and glorious triumph of symbolic interactionism". Anmulal Review of Sociology, 19:61-87.

Gazendam, H.W.M. (1997), 'Het waarom en hoe van een pluriforme bestuurlijke informatiekunde'. Imformatie, maandblaid voor de informatievoorzlening, 37, november: 68-72.

Geyer, R.F., and Van der Zouwen, J. (1978), Sociocybernetics wol.1. An actor-oriented social systems approach', Leider, Nïhoff.

Giddens, A. (1979), "Central problems in social theory: action, structure and contradiction in social analys is '. London, etc., Macmillan.

Giddens, A. (1984), "The constitution of society; outline of the theory of structuration". Oxford, etc., Blackweil.

Gils, M.R. van (1977), 'De organisatie van organisaties: aspecten van interorganisationele samenwerking'. Groningen, Rijksuniwersiteit Groningen.

Glaser, B., and Strauss, A. (1967), "The discovery of grounded theory: strategies for qualitative research". Chicago, Aldine Pub. $\mathrm{Co}$.

Glaser, EM., Abelson, H.H. and Garrison, K.N. (1983), 'Putting knowledge to use". San Francisco etc. Jossey-Bass Publishers.

Godfroili, A. (1981), 'Nelwerken van organisaties. Strategieën, spelen, structuren'. "s-Gravenhage, VUGAUitgeverij B.V.

Goffman, I. (1959), 'The presentation of Self in Everyday Life". Garden City N.Y., Double Day and Company.

Goris, W. (1986), 'Kunstschildersolieverven. Materiaal, hulpmiddelen en techniek'. Apeldoorn, Koninkligke Talens B.V.

Groat, J. de, Jongerius-de Gier, G., Tijssen, I., en Mur-Veeman, I. (1989), 'Concept evaluatie-opzet Programma Zorgvernieuwingsprojecten Thuiszorg van WVC'. Maastricht, Onderzoeksgroep Zorgvernieuwing, vakgraep Beleidswetenschap, Rijksuniversiteit Limburg.

Grool, R. de, en Ketelaars, A. (red.) (1993), "Imnovatie in de zorgsector: jaarboek 1994". Utrecht, Tijidstroom.

Hall, P. (1987a), 'Interactionism and the study of sacial organization'. In: The Sociological Quarterly, $28 \mathrm{nr}$. $1: 1-22$

Hall, R.H. (1987b), 'Organizations, Processes and Outcomes'. Englewood Cliffs, N.J., Prentice Hall Inc.

Hanf, K., en Scharpf, F. (1978), "Interorganizational policy making. Limits to coordination and central control'. London/Beverly Hills, Sage Publications.

Harre, R. (1974), "Some remarks on "Rule" as a scientific concept". In Mischel, T. (ed), Understanding other persons. Oxford, Blackwell.

Hendrix, H. en Raak, A. van (1994), 'Koning klant thuis'. In: Tijdschrift woor Gezondheid \& Politiek, 12, nr. 5: $14-16$.

Hoffstede, $6 .(1985)$, 'National cultures and organizational cultures. Symbols, heroes, rituals and valies'. In: The Finnish Journal of Business Economics, 1: 3-19.

Hofstede, G. (1991), 'Cultures and organizations: software of the mind'. London etc. McGraw-Hill.

Homans, G. (1961), 'Social behavior, its elementary forms'. New York, The Free Press.

Hoof, J.J.B.M. van (1983), "Symbolisch Interactionisme'. In: Rademaker, L., en Bergman, H. (red.), Sociologische stroningen. Utrecht, Het Spectrum/Intermediair (3e druk). 
Huse, E.F. and Cummings, T.G. (1985), 'Organization development and Change'. St. Paul elc. West Publishing Company

Jacobs, D. (1974), "Dependence and vulnerability: an exchange approach tot the control of organizations". In: Administrative Science Quarterly. 19: 45-59.

Jongerius-de Gier, G., Tijssen, I., en Mur-Veeman, I. (1990), 'Evaluatie-opzet Programma Zorgvernieuwingsprojecten Thuiszorg van WW'. Maastricht, Onderzoeksgroep Zorgvernieuwing, vakgroep Beleidswetenschap, Rijksuniversiteit Limburg

Josselin de Jong, P. de (1978). "Claude Lévi-Strauss'. In: Redemaker, L. (red.), Hoofdfiguren uit de sociologie. Deel 3: Modemen-2. Utrecht/Antwerpen, Het Spectrum.

Keuming. D. en Eppink, D.J. (1987), 'Management en organisatie. Theorie en toepassing'. Leiden/Aritwerpen, Stentert Kroese B.V. (3e, herziene druk).

Keuning, D. en Eppink, D. J. (1993), 'Management en organisatie. Theorie en toepassing' Leiden, etc., Stenferk Kroese B.V. (5e, herziene druk).

KIijn, E.H., en Teisman, G.R. (1992), 'Beleidsnetwerkem: analyse en management". Onderzoeksprogramma Beleid en sturing in complexe netwerken, Working paper nr. 2. Rotterdam, Erasmus Universiteit.

Knoke, D. (1993), 'Networks of elite structure and decision making'. In: Sociological Methods \& Research, 22, nr. 1: $23-45$

Können, E. (1980), 'Interorganisationele samenwerking in het licht van ruiltheorie en coalitietheorie', In: Greve, W.B. de, en Vrakking, W.J. (red.), Strategie van samenwerking tussen organisaties in welzijns- en gezondheidswerk. Lochem. Tijdstroom.

Kuhn, T.S. (1970). 'The structure of scientific revolutions'. Chicago, University of Chicago Press.

Kuhn, T.S. (1979), 'De structuur wan wetenschappelike revoluties'. Meppel/Amsterdam, Boom, (3e, herziene druk).

Lammers, G.J. (1983), "Organisaties Vergelijkenderwijs. Ontwikkelingen en relevantie van het sociologisch denken over organisaties". UtrechtiAntwerpen, Het Spectrum.

Landelijke Vereniging Thuiszorg (z.j.), 'Wegwizer thuiszorg'. Bunnik, LVT.

Leeuw, A. de, en Mur-Veeman, I. (1990), 'De Nederlandse gezondheidszorg als systeem: systematiek, samenhang en besturing". In: Maarse, I.A.M., en Mur-Veeman, I.M. (red.), Beleid en beheer in de gezondheidszorg. Assen/Maastricht, Van Gorcum.

Leeuw, A (1994). 'Besturen van veranderingsprocessen. Fundamenteel en praktijkgericht management van organisatieveranderingen'. Assen, Van Gorcum.

Lindenberg, S. (1985), "An assessment of the new political economy". In: Sociological Theory, 3: 99.113.

Litwak, E., and Hylton, L.F. (1962), 'Interorganizational analysis: a hypothesis on coordinating agencies'. In: Administrative Science Quarterly, 6: 395-420

Litwak, E., and Rothman, J. (1970), 'Toward the theory and practice of coordination between formal organizations". In: Rosengren, W.R., and Lefton, M. (eds.). Organizations and clients. Essays in the sociology of service. Columbus, Ohio, Merrill.

Maines, D. (1977), 'Social organization and social structure in symbolic imferactionist thought'. In: Annual Review of Sociology, 3: 235-259.

Man, H. de (1992), 'Organisatiecultuur. Werkboek'. Heerlen, Open Universitteit.

Margulies, N. and Adams, J. (1982), 'Organizational Development in Health Care Organizations'. Reading Massachuisetts, Addisan-Wesley Publishing Company.

Massop, J., Tijssen, 1., en van der Made. J. (1991). 'Thuis in het kruiswerk. Organisatie, regelgeving. financiering en beleidswrïheid'. Maastricht, Onderzoeksgroep Zorgvernieuwing, wakgroep Beleidswetenschap, Rijksuniversiteït Limburg.

Mastenbroek, W.F.G. (1992), 'Onderhandelen'. Utrecht, Het Spectrum.

Mead, G.H. (1934), 'Mind, self; and society. From the standpoint of a social behaviorist'. Chicago, University of Chicago Press. 
Selznick, P. (1957). "Leadership in Administrattion". New York, Harper and Row.

Shimanoff, S. (1980). "Communication rules. Theory and research". Beverly Hills, Sage Publications.

Simon, H.A. (1957). "Administrative behavior". New York, Macmillan (2nd edition).

Strauss, A., Sichatzman, L., Ehrlich, D., Bucher, R., and Sabshin, M. (1963), 'The hospital and its negotiated arder". In: Freidson, E. (ed), The hospital in modern society. New York, Free Press.

Subcommissie Willems (1994), 'Onderzaek besluitworming volksgezondheid". "S-Gravenhage, SDU. Uitgeveril.

Swanborn, P.G. (1987), Methoden wan sociaal-wetenschappelijk onderzoek:. Meppel/Amsterdam, Boom (nieune editie).

Tijssen, I., Jongerius-de Gier, G. Raak, A. van, en Mur-Veeman, I. (1991), Over starten en volhouden. Evaluatie "Programma Zorgvernieuwingsprojecten Thuiszorg" van WV. Voortgangsrapportage 1990". Maastricht: Onderzoeksgroep Zorgwernieuwing, vakgroep Beleidswetenschap, Rijksuniversiteit Limburg.

Van Dale (1989), 'Groot woordenboek der Nederlandse taal'. Utrecht/Antwerpen, Van Dale Lexicagrafie (11e, herziene druk).

Van Maanen, J. (1976), 'Breaking in: Socialization to work', In: Dubin, R. (ed.), Handbook of work, organization, and society. Chícago, Rand McNally.

Verhoeff, E. (1991), 'Veranderingsmanagement in de gezondheidszorg'. 's-Gravenhage, Mirananda.

Warren, R.L., Rose, S.M., and Bergunder, A.F. (1974). 'The structure of urban reform: community decision organizations in stability and change'. Lexington, Mass., Heath.

Wassenberg. A. (1992), 'Onderhandelen: een stakeholders-visie'. In: Negotiation Magazine, 3: 109-115.

Weber, M. (1969), "Basic concepts in sociology". Westport, Connecticut, Greenwood Press Publishers.

Weber, M. (1976), 'Soziologische Grundbegriffe'. Tübingen, J.C.B. Mohr (Paul Siebeck), (3e, herziene druk).

Weick, K. E. (1969), 'The social psychology of organizing'. Reading, Mass., Addison-Wesley.

Wissema, \&.G., Messer, H.M., en Wijers, G.J. (1988), 'Angst voor veranderen? een mythe!, of: Hiae u veranderingsbereidheid op de werkvloer vergroot". Assen, Van Gorcum \& Comp. B.V.

Wijnen, G, Renes, W., en Storm, P. (1991), 'Projeclmatig werken". Utrecht, Het Spectrum B.V.

Yin. R.K. (1989), 'Casie study research. Design and Methods'. Applied Social Research Methods Series Volume 5. Newbury Park etc., Sage Publications Inc. (revised edition).

Yin, R.K. (1994), 'Case study research. Design and Methods'. Applied Social Research Methods Series Volume 5. Thousand Oaks etc. Sage Publications lnc. (2nd edition).

Yuchtman, E, and Seashore, S. (1967), 'A system resource approach to organizational effectiveness'. In: American Sociological Review, 32, nr, 6: 8911-903.

Ziekenfondsraad (1991), 'Regeling subsidiëring ziekenfondsraad intensieve thuiszorg 1992'. Amstelveen. 


\section{Overzicht databronnen}

\section{Registratieformulieren}

Nr. Omschrijuing

R1 Registratieformulieren meiljuni 1990

R2 Voortgangsregistratie projecten najaar $1990-14$ oktober 1991

R3 Voortgangsregistratie projecten najaar 1992

\section{Verslagen vraaggesprekken}

\section{Nr. Omschrijving}

V1 Verslag vraaggesprek directeur amw 3.10.1990, met als billage jaarverslag 1988-1989 en nota "S.M.W. in beeld" van september 1989

V2 Verslag vraaggesprek directeuren stedelijke gezinszorg 3.10 .1990 , met als bijlage jaarwerslag 1989

V3 Verslag vraaggesprek directeur regionale gezinszorg 8.10.1990, met als bijlage jaarverslag 1989

V4 Verslag vraaggesprek projectleider 9.10 .1990

V5 Verslag vraaggesprek directeur kruiswerk 9.10 .1990

V6 Verslag vraaggesprek projectleider 28.11.1991

V7 Verslag vraaggesprek projectleider 3.12.1992

\section{Documenten}

$\begin{array}{lll}\text { Nr. } & \text { Datum } & \text { Kenmerk } \\ \text { D1 } & 14.12 .1989 & \begin{array}{l}90008-p v t z \\ \text { D2 }\end{array} \\ 21.12 .1989 & \text { pvtz 55589 } \\ \text { D3 } & 22.12 .1989 & \text { pvt-55989 } \\ \text { D4 } & 22.12 .1989 & \text { 00590-pwt } \\ \text { D5 } & 8.1 .1990 & 00390-z k \\ \text { D6 } & 11.1 .1990 & 90004-p w t \\ \text { D7 } & 19.1 .1990 & 90006-p w t z\end{array}$

$\begin{array}{lll}\text { D8 } & 19.1 .1990 & 90009-p v t z \\ \text { D9 } & 23.1 .1990 & 90010-\text { pvtz } \\ \text { D110 } & 25.1 .1990 & 90017-\text { pvtz } \\ \text { D11 } & \text { Jan. } 1990 & 90021-\text { pvtz } \\ \text { D12 } & 2.2 .1990 & - \\ \text { D13 } & 5.2 .1990 & 90018-\text { pvtz } \\ \text { D14 } & 7.2 .1990 & 90019-p v t z \\ \text { D15 } & - & 90020-p v t z \\ \text { D16 } & 14.2 .1990 & 90022-p v t z \\ \text { D17 } & - & - \\ \text { D18 } & 14.2 .1990 & \text { eo/cv/14.2.1990 }\end{array}$

\section{Inhoudsaanduiding}

besluitenlijst vergadering 14.12. 1989 van projectgroep itz brief van WVC. WVC versitrekt nog geen subsidie; verzoekt om herziening projectwoorstel

brief over startconferentie Programma van WVC op 2.2.1990. verzoek beschrijwing project

brief van WVC: uitnodiging voor startconferentie op 2.2.1990 brief van $\mathrm{VOH}$ over voordracht tijdens startconferentie op

\subsubsection{0}

brief van projectieider met korte projectbeschribing notitie projectleider naar aanleiding wan WVC-brief dd.

21.12.1989 over opschorten subsidie: voorstel voor voorliopige andersteuning en woorstellen met betrekking tot de eisen van WVC

agenda vergadering projectgroep itz 25.1.1990

concepl raarnwerk voor draaiboek project

besilutemlijst vergadering 25.1 .1990 stichting itz i.o.

overeenkomst convergentiecollege

presentatie project tijdens eerste werkiconferentie van

Programma van $\mathrm{MNC}$

verslag wergadering dd. 30.1.1990 betrokkenen bij beide projecten in regio

brief projectieider aan redactie nieuwsbrief met artikel over project itz

concept-statuten stichting itz ten behoeve van vergadering projectgroep itz 99.2 . 1990

agenda vergadering projectgroep it $z$ 19.2.1990

overzicht werkzaamheden voor vergadering projectgroep itz $\$ 9.2 .1990$

budgetwoorstel ziekenfonds woor project ilz 
$90031 \mu \mathrm{pv} z$

D20 5.3 .1990

D21 $\quad 5.3 .1990$

022

5.3.1990

D23

8.3 .1990

13.3 .1990

14.3 .1990

89509-putz

$90028-p v t z$

$\mathbb{0 2 4}$

D25

$90038 \mathrm{mpltz}$

D26

90040upviz

D27

$90041-p w z z$

16.3 .1990

D28

D29

D30

D31

D32

2.4.1990

D33

พ5.4.1990

D34

5.4.1990

D35

20.4.1990

D36 25.4.1990

D37 26.4.1990

D38

D39

D40

D4 4

D45

D46

047

D 48

D49

D50

D51

D52

15.5 .1990 mei 1990

15.5 .1990

mel 1990

mei 1990

mel 1990

28.5 .1990

30.5 .1990

30.5 .1990

90042-pviz

90051-pvtz

90054-pivtz

$90053-p v t z$

$90057-p v t z$

90063-pvlz

C.EOIEUJ

90072-pvtz

90056-pviz

90080-pvtz

90062-pvtz

90060-pvtz

$90061-p v t z$

90075-pvtz

$90101-p v t z$

90102-pvtz bes luitenlijst vergadering 28.2 .1990 projectgroep itz

projectbeschrijwing project itz

brief van projectgroep tz aan de besturen wan participerende instellingen, naar aanleiding van overleg met ziekenfonds

brief van projectgroep itz aan colleges wan Burgemeester en

Wethouders en anderen over ontwikkelingen rond zorgver-

nieuwing

brief projectleider met als bijtagen projectbeschrijving en budgetwoorstel ziekenfonds

brief van projectleider aan WVC over afstemming tussen de organisalties wan beide projecten in de regio

brief van projectleider aan andere project in regio over aanvraag subsidie voor projectondersteuning bij WVC concept-pir-plan project itz ten behoeve van vergadering projectgroep itz 21.3.1990

draaiboek voor start met aanvullende thuiszorg ten behoeve van vergadering projectgroep itz 21.3.1990

$\mathrm{KGZ} / \mathrm{SG} / / \mathrm{KH}$

agenda wergadering projectgroep itz 21.3.1990

verslag vergadering 24.3 .1990 projectgroep itz

agenda wergadering projectgroep itz 5.4.1990

concept-brief van regionale ondersteunende organisatie aan

WVC: subsidie-aanvraag met begroting woor project

notitie verduidelijking werkwijze bureau itz: voorstellen van werkgroep 'werkwijze'

verslag vergadering 5.4.1990 projectgroep itz

brief van ziekenfonds aan projectgroep itz met kanttekening en bij projecivoorstel in kader wan regeling zlekenfondsraad agenda vergadering projectgroep itz 26.4.1990

brief regionale ondersteunende organisatie aan WVC met

begroting project

verslag vergadering stichting itz i.o. dd. 26.4.1990

aanvullingen op pr-plan ten behoeve van vergadering

projectgroep itz 26.4.1990

concepttekst voor a-folder (algemene folder over project itz ten behoeve van vergadering projectgroep itz 26.4.1990 concepttekst voor $b$-folder (extra folder voor voorzieningen) over project itz ten behoeve van vergadering projectgroep itz. 26.4 .1990

concepttekst voor c-falder (publieksfolder) over project itz ten behoeve van vergadering projectgroep itz 26.4.1990

ontwerp-communicatieschrift als woorbeeld wan logboek ten behoeve van vergadering projectgroep itz 26.4.1990

voorbeedd-logboek van thuisverplegingsproject uit Amster * dam ten behoeve van vergadering projectgroep itz 26.4.1990 agenda vergadering projectgroep itz 15.5.1990

statutern stichting itz

verslag laatste vergadering projectgroep itz 15.5 .1990

tijdsplanning, vergaderdata en agendaplanning directorium

interne folder itz voor hulpwerleners

externe folder itz voor hulpwerleners

agenda eerste vergadering directorium 5.6.1990

afschrift van de akte van oprichting stichting itz

brief stichting itz aan bestudirsleden van de stichting itz met info over subsidie-aanvraag en -besluiten, statuten, directorium, projectlieiderschap

notitie I.b.v. directoriumvergadering van 5.6.1990: oprichting stichting itz op 30.5 .1990 (wordt verwezen naar bijlage met statuten), projectmanager; inrichting bureau itz; materiële en organisalorische aangelegenheden; begroting 


\section{D54}

D55 $-$

D56

D57

v5.6.1990

25.6.1990

D58

25.6 .1990

D59

28.6 .1990

D60

064

D62

D63.

D64

D65

D66

19.7.1990

25.7 .1990

6.8 .1990

30.8 .1990

D67

\section{0pvtz2}

$90113-p$ wtz

05590-pvtz

pviz-90128-st

PF'0628'ITC(16)

90120-pvitz

90122-pwtz 90126-pwtz g0127pvtz.st

90139-pvtz 90140pvtz.dir

90141putz,dir

itz-01290-bu

itz-01390-bu

$90147 \mathrm{pwtz}$

865.90

7320.90

163pvtzdir

$184 p v t z$ dir

D74 17.10.1990

D75

D76

D77

D78

D79

D80

D81

$\begin{array}{lll}\text { D82 } & 3.12 .1990 & 1142.90 \\ \text { D83 } & 5.12 .1990 & \text { 206pwtzdir } \\ \text { D84 } & 10.12 .1990 & 212 \mathrm{pwtz} \text { dir } \\ \text { D85 } & - & 8422 \mathrm{Q}\end{array}$

D86 okt. 1990

8.11 .1990

14.11 .1990

pvtz189

206pvtzdir

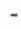

209putz dir logboek itz ten behoeve van vergadering directorium 5.6 .11990

ijst met bestuursleden stichting itz ten behoeve van vergadering directorium 5.6.11990

verstag vergadering 5.6.1990 directorium

brief van WMC aan convergentiecollege 1.0.: goedkeuring project en subsidieveriening

eerste overzicht financiële kosten projectieiding, projectmew nager, uitwoering itz, bureau itz

arbeidsovereenkomst tussen stichting ITZ en projectmanager notitie gang van zaken bij bureau itz ten behoeve van vergadering directorium 25.7 .1990

overzicht kosten bureau itz in 1990 ten behoeve van vergadering directorium 25.7 .1990

agenda vergadering directorium 25.7.1990

verslag vergadering 25.7 .1990 van directorium

agenda vergadering bestuur 13.8 .1990

agenda vergadering directorium 12.9 .1990

mededelingen met betrekking tot itz ten behoeve van

directoriumvergadering 12.9. 1990: onder andere huisvesting, gironummer, samenwerking met hulpwerleners, problemen

aandachtspunten voor ilz ten behoove van directoriumvergadering 12.9.1990 onder andere doelgroep, exira hulp.

aanbod aan $\mathrm{pg}$, afstemming van itz mel gezinsverzorging en kruiswerk, voorlichting, budgetbewaking, administratie rekeningen, aanbod arrw

brief van ziekenfonds aan projectmanager: voomemens tot procedure verstrekking voedingsmididelen

brief van regionaal apothekers overieg aan projectmanager: voorstel tot overleg over integratie van activiteiten van apothekers in project

versllag vergadering 12,9,1990 van directorium brief van stichting ITZ aan WVC: korte beschrijving vergaderingen, startfase en problemen in project itz brief van RL aan project met als bijlage beschrijwing project agenda vergadering directorium 17.10 .1990 verslag vergadering $17,10.1990$ van directorium ciffermatig overzicht hulpvragen itz ten behoeve van directoriumvergadering van $\$ 7.10 .1990$

uilnodiging van NIVEL voor jaarmakt zorgvernieuwing in 1991

agenda vergadering directorium 1.4.11.1990

verslag vergadering 14.11 .1990 van directorium notitie ten behoeve van directoriumvergadering wan 14.11.1990 over werkafspraken mel ziekenhuizen-onisiagprotocol

notitie ten behoeve van directoriumvergadering van

14.11.1990 inzake onderhandelingsruimte projectmanager concept werkovereenkomst met de

hospice/vrijwilligersorganisaties ten behoeve van directoriumwergadering wan $14,11.1990$

overzicht activiteiten woor bekendmaking huiswesting indicatiebureaus agenda vergadering directorium 10.12 .1990 verslag vergadering 10.12 .1990 van directorism ontwerp-besluit subsidiëring itz ingaande januar 1991 ten behoeve wan wergadering directorium 10.12.1990 concept-begrating stichting itz 1991 ten behoeve van vergadering directorium 10.12 .1990 
087

D88

D89

D90

D91

092

093

D94.

D95

D96

D97

D98

D99

D 100

D101

D 102

24.1 .1991

D103

D104

30.1 .1991

5.2 .1991

D405

v5.2.1991

D106

0107

D108

D109

D110

D111

6.2.1991

6.2 .1991

6.2 .1991

v7.2.1991

D 112

13.2.1991

D) 113

D114

D115

8.2.1991

19.2.1991

febr. 1991

febr. 1991 016pvtz.dir

$333.91 / \mathrm{ptz} / \mathrm{dir}$ $017 p v t z . d i r$ voortgangsverslag bureau itz: onder andere aantal zorgdagen. werkovereenkomst met de hospice, protocol ontslag uit zlekenhuis, wewerking van aanmeldingen, lijst met ingevoerde verzekerden ten behoeve van vergadering directorum 10.12 .1990

vergaderschema directorium-bestuur 1994 ten behoeve van vergadering directorium 10.12.1990

versiag gesprek van projectmanager met kiniek over acute opvang vanuit thuissituatie door de kliniek

brief aan bureau itz van hospice met folder

verslag vergadering projectgroep psychogeriatrie van 19.12 .1990

woortgangsrapportage zorgvernieuwingsproject aan WVC brief RL aan stichting ITZ met als bijlagie projectbeschrijving uithodiging voor vergadering van bestuur op 5.2.1991 agenda wergadering directorium 23.1.1991

mededelingen van projectleider aan directorium ten behoeve van vergadering directorium 23.1.1991

begroting stichting ITZ, met verwijzing naar conceptw begroting ten behoeve van vergadering directorium 23.1.1991

concept-taakopdracht projectgroep psychogeriatrie ten behoeve wan vergadering directorium 23.1.1991

verslag vergadering 23.1.1991 van directorium brief projectleider aan RL: goedkeuring projectbeschriving brief projectleider over onduidelinkheid over bij het bureau itz te declareren huisartsenthulp. Bijlage: protocol patienten die in aanmerking komen woor itz

brief aan stedelijke gezinszorg naar aanleiding van diens brief dd. 23,1.1991 ander andere over participatie wan gezinsverzorging bij casusbesprekingen; overleg van kruiswerk en gezinszorg mett verzekeraar op 4.2.1991 voortgangsverslag project itz 1990

brief projectleider aan projectgroep pg met bijlagen: verslag van vergadering 19.12.1990 van projectgroep pg; notitie itz voor pg-patiënten

verslag vergadering 5.2 .1991 van bestuur

concept-taakopdracht wan projectgroep pg

agenda vergadering directorium 13.2.1991

concept-begroting stichting itz 1991

verslag vergadering van convergentiecollege 7.2 .1991 interim-advies van ziekenfondsraad ower invoering van itz, ten behoeve van vergadering directorium 13.2.1991 uitnodiging van verzorgingshuizen en verpleegtehuizen voor overleg over nieuwe situatie na samenvoeging indicatiestructuren voor verzorgingstehuizen en verpleeghuizen verslag vergladering 13.2.1991 van directorium taakstelling convergentiecollege brief van verzorgingshuizen en verpleegtehuizen met voorstel tot instellen van plaatsingscommissies in regio brief van gedeputeerde staten Noord-Holland aan Burgemeester en Wethouders in de gemeenten in de regio: uithodiging voor bijeenkomst op 22.2.1991 over inventarisatie van thuiszorgaanbod, participatie van gemeenten, samenwerking provincie-gemeente inzake zorgvernieuwing agenda vergadering directorium 13.3.1991 verslag vergadering directorium 13.3.1991 toelichting bij wijziging begroting ten behoeve van vergadering directorium 13.3 .1991 


\section{Di19 - a18pvtz}

D120 21.3.1991 O29pviz.co

$\begin{array}{lll}\text { D121 } & 21.3 .1991 & - \\ \text { D122 } & 5.4 .1991 & 331.91-\mathrm{ptz} \\ \mathrm{D} 123 & 5.4 .1991 & 332.91-\mathrm{ptz} \\ \mathrm{D} 124 & 8.4 .1991 & - \\ & & \\ \text { D125 } & 10.4 .1991 & 378.91 / \mathrm{plz} \\ \mathrm{D} 126 & - & 035 \mathrm{pwtz} \text { dir } \\ \text { D127 } & - & \\ \text { D128 } & - & \\ \text { D129 } & \end{array}$

$\begin{array}{lll}\text { D130 } & 11.4 .1991 & 392 / 91 . \mathrm{ptz} \\ \text { D131 } & 15.4 .1991 & 330.91 \text { ptz } \\ & & \\ \text { D132 } & 15.4 .1991 & 379.91 / p t z \\ \text { D133 } & 22.4 .1991 & 438 / 91 . \mathrm{ptz} \\ \text { D134 } & 22.4 .1991 & 428 / 91 . \mathrm{ptz} \\ & & \\ \text { D135 } & 2.5 .1991 & 498 / 91 . \mathrm{ptz} \\ \text { D136 } & - & 453.91\end{array}$

D137 v8.5.1991

D138 v8.5.1991

D139 8.5.1991

D140 8.5.1991

D141 8.5.1991

D142

D 143

D144 29.5.1991

D 145

D146

D 147

D148

D 149

3.6. 1991

v5.6.1991

5.6.1991

D150

5.6. 1991

D151

D152

D153

6.6.1991

12.6 .1991

juni 1991

584/91 ptz $589 / 91 . \mathrm{ptz}$ oszror $151.94 c$

$502 / 91 . p t z$

$603 / 91 . p t z$

$652191 . \mathrm{ptz}$ 653/91.ptz

7月9/91.ptz 842791.ptz 6355.91

718/91.ptz 830/91.ptz

\section{D154}

D155 concept-begroting stichting itz 1991 met toelichting ten behoeve van vergadering directorium $13.3,1991$

brief wan projectleider aan taakgroep taekstelling convergentiecollege: onder andere info over talakstelling corvergentie. college

tekst rede van staatssecretaris in slaatscourant 57 agenda vergadering directorium 10.4.1991

agenda vergadering convergentiecollege 11.4.1991 verslag bijeenkomst van maatschappelik werkenden van de stedelijke ziekenhuizen en verpleeghuizen

verslag vergadering 10.4.1991 van directorium

eerste concept invenlarisatie en start zorgaanbod pg. patiënten ten behoeve van vergadiering directorium overzicht gegevens aanmeidingen itz matrt 1991 ten behoeve van vergadering directorium 10.4.1991 vraagstellingen voor een studiedag ten behoeve van vergadering directorium 10.4.1991

5 ondewerpen van taakgroep convergentiecollege voor bespreking in convergentiecollege ten behoeve van vergadering convergentiecollege 11.4.1991

verslag vergadering convergentiecollege 11.4.1991

concept-brief aan WVC over verdere integratie projectorganisaties

actiepuntenlijst projectactiviteiten

verslag vergadering taakgroep convergentie 22.4.1991

concept-checklist met betrekking tot convergentie-ondenwerp 5: indicatiebureaus/bureaustructuur agenda vergadering directorium 8.5.1991 onderbouwing van tarieven van amw ten behoeve van vergadering directorium 8.5.1991

verslag vergadering directorium 8.5.1991

besiuitenligst vergadering directorium 8.5 .1991

overzicht kosten armw

rapporfage bureau itz april 1991

brief van ziekenfonds over tarieven zorginzet itz

notitie doelgroepen in begroting 1991 ten behoeve van vergadering directorium 8.5.1991

bijeenkomst taakgroep convergentiecollege 23.5 .1991 : notitie beshitutyormingsprocedures

agenda bezinningsdag directorium 5.6.1991

notitie ten behoeve van bezinningsdag op 5.6.1991: ochtendthema 'het onderscheid reguliere zorg-intensieve zorg' somatische casus ten belroeve van inhoudelike discusste op bezinningsdag op 5.6.1991 over doel etc.

overzicht praktijkproblemen itz

verslag bezinningsdag 5.6.1991

notitie 'itz en amw', met begeleidende brief van amw aan ziekenfonds

concept huishoudelijk reglement stichting itz

agenda wergadering directorium 12.6 .1991

samenvattend verslag vergadering directorium 12.6 .1991

overzicht van stedelijke gezinswerzorging itz, wachtlijst en urgentielijst psychogeriatrie

concept huishoudelijk reglement stichting itz ten behoeve van vergadering directorium 12.6.1991

vergaderingen directorium zomerperiode: vergaderctata en agendapunten len behoeve van vergadering direchorium 12.6.1991

overzicht gegevens aanmeldingen bij bureau itz mei 1991 ten behoeve van vergadering directorium 12.6.1991 


\begin{tabular}{|c|c|c|}
\hline 0157 & 10.6 .1991 & 750/91.ptz \\
\hline 0158 & 10.6 .1991 & $751 / 91.012$ \\
\hline D159 & 12.6 .1991 & 830/91.ptz \\
\hline$D 160$ & 13.6 .1991 & 934.191.ptz \\
\hline D 161 & - & arsputz \\
\hline D 962 & 17.6 .1991 & $782 / 91 . p t z$ \\
\hline 0163 & 20.6 .1991 & 831/91.ptz \\
\hline 0164 & 3.7 .1991 & 6526.94 \\
\hline 0165 & - & - \\
\hline$D=66$ & 10.7 .1991 & $940 / 91$ ptz \\
\hline D 167 & 10.7 .1991 & $942 / 91 . \mathrm{ptz}$ \\
\hline D168 & 7.8 .1991 & 994/91,ptz \\
\hline D169 & - & 943/91.ptz \\
\hline D170 & - & 944/91.ptz \\
\hline D171 & . & $995 / 91 . \mathrm{pt}$ \\
\hline
\end{tabular}

$\begin{array}{lll}\text { D172 } & 7.8 .1991 & \text { 1006/91.ptz } \\ \text { D173 } & 14.8 .1991 & 105491 . \mathrm{ptz} \\ \text { D174 } & 26.8 .1991 & 1109 / 91 . \mathrm{ptz} \\ \text { D175 } & 11.9 .1991 & 146 \mathrm{pvt} . z \\ \text { D176 } & 19.9 .1991 & 1244 / 91 . \mathrm{ptz} \\ \text { D177 } & \text { sept. } 1991 & 1245 / 91 . \mathrm{ptz} \\ & & \\ \text { D178 } & 25.9 .1991 & 6970-91\end{array}$

\begin{tabular}{|c|c|c|}
\hline $\begin{array}{l}\text { D179 } \\
\text { D180 } \\
\text { D181 }\end{array}$ & $\begin{array}{l}27.9 .1991 \\
3.10 .1991 \\
15.10 .1991\end{array}$ & $\begin{array}{l}\text { 1417/91.ptz } \\
\text { 1333/91.ptz } \\
\text { 1513/91.ptz }\end{array}$ \\
\hline $\begin{array}{l}\text { D } 182 \\
\text { D183 }\end{array}$ & 15.10 .1991 & $1335 / 91 . \mathrm{ptz}$ \\
\hline 0184 & - & $1049 / 91 \mathrm{plz}$ \\
\hline D185 & - & 1268/91.ptz \\
\hline D. 186 & . & $1050 / 91 . \mathrm{ptz}$ \\
\hline 0187 & 16.10 .1991 & $1415191 . \mathrm{ptz}$ \\
\hline $\begin{array}{l}\text { D188 } \\
\text { D189 } \\
\text { D190 } \\
\text { D191 }\end{array}$ & $\begin{array}{l}17.10 .1991 \\
22.10 .1991 \\
6.11 .1991 \\
6.11 .1991\end{array}$ & $\begin{array}{l}\text { 1421/91.ptz } \\
1760 / 92 . \mathrm{ptz} \\
1507 / 91 . \mathrm{ptz} \\
1514 / 91 . \mathrm{ptz}\end{array}$ \\
\hline$D 192$ & 13.11 .1991 & $1308 / 91 . \mathrm{ptz}$ \\
\hline $\begin{array}{l}D 193 \\
0194\end{array}$ & $\begin{array}{l}13.11 .1991 \\
21.111991\end{array}$ & $\begin{array}{l}\text { 1580/91.ptz } \\
1607 / 91 . \mathrm{ptz}\end{array}$ \\
\hline
\end{tabular}

agenda vergadering bestuur 13.6.1991

woortgang project itz: overzicht ontwikkelingen en discussiepunten februari - juni 1991

samenvattend verslag vergadering directorium 12.6.1991

verslag vergadering bestuur 13.6.1991

begroting 1991 ten behoeve van vergadering bestuur 13.6.1991

voorstel voor ordening van de discussie in de taakgroep convergentie

agenda vergadering directorium 10.7.1991

notitie van ziekenfonds ower stand van zaken project itz overzicht gegewens aanmeldingen bil bureau itz juni 1991 ten behoeve van vergadering directorium 10.7.1991

verslag vergadering directorium 10.7 .1991

afspraken van de taakgroep convergentie, gemaakt op $10.7,1991$

agendla wergadering directorium 14.8.1991

concept woortgangsverslag januari 1991-juni 199: aan WWC ten behoeve van vergadering directorium 14.8.1991

concept-brief aan WVC over voortgang project januari-juni

1991 ten behoeve van vergadering directorium 14.8.1991

notitie hoe binnenkort verder met de pg-groep: een eerste

gespreksronde; ten behoeve van vergladering directorium

14.8.1991

begroting 1991 stichting itz

verslag vergadering directorium 14.8.1991

brief met notitie aan werkgroep praktijkproblemen

brief projectleider: ledenlijst van convergentiecollege en van

bestuur en directorium

agenda vergadering directorium 27.9.1991

een jaar project itz. Enkele cijfers over de periode 1 juli 1990 tot 1 juli 1991

brief van hospice aan directorium: verzoek om samen met: hospice mogelijkheden na te gaan van voortzetting van werk hospice

verslag wergadering directorium 27.9.1991

agenda vergadering bestuur 22.10.1991

samenvattend verslag gesprek tussen vertegenwoordigers van projectorganisaties in de regio op 15.10.1991

huishoudelijk reglement stichting itz versie 15.10.1991

overzicht ontwikkelingen juri - oktober 1991 ten behoeve wan vergadering directorium 22.10 .1991

financieel overzicht 1990: kosten ilz ten behoeve van vergadering directorium 22.10 .1991

financiele jaarrekening 1990 ten behoeve van vergadering directorium 22.10,1991

halfjaaroverzicht itz 1991: kosten itz ten behoeve van vergadering directorium 22.10.1991

brief van projectleider aan directorium over discussies met betrekking tot de pg-groep

notitie beleidsplan 1992 en begroling 1992

verslag vergadering bestuur 22.10.1991

agenda vergadering directorium 13.11.1991

vorderingen pg-groep en onderlinge afstemming van

discussies ten aanzien van hulp aan pg-patiënten

concept-evaluatie project itz voor terminale patiënten juni

1990 - juli 1991

verslag wergadering directorium 13.11.1991

brief wan projectleider aan vereniging van verpleeghuizen

over werkennende bespreking over pg 


\begin{tabular}{|c|c|c|c|}
\hline D195 & 21.11 .1991 & $1617 / 91 . \mathrm{plz}$ & $\begin{array}{l}\text { brief van projectleider aan hospice over financiéle bijdragen } \\
\text { aan werk van hospice }\end{array}$ \\
\hline D196 & 21.11 .1991 & 1630/91.ptz & $\begin{array}{l}\text { besluitvorming evaluatie itz dd. } 20.11 .1991 \text { en inbreng in } \\
\text { overleg met ziekenfonds }\end{array}$ \\
\hline D197 & 24.11 .1991 & 7399.91 & notitie van huisartsenvertegenwoordiger over itz \\
\hline D198 & 25.11 .1991 & $1665 / 91 . p t z$ & verslag gesprek met ziekenfonds dd. 25.11 .1991 \\
\hline D199 & 5.12 .1991 & $1711 / 91 . p t z$ & agenda vergadering directorium $\| 1.12 .1991$ \\
\hline 0200 & 9.12 .1991 & $1741 / 91 . \mathrm{ptz}$ & reactie hoofdwijkwerpleegkundigen op handleiding itz \\
\hline D201 & 11.12 .1991 & $1761 / 91 . p t z$ & verslag vergadering directorium 11.12 .1991 \\
\hline D202 & 11.12 .1991 & - & $\begin{array}{l}\text { notitie "wanneer nachtverpleging en wanneer nachtzorg bij } \\
\text { terminale patiënten" }\end{array}$ \\
\hline D203 & - & $1581 / 91 . p t z$ & $\begin{array}{l}\text { overzicht bestispunten in evaluatierapport itz ten behoeve } \\
\text { van wergadering directoritum } 11.12 .1991\end{array}$ \\
\hline D204 & 8.1 .1992 & $1631 / 91 . p t z$ & voorstellen van de pg-werkgroep aan het directorium \\
\hline D205 & jan. 1992 & $1693 / 91 . p t z$ & $\begin{array}{l}\text { handleiding ilz voor terminale patiënten van werkgroep } \\
\text { praktijkproblemen }\end{array}$ \\
\hline D206 & 9.1 .1992 & $048 / 92 . \mathrm{ptz}$ & agenda vergadering directorium $15,1,1992$ \\
\hline D207 & 15.1 .1992 & 094/92.plz & verslag vergadering directorium 15.1 .1992 \\
\hline D208 & 20.1 .1992 & 049/92.ptz & inbedding en taken van de operationaliseringsgroep itz \\
\hline $\mathrm{D} 209$ & - & $050 / 92 \cdot \mathrm{ptz}$ & $\begin{array}{l}\text { notitie over poolvorming ten behoeve van vergadering } \\
\text { directorium } 29.1 .1992\end{array}$ \\
\hline D210 & 20.1 .1992 & $116 / 92 . \mathrm{ptz}$ & agenda vergadering bestuur 30.1 .1992 \\
\hline D211 & 22.1 .1992 & 141/92.ptz & verslag overleg directorium-ziekenfonds-riagg dd 22.1.1992 \\
\hline $\mathrm{D} 212$ & 291.1992 & 190/92.ptz & besluitenlijst directorium dd. 29.1.1992 \\
\hline $\mathrm{D} 213$ & 30.1 .1992 & 264/92.ptz & verslag vergadering bestuur 30.1 .1992 \\
\hline $\mathrm{D} 214$ & - & 1117/92.ptz & $\begin{array}{l}\text { overzicht van projectontwikkelingen oktober - januari ten } \\
\text { behoeve van vergadering bestuur } 30.1 .1992\end{array}$ \\
\hline D215 & 10.2 .1992 & $241 / 92 . p t z$ & $\begin{array}{l}\text { brief van stichting itz aan ziekenfonds over financiering tzz } \\
1992\end{array}$ \\
\hline $\mathrm{D} 216$ & 27.2 .1992 & 5443.92 & $\begin{array}{l}\text { brief van ziekenfonds aan stichting itz over financiering itz } \\
1992\end{array}$ \\
\hline D217 & 6.3 .1992 & $441 / 92 . \mathrm{ptz}$ & agenda vergadering directorium 11.3 .1992 \\
\hline $\mathrm{D} 218$ & 11.3 .1992 & $474 / 92 . p t z$ & $\begin{array}{l}\text { besluiten dd. } 11.3 .1992 \text { van directorium met betrekking tot } \\
\text { concept 'rearganisatie project itz' nr } 338 / 92 \text {. ptz versie van } \\
5.3 .1992\end{array}$ \\
\hline D219 & 11.3 .1992 & $607 / 92 . \mathrm{ptz}$ & verslag vergadering directorium 11.3 .1992 \\
\hline 0220 & 12.3 .1992 & 465/92.ptz & $\begin{array}{l}\text { brief van directorium aan ziekenfonds over financiering itz } \\
1992\end{array}$ \\
\hline D221 & 12.3 .1992 & 475/92.ptz & agenda vergadering bestuur 16.3 .1992 \\
\hline D222 & * & $463 / 92 . p t z$ & $\begin{array}{l}\text { herziene concept-begroting 1992: versie van directorium woor } \\
\text { bestuursvergadering } 16.3 .1992\end{array}$ \\
\hline $\mathrm{D} 223$ & 16.3 .1992 & $338 / 92 . p t z$ & $\begin{array}{l}\text { handleiding itz voor terminale patiënten van werkgroep } \\
\text { praktijkproblemen }\end{array}$ \\
\hline D224 & 2.4 .1992 & 610/92.ptz & agenda vergadering directorium 8.4 .1992 \\
\hline D225 & - & $611 / 92 . p t z$ & $\begin{array}{l}\text { aanvullende opmerkingen bij de stukken voor de directorium- } \\
\text { vergadering van } 8.4 .1992 \text { over reorganisatie en zorg aan pg- } \\
\text { patiénten }\end{array}$ \\
\hline D226 & - & 515/92.ptz & $\begin{array}{l}\text { instructie nieuwe werkwijze in kader project itz len behoreve } \\
\text { van directoriumvergadering van } 8.4 .1992\end{array}$ \\
\hline D227 & 17.4 .1992 & - & $\begin{array}{l}\text { brief van penningmeester aan bestuur over accountantscon- } \\
\text { trole van jaarrekening } 1990 / 191\end{array}$ \\
\hline D228 & 23.4 .1992 & $748 / 92 . p t z$ & agenda extra vergadering directorium 4.5 .1992 \\
\hline D229 & - & 1257/92.ptz & voortgangsverslag $1 \mathrm{e}$ helff 1992 project it 2 \\
\hline D230 & - & $749 / 92 . p t z$ & $\begin{array}{l}\text { voorstellen financiële afwikkeling } 1-7-1990 / 1-4-1992 \text { en } \\
\text { voorstellen administratiewe organisatie met ingang van } 1-4 \text { - } \\
1992 \text { ten behoeve van vergadering directorium } 4,5.1992\end{array}$ \\
\hline D231 & - & 751/92.ptz & $\begin{array}{l}\text { vraag over te declareren kosten bij inzet van itz ten behoeve } \\
\text { van wergadering directorium } 4.5 .1992\end{array}$ \\
\hline 0232 & mel 1992 & 817/92.ptz & brief projectleider aan instellingen met info over folders itz \\
\hline D233 & mei 1992 & $846 / 92, \mathrm{plz}$ & brief projectleider aan instellingen met info over folders itz \\
\hline
\end{tabular}




\begin{tabular}{|c|c|c|}
\hline D234 & mei 1992 & $768 / 92$ \\
\hline D235 & mei 1992 & 777192 \\
\hline D236 & $\vee 4.5 .1992$ & $978 / 92 \mathrm{ptz}$ \\
\hline D237 & 7.5 .1992 & 825/92.ptz \\
\hline D238 & 4.6 .1992 & 977/92.ptz \\
\hline 0239 & - & 979/92.ptz \\
\hline D24:0 & 5.6 .1992 & 993.92 \\
\hline$D 241$ & 10.6 .1992 & 1214/92.ptz \\
\hline 0242 & - & 992.92 \\
\hline D243 & 11.6 .1992 & $1243 / 92 \mathrm{ptz}$ \\
\hline D244 & 2.7 .1992 & $1132 / 92 \mathrm{ptz}$ \\
\hline D245 & 14.7 .1992 & $1198 / 92$ ptz \\
\hline D246 & 16.7 .1992 & $1222 / 92$ ptz \\
\hline$D 247$ & 16.7 .1992 & 8.9.JdK/WW/ \\
\hline
\end{tabular}

D248 26.7 .1992

D249 29.7.1992 1226/92.ptz

D250 29.7.1992 1256/92.ptz

D251 24.9.1992 1475/92.ptz

D252 - 1476/92.ptz

D253

1478/92.ptz

0254

1479/92.ptz

D255

$-$

1480/92.ptz

D256

D257

D258

- $74992 \mathrm{ptz}$

D260

30.9 .1992

D261 okt. 1992

1941/92.ptz 4598.92

D262 20.10.1992

D263 20.10.1992

0264 26.10.1992

D265 26.10.1992

$1607 / 92 . p t z$ 1634/92.ptz 7106.92 folder ITZ voor verwijzers

agemene folder ITZ

besluiten exira directoriumvergadering 4.5 .1992

brief aan ziekenfonds over vertrek projectmanager

agenda vergadering directorium 10.6.1992

eindrapport pg-werkgroep ten behoeve van vergadering directorium 10.6.1992

agenda vergadering convergentiecollege 11.6.1992

verslag vergadering directorium 10.6 .1992

notitite taakstelling convergentie college etc. ten bethoewe van wergadering convergentiecollege 11.6.1992

verslag veirgadiering comvergentiecollege 11.6.1992

brief van operagroep aan kruiswerk met advies over interne

herschikking vantaken bij organisatie wan itz

herzlene begroting stichting itz ten behoeve van vergadiering directorlum 30.9.1992

brief van bestuur aan directorium ower ontevredenheid van

gang van zaken bilitz aan terminale patiënten

brief van kruiswerk aan belanghebbenden over interne

herschikking wan laken bij organisatie wan itz

brief van huisartsenvertegenwoordiger aan projectleider waarin deze werk als lid wan directorium neerlegt

brief van projectleider aan participanten stichting $\| t z$ met als bijlagen: financieel jaaroverzicht 1994 en begrating 1992

brief van convergentiecollege aan WVC over voortgang $1 \mathrm{e}$ hellft 1992

agenda vergadering directorium 30.9 .1992

notitie huidige constructie met betrekking lot terminale

patiènten ten behoeve wan vergadering directorium

30.9 .1992

aanbevelingen operagroep ten behoeve van wergadering directorium 30.9 .1992

aanvullingen van projectieider en stedelijke gezinszorg op aanbevelingen operagroep ten behoeve van wergadering directortum 30.91992

notitie overleg met ziekenfonds ten behoeve wan vergadering directorum 30.9.1992

vergaderdatalagendaplanning bestutur en directorium ten

behoeve van vergadering directorium 30.9 .1992

informeel jaarowerzicht 1991 itz ten behoeve van vergadering directorium 30.9 .1992

registratie 1991: kosten wan stichting iitz volgens geaccordeerde declaraties ten behoeve van vergadering directorium 30.9 .1992

financièle afwikkeling $1990 / 1991$ en administratieve reorganisatie 1992 ten behoeve van vergadering directorium

30.9 .1992

verslag vergadering directorium 30.9 .1992

stand van zaken project ten behoewe van convergentiecollege

conceptbeleidsplan 1993 van de stichting itz

agenda vergadering convergentiecollege 27.10.1992

brief van verpleeghusis-riagg-stichting itz aan ziekenfonds over plan dagopvang pg-patiënten extramuraal

notitie van verpleeghuis-riagg-stichting itz aan ziekenfonds:

plan dagopvang pg-patiènten extramuraal

brief van indicatiebureau aan inspectie geestelijke volksge-

zondheid aver beperken van bewegingsvrijheid wan cliënten

in thuissituatie 


\begin{tabular}{|c|c|c|c|}
\hline 0267 & 10.11 .1992 & $1829 / 92 . \mathrm{ptz}$ & $\begin{array}{l}\text { brief wan stichting ilz aan ziekenfonds betreffende overleg op } \\
16.11 .1992\end{array}$ \\
\hline D268: & 16.11 .1992 & $1942 / 92 \mathrm{ptz}$ & $\begin{array}{l}\text { werslag overleg van directorium/huisartsenvereniging/riagg } \\
\text { met zlekenfonds dd. } 16.11,1992\end{array}$ \\
\hline D269 & okit-lnov 92 & 1801/92.ptz & $\begin{array}{l}\text { concept protocol indicatiesteling en zorgtoewijzing psycho- } \\
\text { geriatrische patiënten }\end{array}$ \\
\hline 0270 & 17.11 .1992 & $1943 / 92 . p t z$ & verslag vergadering operagroep dd. 17.11 .1992 \\
\hline D27: & 24.11 .1992 & 1946/92.ptz & agenda vergadering directorium 2.12 .1992 \\
\hline $\mathrm{D} 272$ & - & $1830 / 92 . \mathrm{ptz}$ & $\begin{array}{l}\text { budgetvoorstellen itz } 1993 \text { ten behoeve van wergaderig } \\
\text { directorium } 2.12 .1992\end{array}$ \\
\hline $\mathrm{D} 273$ & nov. 1992 & $92-3203 / \mathrm{h} / \mathrm{k} / \mathrm{nd}$ & $\begin{array}{l}\text { notitie van verpleeghuizen over overbruggingszorg en } \\
\text { plaatsing van verpleeghuisgeñndiceerde patienten in de reglo }\end{array}$ \\
\hline $\mathrm{D} 274$ & dec. 1992 & 2049/92.ptz & rapport van operagroep: evaluatie van de itz \\
\hline D275 & 2.12 .1992 & 2095/92.ptz & verslag vergadering directorium 2.12.1992 \\
\hline D276 & 3.12 .1992 & js/aw/921693 & $\begin{array}{l}\text { brief van inspectie geestelijke volksgezondheid aan indicatie- } \\
\text { bureau over beperken van bewegingsvrijheid van clierten in } \\
\text { thuissituatie }\end{array}$ \\
\hline D277 & 21.12 .1992 & 2096192.ptz & $\begin{array}{l}\text { aanbiedingsbrief van projectleider alan directies over protocol } \\
\text { indicatiestelling }\end{array}$ \\
\hline $\mathrm{D} 278$ & 21.12 .1992 & $2097 / 92 . p t z$ & $\begin{array}{l}\text { brief van projectleider aan directorium: aanbieding van } \\
\text { verslag vergladering } 2.12 .1992 \text { en van rapportage van } \\
\text { werkgroep indicatiestelling etc. pg. }\end{array}$ \\
\hline D279 & dec. 1992 & 036/93.ptz & $\begin{array}{l}\text { brief aanbieding voortgangstapportage } 2 \text { e hellt } 1992 \text { en } \\
\text { eindrapportage aan WVC }\end{array}$ \\
\hline D280 & - & 037/93.ptz & voortgangsrapportage $2 \mathrm{e}$ helft 1992 aan WVC \\
\hline$D 281$ & 7.1 .1993 & 038/93.ptz & $\begin{array}{l}\text { aanbiedingsbrief vam operagroep aan directies van insthelling- } \\
\text { en met betrekking tot evaluatierapport itz }\end{array}$ \\
\hline $\mathrm{D} 282$ & 8.1 .1993 & 043/93.ptz & $\begin{array}{l}\text { brief van projectleider aan huisartsen: onder andere ophef- } \\
\text { fing stichting itz }\end{array}$ \\
\hline 0283 & febr. 1993 & - & $\begin{array}{l}\text { nota "sociale zorg als functie van een geordende thuiszorg in } \\
\text { het kadier van verpleging en verzorging' van amw" }\end{array}$ \\
\hline D284 & 17.3 .1993 & osbet $161.93 \mathrm{c}$ & $\begin{array}{l}\text { brief van amw aan RL over amw-nota 'sociale zorg als functie } \\
\text { van een geordende thuiszorg in het kader van verpleging en } \\
\text { verzorging' }\end{array}$ \\
\hline
\end{tabular}





\section{Instrumenten voor dataverzameling}

\section{1 'Themalijst interviews projectleiders, najaar 1990' (selectie)}

\section{SAMENWERKING TUSSEN PARTICIPANTEN IN HET KADER VAN HET PROSECT EN DRAAGVLAK}

6a. Hoe de organisatie van het project als netwerk er formeel uitziet, is af te leiden uil de registratieformulieren van meiljuni. In hoeverre wijkt de praktijk ervan af?

6b. In hoeverre is de formele projectorganisatie, zoals weergegeven in de registratieformulieren van melifuni, gewijzigd?

\section{Sleutelwoorden:}

NB: Uitgaan van de gegevens in de registratieformulieren en alleen aanvullende gegevens vragen

* werdeling taken/functies en (beslissings-)bevoegdheden

* intensiteil en aard (a.a. samenwerking-competitie) van relaties tussen participanten

* communicatiekanalen/-mechanismen

* coôrdinatie (o.a. coördinerend orgaan)

* regels en procedures (standaardisering)

* vasitgelegde sanctiemogelijkheden

* machts-, zeggenschapsverhoudingen

* informelle coalities

* opkomst en frekwentie vergaderingen

8a. Op welk niveau (management-zorgverleners) wordt er samengewerkt?

8b. Hoe verloopt de samenwerking tussen de participanten?

8c. Welke participanten tonen de meeste betrokkenheid bij het project, en welke de minste? Hoe verklaarl u dit?

\section{Sleutelwoorden:}

* "kartrekkers"

* inbreng/betrokkenteid participanten: actief-terughoudend

* bereidheid tot samenwerken

* belangen/motieven

9. Hoe schat $u$ het draagulak in?

\section{Sileutelwoorden:}

* motivatie per participant

* bereidheid afzonderlijke participanten tijd, energie en (personele em financile) middelen in het project te steken

* feitelijke inbreng

* bereidheid autonomie in te leveren

* bereidheid organisatieveranderingen door te voeren indien nodig

* bereidheid werkwijze zo nodig ingrijpend aan te passen

* onderschrijven van de doelstellingen

* prioriteitstelling binnen het beleid van de instelingen/participanten

* nakomen van afspraken, toezeggingen waarmaken

10ic. In hoeverre hebben de participanten dezelfde filosofie ten aanzien van zorgverlening? Levert dil problemen op?

11. In hoeverre erkennen de participanten elkaars aanspraken op werkgebied taken, en functies bij zorgverlening (domeinconsensus)? Levert dit problemen op? 


\section{2 'Vragenlijst interviews projectleiders, najaar 1991 (selectie)}

\section{BELANGRIJKSTE PROBLEMEN EN KNELPUNTEN IN PRO.JECT}

1. Omschrijwing wan de samenwerking en relaties tussen betrokkenem.

\section{Sleutelwoorten:}

* onderscheid zorgverleners-management, organen

* samenwerkingsklimaat:

* samenwerking competitie

* machts- en zeggenschapsverhoudingen, informele coalities

* free riders, aftasten/afwachten, deelnemen om te zien wat gaande is

* samenwerking bemoeilijken: hindermacht

* opkomst bij wergadieringen

* intensiteht van de relaties

* culltuurverschillen

* verschillen in normen/waarden

* visie op wat moet gebeuren en hoe

\section{SUBJECTIEVE INSCHATTING: DRAAGVLAK VOOR HET PROIECT OP DIT MOMENT}

1. Motieven van de participanten voor deeiname aan project.

\section{Sleutelwoorden:}

* verwachtelervaren voordelen voor participant

* verwachtelervaren nadelen voor participant

2. Oordeel over betrokkenheid van de participanten bij project.

\section{Sleutelwoorden:}

* onderscheid management - zorgverleners

* toegezegde inbreng: bereidheid tat overdracht bevoegdheden, inleveren autonomie, geld, menskracht, faciliteiten

* feitelijke inbreng: nakomen van afspraken/toezeggingen

* versichillen tussen participanten: actief-terughoudend, "kartrekkers" "wel-niet gemotiveerd

3. Belang project voor de participanten.

\section{Sleutelwoorden:}

* onderscheid management - zorgverleners

* onderschuriven van de projectdoelstellingen

* priorileit project in eigen beleid

* belang project voor eigen doelstellingen

* relatief belang project $4.0 . \%$. andere initiatieven

\section{3 'Themalijst interviews projectleiders, najaar 1992' (selectie)}

\section{INSTRUMENTEN T.B.V. PRIMAIR PROCES}

1. Acceptatie instrumenten door instellingen-hulpverleners.

\section{Sleutelwoorden}

* onderschrijven-weerstand tegen gebruik

* aansluiting bij visie-cultunur-bielangen

* (bedreiging) professionele autonomie

* centrale intake/indicatiestelling

* scheiding vaststellen zorgaanbod e.d. van zorgvertening 


\section{DE ORGANISATORISCHE INBEDDING VAN HET PRIMAIR PROCES}

1. Coördinatie gehele primaire proces.

\section{Sleutelwoorden}

* door wie: functionaris(sem)

* formeel/inhoudelijk werkgever coördinerende functionaris(sen)

* taken-verantwoordelijkheden

* bevoegdheden t.a.v. instellingen en hulpverleners

2. Organisatorische inbedding primair proces.

\section{Sleutelwoorden}

* instelling/organisatie-netwerk waaronder de coördinatie van gehele proces ressorteert

* rechtspersoon

* (on-)afhankelijk t.o.v. participanten

\section{FACTOREN BIJ VOORTGANG: PROJECT-EVALUATIE DOOR PROJECTLEIDER}

1. Samenwerking en relaties tussen betrokkenen.

\section{Sleutelwoorden}

* participanten:

* samenwerking-competitie-coalities-strijd-afwachten-belemmeren

* verschillen tussen participanten: actief-tenughoudend, "kartrekkers", wel-niet gemotiveerd. "free riders"

* machtsverhoudingen

* onderling vertrouwen, intensiteit van de relaties

* opkomst bil vergaderingen

" welke netwerken haalbaar: mate van vrijbljvendheid-binding (fusie, strategische alliantie, opgaan in nietwe organisatie)

* samerwerking tussen hulpverleners

3. Belangen van de participanten.

\section{Sleutelwoorden}

* belang, prioriteill en voor- en nadelen van project

* tegenstrijdigheid projectbelangen-instellingsbelangen

* overeenkomsten-verschillen in belangen tussen participanten: verholen-openilik (beslechingsorgaan)

4. Overeenstemming in domein en cultuur tussen de betrokkenen.

\section{Sleutelwoorden}

* problematische verschillen

* taken-domein-functie, werkwijze-werkgebied (domeinconsensus)

* rormen-waarden-cuitulu-visie op zorgverlening (id eologische consensus)

5. Overheidsbeleid, wet- en regelgeving.

\section{Sleutelwoorden}

* stelselherziening: inhoud, tempo, onduidelikheden

* wet-en regelgeving: invoering cluster verzorging en verpleging per 1-4-1993

* gevolgen voor inzet-opstelling participanten: passief-anticipatie

6. Omgaan met mogelijkheden - onzekemeden m. b.t. financiering. 
Sleutelwoorden

" financieringsstromen en schotten: overheveling budgetten, ruimte voor subistifutite van financiële middelen

- subsidieregelingen: gebrük, kansen en beperkingen

* subsidie WVC voor projectondersteuning

* functionele financiering

7. Opstelling verzekeraars to.y. project.

\section{sleutelwoorden}

* stimulans-belemmering: houding ta.v. aanbieders en project.

* regisseur: begeleidend-ondersteunend-meedenkend-initiërend-flexibel

- administratie- of betaalkantoor: passief-terughoudend-awachtend-star

* ontwikkelingen in ral/opstelling verzekeralar

- relatie met verzekeraars: communicatie, vertrouwen, waardering

* wat doen verzekeraars in regio met zorgplicht. afschuiwen naar aanbieders?

* trends naar meer regionale regie (boven de instellingen)

* verzekeraars en een gespreks- of contractpartner: netwerkem van voorzieningen

* onderhandelingspositie:

* machtsbronnen aanbieders: onderlinge bundeling (o.a. concurrentiebeperking), beperkt regionaal aanbod, schaarste aan personeell, barrieres voor toetreding nieuwe aanbieders (commercie)

* machtsbronnen verzekeraar: contracteervijheid, werschuiving zongplicht "pseudo-overheid toedelling financiële middelen

* verschuivingen in machtswerhouding aanbieders-verzekeraars

\section{4 'Themalijst interviews directeuren gezinszorg en kruiswerk, najaar 1990" (selectie)}

\section{THUISZORGAANBOD}

1a. Wat houdt het thuiszorgaanbod van uw instelling op dit moment in?

1b. Wat is daarvan regulier, wat aanvullend?

1c. Hoe wordt de aanvullende zorg gefinancierd?

\section{Sleutelwoorden:}

* Organisatorische toegankelikheid, beschikbaarheid/capaciteit, bereikbaarheid

- maximatal aantal uren per kontakt maxmale frekwentie kontakten, tijdstippen

* aard wan de zorg:

" Kruiswerk: billage Erkenningsnormen

" Gezinszorg: biliage

- geografisch werkgebied-bewolkingsomvang

* standaardisatie van zorg (protocollen/vepleegplannen): voor welke doelgroepen? (methodisch verpleegkundig handelen)

* wachttijd, wachttijsten, urgentiebepaling (vastgelegde criteria): oorzaken

* Kruiswerk: omvang contributie

2a. Hoe ziet het primaire proces eruil bij gecompliceerde hulpwragen, waarbij de inzet van meerdere disciplines noodzakelijk is?

2b. Hoe vindt daarbij afstemming plaats met andere hulpwerleners/organisaties? 
Sleutelwoorden:

* aanmelding

* intake, indicatiestelling (vaststelling benodigde zorg)

* opslellen zorgplan: vertaling van zorgwraag in zorgaanbod

* uitvoering van de zorg: vertalen van zorgplan in zorgverlenendie activiteiten

* evaluatie tijdens en na afloop van de zorgverlening

3a. Wat zijn de toekomstplannen van uw instelling ten aanzien van organisatie en product van de thuiszorg?

3b. In hoeverre zijn deze plannen formeel vastgelegd in een (strategisch) beleidsplan?

\section{Sleutelwoorden:}

* oordeel over de wenselijkheid wan deze planmen

* geneigdheid tot veranderen van de organisatie van thuiszorg

* financiële en operationele ruimte voor verandering

* centrale aanmelding-intake-indicatiestelling

* coördinatie van zorgverlening

* verandering van het thuiszorgaanbod: taken/functies/doelgroepen

* integratie met andere instellingen

\section{ZORGVERNIEUWINGSPROJECT}

8c. In hoeverre hebben de participanten dezelfde filosofie ten aanzien van zorgverlening?

9. In hoeverre erkennen de participanten elkaars aanspraken op werkgebied, taken, en functies bij zorgwerlening (domeinconsensus)? 


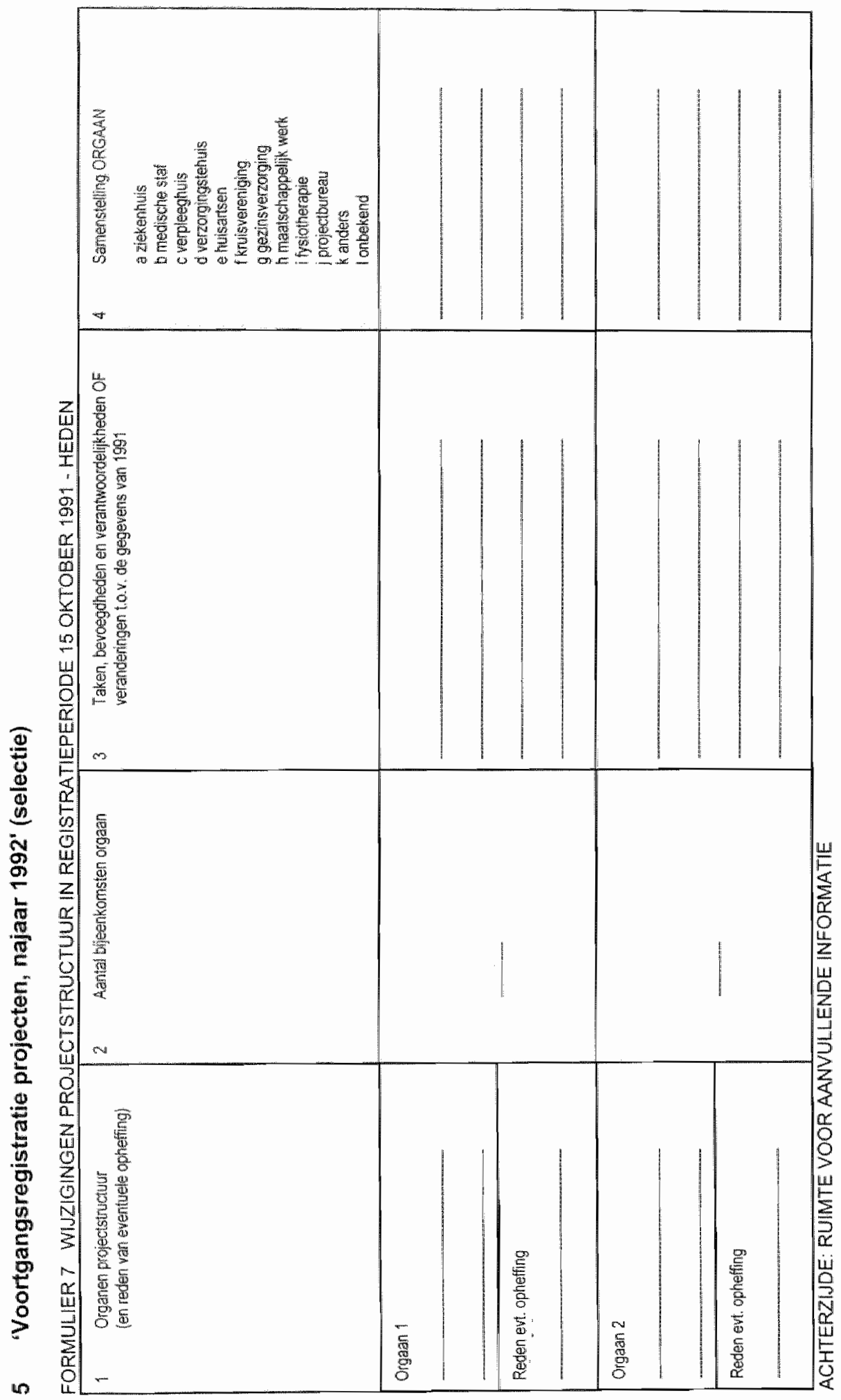




\section{Dankwoord}

Terugkijkend op de periode waarin ik aan mijn proefschrift heb gewerki, besef ik hoezeer anderen mij hebben geholpen. Ik dank hen daarvoor. Dit geldt om te beginnen voor de deelnemers aan het Programma Zorgvernieuwingsprojecten Thuiszorg van WVC, die hebben bijgedragen aan het evaluatie-onderzoek waarop deze studie is gebaseerd. Hans Maarse, mijn promotor, heeft mij waardevolle aanwijzingen gegeven. Harm Lieverdink, Saskia van der Lyke, Frits van Merode en Aggie Paulus deden nuttige suggesties.

In het bijzonder zijn het de leden geweest van de Onderzoeksgroep Zorgvernieuwing, die deze studie mogelijk hebben gemaakt. Ingrid Mur-Veeman, ingrid Tijssen en Gerry Jongerius-De Gier, vooral zij waren degenen met wie ik tijdens het Programma van WVC het evaluatie-onderzoek heb opgezet en uitgevoerd. Ik denk met plezier aan de bijzondere sfeer van openheid en sportiviteit binnen de Onderzoeksgroep, die van dit netwerk een "oog in de orkaan" maakte. Heel belangrijk was de inbreng van Ingrid Tijssen. Haar bijdragen hebben veel voor mij betekend.

Datzelfde geldt voor de steun van Ingrid Mur-Veeman, mijn co-promotor. Het enthousiasme waarmee zij steeds met mij in discussie ging, haar commentaren en aanwijzingen, evenals de randvoorwaarden die zij schiep, ik heb het allemaal zeer gewaardeerd.

Ik koester de herinnering aan mijn gesprekken met Gerard Houben, zowel tijdens het werk ais daarbuiten.

Carla, Laura, Ellen en Stijn, jullie zijn mijn drijfveer. 



\section{Curriculum vitae}

Arnoldus Johannes van Raak werd op 18 januari 1959 geboren in Kaatsheuvel, gemeente Loon op Zand. Van 1971 tot 1977 bezocht hij het Gymnasium A aan het Theresialyceum te Tilburg. Na een kortstondig verblijf als student aan de Rijksuniversiteit Utrecht (sociale geografie, 1977-1978) en een vijf jaar durend intermezzo in het bedrijfsleven (importeur van schaatssport-artikelen), stuideerde hij van 1983 tot 1988 sociologie aan de Katholieke Universiteit Brabant. Van 1986 tot 1989 was hij als student-assistent werkzaam bij het IVA, instituut voor sociaal-wetenschappelijk onderzoek te Tilburg. Daarnaast werkte hij -van 1988 tot 1990-als 'onderzoekercoördinator preventie veel voorkomende criminaliteit' bij de gemeente Harderwijk. Sinds 1990 is hij verbonden aan de Universiteit Maastricht, alwaar hij de promotie-studie uitvoerde. Aanvankelijk was hij toegevoegd onderzoeker bij de vakgroep Beleidswetenschap van de Faculteit der Gezondheidswetenschappen. In 1997 werd hij aangesteld als universitair docent bij de vakgroep Beleid, Economie en Organisatie van de Zorg (BEOZ), waarin de vakgroep Beleidswetenschap is opgegaan. 